UNIVERSIDADE DE SÃO PAULO

FACULDADE DE EDUCAÇÃO

CELSO HIROSHI IOCOHAMA

O ENSINO DO DIREITO E A SEPARAÇÃO DOS EIXOS TEÓRICO E PRÁTICO: INTERRELAÇÕES ENTRE APRENDIZAGEM E AÇÃO DOCENTE

SÃO PAULO 
CELSO HIROSHI IOCOHAMA

\section{O ENSINO DO DIREITO E A SEPARAÇÃO DOS EIXOS TEÓRICO E PRÁTICO: INTERRELAÇÕES ENTRE APRENDIZAGEM E AÇÃO DOCENTE}

(versão corrigida - original disponível no setor da Pós-Graduação da FEUSP)

Tese apresentada ao Programa de PósGraduação em Educação, da Faculdade de Educação da Universidade de São Paulo, com requisito parcial à obtenção do título de Doutor em Educação

Área de concentração: Didática, Teorias de Ensino e Práticas Escolares.

Orientadora: Professora Doutora Sonia Teresinha de Sousa Penin.

São Paulo - SP 
AUTORIZO A REPRODUÇÃO E DIVULGAÇÃO TOTAL OU PARCIAL DESTE TRABALHO, POR QUALQUER MEIO CONVENCIONAL OU ELETRÔNICO, PARA FINS DE ESTUDO E PESQUISA, DESDE QUE CITADA A FONTE.

Catalogação na Publicação

Serviço de Biblioteca e Documentação

Faculdade de Educação da Universidade de São Paulo

375.46 locohama, Celso Hiroshi

I64e O ensino do Direito e a separação dos eixos teórico e prático: interrelações entre aprendizagem e ação docente / Celso Hiroshi Iocohama; orientação Sonia Teresinha de Sousa Penin. São Paulo: s.n., 2011.

319 p.; tabs.; grafs.; anexos

Tese (Doutorado - Programa de Pós-Graduação em Educação. Área de Concentração: Didática, Teorias de Ensino e Práticas Escolares) - - Faculdade de Educação da Universidade de São Paulo.

1. Direito - Ensino 2. Ensino jurídico 3. Prática de ensino

4. Aprendizagem 5. Ensino superior 6. Professores I. Penin, Sonia Teresinha de Sousa, orient. 
IOCOHAMA, C. H.

\title{
O ENSINO DO DIREITO E A SEPARAÇÃO DOS EIXOS TEÓRICO E PRÁTICO: INTERRELAÇÕES ENTRE APRENDIZAGEM E AÇÃO DOCENTE
}

\begin{abstract}
Tese apresentada ao Programa de PósGraduação em Educação, da Faculdade de Educação da Universidade de São Paulo, com requisito parcial à obtenção do título de Doutor, na área de concentração Didática, Teorias de Ensino e Práticas Escolares, sob a orientação da Professora Doutora Sonia Teresinha de Sousa Penin.
\end{abstract}

Aprovada em:

Banca Examinadora

Professora Doutora Sonia Teresinha de Sousa Penin (Orientadora)

Professora Doutora Helena Coharik Chamlian

Professora Doutora Bernadete Angelina Gatti

Professora Doutora Marli Eliza Dalmazo Afonso de Andre 
Ao Caio, filho querido, que me faz aprender mais do que ensinar. 


\section{AGRADECIMENTOS}

Como se já não bastassem as tempestades normais que passam por todo grande projeto, este, em especial, conseguiu se destacar - no meu plano pessoal pelas tantas interferências que sofreu. Entretanto, como sempre, algumas pessoas especiais surgem para dar o abrigo necessário nas formas e nos momentos adequados e agora é tempo de agradecer.

Minha orientadora, Professora Doutora Sonia Teresinha de Sousa Penin é, inegavelmente, a quem devo os maiores e sinceros elogios. Acolheu-me como seu orientando desde meu ingresso na USP. Apontou-me importantes caminhos, cobroume escolhas, atitudes e esteve presente com ações incentivadoras a todo momento. As orientações presenciais foram verdadeiras aulas e me fizeram rever até mesmo minhas atitudes como orientador. Assim, registro meus especiais agradecimentos, ressalvando, entretanto, sua completa isenção em relação aos encaminhamentos que tomei pelas abordagens apresentadas que eventualmente não puderam contemplar a bom termo as orientações recebidas.

Pelas inspirações direcionadas aos meus estudos na área da Educação, agradeço a Professora Doutora Maria Aparecida Monteiro da Silva, parceira de tantas discussões pedagógicas realizadas quando exercia minhas funções como coordenador de Curso e ela como ativa docente do Curso de Direito, ventilando o ambiente isolado da área com seus conhecimentos e formação como pedagoga. Do mesmo modo, à Professora Doutora Roseli Baumel, incentivadora ao tempo da especialização em Docência do Ensino Superior em Umuarama, Paraná, ainda que por tão poucos contatos, ao lado do Professor Doutor Luiz Roberto Prandi, coordenador do referido Curso e colega na docência junto ao Curso de Direito há tantos anos. Neste mesmo plano agradeço à Professora Cacilda Zafanelli, educadora que é exemplo ímpar por suas contínuas manifestações em prol da formação docente, sempre disposta a refletir e contribuir sobre o tema.

Agradeço também aos professores e amigos Valdecir Pagani, Alessandro Otavio Yokohama, Paulo Cesar de Sousa, Miriam Fecchio Chueiri, Mariceles Cristina Fecchio, Bruno Smoralek Dias, Silvia Matei e Fábio Caldas de Araújo, pelas manifestações e disposição que contribuíram ao enfrentamento de importantes questões surgidas durante o tempo da pesquisa. 
Pelo apoio em razão do meu afastamento temporário do escritório de advocacia, agradeço em especial aos advogados Daniel Martins e Nilton Giuliano Turetta, bem como ao acadêmico de Direito Guilherme Druciak de Castro, este último também pela colaboração na organização de parte dos dados da pesquisa.

Registro meus agradecimentos, pelas importantes palavras de incentivo, à Karoline Guimarães e Isabel Cristina Rodrigues, presentes mesmo à distância, mas com atitudes que muito influenciaram a superação de diversas barreiras.

À Professora Amparo Fecchio dos Santos, manifesto meus agradecimentos pelas leituras e apontamentos na correção dos textos e ao Professor Adalberto Valderrama Gerbasi pelo apoio prestado para as análises e demonstrações estatísticas.

Por fim, manifesto meus agradecimentos a Deus pelas inspirações em todas as horas. 


\section{RESUMO}

\section{IOCOHAMA, C. H. O ensino do direito e a separação dos eixos teórico e}

prático: interrelações entre aprendizagem e ação docente. 2011. Tese (Doutorado) - Faculdade de Educação, Universidade de São Paulo, 2011.

O estudo objetivou identificar o afastamento entre a teoria e a prática no ensino do Direito, analisando problemas decorrentes para a aprendizagem do aluno, considerando propostas curriculares de quarenta cursos de Direito. Observando a crise ontológica do próprio Direito e a necessidade da visão crítica para um pluralismo de seus paradigmas, procurou-se analisar as dificuldades enfrentadas pelo ensino do Direito desde a sua origem até a atualidade, sob um olhar direcionado às ações docentes, considerando os seus reflexos nas ações discentes. Reconhecendo a inexistência de uma formação pedagógica bem definida e sistematicamente realizada para o professor do ensino superior de modo geral, acrescentou-se, no caso do Direito, as relações entre a docência e as especificidades do meio jurídico. Sobre o afastamento entre a teoria e prática, o estudo mostrou, inicialmente, a estrutura organizacional do Curso de Direito a partir das Diretrizes Curriculares Nacionais fixadas para a área, com a concepção de eixos de formação fundamental, profissional e prática. Comparando-se matrizes curriculares de quarenta Cursos de Direito, afirmou-se um padrão de distribuição das disciplinas que concebem este afastamento teórico-prático em razão do estágio praticado nos últimos anos do Curso, e as dificuldades para a aplicação interdisciplinar pela visão compartimentada vivenciada para o ensino do Direito. Propondo-se analisar as manifestações discentes e docentes de cursos de Direito de uma universidade particular, a atenção focou vivências durante estágio de Direito Processual Civil e as suas relações com as disciplinas teóricas de Direito Processual Civil lecionadas no segundo e terceiros anos. Identificou-se o predomínio da exposição oral transitando por tais momentos, a menor utilização de procedimentos de ensino diversificados, bem como a prevalência da não valorização de atividades práticas durante a realização das aulas teóricas. Considerando a aprendizagem, procurou-se demonstrar a contribuição da Teoria da Aprendizagem Significativa em Ausubel, para enriquecer a relação teórica e prática mesmo no contexto das aulas denominadas teóricas. À guisa de propostas para a diversificação de ações junto ao Curso de Direito, salientou-se a importância do papel docente na aprendizagem. A aula expositiva também foi revisitada, para reconhecê-la como procedimento possível de aprimoramento, na medida em que se promovam ações práticas para acompanhamento dos conteúdos teóricos. Por fim, apresenta-se a metodologia da Aprendizagem Baseada em Problemas (ABP) como alternativa de reflexão para a transformação do ensino do Direito, estruturada numa formatação caracterizada pela concentração na ação discente e sua aprendizagem.

Palavras-chave: Ensino do Direito. Teoria e Prática. Aprendizagem. Docência no Ensino Superior. Currículo do ensino do Direito. 


\begin{abstract}
IOCOHAMA, C. H. Legal education and the separation between theoretical and practical aspects: interrelations between learning and teaching activities. 2011. Thesis (Doctorate) - Faculty of Education, University of São Paulo, 2011.
\end{abstract}

The purpose of this study is to identify the gap between theory and practice in the teaching of Law and to analyze the resulting problems for learning by students, by studying what is on offer in the curricua of 40 law schools. Given the existential crisis in Law itself and the need for a critical view of the pluralism of its paradigms, the difficulties faced by the teaching of law were examined from its beginnings up to the present time, by focusing on teaching activities, taking into account their repercussions on the actions of the teaching body. In addition to recognizing the lack of well-defined educational training which is systematically undergone by teachers in higher education generally, in the case of Law, there is in addition the question of the relationship between teaching and the specific characteristics of the environment of Law. As concerns the gap between theory and practice, the study covered initially the organizational structure of the law school courses, beginning with the National Curriculum Guidelines covering the subject, including the concept of basic, professional and practical education. By comparing the curricula of 40 law school courses, it was noted that there is a pattern of distribution of the subjects taught comprising this gap between theory and practice, as a result of the internship during the latter years of the law school course and the difficulties for the interdisciplinary application as a result of the compartmentalized view experienced in the teaching of Law. An attempt was made to analyze inputs from both students and teachers in law courses at a private university, focusing attention on experiences during an internship of Civil Procedural Law and its relations with the theoretical subject of Civil Procedural Law taught during years two and three. The predominance of verbal explanations during the whole of this period was identified, and the reduced the use of diversified teaching procedures, as well as the prevalence of a failure to appreciate the value of practical activities during theory lectures. Regarding learning, an attempt was made to show the contribution of Ausubel's Meaningful Reception Learning Theory in enriching the relationship between theory and practice, even in the context of so-called theory classes. In the proposals for the diversification of the actions within law courses, the importance of the role of the lecturers in learning was noted. Lectures were also reviewed so as to be recognized as a procedure which can be improved by promoting practical work as a follow-up to theoretical content. Finally, the Problem Based Learning (PBL) methodology is presented as a possible alternative for the transformation of the study of Law, structured around a format which is characterized by focusing on the activities of students and their learning.

Key words: Teaching of Law. Theory and Practice. Learning. Teaching in Higher Education Teaching. Law School Curriculum. 


\section{LISTA DE TABELAS}

Tabela 01 - Respostas apresentadas por Discentes na avaliação das ações docentes em Direito Processual Civil I

Tabela 02 - Respostas apresentadas por Discentes na avaliação das ações docentes em Direito Processual Civil II.

Tabela 03 - - Respostas apresentadas por Discentes em relação às dificuldades enfrentadas perante as disciplinas de Estágio Simulado de Processo Civil.

Tabela 04 - Respostas apresentadas por Docentes das disciplinas teóricas de Direito Processual Civil sobre a utilização de procedimentos para as aulas

Tabela 05 - Respostas apresentadas por Docentes das disciplinas teóricas de Direito Processual Civil relacionando os procedimentos de ensino com a aprendizagem.

Tabela 06 - Respostas apresentadas por Docentes das disciplinas teóricas de Direito Processual Civil apresentando sua expectativa quanto à prática dos conteúdos abordados.

Tabela 07 - Respostas apresentadas por Docentes das disciplinas teóricas de Direito Processual Civil indicando o relacionamento com a disciplina de estágio/prática de processo civil.

Tabela 08 - Respostas apresentadas por Docentes da disciplina prática de Direito Processual Civil sobre a utilização de procedimentos para as aulas .......

Tabela 09 - Respostas apresentadas por Docentes da disciplina prática de Direito Processual Civil sobre as dificuldades observadas nos alunos em relação aos conteúdos de Direito Processual Civil I e Direito Processual Civil II

Tabela 10 - Respostas apresentadas por Docentes da disciplina prática de Direito Processual Civil sobre as relações com os professores das disciplinas teóricas de Direito Processual Civil.

Tabela 11 - Recorte das respostas dos discentes sobre as ações do professor de Direito Processual Civil I quanto às atividades simuladas.

Tabela 12 - Recorte das respostas dos discentes sobre as ações do professor de Direito Processual Civil II quanto às atividades simuladas.

Tabela 13 - Descrição das etapas para o desenvolvimento da aprendizagem baseada em problemas 


\section{LISTA DE GRÁFICOS}

Gráfico 01 - Distribuição de titulação entre docentes segundo o gênero .................... 148

Gráfico 02 - Distribuição de tempo de atuação entre docentes das disciplinas teóricas segundo o gênero

Gráfico 03 - Distribuição de tempo de atuação entre docentes das disciplinas práticas/estágio segundo o gênero 


\section{LISTA DE ESQUEMA E FIGURAS}

Esquema 01 Processo de comunicação (GIL, 2005, p. 69)

Figura 01 - Descrição da organização curricular da 1ª Série do Curso de Medicina da Universidade Estadual de Londrina

Figura 02 - Descrição de uma grade curricular de um Curso de Medicina que não indica adotar a metodologia da aprendizagem baseada em problemas.

Figura 03 - Caracteristics of PBL and its cognitive psychological processes (MOUST, VAN BERKEL, SHMIDT, 2005) 


\section{ABREVIATURAS}

ABEDi Associação Brasileira do Ensino do Direito

ABP Aprendizagem Baseada em Problemas

CFE Conselho Federal de Educação

CNE Conselho Nacional de Educação

CNE/CES Conselho Nacional de Educação/Câmara de Educação Superior

ENADE Exame Nacional de Desempenho dos Estudantes

IES Instituição de Ensino Superior

INEP Instituto Nacional de Estudos e Pesquisas Educacionais Anísio Teixeira

LDB Lei de Diretrizes e Bases da Educação Nacional

MEC Ministério da Educação e Cultura

OAB Ordem dos Advogados do Brasil

PBL Problem-based learning

SESU Secretaria de Educação Superior

SINAES Sistema Nacional de Avaliação da Educação Superior 


\section{SUMÁRIO}

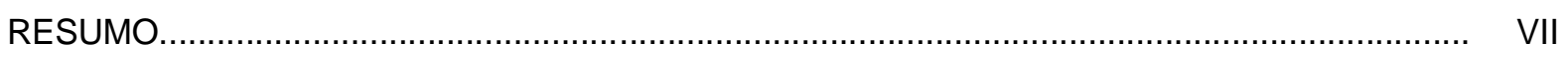

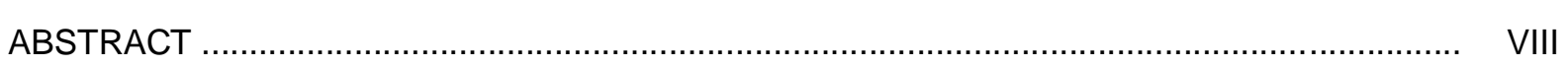

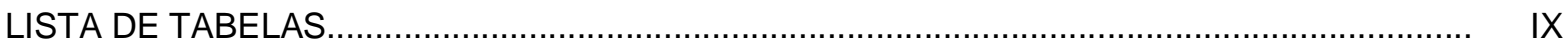

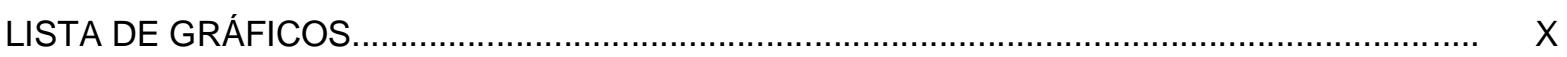

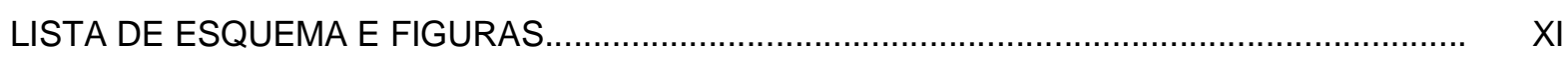

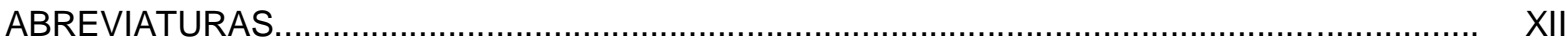

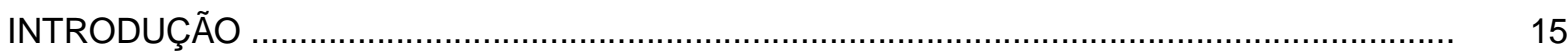

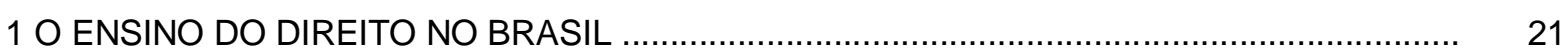

1.1 Breve Histórico dos Cursos de Direito no Brasil........................................................... 23

1.1.1 Momentos iniciais da criação dos Cursos de Direito................................. 25

1.1.2 Os Cursos de Direito a partir do período Republicano................................ $\quad 30$

1.1.3 A estruturação histórica das disciplinas ................................................. 35

$1.2 \mathrm{O}$ ensino do Direito e a crise ontológica do próprio Direito .......................................... 42

1.2.1 A alteração do paradigma jurídico ......................................................... 53

\section{A CRISE DO ENSINO DO DIREITO PELA CRISE PEDAGÓGICA: DOCENTES E} DISCENTES

2.1 As dificuldades pedagógicas em relação ao docente ................................................... 65

2.1.1 A formação pedagógica do professor de Direito ..................................... 65

2.1.2 A docência no ensino do Direito com profissão ........................................ 73

2.1.3 O reconhecimento como educador e a valorização da aprendizagem ...... 76

2.1.4 $\mathrm{O}$ afastamento docente, a autoridade e a arbitrariedade.......................... 83

2.1.5 A atividade docente na seleção das verdades e sua postura como fonte

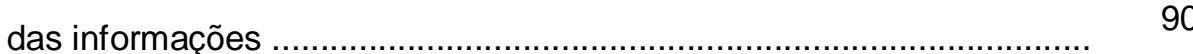

2.2 As dificuldades decorrentes do corpo discente …................................................. $\quad 97$

2.2.1 A ausência de conscientização sobre os objetivos pessoais profissionais 99

2.2.2 Os efeitos da formação anterior .......................................................... 104

2.2.3 A ausência de interação discente-mundo ................................................ 106

3 A ESTRUTURAÇÃO DO ENSINO DO DIREITO EM EIXOS E A SUA PROBLEMATIZAÇÃO: A NORMATIZAÇÃO E A COMPREENSÃO INTERDISCIPLINAR

3.1 A proposta das Diretrizes Curriculares para o Curso de Direito .................................... 113

3.2 Os eixos para o desenvolvimento do Curso de Direito

3.3 A tradicional divisão das disciplinas em matrizes curriculares para o Curso de Direito e a polêmica sobre a formação profissional no Direito 
4.1 Levantamentos sobre uma experiência do Estágio e sua relação com disciplinas teóricas

4.1.1 O discurso dos acadêmicos ...

4.1.2 O discurso dos professores

4.2 $\mathrm{A}$ aprendizagem

4.2.1 A aprendizagem significativa em Ausubel

4.2.1.1 Aprendizagens por descoberta, recepção, mecânica e significativa.

4.2.1.2 Estrutura cognitiva, subsunção e princípios facilitadores da aprendizagem significativa.

4.3 A motivação

4.4 A relação teoria-prática

5 MEDIDAS PEDAGÓGICAS DOCENTES PARA O ENVOLVIMENTO DA AÇÃO DISCENTE: A APROXIMAÇÃO DA TEORIA E DA PRÁTICA

5.1 A importância do professor mediador/facilitador.

5.2 A revisão da aula expositiva no contexto do ensino do Direito

5.3 A inserção da prática nas abordagens teóricas e a ampliação da ação discente sem o distanciamento temporal .

5.4 A contribuição da aprendizagem baseada em problemas para o ensino e estudo do Direito

ANEXO A - Matrizes curriculares de 40 (quarenta) cursos de Direito...

ANEXO B - Questionário aplicado aos discentes

ANEXO C - Questionário aplicado aos docentes das disciplinas teóricas

ANEXO D - Questionário aplicado aos docentes das disciplinas práticas 306

ANEXO E - Planos de Ensino de Direito Processual Civil I e Direito Processual Civil II 


\section{INTRODUÇÃO}

A vivência e a convivência em qualquer ambiente fulcrado num sistema democrático e de garantia de liberdade dão ao sujeito a opção de participar efetivamente dos acontecimentos que compõem o seu entorno, do mesmo modo que the permite escolher vivenciar seus atos mínimos, cumprindo obrigações institucionalizadas, considerando seus interesses pessoais a par de outras ações envolvendo a alteridade.

Neste ambiente de escolhas, dei um primeiro passo ousando iniciar a carreira acadêmica como professor, após receber a indicação para assumir essa função pelas mãos, à época, de meu ex-professor de Direito e então Diretor da Faculdade de Direito de Umuarama. Era o tempo dos riscos de se contratar profissionais da área do Direito para dar aulas pela confiança, mais do que pela competência docente, já que ela não existia na absoluta maioria dos novos professores. A experiência docente que tinha era a experiência apenas observada pelos exemplos de professores. Minhas credenciais se sustentavam na participação como aluno do Programa de Mestrado em Direito das Relações Sociais da Universidade Estadual de Londrina e no vínculo de proximidade com o então Diretor, já que trabalha em seu escritório de advocacia, antes como estagiário e naquela oportunidade como advogado. Era início da década de 90 e para agravar a complexidade da situação, passei a responder pela coordenação do Curso de Direito assim que a Instituição transformou-se em Universidade, em 1993. Creio que esta data pode ser considerada o marco inicial para minhas preocupações com os aspectos pedagógicos. As inúmeras situações vivenciadas por conflitos, debates pedagógicos e exigências técnico-administrativas, num ambiente que chegou a envolver mais de 1500 alunos (apenas do Curso de Direito) e quase uma centena de docentes e funcionários exigiam muito mais do que uma experiência pautada em observação de experiências anteriores.

Assim, começaram a ser somadas outras ações direcionadas propriamente à formação docente e a compreensão dos fundamentos pedagógicos para o desenvolvimento do processo educativo. A função de coordenador de Curso permitiu o envolvimento com eventos nacionais onde o ensino do Direito era tema principal. Foi possível acompanhar o movimento da Ordem dos Advogados do Brasil direcionado à qualidade dos Cursos de Direito e o envolvimento com a Comissão de 
Especialista da área junto ao Ministério da Educação e INEP. Muitos debates acalorados surgiam por conta das exigências das avaliações externas de Curso e elas aconteciam com visitas in loco, em recredenciamentos e autorizações. Nestes debates em Congressos, os problemas apareciam de toda natureza. Havia denúncias de ambientes estruturais simulados para induzir em erro as comissões de avaliação. Exigia-se a titulação de professores num ambiente onde a obtenção de títulos dependida da escassez de Programas de Pós-Graduação Stricto Sensu. Vivenciava-se um movimento crítico dentro do próprio Direito, em recusa ao insistente e predominante ambiente legalista, reiterado pelos ambientes acadêmicos, onde o tecnicismo e a formalidade sobrepunham as necessidades sociais evidentes. Estes e muitos outros pontos indicavam, de um lado, uma espécie de caos na formação jurídica e, de outro, a existência de um movimento preocupado com essa situação.

Na maioria dos discursos, contudo, era a negligência da questão pedagógica. Ainda que mencionada, não esclarecia o que poderia ser feito. Contratar professores para lecionar no Curso de Direito com a condição de sua formação pedagógica anterior não era plausível (se nem havia titulados para se contratar, imagine-se titulados com formação pedagógica). Além disso, havia um corpo docente já atuando sobre o qual algo precisava ser feito.

A titulação não se demonstrou um caminho seguro para encontrar professores cientes das questões pedagógicas necessárias para o desenvolvimento de um Curso. Nem todos os mestrados e doutorados contemplavam a formação pedagógica e quando o faziam, concentravam as ações em disciplinas de Metodologia do Ensino Superior, que, apesar de importantes, nem sempre produziam inspirações duradouras.

Mostrava-se então coerente imaginar uma formação continuada do professor para o exercício da sua docência. Como consequência, buscou-se compreender medidas para incentivar a formação pedagógica do professor de Direito. Mesmo com o irrestrito apoio institucional da Universidade, encontravam-se agora resistências dos professores de Direito, pautadas na participação de um ambiente paradoxalmente estranho: discutir didática e a própria pedagogia com pedagogos parecia não fazer parte do ambiente do ensino de Direto. A autoridade atribuída pelos alunos-professores ao professor pedagogo era questionada, porque se 
supunha existir autoridade para tratar do ensino do Direito a apenas quem soubesse o que era o Direito.

Numa tentativa - de certo modo ingênua - de demonstrar os equívocos de tal interpretação, resolvi fazer uma nova escolha e participar neste ambiente de formação dos professores de Direito, na esperança de romper com este mito da autoridade como requisito para discutir o ensino do próprio Direito. A ideia era entrar neste discurso como autoridade do Direito, para demonstrar que ela (a autoridade jurídica), em si, era insuficiente para compreender o processo educativo. A escolha, assim, acontecendo já nos idos de 2002, entre a opção de lecionar uma disciplina junto a um Programa de Mestrado em Direito: as ofertas transitavam entre uma disciplina na área de processo civil, onde havia obtido o título de doutor há um ano antes, ou encarar uma disciplina de Metodologia do Ensino Superior Jurídico. A oportunidade estava apresentada e a escolha aconteceu pela segunda opção, motivada pela esperança de poder produzir mais efeitos num ambiente de futuros professores (ou até mesmo professores) do Direito. A ingenuidade, porém, configurou-se por imaginar que esse movimento fosse simples, mas encarou uma dificuldade óbvia: rompido o mito da autoridade, restava agora o conhecimento pedagógico e a dúvida de como ele estaria formado em mim. Onde estaria a autoridade pedagógica em quem jamais participou de uma licenciatura? Seriam suficientes as experiências como coordenador de curso, ainda que somadas em quase uma década nesta função, além de realizar uma especialização em docência do ensino superior?

Colocando-me numa situação de desafio constante, pude vivenciar a importância da experiência que foi acompanhada do sentimento de responsabilidade por fazer melhor e superar as expectativas dos envolvidos. Desde então, os estudos da Educação acompanham meus estudos do Direito, e para ambos o desafio da compreensão e da aplicação são constantes, sempre acompanhado da certeza da incerteza.

Neste contexto, fui acumulando desconfortos envolvendo o ensino do Direito que me provocavam a focar seu estudo. Muitos pontos problemáticos foram sendo identificados e a possibilidade de transpô-los para o ambiente de pesquisa da PósGraduação invocou a nova responsabilidade de estabelecer um objeto de estudo e ter uma proposta para sua análise. 
No início, via nas habilidades e competências esperadas para os alunos de Direito uma importância projetada para as ações docentes. Pensava estudar o reconhecimento dos professores em relação às referidas habilidades $e$ competências, para analisar quais medidas eram adotadas para sua realização, mas fui levado a perceber as dificuldades e questionamentos existentes sobre o tema. Estava partindo para uma investigação sem perceber a ideologia que envolvia o assunto, afastando-se do âmbito didático onde pretendia desenvolver meus estudos.

Sob importantes discussões promovidas em seminários e aulas durante a realização dos créditos junto ao Programa, pude compreender que o tema de fundo dos meus incômodos estava atrelado às dificuldades da aprendizagem e às ações docentes. O problema não estava efetivamente em habilidades e competências esperadas, mas sim na interrelação da teoria e da prática e os procedimentos para provocar as ações discentes focando a aprendizagem, com a integração da ação docente neste caminho. Logo, o estudo do Direito permaneceu como ambiente da pesquisa e a seleção de alunos e docentes para fins de uma investigação exploratória foi o marco para desenvolvimento das análises.

Assim, este estudo parte de uma breve demonstração do histórico do ensino do Direito, apontando a influência estatal na sua constituição. Registra-se ainda, no primeiro Capítulo, a crítica desenvolvida para a compreensão do próprio Direito, que se consubstancia na base de qualquer discussão pedagógica, afinal, não há ensino do Direito sem se pensar no seu próprio objeto. A análise de seu paradigma, portanto, constitui-se um requisito necessário para que não se desenvolva um debate sobre como ensinar, sem entender o que ensinar.

$\mathrm{Na}$ identificação dos sujeitos considerados como foco da pesquisa, relacionaram-se no segundo Capítulo algumas dificuldades envolvendo o docente e o discente de um curso de Direito. Tratou-se da formação pedagógica do professor, da visão profissional da docência do papel do professor e como educador, além de demonstrar os seus reflexos no ambiente da aprendizagem. Algumas peculiaridades do ambiente jurídico foram trazidas para esta parte das dificuldades enfrentadas, com destaque para a figura da autoridade, a postura como fonte de informações e as limitações das verdades como objeto do ensino. Ao discente foram abordadas as questões envolvendo sua alienação em relação as ações para seu futuro profissional e o debate que surge pela sua formação anterior, além do seu envolvimento no plano da alteridade. 
Contextualizando a presença destes sujeitos no ambiente estrutural em que vivem, o terceiro Capítulo procura demonstrar as propostas das Diretrizes Curriculares Nacionais para o Curso de Direito e a sua divisão entre eixos, bem como os desafios existentes para a formação do profissional do Direito e o envolvimento da integração e da interdisciplinaridade nesta conjuntura acadêmica.

O quarto Capítulo apresenta os dados relativos aos questionários aplicados aos discentes e docentes de um Curso de Direito. Os discentes, cursando o último ano do Curso, manifestaram-se sobre as dificuldades enfrentadas no Estágio de Processo Civil e as ações tomadas pelos professores das disciplinas teóricas de Processo Civil. O conteúdo de Direito Processual Civil foi escolhido pela proximidade com o tema, pelos anos lecionando a disciplina para o segundo ano (Direito Processual Civil I), além de ter presenciado inúmeros discursos, partindo de outros lugares, mas sob o mesmo tema, referente às dificuldades enfrentadas no estágio em razão das deficiências dos conteúdos teóricos. Os professores do mesmo curso e de outras Unidades da mesma Instituição de Ensino também prestaram informações sobre sua própria prática e o interrelacionamento entre as disciplinas de estágio e de teoria.

No mesmo quarto Capítulo também são apresentadas considerações sobre a aprendizagem, entre seus fundamentos e elementos, acrescentando-se a abordagem realizada pela Teoria da Aprendizagem Significativa de Ausubel, de onde foram retirados elementos que contribuem para as ações docentes envolvendo a retenção do conhecimento. Ainda que tal teoria não constitua um marco teórico exclusivo para o presente estudo, contribui de forma instrumental para a compreensão das estruturas cognitivas e as ações para o seu envolvimento para com a aprendizagem, aptas não somente para a utilização nas aulas expositivas, mas também para outras inferências da pesquisa para o Curso de Direito. A este estudo acrescentou-se a análise da motivação, na medida de sua importância para a aprendizagem, bem como da relação teoria e prática, outro pilar para a forma como se pode ver a aprendizagem no Direito.

Por certo, o último Capítulo trata da reflexão de questões pontuais dentro do estudo do Direito. A figura do docente considerando-o como facilitador da aprendizagem na mediação das relações sob sua responsabilidade, bem como a compreensão das possibilidades da aula expositiva foram tratadas pela sua inegável importância na construção de qualquer olhar sobre o Curso. O redimensionamento 
de ambos (professor e aula expositiva) segue como uma sugestão em atenção à aprendizagem esperada.

Assim, finaliza-se com uma análise da inserção da prática nas abordagens teóricas do ensino do Direito, além de apresentar a metodologia da Aprendizagem Baseada em Problemas (ABP) para fomentar expectativas diferenciadas para o desenvolvimento da aprendizagem ativa pelo discente.

Ainda que toda proposta e pesquisa se insiram sob as regras do tempo e da temporalidade, acredito que este estudo participe das inquietudes que me envolvem mas prossegue muito além. Espero que ao contar o que já se poderia saber (dos problemas envolvendo o ensino e estudo do Direito e das perspectivas considerando a aprendizagem), permita ao leitor o olhar das possibilidades que envolvem a educação neste contexto, considerando pressupostos e experiências numa perspectiva dialética de reflexão e superação. 


\section{O ENSINO DO DIREITO NO BRASIL}

Na perspectiva do ensino superior, o Curso de Direito tem recebido especial destaque, já há alguns anos, diante da polêmica que tem sido causada pelo denominado Exame de Ordem, instituído como obrigatório para todos os bacharéis em Direito interessados no exercício da advocacia, de acordo com a Lei 8.906/94.

De fato, diferenciando-se de outras atividades profissionais, a advocacia brasileira, ao ser regulamentada por normas federais, trouxe em seu bojo regras que passaram a submeter os bacharéis em Direito a uma espécie de concurso, sem o qual o exercício da advocacia não é permitido. Logo, para ser advogado não basta fazer o Curso de Direito, devendo enfrentar esse concurso e nele ser aprovado.

Note-se que tal sistema de submissão ao Exame de Ordem era diferenciado até 1994. A sistemática revogada pela Lei 8.906/94 permitia que os Exames de Ordem fossem realizados na própria Instituição de Ensino Superior conveniada com a Ordem dos Advogados do Brasil (sistema regido pela Lei 4.215 de 27 de abril de 1963). Nessa sistemática, o Exame de Ordem existia numa simbiose com o contexto do sistema de avaliação do Curso, circunstância que amenizava a pressão existente sobre o mesmo. Com isso, somente os alunos aprovados no Estágio (através do qual o Exame de Ordem era aplicado) é que poderiam colar grau e, quando o fizessem, também já estariam aptos ao exercício profissional da advocacia, dependendo apenas de um ato solene de juramento profissional.

Como não eram todos os Cursos de Direito que mantinham tal convênio, os bacharéis que neles cursassem precisavam prestar o Exame de Ordem após a conclusão do curso e no momento que julgassem conveniente, aplicado pela Ordem dos Advogados do Brasil de cada Estado (nesta hipótese sem a participação da Instituição de Ensino).

É certo que o foco do ensino do Direito não se restringe à advocacia e ela é apenas uma parte dentre as diversas atividades profissionais que exigem o bacharelado em Direito como requisito. A magistratura, em seus diversos cargos (juiz estadual, juiz federal, juiz do trabalho e juiz militar), o Mistério Público (promotor de justiça, procurador da República, procurador do Trabalho e procurador Militar) e a função de delegado (estadual ou federal), são outras atividades de idêntico modo importantes, mas a repercussão provocada pelo Exame de Ordem tem recebido foco 
da mídia há muito tempo, atrelando-se os resultados da aprovação no referido Exame à qualidade do ensino superior.

De fato, ainda que um Exame de Ordem não se apresente como um adequado instrumento de avaliação (para qualidade de cursos jurídicos), por conta de todas as características que uma avaliação possui e pelas limitações em que um exame se baseia, ainda assim assume um importante papel para colocar em foco a discussão sobre o ensino superior.

Como de regra, os concursos jurídicos (tanto o Exame de Ordem como em especial aqueles para o ingresso na magistratura ou no Ministério Público) exigem conhecimento teórico e prático, dentro dos moldes dos cursos e sua formação profissional, pretende-se, com a escolha da área do Direito, realizar um estudo sobre um objeto de nossa própria experiência.

Por certo, dos anos envolvidos com a docência no ensino do Direito (desde 1991), inclusive assumindo a coordenação pedagógica de um Curso de Direito de uma Instituição particular por aproximadamente dez anos e pela atividade também exercida como membro da diretoria da Ordem dos Advogados do Brasil (onde pude exercer por nove anos o cargo de vice-presidente da Subseção de Umuarama, Paraná, somados aos três anos como Presidente da mesma Subseção no período de 2007-2009, reeleito por mais três anos a partir de 2010), foi e está sendo possível agregar experiências voltadas às práticas de ensino e no envolvimento nas discussões sobre a qualidade dos Curso de Direito, até o ponto de permitir reflexões sobre alternativas para o tema, em especial, atento à aprendizagem que é assunto fundamental neste estudo.

Com efeito, o ponto principal do presente estudo envolve a interrelação entre a aprendizagem e as ações docentes com foco na postura ativa do discente, de maneira a não se colocar a prática do Estágio como a ferramenta exclusiva para se compreender a aplicação dos estudos jurídicos. O que se põe em questão, portanto, é o rompimento com uma tradição de se separar os momentos teórico e prático e a necessária reflexão sobre a postura do docente frente às ações dos discentes. Isso, de certo modo, atende ao alerta realizado por Bastos (2000, p. 204), ao afirmar:

A tradição do ensino jurídico brasileiro não é prática, ou seja, não se desenvolve estudos jurídicos à luz da legislação, da jurisprudência e da doutrina a partir de casos concretos, o que acaba por incentivar modelos dissertativos e discursivos de aulas-classe, privilegiando a memorização e 
não o raciocínio. De certa forma, o sistema de cátedras contribuiu para essas situações especiais, especialmente porque privilegiava o monopólio de áreas do saber, o que, necessariamente, rompe com o ensino prático, que não deve ser confundido com a prática forense, devido à descompartimentalização do conhecimento que essa didática provoca. Na verdade, evoluímos, no ensino jurídico brasileiro, desde sempre, para a prática forense, desprezando de qualquer forma o ensino prático, ou o praxismo didático, cujos efeitos são visíveis na formação de nossos bacharéis e com acentuados efeitos no processo de criação jurídica e jurisprudencial e, principalmente, no ensino do Direito Processual.

Desta maneira, partindo-se da contextualização histórica dos Cursos de Direito no Brasil, neste Capítulo será feita uma exposição sobre os pontos em que os discursos sobre a crise em que o ensino jurídico perpassa (com especial atenção ao envolvimento docente e discente), estabelecendo-se indicativos para o tratamento da tese proposta.

\subsection{Breve Histórico dos Cursos de Direito no Brasil}

A História do ensino do Direito é repleta de experiências que auxiliam a compreensão dos valores que permeiam o seu papel e os efeitos produzidos no processo de ensino-aprendizagem. É possível olhar-se para o presente e reconhecer experiências de séculos atrás com as mesmas circunstâncias que outrora já fortaleciam as discussões sobre a eficácia de seu papel na formação do corpo discente e, por via de conseqüência, os reflexos que isso provocava no contexto social.

Como o Direito, inevitavelmente, está atrelado à própria concepção do Estado, até pela ligação que possui com a regulamentação da sua existência e de seu funcionamento, é compreensível que exista uma grande convergência de interesses voltados à organização do ensino do Direito, o qual, de certo modo, capacita indivíduos que participarão desse processo de formação do próprio Estado.

De qualquer modo, a análise histórica do ensino do Direito perpassa por dois caminhos: é possível visualizar-se qual seria o objeto do estudo do Direito e para compreendê-lo, qual era a ideologia envolvida em suas ações e, de modo paralelo, as regulamentações que o Curso de Direito recebeu, estas, mais especificamente, perante o sistema brasileiro.

A análise do objeto de estudo do Direito afasta-se para um passado longínquo, desde que se necessitou estabelecer regras para a convivência humana. 
A História, neste ponto, tem registro de muitos séculos e a compreensão do Direito, como em muitas áreas, recebeu o tratamento segundo os interesses que predominaram a cada tempo, os quais não serão tratados especificamente pela pesquisa ora desenvolvida, mas merecerão resgate na medida de sua relevância para a compreensão do momento atual vivido pelo ensino do Direito.

Em relação à regulamentação dos Cursos de Direito, é interessante sua visão para o presente estudo, na medida em que se percebe a intervenção Estatal na sua formatação e isto, para a área, produz fortes vínculos aptos a impedirem muitas reflexões sobre sua eficácia.

Por certo, um dos grandes problemas envolvidos na formação jurídica, é a forte ideologia que estabelece a necessidade de se respeitar a lei acima de tudo. Num verdadeiro círculo vicioso, estabelece-se o argumento de que se a lei é produzida por manifestação do interesse social (daí decorre a expressão "representatividade popular" atribuída à pessoa eleita), ela deve ser respeitada e cumprida, até que outra lei a substitua, tudo em nome de um Estado democrático de Direito e da segurança jurídica que ele exigiria.

Entretanto, um estudo mais acurado dessa concepção permite observar que nem todas as manifestações legislativas são absolutas representações dos interesses sociais ou, mais profundamente, muitas vezes os próprios interesses sociais são objeto de manipulação. Logo, nem tudo que se pratica em nome do Direito, tem, necessariamente, uma justificativa que implique na melhoria do convívio social ou da atenção à dignidade humana ou, mais amplamente, aos valores necessários para uma evolução que proteja garantias mínimas a todos os sujeitos pertencentes a uma sociedade.

Nesse ponto, quando se analisa os sujeitos diretamente ligados ao ensino do Direito, é possível constatar que, tradicionalmente, impera uma formação legalista, seguindo-se o círculo vicioso já indicado: as leis são feitas supostamente por representantes do interesse da maioria, logo devem ser respeitadas. Os Cursos de Direito submetem-se às regulamentações que, por assim serem, devem ser respeitadas; professores e a alunos têm a tendência - por tal formação - de sustentar suas argumentações no legalismo (ou num dogmatismo que a ele se assemelha) o que, porém, não impede que esse círculo vicioso seja rompido quando não atenda mais as circunstâncias exigidas por conta de novas ideologias. 
Neste contexto, a tradição é algo que permeia a formação jurídica de tal maneira que podem ser verificados prejuízos à compreensão, até mesmo, das práticas pedagógicas. Por exemplo, na tradição da aula-conferência, no Brasil de inspiração portuguesa ao tempo da colonização, se vê a repetição da mesma postura por parte dos docentes, que seguem o modelo de um ex-professor, que por seu turno fez a mesma coisa. A tradição histórica da formação jurídica está ínsita neste contexto pedagógico, como não haveria de ser diferente por conta dos valores culturais incorporados.

Nesta esteira, já se pode perceber o ponto que toca o presente estudo: a própria tradição confirma uma postura passiva para o discente, atuando mais como ouvinte do que sujeito ativo para uma aprendizagem dinâmica e dominadora para o docente, que costumeiramente se vê como centro das atenções na sua prática no contexto educacional.

\subsubsection{Momentos iniciais da criação dos Cursos de Direito}

Analisando-se o início da História do ensino do Direito no Brasil, a sua regulamentação exigiu um longo passar de anos a partir do descobrimento do país, até porque a própria criação do ensino superior, no Brasil, dependeu de uma maturidade conquistada aos poucos. Assim, inexistindo cursos de Direito ao tempo da colonização, a formação jurídica exigia dos interessados que estudassem em Portugal ou em outro lugar do estrangeiro - o que já indicava o quão elitizada seria esta possibilidade.

De fato, no Período Colonial, não se falou de escolas de Direito (bem como não surgiu outra instituição de ensino superior), até porque a política adotada pela colonização portuguesa resistia à ideia de fortalecer uma cultura que pudesse criar uma insubordinação, divergindo da política seguida pela Espanha, que criou universidades em Lima, México e tantas outras. Aqui, exigia-se que os interessados pelo conhecimento superior se dirigissem aos cursos do reino e no estrangeiro. Logo, no Brasil, a política do colonizador foi impedir a educação de nível superior como forma de controle e subordinação (VENANCIO FILHO, 2004, p. 7-9).

Com o advento da Independência, o interesse na criação de Cursos de Direito envolvia a pretensão de se ter a formação de quadros "que pudessem participar, administrativamente, do governo e que estes quadros fossem formados por homens 
que coadunassem suas visões políticas, jurídicas e ideológicas com a expectativa do império". Ademais:

Moços nobres e ricos saiam do país em busca de formação profissionalizante e, ao retornarem, podia acontecer de terem sido condicionados por outros ideais que não aqueles que podiam interessar à nação. Por isso, os cursos que seriam criados deveriam abrigar especialmente esta mocidade, oriunda das elites que já ocupavam o poder, então, a fim de dar continuidade à condução política do Brasil. (HIRONAKA e MONACO, 2008, p. XVI).

Neste sentido, como salienta Bittar (2006, p. 105), além de ser um interesse do Império, a criação do Curso de Direito "tornava o Brasil capaz de produzir conhecimentos, de formar seu próprio povo dentro da cultura erudita de além-mar, a exemplo dos centros exportadores de saber, quais Coimbra, Paris, Montpellier e Bolonha".

Os primeiros cursos de Direito no Brasil foram criados em São Paulo e em Olinda, instituídos pela Lei de 11 de agosto de 1827 (BRASIL, 2009a):

Crêa dous Cursos de sciencias Juridicas e Sociaes, um na cidade de S. Paulo e outro na de Olinda.

Dom Pedro Primeiro, por Graça de Deus e unanime acclamação dos povos, Imperador Constitucional e Defensor Perpetuo do Brazil: Fazemos saber a todos os nossos subditos que a Assembléia Geral decretou, e nós queremos a Lei seguinte:

Art. $1 . \cong$ - Crear-se-ão dous Cursos de sciencias jurídicas e sociais, um na cidade de S. Paulo, e outro na de Olinda, e nelles no espaço de cinco annos, e em nove cadeiras, se ensinarão as matérias seguintes:

$[\ldots]$

Mandamos portanto a todas as autoridades, a quem o conhecimento e execução da referida Lei pertencer, que a cumpram e façam cumprir e guardar tão inteiramente, como nella se contém. O Secretario de Estado dos Negocios do Imperio a faça imprimir, publicar e correr. Dada no Palacio do Rio de Janeiro aos 11 dias do mez de agosto de $1827,6 .^{\circ}$ da Independencia e do Imperio.

Interessante observar que a criação do Curso de Direito em São Paulo foi precedida de destacável debate, tendo como argumentos contrários até mesmo a consideração de ser "cruel a criação de um curso jurídico em uma cidade que não teria infra-estrutura capaz de receber, hospedar e alimentar os jovens mais 
brilhantes da Corte, capazes de frequentar e acompanhar o curso em razão de sua formação de base", além da cidade ser uma "pequena e pobre vila, distante do porto, muito úmida, e na qual se falava um português com sotaque criticável, para padrões da época". Por outro lado, em favor da instalação em São Paulo, "registrava-se o fato de que a vila possuía clima ameno e baixo custo de vida", sendo que razão decisiva para a aceitação foi "o fato de que na vila de São Paulo não havia diversão que pudesse afastar o jovem de seus estudos" (HIRONAKA e MONACO, 2008, p. XVI).

Instalados os Cursos de Direito em 1828, sendo o de São Paulo no Convento de São Francisco (em março) e em Olinda no Mosteiro de São Bento (em maio), em 1854 passaram a se denominar Faculdades de Direito, sendo que o Curso de Olinda, neste ano, foi transferido para Recife (RODRIGUES, 1995, p. 09-10).

Com efeito, durante o Império, o ensino do Direito era totalmente controlado pelo governo central, que determinava "o currículo, a metodologia de ensino, a nomeação dos lentes e do diretor, definição dos programas de ensino e até dos compêndios adotados". As aulas eram realizadas em forma de aulas-conferência, seguindo o estilo de Coimbra e seus freqüentadores eram da elite econômica brasileira, que seriam indicados para ocupar "os primeiros escalões políticos e administrativos do país" (RODRIGUES, 1995, p. 10).

Por certo, como salienta Bittar (2006, p. 108), a academia representada um "laboratório para aprendizes do poder, local de reprodução das diferenças sociais e de fermentação das elites jurídicas e administrativas do Estado brasileiro". Logo, o perfil ativista da academia de Direito estava demonstrado pelo "engajamento estudantil nos atos políticos do país, a vocação acadêmica pelos atos do poder, a atenção dos holofotes estudantis para as políticas imperantes", de maneira a provar, historicamente, "que o ambiente acadêmico servia pouco para a exclusiva ilustração intelectual e formação profissional estrita, e servia muito para a construção e projeção de figuras do cenário político nacional”.

De qualquer maneira, no que respeita à regulamentação desses primeiros cursos de Direito, a eles foram aplicados os Estatutos do Visconde de Cachoeira, por força da própria Lei de 11 de agosto de 1827, que assim previa em seu art. 10ํ: 
Congregação dos Lentes formará quanto antes uns estatutos completos, que serão submettidos á deliberação da Assembléa Geral.

Com efeito, tais estatutos haviam sido destinados ao "curso criado provisoriamente pelo decreto de 9 de janeiro de 1825, que deveria funcionar no Rio de Janeiro", sendo que o Visconde de Cachoeira era José Luís de Carvalho e Melo, com formação em Direito na Universidade de Coimbra, deputado e depois senador pela Bahia, participante da elaboração da Constituição do Império e falecido em 1826 (VENANCIO FILHO, 2004, p. 31).

A instalação do curso no Rio de Janeiro não aconteceu, mas os estatutos criados sob a perspectiva de sua existência foram seguidos, inicialmente, como um dos pontos de independência de Portugal. Preocupado com a eficiência do ensino, Visconde de Cachoeira recomendava que não se adotassem os Estatutos da Universidade de Coimbra, reputando-os descompassados com a realidade brasileira, afirmando:

Deve-ser, portanto, sem perder de vista o que há de grande, e sábio em tão famigerados estatutos, cortar o que for desnecessário, instituir novas cadeiras para as matérias que neles não se faz menção, as quais são entrelaçadas pelos mais fortes vínculos com a jurisprudência em geral e de nímia utilidade para o perfeito conhecimento dela, e dirigirmo-nos ao fim de cirar jurisconsultos brasileiros, enriquecidos de luminosas doutrinas e ao mesmo tempo úteis, e, que pelo menos o obtenham nesse Curso bastantes e sólidos princípios, que lhes sirvam de guias nos estudos maiores e mais profundos que depois fizerem; o que é o mais que se pode esperar que obtenham estudantes de um curso acadêmico. (VENANCIO FILHO, 2004, p. 32).

Tais estatutos têm importância particular no presente estudo, na medida em já alertavam para um dos aspectos que se desenvolverá no decorrer dos trabalhos ora desenvolvidos: a necessidade de se conjugar o ensino teórico com o ensino prático. Seu detalhamento neste sentido é digno de destaque, a ponto de demonstrar a preocupação então existente para com a prática do conhecimento adquirido. Para isso, no terceiro e no quarto ano, em que seria estudado o Direito nacional, deviam os professores "mostrar aos seus discípulos o uso prático que tem no foro as doutrinas que ouviram e expender as diversas maneiras porque se emprega tanto no foro civil como no criminal", sendo que na prática do processo, havia previsão para que os alunos se envolvessem nas atividades, assumindo a posição de advogados, 
juízes, escrivão, produzindo seus arrazoados e documentos utilizados na prática (VENANCIO FILHO, 2004, p. 33-34).

Identicamente interessante, ainda orientava que o professor deveria ser

mui breve e claro nas suas exposições. Não ostentará erudição por vaidade; mas aproveitando o tempo com lições úteis, tirará só da doutrina o que for necessário para perfeita inteligência das matérias que ensinar, e trabalhará, quanto lhe for possível, por terminar o compêndio a tempo de poder os estudantes, ainda no mesmo ano, ouvir todas as lições de Direito Público. (idem, p. 35).

Posteriormente aos estatutos do Visconde de Cachoeira, foram editados os Estatutos dos cursos de Ciências Jurídicas e Sociais do Império, aprovados pelo Decreto de 7 de novembro de 1831 que, "ao contrário dos do Visconde de Cachoeira, dispensam qualquer fundamentação doutrinária, e se mantêm numa linha que, a partir daí, se repetir de um mero regulamento de disposições legais e administrativas regendo essas instituições de ensino", vigorando até 1854, quando da reforma Couto Ferrás (idem, p. 50).

Assim, ainda sob o regime do Império, foram editadas importantes normas regulamentando os cursos de Direito, como o foi o decreto 1386, de 28 de abril de 1854, assinado pelo Ministro do Império, Luís Pedreira de Couto Ferrás, novamente dispondo detalhadamente sobre as atribuições dos diretores, dos lentes, dos alunos, das aulas, que vigorou até a "modificação radical, empreendida pela reforma do ensino livre, do Conselheiro Carlos Leôncio de Carvalho, em 1879" (VENANCIO FILHO, 2004, p. 65-67).

Contudo, este período anterior à reforma do ensino livre indicava a "falta absoluta de propósitos educacionais do Império, principalmente para o ensino jurídico, mergulhado na profunda crise de sua natureza institucional: a desarticulação entre a infra-estrutura administrativa, apoiada na lgreja, e a orientação política imperial". O afastamento entre o Estado e a Igreja provocou, inclusive, as "tentativas de se viabilizar o ensino livre como alternativa para a Igreja, para a expansão e o atendimento das demandas educacionais e para se descentralizar o processo educativo sem que se descentralizasse o controle político e administrativo", instaurando-se, em 1865, uma questão educacional que abalaria o Império (BASTOS, 2000, p. 79). 
O movimento liberalista no Brasil incentiva a apresentação de projetos buscando a liberdade de ensino, o que foi empreendido por Carlos Leôncio de Carvalho com a pretensão de sanar os problemas enfrentados pelo sistema então em vigor. Na verdade, o movimento liberal era amplo na época mas, em atenção ao ensino, gerou grandes repercussões, até mesmo se apregoando a liberdade de presenças dos alunos e abertura não estatal para as escolas. Assim, Carlos Leôncio de Carvalho assume a função de Ministro do Império, tendo influência decisiva na edição do decreto n. 7247 de 19 de abril de 1879, estabelecendo a reforma do ensino primário e secundário no município da Corte e o superior em todo o Império (VENANCIO FILHO, 2004, p. 78-86).

Entretanto, como bem observa Bastos (2000, p. 151) "o ensino livre no Brasil não se consolidou propriamente como liberdade de ensino (de ensinar)", aplicandose mais para a liberdade de "organizar cursos alternativos aos cursos oficiais e não de ensinar idéias alternativas através de programas alternativos, como aconteceu na Europa", desenvolvendo um "embrião do sistema brasileiro de ensino particular, inclusive católico, que em muitas ocasiões se integrou às escolas oficiais para viabilizar a implantação da universidade e, em outras, se desenvolveu com eficiência e autonomia".

\subsubsection{Os Cursos de Direito a partir do período Republicano}

A proclamação da República em 15 de novembro de 1889 não veio acompanhada por um programa educacional definido, mas recebeu uma importante contribuição realizada por Benjamim Constant com a aprovação do Decreto n. 1232h, de 2 de janeiro de 1891, novamente dispondo sobre a escolha e a atuação dos professores, procedimentos administrativos, sendo de destaque a separação do Curso de Direito em três: de ciências jurídicas, de ciências sociais e de notariado, bem como permitindo aos poderes dos Estados Federados fundar faculdades superiores desde que seguissem os mesmos procedimentos das faculdades federais e se sujeitasse à fiscalização do Conselho de Instrução Superior, provocando um espírito de descentralização educacional (VENANCIO FILHO, 2004, p. 179-185).

Com o advento da Lei 314 , de 30 de outubro de 1895, houve uma nova reorganização das Faculdades de Direito, passando o curso a ser novamente de cinco anos, exigindo maior rigor "em comparação às disposições liberais da Reforma 
Benjamim Constant", reestabelecendo a freqüência, suprimindo-se o curso de Notariado, com a união do Curso de Ciências Jurídicas e o de Ciências Sociais (idem, p. 190-192).

Em 1901, com o Decreto n. 3.903, de 12 de janeiro, o Curso de Direito sofreu nova alteração em sua estrutura curricular, com determinação de deslocamento de disciplinas (BASTOS, 2000, p. 166), demonstrando-se, mais uma vez, o intervencionismo estatal na organização das disciplinas. Além disso, tratou amplamente de "toda a organização das instituições federais de ensino superior e secundário, cuidando da diretoria, congregações, membros do magistério, provimento dos cargos docentes, regime escolar, matrícula, exercícios escolares, exames, colação de grau e outros problemas de caráter administrativo" (VENANCIO FILHO, 2004, p. 201-202),

Seguindo a preocupação com a melhoria do próprio ensino, em 5 de abril de 1911 foi editado o Decreto n. 8.662, baseado no Decreto n. 8.659, este por sua vez produzido sob a égide da Lei n. 2.356 de 31 de dezembro de 1910, no período conhecido como Reforma Rivadávia Corrêa, alterando-se novamente a estrutura curricular, ampliando-se o curso para 6 anos, modernizando-se a abordagem de temas como o Direito Civil, apesar de se manter sem exigir o Direito Processual Civil (como disciplina teórica), já que até então não havia sido submetido à codificação nacional, caracterizando um ensino ou excessivamente teórico ou excessivamente prático (BASTOS, 2000, p. 170).

Nova reforma acontece em 1915, com a promulgação do Decreto n. 11.530, de 18 de março, que levou o nome do Ministro da Justiça e Negócios Interiores Carlos Maximiliano, estabelecendo-se uma reorganização do ensino superior na República, com novas mudanças na estrutura curricular, com a criação de um instituto de ensino jurídico na cidade do Rio de Janeiro, tratando da frequência escolar, evidenciando inexistir alunos gratuitos, mesmo em se tratando de ensino oficial, sendo a primeira proposta para o pagamento de taxas, não produzindo uma inovação como a que ocorreu em 1931 (BASTOS, 2000, p. 172).

A reforma Francisco Campos (então Ministro da Educação) na época da Revolução de 1930, trouxe importantes mudanças, em especial por força do Decreto n. 19.851 de 11 de abril de 1931, que estabeleceu o Estatuto das Universidades Brasileiras, bem como o Decreto n. 19.852, de mesma data, dispondo sobre a organização da Universidade do Rio de Janeiro. A perspectiva da reforma e 
especial para o curso de Direito fica bem clara nas palavras do referido Ministro (VENANCIO FILHO, 2004, p. 305):

[...] o curso de bacharelado foi organizado atendendo-se a que ele se destina a finalidade de ordem puramente profissional, isto é, o seu objetivo é a formação de práticos do Direito. Da sua seriação foram, portanto, excluídas todas as cadeiras que, por sua feição puramente doutrinária ou cultural, constituem antes disciplinas de aperfeiçoamento ou de alta cultura do que matérias básicas ou fundamentais a uma boa e sólida formação profissional.

Mesmo com a turbulência política vivida na década de 30, duas Leis (114, de 11 de novembro de 1935 e 176, de 8 de janeiro de 1936) foram editadas tratando do Doutorado e do bacharelado de Direito, as quais, somadas à Reforma Francisco Campos, foram as que se prolongaram, mesmo com algumas outras modificações menos substanciais, até a reforma decorrente da Lei de Diretrizes e Base da Educação, pela Lei 4.024 de 20 de dezembro de 1961 (BASTOS, 2000, p. 219).

Em ato seguido à promulgação da Lei 4.024/61, o Conselho Federal de Educação fixou o currículo mínimo para o curso de bacharelado das faculdades de Direito através do "Parecer CFE n. 215 de 15.9.1962, que não fugiu dos parâmetros tradicionais da sua evolução e tornou-se obrigatório ao partir de 1963", não trazendo mudanças substanciais ao modelo Francisco Campos de 1931 (BASTOS, 2000, p. 283).

Posteriormente, para tratar especificamente do bacharelado em Direito, procedeu-se a edição do Parecer CEF n. 162, de 27 de janeiro de 1972, que resultou na edição da Resolução n. 3, de 1972, reduzindo-se a carga horária de 3.300 horas (fixada pela Portaria MEC n. 159, de 14 de junho de 1965) para 2.700 horas para o currículo mínimo, admitindo-se projetos específicos de acordo com as exigências regionais, sendo que a integralização do currículo deveria ser feita entre no mínimo em quatro e no máximo em sete anos letivos (BASTOS, 2000, p. 302303).

Além disso, a Resolução n. 3 do Ministério da Educação e Cultura (MEC) estabeleceu expressamente um currículo para o curso de Direito uma estrutura baseada em disciplinas formativas (Economia, Sociologia, Introdução ao Estudo do Direito), disciplinas profissionalizantes (mencionando a possibilidade de disciplinas optativas), afirmando a Prática Forense como obrigatória, conforme estabeleceu seu artigo 1ำ (BASTOS, 2000, p. 303). 
Como aponta Cury, tal Resolução "trouxe a flexibilidade curricular necessária para uma maior elasticidade no ensino jurídico, permitindo que as Faculdades de Direito inserissem disciplinas e/ou criassem habilitações que considerassem as diferenças regionais e as necessidades advindas de cada região". Assim, mesmo sob a égide de um Estado autoritário, a Resolução "não impôs um modelo ou proposta autoritária ou conservador para o ensino jurídico", apesar de tal liberdade não ter sido assimilada pelas Faculdades de Direito, que não Ihe deram a eficácia esperada, muito provavelmente pelo quadro político autoritário predominante e a "ausência de mecanismos abertos e transparentes de decisão" (2002, p. 177-178).

Voltando-se para a reestruturação dos Cursos de Direito, o Ministério da Educação nomeou, em 1980, uma Comissão de Especialistas em Ensino Jurídico de composição plurirregional que, reformulada em 1981, apresentou diversas propostas sobre as quais o Conselho Federal de Educação não tomou qualquer medida (RODRIGUES, 1993, p. 43-54).

Diante dos inúmeros debates envolvendo a crise no ensino do Direito, o MEC resolveu instituir uma nova Comissão de Especialistas em Ensino Jurídico em 1993, que, adotando a estratégia de organizar seminários regionais, culminou na realização de um evento nacional, onde, por meio da representação de escolas de Direito brasileiras, de docentes e discentes, produziu-se documento que fundamentou a proposta de anteprojeto para a Portaria 1886 de 30 de dezembro de 1994 (RODRIGUES, 1995, p. 57-60).

A Portaria 1886/94 é, sem dúvidas, um instrumento que causou grande impacto no ensino do Direito no Brasil, dadas as diversas regulamentações que promoveu: fixação de 3300 horas como tempo mínimo para o curso (no mínimo em cinco e no máximo de oito anos); desenvolvimento do curso com a integração de atividades de ensino, pesquisa e extensão; inserção de atividades complementares em $10 \%$ de carga horária do curso, diversas das disciplinas previstas no currículo pleno; acervo bibliográfico com o mínimo de dez mil volumes de obras jurídicas e de referência às matérias do curso, além de períodos de jurisprudência, doutrina e legislação; conteúdo mínimo com disciplinas categorizadas em fundamentais e profissionalizantes; monografia final para a conclusão do curso a ser defendida perante banca examinadora com tema e orientador escolhidos pelo ano e estágio de prática jurídica num total mínimo de 300 horas de atividades práticas simuladas e reais. 
O advento da Lei de Diretrizes e Bases (Lei n. 9394 de 20 de dezembro de 1996), não alterou as orientações estabelecidas pela Portaria 1886/94. De fato, é possível afirmar que a Portaria antecedeu "alguns significativos propósitos da (futura) LDB de 1996", conseguindo "traduzir com pertinência e eficácia as principais expectativas dos movimentos críticos do ensino jurídico consolidado nos anos 80 " (BASTOS, 2000, p. 386).

De qualquer modo, como salienta Bastos (2000, p. 386-387), a referida Portaria procurou "superar o tecnicismo atribuído à Resolução CFE n. 3 de 1972, que esvaziou o humanismo da formação jurídica, e absorver novos parâmetros capacitativos do aluno de Direito, voltados principalmente para as novas exigências sociais e tecnológicas e para o imprescindível aprendizado interdisciplinar e prático", tudo apoiado "em novos propósitos e modelos metodológicos de ensino e aprendizagem que refletissem as novas exigências sociais e as esperanças acumuladas nos debates acadêmicos e encontros da OAB".

De fato, some-se à Portaria, a atribuição à Ordem dos Advogados do Brasil (em especial ao Conselho Federal) a função de "colaborar com o aperfeiçoamento dos cursos jurídicos, e opinar, previamente, nos pedidos apresentados aos órgãos competentes para criação, reconhecimento ou credenciamento desses cursos", conforme dispõe o inciso XV do art. 54 da Lei 8.906/94 (Estatuto da Advocacia e da Ordem dos Advogados do Brasil).

Assim, num contexto histórico, percebe-se o forte entrelaçamento entre a Ordem dos Advogados do Brasil e os órgãos governamentais para o ensino jurídico, sendo o início mais fortalecido de uma participação que seria ainda mais crescente.

Isso ficou claramente demonstrado com a intervenção que a Ordem dos Advogados do Brasil fez diante do Parecer CNE 146/2002, cujo teor provocou reação da referida entidade de classe a ponto de levar a discussão ao Poder Judiciário, por apresentar diversos pontos polêmicos para o ensino jurídico. Para começar, tratou das diretrizes curriculares de diversos cursos através de um único parecer, quais sejam: Direito, Ciências Econômicas, Administração, Ciências Contábeis, Turismo, Hotelaria, Secretariado Executivo, Música, Dança, Teatro e Design (BRASIL, 2009b).

Entendendo que a referida Resolução procurava revogar indevidamente o currículo mínimo do Curso de Direito e prejudicar a sua qualidade ao reduzir a sua duração para três anos, além de outros aspectos, a OAB propôs um mandado de 
segurança perante o Superior Tribunal de Justiça (autos n. 8592/2002), que, através de decisão liminar (BRASIL, 2009c) e com o julgamento final (BRASIL, 2009d) pelo Superior Tribunal de Justiça, impediu-se o seu vigor, mantendo a aplicação da Portaria 1886/94.

Com efeito, o Parecer CNE 146/2002 apresentava interpretação afirmando estar revogada a Portaria 1886/94, de maneira que, a partir de seu novo conteúdo, provocar-se-ia uma grande confusão nos Cursos de Direito que já estavam procurando seguir os critérios da Portaria 1886 desde o seu vigor (em 1997).

Com o advento da Resolução CNE/CES n. 9, de 29 de dezembro de 2004, de certa forma, a regulamentação dos Cursos de Direito se estabilizou, revogando-se finalmente a Portaria 1886/94 e estabelecendo expressamente as Diretrizes Curriculares para o Curso de Direito, indicando elementos estruturais para o projeto pedagógico, mantendo o trabalho de conclusão de curso como obrigatório relacionando as habilidades e competências esperadas, um perfil humanista declarado, eixos de formação interligados (fundamental, profissional e prática) e mantendo as atividades complementares (BRASIL, 2009e).

\subsubsection{A estruturação histórica das disciplinas}

Ponto de destaque na História e que serve de importante indicador para o presente estudo é notar-se que sempre houve a separação do eixo teórico do eixo prático enquanto estruturação do Curso.

Para a organização dos primeiros cursos de Direito no Brasil (com sede em São Paulo e Olinda), seguindo a orientação da Universidade de Coimbra, estabeleceu-se (BRASIL, 2009a):

Art. 1. - Crear-se-ão dous Cursos de sciencias jurídicas e sociais, um na cidade de S. Paulo, e outro na de Olinda, e nelles no espaço de cinco annos, e em nove cadeiras, se ensinarão as matérias seguintes:

1.․ ANNO

$1^{\text {a }}$ Cadeira. Direito natural, publico, Analyse de Constituição do Império, Direito das gentes, e diplomacia.

2.․․ ANNO

1a Cadeira. Continuação das materias do anno antecedente.

2a Cadeira. Direito publico ecclesiastico. 
3.․ ANNO

$1^{\text {a }}$ Cadeira. Direito patrio civil.

$2^{\mathrm{a}}$ Cadeira. Direito patrio criminal com a theoria do processo criminal.

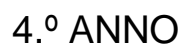

1․ Cadeira. Continuação do direito patrio civil.

$2^{\text {a }}$ Cadeira. Direito mercantil e marítimo.

5. ANNO

$1^{\text {a }}$ Cadeira. Economia politica.

$2^{2}$ Cadeira. Theoria e pratica do processo adoptado pelas leis do Imperio.

Percebe-se, para efeitos do presente estudo, que a atenção à prática do conhecimento estava relegada ao momento do $5^{\circ}$ ano e estruturada como disciplina (cadeira) própria.

Pela reforma de Benjamim Constant (Decreto republicano n. 1.232-H, de 2 de janeiro de 1891), ao dividir o curso de Direito em três cursos, estabeleceu a seguinte estrutura curricular (BASTOS, 2000, p. 148):

\begin{tabular}{|c|c|c|c|}
\hline Séries & Ciências Jurídicas & Ciências Sociais & Notariado \\
\hline $\begin{array}{l}\underline{\underline{a}} \\
\text { Série }\end{array}$ & $\begin{array}{l}\text { Filosofia e História } \\
\text { do Direito } \\
\text { Direito Público e } \\
\text { Constitucional }\end{array}$ & $\begin{array}{l}\text { Filosofia e História } \\
\text { do Direito } \\
\text { Direito Público e } \\
\text { Constitucional }\end{array}$ & $\begin{array}{l}\text { Noções de Direito } \\
\text { Pátrio, Constitucional } \\
\text { Noções de Direito } \\
\text { Pátrio e } \\
\text { Administrativo, } \\
\text { Criminal, Civil e } \\
\text { Comercial }\end{array}$ \\
\hline $\begin{array}{l}2^{\mathrm{a}} \\
\text { Série }\end{array}$ & $\begin{array}{l}\text { Direito Romano } \\
\text { Direito Civil } \\
\text { Direito Comercial } \\
\text { Direito Criminal }\end{array}$ & $\begin{array}{l}\text { Direito das Gentes } \\
\text { Diplomacia e História } \\
\text { dos Tratados } \\
\text { Economia Política } \\
\text { Higiene Pública }\end{array}$ & $\begin{array}{l}\text { Noções de Direito } \\
\text { Pátrio } \\
\text { Processual } \\
\text { Prática Forense }\end{array}$ \\
\hline $\begin{array}{l}3^{\underline{a}} \\
\text { Série }\end{array}$ & $\begin{array}{l}\text { Medicina Legal } \\
\text { Direito Civil } \\
\text { Direito Comercial }\end{array}$ & $\begin{array}{l}\text { Ciência da } \\
\text { Administração e } \\
\text { Direito Administrativo } \\
\text { Ciência das } \\
\text { Finanças e } \\
\text { Contabilidade do } \\
\text { Estado } \\
\text { Legislação } \\
\text { Comparada de } \\
\text { Direito Privado }\end{array}$ & \\
\hline $\begin{array}{l}4^{\underline{a}} \\
\text { Série }\end{array}$ & $\begin{array}{l}\text { História do Direito } \\
\text { Nacional } \\
\text { Processo Criminal, } \\
\text { Civil e Comercial }\end{array}$ & & \\
\hline
\end{tabular}


Nesta estrutura, percebe-se a redução do curso de Direito para quatro anos, atrelando-se o estudo do processo para a última série, não existindo disciplina própria para a prática, que recebeu inclusão na formação do Notariado.

Pela Lei n. 314 de 30 de outubro de 1895, determinou-se o retorno do Curso de Direito para cinco anos, com a seguinte distribuição (VENANCIO FILHO, 2004, p. 190-191):

1ํaㅇ ${ }^{\text {a }}$ Cadeira - Filosofia do Direito; $2^{\underline{a}}$ Cadeira - Direito Romano; $3^{\underline{a}}$ Cadeira - Direito Público Constitucional.

$2^{\circ}$ ano: $1^{\text {a }}$ Cadeira - Direito Civil; (1 ${ }^{\underline{a}}$ Cadeira); $2^{\underline{a}}$ Cadeira - Direito Criminal. (1 ${ }^{\text {a }}$ Cadeira); $3^{\text {a }}$ Cadeira - Direito Internacional Público e Diplomacia; 4 Cadeira - Economia Política.

3ำ ano: $1^{\text {a }}$ Cadeira - Direito Civil (2 ${ }^{\text {a }}$ Cadeira); $2^{\text {a }}$ Cadeira - Direito Criminal, especialmente Direito Militar e Regime Penitenciário (2ª Cadeira); 3a Cadeira - Ciências das Finanças e Contabilidade do Estado (continuação da $4^{\underline{a}}$ Cadeira do $2^{\circ}$ ano); $4^{\text {a }}$ Cadeira - Direito Comercial; ( $1^{\text {a }}$ Cadeira).

$4^{\circ}$ ano: $1^{\text {a }}$ Cadeira - Direito Civil (3 $3^{\underline{a}}$ Cadeira); $2^{\text {a }}$ Cadeira - Direito Comercial (especialmente Direito Marítimo, Falência e Liquidação Judiciária); 3ª Cadeira - Teoria de Processo Civil, Comercial e Criminal; 4a Cadeira - Medicina Pública.

$5^{\circ}$ ano: $1^{\underline{a}}$ Cadeira - Prática Forense (continuação da $3^{\text {a }}$ Cadeira do $4^{\circ}$ ano); $2^{\underline{a}}$ Cadeira - Ciência da Administração e Direito Administrativo; 3a Cadeira História do Direito e especial doe Direito Nacional; 4ª Cadeira - Legislação Comparada sobre Direito Privado.

De tal reforma, percebe-se a imposição da prática forense ( $5^{\circ}$ ano) como uma continuação da disciplina de processo (lecionada no $4^{\circ}$ ano). Assim, resgata-se a visão inicial da presença da prática como disciplina específica. Isso se seguiu nas modificações posteriores, como se pode notar pelo conteúdo das alterações legislativas seguintes.

Neste sentido, pelo Decreto n. 8.662, de 5 de abril de 1911, baseado no Decreto n. 8.659, de 5 de abril de 1991 (durante a reforma chamada Rivadávia Corrêa) regulamentou-se o currículo das faculdades de Direito e com a indicação de que elas seriam designadas pelo nome da cidade em que tivesse sede, seguindo, ainda, a seguinte estrutura (BASTOS, 2000, p. 169): 
1a série: Introdução Geral ao Estudo do Direito ou Enciclopédia Jurídica, Direito Público e Constitucional.

$2^{\text {a }}$ série: Direito Internacional Público e Privado e Diplomacia, Direito Administrativo, Economia Política e Ciência das Finanças.

$3^{\underline{a}}$ série: Direito Romano, Direito Criminal (1 ${ }^{\underline{a}}$ parte), Direito Civil (Direito de Família).

4 ${ }^{\underline{a}}$ série: Direito Criminal (especialmente Direito Militar e Regime Penitenciário), Direito Civil (Direito Patrimonial e Direitos Reais) e Direito Comercial ( $1^{\text {a }}$ parte).

5 ${ }^{\underline{a}}$ série: Direito Civil (Direito das Sucessões), Direito Comercial (especialmente Direito Marítimo, falência e liquidação judicial), Medicina Pública.

6 ${ }^{\underline{a}}$ série: Teoria do Processo Civil e Comercial, Prática do Processo Civil e Comercial, Teoria e Prática do Processo Criminal.

Com o Decreto n. 11.530, de 18 de março de 1915, o Curso de Direito sofreu nova reforma curricular, passando a ter a seguinte organização (BASTOS, 2000, p. 172-173):

1ํano: Filosofia do Direito, Direito Público e Constitucional, Direito Romano;

2ำ ano: Direito Internacional Público, Economia Política e Ciências das Finanças, Direito Civil ( $1^{a}$ parte);

$3^{\circ}$ ano: Direito Comercial ( $1^{\underline{a}}$ parte), Direito penal (1 $1^{a}$ parte), Direito Civil $\left(2^{a}\right.$ parte);

4ำ ano: Direito Comercial ( $2^{\underline{a}}$ parte), Direito penal ( $2^{\underline{a}}$ parte), Direito Civil (3 $3^{\underline{a}}$ parte), Teoria do Processo Civil e Comercial ;

5o ano: Prática do Processo Civil e Comercial, Teoria e Prática do Processo Criminal, Medicina Pública, Direito Administrativo, Direito Internacional Privado.

Pela reforma Francisco Campos (decorrente dos Decretos n. 19.851 e 19.852, ambos de 11 de abril de 1931), houve uma mudança no ano para tratar da prática. Não se restringindo mais ao $5^{\circ}$ ano, a prática começou a ser vista também no $4^{\circ}$ ano, conforme se depreende da seguinte estrutura curricular (BASTOS, 2000, p. 204): 
1ํ ano: Introdução à Ciência do Direito (aulas diárias), Economia Política e Ciência das Finanças (aulas diárias);

$2^{\circ}$ ano: Direito Civil (parte geral e obrigações), Direito Penal (parte geral) e Direito Público e Constitucional;

3ำ ano: Direito Civil, Direito Penal (Teoria dos crimes em espécies), Direito Comercial (parte geral e teoria dos contratos e obrigações comerciais), Direito Público Internacional;

4ำ ano: Direito Civil, Direito Comercial (Direito Comercial Marítimo e falências), Direito Judiciário Civil, (Teoria e Prática do Processo Civil), Medicina Legal;

5o ano: Direito Civil, Direito Judiciário Civil (Teoria e Prática do Processo Civil), Direito Judiciário Penal, Direito Administrativo.

Pelas Leis 114, de 11 de novembro de 1935 e 176, de 8 de janeiro de 1936, o curso de bacharelado passou a ter a seguinte ordenação curricular (BASTOS, 2000, p. 216). Observe-se que a prática, como Direito Judiciário, aparece nos $4^{\circ}$ e $5^{\circ}$ anos:

1ำ ano: Introdução à Ciência do Direito (que manteve a carga horária diária semanal); Direito Romano (acrescido); Economia Política.

$2^{\circ}$ ano: Direito Civil; Direito Penal; Direito Público e Constitucional; Ciência das Finanças (acrescida).

3o ano: Direito Civil; Direito Penal; Direito Comercial; Direito Público Internacional.

4º ano: Direito Civil; Direito Comercial; Direito Judiciário Civil; Medicina Legal.

5o ano: Direito Civil; Direito Judiciário Civil; Direito Judiciário Penal; Direito Administrativo; Direito Internacional Privado e Direito Industrial e Legislação do Trabalho.

Após a promulgação da Lei de Diretrizes e Bases de 1961 (Lei 4.024), pelo Parecer CFE n. 215 de 15.9.1962 foi fixado um currículo mínimo para os Cursos de Direito, mas já não se estabelece o ano da respectiva disciplina:

Introdução à Ciência do Direito

Economia Política

Direito Romano

Direito Penal

Direito Civil

Direito Constitucional (incluindo Teoria do Estado)

Direito Internacional Público

Direito Internacional Privado 
Direito Comercial

Direito Judiciário Penal (incluindo prática)

Direito Judiciário Civil (incluindo prática)

Direito Administrativo

Medicina Legal

Direito do Trabalho

Direito Financeiro e Finanças

Pela Resolução n. 3, de 1972, fixou-se o currículo mínimo do Curso de Direito com as seguintes matérias:

Art. 1․ O currículo mínino do curso de graduação em Direito compreenderá as seguintes matérias:

A - Básicas

1. Introdução ao Estudo do Direito.

2. Economia.

3. Sociologia.

$\mathrm{B}$ - Profissionais

4. Direito Constitucional (Teoria do Estado - Sistema Constitucional Brasileiro).

5. Direito Civil (Parte Geral - Obrigações. Parte Geral e Parte Especial Coisas - Família - Sucessão).

6. Direito Penal (Parte Geral e Parte Especial).

7. Direito Comercial (Comerciantes - Sociedades - Títulos de Crédito Contratos Mercantis e Falências).

8. Direito do Trabalho (Relação de Trabalho - Contrato de Trabalho Processo Trabalhista).

9. Direito Administrativo (Poderes Administrativos - Atos e Contratos Administrativos - Controle de Administração Pública - Função Pública).

10. Direito Processual Civil (Teoria Geral - Organização Judiciária - Ações Recursos - Execução).

11. Direito Processual Penal (Tipo de Procedimento - Recursos - Execução). 12/13. Duas dentre as seguintes:

a) Direito Internacional Público.

b) Direito Internacional Privado.

c) Ciências das Finanças e Direito Financeiro (Tributário e Fiscal);

d) Direito da Navegação (Marítima).

e) Direito Romano.

f) Direito Agrário

g) Direito Previdenciário.

h) Medicina Legal.

Parágrafo único. Exigem-se também:

a) A Prática Forense, sob a forma de estágio supervisionado;

b) O Estudo de Problemas Brasileiros e a prática da Educação Física, com predominância desportiva de acordo com a legislação específica.

Com o advento da Portaria 1886/94, a mesma manteve idêntica política da Resolução n. 3/72 no sentido de não indicar mais para qual ano são destinadas as 
disciplinas, limitando-se a elencar o rol daquelas que devam integrar um currículo mínimo:

Art. 6ํ․ O conteúdo mínimo do curso jurídico, além do estágio, compreenderá as seguintes matérias, que podem estar contidas em uma ou mais disciplinas do currículo pleno década curso:

I - Fundamentais: Introdução ao Direito, Filosofia (geral e jurídica; ética geral e profissional); Sociologia (geral e jurídica), Economia e Ciência Política (com Teoria do Estado).

II - Profissionalizantes: Direito Constitucional, Direito Civil, Direito Administrativo, Direito Tributário, Direito Penal, Direito Processual Civil, Direito Processual Penal, Direito do Trabalho, Direito Comercial e Direito Internacional.

Parágrafo único. As demais matérias e novos direitos serão incluídos nas disciplinas em que se desdobrar o currículo pleno de cada curso, de acordo com suas peculiaridades e com observância da interdisciplinaridade.

Com o advento da Resolução n. 9/2004, fixou-se a distribuição de disciplinas em três eixos (conforme artigo seu $5^{\circ}$ ):

I - Eixo de Formação Fundamental, tem por objetivo integrar o estudante no campo, estabelecendo as relações do Direito com outras áreas do saber, abrangendo dentre outros, estudos que envolvam conteúdos essenciais sobre Antropologia, Ciência Política, Economia, Ética, Filosofia, História, Psicologia e Sociologia.

II - Eixo de Formação Profissional, abrangendo, além do enfoque dogmático, o conhecimento e a aplicação, observadas as peculiaridades dos diversos ramos do Direito, de qualquer natureza, estudados sistematicamente e contextualizados segundo a evolução da Ciência do Direito e sua aplicação às mudanças sociais, econômicas, políticas e culturais do Brasil e suas relações internacionais, incluindo-se necessariamente, dentre outros condizentes com o projeto pedagógico, conteúdos essenciais sobre Direito Constitucional, Direito Administrativo, Direito Tributário, Direito Penal, Direito Civil, Direito Empresarial, Direito do Trabalho, Direito Internacional e Direito Processual; e

III - Eixo de Formação Prática, objetiva a integração entre a prática e os conteúdos teóricos desenvolvidos nos demais Eixos, especialmente nas atividades relacionadas com o Estágio Curricular Supervisionado, Trabalho de Curso e Atividades Complementares.

Esta caracterização histórica do currículo mínimo é importante para demonstrar a intervenção governamental nos Cursos de Direito, verificando-se a determinação política voltada à existência de momento prático, o qual, contudo, constrói-se cindido estruturalmente da abordagem teórico-profissionalizante. 


\subsection{0 ensino do Direito e a crise ontológica do próprio Direito}

Amplamente analisada, a educação tem sido alvo de preocupações voltadas à sua qualidade, sendo que o ensino superior - em especial o ensino jurídico -, não escapa do mesmo contexto, até porque a contínua eficácia de qualquer área depende da constante revisão de seus pressupostos e seus efeitos.

Por certo, o ensino jurídico tem sido objeto de discussões incessantes no Brasil, com momentos históricos visíveis desde a sua criação. Alguns pontos pedagógicos, como o aspecto didático, sempre foram alvo de críticas, com reclamações sobre condutas de professores e de alunos desde os primeiros cursos.

Antes da análise do próprio Direito, é importante registrar que a crise na Educação também tem sido apontada. Os dilemas que envolvem a Educação são amplos porque sofrem inúmeras variáveis que afetam sua existência e sua eficácia. São pontos que vão desde a cultura de um povo, as políticas públicas, o momento histórico, os sujeitos envolvidos, as ideologias, os dogmas, seus fundamentos, sua dialeticidade, entre outros.

Cortella (2001, p. 9), partindo da frase "a educação está em crise!", indaga se "em algum momento de nossa história republicana (nascedouro, ainda que pífio, do tema da escola pública), essa frase terá deixado de ser dita". Nota, ainda, que esta crise "tem sido inerente à vida nacional porque não atingimos ainda patamares mínimos de uma justiça social compatível com a riqueza produzida pelo país e usufruída por uma minoria", não se tratando a crise de um "privilégio" da Educação, já que "todos os setores sociais vivem sucessivas e contínuas crises".

Ao lado da crise que aponta o referido autor, inspirado pelo movimento de dominação/exclusão, é possível arriscar afirmar que, dificilmente, em algum momento de nossa história moderna e de um futuro de médio prazo, será possível concluir pela inexistência de uma crise, não no estágio de evolução dos seres humanos. Ainda que se possa afirmar, em algum momento, pela estabilidade das relações sociais, a crise na educação poderá surgir a qualquer momento, seja decorrente da dialeticidade existente entre cada nova geração, ou em razão de cada nova perspectiva possível de existir (variações ideológicas, tecnológicas, culturais etc).

Essa visão, aparentemente pessimista, deve ser ressalvada sob o ponto de vista que a crise sempre é importante, na medida em que provoca uma reflexão 
sobre o status quo. Vivenciar a crise pode ser um elemento motivador para que se possa repensar o que se está vivendo e optar por escolhas como ficar se lastimando ou buscar soluções. Isso confirma e multiplica a incidência da curva de Gauss, na medida em que os movimentos tendem a um padrão, mas que se modificam quando encontram situações que precisam ser superadas, levando a possibilidades infinitas, que podem inclusive a repetir ações e conclusões já vividas. Hoje apontamos crises, algumas que se mantêm há tempos e outras que já foram superadas e acabaram retornando. Já vimos ditaduras serem construídas e serem dissipadas e aparecem em um ou outro lugar. Isso não é uma regra absoluta, mas não pode ser descartada. O que se pode concluir é que toda crise tem suas razões e, ao final, não são problemas sempre finais, mas sim iniciais para novos processos de superação.

De fato, Marpeau (2002, p. 52), afirma que a crise "é um momento crucial, uma encruzilhada; designa um ponto crítico, no qual o futuro enfrenta 0 desconhecido", tratando-se de um "momento de indecidível quando é urgente tomar uma decisão", ligando-se à ideia "de uma mudança brutal, que vai modificar um conjunto e o lugar ocupado nesse conjunto", devendo ser pensada com "um momento entre dois, apelando à noção de passagem de um estado estável a outro estado que tenha novamente um caráter de estabilidade".

Entretanto, a noção de estado de crise conduz à ideia "de sistema complexo, no qual a perturbação de certos elementos de um conjunto provoca perturbações e reorganizações em cadeia entre os outros elementos desse conjunto". Por se tratar de um estado, "pressupõe uma instabilidade duradoura, para qual ninguém possui mais modelos de organização de seus atos diante da aparição constante de novos elementos" (MARPEAU, 2002, p. 52-53).

Esse ambiente reflete no ser humano, em razão da importância da abertura "ao múltiplo e à diversidade, ainda que toda mudança provoque uma modificação não só nos referenciais anteriores, mas também nos modos de organização dos componentes da vida". Variações mínimas no sistema humano complexo podem provocar modificações imprevisíveis, tanto decorrentes de componentes externos ou internos e, paradoxalmente, a crise "parece permitir a elaboração das capacidades necessárias à decisão". Logo, a crise é um processo próprio do desenvolvimento humano e é constituída de "um conjunto de contradições ligadas ao processo de humanização" (idem, p. 53-54). 
Assim, a crise pode ser pensada como espaço educativo e considerada como uma necessidade em razão de diversos aspectos: é diante da crise que há momento de "ruptura das modalidades de ser, um momento de incerteza, de dúvida e de risco, que confronta o sujeito com a capacidade de dar continuidade ao seu próprio ser". Ela exige confiança em si mesmo, tornando possível "a projeção no desconhecido do futuro, mas também a auto-estima, que permite assumir a perda parcial do que era, isto é, a alteração", possibilitando reconhecer a capacidade de enfrentar desafios desconhecidos. Ela provoca mal-estar, que pode fazer o indivíduo se projetar na "busca desesperada da restauração de um lugar perdido, o qual não pode mais ser", mas assim constrói "uma dinâmica que obriga a sair da repetição e da reprodução por meio da instauração da função crítica". Desta maneira, por "meio de sucessivas experiências de perdas e de reorganizações criativas é que o sujeito pode se perceber como um ser em mutação" (MARPEAU, 2002, p. 54). Daí reconhecer que mais do que reconhecer um problema, reconhecer uma crise é ter a possibilidade de buscar soluções.

Para o presente estudo e por ordem de abordagem, propõe-se analisar, primeiramente, ainda que de forma sucinta, uma crise que antecede o aspecto didático, que é justamente a crise do que é efetivamente o próprio Direito, constituindo a base de conteúdo do processo ensino-aprendizagem.

De fato, antes que se passe a discutir as dificuldades enfrentadas pelo processo ensino-aprendizagem na área do Direito, é importante destacar que até mesmo o seu conteúdo-objeto do processo de ensino-aprendizagem é sujeito de um amplo debate. A questão é, afinal, saber qual Direito deve ser ensinado.

O destaque para este problema se justifica porque a raiz do que é o Direito, inevitavelmente, se projeta na qualidade da formação do futuro profissional. $O$ Direito projetado na imaginação do professor quase sempre é o Direito que se repassa para a visão dos alunos e a ausência de um elemento crítico, combinado com a concepção de verdades inquestionáveis neste processo, acarreta um problema que precisa ser colocado em discussão.

Neste sentido, é possível perceber que a concepção do que é o Direito já se demonstra um problema que está incrivelmente presente aos indivíduos da área jurídica. Kipper (2000, p. 67) faz referência à noção vaga que o acadêmico de direito tem dos principais institutos jurídicos e do próprio conceito de direito, destacando que, apesar "do direito ser o seu objeto de estudo e durante a vida acadêmica e 
profissional estar constantemente se referindo ao direito, seja no singular como no plural, se questionado a respeito muito provavelmente não terá convicção do que dirá ou ainda nem saberá o que dizer".

De fato, soa estranho imaginar que alguém da área jurídica possa ter dificuldades para conceituar o Direito, mas isso é muito mais comum do que se possa imaginar, a ponto de se poder afirmar que esse problema conceitual vai além dos bancos acadêmicos e se dissemina pelo contexto profissional. Ademais, é mais provável que a resposta para a conceituação do Direito apareça dentro de uma visão simplificada, como um "conjunto de normas", muitas vezes desvinculado de um contexto social.

Isso decorre do discurso predominante, que surge nas salas de aula e permanece na formação daqueles que não tiveram a oportunidade de se envolver num debate mais aprofundado sobre todas as interferências ideológicas inerentes ao conceito de um determinado objeto e, com efeito, a ausência de uma visão crítica pode decorrer de vários fatores, que vão desde a formação cultural de cada indivíduo (muitas vezes levado a não criticar em razão do próprio contexto passivosubserviente em que foi criado) como, no caso da formação acadêmico-científica, na ausência de um despertar reflexivo diante do próprio discurso ao qual foi submetido pelo ambiente educacional onde esteve envolvido.

A formação educativa do indivíduo pode levá-lo ao discurso repetitivo, adotando a cômoda postura de se manifestar sobre a vida de acordo com o que dizem dela e não a partir da sua própria análise, sistematização e conclusões. A dominação havida por conta da educação familiar, a dominação decorrente de uma formação escolar inflexível, a dogmatização decorrente de uma formação até mesmo religiosa, pode produzir um indivíduo inapto a questionar as incongruências perante as quais se depara, escolhendo reprimir o sentimento de inconformismo por conta da cultura subserviente que se Ihe estabeleceu. Esse sujeito, já (con)formado com a dominação que the foi imposta muitas vezes sem ter clareza disso, vem para os bancos acadêmicos do Curso de Direito e se depara com novas autoridades, em profissionais que acumulam a função docente com cargos (ou sentimento) de autoridades. O resultado é manter-se um ambiente autoritário-dominador, o qual produzirá sujeitos limitados, que muito provavelmente enfrentarão as dificuldades da vida projetando a culpa no mundo e não por conta de sua própria limitação. 
Infelizmente, com a ausência do importante papel educativo envolvendo o professor de Direito (como pode ocorrer em qualquer outra área), ele acaba se reduzindo a servir de informador de um conhecimento dogmatizado, a ponto de, até mesmo, limitar quais e tais autores o aluno pode estudar, além de induzir a repetição do que a lei está afirmando, como se ela não dependesse de uma maior interpretação além da visão semântica ou sintática. Assim, tende-se a reforçar toda essa problemática envolvendo a capacidade crítica, induzindo à formação de profissionais carentes de atitudes de enfrentamento e superação.

É claro que a postura crítica dos alunos não se construirá apenas com a postura crítica do professor, mas esta é uma condição mínima para que o processo possa ser desencadeado. Se a postura extremamente dogmática do professor pode até prejudicar sua própria visão de si mesmo como profissional da educação, o que, então, não se poderia dizer da forma como ele vê o conteúdo a ser trabalhado e, também, a própria capacidade de ver o aluno se transformar.

De fato, na esteira do que afirma Miaille (1994, p. 22), o pensamento crítico suscita "o que não é visível, para explicar o visível", recusando-se "a crer e a dizer que a realidade se limita ao visível". Ele "sabe que a realidade está em movimento, quer dizer, que qualquer coisa para ser apreendida e analisada tem de o ser no seu movimento interno. Não se pode, pois, abusivamente reduzir o real a uma das suas manifestações, a uma das suas fases".

O papel de uma teoria crítica é importante na medida em que se caracteriza como um "instrumental pedagógico (teórico-prático) que permite a sujeitos inertes e mitificados uma tomada histórica de consciência, desencandeando processos que conduzem à formação de agentes sociais possuidores de uma concepção de mundo racionalizada, antidogmática, participativa e transformadora" (WOLKMER, 2001, p. 5). Desta maneira, quando o professor reconhece a necessidade de estar aberto às novas percepções sobre seu conhecimento e o conhecimento que se produz pelas mais diferenciadas formas; se admite que sua visão de mundo pode mudar; se admite que as circunstâncias da vida também são passíveis de mudança; se reconhece a possibilidade de discursos ideológicos que possam desvirtuar as informações - entre tantas outras formas de não se limitar a dogmas inquestionáveis -, tende a fomentar a liberdade de expressão do aluno, dando-lhe oportunidade para somar ideias e não apenas repeti-las. 
Acresça-se, ainda, a dificuldade enfrentada por todo conhecimento crítico, ao partir de um conhecimento já assentado, para revê-lo e reconstruí-lo. É utópico imaginar que o aluno (de Direito ou de qualquer outra área), deparando-se com um novo conhecimento, possa ter a plena capacidade de construir uma visão crítica sobre ele, a ponto de revisá-lo. Porém, a forma como se proporciona o conhecimento jurídico pode contribuir para essa visão crítica e necessária na formação dos futuros profissionais do Direito (como nas demais áreas), registrandose que esse mesmo aluno poderia contribui, com sua visão de mundo (sob os cuidados da atenção ao senso comum), numa somatória de abordagens que 0 professor poderia não ter.

Percebendo-se que a base fundante do próprio Direito - que é compreender, no mínimo, seu significado e amplitude -, possui sérias dificuldades, permite-se uma prévia conclusão sobre um especial problema envolvendo o ensino do Direito: a concepção do que é o Direito vai acarretar um processo de ensino-aprendizagem inspirado no mesmo ambiente. Logo, se não se tem claramente qual o Direito a ser ensinado, não faltarão argumentos para se colocar em cheque a qualidade do curso que o tem como objeto, pois a sua base conceitual já é um problema em si.

Por outro lado, acreditando-se que o Direito tem um significado imutável, gera-se o mesmo problema. Quando se parte de uma noção inquestionável para o significado do Direito, não se viabiliza a necessária discussão sobre seu conteúdo e aplicação e, obviamente, o processo de ensino-aprendizagem transitará dentro do mesmo ambiente, onde o papel da autoridade é quem ditará as regras do que se pode ser ou fazer.

Historicamente, os discursos sobre o que é o Direito transitaram entre duas fortes posições: o jusnaturalismo e o juspositivismo. Essa observação é recorrente nas abordagens sobre a questão ontológica do Direito: o debate, assim, gira em torno de considerar a origem do Direito a partir de princípios de ordem natural, consagrados historicamente (jusnaturalismo), ou da manifestação positivada através da intervenção do Estado, consubstanciada em dispositivos legais postos pelo homem em razão de interesses predominantes (juspositivismo).

O jusnaturalismo, por muito tempo, procurou sustentar na formação do jurista a noção de que o Direito a ser aplicado (e, portanto, ensinado), decorreria de valores eternos e imutáveis, vinculados à existência do homem em sociedade. Em alguns momentos, essa noção do Direito Natural vinculou-se fortemente à própria 
participação de Deus, o que "legitimava" as imposições normativas decorrentes desta linha de pensamento. Em outros, mais modernos, representou uma vinculação histórica com a natureza humana.

Como observa Diniz (1995, p. 34-35), na Idade Média, o jusnaturalismo "concebia o direito natural como um conjunto de normas ou de primeiros princípios morais, que são imutáveis, consagrados ou não na legislação da sociedade", resultantes "da natureza das coisas e do homem, sendo por isso apreendidos imediatamente de sua cultura ou civilização". Nesse aspecto, o Direito Natural encontrava suas razões fora do homem, em regras concebidas a partir da natureza e, assim, justificável a interferência divina em sua elaboração. Neste ponto, demonstrava-se a existência de um direito natural "metafísico", atribuindo-se a origem de sua existência a um momento anterior ao ser humano e ao Estado, decorrente "não propriamente da natureza, mas de uma entidade metafísica, como Deus, a providência divina ou alguma razão universal", de onde decorreria que os direitos fundamentais seriam revelados "a homens escolhidos por Deus, pessoas privilegiadas, que têm o dom de se comunicar com a divindade" (COELHO, 2004, p. 123).

Tal pensamento foi paulatinamente substituído, a partir do século XVII, acompanhando o movimento racionalista, por uma consideração subjetivista, atrelada ao homem e ao sentido humano que o mesmo designaria. Desse modo, buscando seus fundamentos de validade na identidade da razão humana, concebese "a natureza do homem" como "uma realidade imutável e abstrata, por ser-lhe a forma inata, independente das variações materiais da conduta" (DINIZ, 1995, p. 35).

Por outro lado, o juspositivismo se atrela ao movimento positivista de caracterizar como científicas as abordagens que se afastem de um subjetivismo, construindo pressupostos a partir de raciocínios lógicos. A participação estatal na produção de normas jurídicas e a existência de um sistema legislativo para justificar a legitimidade do ordenamento jurídico em decorrência da representatividade (em sistemas democráticos, como o brasileiro) passaram a caracterizar um processo racional que justifica a existência desse juspositivismo, onde a influência da legislação se projeta também para a forma de ensinar o Direito, que, no caso, se apresenta como ensinar as leis.

Com efeito, ressalta Mesquita (2008, p. 86) que "o ensino do Direito, quando inspirado pelo positivismo jurídico, tende a reduzir-se ao ensino da lei”, de maneira 
que a "concepção normativista do Direito influencia decisivamente o conteúdo programático das disciplinas dos cursos jurídicos, que tendem a reproduzir os textos legais correspondentes". Assim, segundo o autor, as principais consequências do ensino jurídico positivista do Direito seriam:

a) A desvalorização das disciplinas incluídas no denominado eixo de formação fundamental, e a forma como têm sido ministradas, de maneira paralela e não efetivamente fecundante de todo o ensino;

b) a valorização do conhecimento das normas jurídicas abstratamente consideradas, em detrimento da solução de casos concretos, dificultando a introdução de novas técnicas de ensino e aprendizagem;

c) a desvalorização do ensino da dimensão história do Direito e dos fatores sócio-econômicos condicionantes da produção das normas jurídicas, a resultar numa visão tecnicista e acrítica.

A necessidade de compreensão do sistema legal vigente faz com que os estudos do Direito perpassem pelas normas jurídicas estatais. Os Códigos e as leis de um modo em geral, envolvem o processo de ensino de maneira a exigir um grande tempo de atenção e esse contexto transmite, mesmo implicitamente, uma importância que desvirtua o efetivo conteúdo do Direito, que vai além de normas jurídicas produzidas pelo Estado.

A título de exemplo, veja-se o ensino do Direito Civil. Ainda que o mesmo não se prenda ao Código Civil (Lei 10.406/2002) - até porque muitas outras Leis se somam ao estudo da área do Direito Civil, induz-se que a análise do referido Código Civil seja imprescindível, exigindo a abordagem de 2146 artigos (só de tal Código). De regra, para esse estudo, distribuem-se a disciplina de Direito Civil ao longo dos cinco anos de Curso, fazendo com que professor e aluno trabalhem o Código Civil durante todo este longo período. E tudo isso para apenas um Código, ao qual se podem somar outros estudos envolvendo o Código de Processo Civil, o Código de Processo Penal, o Código Penal, o Código Tributário Nacional, a Consolidação das Leis do Trabalho, o Código de Defesa do Consumidor e a própria Constituição Federal, isso notando-se que esta relação indica somente as mais expressivas fontes normativas.

Ora, parece simples concluir que essa quantidade de artigos a serem estudados vai estabelecendo um conhecimento implícito na formação acadêmica: a lei tem extrema importância! A repetição no tratamento da lei, a constante consulta 
aos termos legais, a exigência da sua aplicação nas avaliações de aprendizagem, não poderiam fazer outra coisa senão estabelecer uma visão positivista do sistema, caracterizando o chamado fetichismo da lei, elevando-a a um grau de "entidade superior", a ser respeitada, muitas vezes sem a necessária visão crítica.

Desse modo, o fenômeno jurídico permanece "estruturado a partir de dogmas mantidos fora de discussão e que são, regra geral, o direito estatal vigente", mantendo o conhecimento produzido na área com ênfase à legalidade, confundindo "a norma com o Direito e crê na isenção valorativa e na objetividade e neutralidade ideológicas do ato cognoscente". Por isso, o ensino do Direito não consegue superar as suas deficiências ao ficar atrelado ao paradigma positivista, caracterizado pela representação do mundo de uma forma unívoca, consensual e não democrática, estruturado na visão legalista. As salas de aula se "transformaram em lugares de reprodução de leis mortas que se chocam com a realidade social" e o aluno "é preparado para trabalhar com códigos e esses são insuficientes para embasar atividades profissionais que busquem atender aos diversos e conflitantes interesses sociais" (RODRIGUES, 2004, p. 98).

Ademais, observa Streck (2004, p. 88) que o processo de interpretação das leis divaga sobre a ficção da "vontade do legislador, do espírito do legislador, da vontade da norma ( $\mathrm{sic}$ )". Sobre essa ficção há "um conjunto de crenças e prática que, mascaradas e ocultadas pela communis opinio doctorum, propiciam que os juristas conheçam de modo confortável e acrítico o significado das palavras, das categorias e das próprias atividades jurídicas", tornando a profissão como um mero habitus, exercendo-a de um "modo rotinizado, banalizado e trivializado de compreender, julgar e agir com relação aos problemas jurídicos”, convertendo seu saber profissional "numa 'riqueza' reprodutiva a partir de uma intrincada combinatória entre conhecimento, prestígio, reputação, autoridade e graus acadêmicos".

De fato, como salienta Cambi, a tendência ao legalismo foi acompanhada de uma tentativa de "manipular ideologicamente o Direito com o fundamento de que a lei seria a tradução da vontade geral e do bem comum" (2009, p. 84). Por tal discurso, denota-se uma manipulação ideológica que parte da "burguesia que, pretendendo a manutenção do status quo, visou ocultar o conflito de classes e de interesses, difundindo a idéia de paz e harmonia, ordem e progresso, consenso e felicidade, uma vez que, etimologicamente, a palavra 'Direito' traduz, no senso 
comum, a idéia daquilo que se dirige para o caminho do bem, como algo essencialmente bom e justo (COELHO, 1993, p. 18-19).

Com efeito, essa "visão do Direito como ciência dogmático-normativa se afasta da realidade para habitar um mundo de abstrações que, muitas vezes se choca com a justiça, levando a sentenças ou a outras decisões que afirmam valores dissociados dos valores do grupo a que o procedimento jurídico se dirige" (RIBEIRO JÚNIOR, 2003, p. 18).

Mas, como lembra Iserhard (2009, p. 97), "cumpre não esquecer que a vida é por demais rica para se deixar aprisionar em codificações anacrônicas e que não raro os fatos se revoltam contra os códigos, exigindo do operador do direito uma postura metódica, a exemplo do método indutivo que permite descobrir o direito nas relações sociais, rentes aos fatos da vida".

De fato, a manutenção de um paradigma, supostamente considerado como verdadeiro e inquestionável, como é o caso do positivismo jurídico, se encontra debilitada, como observa Kipper (2000, p. 69), não sendo mais possível sustentá-lo "como o único paradigma possível para o ensino jurídico, mesmo porque não há 0 paradigma, mas os paradigmas, nenhum mais certo que o outro, pois trata-se meramente de uma opção ideológica".

Como bem alerta Rodrigues (2004, p. 107), o grande erro, tanto do jusnaturalismo como do juspositivismo, é pretender apreender um objeto dinâmico como o Direito através de métodos estáticos. Por isso, demonstrado que um dos motivos da crise do Direito é a própria concepção do que ele é, faz-se necessária a superação das concepções tradicionalmente estabelecidas de que ele se sustenta num jusnaturalismo ou, como mais comumente se afirma, num juspositivismo amarrado às leis de um modo em geral, sob pena de se promover em sala de aula, um discurso que apenas repete um sistema que não é suficiente em si mesmo.

Neste contexto de pensar o Direito num conjunto de normas, por certo, não "esgota as virtualidades de expressão da normatividade jurídica nem alcança o significado global do direito" e acreditar que as normas já elaboradas e integradas ao sistema jurídico são o único foco de atenção despreza a "múltipla gama de fatores, de variada ordem, tradutores das forças sociais, da luta de interesses e do confronto de valores que presidem sua criação", de maneira a considerar a "ordem jurídica de modo asséptico e estático", menosprezando e falseando "seu aspecto dinâmico, a razão mesma de sua existência, que tão somente se desvela no momento em que 
suas normas são aplicadas" (AZEVEDO, 1989, p. 11). O discurso dogmático, desta forma, tende a aparecer, "aos olhos do usuário/operador do Direito, como, ao mesmo tempo, seguro, justo, abrangente, sem fissuras, e, acima de tudo, técnico e funcional". Porém, o preço por tal situação "é alto, uma vez que ingressamos, assim, num universo de silêncio: um universo do texto que sabe tudo, que diz tudo, que faz as perguntas e dá as respostas" (STRECK, 2004, p. 91).

Assim, decorrente desta mentalidade e em nome da cientificidade do Direito, cria-se um "mundo à parte, o mundo dos juristas, que os afasta, por escolha e imposição metodológica, da fecundidade da colaboração interdisciplinar", mantendo um sistema fechado do ensino jurídico e do raciocínio jurídico, que acarreta a sua perda de prestígio, não encontrando salvação "no preciosismo de sua linguagem, precisamente porque ela Ihes é demasiado peculiar e, por isso, incapaz de comunicar significados por que o povo anseia e espera" (AZEVEDO, 1989, p. 14).

Neste plano, "o ensino jurídico continua preso às velhas práticas", representado por uma "cultura calcada em manuais, muito de duvidosa cientificidade", que ainda predomina na maioria das faculdades de Direito, formandose um “imaginário que 'simplifica' o ensino jurídico, a partir da construção de standards e lugares comuns, repetidos nas salas de aula e posteriormente nos cursos de preparação para concursos, bem como nos fóruns e tribunais", calcandose em "casuísmos didáticos", onde o positivismo prevalece como regra geral, considerando o direito como "uma mera racionalidade instrumental" (STRECK, 2004, p. 82-83).

De fato, somente com a noção de que as normas jurídicas são mera representação histórica de valores (que podem ser alterados), decorrentes de uma ideologia que as justifica (porque toda produção normativa tem por fundamento uma representação de interesses) e que o paradigma estatal não é isento de falha (até porque uma lei não é perfeita apenas por ter sido regularmente aprovada), é que se pode começar a imaginar um ensino jurídico aberto à construção e criatividade necessárias para tratar de um fenômeno tão dinâmico como é a interação entre as pessoas, atendendo ao seu papel maior que é estabelecer regras de convivência necessárias para a vida em comum. 


\subsubsection{A alteração do paradigma jurídico}

A inconsistência da manutenção do discurso jurídico baseado num Direito fixado na dicotomia positivismo-jusnaturalismo, é um indicativo necessário para a revisão dessa postura e do círculo vicioso que tende a repetir essa ideologia: o conceito que se tem do Direito, vinculado a uma ou outra linha, dá o embasamento para o professor proferir sua fala sobre o próprio Direito. Os alunos apreendem essa informação e assumem a visão de um mesmo Direito, agindo com base nessa estrutura, propagando esse conteúdo em sua atividade jurídico-profissional e na docência, quando passam a assumir esse papel.

Desta maneira, sistematizar uma reflexão sobre o problema ontológico do Direito é um importante passo para se tratar do ensino jurídico. Ainda que possa não existir uma "melhor verdade" para o que poderia ser atribuído ao conceito do Direito, colocar a possibilidade de sua discussão já é uma evolução que rompe com o comodismo predominante em grande parte dos discursos jurídicos, que se mantém, de regra, na visão simplista de que o Direito se resume a um conjunto de normas.

Este espírito reflexivo está pautado na corrente zetética, referida no Brasil pelos Professores Tércio Sampaio Ferraz Júnior e Luiz Fernando Coelho, que se enquadra como um fundamento de base para o raciocínio empregado.

Ferraz Júnior aplica a terminologia usada por Viehweg, para trabalhar as possibilidades entre o enfoque dogmático e o enfoque zetético sobre o Direito. Neste sentido, ressalta que zetética vem de "zetein que significa perquirir, dogmática vem de dokein que significa ensinar, doutrinar". Assim, enquanto o "enfoque dogmático releva o ato de opinar e ressalva algumas das opiniões", o "zetético, ao contrário, desintegra, dissolve as opiniões, pondo-as em dúvida", com função especulativa explícita e infinita, visando saber "o que é alguma coisa" (1994, p. 41).

No estudo das escolas hermenêuticas do Direito, Coelho classifica-as como zetéticas por não aceitarem acriticamente o princípio jurídico, tratando da lei, do conceito e do método sempre subordinadas às situações reais e cambiantes da vida social, considerando que o direito "não é imóvel, nem vazio, mas essencialmente mutável, devendo se adaptar às condições sempre renovadas da sociedade", existindo para "solucionar problemas sociais concretos e não para manter dogmas, teorias e princípios abstratos, afastados da realidade da vida" (2004, p. 334). 
Com efeito, no plano do conhecimento jurídico, o movimento zetético elabora uma teoria do direito "vinculada, não às suas formas de expressão, mas às situações sociais que constituem objeto da normação, situações essas referidas ao momento dialético da possibilidade, oportunidade e critérios ideológicos da normação" (COELHO, 1981, p. 53). Desta maneira, invocamos o pensamento zetético para a compreensão do problema ontológico do Direito, colocando em discussão não a sua aplicação, mas sim a dinâmica do seu significado e amplitude.

Partindo-se de uma visão zetética para a concepção de um paradigma diverso à compreensão do Direito, é certo afirmar que nenhuma proposta será suficiente para dar fim ao discurso sobre o que é o Direito. A afirmação do modelo para ele corresponderá sempre ao momento histórico que a justifica. Sem esta mentalidade provisória sobre a conceituação do Direito certamente estaríamos ainda vinculados ao pensamento dogmático e, do mesmo modo, o discurso pela manutenção de uma "verdade" para o Direito estaria sendo imposto.

Com isso, é importante fixar-se que qualquer modelo para a concepção do Direito deve visualizar a dinâmica que envolve a própria vida. Para pretender regulamentar as relações humanas o Direito tem que possuir uma natureza dinâmica tal como é a própria vida, como alerta Fagúndez:

O direito novo da sociedade nova deverá se voltar para o futuro, estimulando
condutas. Não pode continuar sendo apenas um sistema de amordaçamento
dos sonhos e desejos. Ser apenas uma programação voltada para atingir
condutas pretéritas não se constitui no principal do direito. O direito do dever
ser nem sempre traz a previsão das condutas que são levadas a cabo no
plano imprevisível da realidade. A sociedade é complexa e está sujeita ao
risco e ao perigo. O direito não é o ser nem o dever ser, sendo, sobretudo,
expressão do desejo incontido do homem. O direito quer é dominar a vida,
que é indomável, haja vista que é regida pelo princípio da incerteza, que tem
contribuído para a revolução do conhecimento científico. (2000, p. 43$)$

Uma interessante proposta para se rever ontologicamente o próprio Direito é trazer para sua construção e seu ensino a importância necessária ao ser humano, razão que sempre deveria estar presente em toda proposta de discussão e aplicação de seu conteúdo. O Direito foi construído a partir da necessidade da regulamentação do convívio entre as pessoas e não poderia se afastar desse seu bem maior que é o ser humano.

De fato, pode chegar a surpreender tal afirmação, quando o olhar sobre o Direito se restringe apenas ao que a mídia vem a destacar, em situações polêmicas. 
Vê-se o Direito em discussão quando se envolve a vida de pessoas perante a imprensa (com crimes de grande repercussão, principalmente), mas o discurso acadêmico-jurídico corre o risco de se perder entre suas regras e dogmas. Como já se viu no item anterior, a centralização tecnicista e o fetichismo à lei desvirtuaram o fim principal do Direito e o resgate do valor do ser humano é importante quando e objetiva estabelecer um norte para a humanização do problema existente.

O rompimento absoluto com o sistema atual (seja de criação, interpretação ou ensino do Direito) não é necessário. É preciso apenas que o olhar sobre o objeto (Direito) se amplie a ponto de reconhecer outros valores que não se resumam apenas ao conteúdo normativo e, de uma forma simplista, colocar o ser humano como foco principal das atenções.

Souza (2002, p. 6-7) bem trata do tema, afirmando que humanizar o direito "é trazer o homem para o centro das operações jurídicas, seja legislando, seja administrando, seja decidindo causas, em que o homem deve sempre ser privilegiado, como fim último das atitudes humanas". Para o ensino jurídico, isso se projetaria em "transpor para o currículo das Faculdades a figura da pessoa humana com toda a dignidade que a caracteriza e que a Constituição Ihe confere e garante", tornando-a "destinatária última de todos os ensinamentos".

De fato, o contexto histórico atual permite a escolha deste caminho para o conceito do Direito. Muito se tem trabalhado em prol do assunto "Direitos Humanos" durante o Século XX e em continuação pelo Século XXI, dada a grande importância que é o resgate do ser humano como centro de atenção do desenvolvimento científico, seja nas garantias de seus direitos (a exemplo da liberdade, do direito à democracia) como na limitação de suas ações (como no caso do uso equilibrado do meio ambiente). Na observação de Coelho (2004, p. 390), esses direitos são compreendidos como "superação da barbárie e consolidação das conquistas da civilização".

Certamente que, como base desse movimento jurídico (mas também sociológico, histórico, antropológico entre outros) voltado aos Direitos Humanos, tem-se o próprio ideal político-filosófico que envolve a proteção da dignidade do ser humano, assumida no Brasil como um fundamento do Estado Democrático de Direito, conforme art. $1^{\circ}$, inc. III da Constituição Federal.

Nessa esteira, a educação também tem em destaque a abordagem humanista, que se consubstancia tanto no aspecto legal como doutrinário. 
No plano legislativo, a diretriz principal que confirma o foco no ser humano, de maneira a indicar que a abordagem humanista deve ser uma direção para o processo educativo, é também a Constituição Federal, que em seu artigo 205 da Constituição Federal, dispõe que a "educação, direito de todos e dever do Estado e da família, será promovida e incentivada com a colaboração da sociedade, visando ao pleno desenvolvimento da pessoa, seu preparo para o exercício da cidadania e sua qualificação para o trabalho", regra que é repetida pelo art. $2^{\circ}$ da Lei 9.394/1996 (Lei de Diretrizes e Bases da Educação Nacional).

É importante salientar, a esta altura, que o enfoque humanista que se pretende afirmar para a Educação não é necessariamente o partilhando por um momento doutrinário específico, como o seria pelas abordagens de Rogers ou Neill, ressaltadas por Mizukami (2007, p. 37-57). O que se afirma é que a identificação do ser humano como centro de atenção para a educação (como não poderia ser diferente) é apenas um referencial que reforça um elemento comum a toda ciência: o ser humano e suas interações entre si e com o meio, como uma destinação de destaques para qualquer estudo.

A partir dessa confirmação, retoma-se que um paradigma importante para 0 estudo do Direito (e, portanto, para o processo educativo), é colocar o ser humano como elemento de sua destinação, resgatando-se o que a história do Homem sempre apontou para a compreensão e formação jurídica das relações: que só há o Direito porque há o ser humano em relação, por mais óbvia que possa parecer esta afirmação - tendo em vista a tendência legalista-normativista pela qual o ensino jurídico se envereda.

Há que se acrescentar, para esta concepção de mudança do paradigma do Direito, que se reconheça também o movimento caracterizado como pluralismo jurídico, ampliando-se a base das relações sociais que proporcionarão a compreensão do direito a ser aplicado.

De fato, a proposta do pluralismo compartilha das discussões envolvendo as ciências humanas sobre a crise de paradigmas. Como salienta Wolkmer (1994, p. 313-314), tem-se "como ponto de partida a premissa de que os modelos culturais, instrumentais e normativos são limitados e insuficientes para contemplar as novas formas de vida cotidiana, de organização político-social e dos parâmetros de saber e de cientificidade". Logo, com o abalo dos paradigmas estabelecido pelo "idealismo individual, pelo racionalismo liberal e pelo formalismo positivista", que "mantiveram o 
rigor lógico do discurso filosófico, científico e jurídico", em razão de "novos padrões valorativos de referência, de fundamentação e de legitimação", tem-se colocado em relevo a tendência pela "descentralização, autonomia e autogestão das formas de organização sócio-políticas e pelas novas modalidades de relações individuais/coletivas (interclassistas), calcadas na diversidade, alteridade e informalidade de identidades (atores, agentes e movimentos) históricos".

É certo que esta visão pluralista amplia a concepção ideológica sobre o conteúdo do Direito (que não se identifica com o paradigma legal e nem mesmo Estatal), transitando pelos choques não entre o Direito Estatal e o Direito Comunitário (produzido mesmo à margem do Estado), mas tendo como foco a questão do Direito justo e o Direito injusto. Como salienta Wolkmer (1994, p. 317/318):

Por ora, não existe um consenso de que o Direito Estatal impor-se, pois este não é, necessariamente, o Direito mais justo para certos tipos de coletividade. Não se pode mais visualizar num conflito de leis o Direito Estatal como a instância mais justificável, correta e legítima para exercer a hegemonia em nome da maioria social. Prevalecendo o Direito mais justo, há que se estabelecer os critérios e a medida do que seja 'justo', bem como há que saber quem terá legitimidade para dizer o que mais seja mais 'justo'. Neste caso, o 'justo' é definido por aquilo que corresponde às aspirações legítimas e à satisfação das necessidades estabelecidas democraticamente pelas própria Sociedade.

É importante lembrar que a visão sobre a justiça sempre transitou entre a concepção subjetivista do justo (na noção de cada indivíduo) como pela concepção objetivista (construída pelo regramento social). Entretanto, considerando-se a teoria axiológica, lembrada por Coelho (2004, p. 390-393), tem-se a superação deste dualismo, de maneira a identificar a justiça "com um valor, o qual incide sobre um setor do humano - ou seja, a própria conduta social". Assim, ela "não se exaure nem no princípio subjetivo da virtude nem no objetivo do equilíbrio, mas abrange a ambos e os sintetiza, já que deve ser vivenciada emocionalmente e realizada normativamente".

Para o contexto do presente estudo, é importante verificar-se que o conceito de justiça está atrelado ao movimento humanista (COELHO, 2004, p. 390), porque estão umbilicalmente ligados, até por conta do critério valorativo vinculado à vida social dinâmica e em transformação. Decorrente disso, vale ressaltar a conclusão apresentada por conta da experiência do autor: 
O exame a que procedemos do significado da justiça como valor e suas repercussões de natureza ontológica, epistemológica, lógica metodológica e dogmática, levam-nos a constatar uma verdade que, sem ser exatamente uma novidade, nunca será suficientemente enfatizada: que é muito mais importante para o aperfeiçoamento da ordem jurídica formar os profissionais que vão lidar com as leis do que as próprias leis. (COELHO, 2004, p. 396)

Indo além, o "estudo do Direito deverá propiciar o diálogo com o universo não só jurídico, pois o universo é a realidade na sua totalidade, com suas verdades e inverdades, num diálogo constante do sujeito, com o conhecido e o desconhecido, na medida em que está situado num determinado espaço e tempo, numa sociedade que deve deixar de lado o individualismo para uma retomada da solidariedade nas suas relações interpessoais" (CURY, 2002, p. 188).

Desta maneira, à guisa de conclusão sobre a mudança de paradigma, na intenção consciente do afastamento de qualquer vinculação a um único modelo, ou dos dogmas que impedem o avanço para outras concepções além daquelas já assimiladas, seria importante estabelecer, como critério de destinação da concepção do Direito que:

a) A visão zetética fosse uma constante, no sentido de se admitir uma afirmação jurídica até que perdure os elementos que a justificam. Logo, uma verdade para o Direito jamais seria absoluta e sua existência exigiria um constante refletir sobre seus fundamentos. Isso produziria importantes reflexos nas ações docentes, na medida em que se superasse a arbitrariedade empregada na imposição de verdades jurídicas, as quais devem ser consideradas temporárias e passíveis de constante revisão;

b) A visão humanista estivesse presente em todos os discursos e interpretações sobre o Direito, de maneira a permanecer o vínculo imprescindível para a compreensão do que ele é e para quem deve servir (o ser humano), assegurando-se contra o risco do interesse do Estado predominar sobre o interesse dos indivíduos, na confusão intencional de se substituir o criador (sujeitos em sociedade) pela criatura (Estado) em nome do afastamento dessa responsabilidade humana de se tratar dos respectivos pares. A condução do trabalho docente, em consideração dessa importância 
humanista, promoveria um constante refletir sobre os efeitos do Direito sobre a vida, não se limitando ao discurso ao serviço do respeito cego à lei;

c) O pluralismo jurídico seja considerado para se vincular ao conceito de Justiça, não se restringido ao Direito que o Estado produz, mas sim ao plano de legitimidade e efetividade para com os seus destinatários (seres humanos em relação), numa compreensão ampla das relações sociais.

Desta maneira, reconhecendo-se a evolução histórica das regulamentações do Curso de Direito como ponto de partida para o presente estudo, é importante que se busque tratar da crise que o ensino jurídico enfrenta, tendo-se como premissa um trabalho efetivo para que se rompam os paradigmas sobre o significado do próprio Direito. Isto permitirá sua evolução através de uma aplicação consciente e crítica, procurando atualizar o seu significado pela necessidade de revisão constante de seu conteúdo em face da realidade social, sem reduzi-lo a um modelo hermético e dogmático.

Além da visão crítica sobre o próprio Direito, é preciso que se reproduza idêntica preocupação sobre aspectos pedagógicos que envolvem as ações docentes e discentes, como um passo a mais na visualização do ambiente no qual tem se desenvolvido o ensino do Direito. 


\section{A CRISE DO ENSINO DO DIREITO PELA CRISE PEDAGÓGICA: DOCENTES E DISCENTES}

Há muito tempo se discute a questão pedagógica envolvendo o ensino do Direito. Se hoje o tema aparece recorrente e culturalmente já imbuído na visão sobre a educação jurídica, a História está repleta de momentos indicando as dificuldades enfrentadas.

Como anota Venancio Filho, há muitas passagens na História que indicam movimentos que criticam as posturas (não)pedagógicas no Curso de Direito, observando-se que a "má qualidade do ensino se revelava logo nos primeiros anos, pois já em 5 de agosto de 1831, o Ministro do Império, José Lino Coutinho, baixa um aviso sobre a incúria e desleixo de alguns lentes do curso jurídico de São Paulo, indiferentes à falta de freqüência dos seus discípulos e fazendo aprovações imerecidas", o que gerou descontentamento e protestos (2005, p. 49).

Em 1836 e 1837, relatórios indicavam problemas em Olinda e São Paulo, respectivamente. Enquanto em São Paulo se constatavam um excesso de falta dos lentes e dos estudantes, em Olinda indicavam-se problemas com estudantes do quinto ano, afirmando-os como "moços perfeitamente estúpidos e escandalosamente vadios". Além disso:

Estudantes vadios e mal-educados (que nunca faltam em corporação tão numerosa), vendo que os lentes, além de pobres, não os podem chamar a seus deveres, pouco ou nada respeitam, e era coisa muito originária e comezinha, desde a criação desta Academia ouvir-se todos os dias este ou aquele estudante dizer de público que daria uma bofetada, uma facada, etc., ao lente que ousasse deitar-lhe um "R"; e o mais é que o medo de tais ameaças tem concorrido, em grande parte, para serem aprovados, plenamente, sujeitos indignos, quer pela sua ignorância, quer pelo seu repreensível procedimento. (VENANCIO FILHO, 2005, p. 54)

O problema da ausência de preparo do professor também foi apontado. $\mathrm{Na}$ falsa compreensão de que a boa oratória dispensaria o estudo sobre 0 conhecimento do conteúdo da disciplina, Venancio Filho (2005, p. 117) relata registros sobre o lente em São Paulo e parlamentar Antonio Carlos Ribeiro de Andrade Machado, considerado "desajudado por inveterada vadiação", criticado por um amigo pela falta de estímulo, 
referiu-se inicialmente que era estudioso, entregava-se ao preparo das preleções, ao afanoso trabalho. Mas que, sucedendo um dia dar aula sem o suficiente preparo, teve para isso de encher o tempo valendo-se de imagens retóricas e digressões oratórias. Com surpresa sua, agradou muito e, ao bater da hora, teve palmas dos seus discípulos. Este fato o convenceu de que, para agradar a um auditório acadêmico, não era necessário o estudo das preleções. Aí estava a razão pela qual ele não se matava a aprofundar as matérias.

O destaque ao referido lente se justificava pelos seus excessos: reproduzia literalmente o que autores diziam, reputando-os claros e convincentes o suficiente para não ser possível se dizer melhor nem tão bem, sendo que em outras vezes

Espirrava, depois assoava vagarosamente. Depois fazia, sobre a constipação, uma digressão médico-jocosa - que era coisa muito incomodativa, curável em trinta dias por meios terapêuticos, e em trinta e um à lei da natureza; a propósito, referia a uma anedota sobre o espirro e depois, por fim, voltava aos fio da explicação... e seguia-o, até que viesse outro incidente obstrucionista. (VENANCIO FILHO, 2005, p. 117)

Acrescente-se, também, a prática de "aulas lidas". Em 1878, menciona-se de um professor (Silveira de Souza), as aulas como monótonas, pois que seu sistema reduzia-se a levá-las escritas e as lia. Assim, chegava "envolvido na sua beca negra, tomava assento na cátedra e, erguido ao fundo da sala, levantava os óculos de presbita para a frente e punha-se a ler fluentemente, mas sem calor, sem interrupções, seguidamente até que a sineta dava o sinal de estar finda a aula" (VENANCIO FILHO, 2005, p. 118).

Certamente que tais referências históricas não têm o condão de concluir que o ensino jurídico foi falho desde a sua criação. Mas é interessante perceber que problemas envolvendo ações pedagógicas sempre receberam questionamentos em um ou em outro momento. Um estudo aprofundado dos registros acadêmicos ou da história deste ou daquele Curso de Direito provavelmente encontraria passagens onde se constou uma tensão na relação acadêmica, servindo para se dizer que a crise pedagógica do ensino jurídico não é fato recente.

É certo que quando se invoca neste item a questão da crise pedagógica, ela não deixa de se envolver com a abordagem anterior, tratando da compreensão do que é o próprio Direito a ser objeto de ensino. Quando não se tem claro o objeto, a ação educativa corre o risco de atentar contra questões pedagógicas, porque elas envolvem um complexo de atos, dentre os quais o próprio conteúdo. 
De qualquer maneira, este trabalho procura analisar os elementos que circundam a crise do ensino jurídico, dentro de uma complexidade que não se resume em um ou outro ponto. A tese que se fundamenta o presente estudo tem como destaque a ação docente focada na valorização da ação discente e, para que se possa tratar destes temas, não basta invocar ferramentas pedagógicas ou psicopedagógicas. Não se trata apenas da aprendizagem em si (sobre qualquer objeto), mas também estar atento sobre o que aprender e como aprender.

Para uma análise pedagógica da crise no ensino jurídico, divide-se a questão em dois pontos principais: a que envolve o corpo docente e sua formação e a que afeta a questão discente.

Por certo, é equivocado imputar-se à formação docente toda a responsabilidade pela crise pedagógica. O processo educativo não se forma apenas pelas melhores intenções e técnicas do professor, mas também pela contribuição que o corpo discente pode promover.

Não se despreza, outrossim, a influência que o ambiente educativo tem nesse contexto. Não se ignora que os recursos fornecidos pela própria instituição de ensino podem auxiliar, em muito, as condições de trabalhos. Da mesma forma, sabe-se que a ideologia institucional pode contribuir (ou não), na qualidade do corpo docente, na qualidade dos recursos utilizados (como em acervo bibliográfico, acesso à internet, ambientes de estudo, pesquisa e extensão), como na própria qualidade da cultura educativa que permeia todo ambiente educativo. Porém, ressalva-se que não se tratará especificamente destes temas, reservando-se as abordagens para alguns momentos em que $o$ assunto possa produzir efeito sobre as ações docentes e discentes.

Para a definição de questão pedagógica objeto deste estudo, invoca-se o seu enquadramento no contexto da Didática, compreendida como parte da Pedagogia.

De fato, sendo a Educação uma "prática social que ocorre nas diversas instâncias da sociedade", com objetivo de "humanização dos homens", utiliza-se da Pedagogia para o fim de "conhecer e explicitar os diferentes modos como a educação se manifesta enquanto prática social, bem como contribuir para a direção de sentido que se quer colocar para o humano" (PIMENTA, 2001, p. 83-84).

A Didática surge como "uma das areas da Pedagogia", trabalhando, na sua especificidade, a finalidade prática da educação, sendo "um dos determinantes do 
processo de ensino-aprendizagem, essência da atividade docente" (PIMENTA, 2001, p. 84).

Como contextualiza Gil (2006, p. 2), o "termo didática deriva do grego didaktiké, que tem o significado de arte de ensinar", sendo difundido a partir da obra de "Jan Amos Comenius (1592-1670), Didactica Magna, ou Tratado da arte universal de ensinar tudo a todos”, publicada em 1657.

Há diversas considerações históricas sobre as tendências através das quais transitou a concepção da Didática, como bem observa Gil (2006, p. 2-6), sendo importante destacar que a visão tecnicista a ponto de caracterizar uma neutralidade científica em sua aplicação recebeu críticas de maneira a se dar maior atenção às realizações humanas, reconhecendo os alunos como sujeitos pensantes, dentro de um projeto de sociedade que precisa ser refletido. A Didática, desta forma, "deve questionar por que estudar, por que ensinar, o que ensinar, a quem ensinar, quando ensinar, como ensinar e com quem ensinar" (SANT'ANNA e MENEGOLLA, 2002, p. 7).

Certamente, é importante fazer-se a ressalva de se compreender a didática como uma ciência. Sua natureza transdisciplinar - decorrente de seu trânsito por diversas áreas do conhecimento -, a habilita para centrar o olhar "num aspecto específico do ensino - o acontecimento - que geralmente ocorre numa situação denominada aula". Logo, a didática "pensa o ensino como algo que está acontecendo, na dinâmica viva, na fala e no gesto e sempre numa interação face a face", de maneira que seu campo de conhecimento preocupa-se com o ensino de forma investigativa (ao ver o que se passa no acontecimento ensino) e de forma prescritiva (a "busca de um ideal pressupõe o percurso de um caminho, orientado por prescrições e metas"). Não comportaria, assim, elementos suficientemente individualizados para caracterizar-se como uma ciência, indicando-se "maior propriedade" designá-la como disciplina, segundo os critérios de Foucault, considerando-se até mesmo seu entendimento que as ciências humanas "não tem as características do modelo clássico da ciência, já que estudam "o que está aquém do objeto" (não tratando propriamente dos objetos, "mas da forma como o homem os representa"), apresentando uma posição de "meta ou hipo-epistemologia" (PENIN, 1996, p. 17-22).

De qualquer maneira, coloca-se a questão pedagógica (para delimitação do objeto de estudo da crise pedagógica), como envolvendo o processo didático e seus 
elementos, dentre os quais a compreensão de que os recursos envolvendo o ensinoaprendizagem devem ser correlacionados com objetivos para a educação e o desenvolvimento do indivíduo.

Cabe-se, registrar, com Gil (2006, p. 5), que a polêmica envolvendo a Didática "não aparece com tanta ênfase em relação ao ensino universitário" pois, embora "os estudiosos da educação insistam na importância da aquisição de conhecimentos e habilidades pedagógicas pelos professores também nesse nível de ensino, muitos professores universitários não reconhecem a importância da Didática para a sua formação", e, pela ausência de formação pedagógica, tendem a "conferir menos atenção às questões de natureza didática que os professores dos demais níveis, que são os que receberam sistematicamente formação pedagógica". Essa tendência aparece em ampla pesquisa realizada por Campos (2010, p. 207), quando relata discursos onde predominam a preocupação com o conhecimento específico em relação ao conhecimento didático de alunos de programas de Pós-Graduação Stricto Sensu. A pesquisa também apresenta um discurso uníssono afirmando que "a formação inicial (especial e mestrado) e continuada (doutorado e cursos de formação oferecidos pelas (ES) para a docência do ensino superior, nos cursos de pós-graduação não contemplam a complexidade da atividade docente", ressaltando que tal carência mesmo em cursos de licenciatura.

Por consequência dessa carência, no "Ensino Superior é onde menos se verifica menor diversidade em relação às práticas didáticas", sendo que as aulas expositivas são mais frequentes "e o professor de modo geral aprende a ensinar por ensaio e erro", constituindo a "principal fonte de sistemática de informações, e uma das habilidades que mais incentivam nos alunos é a memorização" (GIL, 2006, p. 5$6)$.

Desta maneira, pretende-se, neste item, invocar as causas da crise do ensino jurídico pelo aspecto envolvendo mais diretamente o processo educativo, a questão pedagógica e seus atores principais (docentes e discentes), selecionadas dentre diversos olhares sobre esta área da Educação. 


\subsection{As dificuldades pedagógicas em relação ao docente}

Muitos aspectos podem ser apresentados para tratar dos problemas atinentes às ações docentes no ensino jurídico e é certo que nem todos os problemas apontados são necessariamente reconhecidos por seus próprios atores.

$\mathrm{Na}$ verdade, há tantas interferências para a compreensão adequada de problemas que podem surgir no ambiente acadêmico que qualquer pretensão de esgotar o seu tratamento é arriscada. Uma ação pedagógica problemática pode ter falhas que vão desde as técnicas escolhidas, as metodologias empregadas, os recursos disponíveis, o ambiente envolvido, as datas e horários escolhidos, os assuntos abordados, a contextualização mal realizada, avaliações distorcidas (em seu instrumento, em seus objetivos, em sua função etc.), por problemas que afetam os alunos, e problemas de ordem pessoal que afetam o próprio professor e essa relação nem pode ser taxativa ou completa.

Porém, somando-se a experiência na área docente específica do ensino do Direito, é possível enumerar algumas situações que se destacam, certamente correndo o risco de não apontar aquilo que a limitação da visão pessoal afeta (pela dificuldade inerente a se observar a própria ação).

\subsubsection{A formação pedagógica do professor de Direito}

Como em diversas áreas da formação educativa no ensino superior, não se exige a formação pedagógica do professor como requisito para o exercício docente. De fato, a própria Lei de Diretrizes e Bases da Educação toca a questão da titulação dos professores, mas não menciona qualquer dispositivo que estabeleça como obrigatória a formação pedagógica do professor, a não ser para a educação básica (art. 63 e $\S \S$ da Lei 9.394/96).

Registre-se que a "formação pedagógica" mencionada abrange a formação básica do professor em cursos de Pedagogia, mas isto não exclui a possibilidade de o professor receber informações pedagógicas que contribuam para a sua visão profissional docente, no âmbito de sua formação continuada.

De qualquer modo, a LDB, ao tratar do ensino superior (arts. 43 a 47) não determina qualquer formação pedagógica ao professor, quando muito fazendo referência à formação em mestrado ou doutorado (art. 52, II). 
Mesmo quando o mencionado diploma trata do profissional da Educação (arts. 61 a 67), não há indicação de qualquer obrigatoriedade voltada à formação pedagógica, limitando-se a mencionar especificamente no art. 66 que:

Art. 66. A preparação para o exercício do magistério superior far-se-á em nível de pós-graduação, prioritariamente em programas de mestrado e doutorado.

Como ressalta Gil (2006, p. 19), a partir da década de 30, houve uma disposição dos órgãos governamentais em implementar ações "para conferir maior competência técnica aos professores universitários", promovendo a pós-graduação, a partir da qual passou a exigir a obtenção do grau de mestre e de doutor para ingresso aos cargos de carreira nas universidades públicas, em especial por conta da "edição da Lei 5.540, de 28 de novembro de 1968, que instituiu a Reforma Universitária", enquanto as escolas particulares "passaram a contar principalmente com professores com cursos de especialização (lato sensu)".

Por certo, é comum ouvir-se que a titulação não qualifica necessariamente a atuação pedagógica do professor, até porque qualquer que seja a formação dada em âmbito de disciplina de Metodologia do Ensino Superior ou congênere, seja em qual carga horária for (inserida em programas "Stricto Sensu" ou não), não haverá plena garantia de aptidão para um professor profissional. Esta questão faz parte do problema que aparece por diversas vezes no presente estudo, concernente à aprendizagem: conhecer, compreender, aplicar e renovar informações/técnicas é algo muito complexo, de maneira que não há garantia que um professor, que passou por todas as fases possíveis de aprendizagem sobre sua própria função, só produza ações que sejam sempre eficazes e até mesmo coerentes com o que observou durante o processo de formação, o que, porém, não exclui a necessidade de que todo este processo aconteça.

De qualquer maneira, começa-se pela situação presumível que a grande maioria dos professores de Direito não possui formação específica em Pedagogia (quando muito, possuem a abordagem genérica de Metodologia do Ensino Superior inserida num programa de Pós-Graduação). De regra, sua participação como docente envolve seu conhecimento em área específica do Direito. Ser professor de Direito corresponde, inicialmente, a ter conhecimento sobre uma determinada área e demonstrar este conhecimento perante concursos (quando exigidos) ou apenas 
somar seu conhecimento à aproximação pessoal de pessoas envolvidas com a captação de professores (a exemplo, coordenadores de cursos, de instituições particulares, onde o ingresso docente não depende de concurso, mas sim de ser indicado para o cargo).

Opera-se, neste momento, um senso comum bem ressaltado por Luckesi (1994, p. 97), quando se acredita que para ser professor "basta tomar um certo conteúdo, preparar-se para apresentá-lo ou dirigir o seu estudo; ir para uma sala de aula, tomar conta de uma turma de alunos e efetivar o ritual da docência", representada pela "apresentação de conteúdos, controle dos alunos, avaliação da aprendizagem, disciplinamento etc", constituindo-se de uma "rotina comum, sem que se pergunte se ela implica ou não decisões contínuas, constantes e precisas, a partir de um conhecimento adequado das implicações do processo educativo na sociedade".

A história justifica tal pensamento, como observa Masetto (1998, p. 10-11), quando destaca que o movimento de criação de faculdades no Brasil buscava a formação de profissionais que exerceriam uma determinada profissão, de maneira que os cursos foram construídos baseados nessa perspectiva, por meio de um "processo de ensino no qual conhecimentos e experiências profissionais são transmitidos de um professor, que sabe e conhece, para um aluno que não sabe e não conhece, seguido por uma avaliação que diz se o aluno está apto ou não para exercer aquela profissão". Por via de consequência, os professores seriam aqueles profissionais renomados, com sucesso em atividades profissionais que eram convidados para "ensinar seus alunos a serem tão bons profissionais como eles", seguindo uma crença inquestionável

até bem pouco tempo, vivida tanto pela instituição que convidava o profissional a ser professor quanto pela pessoa convidada ao aceitar o convite: quem sabe, automaticamente, sabe ensinar. Mesmo porque ensinar significava ministrar grandes aulas expositivas ou palestras sobre um determinado assunto dominado pelo conferencista, mostrar, na prática, como se fazia; e isso um profissional saberia fazer.

Para a área do Direito, essa situação ainda é facilmente encontrada e o conhecimento pedagógico não aparece como requisito exigido, a não ser, quando muito, numa rápida demonstração em "prova didática", como já se mencionou, em concursos para ingresso na carreira (isso se existirem). 
De qualquer maneira, ainda que a formação pedagógica, por si só, não garanta a atuação docente isenta de problemas, a passagem por essa formação é um importante momento para agregar conhecimento apto a ser mais bem assimilado pela prática. Tal formação vai necessitar que o profissional mantenha-se atualizado ou pratique, sobre si, uma ação reflexiva, apta a ser alertado pelas necessárias reformulações de suas ações e do seu próprio conhecimento. Nenhuma formação garante absolutamente a qualidade do profissional, mas a sua existência pode proporcionar informações que certamente aquele que não se submeteu aos seus estudos não o terá. Daí a diferença substancial entre aquele que recebeu uma formação pedagógica daquele que a obteve por experiências de tentativas com erros e acertos: o olhar pode tender à desalienação muito mais entre o que tem oportunidades de conhecer melhor seu objeto daquele que não as tem.

De fato, a existência de uma formação continuada é uma importante ação a ser adotada em qualquer profissão, pois possibilita ao profissional que reveja seu conhecimento sobre a sua área de atuação como a sua própria prática no domínio e tratamento deste conhecimento. A dialética necessária entre o conhecimento do sujeito e as manifestações sociais são importantes para qualquer área, pois fomenta o progresso do conhecimento e sua evolução para outros patamares além daqueles já consagrados (cabe aqui a lembrança do espírito zetético anteriormente tratado, onde a capacidade de constante questionamento deve ser um padrão para qualquer sujeito que se diga profissional).

Como observam Mizukami et al (2002, p. 27), estudos realizados sobre a formação continuada, em especial os produzidos por Candau, demonstram que "a preparação dos professores, na grande maioria dos projetos realizados, tem sido pautada por uma perspectiva clássica que enfatiza a reciclagem desses profissionais, vista como atualização da formação recebida". Isso aponta para uma Universidade que assume um papel de produzir o conhecimento, cabendo aos professores sua recepção por via de cursos de diferentes níveis (aperfeiçoamento ou pós-graduação), para aplicá-lo, sociabilizá-lo e transpô-lo didaticamente, num modelo que precisa ser revisto.

Numa perspectiva crítica, tais estudos ressaltavam "novos caminhos para o seu desenvolvimento, deixando de ser reciclagem, como preconizava o modelo clássico, para tratar de problemas educacionais por meio de um trabalho de reflexividade crítica sobre as práticas pedagógicas e de uma permanente 
(re)construção da identidade do docente", sendo necessária a "articulação dialética entre as diferentes dimensões da docência: aspectos técnicos, científicos, políticosociais, psicopedagógicos, ideológicos e éticos-culturais", considerando "as diferentes práticas que ocorrem no âmbito escolar" (MIZUKAMI et al, 2002, p. 2829). Ainda que tais estudos tratem da formação continuada dos professores de ensino fundamental e médio, podem ser perfeitamente aplicados para o tratamento da formação docente no Direito.

Lançando-se o olhar sobre esta área, é certo ser possível encontrar um sujeito agindo na prática (docente) sem uma precisa noção sobre as implicações teóricas que sustentem suas ações, seja pela completa ausência de formação pedagógica, seja por uma formação prévia (pela participação num modelo clássico anteriormente apontado de ter realizado um aperfeiçoamento ou uma pósgraduação), sem a continuação dos estudos. Ainda que sob a visão educativa seja evidente que o conhecimento teórico do processo educativo (e sua revisão permanente) é fundamental, isso pode não ser tão claro para grande parte do corpo docente, muitas vezes altamente resistente em atividades que envolvam discussões pedagógicas em geral.

Durante aproximadamente por dez anos, atuando como coordenador de um curso de Direito, pude vivenciar inúmeras situações onde a resistência principal dos professores se justificava na noção primária de que tudo estava bem e que as discussões pedagógicas seriam apresentadas por professores estranhos à área (do Direito), os quais não teriam (aprioristicamente) conhecimento necessário para compreender a realidade do ensino jurídico. Diante disso, ou os professores de Direito boicotavam as atividades de formação continuada, ou compareciam dissimulando sua resistência para "cumprir uma obrigação", envolvendo-se o mínimo possível (ressalvadas as exceções, por certo).

Acrescente-se a este dilema o problema da própria formação anterior dos professores no plano pedagógico. Aqueles que não a tinham, por não imaginarem a importância de seu conhecimento, resistiam utilizando-se do argumento exposto, de que professores de outra área não sabem o que acontece no ensino jurídico. Aqueles que já possuíam um conhecimento prévio, acreditavam que já eram detentores do conhecimento suficiente sobre o assunto, não necessitando "perder tempo" com novas "divagações". 
De fato, há um fenômeno que aparentemente produz a expressão "ensino jurídico". Ela gera uma falsa noção de que os elementos que envolvem o processo educativo no Direito são diferentes de outras áreas. Há uma confusão entre o conteúdo do Direito e os fundamentos que explicam as ações docentes, abarcando questões psicológicas, antropológicas, sociais, interpessoais etc. São argumentos que reduzem o ensino do Direito ao conhecimento do próprio Direito, sendo esta uma prática reducionista muito comum que, por si, dificulta a inserção de conhecimentos voltados à própria Educação.

Assim, a formação continuada para o professor de Direito deve enfrentar essas circunstâncias de resistência, e certamente o envolvimento do professor em sua própria prática reflexiva contribui para superá-las.

Outro ponto de destaque que decorre dessa ausência de formação pedagógica é que ao enfrentar dificuldades no processo educativo, o professor de Direito muitas vezes conclui que a causa não está nele, mas sim no aluno. Em sua concepção, problemas de disciplina são sempre causados pelos alunos, sem que possa ter contribuído pessoalmente em algo para toda esta questão.

De certo modo, essa projeção também ocorre no tratamento do rendimento escolar. O discurso que aparece é algo como "se os alunos estão indo mal nas avaliações, a culpa é única e exclusiva deles", isso por conta de inúmeras justificativas como pouco interesse, descaso com o estudo, má formação anterior, exame vestibular sem qualificação etc. É muito difícil assumir a possibilidade - pelo professor de Direito sem formação pedagógica - que as causas de tais problemas possam estar presentes no próprio instrumento, nas concepções sobre sua finalidade e no próprio conhecimento do professor sobre o que é avaliar dentro do processo educativo. Isso também ocorre diante de situações de indisciplina, onde se atribui à classe ou a alguns alunos a culpa pela desorganização da sala quando, ao contrário, pode estar justamente nas ações do próprio professor, como bem lembra Antunes (2002a, p. 23-26).

A equivocada visão de que o ensino do Direito não necessita de informações da Pedagogia, por conta de sua "especialidade", despreza o fato de que a ação educativa compartilha dois grandes importantes conhecimentos: o do conteúdo a ser trabalho e do processo para realizá-lo. Toda ação educativa envolve conteúdos e procedimentos, daí a razão de se afirmar a existência de um processo de aprendizagem, ou como mais comumente afirmado, processo de ensino- 
aprendizagem, caracterizando-se, como aponta Libâneo (1994, p. 90-91), numa relação dinâmica e recíproca entre o ensino e a aprendizagem.

Insiste-se em ressaltar que as observações realizadas não atribuem a única responsabilidade do processo educativo ao professor, mas o que se pretende destacar é que, quanto mais há conhecimento sobre o processo educativo, melhor se pode compreender qualquer um de seus fenômenos. Em outras palavras, se o professor tem conhecimento teórico de sua prática, pode reconhecer muitas outras possibilidades em suas ações e feedback das mesmas, do que aquele que acredita ser suficiente apenas o domínio de um conteúdo para que o processo educativo funcione bem.

O que se coloca em atenção, portanto, é a importância de se conhecer a Pedagogia para que se permita ter olhares diferentes daqueles que não possuem as mesmas informações. E que essa diferença no olhar possibilite evitar erros ou, diante de problemas envolvendo o processo educativo, ter em mãos as diversas possibilidades de sua solução.

É importante lembrar, com Libâneo (1994, p. 28), que há quem acredite que a vocação natural ou somente a experiência prática, possa servir para garantir o desempenho satisfatório do professor em sala de aula, descartando-se a teoria, mas, ainda que seja verdade "que muitos professores manifestam especial tendência e gosto pela profissão, assim como se sabe que mais tempo de experiência ajuda no desempenho profissional", o "domínio das bases teóricocientíficas e técnicas e sua articulação com as exigências concretas do ensino, permitem maior segurança profissional, de modo que o docente ganhe base para pensar sua prática e aprimore sempre mais a qualidade do seu trabalho".

Houve um tempo (e talvez isso ainda se faça presente), que ser professor de Direito era um status e por conta dessa qualificação é que a docência era procurada. Assim, o profissional na área jurídica (advogado, juiz, membro do Ministério Público, delegado de polícia), no âmago da sua autoridade profissional somava a autoridade professoral e nessa soma, produzia-se (como ainda produz) um sentimento de competência transmitida, ou seja, a noção de que se sou competente de um lado (como profissional da área jurídica), sou de outro (como docente). Logo, justificável, mas de imperiosa revisão, a resistência pedagógica dos professores da área jurídica, que conciliam a sua função técnico-profissional da área à de professor. 
Somando-se este sentimento do professor à política de sua contratação baseada no falso pressuposto de que "um bom advogado, juiz ou promotor da região poderá se transformar em professor eficiente", muitos acabam sendo "jogados em sala de aula" para agir por "via da empiria". Assim, tais professores acabam sendo "improvisados, sem nenhuma percepção de sua missão de educadores, tornandose, com o tempo, discursadores que passam informações requentadas e repetitivas" (AGUIAR, 2004, p. 211).

Logo, a visão do professor de Direito sem formação pedagógica pode até concluir pela culpa dos outros diante dos problemas educativos, pois, quando há uma limitação na visão, consegue-se enxergar apenas aquilo que pode ser associado às informações existentes. Se o professor não reconhece explicações pedagógicas para o fenômeno que vive, só poderá concluir pelas experiências que já teve ou já ouviu, na maioria das vezes ausentes de explicações cientificamente estudadas (construídas pela contribuição da Pedagogia).

Assim, é importante compreender a separação existente entre o conhecimento da área de formação técnica daquele conhecimento envolvendo o processo educativo. Ser professor (de qualquer área) exige a combinação de ambos os conhecimentos e esta somatória estabelece possibilidades de maior eficácia aos resultados esperados, dentre as quais a formação educativa dos sujeitos participantes.

A ausência de formação pedagógica, portanto, não implica uma consequente incompetência profissional/docente do professor de Direito. Contudo, a formação pedagógica - e, principalmente, aquela advinda da formação continuada -, pode viabilizar que o professor reconheça as explicações teóricas das ações em que se envolve como docente, possibilitando tomadas de atitudes embasadas em argumentos que poderão produzir melhores resultados em suas ações. Assim, como toda aprendizagem, ter a oportunidade de conhecer argumentos, teorias, debates, reflexões, experiências, todas elas voltadas à explicação dos fenômenos que envolvem a Educação, pode ser um importante passo para que o ensino jurídico se edifique com bases sólidas, afastando-se do puro tecnicismo ou dogmatismo que the são tão incorporados. 


\subsubsection{A docência no ensino do Direito como profissão}

Tratando-se especificamente da figura do docente, cabe resgatar-se a visão profissional sobre esta função, que também se aplica independentemente de uma área de atuação.

Zabalza (2004, p. 107) tem um importante exemplo para se compreender a visão profissional docente, do qual podemos fazer uma analogia. Imagine-se, num primeiro momento, que dois profissionais da área do Direito, formados na mesma época, encontram-se dez anos depois e um deles afirme que, mesmo atuando como profissional da área do direito (um advogado, por exemplo), jamais fez qualquer outro curso; nunca voltou a estudar a área do Direito; jamais pegou um livro tanto para rever seu conhecimento ou atualizá-lo. Certamente, para o outro colega, esta informação seria espantosa e assim pensaria: como pode alguém ter a suposição de acreditar ser um profissional da área do Direito sem nunca ter voltado a estudar sobre o assunto? Provavelmente que uma pessoa não se pode auto-intitular profissional por tal limitação. No mínimo já deveria estar excluído do mercado de trabalho, dada sua desatualização evidente.

Pois bem, projete-se o mesmo exemplo a dois professores de Direito. Ambos, considerando-se profissionais da área, depois de dez anos atuando como docentes. Um volta-se para o outro e diz que durante estes dez anos que se passaram, jamais pegou um livro ou artigo na área de Educação para "atualizar" seu conhecimento sobre a docência e nunca fez um curso voltado à formação continuada de professor. $\mathrm{Na}$ esteira do que muito se vê na área jurídica, a resposta provável do colega seria "eu também!". Mas o pior de tudo seria se ambos olhassem para esta situação e achassem tudo normal e que ser um profissional docente é diferente de ser profissional da área do Direito (ou qualquer outra área). Talvez e mais provável, é que esse último diálogo sequer aconteça, porque normalmente só se coloca uma situação em discussão quando ela pode ser observada por um interlocutor. Se ambos (professores de Direito), sequer cogitam da importância pedagógica na sua formação profissional, por que estariam discutindo sobre isso?

Esperando-se que a existência e a resposta para este último diálogo sejam diferentes (e que ele aconteça sob um aspecto de autoconsciência), tem-se a possibilidade de perceber que o conhecimento científico da área da Educação é um fator importantíssimo para que a crise pedagógica do ensino jurídico possa ser 
revista. A pretensão de superação da crise atual não significa evitar crises futuras, mas o momento presente (e já repetido há algum tempo) tem apontado para um caminho de revisão. Aquele que recebe a qualificação de "professor de Direito" precisa assumir a responsabilidade decorrente deste enquadramento. A participação como docente demanda compreender a amplitude de seu papel no contexto da Educação, independentemente da área de sua formação superior, e isso exige estudos, revisões e um constante trabalho de compreensão dos fundamentos teóricos e profissionais da Educação. Manter-se alheio a esta responsabilidade é manter-se alienado de seu papel profissional e social, ensejando o risco de não cumprir o papel de educador, que passa pela vida das pessoas deixando caminhos de possibilidades que até então podiam não ter sido vistos pelo sujeito educando.

Muitas vezes, a autovisão sobre a profissão docência já é um problema. 0 simples fato de assumir a profissão de professor pode ser obstaculizado pela outra profissão exercida. Vasconcelos (2000, p. 36) relata um discurso que apareceu em suas pesquisas apontando neste sentido:

Quando perguntada a profissão desse professor (profissional liberal), a maioria, mesmo quando dedicava elevado número de horas ao exercício do magistério, não se intitula professor, indicando apenas sua profissão original. Nitidamente, tal atitude reflete evidente desvalorização de uma carreira. Ser engenheiro, advogado ou qualquer outra profissão liberal confere maior prestígio ao indivíduo, mesmo àquele que, exercendo exclusivamente a docência como profissão, segue não se intitulando professor.

Esse problema relativo à visão profissional extravasa o Direito e tem referência histórica, lembrando Imbernón (2006, p. 13-14) que o contexto social já a viu como uma "semiprofissão", tratando-se a docência "como 'profissão' genérica e não como ofício, baseada numa concepção simplista de que bastaria relacionar certo conhecimento formal com a capacidade de ensiná-lo, mas que não subsiste à complexidade do que é o magistério:

A especificidade dos contextos em que se educa adquire cada vez mais importância: a capacidade de se adequar a eles metodologicamente, a visão de um ensino não tão técnico, como transmissão de um conhecimento acabado e formal, e sim como um conhecimento em construção e não imutável, que analisa a educação como um compromisso político prenhe de valores éticos e morais (e, portanto, com a dificuldade de desenvolver uma formação a partir de um processo clínico) e o desenvolvimento da pessoa e a colaboração entre iguais como um fator importante no conhecimento profissional...; tudo isso nos leva a valorizar a grande importância que têm 
para a docência a aprendizagem da relação, a convivência, a cultura do contexto e o desenvolvimento da capacidade de interação de cada pessoa com o resto do grupo, com seus iguais e com a comunidade que envolve a educação. $O$ contexto em que trabalha o magistério tornou-se complexo e diversificado. Hoje, a profissão já não é a transmissão de um conhecimento acadêmico ou a transformação do conhecimento comum do aluno em um conhecimento acadêmico. A profissão exerce outras funções: motivação, luta contra a exclusão social, participação, animação de grupos, relações com estruturas sociais, com a comunidade... E é claro que tudo isso requer uma nova formação: inicial e permanente.

De fato, é ilusória a percepção de que a profissão docente é simples de praticar, na mera relação "conhecer-ensinar". Num paralelo com qualquer profissão jurídica, demanda da mesma forma o conhecimento de informações e sua interação com o ser humano, no que adentra num campo de inúmeras variáveis. Mas o grande "brilho" da educação consiste na busca constante da compreensão da natureza humana (incluindo-se a do próprio educador) e as possibilidades de sua (re)construção, as quais podem repercutir profundamente na própria prática do Direito em suas interações. Arrisco dizer que aprofundar o conhecimento dos elementos caracterizadores de uma profissão docente é agregar um importante conhecimento para a prática do próprio Direito. A humanização evidente nas relações educativas é de grande valia para uma melhor compreensão dos conflitos e dos seus efeitos nas relações sociais, através da qual um juiz, um advogado ou um membro do Ministério Público, poderiam interagir com o seu conhecimento técnico em prol de um Direito mais justo e concreto. Percebo estes efeitos na advocacia voltada para a área da Família, onde as interações decorrentes de uma relação educativa ficam tão evidentes.

Mas focando-se a questão especifica da docência no ensino jurídico, na medida em que se reconhecem os fundamentos para os procedimentos que adota para a docência, muitas coisas podem ser modificadas ou até mesmo melhoradas. Se o professor de Direito utiliza-se da aula expositiva principalmente, conhecer melhor sobre esta técnica, compreender os estudos envolvendo o processo comunicativo, as formas de inteligência que possam estar presentes em seus alunos, o funcionamento adequado de recursos audiovisuais, os elementos para que a aprendizagem seja mais bem proporcionada e até mesmo como deve ser operada a avaliação por conta de sua interação com os alunos, pode obter resultados muito mais precisos, proporcionando não somente uma melhor satisfação pessoal como 
também a satisfação de seus alunos (e mais amplamente, do cumprimento da função de uma Instituição de Ensino e a promoção da própria sociedade e do país).

Da mesma forma, colocando-se diante de uma situação inóspita dentro do processo educativo e reconhecendo a diversidade psicológica de um ambiente educacional e das pessoas em interrelacionamento, tem condições para poder enfrentar tais dificuldades, dando encaminhamentos por conta de experiências e estudos já desenvolvidos em situações semelhantes, pois como profissional, deve reconhecer e aprimorar seus instrumentos de trabalho.

É claro que o reconhecimento da docência como profissão vai muito além do reconhecimento de suas ferramentas. A consciência profissional desencadeia a valorização de sua própria atividade, a compreensão das exigências que a profissão exige em termos de organização, preparação, execução e qualidade nos resultados. O profissional não pode ser assim qualificado simplesmente por apenas pertencer a uma categoria (ainda que isso possa acontecer na prática). A descrição de um profissional deve agregar o valor de competente, que exige bem mais.

Para a compreensão dessa competência é importante invocar Rios (2006, p. 48), quando se a atribui ao somatório do saber e do saber fazer, conciliando o "domínio dos conteúdos de que o sujeito necessita para desempenhar o seu papel, aquilo que se requer dele socialmente, articulado com o domínio das técnicas, das estratégias".

As indicações de posturas e ações no presente estudo permitirão o reforço à conclusão dos elementos para que essa competência se opere, bastante, neste turno, vincular à noção de profissionalismo docente com a de competência, reconhecendo-se a amplitude de elementos fundamentais para a função de professor muito além do conhecimento técnico.

\subsubsection{O reconhecimento como educador e a valorização da aprendizagem}

Outro importante ponto de dificuldade para o ensino jurídico é o auto reconhecimento como educador. Pode parecer impressionante afirmar-se que nem todos assim se reconheçam, mas basta fazer a seguinte pergunta para profissionais que não tem formação pedagógica: o professor de ensino superior também é um educador? Muitas vezes, como resposta, o ar da dúvida fica evidenciado e surge a reflexão se além de proporcionar o ensino sobre tal conhecimento (da área), 
também se está educando (até porque, para quem não tem formação pedagógica, pode-se acreditar que a educação é proporcionada por valores trabalhados no ambiente principalmente familiar).

A educação, porém, não tem essa cisão a ponto de ser algo que acontece em determinados momentos da vida (como, apenas num ambiente familiar entre pais e filhos). A educação é um fenômeno que está presente em infinitos momentos, podendo assim ser classificados como fenômenos educativos quando proporcionam ao educando a visão de possibilidades de ação ou não. Em outras palavras, a educação proporciona possibilidades e isso pode ser adquirido por intervenção alheia ou pela autopercepção.

No papel da intervenção alheia, o processo de ensino se funde num processo de educação, na medida em que a ação do professor não afeta apenas o aspecto intelectual, como auxiliar à formação de um "senso de observação, capacidade de exame objetivo e crítico de fatos e fenômenos da natureza e das relações sociais, habilidades de expressão verbal e escrita etc". A ação do professor educa quando:

\begin{abstract}
estimula o desejo e o gosto pelo estudo, mostra a importância dos conhecimentos para a vida e para o trabalho, exige atenção e força de vontade para realizar as tarefas; cria situações estimulantes de pensar, analisar, relacionar aspectos da realidade estudada nas matérias; preocupase com a solidez dos conhecimentos e com o desenvolvimento do pensamento independente; propõe exercícios de consolidação do aprendizado e da aplicação dos conhecimentos. A realização consciente e competente das tarefas de ensino e aprendizagem torna-se, assim, fonte de convicções princípios de ação, que vão regular as ações práticas dos alunos frente a situações postas pela realidade. (LIBÂNEO, 1994, p. 99).
\end{abstract}

Nota-se que a ação educativa não é conciliável com a postura dogmática de se praticar um processo de ensino mecânico, onde o aluno apenas deve repetir 0 que o professor diz. Nessa atitude ocorre uma educação às avessas, na medida em que não se educa para a dependência e autonomia. Ainda que a consciência do papel de educador de um professor de Direito já se configure uma conquista inicial, é importante que o aspecto crítico acompanhe essa evolução, aproximando-se do que Libâneo indica como um ensino crítico, caracterizado por ser aquele que “implica objetivos sócio-políticos e pedagógicos, conteúdos e métodos escolhidos e organizados mediante determinada postura frente ao contexto das relações sociais vigentes na prática social (1994, p. 100). 
Não há dúvidas também que a compreensão da educação tenha suas intempéries. Como lembra Rohden (1998, p. 19), a educação se envolve em um grande paradoxo: o de que ninguém educa alguém, na medida em que o processo educativo não se opera de fora para dentro, mas sim ao inverso. Neste ponto, a educação só consegue ser realizada na medida em que o sujeito educando a autoriza. A educação só se efetiva se o educando permitir que ela se concretize.

Entretanto, tal afirmação não pode ser levada ao ponto de um nihilismo, anulando-se qualquer possibilidade de atuação do professor (ou mesmo concluir pela sua menor importância). Deve sim, servir de alerta para que o processo educativo envolva-se num ambiente favorável para isso. Este também é um fundamento do presente estudo, pois toca a questão da aprendizagem que, como se verá em capítulo próprio, é fortalecida pelo ambiente no qual está envolvido o educando e a ação do professor nessa percepção é de fundamental importância.

Fagúndez (2000, p. 45) bem observa que a verdadeira educação visa revolucionar o seu objeto sempre, trazendo uma nova proposta, sem impor métodos ou caminhos, permitindo sonhar, estimulando a criatividade sempre. Além disso, "a educação tem que proporcionar autonomia, despertando a consciência no estudante para que possa construir a partir de sua atitude uma vida melhor", de maneira que "não haverá ruptura se o processo educacional continuar a formar agentes do sistema, reprodutores da ideologia da classe dominante. A palavra de ordem é a auto-educação".

Desta maneira, a ausência dessa percepção como educador reflete nas conseqüências da responsabilidade que assume pelo papel exercido. O professor de Direito que vai à aula sem essa percepção, deixa de considerar os importantes efeitos que está produzindo nos seus alunos além daqueles que o conhecimento técnico pode produzir.

Outro ponto a se acrescentar, como de destaque para todo o problema pedagógico, é a questão do quanto o professor reconhece os elementos que envolvem a aprendizagem, que se efetua no plano do sujeito educando.

Como registra Vasconcelos (2000, p. 21), ao invés da "polarização existente, colocando de um lado o professor, como aquele que ensina, e de outro, o aluno que tem que aprender, dever-se-ia sempre pensar a Educação reunindo esses dois elementos-chave num único processo, o ensino-aprendizagem, equilibrando, na valoração de cada um, a importância de ambos". Ademais: 
De que adiantará um professor que apenas se preocupe com o ato de ensinar, transmitindo seus conhecimentos e experiências, em se inquietar com o fato de estar, ou não, o seu aluno aprendendo? Existe "ensino" onde não há aprendizagem? Este tipo de docente, preocupado exclusivamente com a "instrução", embora bastante freqüente ainda nas escolas brasileiras de qualquer nível de ensino, surge em completa dissonância com as necessidades e/ou aspirações de seu alunado.

Podemos acrescentar que além das necessidades pessoais do alunado, decorrem os efeitos sociais dessa atitude. Aluno que não aprende não é sujeito apenas à retenção em série. Ele pode, em escalada sofrida, mas possível, progredir nas séries e obter seu esperado diploma, deixando à sociedade os efeitos das lacunas de sua aprendizagem. Logo, a aprendizagem é um ponto de extrema importância e diretamente afeto ao presente estudo, pois o desconhecimento sobre os caminhos percorridos para sua realização muitas vezes levam ao equívoco na interpretação dos problemas encontrados.

A exemplo, esta questão da aprendizagem sempre aparece recorrente quando se trata das avaliações. Resultados ruins provocam sentimentos de frustração - com mais força no aluno, que se sente pressionado pelo risco da não aprovação. Um diálogo comum que aparece nessas oportunidades é algo como, por parte do aluno, a reclamação, e por parte do professor, a orientação para que se estude mais.

Neste sentido, quando o aluno efetivamente acreditou que havia estudado o suficiente, mas submetido ao instrumento de avaliação não logra êxito em demonstrar o conhecimento adquirido, resultará inconformado com esta situação, apresentando, assim, inúmeras causas para sua frustração (instrumento mal elaborado, ausência de didática do professor etc).

Caso, efetivamente, o instrumento de avaliação tenha superado os problemas que podem envolvê-lo, especialmente numa construção equivocada sem a interligação com o desenvolvimento de objetivos durante as aulas que agora (no instrumento) deveriam ser objeto de apuração (como num feedback pelo trabalho realizado), entre outros aspectos (IOCOHAMA, 2004a), é de se supor que ainda resta um problema a ser resolvido, que é o resultado não satisfatório do aluno.

Logo, quando o professor tem conhecimento sobre os diversos elementos que integram a aprendizagem, ao invés de o aluno receber como resposta à sua 
indignação pela nota obtida algo como "você deve estudar mais!" (resposta tradicional), a resposta do professor seria algo próximo a "como você estuda?". Só assim se pode imaginar o papel do docente coerente com a preocupação voltada para a aprendizagem e as ações adotadas pelo aluno, compreendendo amplamente o processo e não apenas o seu fim.

Um tema que necessariamente deve ser amplamente trabalhado - e que afeta substancialmente o aspecto pedagógico - é a própria aprendizagem, em seus elementos e princípios. $O$ professor que tem uma visão ampliada sobre esse momento do processo educativo adota atitudes preventivas para melhorar a aprendizagem no momento em que realiza sua intervenção, faz intervenções para saber se ela está perdurando (procedendo avaliações) e interfere a partir dos resultados a ponto de indicar outros caminhos.

De fato, as teorias do ato de aprender quase nunca são trabalhadas conscientemente pelo próprio aluno. Ele mesmo muitas vezes desconhece quais são as características e elementos da aprendizagem, acreditando que uma leitura é suficiente para que o conhecimento possa ser adquirido. Talvez em algum momento da vida escolar, caberia existir uma formação do aluno no sentido de como estudar. De regra, as pessoas acabam aprendendo empiricamente como estudar e isso nem sempre indica caminhos de uma aprendizagem eficaz. Às vezes, aprendem que estudar é repetir o que o professor diz, e como obtêm nota com isso, acreditam que esse pode ser o melhor caminho. Muito se perde quando não se entende como estudar e aprender e, às vezes, um professor pode ser tão útil ao aluno passandoIhe informações de como fazer isso quanto sobre o que estudar.

Para o Direito, que trabalha com leis, julgamentos e comentários doutrinários sobre eles, a tendência para o tratamento da palavra escrita é a leitura, levando à aparentemente lógica conclusão (mas falsa) de que basta ler para entender e aprender. Falha tão comum e que ainda muito se repetirá, dadas as perspectivas que o ensino do Direito aponta.

De outro lado, somente com estudos efetivos voltados à aprendizagem é que se percebe o quanto há nesta área para se compreender. A complexidade deste processo já indica que sua realização não se resume num ou noutro ponto, invocando estudos de diversas naturezas e áreas, de difícil esgotamento.

Nesta esteira, se o professor não passar pelo momento pedagógico de conhecer a construção do conhecimento pelas características da aprendizagem, 
pode perder esta importante oportunidade que é auxiliar o aluno nos caminhos que podem ser seguidos para que ele aprimore sua forma de conhecer e ampliar seu conhecimento. Ao invés do professor simplesmente "mandar" o aluno estudar mais, pode intervir de maneira a investigar as formas de estudo, e apontar técnicas e instrumentos que atuarão em prol da aprendizagem. Não é por outra razão que a expressão "facilitador da aprendizagem" tenha vinculação ao efetivo papel do professor no contexto da educação, em especial no que respeita às suas ações e experiências.

Encaixe-se nesta perspectiva a importante observação que Zabalza (2004, p. 169) faz, quando afirma que o "desafio da formação dos professores universitários (e dos professores em geral) é ter uma orientação distinta para sua função, é transformá-los em profissionais da 'aprendizagem', em vez de especialistas que conhecem bem um tema e sabem explicá-lo", deixando "a tarefa de aprender como função exclusiva do aluno, o qual terá de esforçar-se muito até conseguir assimilar, de fato, o que o professor lhe ensinou".

No mesmo sentido, quando trata da relação entre as aulas, a prova e a aprendizagem, Demo (2002, p. 44) afirma que a "maior contradição performativa dos professores e pedagogos" é que "não sabem aprender", tendo em vista que "se o objetivo maior fosse aprender, aula e prova seria apenas expedientes possíveis e secundários, jamais o centro da didática como ainda é hoje". Conclui que, na prática, "a questão central está em não saber colocar no devido lugar o que afinal é aprender", sendo que isto ocorre porque "professor e pedagogo não são profissionais da aprendizagem - como deveriam ser - mas do ensino", sendo coerentes, "até certo ponto, com a LDB, que é lidimamente lei de ensino", a exemplo da exigência de "200 dias de aula, acreditando que o aluno aprende tanto melhor, quanto mais aulas tiver". Daí é possível acrescentar, com Feldman (2001, p. 23), que o "maior desafio que se enfrenta hoje, do ponto de vista didático, não é resolver como ensinar, mas como ajudar muitos outros a ensinar".

Abreu e Masetto (1990, p. 5) observam que aos professores do ensino superior, falar-se sobre aprendizagem soa "como algo fora de tempo ou fora de moda", dada a visão dos professores de conceber a sala de aula como um ambiente os alunos têm expectativa de "conhecer os grandes mestres e especialistas nos assuntos e no ouvir suas brilhantes preleções, bem como saber de suas melhores experiências no campo profissional". 
Diante desta situação, há muito mais foco no ensino do que na aprendizagem, pois o significado de ensino se atrela a verbos como "instruir, fazer saber, comunicar conhecimentos ou habilidades, mostrar, guiar, orientar, dirigir - que apontam o professor como agente principal", enquanto o aprender está ligado à "buscar informações, rever a própria experiência, adquirir habilidades, adaptar-se às mudanças, descobrir significados nos seres, fatos e conhecimentos, modificar atitudes e comportamentos", apontando o aprendiz como agente principal (ABREU e MASETTO, 1990, p. 6). Destes dois focos, há que se buscar a valorização da aprendizagem, em razão da própria ideia original de todo processo educativo, que não deveria ser direcionado para enaltecer o professor, mas sim para propiciar a formação dos alunos.

Por isso, antes do "compromisso com sua disciplina, está o compromisso do docente com seus alunos, motivo pelo qual ele deve buscar fundamentos para poder servir como facilitador, fazendo o que estiver ao seu alcance para que os alunos tenham acesso intelectual aos conteúdos e às práticas de sua disciplina", de onde se justifica a denominada "dupla competência" dos professores, consistentes na "competência científica, como conhecedores fidedignos do âmbito científico ensinado, e a competência pedagógica, como pessoas comprometidas com a formação e com a aprendizagem de seus estudantes (ZABALZA, 2004, p. 169). Tal entendimento também é compartilhado por Périssé (2004, p. 19-20), quando propõe o desaprender para possibilitar que se esteja "aberto para enxergar o mundo de outra maneira", com uma "mente sempre indagativa, sem certezas construídas como verdades", desfazendo-se a noção de que "o papel do educador é ensinar e ser professor", para se transformar em "educadores-aprendedores, isto é, especialistas na difícil arte de aprender".

De fato, como alerta Masetto (1998, p. 12), o "mais grave (ainda hoje, em muitas faculdades e universidades brasileiras) diz respeito ao seguinte: não se têm consciência na prática de que a aprendizagem dos alunos é o objetivo central dos cursos de graduação e que nosso trabalho de docentes deve privilegiar não apenas o processo de ensino, mas o processo de ensino-aprendizagem, em que a ênfase esteja presente na aprendizagem dos alunos e não na transmissão de conhecimentos por parte dos professores", sendo que a figura de "repassadores de conhecimento" está em crise e já há algum tempo ultrapassado. 
De fato, como alertam Ausubel, Novak e Hanesian (1980, p. 12), o ensino não pode ser descartado da aprendizagem. Mesmo que ambos sejam distintos (alunos podem aprender sem ser ensinados, como autodidatas; e ensino eficaz, não garante que os alunos vão aprender, por outros motivos externos), não haveria lógica que justificasse essa visão separada, pois o "ato de ensinar não se encerra em si mesmo, pois a finalidade do ensino é o aprendizado por parte do aluno" e, "muito embora o insucesso na aprendizagem dos alunos não indique necessariamente a competência do professor, o produto da aprendizagem é ainda a única medida possível para se avaliar o mérito do ensino".

Desta forma, é possível se imaginar a importante contribuição que o ensino jurídico terá na medida em que o professor de Direito se reconheça como educador, assumindo efetivamente a responsabilidade que esta função tem no contexto amplo da sociedade e na formação individual de seus alunos, especialmente buscando compreender as tantas nuances que a aprendizagem possui para aplicá-la em favor destes.

\subsection{4 $O$ afastamento docente, a autoridade e a arbitrariedade}

Indicamos também a questão do afastamento docente como um ponto a ser tratado por ocasião das dificuldades pedagógicas que afetam sua ação, considerando este ato a demonstração de seu não envolvimento em situações que extrapolem o ambiente de sua aula.

Pensando sempre na ação do professor de Direito sem formação pedagógica (ainda que as hipóteses a serem tratadas não sejam excluídas do contexto de professores com essa formação), o afastamento que se destaca é o verificado na relação professor-aluno. Esse afastamento "aliena" o professor de importantes partes do processo educativo e merece destaque no presente estudo.

Num primeiro aspecto, o professor de Direito incorre no risco de considerar o seu afastamento como um elemento importante para buscar uma situação de imparcialidade, argumento de trânsito comum nos discursos jurídicos, que acaba invertido na relação educacional. Assim, ele age intencionalmente buscando o afastamento, com base na falsa noção de preservar a identidade e a distinção de sua postura no contexto do processo educativo. 
A imparcialidade, no meio jurídico, representa uma aproximação do sentimento de justiça, na medida em que não promove a desigualdade. Exemplo clássico é a imparcialidade que o juiz deve ter, fundamentada numa base democrática de um Estado de Direito, onde todos devem ser tratados de forma igualitária. É um discurso político-ideológico cujas falhas são facilmente apontadas, mas que se impregna na cultura do Direito como um instrumento de "segurança jurídica" (outra expressão passível de muitas críticas). A imparcialidade, em sua prática, promove um afastamento formalmente lógico. No âmbito de um processo judicial, diz-se que o juiz deve estar "equidistante das partes", de maneira a não tender pela proteção de uma em desfavor de outra. É um argumento para o não envolvimento evitando o risco de beneficiar um em prejuízo de outro.

Certamente que a cultura de conceitos que fundamentam as ações dos profissionais da área jurídica pode ser transportada para suas ações docentes onde novamente se projetam. Se há um reforçado discurso afirmando a necessidade de imparcialidade e de igualdade, como imaginar relações interpessoais num ambiente acadêmico que desrespeitem isso?

Este afastamento do professor muitas vezes é paradoxal: ele se recusa a olhar com mais atenção a manifestação de um aluno seu "desconhecido" (por conta de uma avaliação aplicada), mas antes corrigiu os instrumentos lembrando que um outro é filho do fulano de tal. Chega a realizar um controle de presenças pela chamada do número, mas visualmente sabe quem são seus "mais próximos". Defende os percalços pessoais de um aluno (conhecendo seus problemas pelo contato pessoal que tem por conta de alguma relação de amizade), mas despreza as dificuldades não reveladas por outro não tão conhecido. Essas e outras ações podem demonstrar que o fato de não se envolver com as situações pessoais que the são apresentadas no ambiente escolar pelo argumento da imparcialidade pode ser falho e incoerente.

Entretanto, assumir a importância dessa aproximação é um importante passo para uma ação educativa concreta, ressaltando-se, como constata Gil (2006, p. 40), a preocupação com o discente é assunto atualmente destacado por qualquer livro de Didática ou Metodologia do Ensino, ainda que se trate de um momento histórico recente, já que durante muito tempo "o corpo discente das escolas foi constituído por alunos provenientes de estratos sociais pouco diferenciados". No Ensino Superior havia "até mesmo identidade de gênero, pois os alunos eram do sexo masculino", o 
que foi modificado pelo processo de "democratização (ou de massificação) do ensino", quando se oportunizou acesso às "pessoas provenientes de outros estratos sociais, com interesses, motivações e heranças culturais diferentes e com competências e conhecimentos em diferentes graus de desenvolvimento", tornando inviável a "postura secular do professor de desenvolver sua atividade para um alunado típico".

Interessante observar que esta visão das diferenças nos discentes nem sempre é percebida pelo docente, e a conclusão do autor de que tal postura secular seria inviável na atualidade, acaba passando despercebida para muitos que não imaginam que conhecer o aluno faz parte da função profissional docente. Numa prática corriqueira, o professor de Direito passa pelas aulas muitas vezes sentindose sem a responsabilidade de ter que reconhecer a individualidade de seus alunos. Nota-se, muitas vezes, que o acesso ao professor e a relação dele com o aluno limita-se ao momento em sala de aula. Em muitos casos, o aluno não tem qualquer outro acesso que não seja este limitado momento.

É certo que a interferência provocada pela massificação da Educação Superior deve ser considerada, como observa Zabalza (2002, p. 182), a ressaltar que a expectativa de ingresso na universidade cresceu muito por conta da "contínua análise do acesso ao ensino superior como recurso de ascensão social", ultrapassando a antiga concepção elitista de ser um privilégio social para "poucas pessoas (normalmente provenientes da classe social média alta)", transformando-se em "aspiração plausível para camadas cada vez mais amplas da população", projetando-se tanto no sentido horizontal "(jovens de diferentes classes sociais e de diferentes localizações geográficas)", como também no "sentido vertical (indivíduos de diferentes faixas-etárias começam ou continuam seus estudos)".

Nesse plano da massificação, não se destaca apenas o aumento do número de alunos, mas também outras variáveis, que podem ser exemplificadas, conforme observa o referido autor (ZABALZA, 2002, P. 188-183), nas seguintes situações:

- na necessidade de atender a grupos muito grandes;

- na maior heterogeneidade dos grupos;

- na pouca motivação pessoal para estudar;

- na necessidade de contratar de modo precipitado novos professores ou de fazê-los iniciar no magistério antes mesmo de estarem em condições idéias para isso (estagiários, monitores, pessoal sem experiência docente nem preparação pedagógica); 
- no retorno aos modelos clássicos da aula para grupos com muitos alunos frente à impossibilidade de implementar um procedimento mais individualizado;

- na menor possibilidade de responder às necessidades específicas de cada aluno;

- na menor possibilidade de organizar (planejar e fazer o acompanhamento), em condições favoráveis, os períodos de prática em contextos profissionais.

Com efeito, a existência de turmas grandes já foi objeto de contínuas críticas, pelas repercussões provocadas no plano didático-pedagógico. Rodrigues (1995, p. 32) ressalta as dificuldades para a aplicação de técnicas de ensino diante da realidade "de salas de aula que possuem, em média, de 50 a 60 alunos (para não falar naqueles "amontoados" com mais de 100 estudantes em cada sala, existentes principalmente nos cursos particulares de São Paulo)". Este contexto massificado contribui para o afastamento das relações interpessoais entre discente e docente, mas isso também deve ser visto como um desafio a ser enfrentado, não somente por uma política educacional, mas também por meio de ações diversificadas, para que se busquem outras formas de desenvolver os estudos e a aprendizagem.

Ainda que a massificação exija novas posturas do docente - que não se pode abater por conta as diversidades que sempre enfrentou (por mais diferenciadas que fossem) - é certo que constitui uma variável a ser considerada (inclusive para o presente estudo).

Mas o afastamento docente pode também ter outras razões. Uma delas é a ausência de disponibilidade do professor por conta do tempo, utilizado para dar atenção às outras atividades profissionais, como juiz, advogado, membro do Ministério Público, professor de outras instituições, outras salas de aulas. Professores sobrecarregados de atividades podem não promover uma aproximação com seus alunos ou mesmo com as ações institucionais, por conta de não vencer o relógio e o calendário no cumprimento de suas funções formais.

De fato, por razões econômicas (entre outras), a pretensão de acumular diversas funções acarreta uma exigüidade de tempo para empreender ações inclusive as educativas. Exemplos na área do Direito desta ocorrência são professores que não dão aulas ou se atrasam por conta de viagens ou horários de audiências. Em quantas vezes professores avisaram já no horário de início das aulas que não compareceriam por conta do impedimento provocado por outra atividade profissional? E quantos alunos não tiveram que aceitar isso como desculpa 
para a não realização de aulas ou mudanças de planos de última hora sobre a atividade a ser realizada?

Não há dúvidas de que situações excepcionais (e muitas vezes imprevisíveis) podem ocorrer, que tolhem o tempo do professor a ponto de acarretar reflexos na condução de suas aulas. Mas a consciência pedagógica de todos os reflexos que isso produz no ambiente educacional exige especial atenção do docente sobre este problema. Quando esta consciência não existe prejuízos maiores são inevitáveis.

Outra consideração muito fluente no âmbito do ensino jurídico para promover o afastamento é a construção mitificada da figura do professor como naturalmente alguém inacessível, por conta da postura de autoridade que acarreta uma perspectiva de arbitrariedade quando se revela em atitudes hostis engendradas pelo próprio professor.

Destacando essa linguagem de poder que transita no ambiente acadêmico do Curso de Direito, Cruz et al (2007, p. 213) ressalta um certo tipo de docente que se blinda "pela máscara do terno e da gravata, pelo distanciamento imposto pelo tablado" e se enverniza "pelo discurso que exala os vícios da outra atividade profissional exercida (juiz, promotor, advogado, delegado de polícia...)", produzindo uma "docilidade conformista" no aluno, "que teme a figura do docente quando a vê em conjunto com a dupla autoridade, simbolicamente potencializada".

Ocorre que o professor pode trazer sua suposta autoridade para a sala de aula, desvirtuando-a para uma arbitrariedade decorrente da obscurecida visão de sua condição profissional fora da sala de aula. Esta, ainda que respeitada pela conquista de seu esforço, concursos e funções, não pode ser a simples razão de lhe produzir um poder de autoridade em sala, mediante a famosa frase (pelo menos até muitas vezes assimilada passivamente nos meandros da prática jurídica) de que “aqui, quem manda sou eu!". O suposto poder atribuído fora da sala de aula é teletransportado para o seu momento docente, quando se inspira a repetir o que faz na sua prática jurídica, confundindo respeito com temor reverencial.

Sem dúvida que a pedagogia do medo contribui para reforçar uma posição de autoridade que assume a forma de arbitrariedade. A utilização do "poder da nota" pode perfeitamente ser uma das armas do professor que se afasta das melhores orientações pedagógicas, conduzindo um terrorismo totalmente contrário ao Estado democrático de Direito que o ele mesmo prega durante suas preleções. 
Esse problema também pode ser bem maior do que apenas a relação professor-aluno. Kipper (2000, p. 66) destaca que essa "relação de poder inerente entre os principais sujeitos do processo de comunicação que existe no ambiente de ensino não se constitui "simplesmente de um saber/poder que perpassa unicamente entre um sujeito que sabe, finge ou aparenta saber e um que passivamente recebe e assimila esse conhecimento". A questão é bem mais complexa, projetando-se para um nível institucional, onde as "instituições político-sociais são as que efetivamente conduzem o processo, através da reprodução de mitos, arquétipos, que representam o conjunto de idéias/valores que querem que sejam devidamente reconhecidos e seguidos".

De qualquer modo, não se postula pela inexistência da prática de uma autoridade representativa do exercício de um poder em sala de aula. Paulo Freire (1996, p. 104) já alertava para o risco de se apontar um autoritarismo quando na verdade se tratava de um exercício legítimo da autoridade. É importante sim compreender os "limites sem os quais a liberdade se perverte em licença e a autoridade em autoritarismo", já que a "liberdade sem limite é tão negada quanto a liberdade asfixiada ou castrada", sendo certo que o "grande problema que se coloca ao educador ou à educadora de opção democrática é como trabalhar no sentido de fazer possível que a necessidade do limite seja assumida eticamente pela liberdade.

Não se pretende, em interpretação a contrario sensu, que o professor do ensino superior seja tão presencial como aquele do ensino fundamental. Nem se cogita também um professor invasivo, que desrespeita a intimidade do aluno. A ideia de autoridade expressada por Demo (1993, p. 140) é bem apropriada para este momento: ela não precisa se ancorar não "na distinção falsa entre alguém que ensina e outro que aprende, mas na competência superior, comprovada, visível do professor, frente a um aluno que está começando a vida acadêmica".

Uma interessante abordagem feita sobre as vivências na aprendizagem é feita por Madalena Freire (2001, p. 13) ao tratar do seu sentido dramático, adequado para esse momento de discussão sobre autoridade e autoritarismo e a importância do movimento que este assunto comporta:

Expressamos nossos desejos de morte também de outra maneira: quando sonhamos com um espaço onde não existem conflitos, nem diferenças, nada em desequilíbrio, nada em movimento, processo, 
transformação; tudo jaz na perfeita e absoluta calmaria do homogêneo massificado.

A rigidez, o sectarismo, a imutabilidade de idéias, pensamento e ação, retratam este estado.

A concepção autoritária, quando nega, castra a expressão do desejo do educando (e do educador), quando defende a passividade, a homogeneidade, quando doa mecanicamente o conhecimento, fazendo do educando um mero repetidor de conhecimentos e de desejos alheios ao que seu coração e inteligência sonham, educa para a morte. Pois desejo e criação foram soterrados.

Neste sentido, o autoritarismo é uma paixão triste, que produz medo, fatalismo, desesperança, cinismo, amargura.

Paixão alegre, desejos de vida, dão muito trabalho, porque gestados no conflito, nas diferenças, no heterogêneo, no desequilíbrio das hipóteses, no choque do velho e do novo, da mudança, na transformação, no enfrentamento do caos da ação criadora, na ação do imaginar, sonhar os desejos juntamente com os outros ("Um sonho que se sonha só, é só um sonho; um sonho que se sonha junto, é realidade").

Estar vivo é estar em conflito permanentemente, produzindo dúvidas, certezas sempre questionáveis.

Desta maneira, o contexto educativo deve ter espaço para as diferenças e o afastamento do professor não acaba sendo o melhor para sua atuação, ainda que Ihe traga um conforto aparente. A partir da compreensão que o professor tem da importância de se reconhecer e aceitar as individualidades, apesar de todas as dificuldades que isso representa, aprimora a relação educacional, com uma melhor compreensão da diversidade humana. Ademais, num processo comunicativo como o é o educacional, é imperioso que o professor compreenda os sujeitos que fazem parte da sua interlocução.

Gil (2006, p. 41) destaca que a obtenção de diagnósticos dos alunos é importante para reconhecer tais diferenças, e a definição de "objetivos de ensino, selecionar os conteúdos e determinar as estratégias de ensino", que, de regra, levam em conta certa homogeneidade da classe, pode ser aprimorada a partir deste levantamento. Mas, apesar de algumas escolas manterem um prontuário com informações, elas nem sempre são suficientes para propósito didáticos neste sentido.

De fato, acreditamos que é preciso haver um conjunto de ações entre professores e Instituição de Ensino para que esses levantamentos da diversidade acadêmica possam ser produzidos e tenham aptidão para também realizar a aproximação entre discente e docente. Esse pode ser um entre tantos passos necessários para a melhoria do ambiente educacional, mas, antes de tudo, precisa 
existir o reconhecimento do professor de que esta medida é importante para o resultado de suas ações.

Ademais, o ensino como acontecimento aponta uma singularidade na situação comunicativa em razão de constituir momentos únicos, tornando importante a consideração da vivência e do vivido, de maneira que a "definição da situação e a qualidade do acontecimento" dependerão "em grande medida da disponibilidade do professor em viver a comunicação presente, incluindo o diálogo com os participantes e o crescente conhecimento da situação de vida desses - tanto a social, relativa à cultura de modo geral, quanto a específica, referente à cultura escolar" (PENIN, 1996, p. 22).

Desta maneira, "viver em plenitude uma situação comunicativa" decorrente das interações entre o professor e o aluno e aprender com ela, "pressupõe que o profissional da cena não somente lance mão do conhecimento acumulado sobre a especificidade do acontecimento, mas também se disponha a inquirir a respeito do desconhecido ou do saber pouco rigoroso que rodeia tal situação", desconfiando também do saber já sistematizado, submetendo-o à prova a partir da realidade vivida" (PENIN, idem).

Assim, não há como se ignorar essas situações de afastamento por conta inclusive - do sentimento de poder desvirtuado, de maneira que o tema merece ser aventado, tendo em vista a importância da proximidade para o reconhecimento do sujeito-aluno no contexto educacional.

\subsubsection{A atividade docente na seleção das verdades e sua postura como fonte das informações}

Outro grande desafio a ser enfrentado na docência no ensino jurídico é saber o que ensinar, sob o risco de se estabelecer verdades que são apenas aquelas que atendam aos interesses visualizados pelo próprio professor. Nesse dilema do que ensinar, alguns problemas merecem destaque e reflexão.

Como já foi tratado no item 1.2, o Direito enfrenta a crise da sua própria significação, e muitas vezes, a ausência de um paradigma claro para a condução dos trabalhos educativos permite que o professor escolha a abordagem que lhe é mais conveniente e, dependendo de como seu discurso a afirmar, pode constituir um grande problema para o desenvolvimento do espírito crítico do aluno. 
O discurso docente, quando sustentando pela posição de poder (acumulando a figura do professor e status que carrega de outras profissões exercidas), tem a força de impedir reflexões críticas sobre o próprio conteúdo, muitas vezes repetido anos a fio sem uma concreta verificação de sua aplicabilidade e atualização. O ambiente autoritário de que antes se tratou promove nos envolvidos um sentimento muitas vezes inconsciente de dominação. Aceita-se a verdade do professor porque ela parte de uma autoridade assim considerada.

O argumento de autoridade para o estabelecimento de verdades é um problema muito comum no Direito, que afeta seus próprios profissionais. Criou-se no ambiente jurídico uma cultura que atribui veracidade à manifestação de um autor não pelas razões de sua exposição, mas tão somente pelo fato de se apresentar com uma suposta autoridade no assunto. O círculo vicioso deste tipo de conduta é que uma verdade acaba sendo apresentada porque um autor assim disse. Essa verdade é aceita por quem a escuta, especialmente numa relação de poder professor-aluno (ainda que o autor não seja o próprio professor). Este aluno, ao realizar seus estudos, produz pesquisa usando do mesmo artifício (repisando uma ideia baseada num autor e não nos seus fundamentos) e assim o discurso da autoridade se mantém.

Rodríguez (2010) tem um interessante estudo sobre o assunto, demonstrando os diversos momentos em que o argumento de autoridade pode ser invocado dentro do Direito, relacionando suas fragilidades, insistindo na sua deficiência, por dar mais valor à autoridade do que aos seus fundamentos (já que os fundamentos, por si, não são considerados). Logo, não é de se estranhar o fato de existir, num trabalho acadêmico na área do Direito, uma ideia que é apresentada porque alguém assim a disse, sem a investigação necessária de sua origem e pressupostos.

Num capítulo específico sobre o tema do argumento de autoridade, Demo (1995, p. 41), lembra que ela (a autoridade), embora em si mesma não represente argumento algum, produz um fenômeno constante "de que a evocação de certas autoridades desperta imensa respeitabilidade", alertando que talvez "seja um dos pontos mais infantis da produção científica o apego exagerado à crendice na autoridade, o substituto moderno e elegante da justificação dogmática, típica da abordagem teológica".

$\mathrm{Na}$ esteira dos problemas decorrentes do argumento de autoridade, Demo (1995, p. 46-50), ressalta a fragilidade da consciência verdadeira, estabelecida para 
justificar imposição autoritária de um discurso, que se faz predominar. Por isso, observa que onde "há muita verdade, há mais autoridade que ciência" e a intersubjetividade (compreendida como "a predominância de posturas reconhecidas como científicas apenas porque predominam"), justifica como possíveis e discutíveis dois momentos da presença do argumento de autoridade, formulados pela posição do perito e na obtenção/atribuição de prestígio, mas em ambas as situações não se pode estabelecer a figura em si como justificativa para conclusões definitivas. A especialização do perito deve estar pautada na sua competência (e não na sua pessoa) e o prestígio (decorrente da experiência), não poderia ser desvirtuada pelo seu abuso (abuso de competência, quando uma pessoa perita no ramo usa da ignorância de quem the pede assessoria para afirmar questões em proveito próprio; ou abuso de prestígio, para se fazer detentora de um saber pleno apenas pela fama que lhe é atribuída).

Projete-se este mesmo raciocínio, por exemplo, sobre um órgão do Poder Judiciário, que ao proferir seus julgamentos constrói um ambiente de hierarquia, por conta do raciocínio de que é o Poder Judiciário quem dá a última palavra sobre uma determinada interpretação. Logo, um posicionamento jurisprudencial também se constitui um forte "argumento de autoridade" (acrescente-se que o Supremo Tribunal Federal pode editar súmulas vinculantes, cuja força constitucional - art. 103-A consolida ainda mais esta autoridade). Certamente que a ciência jurídica corre o risco de se paralisar por conta de um conformismo de verdades emitidas por autoridades, mas o contexto formal acaba criando barreiras para outras conclusões, fazendo com que se termine aceitando um julgamento pela sua representação de poder, novamente prejudicando a capacidade crítica por conta de um conformismo sistematicamente imposto.

Esse sistema de ver o Direito por determinações de autoridades (lato sensu) pode incorporar de tal modo as ações do professor de Direito em sua prática jurídica, que a representa no contexto de suas aulas, reproduzindo verdades com críticas bem limitadas.

O sistema jurídico brasileiro acompanha o modelo romano-germânico, onde a fonte principal do Direito é a lei (GUSMÃO, 2000, p.112-113; FERRAZ JÚNIOR, 1995, p. 227; COELHO, 2003, p. 28; MONTEIRO, 2003, p. 12-13, GAGLIANO e PAMPLONA FILHO, 2006, p. 11 entre inúmeros outros). Com isso, tradicionalmente se realiza a aplicação da lei pelo método dedutivo (ZITSCHER, 1999, p. 27), o que 
também se projeta para outras formas representativas do Direito, como os costumes, considerados não pelo caso concreto, mas sim pela sua generalização.

De fato, o método dedutivo é caracterizado por partir de premissas enquadradas como verdadeiras para obter conclusões verdadeiras. Como afirmam Marconi e Lakatos (2009, p. 92), "os argumentos dedutivos ou estão corretos ou incorretos, ou as premissas sustentam de modo completo a conclusão ou, quando a forma é logicamente incorreta, não a sustentam de forma alguma".

Desta maneira, incide-se numa forte tendência a se praticar raciocínio dedutivo através de silogismos, onde a premissa maior é a lei (ou o direito que se presume existir) e a premissa menor é a situação objeto de análise, gerando uma conclusão a partir da interpretação dentro desta lógica. Certamente há inúmeras discussões sobre esse processo lógico de aplicação do Direito em diversos movimentos críticos (que postulam pela necessidade da revisão desse modelo positivista há muito tempo), mas o que se quer destacar é que essa forma de agir está na raiz das análises dogmáticas sobre o próprio Direito, gerando, inevitavelmente, reflexos nas ações de alguns (ou muitos) professores.

Por certo, este raciocínio tem efetivas projeções na forma como o professor conduz a abordagem de seus conteúdos e, mediante isso, estabelece raciocínios de verdades, colocando o método dedutivo como o instrumento apto a justificar suas conclusões. Logo, seus argumentos reforçam seus juízos de autoridade, atribuindo força a seus discursos de maneira a prejudicar a capacidade de análise crítica e reflexiva dos seus alunos.

De fato, como se demonstrou no primeiro Capítulo do presente estudo, há que se cuidar quanto ao conteúdo do que se estabelece como a premissa maior neste contexto de raciocínio tradicionalmente incorporado, pois dependendo do paradigma adotado para indicar qual é o Direito que se estuda e se ensina, seus resultados poderão ser entre a conclusão de uma (com a certeza dogmática de uma só aplicação ao resultado de método dedutivo) ou de várias possibilidades (com a certeza relativa/zetética elencada entre diversas soluções). Daí a importância de se tratar também do método indutivo para instrumentalizar o ensino jurídico com a abertura para outras possibilidades, como se destacará no último Capítulo, reiterando-se e ampliando-se algumas propostas ainda tímidas neste sentido, quando a revisão da postura do professor será de fundamental importância. 
Assim, quando o professor aparece com essas verdades estabelecidas, repetindo o discurso que vivencia sem uma perspectiva crítica sob o manto de sua autoridade, reforça a continuidade do discurso sem o incentivo de se questioná-las, numa lógica aplicada por conta de um método dedutivo nem sempre compatível com a dinamicidade que o discurso jurídico exige.

Logo, esse quadro é então "potencializado pela postura docente de representante do poder, por uma formação distante da compreensão de uma certa perversidade por trás de uma 'posição doutrinária', e por um perfil curricular que se estabelece em conteúdos estanques", abrindo caminho para as "peripécias do caráter lingüístico do Direito, cujo desvelar ainda não se anunciou na maior parte das escolas jurídicas brasileiras" (CRUZ et al., 2008, p. 215).

Acompanhado o movimento acrítico e confirmar de supostas verdades, é possível encontrar o desenvolvimento das aulas baseadas na análise gramatical das leis, na busca do sentido de cada um de seus artigos, incisos, alíneas e parágrafos. Algumas vezes, a jurisprudência e a doutrina podem aparecer sem serem especificadas, numa forma perversa de afirmar, implicitamente, que conhece a fonte, mas sem realmente demonstrar que isso é verdadeiro (o discurso do professor aparece invocando a "doutrina" ou "os doutrinadores", sem sequer mencioná-los, impossibilitando qualquer juízo crítico por quem o ouve, já que sequer tem a fonte do posicionamento apresentado). Acresceste-se a gravidade da atitude do professor em apresentar suas conclusões escolhendo adotar um ou outro posicionamento, muitas vezes omitindo divergências doutrinárias, exigindo que os alunos pensem da mesma forma que a sua. Quanto já não se viu de professores que, ao procederem avaliações, recusam respostas baseadas num ou noutro autor, sob o argumento genérico de não concordar com a posição por ele adotada (como se eles, professores, pudessem ter a certeza da verdade que escolheram).

Assim, como bem observam Cruz et al. (2008, p. 215), "fundado numa certeza de neutralidade do conhecimento jurídico, criada às pressas para revestir o Direito de segurança científica", o docente "converte seu discurso num amontoado de preconceitos, senso comum, ideologia e de elementos metafísicos ditos emanados da vontade de um legislador onipresente e onisciente, que imprime um espírito ahistórico à norma e independente contextualizações políticas e ideológicas".

Com isso, o grande e inevitável risco que se corre, pela prática docente, é acreditar-se no estabelecimento das verdades que se assumem sem ressalvar as 
possíveis outras verdades que as interpretações (inclusive jurídicas) possam permitir. Na cômoda manutenção de um posicionamento doutrinário aceito, pode estar escondida uma perversa maneira de se alienar os alunos das possibilidades que o próprio Direito permite, conjugando o exercício do poder e autoridade (muitas vezes consentido e assimilado por conta da cultura repetidamente existente) como forma de convencimento para o Direito estático, às custas de inevitáveis prejuízos incidentes na mentalidade crítica necessária para o futuro profissional.

Assim, por mais que as disciplinas tenham conceitos consolidados, a dinâmica que conduz o próprio Direito, em razão das relações sociais às quais se aplica, exige que se repense periodicamente as informações, confirmando a dialeticidade de seus efeitos. Essa dinâmica entre um direito consolidado e a necessidade de sua constante revisão não poderia produzir professores repetidores de uma informação escolhida de fontes doutrinárias ou jurisprudenciais rígidas (em suas verdades aceitas e propaladas). Porém, por conta da ausência de reflexão crítica (até pelas dificuldades que isso produz nas ações docentes para envolver os alunos nesse meio), tendem a conduzir para um comodismo que essa escolha suscita.

É ilustrativo pensar que há professores que ainda repetem suas aulas de uma forma idêntica há anos. Suas fichas de anotações, amareladas pela experiência do uso repetitivo, são a demonstração clara de um conhecimento que se consolida e permanece paralisado no tempo, e suas verdades se repetem como se nada mudasse, nem mesmo seus exemplos.

O processo de avaliação, neste plano, acaba sendo desvirtuado neste mesmo sentido. Na medida em que se constrói uma concepção de que a avaliação é aplicada para medir o quanto o aluno consegue repetir o que o professor disse, não há dúvidas de que esta suposta diretriz oriente o aluno ao que acredita ser o melhor caminho: repetir o professor é obter nota e se essa é a intenção principal, está na "direção certa". Até a noção de aprender estaria ligada a esta capacidade (MASETTO, 1998, p. 12).

Note-se que este sentimento é fundamentado pelo "mecanismo de promoção" que a avaliação possui, envolvendo interesse direto dos alunos, de seus familiares, da instituição de ensino, do sistema social e até servindo como forma de tortura, desviando-se mais para a qualidade de exames do que propriamente avaliação (LUCKESI, 2002, p. 18-20). Logo, pode interessar a todos (ainda que os resultados 
sejam falhos), que um discurso (que o professor escolheu) seja pregado e seguido. Cria-se, portanto, um processo de dependência que o aluno sente do professor, "nada fazendo sem que este oriente ou encaminhe" (RONCA e TERZI, 1996, p. 40).

Essas ações refletem, por certo, o senso comum de que o aluno é um ser dependente do educador desde o que deve aprender até o que deve responder, e a ausência de sua independência para a busca de respostas exige que se lhe dê "a 'certeza' sobre alguma coisa, a resposta pronta. O discurso seria como "se se dissesse que o educando 'não tem querer'; o seu 'querer' deve ser o do professor" e o critério de "certeza sobre a validade dos conhecimentos deve depender do critério do professor" (LUCKESI, 2002, p. 99).

A bem da verdade, essas situações confirmam uma forte tendência à centralização da figura do professor, tendo especial destaque pela cultura que há muito tempo se implanta no contexto das arcadas jurídicas. As ações praticadas pelos próprios professores certamente reforçam essa mentalidade (de que ele é o foco), retomando-se a abordagem tradicional, retratada pelo "processo ensinoaprendizagem que não se fundamenta implícita ou explicitamente em teorias empiricamente validadas, mas numa prática educativa e na sua transmissão através dos anos" (MIZUKAMI, 2007, p. 7).

Nesta espécie de abordagem, a relação professor-aluno "é vertical, sendo que um dos pólos (o professor) detém o poder decisório quanto à metodologia, conteúdo, avaliação, forma de interação na aula etc.", cabendo-lhe "informar e conduzir seus alunos em direção a objetivos que lhe são externos, por serem escolhidos pela escola e/ou pela sociedade em que vive e não pelos sujeitos do processo" (MIZUKAMI, 2007, p. 14). Assim, nessa perspectiva tradicional, o centro do processo é ocupado pelo professor, como exemplifica Masetto (1998, p. 12):

[...] as grandes preocupações eram que os professores fossem competentes, atualizados em seus conhecimentos e suas experiências, especializados, pesquisadores, produtores de conhecimentos, produtores de ciência e, nas aulas, transmissores desses conhecimentos e avaliadores (isto é, verificadores) do aprendizado dos alunos.

Portanto, compreendendo seu papel dentro do processo educativo, o professor certamente não chamaria para si a responsabilidade de toda a fonte do conhecimento, estabelecendo verdades a serem seguidas acriticamente. $E$ a revisão dessa conduta precisa ser resgatada, a ponto de não construir obstáculos à 
aprendizagem necessária, invertendo seu papel para direcioná-lo no caminho de efetivo colaborador para o crescimento individual e social de seus alunos.

\subsection{As dificuldades decorrentes do corpo discente}

Como já se frisou, é importante reconhecer que a responsabilidade sobre o adequado funcionamento do processo ensino-aprendizagem não depende apenas das ações que o professor empreender. Tratando-se efetivamente de um processo, a Educação se desenvolve pela intervenção de diversos sujeitos, cada um com o seu respectivo papel, mas também se entrecruzando em causas, efeitos e interesses.

A participação discente tem sua importância já mencionada, na medida em que sem a sua presença (física ou em termos de objetivo), não há ação docente que importe, considerando-se que o processo educativo tem seu destino na formação de cada sujeito, perdendo sentido se não foca este objetivo.

Certamente o tema é mais complexo do que estas palavras recém lançadas. A posição discente (ou de educando) não se separa do professor (de sua própria pessoa), quando este age como docente (educador). Ao se propor agir como professor, o sujeito também faz sua auto-reflexão, realiza seus próprios estudos numa ação autodidata que o coloca ao mesmo tempo na posição de discente e docente. É docente para os outros e discente para si mesmo, porque não se deve esquecer que a aprendizagem pelo autodidatismo ocorre nestas ocasiões (envolvendo o conteúdo a ser tratado em suas aulas).

De fato, esse raciocínio já foi bem observado por Freire (1996, p. 23), quando afirma não existir docência sem discência, pois as "duas se explicam e seus sujeitos apesar das diferenças que os conotam, não se reduzem à condição de objeto, um do outro", de maneira que quem "ensina aprende ao ensinar e quem aprende ensina ao aprender".

Mas, provavelmente o já citado grande paradoxo de que "ninguém pode educar alguém" pode ser considerado a premissa básica para se compreender a importância do discente neste contexto educativo e para o próprio objeto deste estudo. Se "a única educação verdadeira é uma auto-educação, que é totalmente individual", sendo "essencialmente intransitiva, ou reflexiva, subjetiva", com destaque ao livre-arbítrio, como afirma Rohden (1998, p. 19-20), não há dúvidas de que o 
papel docente estaria ligado a indicar o caminho para a auto-educação, sem qualquer certeza de que tal caminho será seguido.

É importante reconhecer este livre-arbítrio do educando - sem desprezar a importância do professor - para se compreender que um resultado para o processo educativo não é garantido apenas pela prática da "melhor" didática ou do emprego da "mais adequada" técnica. O conceito de "melhor" ou da "mais adequada" depende da variável que é trazida pelo sujeito discente. Logo, reconhece-se que a problematização e as propostas que o presente estudo lançam não garantirão que o ensino jurídico será absolutamente eficaz, mas se tem o consolo de que provavelmente ainda não existe fórmula apta a garantir sucessos na Educação sem a intervenção pessoal do próprio sujeito educando.

Da mesma forma, este tópico do estudo não procura esgotar o tema das dificuldades enfrentadas pelo ensino do Direito produzidas a partir do foco no discente. A pretensão é justamente voltada a demonstrar que o aluno não pode ser ignorado dentro desta análise, mas, pelo contrário, merece registro específico na medida em que constitui sujeito principal, pois sem ele não haveria razão para as tantas inferências e estudos objetos de estudos na área da Educação. Mas também neste plano, não pode ser mero objeto passivo de cuidados e atenção e sim sujeito que também precisa agir em prol de seu próprio bem e da capacidade de evolução social que se espera desse processo educativo, onde a intervenção do professor deve ser caracterizada pela capacidade de mediar o processo de assimilação de outras formas de conhecer.

Esta conclusão pode ser acrescida de importantes observações feitas por Luckesi sobre o tema, na concepção de quem é o educando:

[...] o educando não deve ser considerado, pura e simplesmente, como massa a ser informada, mas sim como sujeito, capaz de construir-se a si mesmo, através da atividade, desenvolvendo seus sentidos, entendimentos, inteligência etc. São as experiências e desafios externos que possibilitam ao ser humano, através da ação, o crescimento, o amadurecimento. $O$ mundo externo exige uma ruptura com a condição existente, sem suprimir todos os seus elementos. Há uma continuidade dos elementos anteriores e, ao mesmo tempo, uma ruptura, formando o novo. [...]

O educando é um sujeito que necessita da mediação do educador para reformular sua cultura, para tomar em suas próprias mãos a cultura espontânea que possui, para reorganizá-la com a apropriação da cultura elaborada. (1994, p. 118) 
De fato, "o educador deve estar atento ao fato de que o educando é um sujeito, como ele, com capacidade de ação e de crescimento - e, por isso, um sujeito com capacidade de aprendizagem, conduta inteligente, criatividade, avaliação e julgamento" (LUCKESI, 1994 p. 119) e, reconhecendo as diferenças e a possibilidade de interferências como as que ora se relaciona, pode melhor intervir para que o resultado das ações educativas possa atingir efetivamente seus objetivos.

Apresentadas estas considerações básicas, é importante também reconhecer que há muitas variáveis que decorrem do corpo discente, seja na particularidade de cada indivíduo, seja do próprio grupo constituído. Destacam-se alguns destes pontos nos próximos subitens.

\subsubsection{A ausência de conscientização sobre os objetivos pessoais profissionais}

Num plano individual, cada sujeito que se submete ao ensino superior precisa encarar o desafio e a responsabilidade de saber efetivamente o que quer para seu futuro pessoal e profissional. A pressão exercida sobre o momento do vestibular, as cobranças para a escolha de um Curso, a pouca idade, a ausência de orientações vocacionais e o reconhecimento sobre as possibilidades que cada área fornecerá para sua vida futura produzem momentos de angústia pessoal que pode refletir no desempenho da aprendizagem.

Por certo, é possível detectar um nível de alienação do aluno que se sujeita a fazer um curso superior sem necessariamente compreender o seu papel neste contexto. Muitas vezes sua presença é uma verdadeira ausência, diante dessa não compreensão.

Aproveitando-se da experiência com alunos de Direito, em especial com alunos do segundo ano, temos adotado uma prática de indagar se naquele ponto do Curso já têm uma expectativa da profissão que irão exercer, dada a ampla possibilidade de escolha em face das diversas carreiras. Para sermos mais provocativos, reduzimos uma proposta de reflexão, perguntando se algum aluno pretende advogar. A partir de tal questionamento, propomos a seguinte raciocínio: se há intenção de advogar e têm ciência que irão fazer um Exame de Ordem para ingresso na advocacia, perguntamos se alguém já consultou alguma prova deste concurso, mesmo estando no segundo ano; aproveitamos, ainda, para perguntar se 
eles acreditam que alguma matéria do primeiro ano pode ser objeto de tal Exame de Ordem e continuamos o raciocínio perguntando se as respostas seriam válidas para outros anos também.

É interessante perceber que na medida em que tais perquirições são feitas, muitos alunos observam que o momento para se preparem para concursos futuros já devia estar iniciado e que procurar reconhecer suas escolhas o quanto antes pode proporcionar seguir o curso com objetivos e metas mais claras. É possível notar a experiência com um pequeno processo de desalienação, despertando as possibilidades aos alunos que ainda não pararam para refletir sobre o tema.

Por certo, é essa alienação que permeia muitos cursos (e certamente não só o do Direito), na medida em que os sujeitos olham levianamente as suas possibilidades profissionais (que aparecem num momento futuro e aparentemente tão distante). Já de plano, muitos demoram a ter uma melhor noção sobre as tantas possíveis carreiras que o próprio Curso de Direito permite, em suas subdivisões de cargos e funções, vivenciando apenas a frágil percepção de que escolherá entre ser advogado, magistrado, promotor de Justiça ou delegado, esquecendo a quantidade de outras subdivisões que essas funções podem ter (Advocacia privada ou pública, Magistratura estadual, federal, do trabalho, da justiça militar, Ministério Público estadual, federal - da República, do Trabalho, da Justiça Militar, delegado estadual e federal), sem contar as tantas outras carreiras que o bacharelado em Direito viabiliza.

Em sua grande maioria, os alunos até vivenciam algumas dessas noções sobre as possibilidades profissionais, mas postergam sua escolha para momentos futuros de tal maneira que só começam a estudar para um concurso depois que obtêm seu diploma, numa conduta paradoxal.

Se todos os alunos tivessem plena consciência das escolhas para seu futuro profissional e compreendessem os resultados futuros de suas ações imediatas, certamente que o desenvolvimento do processo ensino-aprendizagem teria outra formatação. Trabalhar com alunos plenamente motivados (pelo reconhecimento do que pretendem para suas próprias vidas) produz circunstâncias extremamente propícias para resultados mais eficazes. Há, porém, vários pontos que tocam estas últimas afirmações.

Poder-se-ia questionar se a escolha de um curso superior só pudesse ser feita por quem demonstrasse vocação para a área. Será que realmente o direito de 
escolher o curso deveria estar condicionado ao momento prévio de orientação vocacional? Estabelecer esta exigência poderia contribuir para resultados satisfatórios no nível pessoal (para que cada indivíduo não corresse o risco de se frustrar com sua escolha) e também no plano educacional mais amplo (com menor evasão, resultados mais rápidos e de maior qualidade na formação profissional)?

Parece-nos que condicionar a escolha de um curso a uma vocação apontada por análises psicológicas anteriores não seria razoável no plano da obrigatoriedade, mas seria recomendável pela capacidade de realizar uma orientação apta a esclarecer detalhes que muitas vezes o sujeito só conhecerá depois de iniciado o curso. Não é por menos que existe proposta de projeto de lei para tornar este teste vocacional obrigatório, pretendendo-se alterar a LDB com o seguinte teor (BRASIL, 2010a):

Art. $1^{\circ} \mathrm{O}$ art. 35 da Lei 9394 , de 20 de dezembro de 1996, passa a vigorar acrescido do seguinte parágrafo único:

"Art. 35 [...]

Parágrafo único: Os estabelecimentos de ensino públicos e privados deverão oferecer orientação vocacional e profissional aos alunos do ensino médio."

É claro que nenhuma orientação vocacional, devidamente realizada, tem o condão de estabelecer um único caminho ao indivíduo. Longe de traçar soluções únicas, a orientação vocacional deve constituir num mecanismo de apoio para essa amplitude de visão sobre suas qualidades proeminentes, sem que o resultado possa ser considerado a palavra final sobre o seu futuro.

De qualquer maneira, inexistindo um processo prévio que permita ao futuro aluno de um curso saber com mais detalhes como ele ocorrerá, pode acarretar que este sujeito encare uma situação de frustração, que repercutirá na qualidade da educação a ser proposta. Nesse tempo de divagação sobre a certeza ou não da escolha feita, o aluno tende a perder em qualidade do aproveitamento de seu curso. Por isso, um grande desafio a ser enfrentando é promover condições para que o aluno possa compreender melhor as possibilidades de seu curso e despertar, 0 quanto antes, para uma utilização dos recursos educacionais com mais qualidade diante das oportunidades que lhe são dadas.

Diante de todo este contexto, inevitável é o reflexo no plano da motivação, que é essencial para a realização da aprendizagem. Ainda que o assunto seja objeto de abordagem específica (Capítulo 4, item 4.3), é importante reconhecer que o 
elemento "motivação" está ligado com a percepção que o aluno tem de seus objetivos e metas. Quando não tem consciência do que está realizando para seu futuro pessoal ou profissional, há uma inevitável tendência de que essa insegurança se projete nas suas ações dentro do processo educativo.

De um modo em geral, "a motivação é o conjunto dos mecanismos biológicos e psicológicos que possibilitam o desencadear da ação, da orientação (para uma meta ou, ao contrário, para se afastar dela) e, enfim, da intensidade e da persistência: quanto mais motivada a pessoa está, mais persistente e maior é a atividade" (LIEURY e FENOUILLET, 2000, p. 9). Logo, parece evidente que a alienação que afasta a compreensão do discente do contexto em que está inserido repercurte na execução de uma parte fundamental do processo de ensinoaprendizagem.

Há que se acrescer que o despertar para o curso também pode ser promovido durante a sua própria realização e que essa motivação desabroche diante da realidade vivida no âmbito acadêmico. Nada impede que aquele aluno que não reconhecia claramente suas intenções profissionais venha a desenvolver o apreço pelo curso diante das perspectivas que the são apresentadas e muitos fatores podem contribuir para isso, somados ou não, como a qualidade apresentada pelo ambiente físico e didático-pedagógico, dos professores envolvidos, dos funcionários entre outros. Ainda que se trate de elementos para uma motivação extrínseca (que vai depender efetivamente da motivação intrínseca para se concretizar - conforme será estudado no Capítulo citado), são fatores que devem ser lembrados como importantes para o ambiente acadêmico e a progressão da motivação discente.

Pode ocorrer o que alerta Aguiar (2004, p. 207), ao relatar que os estudantes, quando iniciam o curso de direito, "em grau maior ou menor, estão abertos para o encanto, a transformação e o inesperado, mas a monotonia, a linearidade e o texto, que marcam nossas faculdades, as lacunas formativas e informativas vão amortecendo seus sensos utópicos, embotando suas capacidades de sonhar e limitando seus horizontes existenciais e profissionais". Serve de alerta o quanto o ambiente acadêmico pode operar em prol ou contra a qualidade do profissional que se irá formar.

Alunos motivados poderiam provocar mudanças nas ações docentes, na medida em que se exigiria do professor conhecimento atualizado e apto a conduzir os questionamentos que surgiriam. Professores desqualificados não se sustentam 
perante alunos questionadores, salvo se utilizarem das infelizes fórmulas decorrentes da pedagogia do medo e se estiverem apoiados por coordenações pedagógicas incompetentes (o que a médio e a longo prazo vão produzir efeitos inevitavelmente devastadores).

Mas é certo que alunos motivados buscam o conhecimento que está além da sala de aula, em concursos já aplicados, em estudos produzidos por meios impressos e eletrônicos, tendo a aula como mais um elemento a acrescentar para sua estrutura de aprendizagem. Se o que o professor faz está longe de contribuir para seus objetivos, a tendência é que esses alunos cumpram apenas as suas obrigações, joguem o jogo proposto pelo professor e passem por eles muitas vezes até esquecendo seu nome.

Por outro lado, há os alunos que, confusos em suas pretensões, acabam enquadrando-se num papel de comodismo, mantendo-se inertes e agindo mediante provocações. Deixam de assumir a parte que lhes cabe no processo educativo para buscar outras fontes. Acabam até mesmo apreciando o tipo de professor clássico, entendido como aquele que não tem hábito de levar os alunos a pensar sobre o que estão aprendendo, dando respostas prontas ou até ignorando o problema (LIBÂNEO, 1994, p. 105).

De fato, um efeito da ausência de motivação é o incômodo decorrente da necessidade de ações pessoais. Muitos alunos se incomodam quando têm que tomar atitudes, porque isso Ihes faz sair da zona de conforto, muitas vezes mantida por não encontrar razões para sair de sua inércia. É tão cômoda a situação de segurança em se manter na posição de expectador, que não é difícil encontrar alunos e professores conjugando um mesmo sentimento de que usar o ditado para as aulas de Direito é algo perfeitamente normal (e seguro, porque o professor supostamente não erra o que dita e os alunos não errarão no que estão anotando assustadoramente equivocado), além de ser bem mais fácil para ambos os lados, no plano imediato. E, causando espécie, não é de se duvidar que os comentários que seguem os ditados repitam o seu conteúdo em outras palavras e, desde que não se exija nas avaliações algo diverso, tudo está bem.

Esses desvios que a ausência de motivação pode provocar acabam se enquadrando no ambiente que Cruz et al. (2007, p. 213-214) anotam, quando retratam que "é quase impossível ver manifestações de indignação, de discordância expressa, de revolta, contra o discurso do lente catedrático: a reverência hierárquica 
e a pedagogia do medo são regra. Ao mesmo tempo, por ser temido, o docente que se enquadra neste perfil é também respeitado e admirado, inclusive no comportamento arrogante, que vai amoldando, paulatinamente, a formação de bacharéis prepotentes."

Assim, entre ações docentes que ensejam a passividade e a ausência de conscientização sobre as expectativas e necessidades de sua formação acadêmica, é preciso que se dê atenção ao direito do discente de compreender suas possibilidades e responsabilidades, ampliando seu envolvimento.

\subsubsection{Os efeitos da formação anterior}

É importante reconhecer que a formação prévia do aluno que chega a um curso superior pode ter sofrido pela precariedade crítica que muitas vezes é percebida no momento de formação até o ensino médio.

Aguiar (2004, p. 15) destaca a dificuldade de se encontrar alunos renovadores, na medida em que são frutos de "ensino fundamental e médio problemático e decadente, onde os professores não são reciclados, onde tanto as escolas públicas como privadas pouco apresentam de novo, e onde o prazer do texto, a alegria de pesquisar, a inquietação da curiosidade e o desejo de participar da sociedade passam longe das cabeças e corações dessas entidades tayloristas, pouco atraentes e sem viço" e em se tratando do curso de Direito (como ocorre em outros que se assemelham pela forma de lidar com a comunicação), a motivação do aluno também pode ser abalada pela qualidade de sua formação pessoal até então produzida, pelos obstáculos enfrentados, a exemplo do seu próprio vocabulário.

Neste mister, é possível perceber que a grande maioria dos alunos de Direito "adentram nos cursos com vocabulário pobre, com um universo linguístico que transita no mundo da palavra para o da imagem, o que demonstra carência de leituras e exposição excessiva à televisão". Logo, quem tem "vocabulário pobre, e pouco lê, vai desembocar na procura das fórmulas feitas para enfrentar questões jurídicas, vai copiar, no lugar de criar, vai ter pouca habilidade de entender o mundo que cerca a questão tratada, os elementos que a compõem e as alternativas de resolução dos problemas que apresenta" (AGUIAR, 2004, p. 207-208).

De fato, esta dificuldade certamente redunda em problemas na aprendizagem e resultados negativos na avaliação, o que, por consequência, opera em sentido 
contrário ao estímulo no prosseguimento dos estudos e no seu aprimoramento, constituindo um grande desafio que muitas vezes acaba não sendo assumido no ensino superior. É muito comum ouvir-se o discurso de que o problema da má formação na língua portuguesa e no vocabulário é causado pelos anos escolares do ensino fundamental e médio (o que de regra pode ser verdadeiro). Por conta disso, o raciocínio seguinte é que se o aluno ingressou pelo vestibular, ele (o vestibular) não foi "adequado" para impedi-lo e agora não será o professor (do ensino superior) quem deverá resolver o problema. Já presenciei reuniões acadêmicas que, inicialmente organizadas para discutir ações pedagógicas, esgotavam-se sem tocar no seu ponto principal, obstaculizada pelos fervorosos debates em relação à qualidade dos alunos ingressantes (ainda que o problema não fosse generalizado). E o mais frustrante era observar o discurso de que esse problema não era culpa do professor (no que até se concordava) e que nada mais se poderia ser feito pedagogicamente sem resolver isso antes (com o que se indignava).

É bem verdade que o processo de seleção tem importantes efeitos na qualidade do corpo discente e do próprio desenvolvimento do Curso. Há uma grande diferença entre receber alunos altamente qualificados pela formação anterior elitizada daqueles com formação obtida as duras penas, causada por inúmeros fatores. Souza (2002, p. 13), destaca, neste sentido, que "quanto mais precisa for a convocatória de candidatos, selecionados psicologicamente segundo suas mais fortes tendências de estudo e profissionais, maior será a certeza de homogeneidade das turmas a possibilitar aos dirigentes escolares a adequação dos programas às exigências e expectativas dos grupos que ingressam". Porém, acrescenta que:

[...] as Faculdades serão o que forem os cursos colegiais, ou seja, as Faculdades não recebem a clientela que desejam, mas aquela que se produz anteriormente. E como a escolha da Faculdade é liberdade dos colegiandos, resulta que nas escolas superiores da intelectualidade social se fará sempre presente, pela média, em vista da diversidade de formação escolar no segundo grau.

Sem dúvidas que o problema da má formação anterior do aluno que ingressa no curso superior incomoda, pois produz muitas interferências na condução do processo educativo, mas não pode ser simplesmente um fundamento para uma solução nihilista (deixar de se fazer algo por acreditar que nada há de ser feito). 
Parece-nos que faz parte da ação docente o conceito de resiliência, que é justamente agir sob quaisquer condições e diante das mais difíceis circunstâncias.

De fato, a resiliência pode se aplicada tanto à vida humana e animal, e "representa a capacidade de resistência em condições duríssimas e persistentes e, dessa forma, diz respeito à capacidade de pessoas, grupos ou comunidades não só de resistir às adversidades, mas utilizá-las em seus processos de desenvolvimento pessoal e crescimento social" (ANTUNES, 2003, p.13).

$\mathrm{Na}$ verdade, o estudo da resiliência vai muito além do mero problema que ora se apresenta, envolvendo dificuldades na formação anterior ao ingresso no Ensino Superior. Entretanto, é importante que se registre essa capacidade de se desenvolver os agentes envolvidos com a Educação, mesmo diante das piores condições, transformando obstáculos em desafios. llude-se o professor se acredita que a questão da formação anterior é um dos piores problemas a serem enfrentados na Educação, bastando abrir os olhos para quantas dificuldades são enfrentadas nos lugares mais ermos de nosso país.

De qualquer maneira, é importante este registro da má formação anterior, por fazer parte da complexidade que é o "ser discente" no plano do ensino superior atual, em especial o jurídico. Como uma questão de política pública, precisa constar da pauta de problemas a serem enfrentados no plano macro da Educação no Brasil, pois não é apenas o Curso de Direito que sofre com essa situação. Isso não descarta ações educativas promovidas pelo próprio professor com apoio da Instituição de Ensino Superior, por certo.

\subsubsection{A ausência de interação discente-mundo}

É possível ainda se destacar a crise envolvendo o discente por conta de seu afastamento das interações interpessoais, não somente no que diz respeito ao docente, como já tratado, mas pela sua compreensão do outro e também da diversidade humana, conhecimento este que lhe será fundamental para o convívio pessoal e profissional.

Neste ponto, Aguiar (2004, p. 205) tece importantes considerações que afetam particularmente o universo discente do aluno de Direito, a começar pela predominante ausência da tematização no âmbito da ética, considerando que a "escola não tem condições para isso, as famílias, envolvidas em sua luta pela 
sobrevivência, não discutem o tema e não refletem sobre as injustiças, os problemas e as tensões que envolvem pessoal e coletivamente os cidadãos".

Interessante observar que se num momento anterior falávamos da alienação do discente para com seus próprios objetivos e metas, aqui a alienação se apresenta como forma de afastamento das circunstâncias que envolvem o "outro", onde a ética tem suas projeções. Logo, aproveitando do que menciona o autor citado, o "vestibulando adentra nas escolas alienado, sem um olhar mais ou menos consistente sobre o mundo, sem se conhecer, mesmo nos aspectos periféricos de sua própria personalidade, o que leva a escolha pelo direito ser fruto de uma decisão aleatória, conjuntural e mesmo passageira" (AGUIAR, 2004, p. 205-206).

Ademais, "como a história, a política e a ciência não são tratadas com rigor" nos níveis da educação formal, "os estudantes se tornam carentes de consciência do mundo". Desta forma, há uma "completa ausência de tênues modelos para explicar a realidade, além da ingenuidade, agora em sentido perverso, que leva esses estudantes a ignorar os modos de ser, produzir e relacionar da sociedade a que pertence, impedindo que exerça uma conduta transformadora, ou justifique coerentemente o que está vigendo em seus grupos sociais" (AGUIAR, 2004, p. 206).

Por consequência deste contexto, os "estudantes não se sentem sujeitos da história e acreditam que ela anda sem sua colaboração, o que os impede de compreender a luta pelos direitos, o papel da cidadania na constituição do direito, além de tratarem com indiferença todas as culturas que não guardem hegemonia ou semelhança com a sua", levando-se a questionar como poderá ser desenvolvida "uma prática jurídica rica em soluções para as novas demandas e instituidora de novos direitos humanos", diante de tamanho afastamento do outro (AGUIAR, idem).

Certamente, a cultura da convivência com o outro deve ser objeto da ação educativa, na medida em que se promova um equilíbrio entre o respeito à individualidade e a compreensão do outro, sem que isso importe em uma absoluta passividade.

Como afirma Morin (2004, p. 54), numa relação triádica indivíduo/sociedade/espécie, não se "pode tornar o indivíduo absoluto e fazer dele o fim supremo desse circuito; tampouco se pode fazê-lo com a sociedade ou a espécie", porque a "complexidade humana não poderia ser compreendida dissociada dos elementos que a constituem: todo desenvolvimento verdadeiramente humano significa o desenvolvimento conjunto das 


\title{
autonomias individuais, das participações comunitárias e do sentimento de pertence à espécie humana".
}

Não é por outra razão que os Cursos de Direito são orientados a inserir atividades complementares no seu currículo, com vistas à inserção do acadêmico na comunidade, como prevê o art. 8º da Resolução n. 9/2004:

\begin{abstract}
Art. $8^{\circ}$ As atividades complementares são componentes curriculares enriquecedores e complementadores do perfil do formando, possibilitam o reconhecimento, por avaliação de habilidades, conhecimento e competência do aluno, inclusive adquirida fora do ambiente acadêmico, incluindo a prática de estudos e atividades independentes, transversais, opcionais, de interdisciplinaridade, especialmente nas relações com o mercado do trabalho e com as ações de extensão junto à comunidade.
\end{abstract}

Parágrafo único. A realização de atividades complementares não se confunde com a do Estágio Supervisionado ou com a do Trabalho de Curso.

Quando esta orientação surgiu ao tempo da Portaria 1886/94, lembro que uma das orientações era direcionar o acadêmico à prática de ações sociais, sob a intenção de fazê-lo vivenciar experiências em creches, comunidades carentes, recantos de idosos, praticando atividades não-jurídicas, mas que se somassem à sua visão do outro.

Profissionalmente para a área jurídica, é induvidoso que essa experiência com a diversidade humana pode produzir importantes reflexos. A inexperiência de vida repercute na forma de tratamento do problema alheio, muitas vezes transformando-o em objeto inanimado. As dores e angústias das partes muitas vezes não são vistas, no âmbito jurídico, como realidades vividas, mas sim representações na letra fria de papéis e petições, correndo o risco da formalidade superar a realidade. A crítica se projeta muito sobre a inexperiência de juízes, que, fechados em seus gabinetes, não percebem as aflições por detrás dos milhares de processo para sua apreciação.

Neste ponto, sempre houve uma crítica acirrada à inexperiência de magistrados e membros do Ministério Público, recém formados e já aprovados em concursos públicos no sistema brasileiro. O destaque sempre foi dado à falta de percepção sobre a realidade humana e os riscos que isso produzia na aplicação do Direito.

E esse assunto foi de tal maneira debatido, que se concluiu mudar a Constituição Federal. Para o concurso à magistratura, a redação do inciso I, do 
artigo 93 foi alterado pela Emenda Constituição n. 45/2004, exigindo do bacharel em Direito, no mínimo, três anos de atividade jurídica. Para o Ministério Público, esse mesmo requisito foi inserido no $\S 3^{\circ}$ do artigo 129. Ainda que a norma tenha mencionado "atividade jurídica", o que se pretendeu era a experiência, incorporando uma vivência pós graduação.

Essa previsão constitucional, inclusive, provoca questionamentos sobre o que se está fazendo no plano da formação do aluno de Direito ou, no mínimo, projetando uma espécie de "residência" dissimulada, bem diferente da qualificação que se exige da formação médica, mas talvez com a intenção voltada num mesmo sentido.

Tal regra constitucional, por certo, se sujeita a muitas críticas e desvirtuamentos e muito provavelmente está longe de atingir seu intento, na obtenção de profissionais (juízes e membros do Ministério Público) mais experientes em razão da exigência de três anos, mas é um importante sinal de que há um incômodo envolvendo a experiência do bacharel em Direito, incômodo este do qual acreditamos estar ligada a experiencial social, que se percebe estar ausente no âmbito acadêmico, em virtude do grande foco nos conteúdos técnicos e na pequena atenção às ações concretas e envolvimentos sociais.

De qualquer modo, é paradoxal o problema dessa ausência de compreensão do outro e do mundo para o estudante (e em seguida bacharel em Direito). A alteridade é elemento fundamental para essa área, não por conta de uma inclusão sistemática no âmbito das Ciências Sociais Aplicadas como se convencionou enquadrá-la, mas sim pela sua natureza humana de pensar o homem em suas interações. Já é notória a afirmação de que sem o outro, não haveria necessidade de se pensar o Direito. Então, sem essa percepção, o discente deixa de utilizar o que deveria ser seu principal referencial. Daí a importância de ressaltar seu afastamento como um problema que deve ser considerado para a relação pedagógica, servindo como indicador para o presente estudo.

Estas considerações tecidas envolvendo os problemas discentes, longe de enumerar todos os fatos e causas, são apresentadas com a intenção de se pincelar pontos em comum para delinear o corpo do presente estudo, focado em práticas escolares que dependem da compreensão de alguns fenômenos de maior destaque na relação professor-aluno, com o reconhecimento das suas individualidades e seus efeitos. 
De qualquer modo, pensando em todas as dificuldades de formação, motivação e experiências envolvendo o discente, concordamos com Souza (2002, p. 65) que muitas vezes o aparente desinteresse do aluno, pode ser transformado por uma "aula bem motivada em que, transitando da teoria à prática, passa-se a discutir sobre o homem, não o ontológico, mas o real, concreto, com nome, endereço e profissão (ou sem), mas que escreve um momento existencial difícil". Assim, "descrita a realidade, incendeia-se o espírito dos alunos! Todos entendem o fenômeno e o problema e muitos apresentam soluções, sugestões e também críticas". Não fosse a esperança de possibilidades, mais cômodo seria apenas vivenciar o ensino do Direito como mero expectador.

Este Capítulo, portanto, indica o corte produzido no contexto da crise pedagógica envolvendo o Direito, que restringe o olhar sobre as ações (ou omissões) docentes e discentes. Demonstram-se as diversas interferências ocorridas no comportamento dos professores, salientando a ausência de formação pedagógica e a importância de se conceber o papel de educador num contexto de responsabilidade pela aprendizagem, ainda que o ambiente jurídico reproduza manifestações de afastamentos, arbitrariedades e centralização no professor. O afastamento discente também demanda revisão, na esteira de sua conscientização sobre os papéis que representará profissionalmente, com a necessidade de superação dos problemas inerentes a sua formação anterior e de seu envolvimento social.

Assim, apontadas estas dificuldades envolvendo posturas dos professores e alunos, prossegue-se o estudo com a visualização da estruturação do Curso de Direito, possibilitando a compreensão do ambiente normativo que o regulamenta e permitindo inferências sobre a interdisciplinaridade neste contexto. 


\section{A ESTRUTURAÇÃO DO ENSINO DO DIREITO EM EIXOS E A SUA PROBLEMATIZAÇÃO: A NORMATIZAÇÃO E A COMPREENSÃO INTERDISCIPLINAR}

O presente capítulo tem por escopo demonstrar o estado da arte em que se encontra a proposta para um Curso de Direito, de maneira a se compreender melhor o objeto do presente estudo, além de trazer uma problematização fundamental decorrente das dificuldades enfrentadas para a abordagem interdisciplinar.

No plano normativo, desde já se repisa a ressalva de que nenhuma determinação regulamentadora de um curso tem em si a absoluta garantia de resultados e, além disso, não pode ter a perspectiva de impor um padrão de comportamento que não possa ser alterado com o tempo, diante de novas necessidades, advindas por conta da evolução natural das próprias relações humanas.

Este é um importante alerta que já foi registrado por Rodrigues (1995, p. 87, quando do advento da Portaria 1886/94 MEC, que pode ser considerada o marco inicial para a política que hoje predomina na área. À época, observava o referido autor que muitos especialistas em educação na área do Direito viam a reforma curricular apresentada pela referida Portaria como "a solução para os problemas do ensino jurídico no Brasil", mas alertava que tal conclusão era equivocada, por conta de problemas de ordem estrutural relativas ao plano político e epistemológico, o que não desmerecia a série de importantes avanços que consagrava. Esta mesma observação também aparecerá mais adiante, ao tratar da Resolução n. 9/2004, em vista dos alertas realizados quando dos trabalhos preparativos para a edição desta norma.

De fato, a criação da Portaria 1886/94 tem um importante valor histórico, envolvendo muitas discussões sobre as necessidades que o ensino jurídico estava apresentando. A expectativa sobre a mesma era constituir um canal através do qual se pudesse "modificar a própria mentalidade ultrapassada e rançosa presente hegemonicamente nos cursos jurídicos nacionais", pressupondo, entretanto, "uma autocrítica e um deslocamento que talvez nem todos os partícipes desse ensino estejam dispostos a dar" e que, sem isso, a reforma não teria razão e existir, não passando de uma mera formalidade (RODRIGUES, 1995, p. 88-89). 
Neste sentido, reavivar esta história mais recente é uma maneira de ressaltar os pressupostos que inclusive influenciaram a regulamentação em vigor. Assim, é de imperiosa necessidade provocar os sujeitos do processo educativo (em especial no ensino jurídico) a se atentarem para informações que podem melhorar em muito as suas ações e resultados, hoje ainda deficientes por conta de tantos problemas básicos vivenciados, sendo que os anseios ao tempo da edição da Portaria 1886/94 certamente se projetam para a atualidade.

Note-se que o próprio Parecer CNE/CES n. 55/2004, que amparou edição da Resolução n. 9/2004, bem relata essa observação, quando afirma (2010b, p. 11):

A Portaria 1.886/94 trouxe inovações que se constituíam avanços para o ensino jurídico, especialmente pelo seu direcionamento à realidade social e integração dos conteúdos com as atividades, dando a dimensão teóricoprática ao currículo e ensejando a formação do senso crítico dos alunos, além de contemplar mais flexibilidade na composição do currículo pleno, através de disciplinas optativas e diferentes atividades de estudos e de aprofundamento em áreas temáticas.

De qualquer modo, a referida Portaria 1886/94 estabeleceu uma concepção da estrutura de um Curso de Direito a partir da sua divisão em dois eixos, dividindo a abordagem entre as disciplinas fundamentais $e$ as profissionalizantes, acrescentando a abordagem de outras matérias e novos direitos conforme 0 desdobramento de cada curso (art. 6º).

Para o foco do presente estudo, que também toca a concepção da prática e a abordagem teórica, é importante ressaltar que a Portaria 1886/94 estabeleceu o tratamento da questão da prática em artigos específicos sobre o estágio. Também, foi a partir desta norma que os núcleos de prática jurídica foram idealizados (e hoje estão formados em todos os cursos de Direito, muito provavelmente). A determinação da prática não foi apontada por disciplinas (como antes se falava em Direito Processual Civil, Direito Processual Penal e Direito Processual do Trabalho), dispondo genericamente as estruturas que deveriam compor a prática, esta dividida em prática real e prática simulada:

Art. 10. O estágio de prática jurídica, supervisionado pela instituição de ensino superior, será obrigatório e integrante do currículo pleno, em um total de 300 horas de atividades práticas simuladas e reais desenvolvidas pelo aluno sob controle e orientação do núcleo correspondente. 
$\S 1^{\circ} \mathrm{O}$ núcleo de prática jurídica, coordenado por professores do curso, disporá de instalações adequadas para treinamento das atividades de advocacia, magistratura, Ministério Público, demais profissões jurídicas e para atendimento ao público.

$\S 2^{\circ}$ As atividades de prática jurídica poderão ser complementadas mediante convênios com a Defensoria Pública e outras entidades públicas judiciárias empresariais, comunitárias e sindicais que possibilitem a participação dos alunos na prestação de serviços jurídicos e em assistência jurídica, ou em juizados especiais que venham a ser instalados em dependência da própria instituição de ensino superior.

Art. 11. As atividades do estágio supervisionado serão exclusivamente práticas, incluindo redação de peças processuais e profissionais, rotinas processuais, assistência e atuação em audiências e sessões, vistas a órgãos judiciários, prestação de serviços jurídicos e técnicas de negociações coletivas, arbitragens e conciliação, sob o controle, orientação e avaliação do núcleo de prática jurídica.

Art. 12. O estágio profissional de advocacia, previsto na Lei $n^{\circ} 8.906$, de 4/7/94, de caráter extracurricular, inclusive para graduados, poderá ser oferecido pela Instituição de Ensino Superior, em convênio com a OAB, complementando-se a carga horária efetivamente cumprida no estágio supervisionado, com atividades práticas típicas de advogado e de estudo do Estatuto da Advocacia e da OAB e do Código de Ética e Disciplina.

Parágrafo único. A complementação da horária, no total estabelecido no convênio, será efetivada mediante atividades no próprio núcleo de prática jurídica, na Defensoria Pública, em escritórios de advocacia ou em setores jurídicos, públicos ou privados, credenciados e acompanhados pelo núcleo e pela OAB.

Art. 13. O tempo de estágio realizado em Defensoria Pública da União, do Distrito Federal ou dos Estados, na forma do artigo 145, da Lei complementar no 80, de 12 de janeiro de 1994, será considerado para fins de carga horária do estágio curricular previsto no art. 10 desta Portaria.

Art. 14. As instituições poderão estabelecer convênios de intercâmbio dos alunos e docentes, com aproveitamento das respectivas atividades de ensino, pesquisa, extensão e prática jurídica.

Este contexto foi, portanto, o que antecedeu as Diretrizes Curriculares estabelecidas pela Resolução n. 9/2004 e certamente foi o ponto base para a regulamentação atual, ainda que passados dez anos para sua realização.

\subsection{A proposta das Diretrizes Curriculares para o Curso de Direito}

É importante contextualizar que o Parecer CNE/CES n. 55/2004, que fundamentou a edição da Resolução n. 9/2004, mesmo reconhecendo a importância da Portaria 1886/94, retratou a necessidade de sua alteração, por conta de interpretação legal e sistemática vigente para a edição de Diretrizes Curriculares, situação esta que demandava regularização. Com isso, criticando tal Portaria, a manifestação do referido parecer foi a seguinte: 
Ocorre, porém, que essa flexibilização se esbarra em uma rigidez do currículo mínimo nacional para a graduação do bacharel em Direito, uma vez que tal procedimento somente é possível se for, primeiramente, como um prérequisito, "observado o currículo mínimo previsto no art. $6^{\circ "}$ (sic), o que descaracteriza a definição de "diretrizes curriculares", expressão essa adotada na ementa da Portaria e que não corresponde ao que as Leis 9.131/95 e 9.394/96, com os conseqüentes Pareceres do Conselho Nacional de Educação, entendem como "Diretrizes Curriculares Nacionais para a Graduação" e "Diretrizes Curriculares para cada Curso de Graduação", como ora se relata para o curso de graduação em Direito, bacharelado.

Nesse sentido, o Conselho Nacional de Educação, através da Câmara de Educação Superior, aprovou o Parecer CES 507, de 19/5/99, contendo a Indicação para que o Senhor Ministro de Estado da Educação revogasse as Portarias 1.886/94 e 3/96, "para assegurar a coerência nas Diretrizes Curriculares" sob a nova concepção preconizada nas Leis supra referidas, para todos os cursos de graduação, inclusive, portanto, para a graduação em Direito, bacharelado, cujas propostas já estavam em tramitação no âmbito do Ministério e do próprio Conselho, em decorrência do Parecer CES 776/97 e do Edital SESu/MEC 4/97.

No Parecer CES 507/99, alertara-se quanto à necessidade de que se observasse toda a metodologia traçada pelo Edital remetido, de tal forma que a Câmara de Educação Superior pudesse, no momento oportuno, deliberar sobre as Diretrizes Curriculares para o Curso de Graduação em Direito, de acordo com a nova ordem jurídica, de forma a permitir que as instituições definam "currículos adequados, capazes de se ajustarem às incessantes mudanças, não raro muito rápidas, a exigir respostas efetivas e imediatas das instituições educacionais".

De fato, o problema em discussão retrata questão de competência para editar normas relativas às Diretrizes Curriculares, de maneira que estas estariam sob a responsabilidade do Conselho Nacional da Educação, não podendo ser fixadas pela Portaria 1886/94, de competência do Ministro da Educação. Mas veja-se que, independentemente dessa discussão formal, foram as orientações da referida Portaria que perduraram durante os dez anos seguintes, mesmo com o advento da LDB em 1996, quando então produziu o conflito de competência mencionado. Tal Portaria foi, de fato, o único norte que os Cursos de Direito receberam neste período, de maneira que acabou sendo recepcionada e cumprida.

De qualquer modo, para a edição das Diretrizes Curriculares estabelecidas pela Resolução n. 9/2004, além da experiência trazida pela aplicação da Portaria 1886/94, afirma o Parecer 55 que foram colhidas diversas sugestões de diversos setores, governamentais ou não. Neste sentido, afirmar o Parecer 55/2004 (BRASIL, 2010b, p. 18-19): 
Este Parecer, portanto, contempla as orientações das Comissões de Especialistas e as da SESu/MEC, as quais, na sua grande maioria, foram acolhidas e reproduzidas na sua totalidade, não só por haver concordância com as idéias suscitadas no conjunto do ideário concebido, mas também como forma de reconhecer e valorizar a legitimidade do processo coletivo e participativo, que deu origem à elaboração dos documentos sobre Diretrizes Curriculares Gerais dos Cursos de Graduação, cujas propostas foram encaminhadas pela SESu/MEC para deliberação deste Colegiado.

Foram também as contribuições da Ordem dos Advogados do Brasil, por sua Presidência, por seu Conselho Federal, por sua Comissão de Estudos Jurídicos, pelas Seccionais e Sub-Seccionais dos Estados, de diversas entidades públicas e privadas, em particular da Associação Brasileira do Ensino do Direito - ABEDi, e de outras associações correlatas, além da profunda discussão em congressos e audiências públicas.

Por certo, o Parecer n. 55 também destaca a pretensão de fundo para a concepção do Curso de Direito através das Diretrizes propostas, afirmando a importância da formação continuada para o profissional da área na pretensão de revitalizar a área e esperar um comportamento inovador (BRASIL, 2010b, p. 14-15):

Nesse passo, importa conceber a graduação no ensino jurídico como uma "formação inicial" para o exercício da profissão, implicando, como reza a LDB, continuidade e aprofundamento de estudos, sempre renovados em decorrência dos avanços da ciência, da tecnologia e de novas escalas de valores, com implicações na constituição de novas e desafiadoras situações e relações jurídicas, que justificam e exigem especializações em diferentes áreas ou ramos jurídicos, atuais ou novos, e em núcleos temáticos específicos. Assim, o Direito retomará o seu papel de controle, construção e garantia do desenvolvimento da sociedade, evitando que se repita a postura cômoda de nada inovar, dando-se as faculdades por satisfeitas com a simples execução do currículo mínimo em que já se transformara o "currículo pleno", como continua ocorrendo, bastando a realização e aprovação da monografia.

O Parecer também revela a preocupação com a responsabilidade do curso e do próprio aluno com vistas à formação de um profissional crítico e apto à compreensão do pluralismo (BRASIL, 2010b, p. 15):

O ensino jurídico não pode comprazer-se com a emissão de diploma de graduação para aqueles que concluíram com aproveitamento médio, regular, as matérias ou disciplinas jurídicas estabelecidas na norma, muitas vezes cursadas mediana e compulsoriamente, apenas porque a norma (grade curricular) o exigiu, no limite do quantum satis para a sua creditação acadêmica.

Não raro, também, matérias e disciplinas se justificam tão somente pela satisfação tecnicista, dogmática e personalista de grande contingente dos que atuam nos cursos jurídicos, sem o indispensável comprometimento com a nova ordem política, econômica, social, e com seus pluralismos políticos, 
jurídicos, regionais e axiológicos que caracterizam a contemporaneidade brasileira e a comunidade das nações. Com efeito, esse contexto está a exigir bastante autonomia intelectual e lúcido raciocínio jurídico, com as visíveis características de cientificidade e criticidade, epistemologicamente sedimentados, centrados também em uma escala de valor dignificante para o Brasil, para a pessoa humana e para os cidadãos, no pluralismo anteriormente remetido.

Numa crítica à noção de qualidade de um Curso e aos efeitos sobre as matérias, disciplinas estabelecidas e atividades nele estabelecidas, o Parecer 55 alerta para a limitação que o currículo proposto possa ter, reiterando pela noção de que a formação jurídica vai além de sua aplicação (BRASIL, 2010b, p. 15):

O currículo do ensino jurídico não se constitui, pois, instrumento para que algumas pessoas ou um conjunto de pessoas, ainda que de "notoriedade jurídica", se comprazam com as matérias e disciplinas fixadas na norma, até sob a invocação da sólida experiência do magistério ou de cargos das carreiras jurídicas, ao longo dos anos, acrescentando-se ainda a esta "satisfação" pessoal, como se tem freqüentemente verificado, a equivocada afirmação de que a obrigatória realização de uma monografia, que mais revela o determinado momento da conclusão do curso, seja a comprovação da qualidade do curso jurídico e do induvidoso desempenho dos egressos, que não se tem confirmado em ulteriores avaliações, inclusive nos Exames da Ordem, muito menos ao longo da vida profissional que não dispensa estudos permanentes.

Neste seguimento e buscando a ampliação da formação acadêmica, o Parecer 55/2004 registra não haver intenção de se estabelecer um currículo mínimo "constituído de matérias ou disciplinas enfeixadas num conjunto obrigatório para todos os cursos em âmbito nacional", mas sim conceber diretrizes baseadas na "flexibilização, com a liberdade e com a responsabilidade das instituições de ensino para organizarem seus currículos plenos que correspondam aos anseios do mundo contemporâneo e ofereçam formação profissional de qualidade, mas inacabada, suscitando um ininterrupto crescimento no exercício profissional de cada formando" (BRASIL, 2010b, p. 18).

Por certo, com base nesta flexibilização, o Parecer 55 reconhece a importância de aptidões esperadas ao profissional, descrevendo-as da seguinte forma (BRASIL, 2010b, p. 18):

O profissional do direito deve estar apto a apropriar-se de novas e renovadas ferramentas e equipamentos pessoais, por sua autonomia de conhecimento, pelo raciocínio jurídico devidamente consolidado, pelo senso ético informador 
de seus atos e de sua conduta profissional e cidadã, pelo domínio epistemológico com que se atualiza e renova, de forma independente, transversal, interdisciplinar e autônoma, os conhecimentos e domínios teórico-práticos indispensáveis ao profícuo exercício da profissão, posta em permanente desafio das céleres mudanças, científicas, políticas e tecnológicas, na comunidade brasileira e nas suas relações no conjunto das nações, como agente qualificado e indispensável participante na administração da justiça e do bem comum, na preconizada nos arts. 4ำ e 133 da Constituição da República.

Percebe-se, portanto, que o Parecer 55, que embasou a Resolução n. 9, indicou coerentemente as perspectivas para o futuro profissional do Direito, remanescendo, porém, um dos maiores obstáculos à sua realização, consistente exatamente na mentalidade dos envolvidos. Como foi destacado quando se tratou da Portaria 1886/94, a mesma preocupação foi externada por conta dos trabalhos preparativos para a Resolução n. 9, como também relata o Parecer referido:

Diante desse quadro, como alertara a ABEDi - Associação Brasileira do
Ensino do Direito, em outras ocasiões, nos subsídios encaminhados a estes
Relatores e, sobretudo, no recente Congresso realizado em Florianópolis em
2003 , os obstáculos do ensino jurídico somente serão superados se as
Diretrizes Curriculares Nacionais para a graduação em Direito, bacharelado,
encontrarem do corpo docente e das administrações das instituições de
ensino superior, o total compromisso de atender aos reclamos de uma nova
época, constituindo-se efetivas respostas às novas aspirações e às novas
concepções jurídicas, ajustadas às necessidades locais, regionais, nacionais,
internacionais, que estão a exigir uma diversificação curricular, nas
instituições, na proporção direta das mudanças e das demandas regionais,
atuais e emergentes. (2010b, p. 14)

Assim, na continuação da análise à Diretriz Curricular estabelecida pela Resolução n. 9, cabe verificar a proposta dos três eixos indicados, de onde se produzirá inferências acerca da execução do ensino jurídico pela proposta ora vigente.

\subsection{Os eixos para o desenvolvimento do Curso de Direito}

Com o advento da Resolução CNE/CES n. 9, de 29 de setembro de 2004, a organização do Curso de Direito passou a ter como obrigatoriedade 0 desenvolvimento de três eixos, concebidos pelo seu art. $5^{\circ}$ em eixo de formação fundamental, eixo de formação profissional e eixo de formação prática. A explicação para cada eixo é apresentada pelo referido dispositivo: 
Art. 5ำ $\mathrm{O}$ curso de graduação em Direito deverá contemplar, em seu Projeto Pedagógico e em sua Organização Curricular, conteúdos e atividades que atendam aos seguintes eixos interligados de formação:

I - Eixo de Formação Fundamental, tem por objetivo integrar o estudante no campo do Direito, estabelecendo as relações do Direito com outras áreas do saber, abrangendo dentre outros, estudos que envolvam conteúdos essenciais sobre Antropologia, Ciência Política, Economia, Ética, Filosofia, História, Psicologia e Sociologia.

II - Eixo de Formação Profissional, abrangendo, além do enfoque dogmático, o conhecimento e a aplicação, observadas as peculiaridades dos diversos ramos do Direito, de qualquer natureza, estudados sistematicamente e contextualizados segundo a evolução da Ciência do Direito e sua aplicação às mudanças sociais, econômicas, políticas e culturais do Brasil e suas relações internacionais, incluindo-se necessariamente, dentre outros condizentes com o projeto pedagógico, conteúdos essenciais sobre Direito Constitucional, Direito Administrativo, Direito Tributário, Direito Penal, Direito Civil, Direito Empresarial, Direito do Trabalho, Direito internacional e Direito Processual; e

III - Eixo de Formação Prática, objetiva a integração entre a prática e os conteúdos teóricos desenvolvidos nos demais Eixos, especialmente nas atividades relacionadas com o Estágio Curricular Supervisionado, Trabalho de Curso e Atividades Complementares.

Sobre o estágio ainda foi acrescida a orientação do art. 7ํㅡ, de onde se manteve a orientação da obrigatoriedade de um estágio supervisionado mantido pela própria Instituição de Ensino, possibilitando a realização de convênios:

Art. $7^{0}$ O Estágio Supervisionado é componente curricular obrigatório, indispensável à consolidação dos desempenhos profissionais desejados, inerentes ao perfil do formando, devendo cada instituição, por seus colegiados próprios, aprovar o correspondente regulamento, com suas diferentes modalidades de operacionalização.

$\S 1$ ㅇ $O$ Estágio de que trata este artigo será realizado na própria instituição, através do Núcleo de Prática Jurídica, que deverá estar estruturado e operacionalizado de acordo com regulamentação própria, aprovada pelo conselho competente, podendo, em parte, contemplar convênios com outras entidades ou instituições e escritórios de advocacia; em serviços de assistência judiciária implantados na instituição, nos órgãos do Poder Judiciário, do Ministério Público e da Defensoria Pública ou ainda em departamentos jurídicos oficiais, importando, em qualquer caso, na supervisão das atividades e na elaboração de relatórios que deverão ser encaminhados à Coordenação de Estágio das IES, para a avaliação pertinente.

$\S 2^{\circ}$ As atividades de Estágio poderão ser reprogramadas e reorientadas de acordo com os resultados teórico-práticos gradualmente revelados pelo aluno, na forma definida na regulamentação do Núcleo de Prática Jurídica, até que se possa considerá-lo concluído, resguardando, como padrão de 
qualidade, os domínios indispensáveis ao exercício das diversas carreiras contempladas pela formação jurídica.

A expectativa de tais eixos é fazer com que o curso proporcione os objetivos traçados pelo art. 3ำ e a promoção das habilidades e competências descritas na forma do art. $4^{\circ}$ :

Art. 3‥ O curso de graduação em Direito deverá assegurar, no perfil do graduando, sólida formação geral, humanística e axiológica, capacidade de análise, domínio de conceitos e da terminologia jurídica, adequada argumentação, interpretação e valorização dos fenômenos jurídicos e sociais, aliada a uma postura reflexiva e de visão crítica que fomente a capacidade e a aptidão para a aprendizagem autônoma e dinâmica, indispensável ao exercício da Ciência do Direito, da prestação da justiça e do desenvolvimento da cidadania.

Art. 4․ O curso de graduação em Direito deverá possibilitar a formação profissional que revele, pelo menos, as seguintes habilidades e competências:

I - leitura, compreensão e elaboração de textos, atos e documentos jurídicos ou normativos, com a devida utilização das normas técnico-jurídicas;

II - interpretação e aplicação do Direito;

III - pesquisa e utilização da legislação, da jurisprudência, da doutrina e de outras fontes do Direito;

IV - adequada atuação técnico-jurídica, em diferentes instâncias, administrativas ou judiciais, com a devida utilização de processos, atos e procedimentos;

V - correta utilização da terminologia jurídica ou da Ciência do Direito;

VI - utilização de raciocínio jurídico, de argumentação, de persuasão e de reflexão crítica;

VII - julgamento e tomada de decisões; e,

VIII - domínio de tecnologias e métodos para permanente compreensão e aplicação do Direito.

De fato, tratando-se do eixo de formação geral, o mesmo corresponde a uma preocupação que de há muito tem sido tema de debates, que é a aptidão de se reconhecer contextos diversos da técnica jurídica. Há uma nítida atenção em possibilitar ao aluno de Direito a análise de assuntos que possam lhe dar uma visão de mundo ampliada, quiçá além da que até então conhecia.

É interessante ressaltar que a reclamação contra profissionais da área jurídica que deixam de considerar a realidade social por conta do formalismo ou do tecnicismo não é recente.

Por certo, considerando que a história do Direito no Brasil iniciou com a formação de profissionais para atender aos interesses do Estado ou ao status quo, é 
justificado o esforço para que esta tendência se afaste e a intervenção do Direito possa ser dirigida para um bem comum amplo o suficiente para reconhecer as dificuldades enfrentadas pelo ser humano nas mais diversas circunstâncias.

Como observa Saviani (1996, p. 38) a educação, ao promover o homem, procura torná-lo "cada vez mais capaz de conhecer os elementos de sua situação para intervir nela transformando-a no sentido de uma ampliação da liberdade, da comunicação e colaboração entre os homens". Não há dúvidas que muito pode ser discutido sobre os objetivos da Educação (e todas as ideologias que possam acompanhar este debate), mas parece assente que é possível eleger o ser humano em relação como objeto e objetivo (e essa relação para consigo mesmo e para com o outro). Logo, não poderia o ensino do Direito, ao proporcionar ações educativas, ficar alheio a esta perspectiva, de maneira que as Diretrizes Curriculares invocam como essenciais para o Curso de Direito as disciplinas como Antropologia, Ciência Política, Economia, Ética, Filosofia, História, Psicologia e Sociologia.

Como Almeida Júnior (2008, p. 191) registra, deve-se evitar que "o conhecimento jurídico fique isolado das demais áreas do saber, assim como repelir o ensino estritamente técnico-profissional, para gerar no aluno uma formação cultural geral e, assim, muito mais completa e bem mais relacionada à existência da pessoa, envolvendo-a em contextos familiares, políticos, culturais, ideológicos, éticos e religiosos". Com isso, atende-se a uma formação geral e humanística que "cobra de um curso de Direito evitar o puro tecnicismo jurídico e atribuir preferência a um ensino antidogmático, antipositivista, pluralista, democrático e desfragmentado".

Interessante perceber, porém, que nem sempre tais disciplinas são vistas pelos alunos como importantes quando comparadas com outras específicas do Direito, que acabam sendo mais atraentes por conta desta sua especialidade. É muito comum notar certo descaso com a sua realização e tal sentimento acaba sendo provocado até por professores, que, na alienação compartilhada com alguns alunos, chegam a desdenhar da sua existência no currículo.

Quadros (2002, p. 159-160) destaca que a posição das disciplinas básicas para o início do curso "contribui para que haja uma desvalorização delas mesmas, que passam a ser vistas como muito teóricas ou monótonas", questionando se neste momento da grade curricular o aluno tem "condições de compreender a importância dessas matérias", além dos efeitos da "expectativa pelas matérias chamadas mais 
específicas", não permitindo "que se aprofunde nos conceitos que mais tarde lhes farão falta".

Entretanto, acreditamos que a superação de tal dificuldade não se encontra realmente no momento em que são fornecidas as disciplinas durante o Curso e sim como o professor lida com as mesmas. Qualquer disciplina que não expressa a conotação de ser específica do Direito pode enfrentar a dificuldade de não provocar interesse imediato no aluno de Direito (ou de qualquer curso) tanto quanto qualquer outra disciplina, dependendo dos fatores de motivação, técnicas e critérios de condução que possam estimular seus participantes. Ademais, aula sobre Processo Civil pode ser tão monótona quanto qualquer outra, independentemente do momento em que for apresentada.

De qualquer maneira, obviamente que se está apenas exemplificando uma situação onde aspectos de ética, visão de mundo, reconhecimento da importância de outras áreas além do Direito são pontos não assimilados por quem venha a se desinteressar da abordagem de outras disciplinas não especificamente jurídicas. De um lado, na expectativa de ver o Direito aplicado (ou qualquer outra especialidade da área do conhecimento), um aluno pode se sentir como estar "perdendo tempo" ao ser obrigado às aulas de disciplinas aparentemente distintas do Direito. Assim, talvez o problema possa estar na condução dessas aulas pelo próprio docente, que deixa de realizá-las de maneira a demonstrar sua importância e envolver a participação discente.

De qualquer maneira, o trabalho de valorização de tais disciplinas, pela importância que têm na formação de uma visão mais complexa e necessária da realidade social, deve ser encarado por todos os envolvidos no processo, cabendo aos professores a ação conjunta (e interdisciplinar) para que as mesmas possam proporcionar a experiência que o futuro profissional do Direito precisará, agindo consciente de que suas ações afetam vidas e que elas são algo mais do que apenas sujeitos de um processo, afastando-se do risco de se envolver em um insulamento jurídico, como já alerta Azevedo (1989, p. 29), ao apontar a não desejada posição de um Direito hermeticamente fechado em desprezo ao verdadeiro mundo que corre fora de suas paredes ideológicas, conforme também já se discorreu junto ao item 1.2 do presente.

No que se referem ao eixo de formação profissional, as Diretrizes Curriculares relacionam disciplinas teóricas básicas para o conhecimento do Direito, indicando o 
enfoque dogmático (que representa a abordagem tradicional do direito positivado), mas soma a necessidade de sua aplicação e contextualização.

De fato, ao relacionar as disciplinas de Direito Constitucional, Direito Administrativo, Direito Tributário, Direito Penal, Direito Civil, Direito Empresarial, Direito do Trabalho, Direito internacional e Direito Processual, transita pelas abordagens tradicionalmente consagradas do conhecimento jurídico, estabelecendo como critério mínimo o conhecimento sobre seus conteúdos. É justamente o excesso de atenção às referidas disciplinas, sem a compreensão de sua ligação para com outras áreas do conhecimento (e até entre si), que provoca o afastamento do Direito da realidade social que é objeto de preocupação das disciplinas do eixo de formação fundamental.

Por fim, as Diretrizes tratam do eixo de formação prática, através da qual se atribui o papel de realizar a "integração entre a prática e os conteúdos teóricos desenvolvidos nos demais eixos", dando destaque ao Estágio Supervisionado, ao Trabalho de Curso e às Atividades Complementares. Esta prática será melhor tratada no Capítulo 4.

Diante desta estrutura traçada, não se poderia esperar movimento diverso das Instituições de Ensino Superior que não fosse promover ações que atendessem a tais medidas. Assim, matrizes curriculares acabam sendo alteradas, departamentos são criados, estruturas são modificadas, disciplinas são estabelecidas, tudo em prol se de fazer cumprir as determinações, que, por conta do sistema de avaliação, passará por análises em momentos de reconhecimento ou de recredenciamento.

Como o presente estudo não tem por foco a avaliação externa do Ensino Superior envolvendo o curso de Direito, mas sim repensar a realização da aprendizagem por conta da interligação entre a prática e a teoria e as ações docentes e discentes, finaliza-se este item com a confirmação de que as Diretrizes Curriculares para o Curso do Direito contribuíram para fixar importantes metas e objetivos para a área, exigindo, porém, um contínuo esforço para a execução de suas expectativas e orientações, que vão além das normas e intenções governamentais e recaem principalmente pela ação consciente de seus atores principais, as figuras dos docentes e discentes. 


\subsection{A tradicional divisão das disciplinas em matrizes curriculares para o Curso de Direito e a polêmica sobre a formação profissional no Direito}

Para atender à execução dos eixos e compreender-se parte da problemática trazida pelo presente estudo, é importante considerar uma análise de matrizes curriculares, que espelham como a área concebe o desenvolvimento do Curso. A pretensão é ter um olhar, ainda que não completo e generalizado, sobre como os Cursos de Direito têm formulado suas matrizes curriculares, representando a aplicação dos eixos estudados, formulando uma contextualização para a abordagem. Para tal descrição, porém, algumas considerações iniciais devem ser feitas.

A coleta de matrizes curriculares foi realizada a partir de pesquisas em sites mantidos pelas Instituições de Ensino consultadas, no decorrer de 2010. Isso leva a ressalvar que as matrizes podem ter sofrido alteração decorrente do natural processo de reformas.

O levantamento também não pretende afirmar, numa visão indutiva, que todos os Cursos de Direito têm a mesma proposta. Logrou-se êxito de transcrever apenas 40 (quarenta) matrizes curriculares, de um universo de centenas de Cursos, sem uma preocupação metodológica de se diferenciar pela natureza público/privada, referência territorial ou sistema de avaliação externo. A descrição detalhada das matrizes curriculares ficou reservada para o Anexo A. A intenção, portanto, é apenas demonstrar um padrão de matriz curricular, servindo de base para a discussão do presente estudo.

De um modo em geral, os cursos são desenvolvidos em disciplinas anuais ou semestrais. Não há um padrão preciso de disciplinas, mas alguns dados podem ser relacionados a partir das matrizes selecionadas:

a) Em todas as matrizes aparecem disciplinas do eixo fundamental, mas nem todas as disciplinas relacionadas pelas Diretrizes Curriculares são contempladas (Antropologia é uma delas) - o que não exclui a possibilidade de serem tratadas dentro de algum conteúdo programático em disciplina afim. Destaque para a UESC - Universidade Estadual de Santa Cruz com a inclusão de disciplinas tratando das Línguas Espanhola, Inglesa e Francesa; 
b) As disciplinas do eixo profissionalizante estão presentes, mas há variações com inclusão de outras disciplinas (Direito Urbanístico, Criança e Adolescente, Direito Previdenciário etc), acompanhando a liberdade desse acréscimo;

c) As disciplinas de Estágio são tratadas a partir do $7^{\circ}$ Período/Semestre ou $4^{\circ}$ Ano, apesar de algumas exceções, começando no $5^{\circ}$ ou $6^{\circ}$ Período/Semestre ou 3ำ Ano.;

d) A prática tem tratamento sob o título Estágio (Supervisionado ou Real ou de Prática) ou Prática (seguida de uma área como Prática de Processo Civil, ou Prática Forense).

O que importa para o presente estudo é destacar a separação estrutural do Estágio, numa referência até tradicional das Diretrizes Curriculares historicamente demonstradas no item 1.1.3 do presente estudo. É um padrão prever-se um momento para embasamento teórico e outro para aplicação prática do conhecimento.

Para os cursos de Direito, a prática de estágio pode ser realizada de forma simulada, com o acompanhamento de atividades elaboradas diretamente por alunos, sob a supervisão de professores em casos não reais. Por regra, são apresentadas situações-problema, cabendo ao aluno produzir peças jurídicas de conformidade com a posição que lhes for atribuída.

A prática simulada tem uma importante questão ideológica a ser tratada, correspondente a qual prática se pretende ver realizada pelo aluno, já que há uma grande diversidade de possibilidades que o Curso de Direito viabiliza: deve-se preparar um profissional para ser um advogado ou para seguir carreiras na Magistratura, no Ministério Público como Delegado de Polícia ou mesmo na Advocacia Pública?

Certamente, há diferenças de perspectivas para o próprio conhecimento quando se verifica uma função in concreto: a advocacia privada depende do ingresso nos quadros da Ordem dos Advogados do Brasil, mediante Exame de Ordem (Lei 8906/94). A advocacia pública depende deste requisito mais a aprovação em concurso próprio. De um modo em geral, para ser juiz, membro do Ministério Público ou Delegado não há exigência que o candidato já esteja inscrito perante a Ordem dos Advogados do Brasil (o que imporia ao candidato ter sido 
aprovado em Exame de Ordem anterior, o que, porém, não está excluído, caso o edital de concurso assim o estabeleça).

Registre-se um verdadeiro dilema vivenciado pelos Cursos de Direito brasileiros por conta do sistema de avaliação atual, que integra resultados a partir do ENADE - Exame Nacional de Desempenho dos Estudantes, integrante do Sistema Nacional de Avaliação da Educação Superior (SINAES), com os resultados do Exame de Ordem, conforme chegou a ser amplamente noticiado em 2007, decorrente de uma fala do próprio Ministro da Educação (O Globo, 2007; CONSULTOR JURÍDICO, 2007).

Neste sistema de cruzamento de dados, aponta-se para afirmar que cursos de qualidade têm bons resultados no Exame de Ordem. Num raciocínio lógico, está se afirmando, como diretriz para qualquer curso de Direito que pretenda uma boa qualificação, que deve dar aos seus alunos condições para uma aprovação no Exame de Ordem. A conclusão, portanto, é que todo bom curso deve ter ex-alunos aprovados no Exame de Ordem.

O problema que observamos, porém, é que se o Exame de Ordem não tiver a qualidade necessária para contemplar uma generalidade mínima de formação para as diversas profissões (e não só a advocacia), os Cursos que não contemplam a formação de "advogados" não têm como obter qualificações que até lhe sustentem a permanência. Em outras palavras, cabe questionar se um Exame de Ordem está buscando qualificação para ingressantes na advocacia ou qualificação para todo profissional do Direito atuar em quaisquer outras atividades jurídicas (inclusive em carreiras de técnicos ou analistas, também importantes para o bom funcionamento da Justiça).

Digamos, hipoteticamente, que os alunos de um determinado Curso preferem ser juízes, membros do Ministério Público, Delegados e não advogados. Buscam tais concursos e são aprovados (sem terem feito o Exame de Ordem). Mas outra parte dos alunos, seus colegas de turma, querem exercer a advocacia e não obtém sucesso. O mesmo curso que os formou, pode ser paradoxalmente taxado de desqualificado, porque não está contemplando todas as hipóteses de carreira do bacharelado em Direito.

Alguém poderia afirmar que o raciocínio que acabou de ser empregado tem uma premissa equivocada, porque certamente um curso que formou alunos aptos a ingressar em difíceis concursos (de juízes, membros do Ministério Público, 
Delegados e outros), não poderia ter alunos que reprovassem em Exames de Ordem. Mas esta última observação também não está isenta de críticas: os alunos que buscaram o Exame de Ordem podem não ser os mesmos que buscaram outros concursos (de regra podem ser pessoas diferentes fazendo concursos diferentes). $O$ que significa dizer que um curso só terá qualidade ou não apenas por um ponto de vista (Exame de Ordem), pode ser frágil e injusto, porque um Curso de Direito não tem que formar apenas advogados, mas sim profissionais capazes de estarem atuando nas mais diversas profissões.

Logo, pela sistemática aplicada, a prática que se pretende para o aluno de Direito deve passar obrigatoriamente pela formação de futuros advogados, mais do que qualquer outra profissão, porque é isto que está indicando o sistema de avaliação dos Cursos de Direito. Mas será realmente esta a prática que se fomentar para um futuro profissional da área do Direito?

É claro que se deve louvar a pretensão da busca pela qualidade dos Cursos de Direito por todos os meios possíveis e a somatória de olhares acrescenta uma constante preocupação com essa parte da qualificação profissional - com importantes efeitos sociais. O presente estudo persegue o mesmo objetivo. A falha, a nosso ver, está em confundir exames com avaliações, tão bem diferenciados por Luckesi (1994, passim) entre outros. Busca-se avaliar para melhor qualificar, praticando-se a inclusão e a dialeticidade, enquanto a perspectiva do exame envolve selecionar, classificando e excluindo.

Ademais, cabe ir além, aproveitando das observações de Schön (2000, p. 21 25), que ao refletir sobre a crise envolvendo o conhecimento e a educação profissional, sob o título "virando o problema de cabeça para baixo", destaca a importância da análise de outras performances que aparecem em zonas indeterminadas da prática, mas que compõem ações de profissionais reconhecidos como mais competentes. $O$ autor chega a referir-se expressamente à educação jurídica, direcionada tradicionalmente a preparar os estudantes a pensar como um advogado, e, apesar do pioneirismo das escolas de Direito direcionarem os alunos neste sentido, com estudos de casos, "professores de algumas das mais eminentes faculdades de direito têm defendido a necessidade de desenvolver competências que vão além de pensar como um advogado - por exemplo, procedimentos de julgamento, relações com clientes, negociação, advocacia e ética legal". 
De fato, a formatação do modelo aluno de Direito/advogado, é insuficiente para uma ampla compreensão dos elementos de um conflito e de sua solução. Se a relação direta com o cliente é uma experiência ímpar na advocacia, pensar-se como um juiz, ou como um membro do Ministério Público, ou como advogado ou em outras atividades jurídicas tem suas características diferenciadas. Certamente a falta de vivência nestas outras atividades (pela experiência simulada), não contribui para ações empáticas. O advogado que exerce sua atividade sem a compreensão empática (seja com o cliente ou com os demais profissionais), não tem a mesma visão daquele que assim o faz e pode atuar alienado de inúmeras circunstâncias.

Portanto, se ser admitido por um Exame de Ordem é uma qualificação muito importante para o bacharel em Direito, permitindo-o atuar como advogado, não se pode excluir a educação de outras habilidades que não se limitam ao exercício da advocacia. Esse raciocínio permitiria concluir que apenas os Cursos de Direito formadores de futuros advogados é que deveriam ser avaliados com o sistema proposto, mas essa especificação não existe. Logo, o sistema de avaliação do ensino superior relativo ao Direito merece revisões, sob pena de se instalar (ou fortalecer) a cultura da formação de advogados e não de profissionais com qualificação para outras áreas de atuação profissional do Direito.

De qualquer maneira, faz-se o registro destas questões para que não se afirme que o presente estudo ignora pontos que afetam a qualificação dos cursos e o seu processo avaliatório, mas ressalva-se a análise com profundidade do tratamento do tema, por conta do objetivo do estudo que não tratará especificamente da avaliação e de todos os seus fundamentos e critérios.

De qualquer modo, pode-se afirmar que a tradição para a organização curricular para os Cursos de Direito separam os momentos das abordagens teóricas de formação geral e profissional da prática, evidenciando o padrão de eixos apontado na Resolução n. 9/2004.

\subsection{A interligação entre os eixos: da organização de um curso à interdisciplinaridade}

Ainda que o estabelecimento de eixos para o Curso de Direito contribua orientando para sua organização, não se livra do risco de desvios interpretativos 
para sua aplicação. Em outras palavras e como já se tem afirmado durante este estudo, não há "segurança" para se evitar problemas de eficácia de determinadas regras, no que respeita à sua aplicação, tendo em vista que a diversidade de sujeitos envolvidos e a possibilidade de que sua conduta acabe não contribuindo para os objetivos propostos. Mas estudá-las é importante na medida de sua compreensão, a partir do que qualquer intervenção possa ter mais coerência.

Certamente que não se proporiam eixos para dividir um Curso. Sua função é estabelecer caminhos mínimos por onde devem passar as discussões da área, buscando-se uma formação acadêmica que integre conhecimentos específicos e técnicos, ao lado de outros de formação mais ampla, para proporcionar uma visão também mais abrangente de seus sujeitos. Acredita-se, assim, que as Diretrizes propostas e em vigor para o Curso de Direito são exequíveis e razoáveis, até porque são resultado de uma construção que integrou diversas experiências. Ações que desprezam experiências construídas nem sempre são o melhor caminho quando ainda é possível muito fazer sobre o que se propõe.

Um problema que se coloca nesta oportunidade, é o que acreditamos ser ainda um grande desafio, correspondente a superar a visão compartimentada do Curso de Direito, base da qual a aprendizagem sente os reflexos. Anteriormente, tratamos de pontos envolvendo questões pedagógicas de docentes e discentes e agora podemos acrescentar o problema envolvendo uma política educacional de planejamento e suas bases tocando a própria organização de um Curso, somada à complexidade da prática interdisciplinar.

A preocupação principal deste estudo envolve a aprendizagem pelas ações práticas e envolvimento do discente, mas a prática que se pretende depende da sua interligação com a teoria (como adiante será tratado) e ambas precisam estar coesas dentro da organização e execução de um Curso, concebidas no agir docente.

Como cada curso tem uma margem de liberdade para a organização de suas matrizes curriculares (dependente da organização de sua Instituição de Ensino Superior), é importante que sua formatação parta dos princípios básicos pelos quais se estrutura. Quando existe uma clareza sobre os seus objetivos, a estruturação coerente de uma matriz curricular é uma conseqüência natural. Matrizes curriculares dão a coesão para o Curso, na medida em que estabelecem sua organização, pressupondo conhecimentos preliminares necessários para o seguimento da 
aprendizagem. Quando não ocorre esta percepção dos objetivos do curso e sua construção lógico-cronológica, certamente que o seu desenvolvimento causará pontos de colisão, os quais deverão ser superados sob pena de inviabilizar o próprio curso. Isso pode acontecer quando simplesmente se "importam" matrizes curriculares de outros cursos, como se sua realização fosse apenas uma mera formalidade.

Ao lado dessa importante ligação entre a matriz curricular e os objetivos do Curso, destaque-se a importância do seu planejamento pedagógico. Este projeto pedagógico do curso, construído de forma democrática (outro problema a ser enfrentado, em razão do nem sempre envolvimento da comunidade acadêmica com a sua produção), estabelece importantes diretrizes, que são fundamentais para a conscientização e integração dos trabalhos a serem desenvolvidos, os quais, por sua vez, irão repercutir nos planos de ensino e até nos planos de aulas das disciplinas estabelecidas.

Estas questões envolvem uma perspectiva de planejamento integrado, com a participação efetiva de todos os envolvidos (incluindo professores, funcionários, alunos, e outros setores ligados ao Curso). A ausência de planejamento e integração dos seus sujeitos "faz com que o barco do curso fique à deriva, perdido no meio do oceano", sendo necessário que "toda 'tripulação' do curso conheça o plano de navegação e que este seja preferentemente para um porto seguro, ou seja; para a formação de um bom bacharel" (CASTRO, 2009, p. 23). Mas realmente esta intenção é um grande desafio, em razão do que até então já se afirmou sobre as dificuldades pedagógicas. Não é por menos que Rodrigues enquadra essa ideia de um curso planejado como um sonho, diante da realidade observada (1995, p. 35).

De qualquer modo, por seu turno, uma disciplina não pode ser vista fora deste contexto e Fazenda (1999, p. 16-17) apresenta um conjunto de circunstâncias que envolvem sua condução. De um lado, existe o problema da disciplina tradicional apresentar um currículo que conduza os alunos a um "acúmulo de informações que de pouco ou nada valerão na sua vida profissional". Por outro lado, agregar novas disciplinas ao currículo tradicional "só faz avolumarem-se as informações e atomizar mais o conhecimento", produzindo um conhecimento cada vez mais disciplinado. Mas também deixar de lado o conhecimento sistematizado para "uma exploração indiscriminada de conhecimentos do senso comum" corre-se o risco de engendrar pelo conservadorismo que esse senso comum tende a estabelecer, sendo ainda 
mais prejudicial que a própria prepotência que o conhecimento científico pode produzir".

De fato, infelizmente a regra é que se forma uma escola e uma prática pluridisciplinar, como destaca Libâneo (2006, p. 30-31):

\begin{abstract}
A escola plurisdiciplinar é a que conhecemos: as disciplinas do currículo são justapostas e isoladas entre si, geralmente sem integração entre os domínios do conhecimento. O ensino das disciplinas segue uma ordem lógica, horários rígidos, sem considerar as diferenças de aprendizagem entre os alunos. $O$ aluno aprende diretamente do professor e do livro didático. Os problemas da vida real na sociedade (global e local), os interesses em que os alunos estão envolvidos, outras formas de saber, não se fazem presentes na sala de aula. Ou seja, critica-se a organização disciplinar porque ela lida com o conhecimento de forma estanque, fechada, fragmentada e, por isso, põe dificuldades ao conhecimento interdisciplinar.
\end{abstract}

Um curso de Direito não foge desta perspectiva. A necessidade de reorientação curricular já recebeu alertas como mencionou Faria (1987, p. 59), ao denunciar que do modo como o bacharelado em Direito se encontrava estruturado, inexistia interdisciplinaridade pela falta de integração das disciplinas formativas com as disciplinas informativas e a especialização setorizava excessivamente o conhecimento dos alunos, "comprometendo sua visão global do direito e da própria experiência jurídica", podendo levar à "perda da dimensão do todo - isto é, o da alienação subjacente à 'técnica pela técnica"'.

De fato, a "especialização transformou-se numa forma de fragmentação do conhecimento: para que melhor conhecesse o mundo, o conhecimento deveria subdividir-se em pequenas partes". O conhecimento jurídico acompanhou o mesmo movimento, fragmentando a realidade através da "univocidade da dogmática que, elegendo o contexto da cidade (ou o campo jurídico) como o lugar exclusivo da existência do direito, relevou a importância de se conhecer a dinâmica de outros contextos da vida social" (PÔRTO, 2000, p. 58).

A visão interdisciplinar, contudo, busca a "interação de duas ou mais disciplinas para superar a fragmentação, a compartimentalização de conhecimentos, implicando uma troca entre especialistas de vários campos do conhecimento na discussão de um assunto, na resolução de um problema, tendo em vista uma compreensão melhor da realidade", superando-se a especialização excessiva, buscando uma "maior ligação teoria-prática, maior ligação da ciência com sua 
aplicações", não se conhecendo por conhecer, mas ligando o conhecimento científico a uma cognição prática, compreendendo "a realidade para transformá-la" (LIBÂNEO, 2006, p. 31-32).

Neste ponto, é importante destacar que a ausência da interdisciplinaridade tem suas bases no próprio esvaziamento da dimensão humana e sua realidade, provocada pelo movimento de objetivação da coisa conhecida, de maneira que o sujeito cognoscente pudesse ver a realidade dissociada de si próprio e até mesmo de seu modo de vê-la, promovendo "não apenas a disjunção entre diferentes dimensões e aspectos de um mesmo fenômeno, como também do homem em relação a eles" (LÜCK, 1994, P. 29-30). Para o ensino

Essa disfunção se expressa pela preocupação em esquematizar conteúdos
produzidos de maneira divorciada da realidade e até mesmo da investigação
científica que produz o conhecimento. Evidencia-se em seu contexto uma
despreocupação por estabelecer relação entre idéias e realidade, educador e
educando, teoria e ação, promovendo-se assim a despersonalização do
processo pedagógico.
Produziu-se, em última análise, a disjunção do conhecimento em
relação à vida humana e à condição social. Esse aspecto se constitui, por
certo, na base que justifica e apóia a atitude de alienação e irresponsabilidade
do homem em relação a si próprio, a realidade social que constrói e a
realidade natural que perturba.

Pode-se acrescentar a influência do positivismo na nossa cultura e educação, gerando efeitos justamente nesse isolamento das disciplinas, compartimentalizando as estruturas num afastamento da realidade demonstrada pela vida e pela própria sociedade, criando facilitadores para vários tipos de domínio (LÜCK, 2001, p. 50; WERNECK, 2002, p. 56).

Um ponto decorrente dessa visão individualizada das disciplinas, é que mesmo internamente nas disciplinas de uma área do Direito pode não existir um diálogo que estabeleça objetivos comuns. A exemplo, é de se questionar se professores de Direito Civil (que, em princípio, aparece como disciplina teórica em quase todos os anos do Curso), mantêm entre si contatos que estabeleçam o reconhecimento das experiências e conteúdos, tornando coesa a abordagem. Quantas vezes não se encontram planos de ensino que repetem conteúdos ou omitem sequências, pela ausência de uma integração entre as disciplinas.

Esta inquietação é também reproduzida por Castro (2009, p. 21-22), quando sugere que os professores devem se conhecer, a ponto de até mesmo saber qual 
corrente jurídico-filosófica que cada um defende, qual escola jurídica se filia, sua formação, promovendo um interrelacionamento que será a base para se evoluir ao interrelacionamento dos eixos.

É importante lembrar que esta situação muitas vezes decorre da prática costumeira de se contratar professores do ensino superior para "ministrar uma disciplina", colocando-o imediatamente em aula, sem oferecer quaisquer condições de "perceber a inter-relação de sua disciplina com as demais que integram o currículo do curso", como destaca Masetto (2003, p. 59). Logo, a integração do professor já começa desvirtuada pela própria perspectiva que lhe é dada por aquele que se apresentar representante da Instituição.

Além disso, existente também o grau dificultador para a aproximação de professores do Curso de Direito, que pode ajudar a compreender a preocupação de se destacar algo aparentemente tão óbvio: as relações de "poder", egos, disponibilidade, envolvimento etc, podem fluir de modo muito negativo em determinadas organizações dentro de um Curso. Têm-se notícias de Departamentos que brigam entre si para mostrar maior poder (e, por conseqüência, Departamentos que não se comunicam - e muito menos os seus professores). A própria divisão em Departamentos e as disciplinas abrangidas pelo mesmo já apontavam uma disputa de poder e uma divisão que em nada contribui para o próprio Curso. Talvez a boa intenção, no começo da História moderna do Direito, em estabelecer uma visão positivista-analítica-pedagógica em dividir o Direito em áreas (e assim compreendêla "melhor"), desvirtuou-se para o afastamento entre elas, gerando a cultura que ainda se encontra de visões estanques, compartimentalizadas, tendo seus professores como os principais atores.

Mas, certamente, o encontro de professores das diversas disciplinas é um caminho para "analisar as possibilidades de integração entre elas, uma vez que todas cooperam para a formação do profissional", podendo se complementar e evitar repetições, além de outras ações conjuntas que facilitam e promovem aprendizagem (MASETTO, 2003, p. 48).

Assim, alguns obstáculos precisam ser superados para que uma visão interdisciplinar seja promovida perante o Curso de Direito, considerando-se desde o planejamento como o rompimento das barreiras criadas pela cultura jurídica individualista, unidisciplinar e satisfeita em si mesma, sem reconhecer a importância das outras relações para sua própria eficiência. 
Para começar, é preciso superar a completamente descabida "atitude de professores que mal se falam, mal se conhecem, mal sabem qual o objetivo do seu curso, mal avaliam o que está sendo dado em outras matérias e por outros professores" (CASTRO, 2009, p. 23). Isso também se projeta para a relação com professores de outros cursos, muitas vezes completos desconhecidos, colocando-se em questão a própria natureza de uma Universidade que se apresenta cindida pelo isolamento de cada área.

Por outro lado, é importante compreender-se a resistência inerente ao trabalho interdisciplinar, sobretudo por conta de uma ação a que não se está habituado, produzindo "uma sobrecarga de trabalho, um certo medo de errar, de perder privilégios e direitos estabelecidos (por menores que sejam)" e "pelo desalojamento de posições confortáveis que provoca", exigindo "romper com hábitos e acomodações" (LÜCK, 2001, p. 88).

Mas esse empenho de superar os obstáculos tem especial relevância, pois a realização de ações interdisciplinares aponta por uma abertura necessária para o fortalecimento da visão que se espera de um profissional. Werneck (2002, p. 57) destaca que a "preocupação com a interdisciplinaridade em nossas escolas vem trazer uma nova visão didático-pedagógica à problemática da formação humana". Pelo menos, tem condições de proporcionar que o "aluno dentro de uma escola com preocupação interdisciplinar não viverá um currículo que veicule conceituações fechadas, mas sim, interligadas", dando maior significado à visão do mundo e da vida, no momento em que os professores horizontalizam seus currículos", constituindo-a com uma "visão global, uma visão do todo, onde cada parte passa a ter significado, quando adita a um grande conjunto".

É preciso cuidar também para que não se desvirtue a concepção de interdisciplinaridade como alerta Rodrigues (2008, p. 153), já que "a maioria dos juristas vê o ensino interdisciplinar como a inclusão no currículo de uma série de disciplinas de outras áreas do conhecimento e que propiciem, cada uma delas, a sua visão do fenômeno jurídico", já que essas visões diferenciadas também acabam sendo estanques, caracterizando uma multidisciplinaridade, que não é a desejada, pretendendo-se uma "análise do objeto a partir de categorias pertencentes a vários ramos do conhecimento em um mesmo momento, buscando apreender todos os aspectos deste objeto, a sua integridade". 
De fato, o desafio de compreender-se a interdisciplinaridade é também não compartimentalizá-la, como ressalta Ferreira, S. L. (1999, p. 34-35). Ela supera as noções de "integração, interação e inter-relação", constituindo-se num "movimento ininterrupto, criando ou recriando outros pontos para a discussão", não permanecendo apenas na relação entre os mesmos aspectos. Logo, não há razão para Ihe estabelecer um "conceito com definição fechada", sendo importante buscar na interdisciplinaridade uma prática intencional, pautada em elementos claros e objetivos, assegurados por um "grau elevado de maturidade" para permitir encarar e pensar os acontecimentos, concebendo-os nunca como fatos isolados, mas sim por consequência de muitos outros.

Há que se pensar, também, na interdisciplinaridade de vivências no aprendizado coletivo, possibilitando o encontro e desencontro de visões de mundo, onde se deve fazer predominar a cooperação sobrepujando "a tentativa de competição, não devendo "predominar visões hegemônicas sobre o tema, baseadas em saberes presumidamente privilegiados porque "científicos', mas em resultado das diferentes indagações que a realidade viabilizar (PÔRTO, 2000, p. 112).

Por fim, é importante reconhecer que o problema da ausência de interdisciplinaridade não se resolve apenas com as atuais Diretrizes Curriculares ou mesmo com mudanças curriculares, porque depende de ações concretas de envolvimento entre disciplinas, professores, alunos, Instituição de Ensino e políticas de avaliação. A interdisciplinaridade não é impedida por currículos, mas pela forma de concebê-los.

Pelo que já se demonstrou até o presente momento, fica fácil a conclusão de que as dificuldades envolvendo os Cursos de Direto vão muito além de sua organização curricular, sendo efetivamente necessário se integrarem pessoas, para que elas integrem as estruturas de uma forma que compreendam a amplitude de todo este contexto.

Mas se mudanças curriculares não resolvem o problema, pelo menos podem provocar discussões que servirão de base para a compreensão do problema e a construção conjunta de possibilidades. Assim, um currículo

deve ser orgânico, sistemicamente integrado. O conjunto de disciplinas deve estar distribuído de forma a propiciar uma visão integrada e integral do fenômeno jurídico e ao mesmo tempo uma formação profissional voltada ao mercado de trabalho e às necessidades locais e regionais. Neste sentido, não 
pode ser integralmente imposto de cima para baixo, via Ministério da Educação, Ordem dos Advogados do Brasil ou qualquer outra instituição, pois cada realidade concreta deve ser respeitada. (RODRIGUES, 2000, p. 128)

Fazenda (1999, p. 17) ressalta, ainda, que o pensamento interdisciplinar deve assimilar uma "ruptura epistemológica, em que não é possível pensar-se numa racionalidade pura, mas em racionalidades". Logo, a amplitude do pensar interdisciplinar deve ser lembrada, partindo-se do princípio de que "nenhuma forma de conhecimento é em si mesma racional", procurando outras formas de conhecimento sem a resistência de preconceitos, afinal:

No projeto interdisciplinar não se ensina, nem se aprende: vive-se, exerce-se. A responsabilidade individual é a marca do projeto interdisciplinar, mas essa responsabilidade está imbuída do envolvimento - envolvimento esse que diz respeito ao projeto em si, às pessoas e às instituições a ele pertencentes.

Portanto, ao se pensar em medidas interdisciplinares para o ensino do Direito é importante que se compreenda os problemas decorrentes da compartimentação (espalhada na formas de se conceber as ações institucionais, o currículo, as disciplinas, as ações docentes e discentes), reconhecendo-se a amplitude da complexidade humana de maneira a promover sua integração pelas mais variadas formas possíveis.

Este Capítulo, assim, mostra a estrutura estabelecida para o Curso de Direito, colocando em perspectiva os eixos que devem estar presentes para o seu desenvolvimento, em atenção às Diretrizes Curriculares Nacionais. Considerando a projeção dos eixos em disciplinas fundamentais, profissionalizantes e práticas, contextualiza-se a visão pluridisciplinar dos cursos, exemplificada pelas inferências produzidas a partir das matrizes curriculares que compõe o Anexo A do presente estudo, colocando-se em tela a importância de se conceber a formação do aluno de Direito sem a necessária vinculação a uma ou outra profissão, somando-se a compreensão das ações interdisciplinares para compor o movimento de reflexão sobre o ensino do Direito.

Registrada esta visão sobre o Curso de Direito em seus aspectos normativo e finalístico, combinando-se as importantes decorrências da interdisciplinaridade, passa-se a demonstrar os dados coletados por via de questionários relativos aos 
discentes e docentes de um curso de Direito, somando-se apontamentos sobre a aprendizagem e o relacionamento entre a teoria e a prática. 


\section{A MANifEstaÇÃo de PROFESSORES E ALUNOS DE DIREITO, O CONTEXTO DA APRENDIZAGEM E A RELAÇÃO TEORIA E PRÁTICA}

Se de há muito a Educação já tem tratado da aprendizagem com destaque, em especial no momento histórico que chegamos, com o predomínio da valorização humana, entre princípios da autonomia e liberdade, enquadrando-se num contexto crítico de se rever os papéis de seus atores, é fundamental que a comunidade jurídica associe esta responsabilidade, incorporando a necessidade de reconhecer elementos que contribuam com a formação e transformação do sujeito discente, além das limitações de uma aula-conferência.

Além disso, é preciso rever a responsabilidade da teoria em função da prática, para que se possa caminhar no sentido da superação de um afastamento ideológico-cultural, produtor da tradicional concepção de que a vida prática é bem diferente da vida teórica. Elege-se, para isso, a importante compreensão do sentido da aprendizagem e seus elementos, direcionando-se as ações docentes para a valorização das ações discentes, com critérios e objetivos aptos à compreensão de que isso não se resolve pelo ensino jurídico (técnico-conteudista), mas sim, por mecanismos didático-pedagógicos, entre outros aspectos.

Neste Capítulo, portanto, será apresentada uma pesquisa com coleta de dados por via de questionários aplicados aos discentes e docentes, na pretensão de se colher manifestações que mostrem as relações entre a teoria e a prática no estágio. Tendo os resultados como exemplificadores, parte-se para delinear alguns elementos de destaque da aprendizagem, envolvendo a teoria da aprendizagem significativa, desembocando em reflexões sobre relação teoria e prática para se compreender a importância do envolvimento discente em prol da aprendizagem necessária.

Deve-se, ainda, reconhecer as características de um objeto construído, pela consideração dos dados coletados, que não são puros em sua natureza, mas decorrentes de três momentos, como observa Demo (1985, p. 45-47): primeiro, que a realidade que captamos não é imediata e direta, mas sim aquela delineada da forma como conseguimos ver e captar, sendo, desta maneira, mediada a partir de um ponto de vista, reconhecendo o próprio cientista como ser social, e, por isso, faz parte do próprio fenômeno; segundo, a construção do objeto considera uma opção 
pela relevância determinada pelo interesse da sociedade, tratada sob o olhar da estrutura dominante, o que acarreta a conclusão de que "a ciência não transmite a realidade 'objetiva', mas aquela que interessa. Isso não significa má intenção da própria ciência, mas apenas que há um suporte de interesses por trás de toda investigação, que acabam dando-Ihe direcionamento; e terceiro, o objeto construído naturalmente recebe uma dose "de deturpação dos fatos, uma dose de simplificação do fenômeno, uma dose de manipulação", na medida em que ao não conseguir ver "tudo em tudo, vemos por facetas", pois quando "classificamos os fenômenos, recortamos e, assim, estereotipamos. Mas isso não significa a deturpação pura e simples, mas apenas o reconhecimento de que "o sujeito deixa no objeto sua marca".

Desta maneira, a análise dos dados dos dados colhidos juntos aos discentes e docentes do Curso de Direito estudado comporta essas ressalvas inevitáveis à pesquisa da natureza que ora se formula. A relação "entre sujeito e objeto é dinâmica, dialética, no sentido de mútua influência", mostrando precisamente o "fenômeno metodológico da interpretação, ou seja, depende também do intérprete, e, como conseqüência, do seu contexto social" (DEMO, 1985, p. 48).

$\mathrm{Na}$ sequência da apresentação dos dados, discorrer-se-á sobre a aprendizagem, somando-se as facetas instrumentais da teoria de Ausubel à compreensão da abrangência do sentido da aprendizagem, acrescentando-se a análise da motivação e da relação teoria e prática.

\subsection{Levantamentos sobre uma experiência do Estágio e sua relação com disciplinas teóricas}

A experiência pessoal acadêmica, construída pelos vinte anos de magistério superior, tem sido provocada por uma percepção da existência de uma linha de tensão no desenvolvimento das atividades práticas do Curso de Direito. Mesmo não participando diretamente como professor em Estágio, acompanhei muitos comentários decorrentes de dificuldades apontadas por docentes e discentes, especialmente no que se referia ao processo de resgate do conhecimento teórico para solução de situações reais ou simuladas.

Era possível notar, no plano da prática real (realizada em escritórios de advocacia e em órgãos da Justiça entre outros), que estagiários passavam por 
necessários momentos de adaptação para aplicação do conhecimento teórico. Havia (e isso certamente não foi eliminado) um distanciamento entre a sala de aula e as ações práticas no âmbito jurídico que contribuíam (e ainda contribuem) para a manutenção do discurso que "a teoria é uma coisa e a prática é outra", discurso este que repercute costumeiramente em escritórios de advocacia, cartórios e demais ambientes profissionais da área jurídica.

Da mesma forma, nem as atividades simuladas, construídas dentro do próprio curso como parte curricular, escapavam de discussões sobre o distanciamento entre a teoria e a prática. Constantes manifestações ressaltavam a necessidade de revisitar os conceitos teóricos para permitir ações como, por exemplo, a construção de petições e outros atos.

Foi possível vivenciar tal problema mais claramente quando assumi a disciplina de Direito Processual Civil I a partir do ano de 2000, lecionada no segundo ano do Curso. Antes, era responsável pela disciplina básica de Introdução ao Estudo do Direito e neste tempo, minha insatisfação era encontrar dificuldades para apontar uma teoria geral do Direito aos alunos do primeiro ano que não compreendiam a aplicação prática do que estava sendo proposto. Foram quase dez anos vivenciando as dificuldades das quais a ausência de conhecimento pedagógico exigiu seu preço, apesar das tentativas de superação. Quando comecei a trabalhar com o Processo Civil, imaginava que a maior praticidade do assunto diferenciaria a abordagem, tornando-se mais confortável o trabalho em sala de aula.

Porém, as aulas de Direito Processual Civil não encontraram um ambiente diferente. Estar no segundo ano do Curso não recebia alunos mais maduros em relação ao Processo Civil, pois, efetivamente, era a primeira vez que os alunos estavam vendo a disciplina. De novo, passei a reconhecer que havia um grande distanciamento entre a técnica processual e a experiência ainda não adquirida dos acadêmicos e isso realmente dificultava os trabalhos de condução da disciplina. A minha experiência docente indicava que tratar do Processo Civil sem a contextualização das informações na própria experiência dos alunos era um problema que precisava de tratamento.

Entre diversas tentativas, uma ação indicou alguns resultados destacados, não apenas pelo maior envolvimento dos alunos como pela percepção de suas falas posteriores, representadas por avaliações e comentários. Essa experiência foi introduzir, em algumas aulas, processos simulados produzidos por alunos de 
quartos e quintos anos para acompanhamento visual e manuseios, que concretizavam as informações teóricas tratadas. Tal prática foi explicada em artigo divulgado em revista na área do Direito (IOCOHAMA, 2003), gerando interessantes repercussões.

Certamente que essa ação não resolveu todos os problemas enfrentados na experiência docente no que se refere ao processo ensino-aprendizagem, mas ela, somada à adoção de avaliações com consulta (IOCOHAMA, 2004b), amenizaram muitos pontos de incômodo. Levou-se à inevitável conclusão de que o repensar da prática pedagógica deve ser constante, com sinalização para uma valorização da ação discente como um dos caminhos a se adotar.

De qualquer modo, a curiosidade sobre os específicos efeitos da aprendizagem teórica na prática ainda permaneciam e se notou que o discurso das dificuldades ainda ocorria. Até se pensou em construir uma pesquisa voltada a apuração dos efeitos específicos provocados pelas alterações metodológicas na disciplina lecionada nas abordagens do estágio, mas reconheceu-se que muitas variáveis poderiam interferir no resultado, tendo em vista que o Processo Civil I (que leciono) é apenas a parte geral de várias outras partes do Processo Civil. Além disso, a prática (simulada ou real) tem necessidade parcial do Processo Civil, porque os estudos dessa disciplina envolvem principalmente técnicas formais/instrumentais, e o Direito a ser aplicado aos casos não se resume apenas no processo. Pelo contrário, a prática judicial exige conhecimento da técnica processual, mas a solução de um conflito vai além dela, porque depende de conhecimentos envolvendo o que se convencionou chamar de direito material, caracterizado pelas regras que afetam diretamente um bem da vida, além, é claro, de conhecimento extrajurídico, para o qual a interdisciplinaridade tem contribuição fundamental.

Existindo, assim, um problema macro envolvendo a prática e o conhecimento teórico, propôs-se o presente estudo, aproveitando-se da oportunidade de uma PósGraduação para investigar o ensino jurídico neste ponto. A construção de um questionário foi amadurecida com a aplicação de um questionário piloto e, após algumas modificações, sua aplicação foi realizada.

O Curso de Direito investigado é mantido por uma instituição particular de ensino superior considerada como Universidade, com diversos Campi. Em todos eles há um Curso de Direito em andamento. O Curso de Direito da sede tem mais de 
30 (trinta) anos de funcionamento, sendo que os Cursos dos outros dois Campi analisados têm pouco menos de 13 anos.

O Curso de Direito possui uma matriz curricular que se aplica a todos os Campi, com diversificação em cursos e atividades extracurriculares. Os planos de ensino também possuem uma estrutura básica semelhante, de maneira que tanto as disciplinas teóricas como as disciplinas práticas transitam em conteúdos aproximados. As disciplinas teóricas (dos eixos de disciplinas fundamentais e profissionalizantes) são desenvolvidas durante os cinco anos do Curso, reservandose as disciplinas de Prática (de Processo Civil, Processo Penal e Processo do Trabalho) para os dois últimos anos.

Há que se ressaltar que os resultados obtidos pelo questionário não foram direcionados para uma conclusão que buscasse um modelo de investigação padrão para a área. Pretendeu-se colher elementos para verificar a existência ou não de um discurso apontando as dificuldades já imaginadas e percebidas pela experiência pessoal.

Neste sentido, produziram-se questionários direcionados para discentes e docentes. Houve a aplicação de um questionário piloto em um Campus e, depois de revisada sua redação, fez-se nova aplicação em Cursos de Direito de Campi diversos. Em relação aos discentes, todos os que responderam o questionário pertenciam a um Campus. Em relação aos docentes, ampliou-se para Campi diversificados, em razão da pequena quantidade de docentes vinculados às disciplinas teóricas de Processo Civil (I e II) e de supervisão de estágio. Cada instrumento será detalhado por ocasião das análises realizadas.

Para facilitar a leitura dos resultados obtidos optou-se por destacar algumas inferências da leitura proporcionada pelos resultados obtidos, sendo que o detalhamento estatístico das informações ficou reservado para o Anexo B.

\subsubsection{O discurso dos acadêmicos}

O questionário elaborado teve por objetivo levantar informações sobre duas questões principais: forma de condução das aulas teóricas de Processo Civil I e II (no curso investigado, tais disciplinas são fornecidas no segundo e terceiro anos) e as dificuldades enfrentadas com conteúdos teóricos perante as aulas de estágio de 
Processo Civil. Pretendeu-se compreender as técnicas empregadas nas abordagens teóricas e as representações indicadas nos momentos das aulas práticas aplicadas durante o quarto ano do Curso. Assim, o questionário foi proposto a alunos cursando o quinto ano em período noturno, que passaram por todos os momentos investigados. Do total de 26 (vinte e seis) alunos pertencentes a este grupo, 22 responderam ao questionário, sendo 10 (dez) sujeitos do sexo masculino e 12 (doze) do sexo feminino. Destes alunos, 02 (dois) não trabalhavam; 02 (dois) trabalhavam na área jurídica sem remuneração; 01 (um) trabalhava na área jurídica com remuneração e registro em carteira de trabalho; 10 (dez) trabalhavam na área jurídica com remuneração, mas sem registro em carteira de trabalho e 07 trabalhavam, mas não na área jurídica.

No sentido de verificar as aulas de Processo Civil I e II, foram apresentados dois questionários contendo as mesmas questões, diferenciando apenas a indicação da disciplina (Processo Civil I para o segundo ano e Processo Civil II para o terceiro). As questões formuladas eram as seguintes:

\section{Avalie as técnicas utilizadas pelo seu professor de Direito Processual Civil I para o processo de ensino-aprendizagem da disciplina:}

Técnica de aprendizagem
a) Aula predominantemente com exposição oral pelo Professor
b) Discussões em grupo de alunos
c) Pesquisas extraclasses pelos alunos
d) Respostas orais do(s) aluno(s) por perguntas diretas do professor
e) Exposições orais dos alunos em razão de seminários/apresentação de trabalhos em grupo
f) Exposição oral de aluno em razão de seminários/apresentação de trabalhos individuais
g) Leituras de textos pelos alunos em sala de aula
h) Leituras de textos pelos alunos fora de sala de aula
i) Realização de atividades práticas simuladas pelo aluno

Para responder ao questionário, cada aluno poderia assinalar apenas uma vez entre os valores Nunca (Zero), Raramente ( $1 \mathrm{x}$ mês), Regularmente (2x por mês), Quase sempre ( 3 x por mês) e Sempre ( 4 x por mês) para cada das alíneas propostas. Assim, o questionário acima apareceu duas vezes, alterando-se apenas o nome da disciplina. Abaixo seguem os dados coletados para a disciplina de Direito Processual Civil I e Direito Processual Civil II: 


\begin{tabular}{l} 
Avaliação do desempenho sobre a exposição e condução da aula pelo professor de Direito Processual Civil I do Curso de Direito - 2010 \\
\hline
\end{tabular}

Tabela 01 - Respostas apresentadas por Discentes na avaliação das ações docentes em Direito Processual Civil I

\begin{tabular}{l} 
Avaliação do desempenho sobre a exposição e condução da aula pelo professor de Direito Processual Civil II do Curso de Direito -2010 \\
\hline \multirow{2}{*}{ Questão }
\end{tabular}

Tabela 02 - Respostas apresentadas por Discentes na avaliação das ações docentes em Direito Processual Civil II

$\mathrm{Na}$ análise das respostas apresentadas, mereceu destaque a questão da letra a (Q1), onde se indicou que o predomínio da apresentação oral dos conteúdos era alto. Dos 22 alunos, 14 responderam "Sempre", quando se tratou da disciplina teórica de Direito Processual Civil I e 13 responderam a mesma alternativa quando o objeto de análise foi a ação docente perante a disciplina teórica de Direito Processual Civil II. Considere-se que "Regularmente" e "Quase Sempre" ainda somaram mais 6 alunos para a primeira disciplina e 7 para a segunda, o que mostra um padrão de atuação para ambos os docentes.

É importante considerar que no caso explorado, os docentes das disciplinas de Direito Processual Civil I (segundo ano) e Direito Processual Civil II (terceiro ano) não eram os mesmos, apesar de identificar posturas semelhantes quanto ao predomínio da apresentação oral de conteúdos. Estas respostas refletem o que já se indicou sobre a tradição para o ensino jurídico, com ênfase na ação docente pela exposição oral, dentro da cultura das aulas-conferência.

Outro item de especial destaque, é o que envolve a realização de atividades práticas simuladas (questão "i" - Q9). Para ambas as disciplinas, a maior quantidade 
de respostas indicou que nunca houve realização de atividades práticas simuladas. Neste sentido, para a disciplina do segundo ano (Direito Processual Civil I), 10 alunos responderam "nunca" e 5 "raramente", sendo apenas 1 resposta "sempre". Já para a disciplina do terceiro ano (Direito Processual Civil II), foram 11 respostas "nunca" e 5 "raramente", aparecendo 2 respostas "sempre".

Num ponto que se dará destaque posteriormente, a realização de atividades práticas pelo discente envolvendo o conhecimento teórico dificilmente ocorre com o desenvolvimento das aulas desta natureza (teóricas). Este questionário, assim, aponta um indicador de uma prática que se percebe de há muito tempo: abordagens das disciplinas teóricas não contemplam ações práticas imediatas, salvo raras exceções.

As questões de letra "b" a "i", prestavam-se para indicar a predominância para a ação discente, a partir de condutas dirigidas pelo professor. Interessante observar que ambos os professores diversificaram ações neste sentido, havendo, porém, baixa incidência em atividades como exposição de trabalhos em grupo ou individuais (questões "e" - Q4 e "f" - Q5), bem como a pesquisa extraclasse (questão "c" - Q3).

Um padrão também se observa pela valorização da manifestação oral individual dos alunos, em respostas às perguntas feitas pelo professor (letra "d" Q4). Em ambas as disciplinas se percebe uma incidência predominante neste sentido, correspondendo a uma prática nas aulas de Direito que é intercalar a aulaconferência com momentos de questionamentos orais.

Por conta da predominância do estudo do Direito a partir das leis, doutrinas e jurisprudência, percebe-se que o incentivo à leitura de textos dentro e fora da sala de aula também se destaca (questões "g" - Q7 e "h" - Q8), com maior incidência no terceiro ano.

Em relação às aulas práticas, os mesmos tinham como opções as seguintes questões:

Durante suas aulas de Prática de Processo Civil no 4ำ Ano, na Instituição (Estágio Supervisionado Simulado), você necessitou de conteúdos teóricos das disciplinas de Processo Civil I e Processo Civil II. Assim, assinale a alternativa que mais corresponda às dificuldades enfrentadas, durante 0 referido $4^{\circ}$ Ano (na disciplina de Prática de Processo Civil) sobre os conteúdos abaixo: 
Conteúdos teóricos ${ }^{1}$ tratados durante as aulas de Prática do 4 Ano

a) A matéria de princípios de Processo Civil (Processo Civil I)

b) A matéria relativa à competência (Processo Civil I)

c) A matéria de organização Judiciária (Processo Civil I)

d) A matéria condições da ação (Processo Civil I)

e) A matéria atos processuais (Processo Civil I)

f) A matéria petição inicial (Processo Civil II)

g) A matéria contestação (Processo Civil II)

h) A matéria provas (Processo Civil II)

i) A matéria sentença (Processo Civil II)

k) A matéria recursos (Processo Civil II)

Para este questionário, cada aluno poderia assinalar apenas uma vez entre os valores Nunca houve dificuldades ( $0 \%$ das vezes), $25 \%$ das vezes houve dificuldades, $50 \%$ das vezes houve dificuldades, $75 \%$ das vezes houve dificuldades, e $100 \%$ das vezes houve dificuldades.

Neste sentido, o objetivo desta parte do questionário era obter informações sobre a condução das aulas práticas, considerando que as mesmas fazem parte de uma prática simulada. Na formatação do curso analisado, os alunos devem cursar disciplinas de Estágio simulado e real. O Estágio simulado é conduzido pelo Curso, com a ação de professores que conduzem aulas intercalando exposições orais que auxiliam a confecção das atividades práticas simuladas estabelecidas. O Estágio real é executado por meio de convênios com escritórios de advocacia, procuradorias, cartórios e pela assistência judiciária gratuita mantida pela Instituição de Ensino Superior, entre outros. Ambos os estágios são realizados durante os dois últimos anos do Curso (4ํㅜ e 5ํano).

Observe-se que o momento escolhido do Curso de Direito para a coleta dos discursos ressaltando o incômodo do afastamento da teoria é nesse tempo da prática que antecede a experiência profissional. No convívio acadêmico, sempre se percebeu o discurso do afastamento da prática da teoria e das dificuldades enfrentadas no momento do estágio simulado, com os problemas de aprendizagem para resgate do conteúdo teórico. Assim, a proposta do questionário foi justamente

\footnotetext{
1 A expressão "conteúdo teórico", ainda que ausente de tecnicidade, foi utilizada para uma melhor compreensão dos alunos e de maneira a diferenciá-lo das abordagens práticas. Esta alteração ocorreu em razão do questionário piloto aplicado para uma turma distinta, que ressaltou dificuldades na compreensão do referido item. A mesma intenção resultou na utilização da expressão "matéria" para indicar os conteúdos tratados pelas disciplinas de Direito Processual Civil I e Direito Processual Civil II e que poderiam estar produzindo dificuldades no decorrer da disciplina de Prática de Processo Civil (Estágio Simulado), realizada no 4ㅇ Ano do Curso.
} 
conferir a existência dessa manifestação que já se presenciou em diversas mas esparsas oportunidades.

Desta maneira, o questionário apresentou uma lista de dez assuntos, com referência ao nome da disciplina teórica onde o mesmo foi tratado. Para cada um desses assuntos foram formuladas questões que indicariam se houve dificuldade para a sua abordagem quando ela ocorreu durante as aulas de estágio simulado.

Os resultados do levantamento mostram predomínio de alternativas assinaladas tendendo às dificuldades. Pouquíssimos alunos afirmaram que nunca houve dificuldades (de 1 a 3 alunos apenas), o que permite afirmar que a hipótese anterior das dificuldades na condução das aulas de prática não é rejeitada. Assim, pela manifestação dos alunos, os conteúdos anteriormente vistos (nas disciplinas teóricas escolhidas de Processo Civil) geravam dificuldades. Efetivamente, as respostas dos alunos produziram o seguinte:

Avaliação das dificuldades enfrentadas durante as aulas de Prática Jurídica no 4ํAno (Estágio Supervisionado Simulado) devido à deficiência no ensino de conteúdos teóricos nas disciplinas de Processo Civil I e Processo Civil II - 2010

\begin{tabular}{|c|c|c|c|c|c|c|c|}
\hline Questão & Conteúdos teóricos do $4^{\circ}$ ano (Maliação das dificuldades & $\begin{array}{c}100 \% \text { das vezes } \\
\text { houve }\end{array}$ & $\begin{array}{c}75 \% \text { das vezes } \\
\text { houve }\end{array}$ & $\begin{array}{c}50 \% \text { das vezes } \\
\text { houve }\end{array}$ & $\begin{array}{l}25 \% \text { das vezes } \\
\text { houve }\end{array}$ & $\begin{array}{c}0 \% \\
\text { (Nunca houve) }\end{array}$ & Total \\
\hline $\mathrm{Q}_{1}$ & Princípios de Processo Civil (Processo Civil I) & 1 & 7 & 3 & 10 & 1 & 22 \\
\hline $\mathrm{Q}_{2}$ & Relativos à Competência (Processo Civil I) & 3 & 5 & 3 & 11 & 0 & 22 \\
\hline $\mathrm{Q}_{3}$ & Organização Judiciária (Processo Civil I) & 4 & 3 & 3 & 9 & 3 & 22 \\
\hline $\mathrm{Q}_{4}$ & Condições da ação (Processo Civil I) & 5 & 7 & 2 & 8 & 0 & 22 \\
\hline$Q_{5}$ & Atos Processuais (Processo Civil I) & 5 & 8 & 1 & 7 & 1 & 22 \\
\hline$Q_{6}$ & Petição Inicial (Processo Civil II) & 3 & 7 & 4 & 7 & 1 & 22 \\
\hline$Q_{7}$ & Contestação (Processo Civil II) & 2 & 7 & 3 & 9 & 1 & 22 \\
\hline$Q_{8}$ & Provas (Processo Civil II) & 4 & 8 & 2 & 6 & 2 & 22 \\
\hline $\mathrm{Q}_{9}$ & Sentença (Processo Civil II) & 4 & 7 & 4 & 7 & 0 & 22 \\
\hline $\mathrm{Q}_{10}$ & Recursos (Processo Civil II) & 8 & 6 & 3 & 5 & 0 & 22 \\
\hline
\end{tabular}

Tabela 03 - Respostas apresentadas por Discentes em relação às dificuldades enfrentadas perante as disciplinas de Estágio Simulado de Processo Civil

É certo que podem existir diversos fatores para embasar as dificuldades apontadas: a complexidade do conteúdo e a sua utilização (ou não) durante as aulas práticas podem ser alguns deles. É interessante notar que não há um padrão entre a incidência das dificuldades em conteúdos da disciplina de Processo Civil I da disciplina de Processo Civil II, para que se pudesse concluir que o problema estaria no distanciamento do tempo que os conteúdos foram lecionados. Mas é possível afirmar que tratamento apenas teórico dos conteúdos provavelmente conduza às dificuldades durante a realização das aulas práticas, e este era um dado que se esperava efetivamente encontrar na exploração realizada, ainda mais se somando as informações prestadas pelos docentes, com se verá no próximo item. 


\subsubsection{O discurso dos professores}

A escolha dos professores para a obtenção das informações foi baseada em dois grupos: os dos professores das disciplinas teóricas de Processo Civil I e Processo Civil II e os dos professores que atuaram nas disciplinas de estágio. No caso do formato do Curso analisado, estes professores são denominados supervisores de estágio, os quais atuam diretamente com os alunos, executando ações estabelecidas por um Coordenador de Estágio da área (no caso, de Processo Civil). Como o número de professores do Curso analisado era bem reduzido, ampliou-se a amostragem para incluir, além dos professores ligados diretamente aos alunos, também aqueles de outrs Campi, mas pertencentes à mesma Instituição de Ensino Superior, para reproduzirem idêntico ambiente estrutural.

Assim, 14 (catorze) questionários foram coletados de um total de 12 (doze) professores, tendo em vista que dois professores atuaram ao mesmo tempo em disciplinas teóricas e práticas (estágio supervisionado). Todos eles têm vinculo com o Processo Civil (considerando-se as disciplinas teóricas de Direito Processual Civil e a de prática/estágio de Processo Civil). Não pretendi especificar o envolvimento com disciplinas teóricas de outras áreas que não o Processo Civil tendo em vista a pretensão de se cruzar informações apenas nesta área. Logo, é possível que algum professor relacionado apenas como atuante no estágio também lecione outra disciplina teórica que não o Processo Civil, mas isso não está sendo considerado e descrito.

Do mesmo Campus onde foram coletados os questionários dos alunos, 03 (três) professores responderam ao questionário. Deles, 02 (dois) atuaram na disciplina teórica de Processo Civil (I e II) e 01 (uma) responsável somente pela prática. Um dos professores da disciplina teórica também era responsável pela prática. Assim, foram respondidos 04 (quatro) questionários (dois envolvendo atividades junto ao estágio e dois relativos às disciplinas teóricas de Processo Civil I e II).

Os demais professores participantes foram de outros dois Campi (localizados em cidades distintas daquela dos alunos). 01 (uma) professora, responsável pela prática e pela disciplina teórica, participou de um dos Campi, produzindo 02 (dois) questionários. Do outro Campus, 05 (cinco) professores atuaram especificamente 
junto ao estágio e 03 (três) em disciplinas teóricas de Processo Civil, totalizando 09 (nove) questionários.

Assim, o grupo de professores foi composto por 12 (doze) sujeitos, sendo 4 (quatro) mulheres e 08 (oito) homens. Todos os professores e professoras atuam na área jurídica também como advogados(as). 02 (duas) mulheres e 01 (um) homem são especialistas (sendo que o homem atua na disciplina teórica e as mulheres junto ao estágio de prática de Processo Civil. Dos 10 professores restantes, 09 são mestres e 01 é pós-doutor (este do sexo masculino, atuando apenas na disciplina teórica). Com a titulação de mestre, 02 (duas) são mulheres e 07 (sete) são homens.

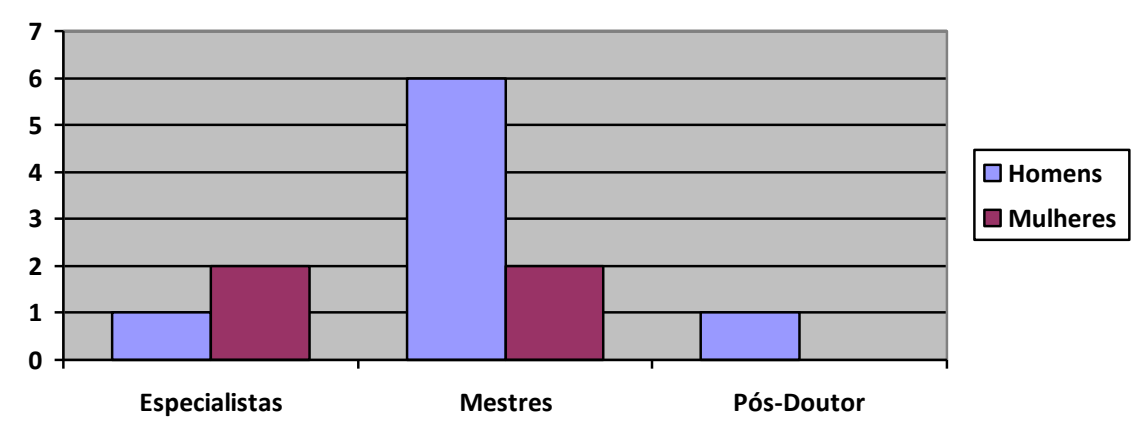

Gráfico 01 - Distribuição de titulação entre docentes segundo o gênero

Em relação à formação pedagógica, 02 (duas) professoras informaram ter licenciatura (uma delas ligada apenas ao estágio e a outra ao estágio e à disciplina teórica). Os professores e professoras com titulação de mestre informaram que cursaram a disciplina com conteúdo pedagógico em cursos especialização ou de mestrado, sendo que apenas 01 informou que não obteve informações pedagógicas neste nível, apontando, porém, que participou de eventos de caráter pedagógico promovidos pela Universidade. O professor pós-doutor também informa ter cursado disciplina pedagógica em curso de especialização ou de mestrado.

No que se refere ao tempo de atuação como docente no ensino superior, dividindo-se os docentes nas categorias de professores envolvidos com as disciplinas teóricas e professores envolvidos com a disciplina de prática, por cinco grupos (considerando o tempo de atuação): a) menos de 02 anos; b) de 02 a 04 anos; c) de 05 a 07 anos; d) de 08 a 10 anos; e) mais de 10 anos.

Assim, em relação aos professores das disciplinas teóricas, do total de 06 (seis), 01 (um) tem de 05 a 07 anos de atuação; 01 (um) tem de 08 a 10 anos e 04 
(quatro) têm mais de 10 anos. Visualizando-se estes dados, tem-se a seguinte gráfico:

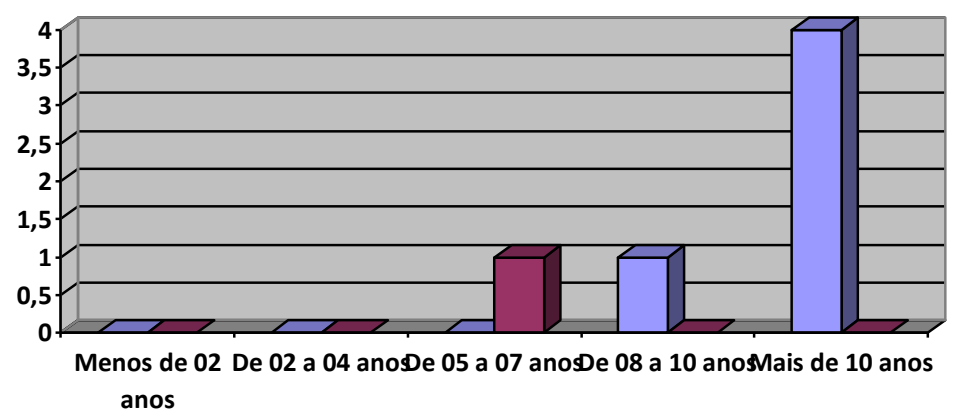

$\square$ Homens

$\square$ Mulheres

Gráfico 02 - Distribuição de tempo de atuação entre docentes das disciplinas teóricas segundo o gênero

Quanto ao mesmo critério de tempo de atuação como docente, porém visualizando-se professores das disciplinas de prática/estágio, do total de 08 (oito), 01 (um) tem menos de dois anos; 02 (dois) têm de 02 a 04 anos; 01 (um) de 05 a 07 anos); 01 (um) tem de 08 a 10 anos e 03 (três) têm mais de 10 anos. Visualizandose estes dados, tem-se a seguinte gráfico:

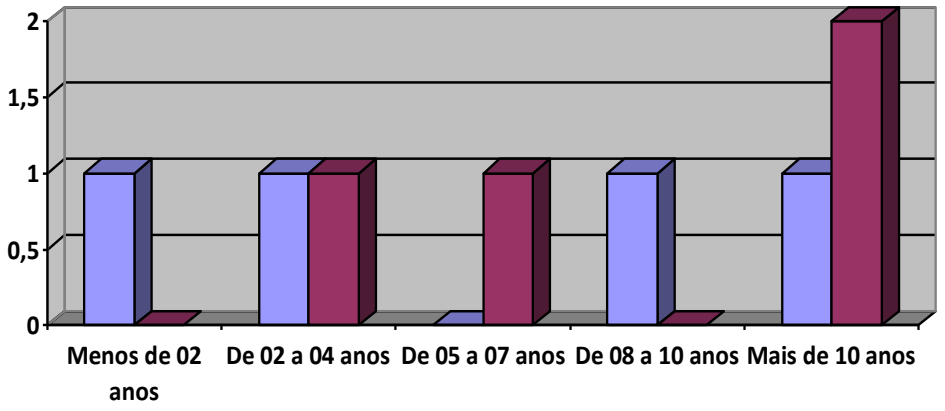

Gráfico 03 - Distribuição de tempo de atuação entre docentes das disciplinas práticas/estágio segundo o gênero

Ressaltadas as características dos docentes, parte-se para a verificação dos dados que os mesmos apresentaram, de conformidade com os questionários proposto, que foram divididos entre as disciplinas teóricas e a prática. Para os professores envolvidos com a parte teórica do Processo Civil, foram apresentadas as seguintes questões, em relação às técnicas utilizadas: 


\section{Avalie as técnicas utilizadas por você para o processo de ensino- aprendizagem da(s) disciplina(s) lecionada:}

Técnica de aprendizagem

a) Aula com exposição oral predominante

b) Discussões em grupo

c) Pesquisas extraclasses

d) Exposições orais do(s) aluno(s) por perguntas diretas do professor

e) Exposições orais dos alunos em razão de seminários/apresentação de trabalhos em grupo

f) Exposição oral de aluno em razão de seminários/apresentação de trabalhos individuais

g) Leituras de textos em sala de aula

h) Leituras de textos fora da sala de aula

i) Acompanhamento de atividades escritas dos alunos com orientações para o desenvolvimento de peças práticas

As respostas para este questionário apresentavam os seguintes valores, perguntados se utilizam as técnicas de aprendizagem relacionadas: Nunca (Zero), Raramente (1x mês), Regularmente (2x por mês), Quase sempre (3x por mês) e Sempre ( 4 x por mês) para cada das alíneas propostas. Os 06 (seis) professores assinalaram as seguintes alternativas:

\begin{tabular}{|c|c|c|c|c|c|c|}
\hline Questão & Técnicas de aprendizagem & $\begin{array}{l}\text { Nunca } \\
\text { (zero) }\end{array}$ & $\begin{array}{c}\text { Rarament } \\
\text { e } \\
(\mathbf{l} \times \text { mês) }\end{array}$ & $\begin{array}{l}\text { Regularmente } \\
\text { (2x mês) }\end{array}$ & $\begin{array}{l}\text { Quase } \\
\text { sempre } \\
\text { (3x mês) }\end{array}$ & $\begin{array}{l}\text { Sempre } \\
(4 \times \text { mês })\end{array}$ \\
\hline $\mathbf{Q}_{1}$ & Aula com exposição oral predominante. & - & - & - & 2 & 4 \\
\hline $\mathbf{Q}_{2}$ & Discussões em grupo. & 2 & 1 & 2 & 1 & - \\
\hline $\mathbf{Q}_{3}$ & Pesquisas extraclasses. & - & 4 & 2 & - & - \\
\hline $\mathbf{Q}_{4}$ & Exposições orais do(s) aluno(s) por perguntas diretas do professor. & - & 1 & 3 & 1 & 1 \\
\hline$Q_{5}$ & $\begin{array}{l}\text { Exposições orais dos alunos em razão de seminários/apresentação de trabalhos em } \\
\text { grupos. }\end{array}$ & 2 & 2 & 2 & - & - \\
\hline$Q_{6}$ & $\begin{array}{l}\text { Exposição oral de alunos em razão de seminários/apresentação de trabalhos } \\
\text { individuais. }\end{array}$ & 3 & 3 & - & - & - \\
\hline$Q_{7}$ & Leituras de textos em sala de aula. & 3 & 3 & - & - & - \\
\hline $\mathbf{Q}_{8}$ & Leituras de textos fora da sala de aula. & 1 & 1 & 3 & 1 & - \\
\hline $\mathbf{Q}_{9}$ & $\begin{array}{l}\text { Acompanhamento de atividades escritas dos alunos com orientações para o } \\
\text { desenvolvimento de peças práticas. }\end{array}$ & 1 & 2 & 1 & - & 2 \\
\hline
\end{tabular}

Fonte: Celso Iocohama

Tabela 04 - Respostas apresentadas por Docentes das disciplinas teóricas de Direito Processual Civil sobre a utilização de procedimentos para as aulas

Na primeira questão, buscando informações sobre a utilização da aula com exposição oral predominante, verifica-se que quatro professores a utilizam sempre, o que não nega o discurso de que as aulas de Direito têm forte tendência à utilização 
da exposição oral por parte do professor. Este dado coincide com as manifestações dos alunos, que revelaram a mesma indicação.

Em relação às ações envolvendo uma maior atuação dos alunos (questões Q2 a Q8), pode-se notar a tendência a não acontecerem, predominando a resposta Nunca ou Raramente, com exceções para as pesquisas extraclasses e as exposições orais pelos alunos por perguntas diretas realizadas pelo professor.

A questão 9, envolvendo o acompanhamento dos alunos, por parte do professor, para a realização de peças práticas, mostra que a maioria dos professores não a utiliza. Importante ressaltar que os dois professores que afirmaram fazê-lo são aqueles que ao mesmo tempo atuam nas disciplinas teóricas e nas práticas. Assim, razoável que assinalassem envolvimento com as atividades práticas dos alunos, mas não significa que isso ocorre ao tempo das aulas teóricas. Esse acompanhamento é inevitável durante as aulas de estágio, onde a metodologia adotada envolve a realização de peças processuais simuladas demanda a respectivo atenção do professor.

Focando-se na aprendizagem do aluno, a segunda parte do questionário procurou investigar quais seriam os procedimentos de ensino mais adequados, na perspectiva dos professores ${ }^{2}$. Assim foram formuladas as questões:

Tendo em foco a aprendizagem do aluno envolvendo o processo civil, avalie as técnicas de aprendizagem abaixo:

a) Aula expositiva com exposição oral pelo Professor

b) Discussões em grupo

c) Pesquisas extraclasses

d) Exposições orais do aluno por perguntas diretas do professor

e) Exposições orais dos alunos em razão de seminários/apresentação de trabalhos em grupo

f) Exposição oral de aluno em razão de seminários/apresentação de trabalhos individuais

g) Realização de atividades práticas simuladas pelo aluno

As respostas para este questionário avaliavam a seguinte consideração: se a aplicação da técnica para conhecimento do aluno pelos seguintes valores: Não necessária (zero), Pouco Necessária (de $1 \%$ a 25\% de importância), Moderadamente Necessária (de $26 \%$ a $50 \%$ de importância), Muito Necessária (de

\footnotetext{
${ }^{2}$ Da mesma forma como explicado no questionário investigando o discurso discente, o questionário aplicado aos docentes procurou apresentar expressões que superassem as dúvidas oriundas no questionário piloto.
} 
$51 \%$ a $75 \%$ de importância) e Altamente Necessária (de 76\% a 100\% de importância). Os 06 (seis) participantes da pesquisa assim se pronunciaram:

\begin{tabular}{|c|c|c|c|c|c|c|}
\hline Questão & Técnicas de aprendizagem & $\begin{array}{c}\text { Não } \\
\text { Necessária } \\
\text { (zero) }\end{array}$ & $\begin{array}{c}\text { Pouco } \\
\text { Necessária } \\
\text { (de 1\% a } \\
25 \% \text { ) }\end{array}$ & $\begin{array}{c}\text { Moderadamente } \\
\text { Necessária } \\
\text { (de 26\% a } \\
50 \% \text { ) }\end{array}$ & $\begin{array}{c}\text { Muito } \\
\text { Necessária } \\
\text { (de } 51 \% \text { a } \\
75 \% \text { ) }\end{array}$ & $\begin{array}{c}\text { Altamente } \\
\text { Necessária } \\
\text { (de } 75 \% \text { a } \\
100 \% \text { ) } \\
\end{array}$ \\
\hline$Q_{1}$ & Aula com exposição oral predominante. & - & $\cdot$ & 1 & 2 & 3 \\
\hline$Q_{2}$ & Discussões em grupo. & - & 1 & 2 & 3 & $\cdot$ \\
\hline$Q_{3}$ & Pesquisas extraclasses. & - & 3 & 2 & 1 & - \\
\hline$Q_{4}$ & Exposições orais do(s) aluno(s) por perguntas diretas do professor. & - & - & 5 & 1 & - \\
\hline$Q_{5}$ & Exposições orais dos alunos em razão de seminários/ apresentação de trabalhos em grupos. & - & 3 & 3 & $\cdot$ & - \\
\hline$Q_{6}$ & Exposição oral de alunos em razão de seminários/apresentação de trabalhos individuais. & - & 3 & 3 & $\cdot$ & $\cdot$ \\
\hline$Q_{7}$ & Realização de atividades práticas simuladas pelo aluno. & - & 2 & 1 & 1 & 2 \\
\hline
\end{tabular}

Tabela 05 - Respostas apresentadas por Docentes das disciplinas teóricas de Direito Processual Civil relacionando os procedimentos de ensino com a aprendizagem

Numa visão mais ampla, é possível observar que os procedimentos de ensino relacionados não são descartados pelos professores, já que nenhum professor chegou a assinalar a primeira coluna, com a indicação de "não necessária". Em sentido oposto, a aula com exposição oral predominante (alínea "a" - Q1) foi apontada como predominante para a visão dos professores em relação à aprendizagem. Note-se também que a intervenção oral pelo aluno não é indicada como muito ou altamente necessária, apesar dos professores manifestarem a utilização deste procedimento no questionário anterior.

Outro aspecto investigado pretendeu verificar a manifestação dos professores envolvendo a relação de sua disciplina com a prática dos assuntos por eles mesmos tratados. As indagações formuladas foram a seguintes:

Assinale a alternativa que mais corresponder à sua expectativa da disciplina de processo civil e a prática sobre o conhecimento que você proporciona:

a) Durante a aula de Processo Civil (I ou II), é necessário fazer com que os alunos realizem atividades práticas, mesmo sem a disciplina de Prática (Estágio Simulado)

b) É possível desenvolver a aprendizagem do Processo Civil (I ou II) sem a realização de atividades práticas pelos alunos

c) O ensino da parte teórica do processo civil não exige que o aluno realize atividades práticas (no segundo ou terceiro ano)

d) Devido ao tempo, o ensino da parte teórica é incompatível com as atividades práticas

As respostas para este questionário poderiam ser escolhidas pelo seguinte critério: Discordo plenamente, Discordo parcialmente, Não concordo nem discordo, 
Concordo parcialmente, Concordo plenamente. As respostas obtidas foram as seguintes:

\begin{tabular}{|c|c|c|c|c|c|c|}
\hline Questão & Técnicas de aprendizagem & $\begin{array}{c}\text { Discordo } \\
\text { plenamente }\end{array}$ & $\begin{array}{c}\text { Discordo } \\
\text { parcialmente }\end{array}$ & $\begin{array}{c}\text { Não } \\
\text { concordo } \\
\text { nem discordo }\end{array}$ & $\begin{array}{c}\text { Concordo } \\
\text { parcialmente }\end{array}$ & $\begin{array}{l}\text { Concordo } \\
\text { plenamente }\end{array}$ \\
\hline $\mathrm{Q}_{1}$ & $\begin{array}{l}\text { Durante a aula de Processo Civil (I ou II) é necessário fazer com que os alunos } \\
\text { realizem atividades práticas, mesmo sem a disciplina de Prática (Estágio Simulado). }\end{array}$ & 1 & - & 1 & 1 & 3 \\
\hline $\mathrm{Q}_{2}$ & $\begin{array}{l}\text { É possível desenvolver a aprendizagem do Processo Civil (I e II) sem a realização de } \\
\text { atividades práticas pelos alunos. }\end{array}$ & 2 & - & 1 & 2 & 1 \\
\hline $\mathrm{Q}_{3}$ & $\begin{array}{l}\text { O ensino da parte teórica do processo civil não exige que o aluno realize atividades } \\
\text { práticas (no segundo ou terceiro ano). }\end{array}$ & 2 & 1 & 1 & 1 & 1 \\
\hline $\mathrm{Q}_{4}$ & Devido ao tempo, o ensino da parte teórica é incompatível com as atividades práticas. & 1 & - & 1 & - & 4 \\
\hline
\end{tabular}

Tabela 06 - Respostas apresentadas por Docentes das disciplinas teóricas de Direito Processual Civil apresentando sua expectativa quanto à prática dos conteúdos abordados.

Sob a ótica dos professores das disciplinas teóricas, percebe-se que há quem afirme categoricamente que não há necessidade de qualquer atividade prática para o desenvolvimento da sua disciplina. Isso aparece claramente na questão "a" (Q1), com um professor discordando plenamente. $\mathrm{Na}$ análise específica de cada questionário respondido, foi interessante verificar que este mesmo professor concorda plenamente com as demais alternativas, as quais afirmam a dispensabilidade das atividades práticas, além de considerar o tempo incompatível para isso.

Interessante observar que dois professores indicaram a importância da prática para o desenvolvimento de sua disciplina, discordando plenamente tanto da afirmação da questão "b" (Q3) como da "c" (Q4). Tais professores são justamente os que também atuam nas disciplinas práticas.

Uma afirmação predominante aparece na questão do tempo para o desenvolvimento das atividades práticas (questão "d", Q4). Nela, quatro professores afirmam que o tempo torna incompatível a realização das atividades práticas no ensino da parte teórica. Dos dois professores que não assinalaram a mesma alternativa, um discordou plenamente da afirmação e outro opinou com indiferença à mesma, sendo os mesmos que haviam opinado pela importância das atividades práticas (ambos lecionam a disciplina teórica como a disciplina prática), significando que utilizariam deste recurso em suas aulas. 
Por fim, para os professores das disciplinas teóricas, questionou-se a sua relação com as ações desenvolvidas diretamente pela disciplina de Estágio supervisionado (Prática de Processo Civil), com as seguintes perguntas:

\section{Sua relação com a disciplina de Estágio/Prática de Processo Civil:}

a) Tem conhecimento das dificuldades enfrentadas pelos alunos quanto ao conhecimento teórico da disciplina de processo civil e sua aplicação na prática/estágio?

b) É consultado pelo professor da Prática/Estágio sobre os procedimentos de aprendizagem aplicados na disciplina teórica?

c) Tem conhecimento das práticas exigidas durante a disciplina de Estágio/Prática de Processo Civil envolvendo o conteúdo da disciplina teórica?

Para este questionário, as respostas eram escolhidas pelo seguinte critério: Discordo plenamente, Discordo parcialmente, Não concordo nem discordo, Concordo parcialmente, Concordo plenamente. Os resultados obtidos foram os seguintes:

Auto-avaliação da relação e comprometimento com a disciplina de Estágio/Prática de Processo Civil

\begin{tabular}{|c|c|c|c|c|c|c|}
\hline Questão & $\begin{array}{l}\text { Avaliação da relação com a disciplina de } \\
\text { estágio }\end{array}$ & $\begin{array}{c}\text { Nunca } \\
\text { (zero) }\end{array}$ & $\begin{array}{l}\text { Raramente } \\
\text { (l x mês) }\end{array}$ & $\begin{array}{l}\text { Regularmente } \\
\text { (2 x mês) }\end{array}$ & $\begin{array}{l}\text { Quase sempre } \\
\text { ( } 3 \text { x mês) }\end{array}$ & $\begin{array}{l}\text { Sempre } \\
(4 \times \text { mês })\end{array}$ \\
\hline $\mathbf{Q}_{1}$ & $\begin{array}{l}\text { Tem conhecimento das dificuldades enfrentadas pelos alunos quanto ao } \\
\text { conhecimento teórico da disciplina de processo civil e sua aplicação na } \\
\text { prática/estágio? }\end{array}$ & 1 & 2 & 1 & 0 & 2 \\
\hline $\mathbf{Q}_{2}$ & $\begin{array}{l}\text { É consultado pelo professor da prática/estágio sobre os procedimentos da } \\
\text { aprendizagem aplicados na disciplina teórica? }\end{array}$ & 5 & 0 & 0 & 0 & 1 \\
\hline $\mathrm{Q}_{3}$ & $\begin{array}{l}\text { Tem conhecimento das práticas exigidas durante a disciplina de Estágio/Prática de } \\
\text { Processo Civil envolvendo o conteúdo da disciplina teórica. }\end{array}$ & 2 & 0 & 2 & 1 & 1 \\
\hline
\end{tabular}

Fonte: Celso Iocohama

Tabela 07 - Respostas apresentadas por Docentes das disciplinas teóricas de Direito Processual Civil indicando o relacionamento com a disciplina de estágio/prática de processo civil.

Apenas uma professora assinalou todas as alternativas "Sempre" deste questionário e foi justamente uma das envolvidas com as duas disciplinas (teórica e prática de Processo Civil). Destaca-se a ausência de contato do professor de estágio sobre os procedimentos de ensino utilizados pelo professor da disciplina teórica (cinco professores assinalaram "Nunca" na letra "b" - Q2). No que respeita ao item "c" - Q3, dois professores indicaram que nunca tomam conhecimento das práticas exigidas durante a disciplina de estágio. Os outros quatro professores indicam que isso ocorre, não havendo condições para se precisar se esse conhecimento decorre 
de informação dada pelo próprio professor da disciplina de prática ou por contato com alunos ou mesmo pelas informações repassadas institucionalmente.

Dirigidas aos professores do estágio (que assim atuaram como supervisores de estágio, responsáveis - de acordo com a organização do Curso analisado - com a abordagem prática, supervisionando atividades simuladas realizadas pelos alunos), foram feitas perguntas dividas em três grupos.

O primeiro grupo de questões buscava informações sobre as técnicas utilizadas pelo professor no desenvolvimento das aulas de estágio:

\section{Avalie as técnicas utilizadas por você para o processo de ensino- aprendizagem da(s) disciplina(s) de estágio/prática:}

a) Aula com sua exposição oral predominante

b) Discussões em grupo

c) Pesquisas extraclasses pelos alunos

d) Exposições orais do(s) aluno(s) por perguntas diretas do professor

e) Exposições orais dos alunos em razão de seminários/apresentação de trabalhos em grupo

f) Exposição oral de aluno em razão de seminários/apresentação de trabalhos individuais

g) Leituras de textos em sala de aula pelos alunos

h) Acompanhamento de atividades escritas dos alunos com orientações para o desenvolvimento das peças práticas

As respostas para este questionário apresentam os seguintes valores, perguntados se utilizam as técnicas de aprendizagem relacionadas para suas aulas práticas: Nunca (Zero), Raramente (1x mês), Regularmente (2x por mês), Quase sempre ( 3 x por mês) e Sempre ( 4 x por mês) para cada das alíneas propostas. Os professores apresentam as seguintes respostas:

\begin{tabular}{|c|c|c|c|c|c|c|}
\hline Questão & Técnicas de Aprendizagem & $\begin{array}{l}\text { Nunca } \\
\text { (zero) }\end{array}$ & $\begin{array}{l}\text { Raramente } \\
\text { (1 x mês) }\end{array}$ & $\begin{array}{l}\text { Regularmente } \\
\text { (2 } x \text { mês) }\end{array}$ & $\begin{array}{l}\text { Quase } \\
\text { sempre } \\
\text { (3 x mês) }\end{array}$ & $\begin{array}{l}\text { Sempre } \\
(4 \times \text { mês })\end{array}$ \\
\hline $\mathbf{Q}_{1}$ & Aula com exposição oral predominante. & - & 2 & 3 & 2 & 3 \\
\hline $\mathbf{Q}_{2}$ & Discussões em grupo. & - & 2 & 6 & 1 & 1 \\
\hline $\mathbf{Q}_{3}$ & Pesquisas extraclasses. & 1 & 2 & 2 & 2 & 3 \\
\hline $\mathbf{Q}_{4}$ & Exposições orais do(s) aluno(s) por perguntas diretas do professor. & 1 & 4 & 2 & 1 & 2 \\
\hline $\mathbf{Q}_{5}$ & $\begin{array}{l}\text { Exposições orais dos alunos em razão de seminários/apresentação de trabalhos } \\
\text { em grupos. }\end{array}$ & 4 & 6 & - & - & - \\
\hline $\mathbf{Q}_{6}$ & $\begin{array}{l}\text { Exposição oral de alunos em razão de seminários/apresentação de trabalhos } \\
\text { individuais. }\end{array}$ & 4 & 6 & - & - & - \\
\hline$Q_{7}$ & Leituras de textos em sala de aula. & 2 & 4 & 4 & - & - \\
\hline $\mathbf{Q}_{8}$ & $\begin{array}{l}\text { Acompanhamento de atividades escritas dos alunos com orientações para o } \\
\text { desenvolvimento de peças práticas. }\end{array}$ & - & 2 & 1 & 2 & 5 \\
\hline
\end{tabular}

Tabela 08 - Respostas apresentadas por Docentes da disciplina prática de Direito Processual Civil sobre a utilização de procedimentos para as 
Tratando-se da visão apresentada pelos professores de estágio, é de se perceber, de uma forma em geral, que exposição oral não tem a mesma predominância do que na manifestação dos professores das disciplinas teóricas, fortalecendo a interpretação de que as aulas das disciplinas teóricas concentram-se mais na fala do professor, enquanto nas práticas isso é amenizado (mas não deixa de ocorrer), conforme respostas da letra "a" - Q1. A tendência em se exigir maior participação do aluno durante as aulas práticas também pode ser verificado pelas respostas apresentadas, conforme sua visualização geral. Discussões em grupo (letra "b" - Q2) e pesquisas extraclasse (letra "c" - Q3) têm uma incidência de destaque, da mesma forma como as manifestações individuais dos alunos por perguntas diretas do professor (letra "d" - Q4). Esta última aparece também como de maior incidência na manifestação dos professores das disciplinas teóricas.

A utilização de seminários não aparece como de relevância nas respostas dos professores de estágio, coincidindo com aquelas apresentadas pelos professores das disciplinas teóricas. A leitura de textos em sala também não é uma conduta com grande incidência, segundo as respostas apresentadas.

O segundo grupo de questões pretendeu destacar as dificuldades encontradas em relação a determinados conteúdos, divididos entre as disciplinas de Direito Processual Civil I e Direito Processual Civil II:

Na sua prática docente (como Professor da disciplina de Prática Estágio Simulado de Processo Civil), assinale a alternativa que mais corresponda à reação dos alunos, em sua maioria, quanto aos assuntos que se relacionam com as disciplinas teóricas de Direito Processual Civil I e II:

a) Dificuldades com os princípios de Processo Civil (Processo Civil I)

b) Dificuldades com a matéria relativa à competência (Processo Civil I)

c) Dificuldades com a matéria de organização Judiciária (Processo Civil I)

d) Dificuldades com a matéria condições da ação (Processo Civil I)

e) Dificuldades com a matéria atos processuais (Processo Civil I)

f) Dificuldades com a matéria petição inicial (Processo Civil II)

g) Dificuldades com a matéria contestação (Processo Civil II)

h) Dificuldades com a matéria provas (Processo Civil II)

i) Dificuldades com a matéria sentença (Processo Civil II)

k) Dificuldades com a matéria recursos (Processo Civil II) 
As respostas para este questionário poderiam ser feitas entre as seguintes escolhas: Nunca, Menos da metade, A metade dos alunos, Mais da metade dos alunos e Sempre. As respostas apresentadas foram as seguintes:

\begin{tabular}{|c|c|c|c|c|c|c|}
\hline Questão & Dificuldades & Nunca & $\begin{array}{l}\text { Menos da } \\
\text { metade dos } \\
\text { alunos }\end{array}$ & $\begin{array}{l}\text { A metade } \\
\text { dos alunos }\end{array}$ & $\begin{array}{l}\text { Mais da } \\
\text { metade dos } \\
\text { alunos }\end{array}$ & Sempre \\
\hline $\mathrm{Q}_{1}$ & Princípios de Processo Civil I(Processo Civil I) & - & 4 & 1 & 3 & - \\
\hline $\mathrm{Q}_{2}$ & Matéria relativa à competência (Processo Civil I) & - & 3 & 2 & 3 & - \\
\hline $\mathrm{Q}_{3}$ & Matéria de Organização Judiciária (Processo Civil I) & - & 3 & 1 & 3 & 1 \\
\hline $\mathrm{Q}_{4}$ & Matéria Condições da Ação (Processo Civil I) & - & 3 & 2 & 3 & - \\
\hline$Q_{5}$ & Matéria Atos Processuais (Processo Civil I) & - & 2 & 5 & 1 & - \\
\hline $\mathrm{Q}_{6}$ & Matéria Petição Inicial (Processo Civil II) & - & 3 & 4 & 1 & - \\
\hline$Q_{7}$ & Matéria Contestação (Processo Civil II) & - & 4 & 3 & 1 & - \\
\hline $\mathrm{Q}_{8}$ & Matéria Provas (Processo Civil II) & - & 3 & 2 & 3 & - \\
\hline$Q_{9}$ & Matéria Sentença (Processo Civil II) & - & 3 & 2 & 3 & - \\
\hline $\mathrm{Q}_{10}$ & Matéria Recursos (Processo Civil II) & - & 2 & 3 & 2 & 1 \\
\hline
\end{tabular}

Nenhum dos professores responsáveis pelas disciplinas práticas assinalou 0 item informando que "Nunca" tiveram problemas relativos ao conhecimento dos conteúdos desenvolvidos pelas disciplinas teóricas, que foram descritos nas questões "a” (Q1) a “j” (Q10). Assim, a hipótese de que há problemas envolvendo a aprendizagem durante as aulas teóricas não pode ser descartada e ela não é afetada pela indicação de um mesmo professor, relacionando como "sempre" existindo dificuldades em dois conteúdos (descritos nas questões "c" - Q3 e "j" Q10).

Note-se que este discurso não se conflita com o discurso produzido pelos próprios alunos, conforme aponta a Tabela 03 (p. 146), na qual os alunos também revelam suas dificuldades com os conteúdos teóricos durante as aulas de estágio.

Por fim, os professores responsáveis pelo estágio foram indagados da sua relação com os professores das disciplinas teóricas envolvidas:

\footnotetext{
Na sua relação com o(s) professor(es) da(s) disciplina(s) teórica(s) de Processo Civil:
}

a. Informa o professor da disciplina teórica de processo civil das dificuldades enfrentadas pelos alunos quanto ao conhecimento teórico da disciplina de processo civil e sua aplicação na prática/estágio?

b. Consulta o professor da disciplina teórica de processo civil sobre os procedimentos de aprendizagem aplicados? 
As respostas para este questionário apresentam os seguintes valores, perguntados na relação com os professores da teoria de Processo Civil: Nunca (Zero), Raramente (1x mês), Regularmente (2x por mês), Quase sempre (3 x por mês) e Sempre (4 x por mês) para cada das alíneas propostas. Os 08 (oito) professores assim se manifestaram:

Auto-avaliação da relação com os professores das disciplinas teóricas de Processo Civil
\begin{tabular}{|c|l|c|c|c|c|c|}
\hline Questão & $\begin{array}{c}\text { Avaliação da Relação } \\
\text { Assunto }\end{array}$ & $\begin{array}{c}\text { Nunca } \\
(\text { zero })\end{array}$ & $\begin{array}{c}\text { Raramente } \\
(1 \times \text { mês })\end{array}$ & $\begin{array}{c}\text { Regularmente } \\
(2 \times \text { mês })\end{array}$ & $\begin{array}{c}\text { Quase } \\
\text { sempre } \\
(3 \times \text { mês })\end{array}$ & $\begin{array}{c}\text { Sempre } \\
(4 \times \text { mês })\end{array}$ \\
\hline$Q_{1}$ & $\begin{array}{l}\text { Informa ao professor da disciplina teórica de Processo Civil das dificuldades } \\
\text { enfrentadas na Prática de Estágio. }\end{array}$ & 1 & 3 & 2 & 1 & 1 \\
\hline$Q_{2}$ & $\begin{array}{l}\text { Consulta 0 professor da disciplina teórica de Processo Civil sobre os } \\
\text { procedimentos de aprendizagem aplicados. }\end{array}$ & 3 & 3 & 1 & 0 & 1 \\
\hline
\end{tabular}

Fonte: Celso Iocohama

Tabela 10 - Respostas apresentadas por Docentes da disciplina prática de Direito Processual Civil sobre as relações com os professores das disciplinas teóricas de Direito Processual Civil

A existência "sempre" de um diálogo entre o professor da prática e o(s) professor(es) das disciplinas teóricas (em ambas as questões) foi assinalada por uma única professora, que também é responsável pelas duas disciplinas. As informações das dificuldades enfrentadas no estágio não são repassadas por todos os professores (um deles nunca o faz e os outros três raramente o fazem), embora a outra metade dos professores consultados mantém algum contato neste sentido. A maioria dos professores de estágio afirma que não consultam os professores das disciplinas teóricas sobre os procedimentos de aprendizagem aplicados.

Desta maneira, com a apresentação destes dados, pode-se contribuir às inferências realizadas para os próximos itens e Capítulo, construídos em consideração às manifestações doutrinárias e suas projeções sobre os discursos ora analisados.

\subsection{A aprendizagem}

Objeto de incontáveis estudos, a aprendizagem precisa ser referida na medida em que está atrelada à crise pedagógica do Curso de Direito, pelas repercussões no papel do professor e nos resultados da formação discente, em vista do foco escolhido. 
Com o fito de estabelecer indicadores para a compreensão da tese que se propõe envolvendo a revisão da ação docente e a estruturação de medidas capazes para se conduzir a ação discente face às representações que se observam, é importante repisar que a aprendizagem participa como peça fundamental na proposta de revisão das ações que a envolvem no ensino do Direito: a postura clássica de se pensar o processo educativo focado em ações docentes, não se atribuindo a importância merecida ao aluno.

De qualquer modo, minha preocupação visa analisar quais elementos são necessários para que se possa compreender a realização do processo de aprendizagem, apto a estabelecer pontos de atenção para ações docentes tendo em vista que já se afirmou, no Capítulo 2, que o movimento de se tratar da aprendizagem mais do que ao ensino é um caminho fundamental para se repensar ações e efeitos ligados à crise da própria Educação, com efeitos maiores no estudo do Direito pelas dificuldades enfrentadas na área em relação à conscientização pedagógica dos envolvidos. Se este movimento já se apresenta claro em debates há tempo formulados na área da Pedagogia, para a experiência do Direito ainda não existe tal clareza.

Não há dúvidas que muito já se escreveu sobre a aprendizagem. A curiosidade e a intenção de compreender o processo de apreensão de um conhecimento já foram vistas e revistas por incontáveis pesquisadores (e não pesquisadores), envolvendo as mais diversas áreas (em especial a Psicologia).

$\mathrm{Na}$ verdade, a amplitude do estudo da aprendizagem transita desde o que é o conhecimento, o que é aprender, como aprender, o que aprender, para que aprender até (e além) das inferências dessas informações (ou não) para a o ensino.

De fato, como salienta Gil (2006, p. 80), o conceito de aprendizagem é bastante complexo, na medida em que envolve comportamento dos seres humanos e todos os animais, decorrentes de grande diversidade de eventos, que vão dentre uma "contração muscular, a aquisição de um conceito simbólico ou de uma regra gramatical, a formação de um preconceito, a aquisição de um sintoma neurótico etc"., não se limitando "a aquisição original de uma resposta aprendida, mas compreende também seu desaparecimento posterior (extinção), sua retenção após um intervalo de tempo (memória) e seu valor na aquisição de uma resposta nova ou diferente (transferência)". 
Sobre os efeitos da aprendizagem no ensino, AUSUBEL, NOVAK e HANESIAN (1980, p. 14) bem destacam que há uma interdependência entre as teorias de uma e de outra, ainda que cada qual tenha sua própria característica, sendo ambas necessárias "para uma ciência completa da pedagogia e nenhuma delas é o substituto adequado da outra". Nessa relação, as "teorias de ensino devem tomar como base as teorias da aprendizagem e ter um enfoque mais aplicado; ou seja, devem preocupar-se em ampla escala com problemas emergentes".

É importante reconhecer que este estudo não pretende avançar sobre a amplitude das teorias da aprendizagem, analisado suas características e elementos para, a partir delas, inferir sobre o ensino do Direito. Entretanto, faz-se opção por invocar a teoria da aprendizagem significativa de Ausubel como referência para projeções envolvendo os processos de aprendizagem. Sua escolha decorre do interesse voltado à instrumentalização dos procedimentos de aprendizagem para realização de práticas educativas que permitem a associação de informações pelos alunos, com tendência a uma maior retenção e aplicabilidade.

De fato, há uma dinamicidade peculiar no conhecimento e na aplicação do Direito (que também pode aparecer em outras áreas), que coloca em xeque o que se pode esperar do processo de ensino aprendizagem. A mecanicidade de alguns conteúdos (em razão das ações dos professores e da própria cultura dogmática do Direito) opera contra a própria área jurídica, formando bacharéis com visão crítica limitada, que por sua vez, tendem a compor os grupos de profissionais que repetirão esse mesmo contexto.

Contra este círculo vicioso e, mesmo reconhecendo a amplitude do problema, que vai além da sala de aula e percorre caminhos político-ideológicos inevitáveis, aventa-se como instrumento o processo educativo e, nesse contexto, a aprendizagem tem especial relevância, porque sua compreensão favorecerá a tomada de medidas mais concretas para uma formação profissional. Como já se afirmou, o docente que se afirma um profissional, no Ensino Superior, deve reconhecer em suas ações o momento que reflete na (re)construção do conhecimento pelo aluno e, aí, falar-se da aprendizagem é uma importante consequência.

Não se pode esquecer que a aprendizagem imaginada para o aluno de Direito não se limita ao plano cognitivo, dependendo também de elementos que afetam suas atitudes e habilidades. Não se poderia conceber que o aluno de Direito seja de 
tal forma espectador para apenas se deparar com o conhecimento proporcionado pelas atitudes docentes, com o fito exclusivo de admirar a beleza dos exercícios de oratória ali praticados. Espera-se que o conhecimento tenha eficácia para a formação de sua estrutura cognitiva, possibilitando reflexões e ações sobre atitudes e habilidades que precisarão ser realizadas, de conformidade com as profissões a serem escolhidas.

Assim, como elemento norteador, é importante reconhecer-se que a aprendizagem tem várias finalidades. Como ressaltam Abreu e Masetto (1990, p. 7), pode-se buscar o desenvolvimento mental do aluno (aspecto cognitivo), dando-lhe condições para "captar e processar informações, organizar dados, aprender e relacionar conceitos, perceber e resolver problemas, criar conceitos e soluções", atendendo "à solicitação de uma sociedade que exige profissionais cada vez mais competentes, mas especializados e mais técnicos".

Pode-se, de outro modo, privilegiar "o desenvolvimento da pessoa singular $e$ como um todo (os aspectos cognitivo, afetivo, social), objetivando que o aluno "realize o desenvolvimento de sua sociabilidade, comunicabilidade, cultura, valores, competência profissional, organização interna, relacionamento com o ambiente e com a sociedade", focando-se a "singularidade de cada indivíduo, às mudanças que venham a ocorrer no próprio indivíduo e a uma nova configuração que venha a ser construída" (ABREU e MASETTO, 1990, p. 8).

Tem-se, ainda, a possibilidade de buscar a aprendizagem com enfoque no "desenvolvimento de relações sociais", dando importância à "interação entre o mundo individual e o mundo social", desenvolvendo o ser humano a aprender sua presença histórica no tempo e no espaço, dando-lhe condições para "captar os fatos, os acontecimentos que agitam a si mesmo, à sua família, ao seu trabalho, à sua classe, à sua cidade, ao seu país, ao mundo, à sociedade da qual é membro", compreendendo-os e relacionando-os com os acontecimentos, participando da vida desta sociedade, com capacidade de análise crítica (idem, ibibem).

Mas, além de todas estas possibilidades, pode-se encontrar uma quarta linha de aprendizagem que "privilegia o desenvolvimento da capacidade de decidir, o desenvolvimento de habilidade para assumir responsabilidade social e política". Procura-se, nestes termos, "levar o aprendiz a uma nova postura diante dos problemas de seu tempo e da sociedade, que se caracteriza por criar disposições 
democráticas através das quais se substituam hábitos de passividade por novos hábitos de participação e ingerência" (idem, p. 9).

Percebe-se, a partir destas quatro concepções sobre a aprendizagem, que o ensino do Direito não poderia estar se contentando apenas com o desenvolvimento mental do aluno, tornando-se um exímio profissional, de conhecimento técnico apurado. Mais do que isso e de seu desenvolvimento enquanto pessoa e membro de uma sociedade é preciso repensar que a aprendizagem a ser proporcionada deve capacitar o aluno à tomada de atitudes, com criatividade apta a promover ações que interfiram em seu meio para superar a tendência à manutenção de tradições e paradigmas presos às zonas de conforto, ainda mais num país como o Brasil, que muito precisa caminhar para respeitar os princípios democráticos afirmados há mais de vinte anos numa Constituição Federal.

Parece sim um grande desafio a ser enfrentado pelo professor de Direito, somados a todos os outros desafios já enumerados, realizar sua prática docente fundamentando-se em ações que garantam essa aprendizagem focada na independência e ação do discente, habilitando-o para intervir ativa e eticamente perante a sociedade. Já é historicamente reservado aos bacharéis em Direito a ocupação de cargos públicos de destacada relevância. O que se pode questionar, a partir desta concepção sobre a aprendizagem, se realmente esta formação promovida pelo ensino do Direito condiz com tal expectativa.

De fato, trazendo-se a aprendizagem para o âmbito escolar, deve assumir condições para que permita acesso ao conhecimento sistematizado, numa relação dinâmica que promove uma ação transformadora de ensinar e aprender (LOPES, 1996, p. 110). O empenho do professor para conseguir definir o que entende por relevante ensinar, "só será realmente efetivado se o professor conseguir que o aluno se aproprie daquilo que ele selecionou para ser aprendido" (PENIN, 1988, p. 4).

A compreensão dessa relação dinâmica é bem destacada por Kamii e Devries, quando apresentam as teorias o conhecimento (1985, p. 29-30), ressaltando o empirismo, o racionalismo e o posicionamento de Piaget. De um lado, haveria os empiristas (como Locke, Van Berkeley e Hume), sustentando que o conhecimento teria sua fonte fora do indivíduo, sendo internalizado através dos sentidos. $O$ indivíduo, ao nascer, seria como uma folha em branco na qual as experiências seriam "escritas" na medida em que ele crescesse. De outro lado, os racionalistas (como Descartes, Spinoza e Kant), mesmo reconhecendo a importância da 
experiência, concebiam o poder da razão para a edificação do conhecimento, tendo em vista a capacidade dela (a razão) em indicar "muitas verdades que a observação sensorial jamais poderia averiguar", além de superar as ilusões provocadas pela experiência sensorial, que não daria segurança para um conhecimento confiável. Logo, o conhecimento estaria no sujeito e não na experiência.

Em Piaget, as autoras afirmam que seu posicionamento, chamando de relativismo, aponta que "os objetos nunca são conhecidos como são 'lá fora' na realidade externa, mas que eles são conhecidos por assimilação nos esquemas que o sujeito traz para cada situação". O relativismo seria concebido pelo "fato de que o objeto como é conhecimento é relativo ao conhecimento que o conhecedor traz para a situação". Logo, sua postura afasta-se do empirismo, mas também não se afirma puramente no racionalismo, pois sua conclusão aponta que "todo conhecimento, incluindo a capacidade de racionar logicamente, é construído pelo indivíduo na medida em que ele age sobre objetos e pessoas e tenta compreender sua experiência". Daí a formação de sua visão ser chamada de Construtivismo (KAMII e DEVRIES, 1985, p. 30-32).

Desta maneira, destaca-se o movimento sócio-interacionista-construtivista, que, ao dar mais ênfase na importância do "outro", sugere que a construção do conhecimento vincula-se a ele, presente ou ausente, de onde se destacam as ideias de Vygotsky, ao fornecer elementos preciosos para o entendimento do ensino, indicando "a importância da interação dos alunos entre si e com o professor na construção do seu conhecimento" (PENTEADO, VALLE FILHO e PENIN, 1992, p. 227-228).

Por certo, como destaca Grossi (2001, p. 132-134), ultrapassando a visão do inatismo (que coloca o centro da produção intelectual no próprio sujeito) e do empirismo (que vê "a realidade exterior ao sujeito que aprende como fonte de todas as suas explicações"), para as quais "não há trânsito de duas vias entre o sujeito e a realidade", tem-se em Piaget a "idéia de uma interação entre o sujeito e a realidade, derivando daí o conhecimento", cabendo-se acrescentar as manifestações de Vygotsky e Wallon na integração do social e do outro para a realização da aprendizagem. Nesta perspectiva, o sujeito perpassa pelos outros, em indispensáveis experiências grupais, envolvendo-se com a realidade e, assim, formando-se a partir dessa correlação. Esta perspectiva acompanha a presente 
pesquisa, ampliando-se a importância da aprendizagem para além do próprio sujeito aprendiz.

Acrescente-se, ainda, como suporte para as inferências trazidas sobre o assunto, a perspectiva do aprender a aprender, expressão que consubstancia uma importante visão para o tratamento da aprendizagem: um movimento que vai além do mero aprender para fundar-se na "construção auto-suficiente do sujeito social competente, com base em conhecimento atualizado", envolvendo uma "metodologia emancipatória, traduzida em competências e habilidades", apta a tornar a pessoa "capaz de saber pensar, de avaliar processos, de criticar e criar". (DEMO, 1993, p. 211-212).

Numa visão didática, o aprender a aprender compõe dois horizontes entrelaçados, diante do processo interativo produtivo de envolver a competência do ser humano de construir a competência em contato com o mundo, com a sociedade. Envolve a "necessidade de se apropriar do conhecimento disponível importante dentro de um processo de socialização", na compreensão de um sujeito histórico, voltada "a cobrir conteúdos úteis ou necessários ao desempenho social", bem como abranger o "desafio emancipatório que o conhecimento pode contribuir a enfrentar, à medida que forma a atitude produtiva do conhecimento, uma das pilastras atuais da construção de um projeto moderno e próprio de desenvolvimento". O aprender a aprender, desta maneira, "não indica propriamente um estoque acumulado de conhecimento, mas uma estratégia de manejar e produzir conhecimento, em constante renovação" para enfrentar os desafios da vida, afastando-se de "táticas clássicas de armazenar conhecimento copiado, como 'decorar', escutar infinitas aulas, fazer prova, reproduzir imitativamente o saber", privilegiando a atitude de "questionamento construtivo, teórico e prático, onde o conhecimento atualizado é modo de ver a realidade e sobretudo base para intervir nela". Logo, há que se se superar a noção de que o conhecer está limitado à apropriação de um farto estoque de saberes, dando-se mais atenção ao saber saber, constituído pela "habilidade de manejar e produzir conhecimento em sentido ativo, produtivo, construtivo" (DEMO, 1993, p. 213-214).

Quando iniciamos o presente Capítulo transcrevendo resultados de um levantamento de posturas com alunos e professores de um curso de Direito, a partir das ações educativas vivenciadas por disciplinas teóricas e práticas, buscávamos sinalizar a pretensão de se verificar a existência de problemas envolvendo o 
conhecimento teórico e sua aplicação. A amostragem não tinha o condão de servir de paradigma para a área, mas analisar o que se passa no discurso envolvendo o tema na área do Direito, apontando a possibilidade de um afastamento entre a teoria e a prática que prejudica a aplicação do conhecimento teórico - num ambiente que antecede à própria formação crítica do educando. De fato, podemos, analogicamente, colocar a preocupação com a teoria e a prática no contexto desse conhecimento há pouco tratado: como se traduz essa relação entre a compreensão racional do direito (pela abordagem teórica) e a compreensão do fenômeno pelo objeto da prática? Será que as dificuldades apontadas não perpassam a ausência desta dialeticidade entre a reflexão do sujeito e a percepção das experiências envolvendo o conhecimento jurídico?

Certamente, numa análise da aprendizagem nesta perspectiva da compreensão do conhecimento, é importante que se alerte dos problemas decorrentes do conhecimento do Direito, o qual não pode apenas focar o seu objeto (normas, procedimentos, conflitos etc.), nem concluir pela exclusiva abstração do aluno na sua formação racional. A dinâmica entre 0 indivíduo e as experiências proporcionadas pela vida e a relação com o outro precisam ser compreendidas nesse movimento dialético que permite a reconstrução contínua do saber.

Por certo, diante da pesquisa proposta, têm-se elementos para analisar o que se passa no ambiente do estudo do Direito, com a possibilidade de se tecer considerações pedagógicas, ainda que restritas à visão decorrentes de apenas um Curso de Direito. Mas para que se possa analisar as repercussões no conhecimento discente que lhe favorecerá à condução profissional, sem desprezar essa importante ressalva da formação crítica que deve ser proporcionada (sob pena do professor continuar sendo um mero repetidor de discursos alheios), é importante que se analise a aprendizagem, a partir do qual se espera somar à reflexão algumas considerações teóricas que darão suporte para ações educativas concretas.

Desta maneira, mesmo partindo-se destas premissas de que a aprendizagem envolve o relacionamento com o outro e a si mesmo, fundada numa perspectiva emancipatória, é possível agregar a teoria da aprendizagem significativa em seu caráter instrumental, acrescendo mecanismos que contribuirão para a compreensão do processo de aprendizagem, somando-se, ainda, as discussões envolvendo a motivação, pela relevância que também merece no contexto do tema, finalizando-se 
com a apresentação da relação teoria e a prática, para dar suporte às abordagens derradeiras do Capítulo 5.

\subsubsection{A aprendizagem significativa em Ausubel}

Quando buscamos em Ausubel uma explicação teórica para a aprendizagem, não pretendemos utilizá-la para a solução dos problemas apontados até este momento no estudo, envolvendo o embate das verdades para o Direito, nem os aspectos pedagógicos que envolvem o comportamento docente e discente especificamente relacionados.

De fato, como se verá, na teoria da aprendizagem significativa não se está a tratar do mérito do conhecimento a ser ensinado e aprendido. Não se discute se está ensinando "o certo ou o errado", mas se pretende, dentro da visão de uma psicologia educacional, compreender o processo cognitivo de maneira a apontar instrumentos que facilitam o processo de assimilação.

Assim, o momento anterior à teoria de Ausubel deve ser delineado com os pressupostos pretendidos por este estudo, envolvendo a visão crítica sobre o que se ensina no Direito e o reconhecimento da visão pedagógica como parte fundamental do profissionalismo do professor de Direito. Com Ausubel, espera-se facilitar a compreensão dos mecanismos envolvendo a aprendizagem, servindo como uma importante teorização de um instrumental ao professor, diante dos resultados que pode proporcionar para o conhecimento Direito e sua aplicação.

Por certo, o principal aspecto da teoria de Ausubel, é o destaque à importância do conhecimento já existente no aluno identificando sua capacidade cognitiva pela construção de conhecimentos a partir de informações já assimiladas.

De fato, como destacam Moreira e Masini (1982, p. 7), o "conceito mais importante da teoria de Ausubel é o de aprendizagem significativa”, constituída por "um processo pelo qual uma nova informação se relaciona com um aspecto relevante da estrutura de conhecimento do indivíduo". Nesse processo, "a nova informação interage com a estrutura de conhecimento específica, a qual Ausubel define como conceitos subsunçores", existentes na "estrutura cognitiva do indivíduo, de maneira que a aprendizagem significativa ocorrerá quando "a nova informação 
ancora-se em conceitos relevantes preexistentes na estrutura cognitiva de quem aprende".

Passa-se, então, a tratar das categorias indicadas por Ausubel, pretendendo-se garantir um suporte teórico para as práticas indicadas no último Capítulo, focadas na perspectiva de se rever as ações docentes e discentes, possibilitando ações para uma aprendizagem diferenciada.

\subsubsection{Aprendizagens por descoberta, recepção, mecânica e significativa}

A compreensão dos processos que atravessam a aprendizagem é ponto de partida para que AUSUBEL, NOVAK E HANESIAN (1980, p. 19-24) mostrem a aplicação da aprendizagem significativa. De um modo em geral, classificam dois processos: um que envolve a aprendizagem por descoberta e por recepção; e outro que trata da aprendizagem mecânica (ou automática) e a significativa.

Pela aprendizagem por descoberta, tanto na formação de conceitos ou solução de problemas, o conteúdo principal daquilo que vai ser aprendido não é dado, ficando a cargo do aprendiz a sua descoberta, antes mesmo de sua incorporação de forma significativa à estrutura cognitiva (AUSUBEL, NOVAK E HANESIAN, 1980, p. 20). Assim, o conteúdo a ser aprendido não é apresentado sob a forma final, de maneira que o aprendiz obtém alguma informação independentemente, integrando-a em sua estrutura cognitiva já existente, reorganizando-a ou transformando-a para produzir uma estrutura cognitiva nova ou modificada (KLAUSMEIER e GOODWIN, 1977, p. 45).

Por sua vez, na aprendizagem pela recepção, "todo o conteúdo daquilo que vai ser aprendido é apresentado ao aluno sob a forma final", de maneira que "a tarefa de aprendizagem não envolve qualquer descoberta independente por parte do estudante", exigindo-se dele apenas internalizar ou incorporar o material que é "apresentado de forma a tornar-se acessível ou reproduzível em alguma ocasião futura" (AUSUBEL, NOVAK E HANESIAN, 1980, p. 20).

Considerando estes dois tipos de abordagem, destacam os autores que "grande parte da instrução realizada em sala de aula está organizada através de linhas de aprendizagem receptiva e grande parte da aprendizagem acadêmica é adquirida por recepção", enquanto que os "problemas cotidianos são solucionados através da aprendizagem por descoberta". Isso não impede que existam algumas 
"superposições de função", quando o "conhecimento adquirido pela aprendizagem receptiva é também usado na solução dos problemas diários e a aprendizagem por descoberta é comumente utilizada em sala de aula tanto para aplicar, ampliar, clarificar, integrar e avaliar matérias, como para testar a compreensão" (AUSUBEL, NOVAK E HANESIAN, 1980, p. 21).

Trabalhando em uma categoria distinta, o processo de aprendizagem também pode ser verificado no que respeita à maneira pela qual as informações objeto de conhecimento se relacionam com a estrutura cognitiva do sujeito aprendiz. A relação arbitrária relaciona-se à aprendizagem mecânica (ou automática), enquanto que e a forma não arbitrária caracteriza a aprendizagem significativa. Assim:

"[...] a aprendizagem significativa ocorre quando a tarefa de aprendizagem implica relacionar, de forma não arbitrária e substantiva (não literal), uma nova informação a outras com as quais o aluno já esteja familiarizado, e quando o aluno adota uma estratégia correspondente para assim proceder. Aprendizagem automática, por sua vez, ocorre se a tarefa consistir de associações puramente arbitrárias, como na associação de pares, quebracabeça, labirinto, ou aprendizagem de séries e quando falta ao aluno o conhecimento prévio relevante necessário para tornar a tarefa potencialmente significativa, e também (independentemente do potencial significativo contido na tarefa) se o aluno adota uma estratégia apenas para internalizá-la de uma forma arbitrária, literal (por exemplo, como uma série arbitrária de palavras). (AUSUBEL, NOVAK E HANESIAN, 1980, p. 23).

É importante registrar que tais dimensões da aprendizagem são independentes, mas podem se relacionar. Alertando que é equivocada a afirmação de que "a aprendizagem receptiva é invariavelmente automática e que a aprendizagem por descoberta é inerente e necessariamente significativa", pode-se afirmar como mais defensável que "tanto a aprendizagem receptiva como a por descoberta podem ser automáticas ou significativas dependendo das condições sob as quais a aprendizagem ocorre" (idem).

Inferindo-se para o ensino do Direito, pode-se perfeitamente projetar estas dimensões da aprendizagem, em todos os seus planos.

De fato, o direito é aprendido predominantemente pela forma receptiva, quando se trata do ensino formal, mas a descoberta também pode ser verificada para o seu conhecimento. Interessante perceber que fora do ambiente acadêmico, a descoberta acompanha a aprendizagem do Direito por constantes momentos da vida de um indivíduo, tratando-se informações que utiliza até mesmo inconsciente (e, portanto, 
não arbitrária). Pense-se nas inúmeras relações de consumo nas quais alguém pode se envolver a todo momento (compras em mercados, uso de transportes públicos ou particulares, envolvimento em uma educação formal etc). De um modo em geral, muitas pessoas estão envolvidas em relações jurídicas e agem de conformidade com suas regras incorporando-as, sem que precisassem de uma instrução direcionada neste sentido.

Essa forma de descoberta também se opera mesmo num ambiente acadêmico, porque nada impede que o aprendiz vivencie experiências que se agreguem em sua estrutura cognitiva. Neste exemplo, é possível perceber que uma aprendizagem por descoberta pode ser significativa ou apenas mecânica (automática). Um mesmo funcionário de um cartório pode compreender, mesmo sem ter estudado o Direito formalmente, que a juntada de um documento é muito importante para a formação de um ato processual que repercutirá na vida das pessoas envolvidas, com responsabilidades e consequências. Neste caso, a aprendizagem por descoberta estará repercutindo significativamente na sua estrutura cognitiva.

O mesmo exemplo pode ser utilizado para se concluir que a aprendizagem pela descoberta pode gerar uma aprendizagem mecânica. Outro funcionário do mesmo cartório, que passa uma tarde inteira juntando documentos em dezenas de processos, pode estar completamente alheio ao significado do que está fazendo, a ponto de que, se alterada alguma etapa, sinta-se inapto para continuar seu serviço. A mecanicidade predomina, mas isso não impede que a aprendizagem significativa venha a ocorrer, na medida em que associação ganhe compreensão na formação de conceitos para novas assimilações não arbitrárias.

Entretanto, como se afirmou, a aprendizagem pela recepção está mais evidente no plano acadêmico. As aulas expositivas, de regra, proporcionam ampla explanação sobre um determinado assunto, apresentando começo, meio e fim da abordagem, de maneira que a aprendizagem discente não está direcionada para a liberdade da descoberta. Na verdade, parece-nos que o senso comum no ambiente do ensino do Direito formate o papel do professor como alguém que sabe as respostas (não sabê-las gera o risco de vê-lo como incompetente). No sistema de professor detentor das verdades como já se tratou, facilita-se a realização da aprendizagem por recepção. Obviamente, não significa que o processo por recepção só promova alunos que pratiquem a repetição, mas isso pode ocorrer (aprendizagem mecânica) como também poderá ocorrer a aprendizagem significativa. Mas alunos 
podem receber uma informação apresentada pelo professor sem conseguir conectála à sua estrutura cognitiva. Isso repercutirá em suas ações baseadas em tal informação, porque na medida em que não as associa, não as consegue operacionalizar para outras circunstâncias, ao contrário do que a aprendizagem significativa possibilitará.

De qualquer maneira, espera-se que este contexto permita compreender os direcionamentos para a aprendizagem, tanto sob a ótica do docente como para o discente.

O docente pode compreender que o aluno não depende apenas dele para aprender, agindo de maneira a incentivar a descoberta que complementará a recepção. Suas ações podem ser direcionadas para favorecer a capacidade do discente em ter informações sem desprezar (e valorizando) sua autonomia.

De outro modo, o docente pode até se preocupar em promover ações educativas que serão apenas automáticas (ou mecânicas) para o discente, mas contribuirá muito mais se analisar a aprendizagem na sua função significativa. Os elementos facilitadores da aprendizagem significativa serão tratados no próximo item.

Para o discente, a compreensão da aprendizagem pela descoberta pode ser um caminho libertador, que the dará autonomia para buscar informações que se agreguem à sua estrutura cognitiva, mas não deve desprezar o conhecimento de princípios básicos que the darão suporte para melhor assimilação. Da mesma forma, pode contribuir para uma aprendizagem significativa durante a dimensão receptiva compreendendo (o que certamente percebe empiricamente) que a ligação entre o novo e seu arcabouço pessoal cognitivo é essencial. O discente pode, ainda, estar atento às situações onde vivencia conhecimentos meramente automáticos, sem vínculos associativos, servindo-Ihe de alerta para os problemas decorrentes de sua utilização posterior.

\subsubsection{Estrutura cognitiva, subsunção e princípios facilitadores da aprendizagem significativa}

A compreensão da organização que o aluno tem sobre o seu conhecimento é considerada como de fundamental importância para a aprendizagem significativa. 
Seus efeitos se projetam em situações de retenção e transferência, os quais indicam a eficiência da aprendizagem.

Por estrutura cognitiva entenda-se o "conteúdo e organização das idéias, conceitos, representações de um aprendiz, numa área de conhecimento; ou conteúdo total e organização das idéias de um dado indivíduo" (MASINI, SANTOS e SHIRAHIGE, 1997, p. 25), correspondendo a uma "estrutura hierárquica de conceitos que são abstrações da experiência do indivíduo" (MOREIRA e MASINI, 1982, p. 8).

Com efeito, afirmam Ausubel, Novak e Hanesian (1980, p. 137-138), que só pode haver apreensão de um material logicamente significativo se houver uma "relação a um conteúdo previamente assimilado de conceitos relevantes". A importância da consolidação de princípios anteriores ao novo conhecimento mas que com ele se relacionam, assegura a retenção e a organização desse conteúdo.

Importa, neste aspecto, perceber a diferença de resultados provocados por estruturas cognitivas que sejam estáveis das instáveis. Se a "estrutura cognitiva for clara, estável e adequadamente organizada, significados precisos não ambíguos emergem, tendendo a reter sua força de dissociação ou disponibilidade”. Ao contrário, se a "estrutura cognitiva for instável, ambígua e desorganizada, tenderá a inibir a aprendizagem significativa e a retenção". Logo, "os detalhes de uma dada disciplina são aprendidos mais rapidamente quando podem ser encaixados dentro de um arcabouço contextual consistindo de um corpo estável e apropriado de conceitos e princípios gerais” (AUSUBEL, NOVAK E HANESIAN,1980, p. 138).

Para que ocorra a ligação entre a estrutura cognitiva do aluno e a informação objeto da aprendizagem, é importante que se compreenda a subsunção, que constitui este processo de assimilação. Em Direito, a palavra subsunção é utilizada para a compreensão do processo de aplicação de um direito a um caso concreto. De certo modo, a analogia pode ser a mesma: existe uma situação que precisa ser resolvida (nova informação a ser apreendida). Para tanto, é preciso que a norma jurídica seja identificada (estrutura cognitiva que estabelece o conhecimento já assimilado). A aproximação das duas situações pela via da interpretação (assimilação) completará o processo de subsunção.

Ausubel, Novak e Hanesian (1980, p. 48-49) anotam que "a estrutura cognitiva propriamente dita tende a ser organizada hierarquicamente em relação ao nível de abstração, generalização e abrangência das idéias, a emergência de uma nova 
estrutura proposicional significativa reflete mais tipicamente uma relação subordinativa do novo material à estrutura cognitiva existente.

A teoria da aprendizagem significativa ressalta duas possibilidades para a subsunção subordinativa. Ela poderá ser uma subsunção subordinada derivativa ou correlativa.

A subordinação derivativa "ocorre quando o material de aprendizagem é compreendido como um exemplo específico de um conceito estabelecido na estrutura cognitiva, ou é uma forma de sustentar ou ilustrar uma proposição geral previamente adquirida". A informação nova, nesta hipótese, é derivada de um conceito já incorporado pela estrutura cognitiva de um sujeito. Desta forma, o novo material derivativo "emerge rapidamente e relativamente sem esforço" (AUSUBEL, NOVAK e HANESIAN, 1980, p. 49). Para o Direito, seria como conhecer a aplicação de um determinado princípio processual num processo judicial na Justiça do Trabalho, sabendo sua previsão constitucional e anteriormente estudada e compreendida (e, portanto, fazendo parte da estrutura cognitiva do sujeito aprendiz). A nova informação (princípio da Justiça do Trabalho) será considerada derivada do conhecimento já existente.

Já na subordinação correlativa, a nova informação "é uma extensão, elaboração, modificação ou qualificação de proposições adquiridas anteriormente". Ela é incorporada e interage "com produtos subordinativos relevantes e mais inclusivos, mas seu significado não está implícito nestes últimos produtos, nem pode ser representado adequadamente por eles (AUSUBEL, NOVAK e HANESIAN, 1980, p. 49). No contexto do Direito, essa situação poderia ser percebida através do seguinte exemplo: o aluno sabe que a parte que altera a verdade dos fatos no processo é considerada litigante de má-fé, devendo sofrer uma sanção. Uma nova informação, apresentando uma situação da parte que apresenta um recurso manifestamente protelatório, será aprendida correlativamente como uma situação de má-fé, pois, apesar de não ser a mesma situação ligada à verdade, tem correlação com a noção de má-fé e os prejuízos que ela causa à parte contrária e ao Estado.

Note-se, porém, que essas duas formas de subsunção subordinadas partem de um conhecimento geral inclusivo, já presente na estrutura cognitiva do sujeito. Mas também é possível que um conhecimento geral inclusivo seja formado por conta de novas informações que são promovidas a partir de outra aprendizagem, que não será de subordinação, mas o que se chama de aprendizagem supeordenada, que se 
dá quando "um conceito ou proposição potencialmente significativo $A$, mais geral ou inclusivo do que idéias ou conceitos já estabelecidos na estrutura cognitiva $a, b$ e $c$ é adquirido a partir destes e passa a assimilá-los". Desta forma, "à medida que ocorre aprendizagem significativa, além da elaboração dos conceitos subsunçores é também possível a ocorrência de interações entre esses conceitos" (MOREIRA e MASINI, 1982, p. 20). Tais autores usam como exemplo a compreensão dos conceitos de cão, gato, leão etc., para aprender, mais tarde, a subordinação deles ao conceito de mamífero. Ausubel, Kovak e Hanesian (1980, p. 50) exemplificam este tema com a compreensão de conceitos familiares de cenoura, ervilha, vagem, beterraba e espinafre para poderem ser agrupados sob o termo vegetal. Para o Direito, o conceito de escrivão, perito, distribuidor, contador, oficial de Justiça, intérprete pode permitir a compreensão mais inclusiva de auxiliares da Justiça.

Para que se possa facilitar uma aprendizagem significativa, indicam-se alguns importantes princípios.

Pelo princípio da diferenciação progressiva, propõe-se que a programação dos assuntos considere primeiramente as ideias mais gerais e mais inclusivas da disciplina, que serão "progressivamente diferenciadas, em termos de detalhe e especificidade", correspondendo a uma "sequência natural de aquisição da consciência e sofisticação cognitiva quando os seres humanos são espontaneamente expostos ou a um campo completamente desconhecido do conhecimento ou a um ramo desconhecido de um corpo de conhecimentos familiar", correspondendo, também, ao modo que "este conhecimento é representado, organizado e guardado no sistema cognitivo humano". Essa compreensão conduz a dois pressupostos:

(1) É menos difícil para os seres humanos compreender os aspectos diferenciados de um todo previamente aprendido, mas inclusivo, do que formular o todo inclusivo a partir das suas partes diferenciadas previamente aprendidas.

(2) Num indivíduo, a organização do conteúdo de uma disciplina particular consiste de uma estrutura hierárquica na sua própria mente. As idéias mais inclusivas ocupam uma posição no topo desta estrutura e abrangem proposições, conceitos e dados factuais progressivamente menos inclusivos e mais diferenciados.

(AUSUBEL, NOVAK e HANESIAN, 1980, p. 159). 
Há, também, o princípio da reconciliação integradora, que se combina e complementa a diferenciação progressiva, porque no processo de aprendizagem, a programação do conteúdo deve "explorar, explicitamente, relações entre proposições e conceitos, chamar atenção para diferenças e similaridades importantes e reconciliar inconsistências reais ou aparentes (MOREIRA e MASINI, 1982, p. 21; AUSUBEL, KOVAK e HANESIAN, 1980, p. 161).

A importância desse princípio conduz a atenção do professor no que diz respeito à clareza da estrutura cognitiva do aluno, com ideias precisamente diferenciadas. A ação do professor, diante de um conteúdo, é indicar "as semelhanças e diferenças entre idéias, quando estas são encontradas em vários contextos”. Assim, a reconciliação integradora deve acontecer quando se está diante de um conteúdo, proporcionando aos alunos as diferenciações internas dele, mas também demonstrando sua relação (em semelhanças e diferenças) entre outros materiais e ideias já previamente incorporadas na estrutura cognitiva do aluno, bem como atentar as relações como o senso comum a respeito do mesmo tema. São ações que fortalecem a compreensão do aluno, tornando ainda mais claras as informações objeto de aprendizagem (RONCA, 1980, p. 68).

No ensino do Direito, esta situação pode ser verificada quando se está tratando da competência/incompetência do juiz, que exige variadas diferenciações, incluindo o afastamento do senso comum, que poderia induzir estar se tratando de um juiz que preenche os requisitos para ser um "bom ou mau agente público", quando na verdade seu significado não tem qualquer relação subjetiva com esta conclusão, já que trata do preenchimento ou não de determinados requisitos legais para poder atuar diante de um processo (ou seja, chamar um juiz de incompetente não tem qualquer relação com a qualidade do seu trabalho, mas sim de um impedimento legal para atuar em determinadas causas respeitando organização judiciária). Esclarecer estas distinções é promover uma reconciliação integradora.

No plano das estratégias, é importante considerar os denominados organizadores prévios, que são utilizados para aplicar os princípios da diferenciação progressiva e reconciliação integrativa, a fim de facilitar a aprendizagem significativa. O organizador "é um material introdutório que é apresentado ao estudante antes do conteúdo que vai ser aprendido. É formulado em termos que já são familiares ao aluno e apresentados num nível mais alto de abstração e generalidade". Logo, consiste em "informações amplas e genéricas, que servirão como pontos de 
ancoragem para idéias mais específicas, mostrando aos alunos, como o caso particular exemplifica os princípios gerais contidos nos organizadores" (RONCA, 1980, p. 69).

Ausubel (2003, p. 12) relaciona os argumentos para fundamentação lógica da utilização dos organizadores:

1. A importância de se possuírem ideias relevantes, ou apropriadas, estabelecidas, já significativas se tornem potencialmente significativas e as novas ideias potencialmente significativas se tornarem realmente significativas (i.e., possuírem novos significados), bem como fornecer-lhes uma ancoragem estável.

2. As vantagens de se utilizarem as ideias mais gerais e inclusivas de uma disciplina na estrutura cognitiva como ideias ancoradas ou subsunçores, alteradas de forma adequada para uma maior particularidade de relevância para o material de instrução. Devido à maior aptidão e especificidade da relevância das mesmas, também usufruem de uma maior estabilidade, poder de explicação e capacidade integradora inerentes.

3. O facto de os próprios organizadores tentarem identificar um conteúdo relevante já existente na estrutura cognitiva (e estarem explicitamente relacionados com esta) e indicar, de modo explícito, a relevância quer do conteúdo existente, quer deles próprios para o novo material de aprendizagem.

O organizador pode se revestir de variadas formas: "pode ser uma afirmação, um parágrafo descritivo, uma pergunta, uma demonstração ou mesmo um filme", mas o que realmente importa é que ele não se confunda com sumários ou introdução, já que são abstrações com um nível muito superficial, lembrando-se que o organizador é uma ideia geral que precede o conteúdo, sendo menos importante a sua forma e mais importante a clareza para seu entendimento, além de estar "continuamente relacionado com o conteúdo que ele está organizando" (RONCA, 1980, p. 70).

Não se pode reduzir a teoria da aprendizagem significativa apenas aos itens até agora elencados. Há várias outras situações detalhadas para a referida teoria, mas dentre elas, acreditamos ser importante elencar as algumas condições de destaque para que o processo se realize, seguindo as explicações de Ausubel, Kovak e Hanesian (1980, p. 34-37).

Consolidado o entendimento de que a essência do processo é a ligação entre o conhecimento já presente na estrutura cognitiva do aluno e as informações a ele proporcionadas, é importante ressaltar a expressão não arbitrária e substantiva, que 
denota idéias relacionadas a um aspecto relevante já existente, como um símbolo, uma imagem, um conceito ou uma proposição.

Também há que se colocar a questão da disposição do aluno para a própria aprendizagem significativa. Como se abordará no próximo item (sobre motivação), a teoria mencionada reconhece a importância dessa disponibilidade para fins de uma maior incorporação do conhecimento.

Por fim, é importante considerar-se o material potencialmente significativo. Os autores se preocupam com esta questão para diferenciar a aprendizagem significativa de uma aprendizagem automática. De nossa parte, acreditamos que um fator importante é evitar-se o que alerta Fagúndez (2000, p. 44) diante do ambiente acadêmico no Curso de Direito: o "que se constata é a absurdidade do conjunto de informações que chega ao aluno, que não serve para nada, que não tem nada a ver com a vida e que mostra uma imagem irreal do quotidiano".

Como destaca Gil (2006, p. 130), a seleção dos conteúdos deve considerar as necessidades e interesses dos alunos para que possam perceber a sua utilidade, que deve ir além da obtenção de bons resultados em provas, o que não significa admitir um conteúdo com caráter essencialmente utilitário ou pragmático (que dificultaria a visão crítica da disciplina).

Por certo, a "tarefa de decidir o que ensinar é, em si mesma, complexa" e importante, pois leva o professor a estar ciente dos programas alternativos que existem e ele mesmo a "ter um ponto de vista estabelecido sobre os mesmos, podendo propor uma opção melhor, desde que mantenha sua autonomia e/ou tenha investigado o assunto em profundidade" e sua decisão final sobre o que ensinar vai Ihe exigir compreender o conhecimento sobre seus alunos e a organização de seus objetivos educacionais, diante do que vale a pena ensinar (PENIN, 1988, p. 4).

Certamente, de nada adianta diversificar técnicas pedagógicas se a preparação do material novo não for condizente com a pretensão educativa que se pretende dar. É importante que o professor desenvolva capacidade crítica suficiente para questionar o conhecimento a ser trabalhado e reflita sobre a coerência dos conteúdos em relação às estruturas cognitivas de seus alunos. Não é raro encontrar afirmações de professores que dizem estar tratando de um assunto apenas porque ele consta do plano de ensino e isso lhe gera a obrigação de lecioná-lo. Sem que se pregue um utilitarismo simplista, é necessário que se compreenda que ensinar aquilo que não tem qualquer utilidade está apontando para uma aprendizagem que 
não tem como ser significativa. E se a aprendizagem está sendo direcionada apenas para uma memorização e repetição incorrerá inevitavelmente nas críticas que se está a produzir pelo presente estudo.

Desta forma, na compreensão desses principais elementos que fundamentam a aprendizagem significativa, é possível compreender um pouco mais o processo de aprendizagem, notando-se que a base da teoria é concretizar o processo em termos de retenção e transferência, com a evolução dos conceitos e da própria estrutura cognitiva do sujeito aprendiz.

\subsection{A motivação}

É importante somar-se ao estudo os reflexos produzidos pela análise da motivação, ainda mais porque se foca em ações de discentes e docentes. $O$ que levaria docentes e/ou discentes a agirem no contexto do estudo do Direito? Os fatores motivacionais externos são fundamentais? Haveria responsabilidade do professor em tal sentido? É preciso de motivação para se aprender?

A motivação é a "predisposição interna que leva a pessoa a comportar-se, proceder ou agir em direção a determinado objetivo" (SCHMITZ, 1984, p. 66). Motivos "são forças que estimulam a satisfação das necessidades humanas, que vão desde as mais essenciais, como as de comida, bebida e repouso, até as mais sofisticadas, como as de estima ou de auto-realização" (GIL, 2006, p. 86).

Muitas teorias foram desenvolvidas para a compreensão da motivação. Já se concebeu a motivação humana como essencialmente a mesma que a motivação em qualquer animal de espécie inferior, como pregava a teoria associacionista, baseando-se na privação de uma necessidade para incentivar uma atividade em busca da satisfação dessa necessidade, "de maneira que o que satisfaz a necessidade se constituía um reforçamento da resposta, fortalecendo-a" (KLAUSMEIER e GOODWIN, 1977, p. 253). Este entendimento reflete posturas que podem ser encontradas no ambiente acadêmico, quando se busca atribuir pontos para que os alunos façam alguma atividade. A necessidade de ser aprovado (quase sempre considerada mais importante do que a própria aprendizagem) pode ser satisfeita com a atribuição de nota para se realizar um ato, inclusive promovendo uma ampliação da participação. Desta prática, é comum encontrar alunos 
perguntando se uma atividade, incentivada pelo professor, será recompensada com algum ponto.

Certamente, este ambiente indica uma postura confortável para o professor: atribuindo nota, todos participam, não há insubordinações, há maior "controle da sala" (disciplina e autoridade pelo "poder da nota") e todos estão aprendendo (?).

Contudo, mesmo para autores dessa teoria, foi necessário reconhecer o chamado efeito Crespi, ao afirmar que um comportamento que "mima" o participante, pode retirar-Ihe o interesse quando o fator motivacional desaparecer. Em pesquisas produzidas entre sujeitos premiados constantemente para realizar algum ato e outros não premiados, aqueles primeiros tendem a perder a motivação quando seus prêmios não aparecem. Os reflexos desta análise são encontrados no dia-a-dia: além de crianças mimadas que se tornam indolentes, observa-se a "síndrome da estrela de cinema ou da medalha de ouro: é sempre espantoso constatar a decepção dos atletas que só conseguem medalha de bronze ou mesmo de prata quando esperam obter a medalha de ouro". (LIEURY E FENOUILLET, 2000, p. 2629).

De qualquer modo, acreditamos que o sistema de recompensas pode até promover a motivação, mas algo a mais deve ser feito (e pensado) para um sistema em que o aluno (universitário) seja estimulado para agir apenas mediante a contraprestação de uma nota (por exemplo), afinal, espera-se que um dia ele se torne um profissional, que não vai ter alguém "dando-lhe pontos" para agir como um ator com responsabilidade pessoal e social. Quem sabe, numa visão extrema (e digamos desvirtuada) do sistema de recompensas, possa ele estar presente entre as causas de ações corruptas e antiéticas que infelizmente tanto se encontra.

Por outro lado, não são poucos os efeitos perversos dos reforços negativos, que podem decorrer não apenas de sanções, mas também por fatores como a desestimulação pela censura ou ações que afetam a auto-estima, no que os reforços positivos sempre indicam uma maior contribuição para a realização das ações (LIEURY E FENOILLET, 2000, p. 24-25). De qualquer modo, o processo educativo não deve manter-se por conta de recompensas ou punições, sob pena de desvirtuarse a compreensão principal da motivação, que é destacada pelo fator condicionante interno do sujeito.

A teoria humanista direciona a compreensão do fenômeno da motivação para a diversidade da identidade humana, envolvendo a personalidade e questões que 
afetam o sujeito. KLAUSMEIER e GOODWIN (1977, p. 260-264), apresentam uma panorâmica desta teoria envolvendo a motivação, baseando-se em estudos de Maslow, considerando uma hierarquia de motivos-necessidades, iniciando-se pelas fisiológicas (pois em seu entendimento, podem provocar falsos resultados nas motivações superiores do homem, pois na ausência delas, domina-se sua atenção e o "indivíduo se comporta como animal inferior"), passando pelas necessidades de segurança, amor e pertinência, estima, auto-atualização, necessidades de conhecimento e compreensão e necessidades estéticas. A teoria humanista se aproxima, portanto, mais da cognitivista do que a associacionista.

Certamente outras teorias podem ser encontradas, buscando explicações para a compreensão da motivação. O que importa, porém, entender estas implicações que se ressaltam das discussões havidas na aprendizagem e no processo educativo, acrescentando-se a distinção entre a motivação intrínseca e a extrínseca, que também é interessante para o tema, que surge na concepção clássica, dependendo dos fatos que provocam a tomada de ações.

Coerente com o que já afirmamos neste estudo, a tendência para que se promova a autonomia do sujeito aprendiz no ensino superior, dando-lhe condições para uma independência intelectual, se associa à afirmação de que a educação deve ser promovida de dentro para fora, isto é, a partir de interesses do sujeito, que se submete ao processo de acordo com sua vontade.

Assim, sob o ângulo da motivação, estar-se-ia tratando daquela classificada como motivação intrínseca, representada pelos motivos que o sujeito aprendiz acata para se envolver no processo educativo, com base nos seus próprios motivos.

Mas, sem dúvidas, há fatores externos que podem operar para convencimento dos fatores internos. Elementos de uma motivação extrínseca podem provocar o sujeito às ações, por meios questionáveis (como os já tratados da punição e recompensa) ou por ações consideradas pedagógicas, empreendidas em favor da aprendizagem.

É importante, registrar, ainda, que a aprendizagem não está absolutamente condicionada à motivação, mas produz inevitavelmente seus reflexos. Com afirmam Ausubel, Novak e Hanesian (1980, p. 331), "embora não indispensável à aprendizagem limitada a curto prazo, é absolutamente necessária para o tipo de aprendizagem continuada envolvida na tarefa de dominar o tema de uma dada disciplina", sendo que seus "efeitos são amplamente mediados através de variáveis 
intervenientes tais como focalização da atenção, persistência e crescente tolerância à frustração".

Pozo (2002, p. 140-141), baseando-se em estudos de Alonso Tapia, e considerando os fatores extrínsecos e intrínsecos relativos à motivação para a aprendizagem, observa que o desejo de aprender (decorrente da motivação intrínseca) produz resultados mais sólidos e consistentes do que quando a aprendizagem é movida por motivos externos, mas reconhece que exista uma mistura ou uma combinação entre ambos. Essa "polaridade extrínseca-intrínseca deve ser entendida como um contínuo, de modo que gerar um desejo por aprender é fazer com o que o aluno interiorize (ou atribua a si mesmo) motivos que inicialmente percebe fora de si".

Como observa Gil (2005, p. 58), um "aluno pode ser inteligente, mas, se ele não quer aprender, ninguém poderá fazê-lo aprender" e ainda que submetido "a uma situação de aprendizagem, como, por exemplo, uma aula, ele provavelmente dedicará sua energia e atenção a fins menos desejáveis". Porém, "um aluno altamente motivado provavelmente fará melhor do que um teste de inteligência pudesse ter previsto".

A motivação, assim, aparece no gostar, revelado pelo aluno através de seus objetivos, que podem ser destinados à resolução de problemas como para o fim de "desvendar ou explicitar melhor os fenômenos que já dão certo e que lhe dão prazer", de maneira que "não é só o fato de querer acertar que nos leva ao conhecimento, mas também o fato der querer saber mais daquilo que tem dado certo e de que gostamos" (PENIN, 1988, p. 13-14).

Desta maneira, considerando-se que os motivos devem surgir no aluno, não se pode culpar ou mesmo atribuir ao professor a única responsabilidade para que a motivação ocorra, ainda que possa ter importante papel neste sentido. A motivação nem é mesmo um problema exclusivamente pedagógico, como lembra Reboul (1982, p. 151), como fatores fisiológicos (exemplo a falta de sono) e psicológicos, com as dissensões familiares e sócio-econômicos.

O papel do professor é assim importante e, como já se insistiu no presente estudo, não pode ser destacado, mas sim aprimorado, inclusive com a compreensão do sistema de motivação, que influenciará o estudante na busca de seus objetivos. Como aponta Reboul (idem), diante de um dilema provocado por alunos que se recusam trabalhar (ajudá-los ou abandoná-los?), poder-se-ia optar pelo abandono 
da pedagogia... ou recusar o dilema, "custe o que custar, apesar da pouca luz que Ihes oferece a ciência e o pouco apoio que lhe concede a sociedade", buscando sair do "atoleiro fatal" tendo motivos para motivar".

Parece fácil transportar os problemas pedagógicos anteriormente vistos envolvendo docentes e discentes pelas repercussões da motivação. A não compreensão dos aspectos pedagógicos pelo professor pode levá-lo a acreditar que sua aula conferência, desenvolvida num monólogo de um mesmo tom, não recebe a participação e atenção dos alunos porque são absolutamente desinteressados e desmotivados por culpa exclusiva deles, como se sua atuação, de um jeito ou de outro, não fizesse diferença (sem perceber que a participação ocorre de forma diferenciada com outro professor), não se preocupando com instrumentos capazes de provocar a motivação dos alunos com maior eficácia.

No plano discente, a não compreensão da importância dos seus motivos próprios - e que são eles os mais importantes para o desenvolvimento de sua aprendizagem - o conduzem para caminhos equivocados, em conclusões como a que a culpa pela ausência de seu conhecimento é apenas do professor ruim ou apenas da sua má formação. A necessidade do sentimento de superação é um importante instrumento para se romper com a zona de conforme que o sistema muitas vezes o conduz, de que fazendo o mínimo necessário e estando aprovado, é o que interessa.

Neste ponto, podem-se acrescentar as reflexões de Grossi (2001, p. 134135), na relevância do desejo para a aprendizagem, para o envolvimento de docentes e discentes nesta perspectiva. $O$ desejo decorre da ausência, pois não desejamos aquilo que já temos e, ao desejarmos o que nos falta, temos nesta falta o sustento de nosso desejo. O caráter positivo da falta se dá justamente nessa provocação ao desejo, sem a qual morremos. Logo, um ambiente motivador pode ser desenvolvido a partir de problemas que toquem os alunos, proporcionando a falta que promove o desejo de descobrir/aprender, para o qual a ação docente e a consideração da prática serão fundamentais.

Com efeito, como observa Cortella (2001, p. 124) a "criação e recriação do Conhecimento na escola não está apenas em falar sobre coisas prazerosas, mas, principalmente, em falar prazerosamente sobre as coisas". Desta maneira, "quando o educador exala gosto pelo que está ensinando, ele interessa nisso também o 
aluno", que não necessariamente vai "apaixonar-se por aquilo, mas aprender o gosto é parte fundamental para passar a gostar".

Assim, é importante reconhecer-se as interferências da motivação no contexto da aprendizagem, para que faça parte das ações envolvendo um processo educativo.

\subsection{A relação teoria-prática}

Outro aspecto fundamental para o presente estudo é a compreensão da relação teoria-prática. Supondo-se uma discussão além da determinação do objeto de conhecimento e teorização (em parte visto pelo capítulo 1, envolvendo o debate sobre os paradigmas do Direito), é importante colocar em discussão as abordagens didáticas da teoria e da prática para o ensino do Direito, como parte da fundamentação para onde se pretende chegar com os argumentos do presente estudo e até mesmo amparado nas indicações apontadas pelas manifestações dos dados coletados.

Entre dois pontos principais transitam os nossos questionamentos a respeito deste item: a) o professor envolvido com as disciplinas teóricas deve promover atividades práticas? b) as atividades práticas devem ser desenvolvidas num contexto específico (no caso, em estágios simulados e reais)?

Primeiramente, as respostas apresentadas pelos professores das disciplinas teóricas indicam que não há um predomínio de adotar, como procedimento para o ensino-aprendizagem, a utilização de atividades práticas em sala de aula. Neste sentido, as manifestações apresentadas pelos 06 (seis) professores consultados indicaram um sentido de não considerar tão importante a atividade prática para o desenvolvimento de suas aulas (vide Tabela 05 - Respostas apresentadas por Docentes das disciplinas teóricas de Direito Processual Civil relacionando os procedimentos de ensino com a aprendizagem, p. 152).

Ainda que os professores não pertençam ao mesmo ambiente dos alunos pesquisados, percebe-se que os discursos apresentados se respaldam. Instados sobre tais atividades práticas promovidas pelos professores das disciplinas teóricas, os estudantes afirmaram: 


\begin{tabular}{|c|c|c|c|c|c|c|c|}
\hline Questão & Desempenho na exposição e condução da aưla & $\begin{array}{l}\text { Nunca } \\
\text { (zero) }\end{array}$ & $\begin{array}{c}\text { Raramente } \\
\text { (1 x mês) }\end{array}$ & $\begin{array}{l}\text { Regularmente } \\
\text { (2x mês) }\end{array}$ & $\begin{array}{l}\text { Quase sempre } \\
\text { (3x mês) }\end{array}$ & $\begin{array}{l}\text { Sempre } \\
\text { (4x mês) }\end{array}$ & TOTAL \\
\hline$Q_{9}$ & Promove a realização de atividades práticas simuladas & 10 & 5 & 2 & 4 & 1 & 22 \\
\hline
\end{tabular}

Fonte:Celsolocohama

Tabela 11 - Recorte das respostas dos discentes sobre as ações do professor de Direito Processual Civil I quanto às atividades simuladas.

\begin{tabular}{l} 
Avaliação do desempenho sobre a exposição e condução da aula pelo professor de Direito Processual Civil II do Curso de Direito - 2010 \\
\hline \multirow{2}{*}{ Questão }
\end{tabular}

Fonte:Celsolocohama

Tabela 12 - Recorte das respostas dos discentes sobre as ações do professor de Direito Processual Civil II quanto às atividades simuladas.

De fato, as manifestações apontam que as atividades práticas podem eventualmente existir, com uma tendência a não serem tão utilizadas.

Esta questão sobre o envolvimento de práticas pelo professor das disciplinas teóricas permite alguns debates, reconhecendo-se certa complexidade sobre 0 tema.

Por certo, o primeiro problema está na própria divisão decorrente da expressão teoria-prática. Essa dicotomia criada para fins de divisão entre 0 conhecimento e a sua aplicação, tem qual finalidade? Por que se separar a teoria da prática?

Poder-se-ia argumentar, que a separação entre a teoria e a prática é uma questão racional e analítica. São objetos distintos conceitualmente, porque é possível conceber uma teoria sem a sua prática e vice-versa, pois há práticas sem sua própria teorização. Portanto, a existência da individualidade de cada uma delas, justifica, em princípio, que se possa estudá-las separadamente. Um pesquisador pode muito bem encontrar na análise puramente teórica de uma ciência (ou parte dela) o seu objeto de pesquisa, o que também pode ser feito analisando-se comportamentos.

Projetando-se esta questão para o processo de ensino-aprendizagem, seria possível manter a mesma conclusão de que a teoria e a prática poderiam ser abordadas de forma isolada, sem a intervenção de uma na outra? 
Note-se que pelo discurso analisado nos dados coletados, pensando-se apenas na abordagem teórica do conhecimento no ensino do Direito, a resposta a esta questão seria sim: é possível a teoria ser ensinada sem o envolvimento da prática por atividades simuladas.

Talvez possa surgir o argumento de que a prática desenvolvida pelo professor das disciplinas teóricas não necessitaria de atividades simuladas, mas apenas da exemplificação, o que certamente ocorre nas ações do professor de Direito. Tratando-se de profissionais da área jurídica em sala de aula, é inevitável que os exemplos de seu cotidiano jurídico sirvam de apoio para suas preleções (inclusive, podendo produzir desvios em que o professor mais narra seus casos assistematicamente, do que promove uma abordagem coerente com alguma proposta educativa).

Assim, um novo questionamento surgiria: dar exemplos em sala de aula é praticar o conhecimento tratado?

Começando-se pelo significado da palavra praticar, a mesma é considerada como sinônimo de fazer, realizar, levar a efeito, executar (FERREIRA, A. B. de H., 1999). Consideremos, portanto, que a prática envolve o agir. Mas em vista da relação educacional, temos que considerar esta ação coerente com determinados objetivos em face de determinados conhecimentos. Queremos falar da prática que compõe o processo de aprendizagem e não uma prática qualquer aleatória, ainda que esta possa ter importância para a visão do próprio educando.

Estamos considerando, porém, a prática que envolve o conhecimento objeto da aprendizagem. Assim, não é o conhecimento em si, mas como utilizá-lo (ou, pensando na ação, na sua utilização, que vai além do "como", já que em si, este momento - do "como" - faz parte da própria teoria).

Tratando as dificuldades da relação teoria-prática, Feldman (2001, p. 28) opina no sentido de que, em contexto educacional, sua utilização pode estar se referindo ao seguinte:

- A relação entre o pensamento e a ação de um sujeito ou uma variante deste problema, que é a realização entre dizer e fazer.

- As interações entre âmbitos especializados de gestão educativa - e os conhecimentos teóricos e técnicos próprios de cada um - e âmbitos práticos de trabalho escolar - e o tipo de conhecimento próprio desses espaços. 
- A relação entre as intenções e a realidade. Talvez também interpretável em termos de relações entre concepção e execução.

- A relação entre teorias de base e teorias "aplicadas" ou práticas. Isso está ligado ao problema de como obter "conclusões práticas" de nossas teorias, ou como torná-las operativas com relação às exigências que as situações educativas propõem.

O desafio do tratamento da relação teoria-prática toca a questão da formação profissional. Como lembra Pimenta (2001, p. 28), o "exercício de qualquer profissão é prático", na "medida em que se trata de fazer 'algo' ou 'ação'. A autora faz considerações sobre a formação do professor que podem perfeitamente adequar-se a formação dos futuros profissionais do Direito. Assim, considera que "se o curso tem por função preparar o futuro profissional para praticar, é adequado que tenha a preocupação com a prática". Considera ainda que, diante da impossibilidade do curso assumir o lugar da prática profissional "(que o aluno exercerá quando for profissional), o seu alcance será tão-somente possibilitar uma noção da prática, tomando-a como preocupação sistemática no currículo do curso".

Ao lado dessa consideração da relação teoria-prática para fins da formação profissional do aluno, podemos acrescentar a questão da aprendizagem, onde também deve ser considerada.

Ausubel, Novak e Hanesian (1980, p. 258-260), tecem um longo capítulo sobre a relação da prática com a aprendizagem, interligando-a à repetição, memorização/retenção. Considerado sua menor importância em relação ao significado e mais importante para memorização, os autores afirmam que a aprendizagem e a retenção implicam ordinariamente em prática, que deve ser "tipicamente específica (restrita à tarefa a ser aprendida) e deliberada (intencional)". Seus efeitos (da prática), "tanto refletem a influência da existência da estrutura cognitiva como também modificam esta estrutura", pois:

"o impacto cognitivo da apresentação inicial do novo material a ser aprendido potencialmente significativo (a emergência de novos significados) é amplamente determinado pelos atributos organizacionais das idéias estabelecidas na estrutura cognitiva com a qual a tarefa de aprendizagem está relacionada. Pelo estabelecimento desses novos significados na estrutura cognitiva, tais apresentações influenciam, por sua vez, a resposta do aprendiz aos ensaios subseqüentes da mesma tarefa e sua aprendizagem de novos materiais relacionados. A prática, portanto, afeta a aprendizagem e a retenção através da modificação que opera na estrutura cognitiva. Em outras palavras, a prática aumenta a clareza e a estabilidade dos novos 
significados aprendidos na estrutura cognitiva. Por isso, ela aumenta sua força dissociativa e sua retenção.

Por certo, é inegável que a prática tem papel fundamental na aprendizagem, na medida em que se apresenta como um elemento que fortalece o processo de retenção de forma significativa. Seguindo-se a linha da aprendizagem significativa, promovendo meios para que o aluno tenha uma estrutura cognitiva preparada para assimilar os conteúdos potencialmente significativos que the serão propostos, exercer a prática de tais conteúdos e do processo de assimilação é uma importante maneira de assegurar esse conhecimento.

Por outro lado, já afirmamos a importância de o conteúdo ter aptidão para ser aplicado. Um professor que se propõe a tratar de um assunto sem qualquer relevância (seja de fundamento ou de aplicação), não está aproveitando-se utilmente do tempo estabelecido para essa relação educativa. Assim, se comparece para o fim de propor algo significativo, não somente para a estrutura cognitiva do estudante, mas também para os efeitos de sua futura atuação profissional, deve pretender que seu aluno utilize aquele conhecimento proposto para este fim.

$\mathrm{Na}$ continuação deste raciocínio, se se pretende que o aluno utilize o conhecimento abordado, quando esperar que isso aconteça? Muitas vezes, um professor do primeiro ano de curso pode dizer: "quando vocês forem advogados, observarão que esta informação será fundamental para a elaboração de um contrato"; ou um professor de Processo Civil, no segundo ano do curso, pode afirmar aos seus alunos que "quando forem procurados por um cliente para defendê-lo, deverão contar o prazo para a defesa da juntada do aviso de recebimento da carta de citação" ou ainda "quando forem juízes, perceberão que em hipóteses de suspeição, é melhor vocês se afastarem do processo antes que alguma das partes alegue essa parcialidade". As projeções para um futuro distante indicam que o conhecimento ali tratado só terá relevância em outro momento (salvo, obviamente, numa avaliação).

É certo que os alunos ainda não são advogados e nem juízes, e, com isso, sua prática profissional ainda não pode ser realizada. Mas a prática de seu conhecimento, que será utilizada para fins profissionais, pode ser executada com o fito de aprimorar a aprendizagem e, ao final, proporcionar meios de retenção para que o conhecimento possa ser resgatado na profissão. 
A esta altura, podemos afirmar que a prática exige ação do aluno, que vai além de apenas ouvir exemplos práticos. E mesmo que a teoria possa ser vista sem a abordagem prática, acreditamos que esta postura precise ser revista, na mesma medida da compreensão de que o foco na aprendizagem demanda o saber fazer com o que se aprende. Além disso, a prática não deve ser pensada apenas no futuro, mas especialmente no tempo em que se está a tratar da abordagem teórica. Isso repercutirá de forma significativa na estrutura cognitiva do aluno e muito provavelmente seus efeitos serão bem mais consideráveis de que mantê-los apenas em abstrações.

$\mathrm{Na}$ verdade, acompanhamos o raciocínio de Rays (1996, p. 35) quando analisa essa relação entre a teoria e a prática, considerando-a muito mais do que momentos compartimentados, já que "toda atividade consciente do homem é guiada pela união da teoria e da prática, na forma histórico-social da atividade-trabalho, envolvendo, a um só tempo, valores cognitivos e valores práticos", de maneira que "toda ação humana realizada com base no princípio da vinculação teoria-prática ocupa posição científica na atividade consciente do homem".

Essa relação faz com que se perceba que a teoria e prática movem-se e transformam-se continuamente, a um só tempo, "em razão de o homem ser um constante produtor de novos conhecimentos, de novos significados, de novos fenômenos e de novos objetos, que acabam se incorporando no modo de ser da humanidade" (RAYS, 1996, p. 36-37).

Desta maneira, no contexto de um pensamento pedagógico crítico, é ponto pacífico a necessidade de conexão teoria-prática no cotidiano escolar, e o direcionamento do trabalho docente deve projetá-la não apenas considerando a "realidade atual para a organização das atividades escolares, mas, também, o ideal de futuro que, metodologicamente, se caracteriza como uma espécie de espiral dialética que resgata o passado num movimento histórico-estrutural", considerando o "passado histórico, realidade atual e ideal de futuro, como motor das perspectivas de desenvolvimento histórico, da modernidade e da busca de qualidade de vida" (idem, p. 42-43).

Assim, estamos num plano maior da relação teoria-prática, que vai além da aprendizagem significativa de um conteúdo teórico com a sua relação com sua prática. É constituída num desafio envolvendo uma "prática pedagógica concreta", que "não estabelece, jamais, a ruptura entre o conhecimento (teoria) e a ação 
(prática), tanto na produção em si, como no processo de transformação do real”. A teoria, seria, portanto, "um conhecimento que funciona como um 'guia' para a ação" e a prática "a ação, a produção", realizada pelo "homem transformando o real" a ponto de até mesmo negar a própria teoria (idem, p. 47-48).

Para a prática pedagógica, o primeiro elemento a ser superado seria, desta maneira, a "elucidação do equívoco político-pedagógico presente em boa parte dos cursos de formação profissional escolarizada: Primeiro conhecer, para depois fazer, ou, Primeiro fazer, depois conhecer", pois o "conhecer e fazer na didática crítica não podem ser tomados em sua dualidade mas na conjugação do ato teórico-prático" (idem, p. 50).

Por certo, a concepção da relação teoria e prática não pode ser vista num plano de dualidade, pois a "continuidade científica de construção da teoria envolve elementos fáticos e reflexões mais abstratas, não apenas um ou outro". Quando se formulam pressuposições, "há a correção entre os dados obtidos e a criatividade, o que não corresponde à perda de conexão das inferências teóricas com o mundo fático", mesmo considerando as "interferências de elementos ideológicos" (SILVA, MAIA e TEIXEIRA, 2008, 357).

Sousa Junior (2006, p. 49), tratando dos desafios das Instituições de Ensino Superior e sua responsabilidade social, alerta para a necessidade de "(re)situar o saber, herança do século XIX, que buscava, como único caminho para o progresso, o desenvolvimento técnico e científico atrelado à lógica da produtividade e do lucro em detrimento da percepção da realidade e da ciência una e múltipla, simultaneamente". Para isso, ressalta a importância de se pressupor mudanças profundas, com a necessidade de "articulação entre teoria e prática, quer pela epistemologia das ciências, quer pela investigação científica com foco na realidade viva e dinâmica", como um "fundamento para a busca da superação de vícios teóricos e das concepções de mundo sob os quais o paradigma do pensamento simplificador vem sendo desenvolvido".

No tratamento do ensino prático reflexivo relacionado aos mundos da Universidade e da Prática, Schön (2000, p. 225), apresenta uma discussão sobre o design das escolas profissionais, e relata um posicionamento de Herbert Simon justamente se referindo a esta divisão: 
Que as escolas profissionais devem temer, de acordo com Simon, é um "estado de equilíbrio morto", no qual os docentes que se orientam pela prática e os que se orientam pela disciplina separam-se uns dos outros. Para evitar esse caminho, as faculdades devem evitar os departamentos e cultivar a comunicação entre suas duas alas.

No desenvolvimento de suas conclusões sobre o assunto Schön considera alguns pontos da teoria de Simon, mas altera o foco em parte:

Minha formulação da situação de design das escolas profissionais é, em certos aspectos, semelhante à de Simon. Como ele, dou um lugar central às distâncias entre escola e universidade, escola e prática e componentes da escola orientados pela disciplina e aqueles orientados pela profissão. Porém, diferentemente dele, estou preocupado com uma outra dicotomia: a separação entre o mundo tecnicamente racional das disciplinas, por um lado, e, por outro, a reflexão-na-ação dos profissionais competentes e a reflexão sobre ao reflexão-na-ação dos pesquisadores que buscam desenvolver uma fenomenologia da prática.

Preocupo-me menos com a divisão entre grupos de professores orientados pela disciplina e os orientados pela prática do que com a possível concretização da visão de Simon: uma profissão procedimentalizada na qual a racionalidade técnica desloca integralmente o talento artístico, e uma escola organizada em torno de uma ciência que desloca integralmente a educação para o talento artístico. (SCHÖN, 2000, p. 225-226)

Ademais, na intenção de se construir pontes entre "a ciência aplicada e a reflexão-na-ação, a aula prática deveria tornar-se um lugar onde os profissionais aprendem a refletir sobre suas próprias teorias tácitas a respeito dos fenômenos da prática, na presença de representantes daquelas disciplinas cujas teorias formais são comparáveis às teorias tácitas desses profissionais", encorajando pesquisadores, "na academia e na prática, a aprenderem uns com os outros" (SCHÖN, 2000, p. 234).

Retomando-se a questão para o estudo do Direito, é fácil perceber que o distanciamento pedagógico do professor constrói facilmente uma concepção de que os momentos teórico e prático devem ocorrem dentro da formatação que o Curso tradicionalmente tem: a teoria se aprende com as disciplinas teóricas e a prática o aluno receberá quando cursar as disciplinas assim denominadas e se encaixarem em estágios reais. Logo, é plenamente razoável não se encontrar professores realizando atividades práticas simuladas durante a abordagem teórica.

Entretanto, parece agora perceptível que esta visão compartimentalizada pode provocar problemas para a ação docente e reconhecer a importância do 
conhecimento prático é um passo para sua superação. Agregando a inafastabilidade das ações humanas (práticas) do intercâmbio com a teoria, seus efeitos para a formação profissional e sua importante repercussão para a aprendizagem, tem-se a abertura para outras possibilidades, que podem conduzir as ações docentes para resultados metodologicamente e substancialmente significativos.

Este Capítulo, assim, apresentou os dados coletados a partir de manifestações de alunos e professores de um curso de Direito. Tais informações constituem um referencial para a análise das questões pedagógicas tratando da aprendizagem e das ações dos referidos sujeitos do processo educativo. Os sinais de afastamento entre a teoria e a prática e na relação entre professores destas categorias, contribuem para respaldar a relevância do estudo. A compreensão da motivação e a revisão de como se pode conceber as ações práticas para os conteúdos teóricos, num intercâmbio de fenômenos, complementam os estudos da aprendizagem significativa, construída a partir de princípios e elementos que formam um importante instrumental para as ações do professor na execução dos objetivos educacionais pretendidos.

O próximo Capítulo aproveita das análises até então realizadas, para apresentar direcionamentos que justificam a escolha do estudo, na pretensão de se indicar pressupostos e possibilidades para um estudo do Direito diferenciado. 


\section{MEDIDAS PEDAGÓGICAS DOCENTES PARA O ENVOLVIMENTO DA AÇÃO DOCENTE: A APROXIMAÇÃO DA TEORIA E DA PRÁTICA}

Ainda que o foco da pesquisa procure fazer um corte de uma representação da realidade, assentada numa experiência de parte de um curso de Direito, retratando situações que afetam o plano pedagógico, deixar-se de abordar elementos que possam contribuir para uma maior reflexão do objeto parece causar uma lacuna indesejada, como se o pensamento crítico pudesse se interromper na crítica por ela mesma, sem qualquer contribuição - o que efetivamente não atende a objetivos que a influência da ideologia educativa apresenta.

Por outro lado, é importante reconhecer um alerta extraído das palavras de Chamlian (2003, p. 62), em razão da declaração de combater sistematicamente a tendência da prescrição pura e simples no campo da formação do professor em geral, sob o risco de contribuir para um equivocado consenso de minimizar a importância da formação pedagógica por concebê-la como "receituário rapidamente adquirido e que pouca influência produz na formação" (no caso, abordando a pósgraduação).

Revendo meus primeiros momentos na atuação da formação de professores de Direito pelos idos de 2002, percebo o quanto essa influência prescritiva me envolvia. Reconhecia a importância dos fundamentos pedagógicos. Fazia continuamente meus estudos pessoais e outros de formação (como uma especialização em docência do ensino superior), mas talvez pela influência da formação jurídica (na qual a função prescritiva tem grande papel), e/ou talvez pela própria ausência de uma formação mais sólida voltada aos conhecimentos dos pressupostos e das teorias pedagógicas, sentia uma forte atração pela prescrição e a empreendi por algum tempo, até perceber que de nada adianta propor discussões e ações sem um amparo nos seus fundamentos. Fazer algo no plano educativo apenas porque deu certo é correr o risco de engessar a ação por falta de compreensão dos princípios que a ampararam, impedindo reflexões e sua própria reconstrução.

$\mathrm{Na}$ busca de um equilíbrio entre o criticar e o sugerir, atento a não prescrever sem fundamentos, é que se chega ao último capítulo desta pesquisa, encaminhando-se para a indicação de certas condições, escolhidas entre diversas outras possibilidades, para que se possa lançar um olhar sobre o Curso de Direito e 
compreendê-lo - ainda que sempre parcialmente -, para pensá-lo além, sob os inevitáveis riscos da incerteza e sob o julgamento da crítica sobre a crítica.

Assim sendo, apresentam-se quatro momentos de centralização do debate que intermediou esta pesquisa, acompanhados de indicações para entrelaçar o estudo e ensino do Direito com os fundamentos até então apontados, com destaque à importância da ação docente envolvendo a aprendizagem e o desenvolvimento do educando para sua autonomia.

\subsection{A importância do professor mediador/facilitador}

Ainda que o tema tenha sido tocado durante este estudo, por conta dos problemas apontados no contexto do ensino do Direito, a postura do professor merece constituir uma premissa para as intervenções sugeridas.

O docente que se assume como profissional, percebe, assim, a importância de reconhecer o lugar onde se encontra. Saber onde está implica em entender quais são as expectativas para suas ações, decorrentes de terceiros afetados por seus atos (sociedade, Instituição de Ensino Superior e alunos) e de si mesmo (por seus objetivos pessoais e profissionais).

No aspecto pessoal, há muitos elementos que podem formar as convicções e fundamentar as ações dos professores, mas é possível ampliar sua satisfação pessoal em razão dos resultados obtidos no processo educativo, por compreender seus atos, vislumbrar objetivos e executá-los em atenção e em direção ao aluno, colhendo os respectivos resultados. Pensar-se a docência sem considerar o professor em sua acepção humana é tão problemático quando negar a humanidade do discente. E a humanidade de ambos passa pelo processo de satisfação pessoal, como sujeito único, sem perder sua projeção e interação social.

No plano educativo, se partimos da preocupação de seus efeitos nos alunos e a importância que o professor tem neste contexto, é coerente reconhecer a necessidade de um envolvimento interpessoal entre eles, o que conduz a algumas circunstâncias de imperiosa reflexão.

De um lado, deve-se reconhecer na relação interpessoal as características de reciprocidade e dialeticidade, dentre outras tratadas por Tavares (2001, p. 35-38). A reciprocidade faz com que as relações interpessoais funcionem nos dois sentidos de maneira incondicionalmente positiva, ou seja, "as duas ou mais pessoas envolvidas 
na relação deverão reconhecer-se, afirmar-se, aceitar-se e confirmar-se mutuamente de um modo positivo e incondicional". A dialeticidade faz com que essa reciprocidade evite que as pessoas envolvidas na relação interpessoal se reduzam ou se anulem, "permanecendo uma em frente à outra com toda a sua dignidade e altura".

Nesse movimento recíproco e dialético, é também importante que o professor reconheça alguns caminhos de possibilidades, que podem contribuir para suas ações profissionais.

O papel de mediador/facilitador contribui neste plano, na medida em que afasta a figura tradicionalmente centralizadora, detentora de todas as verdades e todas as soluções, para se aproximar com presença de quem tem conhecimentos necessários para conduzir o processo educativo, sem se sentir o fim de todas as ações.

Como menciona Luckesi (1994, p. 115), na práxis pedagógica, o educador "assume o papel de mediador entre a cultura elaborada, acumulada e em processo de acumulação pela humanidade e o educando", realizando a "mediação entre o coletivo da sociedade (os resultados da cultura) e o individual do aluno".

Com efeito, entre as novas atitudes docentes diante das realidades do mundo contemporâneo, Libâneo (2006, p. 29) elenca a capacidade de assumir o ensino como mediação, onde a aprendizagem ativa do aluno se realiza com a ajuda pedagógica do professor, que deve superar o "ensino exclusivamente verbalista" e "a mera transmissão de informações, a aprendizagem entendida somente como acumulação de conhecimentos". Logo, o professor atua mediando "a relação ativa do aluno com a unidade e com os conteúdos próprios de sua disciplina, mas considerando os conhecimentos, a experiência e os significados que os alunos trazem à sala de aula, seu potencial cognitivo, suas capacidades e interesses, seus procedimentos de pensar, seu modo de trabalhar".

De fato, o mediador tem uma importante presença, porque é agente fundamental no intercâmbio entre o aluno e o conhecimento. Ao mediar, não interfere dizendo o certo ou o errado, mas aproxima as possibilidades para que 0 aluno tenha condições de construir seu conhecimento para reconhecê-lo e superálo, mantendo-se como sujeito ativo deste processo e não mero receptor. 
É certo que essa figura de mediador (ou facilitador da aprendizagem), exige que reconheça os dois lados de aproximação (o aluno e o conhecimento), e os mecanismos para que isso possa ser realizado.

O reconhecer o lado dos alunos exige o olhar para a diversidade que os envolve por conta de sua pessoalidade e do seu ambiente. Ao contrário do afastamento que se destacava em momento anterior desta pesquisa, quando do apontamento de problemas pedagógicos envolvendo o professor, a aproximação para o reconhecimento da diversidade é passo fundamental para a própria aprendizagem.

Zabala (1998, p. 34) coloca essa atenção à diversidade como eixo estruturador do enfoque pedagógico envolvendo o processo de aprendizagem. Ressalta que os mais de cem anos de estudos e trabalhos experimentais sobre este tema, mesmo tendo em conta as diversas correntes psicológicas e ausência de consenso entre as correntes existentes, não excluem o reconhecimento de alguns princípios, dentre os quais entender que "as aprendizagens dependem das características singulares de cada um dos aprendizes" e elas correspondem, "em grande parte, às experiências que cada um viveu desde o nascimento. A forma como se aprende e o ritmo da aprendizagem variam segundo as capacidades, motivações e interesses de cada um".

Por sua vez, Cortella (2001, p. 125) aponta que "nós, educadores, precisamos ter o universo vivencial discente como princípio (ponto de partida), de maneira a atingir a meta (ponto de chegada) do processo pedagógico", considerando que a "prática educacional tem como objetivo central fazer avançar a capacidade de compreender e intervir na realidade para além do estágio presente, gerando autonomia e humanização".

Libâneo, neste sentido, insiste como uma regra fundamental da Didática a noção de que "o êxito da atividade de ensino depende de que os objetivos escolares entrem em correspondência com o nível de conhecimentos e experiências já disponíveis, com o mundo social e cultural em que vivem os alunos com suas capacidades potenciais de assimilação de conhecimentos" (1994, p. 113-114).

Com isso, o professor "ajuda no questionamento dessas experiências e significados, provê condições e meios cognitivos para sua modificação por parte dos alunos e orienta-os, intencionalmente, para objetivos educativos", ao mesmo tempo que poderá apresentar sua ajuda para o "desenvolvimento das competências do 
pensar, em função do que coloca como problemas, pergunta, dialoga, ouve os alunos, ensina-os a argumentar, abre espaço para expressarem seus pensamentos, sentimentos, desejos, de modo que tragam para a aula sua realidade vivida" (LIBÂNEO, 2006, p. 29). Em termos semelhantes é o que também prelecionam Schmitz (1984, p. 36), Abreu e Masetto (1990, p. 11), Behrens (1996, p. 39), Gil (2006, p. 23) entre outros.

Ainda que os dados coletados não tenham buscado demonstrar o nível de envolvimento do professor numa relação interpessoal com seus alunos, pode-se inferir o quanto essa questão enfrenta dificuldades, por conta, exemplificativamente, do tempo que exige (tempo este que se apresenta escasso até para os professores das disciplinas teóricas aplicarem questões práticas em suas aulas, conforme apontou a Tabela 06 - p. 153).

Nesta esteira do olhar sobre o aluno, há que se vislumbrar as abordagens que mostram a multiplicidade de perspectivas para as inteligências, consoante diversos estudos realizados por Horward Gardner, que propôs sua teoria das inteligências múltiplas em 1983, desafiando diretamente a visão clássica da inteligência, consubstanciada numa noção unitária. Definindo a inteligência como a "capacidade de resolver problemas ou criar produtos que são importantes num determinado ambiente cultural ou comunidade", Gardner propõe inicialmente sete inteligências, observando que este número poderia ser maior ou menor (GARDNER, KORNHABER e WAKE, 2003, p. 214-215). As inteligências apresentadas foram a linguística, a musical, lógico-matemática, espacial, corporal-cinestésica, intrapessoal e interpessoal (idem, p. 217-223), acrescentando, posteriormente, a inteligência naturalista.

Ainda que já se seguiram diversos estudos sobre o tema e mesmo diante da não simplicidade em se identificar as inteligências múltiplas dos alunos (com propostas de inventários para a coleta de informações a partir das quais se pode aproximar as inteligências predominantes) como relata Armstrong (2001, p. 27), acreditamos que o professor de Direito pode ter outro olhar sobre suas ações (inclusive como mediador/facilitador) quando analisa a amplitude das características que tais estudos apontam. Quando se imagina os alunos como indivíduos dentro um padrão de inteligência que não se diferencia, pensa-se que todos estão e são idênticos no processo de raciocínio e compreensão. Isso acarreta um tratamento 
uniforme para a aprendizagem, que nem sempre poderá ser eficaz, justamente por não reconhecer essas diferenças tratadas por Garder.

Neste sentido, quando se nota o predomínio da exposição oral pelos professores (conforme se evidencia, por exemplo, pela Tabela 05 para os professores das disciplinas teóricas, p. 152 e Tabela 08 para os professores das disciplinas práticas, p. 155), percebe-se a utilização predominante do sentido auditivo do aluno, que repercute na inteligência lingüística, mas tem limitações diante da diversificação das inteligências mencionadas. Como destaca Antunes (1999, p. 28), a atenção dos alunos "é sempre muito menor quando devem usar as inteligências em que se apresentam menos pródigos" e considerando esse "diversificado espectro de inteligências que torna cada aluno muito mais diferente dos outros que supúnhamos, é natural concluirmos que um ensino que estimule muito mais uma inteligência, em detrimento de outras, causará desatenção a todos quantos não apresentem um elevado potencial dessa inteligência".

É certo que a abordagem pedagógica das referidas inteligências não se restringe a uma única forma, de maneira que não existe "e nem pode existir 'proprietários' específicos de 'receitas definitivas' sobre como trabalhar essa diversidade de competências humanas" (ANTUNES, 2002b, p. 119), mas se o professor de Direito admitir a existência dessas outras possíveis inteligências (e, por certo, refletir sobre as mesmas) tem-se um importante passo para reconhecer as diferenças entre seus alunos e pensar sobre suas ações envolvendo sua postura mediadora.

Historicamente, Périssé (2004, p. 12) ressalta que a partir dos anos 90, na esteira do construtivismo, as expressões como "mediar, facilitar, provocar desequilíbrio e agir na zona de desenvolvimento proximal do aluno começaram a fazer parte do discurso 'pedagogês'”, e o papel do professor passou "a ser descrito como o de um mediador de aprendizagens, um facilitador da construção de conhecimentos pelo próprio aluno, possibilitando que este se tornasse sujeito do seu processo de aprendizagem", mas ressalta que a mudança do discurso não acompanhou a realidade, decorrente até mesmo da não mudança na própria formação dos professores.

Mas é certo que o ambiente construtivista é coerente com a perspectiva do presente estudo, na medida em que se valoriza o processo de aprendizagem na perspectiva do aprender a aprender. Nela, há um destaque aos procedimentos de 
aquisição do conhecimento, onde a interação professor-estudante é muito forte, na conciliação entre a participação ativa do próprio aluno (mediante pesquisa, experimentação, trabalho em grupo, estímulo ao desafio, desenvolvimento do raciocínio e busca constante do conhecimento) e ações entusiastas do professor, com mente aberta e espírito despojado, disposto a caminhar junto com o aluno neste processo, exercendo muito mais papéis do que na perspectiva tradicional, cabendoIhe ainda "despertar nos estudantes a curiosidade sobre o que vão aprender; encorajá-los a dialogar com o professor e entre si; estimulá-los a assumir responsabilidades e autonomia; permitir que conduzam as aulas, alterem estratégias e conteúdos; e envolvê-los em experiências que impliquem contradição em relação a hipóteses inicialmente estabelecidas e estimulem a discussão" (GIL, 2006, p. 63).

Libâneo (1994, p. 104-105), destacando a importância do estudo ativo do aluno, vê o trabalho docente mediante seus efeitos, considerando-o frutífero quando "o ensino dos conhecimentos e dos métodos de adquirir e aplicar conhecimentos se convertem em conhecimentos, habilidades, capacidades e atitudes do aluno". Partindo da concepção de que é objetivo da escola e do professor formar "pessoas inteligentes, aptas para desenvolver ao máximo possível suas capacidades mentais, seja nas tarefas escolares, seja na vida prática através do estudo das matérias de ensino", conclui o autor que o professor "deve dar-se por satisfeito somente quando os alunos compreendem solidamente a matéria, são capazes de pensar de forma independente e criativa sobre ela e aplicar o que foi assimilado".

É claro que precisamos resgatar a importância do domínio de um conteúdo para que se possa empreender as ações educativas na concepção de um aluno neste sentido. Como advertem Sacristán e Gómez (1998, p. 120), "sem formalizar os problemas relativos aos conteúdos não existe discurso rigoroso nem científico sobre o ensino, porque estaríamos falando de uma atividade vazia ou com significado à margem do para que serve", e, assim, se "há ensino é porque se ensina algo ou se ordena o ambiente para que alguém aprenda algo". Este seria o outro lado da ação mediadora/facilitadora do professor, na complexa compreensão do que ensinar.

Mas além de dominar o conteúdo (para poder conversar com os alunos "sobre os conhecimentos e experiências que trazem para a sala de aula" e ligá-lo "a aspectos da realidade e ao cotidiano da vida", relacionando-os), promover o estudo ativo deve levar os alunos a pensar sobre o que estão aprendendo, não dando respostas prontas ou ignorando problemas quando indagado (LIBÂNEO, 1994, p. 
105). Durante o estudo do Direito, é muito comum que o professor, em resposta à pergunta do aluno, mande-o ler um artigo do Código, sem possibilitar que o mesmo tenha condições de exercer sequer a habilidade de pesquisar o próprio Código (às vezes, porque o professor vê nessa pesquisa imediata e autônoma uma "perda" do tempo precioso, ou às vezes até porque o aluno reclama ao ter que procurar, sem reconhecer a importância deste ato). Com isso, ao dirigir-se diretamente ao artigo sem compreender o processo de sua pesquisa, o aluno não tem tempo de pensar, mas apenas de buscar o artigo e ler. É como a velha história do filho que pergunta a um dos pais o significado de algo e, recebendo a resposta pronta (mesmo possuindo habilidades para encontrá-la) não é estimulado a descobrir por si de uma forma suficientemente interessante, dentro da perspectiva de autonomia desejada.

Neste contexto, o professor precisa construir espaço para as ações discentes que vão além da tradicional forma de compor o cotidiano das aulas de direito: alunos sentados e ouvintes. É importante que o professor possa transformar sua "prática pedagógica de modo a garantir um espaço de interação em que haja a possibilidade de participação e troca de todos os alunos, sem privilegiar apenas aqueles que se destacam nas iniciativas ou na verbalização", promovendo a chamada "relação pedagógica transformadora", considerada como uma "situação dialógica, como espaço de discussões, descobertas e transformações” (LOPES, 1996, p. 111). Essas ações repercutirão na aprendizagem, com o reconhecimento da autonomia discente e na importante contribuição que esta tem para o processo educativo.

Nestes termos, o papel do professor "não é ensinar, mas ajudar o aluno a aprender; não é transmitir informações, mas criar condições para que o aluno adquira informações; não é fazer brilhantes preleções para divulgar a cultura, mas organizar estratégias para que o aluno conheça a cultura existente e crie cultura" (ABREU e MASETTO, 1990, p. 11).

Mesmo compreendendo as possibilidades de ação do mediador para a construção dessa autonomia desejada nos alunos, não há dúvidas que o professor de Direito enfrentará circunstâncias de resistência dos próprios alunos e de seus pares, na medida em que poderá destoar do senso comum predominante em seu cotidiano. Como acontece normalmente em qualquer processo de aprendizagem, a superação de obstáculos partirá da adequada forma de como lidar com os mesmos, o que poderá ser perfeitamente superado pela ação inovadora, desde que planejada e justificada. O desafio é despertar os docentes para essas possibilidades 
decorrentes das ações mediadoras, de maneira que sua motivação se desenvolva a ponto de buscá-las também por conta própria, facilitados por condições formadoras para sua profissão.

De fato, parece-me que o desaprender precisa ser efetivamente trabalhado na formação docente do professor de Direito, para que ele possa olhar reflexivamente sobre suas ações, revisá-las a partir de outros paradigmas e voltar para sua prática e assim novamente verificá-las, num continuum que muitas vezes se enfraquece pelo tempo e que precisa ser retomado pelas necessárias provocações que a formação continuada precisa envolver.

Acredita-se, pois, na possibilidade de transformação do cenário do ensino do Direito, para que também caminhe em direção à abertura de possibilidades para seus sujeitos, não por uma obrigação formal ou normativa, mas pela aceitação e experimentação de outras formas de agir. Nesse contexto, o docente tem papel de extrema importância. Reconhecer o lugar onde ele se encontra (que quase sempre é profissional da área jurídica exercendo outras atividades diferentes da docência) e apresentá-lo às ações mediadoras pode constituir uma oportunidade com grandes repercussões para a formação dos futuros profissionais.

Neste plano, é importante que se institucionalizem ações direcionadas à formação pedagógica do professor de Direito, de maneira estruturada e apta a também viabilizar discussões das diferenças entre a docência e as especificidades do meio jurídico. O fortalecimento da formação continuada reconhecendo essa aproximação poderá dar aos docentes a oportunidade de melhor compreendê-la e transformar suas ações para além de uma posição centralizadora e afastada da aprendizagem.

Passa-se, assim, a trazer algumas considerações sobre a aula expositiva, prosseguindo-se nas expectativas propostas pelo presente estudo.

\subsection{A revisão da aula expositiva no contexto do ensino do Direito}

Longe de ser uma situação exclusiva do Curso de Direito, a aula expositiva (que se evidencia nos discursos dos professores das disciplinas teóricas e de estágio apresentados no Capítulo anterior - Tabelas 05 e 08, p. 152 e 155) não precisa ser excluída do processo. Devidamente elaborada, é um importante recurso a ser utilizado e pode proporcionar aprendizagens, mas deve ser relativizado o seu 
uso quando se é concebida como a única forma possível para desenvolver as aulas de Direito.

Ronca e Escobar (1984, p. 85) bem ressaltam que se uma pesquisa de âmbito nacional fosse realizada no Brasil, uma tranqüila hipótese seria a de que provavelmente a aula expositiva seja a técnica mais empregada do 1ำ ao $3^{\circ}$ graus. Muito provavelmente sua afirmação, passadas mais de duas décadas, ainda continua não rejeitada. Pelo menos, para o estudo do Direito, sua incidência é percebida em qualquer visita realizada a uma graduação e mesmo numa pósgraduação (onde muitas vezes, a exposição ocorre até mesmo por vídeoconferência neste último caso).

Mas no que se traduz efetivamente a aula expositiva? Ronca e Escobar (1984, p. 86) afirmam que ela consiste "numa preleção verbal utilizada pelos professores com o objetivo de transmitir determinadas informações a seus alunos". Neste sentido, o "conteúdo a ser aprendido é apresentado ao aprendiz na sua forma final e a tarefa de aprendizagem não envolve nenhuma descoberta independentemente por parte do estudante", exigindo-se que ele "internalize o material que lhe é apresentado, conhecendo-o e compreendendo-o, tornando-o assim disponível para um futuro uso".

No Direito, é comum usar-se a expressão "aula-conferência", já referida em alguns pontos do presente estudo. Num cerimonial formal que muitas vezes reveste a presença do professor (a começar pelo próprio terno que compõe a vestimenta do docente), o momento da aula expositiva se transforma em conferência na medida em que apresenta o discurso do professor, revestido de exemplos, doutrina e jurisprudência, nem sempre aberto às perguntas e ao diálogo dirigido para numerosa platéia. A atenção ao aluno está voltada principalmente para a atenção que ele dá às preleções do professor e seu silêncio é sinal de respeito, exigido sob olhares fustigantes.

É certo que nem todas as aulas expositivas se desenvolvem dessa maneira. As situações mencionadas no parágrafo anterior acontecem, mas também é possível encontrar exemplos de ações realizadas sob outros ares, abertos ao diálogo e a outros procedimentos. Contudo, parece evidente a inspiração do modelo clássico de aula expositiva para as aulas de Direito.

O sentido clássico da exposição "fundamenta-se na crença de que a melhor forma de ensinar os outros consiste na exposição oral" e, convencidos disto, "muitos 
professores concentram todos os seus esforços no sentido de condensar seus conhecimentos e de expô-los de forma lógica e clara", de onde a participação do professor se apresenta como fundamental e exclusiva, sendo integralmente responsável por seu planejamento e execução (GIL, 2006, p. 135).

Certamente, de tudo que foi exposto até o presente momento, pode-se imaginar que a aula expositiva, pautada neste modelo clássico, elimina muitas possibilidades do processo educativo. Negligenciando a importante participação do estudante, uma exposição sem a preocupação com o conhecimento das expressões utilizadas, o descuido com a entonação, a agilidade ou lentidão da fala, a empolgação com ao discurso ou o seu monólogo, pode apresentar na fala dos alunos a característica de "torturante", como lembra Gil (2006, p. 135).

Em seu modelo, as aulas expositivas têm fatores que explicam a sua ampla utilização no Ensino Superior (GIL, 2006, p. 134). São econômicas, pela forma como são preparadas e realizadas; possuem flexibilidade porque podem ser utilizadas para os mais diversos públicos, com o auxílio de múltiplos recursos ou apenas um quadro-de-giz; tem versatilidade, porque os mais diferentes cursos superiores podem adotá-la para a transmissão dos conhecimentos; tem rapidez, porque seu conteúdo é apresentado na forma final, exigindo dos estudantes o entendimento da mensagem e a incorporação em sua estrutura cognitiva; dão ênfase ao conteúdo, o que enseja a crítica sobre a conclusão de que basta ter conhecimento para se poder ministrar uma aula (no qual tem lugar o professor especialista e não o docente profissional).

Inserida dentro de um processo comunicativo, a exposição pode ser vista pelo esquema apresentado por Gil (2005, p. 69-70), considerando-se o professor como emissor, que, objetivando fazer com que os alunos aprendam, usa do seu sistema nervoso central para ordenar o seu mecanismo vocal (codificador) para exprimir o objetivo, criando uma mensagem que será transmitida por ondas sonoras (anal), as quais serão decodificadas pelos alunos através dos seus mecanismos auditivos, por via de impulsos nervosos que conduzem a mensagem decodificada ao sistema nervoso central, de onde se espera o entendimento. Logo:

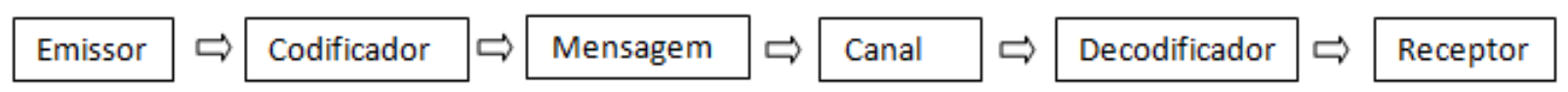


É certo que tal processo pode ensejar análises teóricas mais profundas, mas o que se pretende alertar é que uma exposição preocupada com os resultados da comunicação não pode se limitar à qualidade do emissor. Num processo de interrrelação de pessoas, a eficácia da comunicação "tem a ver não apenas com as habilidades de transmissão, mas também com as características da mensagem, com o canal em que esta é veiculada e sobretudo com a disposição do receptor", ao que se deve acrescentar "a retroinformação (feedback), ou seja, a recepção, pela própria fonte, de informação sobre os efeitos produzidos pela mensagem emitida" (GIL, 2005, p. 70).

Didaticamente, é importante reconhecer as fases de preparação da aula expositiva para que se possa caracterizar este processo comunicativo como apto a exercer uma função educativa. A descrição destas fases contribui para que o docente visualize as particularidades deste procedimento de ensino para que, refletindo sobre sua prática, possa intervir em prol da aprendizagem.

É certo que existe o momento anterior à aula propriamente dita, constituído pela preparação. O planejamento da aula é parte tão importante quanto a sua própria execução, ainda mais se houver preocupação com os objetivos propostos e os resultados esperados pela aprendizagem dos alunos e como isso poderá ocorrer da melhor forma, considerando-se quais procedimentos adotar.

Ronca e Terzi (1994, p. 90), lembram que neste ponto, o professor deve considerar a quem se destina a aula, colocando em pauta quem são os alunos, quais são os conhecimentos que já possuem a respeito do assunto, como poderão ser motivados, quais operações do pensamento dominam e, também quais são as condições materiais para o desenvolvimento da aula (ambiente físico e recursos didáticos auxiliares) adequados para a abordagem pretendida. Neste contexto, o professor poderá preparar a aula selecionando informações, organizando a sequência das ideias, identificando ou criando exemplos incisivos e atualizados, além de preparar um sumário para servir de seu apoio no decorrer da aula.

Para o desenvolvimento da aula propriamente dita, recomenda-se a utilização de uma introdução. Ronca e Terzi (1994, p. 90-91), baseados nos estudos de Cage, salientam que esta introdução tem por objetivos "estabelecer um clima adequado entre professor e alunos"; promover ações que busquem a "atenção do estudante para o conteúdo a ser apresentado", fazendo suposições sobre os interesses dos 
alunos (relacionando o conteúdo com objetivos dos estudantes), além de "prover 'dicas' que motivam".

Além disso, a introdução permite expor os organizadores prévios, já tratados no presente estudo quando da utilização da teoria da aprendizagem significativa (item 4.2.1.2 - Estrutura cognitiva, subsunção e princípios facilitadores da aprendizagem significativa, p. 175-176). Neste ponto, tal teoria tem especial relevância para o professor, na medida em que o orienta a estabelecer as ideias principais que nortearão os novos conhecimentos. O professor poderá investigar na estrutura cognitiva dos alunos as informações necessárias para a aproximação de novas abordagens, caminhando através de materiais potencialmente significativos.

Logo, a aula expositiva pode ser incrementada particularmente pela compreensão desse movimento entre a estrutura cognitiva do aluno e o estabelecimento de organizadores prévios que vão formando uma ponte entre o que o aluno já sabe para o que lhe será apresentado de novo, associando as informações de maneira a considerar o material significativo, permanecendo para sua utilização.

Neste ponto, cabe ressaltar o que se abordou no item anterior sobre a habilidade do professor em reconhecer as circunstâncias que envolvem seu aluno (no que se inclui o seu conhecimento). Nessa investigação, a contextualização é parte fundamental para que se possa proceder com a aula expositiva sem fazer com que os alunos se percam nas elucubrações oralmente expostas.

No Direito (e acredito que em outras áreas isso pode perfeitamente acontecer), o aluno sem conhecimento da área pode ser levado a ouvir novas expressões que são completamente estranhas à sua estrutura cognitiva (ou mesmo desvirtuadas pelo senso comum). Sem os devidos esclarecimentos, o aluno poderá facilmente se perder (pela ausência de conexão com seus próprios conhecimentos) e, certamente, os prejuízos à aprendizagem serão evidentes.

Acredito que a teoria da aprendizagem significativa incorpore, especificamente à aula expositiva esta necessidade contínua de sondar e estabelecer vínculos com a estrutura cognitiva dos alunos, de maneira a prosseguir numa ordem que não seja lógica apenas para o professor, principalmente para o aluno que participa deste processo. O aluno poderá identificar os conceitos e significados, reconhecer as diferenciações, agregar exemplos e estar apto a demonstrar para si, para o professor e para a sociedade, as repercussões de suas 
novas informações, porque agrega condições para a compreensão e processamento das informações que estarão sendo construídas no decorrer da exposição. Daí a importância da reconciliação integradora (vide p. 174-175) já nesta fase introdutória.

Passando ao corpo da exposição propriamente dita, Ronca e Terzi (1994, p. 94-996) também invocam a teoria da aprendizagem significativa para justificar a organização lógica da aula, considerando a diferenciação progressiva e a ainda a reconciliação integradora (conforme p. 174-175). Sua finalidade é orientar que as ideias mais gerais e inclusivas sejam apresentadas em primeiro lugar para serem posteriormente diferenciadas (diferenciação progressiva), e orientar o professor que proceda estabelecendo as semelhanças e diferenças, de maneira a esclarecê-las aos alunos quando estão tratadas em vários contextos. Isso amplia a clareza de significados para os alunos, o que nem sempre ocorre na prática, vez que os professores podem utilizar expressões distintas para o mesmo sentido sem deixar claro isso, tornando o conhecimento isolado quando não haveria necessidade (nem razão) de sê-lo.

Por derradeiro, propõe-se que a aula expositiva tenha seu fechamento com a fase denominada conclusão, quando o professor poderá agir no sentido de chamar a atenção para as ideias mais importantes, mas também contar com ações dos alunos para resumir o conteúdo, dar exemplos, responder a possíveis dúvidas, indicar bibliografia, estabelecer uma conexão do conteúdo tratado com o próximo a ser apresentado (RONCA e TERZI, 1994, p. 98).

Ademais, com os avanços tecnológicos, é possível otimizar as abordagens das aulas expositivas com apoios viabilizados por páginas na rede mundial, contendo informações sobre a disciplina, como plano de ensino, planos de aula (previamente publicados, com indicação bibliográfica) e exercícios, que em muito contribuem para essa aproximação com o aluno. Tenho utilizado este recurso há vários anos e é algo com o qual os alunos se aproximam e acessam. Nos últimos anos tenho apresentado também gabaritos dos instrumentos de avaliação (inclusive das questões dissertativas), o que tem facilitado inclusive o feedback do processo de aprendizagem no plano de sua avaliação.

Certamente que há outras formas de se propor o desenvolvimento da aula expositiva, mas o importante é reconhecer as possibilidades de sua utilização, caminhando para além da exposição tradicionalmente concebida e afastada dos elementos de aprendizagem. 
Observe-se que o professor pode assumir a posição de mediador mesmo diante da aula expositiva. Na construção e condução de sua fala, a postura de não se apresentar como detentor de verdades e planejar os elementos para a aproximação do conhecimento de seus alunos aos novos conteúdos, constitui um reconhecimento da importância da aprendizagem para o sujeito aprendiz, ao mesmo tempo em que assume a responsabilidade de planejar e executar essa aproximação, diante de objetivos que conduzam o processo para os fins estabelecidos de forma consciente.

Logo, ainda que se imagine a aula expositiva dentro da estrutura em que 0 professor assume maior posição, é importante conduzi-la com o aproveitamento que a teoria da aprendizagem significativa instrumentalmente contribui, considerando-se as ações mediadoras do professor e os resultados esperados na aprendizagem para o processo educativo.

\subsection{A inserção da prática nas abordagens teóricas e a ampliação da ação discente sem o distanciamento temporal}

Mesmo reconhecendo as condições de aprimoramento da aula expositiva, de maneira a realizá-la com atenção a todos os elementos que uma comunicação exige para ser eficiente, na conjugação com objetivos do processo educativo $\mathrm{e}$ instrumentos para uma melhor compreensão por parte dos alunos, parece-me necessário refletir sobre a inserção de práticas que se intercalem com as manifestações orais do professor, conduzindo o aluno a tomada de atitudes mesmo antes do estágio.

Com efeito, parte-se da observação de como a prática está inserida na formatação do Curso de Direito, com destaque à separação entre eixos, que pode conduzir a uma visão compartimentalizada: teoria de um lado e prática de outro. Reproduzo a Tabela 06 anteriormente apresentada (p. 153) para uma melhor visualização da questão: 


\begin{tabular}{|c|c|c|c|c|c|c|}
\hline Questão & Técnicas de aprendizagem $\quad$ Avaliação da expectativa & $\begin{array}{l}\text { Discordo } \\
\text { plenamente }\end{array}$ & $\begin{array}{c}\text { Discordo } \\
\text { parcialmente }\end{array}$ & $\begin{array}{c}\text { Não } \\
\text { concordo } \\
\text { nem discordo }\end{array}$ & $\begin{array}{c}\text { Concordo } \\
\text { parcialmente }\end{array}$ & $\begin{array}{l}\text { Concordo } \\
\text { plenamente }\end{array}$ \\
\hline $\mathrm{Q}_{1}$ & $\begin{array}{l}\text { Durante a aula de Processo Civil (I ou II) é necessário fazer com que os alunos } \\
\text { realizem atividades práticas, mesmo sem a disciplina de Prática (Estágio Simulado). }\end{array}$ & 1 & - & 1 & 1 & 3 \\
\hline $\mathrm{Q}_{2}$ & $\begin{array}{l}\text { É possível desenvolver a aprendizagem do Processo Civil (I e II) sem a realização de } \\
\text { atividades práticas pelos alunos. }\end{array}$ & 2 & - & 1 & 2 & 1 \\
\hline $\mathrm{Q}_{3}$ & $\begin{array}{l}\text { O ensino da parte teórica do processo civil não exige que o aluno realize atividades } \\
\text { práticas (no segundo ou terceiro ano). }\end{array}$ & 2 & 1 & 1 & 1 & 1 \\
\hline $\mathrm{Q}_{4}$ & Devido ao tempo, o ensino da parte teórica é incompativel com as atividades práticas. & 1 & - & 1 & - & 4 \\
\hline
\end{tabular}

Fonte: Celso Iocohama

Tabela 06 - Respostas apresentadas por Docentes das disciplinas teóricas de Direito Processual Civil apresentando sua expectativa quanto à prática dos conteúdos abordados.

Colocamos em pauta a visão do professor que discorda plenamente que é necessário fazer com que os alunos realizem atividades práticas sem a disciplina de Estágio (que é o mesmo que concorda plenamente ser possível desenvolver aprendizagem do Processo Civil sem a realização das atividades práticas). Certamente sua resposta não deve ser considerada "errada", já que não é esta a perspectiva que se possa atribuir. Sua afirmação é importante para se reproduzir, de forma indutiva, a possibilidade de se imaginar que outros professores também podem visualizar a execução de uma aula envolvendo conteúdos teóricos sem que se proceda a sua prática e que ela seja necessária.

Por certo, não há dúvidas que as aulas podem ser realizadas sem envolver práticas. Há assuntos que podem ser verbalizados pelo professor sem que se encaminhe o aluno a concretizar seu conteúdo em prática, principalmente quando se trata de conteúdos que têm a finalidade de proporcionar maior compreensão entre o que ele já sabe e o que está por saber. A realização desta ponte entre a estrutura cognitiva do aluno e o novo conteúdo potencialmente significativo pode ser feita sem maiores intervenções do aluno que possam ser enquadradas num conceito de prática.

Entretanto, o que se coloca em questão é o quanto a prática efetiva (considerada aquela onde o aluno age e reage diante de situações) pode contribuir para que a aprendizagem daquele conteúdo se incorpore na estrutura cognitiva do aluno, isso de tal forma que não desapareça depois de uma avaliação (lembrando da velha história do aluno que, ao fazer a prova, deixa todo seu conhecimento nas palavras que escreve... e no segundo seguinte à entrega do instrumento de avaliação, abomina sequer pensar em discuti-lo, considerando-o algo que já foi 
embora, acompanhado do sofrimento pelo esforço da memorização mecânica e pelo sufoco da pressão da nota).

Considerando o que se apresentou sobre a relação teoria e prática junto ao item 4.4 do presente estudo (p. 183-190), seria incoerente afirmar que o intercâmbio nessa relação (teoria e prática) pudesse ser abandonado durante a realização das aulas sobre conteúdos teóricos. O aprimoramento que uma prática pode fazer na estrutura cognitiva do aluno deve ser levado em conta, se o tema aprendizagem assume o papel de relevância que tem para a formação de pessoas em qualquer área - e obviamente, a do Direito.

Na verdade, considere-se uma pergunta simples: se o aluno for submetido à prática dos conhecimentos que estão sendo apresentados pelo professor da disciplina teórica, não terá condições de compreendê-los melhor do que apenas ouvi-los?

Reconheço que o tempo para a execução de atividades práticas é um fator a ser considerado (daí a preocupação com esse tempo aparecer nos dados coletados, conforme a Tabela 06), mas ele se projeta como relevante na medida em que se privilegia o cumprimento do plano de ensino (e de seus conteúdos/unidades) mais do que, efetivamente, a aprendizagem que se possa proporcionar.

De fato, é possível perceber um sentimento de obrigatoriedade no cumprimento dos planos de ensino que pode confundir o objetivo voltado à aprendizagem do aluno e os conteúdos para a sua formação. Muitas vezes, o professor não participa da construção desse plano de ensino (que lhe é entregue para execução quando é contratado para lecionar) e, por conta da visão dogmática envolvendo a concepção sobre o Direito (considerando um profissional sem formação crítica direcionada para essa questão), concebe o plano de ensino (e seu conteúdo) como instrumento não discutível, ou seja, que deve ser aplicado a todo custo. Isso acarreta professores "falando sem parar" com o fito de dar conta do plano; promove reclamações de que o tempo não é suficiente e incentiva pedidos de aumento de cargas horárias, entre outras situações decorrentes.

Contudo, o "desespero" pelo cumprimento do plano de ensino impede uma reflexão anterior sobre os conteúdos ali tratados: será que é possível esgotar-se um assunto por meio das aulas? Será que todas as discussões possíveis podem ser abordadas e resolvidas durante o breve tempo curricular de 200 (duzentos) dias letivos/ano? 
Para o estudo do Direito, onde concentramos nossa experiência, responder que "sim" para estas perguntas será algo temerário. As inferências capazes de serem produzidas por qualquer tema, em qualquer área ou disciplina do Direito, podem produzir tantas elucubrações que uma longa vida não daria conta para esgotar. Daí não é surpresa encontrar obras com o fôlego de 60 (sessenta) extensos volumes - com aproximadamente 500 (quinhentas) páginas cada um (portanto, num total de 30.000 páginas) -, para abordar o Direito Privado, como é a obra clássica de Francisco Cavalcanti Pontes de Miranda, produzida entre tantas outras do mesmo autor, para se ter um exemplo claro do quanto se pode aprofundar o estudo.

De fato, considerar-se esgotado um assunto é uma conclusão pautada num critério subjetivo que acaba sendo de escolha do professor e se limita a uma atitude decorrente da profundidade que se quis dar para a abordagem. Pode-se falar o que é um processo judicial em uma frase, como se pode demonstrá-lo por uma enciclopédia de milhares de folhas. A responsabilidade do que e do quanto inevitavelmente acaba nas mãos do professor, com evidente repercussão na carreira futura do aluno.

Logo, o fator tempo precisa ser repensado, quando ele se apresenta como obstáculo para o empreendimento de outros procedimentos pedagógicos que vão além da exposição oral pelo professor. Se a escolha dos conteúdos e a profundidade de sua abordagem passa inevitavelmente pelas ações do professor, é preciso assumir a responsabilidade nas escolhas, sem que se tolha a capacidade do aluno em ir além. Em outras palavras, se toda escolha de conteúdo e da profundidade de sua abordagem é um ato arbitrário do professor (por mais que planos sejam produzidos para "controlar" está escolha), não se pode fazer uso dela como se também fosse a única abordagem importante para o aluno. É fundamental que o aluno seja incentivado a buscar bem mais do que se consegue tratar durante as aulas, atendendo à regra para qualquer conhecimento a ser trabalhado: ele vale enquanto dura e não é eterno em sua aplicação, especialmente no Direito, onde a dinamicidade das relações sociais promove mudanças constantes.

Desta forma, no tratamento de um assunto/unidade, o professor precisa ter claros os objetivos, para saber a que ponto da aprendizagem o aluno deve chegar e o que se espera que os alunos tenham aprendido (ABREU e MASETTO, 1990, p. 21). Neste planejamento, é importante que o professor faça a si mesmo as 
perguntas envolvendo tais objetivos. Isso provoca uma reflexão sobre as próprias ações a serem tomadas e o que isso repercutirá nos momentos das avaliações.

Com isso, imaginando-se qualquer conteúdo de Direito, é interessante que o professor se questione o que ele proporcionará para o acadêmico, no contexto da formação de sua estrutura cognitiva e quais efeitos isso promoverá em sua capacidade de agir, questionando o âmbito de utilidade do conteúdo a ponto de considerá-lo potencialmente significativo. Neste sentido, se a resposta induzir a efetivas ações do acadêmico, parece clara a importância de fazê-lo sentir esta possibilidade ao tempo em que o conhecimento está sendo proporcionado. Deixar que o aluno apenas "sinta" a importância da informação quando isso acontecer no estágio/futuro não parece coerente. É difícil acreditar que um processo de aprendizagem com tais características possa ser motivador. Aprender algo porque vai ser bom para o futuro não é algo que motiva para o presente (e quiçá, para o futuro). Não é a toa que o presente do aluno se preencha de situações imediatas muitas vezes distintas do conhecimento que se está proporcionando pelos estudos. Infelizmente, aplica-se a regra do imediatismo: se não tem utilidade agora, porque perder tempo com ele?

Mas se efetivamente o conhecimento aprendido só vai ser possível de ser aplicado na prática (quando for realizado o estágio, num primeiro nível e na atuação profissional num nível seguinte), concluir que a prática para aluno em momento anterior é desperdício, pode ser uma visão questionável. Se o conhecimento deve ser aprendido agora para aplicar no futuro, a aprendizagem tem que ocorrer de maneira substancial, a ponto de permitir que o aluno entenda como o processo funciona agora. Isso indica que proporcionar ao aluno a aplicação do conhecimento ao tempo de sua aprendizagem vai permitir que ele possa perdurar o suficiente para continuar sendo utilizado e repensado no futuro. Se não há incorporação na estrutura cognitiva do aluno desse conhecimento que está sendo visto, como se pode esperar que ele possa utilizá-lo no futuro? Além disso, como se pode imaginar que esse conhecimento será revisto e até mesmo superado se não foi compreendido num momento anterior?

Poder-ser-ia afirmar que, se o aluno progrediu nas séries, significa ter evidenciado, no processo de avaliação, que o conhecimento existiu. Ainda que o presente estudo não foque a avaliação, a compreensão de tal momento certamente poderá permitir a conclusão de que notas ou aprovação não representam - 
necessariamente -, um conhecimento incorporado na estrutura cognitiva a ponto de perdurar. A aprendizagem mecânica pode proporcionar resultados idênticos à aprendizagem significativa, por ocasião de uma avaliação. Porém, a diferença dos resultados se apresentará com a capacidade de se reproduzir (e até mesmo revisar) o conhecimento adquirido a qualquer tempo ou enquanto ele for necessário. Isso vai aparecer durante o Curso, no estágio, depois, em exames/concursos e, mais além, na sua vida pessoal e profissional.

Na medida em que se verifica um sentimento de dificuldades durante as aulas de estágio, conforme mostrou a Tabela 09 (Respostas apresentadas por Docentes das disciplinas teóricas de Direito Processual Civil sobre a utilização de procedimentos para as aulas - p. 157), não se exclui a possibilidade de que o problema possa ter sua raiz durante o desenvolvimento das aulas teóricas. Pelo menos esta hipótese não é negada pelos dados coletados. É certo também que não há garantias de que a mudança dos procedimentos durante as aulas teóricas produzam resultados mais eficazes durante as aulas de estágio, mas esta proposição está em consonância com o que se mostrou até então, de que medidas envolvendo a prática pelos alunos facilitam a aprendizagem significativa.

Desta forma, antes de se afirmar que tudo está bem quando o aluno está aprovado, transformando-se num discurso apresentado como um obstáculo às mudanças nas ações pedagógicas envolvendo as aulas das disciplinas teóricas, é importante que se reflita sobre as possibilidades da adoção de atividades práticas para a sua execução. Num passo seguinte, experimentar introduzir tais atividades práticas para, em ato contínuo, refletir sobre seus efeitos.

Sugere-se, então, que o professor analise os objetivos de cada unidade, de maneira a integrar uma participação ativa dos alunos para a concretização das informações apresentadas. A exemplo, se estou tratando de princípios do Processo Civil, é importante que o aluno tenha a oportunidade de observar, por si, a aplicação de tais princípios em julgamentos de tribunais ou em casos práticos, ou mesmo que possa fazer inferências interpretativas e produza manifestações invocando tais princípios em sua aplicação, não apenas imaginando o conteúdo nos exemplos do professor. Se estou tratando de requisitos de uma petição inicial, porque o aluno não pode, mesmo no segundo ou terceiro anos, construir uma petição aplicando tais requisitos? Até mesmo o simples manuseio de uma peça processual concreta (ou até simulada), pode ajudar o aluno a compreender a aplicação do que está 
estudando, pois ele consegue compreender como são aplicados os conhecimentos teóricos que lhe são apresentados. Certamente que isso vai repercutir em suas ações futuras, porque já viu e presenciou a inserção daquele conhecimento teórico no momento em que o estava estudando (não importando a série que se encontra). Quando rever o conteúdo em momento posterior, já poderá ter esta primeira experiência incorporada em sua estrutura cognitiva, de maneira que sua reação à prática será mais para a confirmação de seus conhecimentos do que uma nova abordagem sobre um assunto. O professor de estágio, ao invés de necessitar explicar os conteúdos teóricos para prosseguir com a prática, poderá apenas acompanhar o seu resgate, confirmando-se aquilo que o aluno já sabia e aprimorando suas ações para o enfrentamento dos problemas que sua vida profissional exigirá.

Propõe-se, assim, o resgate da perspectiva de um aluno ativo mesmo durante as abordagens teóricas do conhecimento do Direito, retirando-o de uma postura passiva e acrítica, reconhecendo o alerta de Luckesi (1994, p. 99), quando aponta que o extremo oposto de se entender o aluno nesta postura passiva não é exigir que ele tenha comportamento constantemente ativo, pois o modo de ser ativo depende do conteúdo com o qual se esteja trabalhando, notando-se que, "se o conteúdo ativo refere-se à atividade física, será ativo o aluno que a praticou; porém, se o conteúdo for intelectual, a atividade será mental”, Logo, o "conceito de 'ativo' deve ser bem compreendido, evitando-se um senso comum sobre as ações que promovam um discente ativo na busca de se romper desvairadamente com a figura pejorativa que se pode atribuir a um sujeito em estado de aparente passividade".

Neste sentido, acredito que mesmo o movimento intelectual do aluno pode ser melhor assimilado se ele tiver oportunidade de observar o movimento do conhecimento em interação com a realidade. Podem ser vídeos, julgamentos, contratos, notícias em jornal, processos reais ou simulados, visitações, manuseios, construção de documentos ou quaisquer outras fontes que possam proporcionar a concepção do fazer. Não cabe estabelecer fórmulas para isso, dada a criatividade e dialeticidade demandadas pelo processo educativo. Mas se pode provocar (como sempre) possibilidades, esperando que o cenário do ensino do Direito incorpore outros procedimentos que vão além da aula expositiva.

Interessante acrescentar-se à noção do movimento citado, a perspectiva do movimento como parte provocativa para o ser humano, como já foi destacado por 
Piaget, ao afirmar que a "inteligência é ação!", lembrado por Ronca e Terzi (1996, p. 88), vez que ele (o movimento) dá prazer, exalta sentimentos e sensações, provocando, como se pode perceber por tantos exemplos: "jogo de futebol sem movimento perde a graça; filme sem movimento dá sono; férias monótonas dão vontade de voltar a trabalhar" etc., e "aula em que não há movimento dá vontade de dormir".

Com isso, "colocar os alunos em interessantes desafios, chamados Conflitos Cognitivos, torna-se excelente forma de despertar e manter a Atenção e a Percepção e, principalmente, caminho atraente para torná-los cúmplices no processo do Conhecimento a ser construído!". Através de tais conflitos, pode-se concretizar ao professor "as mais belas funções", dentre as quais "as de incomodar, desaprumar, questionar, desarrumar, romper, desalinhar, instigar para o pensar; exercitar fortemente a curiosidade" (RONCA e TERZI, 1996, p. 92).

Desta maneira, como proposta decorrente das análises realizadas pelo presente estudo, é importante que as abordagens teóricas realizadas pelas disciplinas no Curso de Direito contemplem momentos em que se permita a ação reflexiva discente, na realização de atividades práticas que aprimorem a aprendizagem com experiências aptas a concretizar as informações apresentadas, evitando-se a visão estanque que separa a teoria da prática, para que se possa vivenciar o conteúdo no período em que ele for tratado. As atividades práticas deverão proporcionar a diversidade de visões que poderão surgir no futuro profissional do aluno, colocando-o no lugar do advogado, do juiz, do membro do Ministério Público, do Delegado, de serventuários da Justiça e até mesmo no lugar das partes em conflito, de maneira que muito o auxiliará na compreensão das diversas realidades vivenciadas por tais profissões e situações.

Acrescente-se, por fim, que medidas neste sentido não precisam exigir mudanças estruturais no Curso de Direito. Ainda que o modelo de matriz curricular dos Cursos de Direito apontem o afastamento dos momentos práticos da teoria, em razão do estágio, isso não impede que se incorporem esses dois momentos da prática, cada uma ao seu tempo: pratica-se o conhecimento em aprendizagem no momento da disciplina teórica e reforçam-se as ações da mesma prática durante o estágio, concentrando-se o tempo para esta contextualização nos anos finais do curso. 
$\mathrm{Na}$ época que antecedeu a oportunidade de desenvolver estes estudos neste nível de pós-graduação, a ideia que nos provocava era pensar em mudanças estruturais para o Curso de Direito, ao ponto de se extinguir estágio e toda a formatação normativa de separação dos eixos. Pensava-se que a reconstrução da matriz pudesse ser um caminho para a implementação de medidas práticas no curso de Direito, no reflexo de um sentimento cultural de que tal procedimento deveria ser implementado como acontece com as normas jurídicas (ou seja, à força).

Entretanto, reconhecendo a extenso caminho para construir mudanças epistemológicas sobre o próprio ensino do Direito, urge propalar a possibilidade de se inserir a prática como um instrumento contínuo, que vai do primeiro ao último ano do Curso de Direito. Isso exigirá muito mais dos professores (pela transformação que deverão fazer na sua zona de conforto quando a forma de conduzir sua disciplina por via de aulas-conferência), bem como provocarão resistências nos próprios discentes (pelo mesmo problema de revisão de sua zona de conforto), mas possui fundamentação teórica que justifica sua viabilidade.

Assim, deve-se desconstruir as barreiras culturais já firmadas sobre a forma de condução do ensino do Direito, promovendo-se a inserção de novas ações e possibilidades, a nosso ver, acompanhadas da prática e do conteúdo significativo, acrescidas de um momento interdisciplinar que conjugue resultados decorrentes de várias direções, indispensáveis para que se possa conceber algo diferente do que normalmente tem acontecido.

De qualquer modo, pode-se pensar em um passo a mais na reconstrução do ensino do Direito, com a proposta de se inserir a aprendizagem baseada em problemas, conforme se seguirá no último item.

\subsection{A contribuição da aprendizagem baseada em problemas para o ensino e estudo do Direito}

A proposta metodológica designada como Aprendizagem Baseada em Problemas (ABP), também tem importância ao presente estudo, na medida em que apresenta condições para o reconhecimento dos princípios até então tratados, em ações pedagógicas que remodelam a abordagem do ensino superior, no Brasil já representadas por experiências na área da saúde, em especial da Medicina. 
A aprendizagem baseada em problemas envolve os estudantes em trabalhos que objetivam solucionar um problema, deixando o papel de receptores passivos para assumir o de agentes e principais responsáveis pelo seu aprendizado, tendo o professor como facilitador (GIL, 2006, p. 175-176).

Também assume uma característica de proposta curricular, na medida em que é encarada como uma reformulação da visão tradicional do currículo, estancado em uma matriz curricular compartimentada. Tendo a análise de problemas como seu ponto fundamental, a centralização do processo de aprendizagem projeta-se na ação dos alunos, exigindo uma estrutura organizacional apta para dar o suporte necessário a este desenvolvimento. Não se trata apenas de dar problemas para o aluno resolver, mas sim uma organização de etapas que constroem esta abordagem, para favorecer a intervenção do aluno sobre um processo devidamente planejado.

Neste sentido, enquanto no modelo tradicional a abordagem de um curso de graduação indica uma estrutura curricular baseada em disciplinas que são ministradas por professores, na aprendizagem baseada em problemas, os conteúdos não são mais propostos de formas separadas, mas sim divididos por categorias de problemas.

Como no Brasil não encontramos experiências de um Curso de Direito formatado nesta perspectiva de aprendizagem e considerando a importância de se visualizar a proposta - que já ocorre em alguns Cursos de Medicina - acredito ser suficiente uma comparação entre duas matrizes curriculares: a do Curso de Medicina da Universidade Estadual de Londrina (UEL, 2010) e um outro Curso de Medicina que é omitido propositadamente a fonte, para evitar qualquer juízo de comparação quanto ao mérito de sua qualidade, já que não é esta a perspectiva que se busca. Assim, a diferença da formatação pode ser verificada apenas analisandose a primeira série: 


\section{MEDICINA}

TURNO: INTEGRAL

DURAÇÃO: MÉDIA 6 ANOS - MÁXIMA 12 ANOS

SISTEMA ACADÊMICO: SERIADO ANUAL

$1^{\text {a }}$ Série

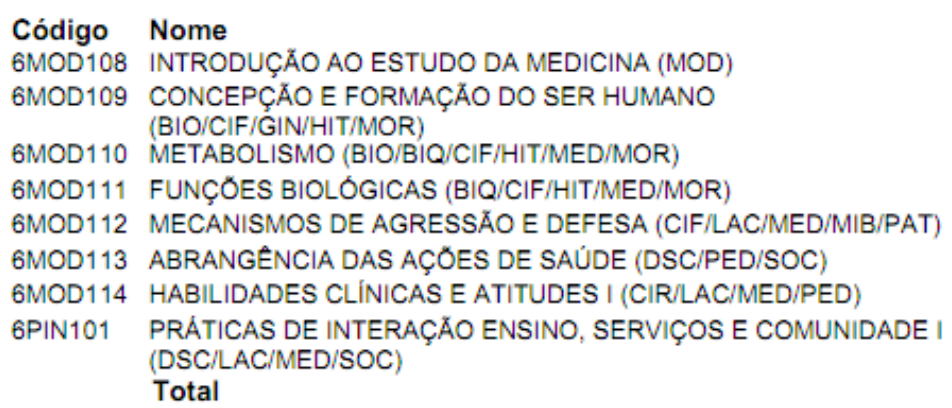

\begin{tabular}{cccccccc}
\multicolumn{8}{c}{ Carga Horária } \\
Oferta & Teór. & Prát. & Tut. E.Or. Av. & Total \\
B & 10 & 80 & 40 & 54 & 6 & 190 \\
B & 10 & 34 & 44 & 62 & 6 & 156 \\
B & 12 & 36 & 44 & 58 & 6 & 156 \\
B & 22 & 34 & 52 & 68 & 6 & 182 \\
B & 16 & 34 & 52 & 74 & 6 & 182 \\
B & 8 & 16 & 32 & 45 & 3 & 104 \\
A & 22 & 104 & 0 & 0 & 6 & 132 \\
A & 20 & 82 & 0 & 0 & 0 & 102 \\
& 120 & $\mathbf{4 2 0}$ & $\mathbf{2 6 4}$ & $\mathbf{3 6 1}$ & $\mathbf{3 9}$ & $\mathbf{1 2 0 4}$
\end{tabular}

Figura 01 - Descrição da organização curricular da 1ª Série do Curso de Medicina da Universidade Estadual de Londrina

\section{Estrutura Curricular}

\begin{tabular}{|l|l|l|}
\hline $\mathbf{1}^{\circ}$ ANO & $\mathbf{1}^{\circ}$ SEMESTRE & CH \\
\hline CÓDIGO & DISCIPLINA & 60 \\
\hline 50101 & Metodologia do Trabalho Científico & 60 \\
\hline 50102 & Introdução à Medicina e História da Medicina & 60 \\
\hline 50103 & Saúde Pública I & 90 \\
\hline 50104 & Anatomia Humana I & 60 \\
\hline 50105 & Sociologia da Educação Médica & 90 \\
\hline 50106 & Bioquímica Celular e Metabólica & 60 \\
\hline 50107 & Filosofia Médica & 60 \\
\hline 50108 & Saúde e Segurança no Trabalho & 540 \\
\hline SUBTOTAL & & \\
\hline
\end{tabular}

\begin{tabular}{|l|l|l|}
\hline $\mathbf{1}^{\circ}$ ANO & $2^{\circ}$ SEMESTRE & CH \\
\hline CÓDIGO & DISCIPLINA & 60 \\
\hline 50211 & Antropologia & 90 \\
\hline 50212 & Anatomia Humana II & 120 \\
\hline 50213 & Fisiologia e Biofísica & 60 \\
\hline 50214 & Histologia & 60 \\
\hline 50215 & Embriologia Humana & 60 \\
\hline 50216 & Didática Especial & 60 \\
\hline 50217 & Psicologia Geral & 60 \\
\hline 50218 & Saúde Pública II & 570 \\
\hline SUBTOTAL & & \\
\hline
\end{tabular}

Figura 02 - Descrição de uma grade curricular de um Curso de Medicina que não indica adotar a metodologia da aprendizagem baseada em problemas. 
Note-se que o Curso de Medicina da Universidade Estadual de Londrina divide a carga horária em teórica, prática, tutoria, estudos orientados e avaliação, tendo em vista as necessidades decorrentes da metodologia aplicada pela aprendizagem baseada em problemas, o que já ressalta a diferença da outra matriz que não adota a abordagem estruturada nesta metodologia.

Por certo, não se está a colocar em questão a qualidade dos cursos e os resultados de sua estrutura. $O$ que se pretende é evidenciar apenas que a formatação da própria matriz curricular já dá indícios do que exige esta metodologia diferenciada de aprendizagem.

A origem desta metodologia da aprendizagem baseada em problemas se identifica a partir de experiências "realizadas no Canadá (em MacMaster) e na Holanda (em Maastricht) principalmente, além de recomendações das Sociedades das Escolas Médicas para países da África, Ásia e América Latina" (BERBEL, 1998, p. 140). São experiências que começaram no final da década de 60 e início da década de $70 \mathrm{em}$ tais faculdades.

Num estudo apresentado sobre a Universidade de Maastricht, afirma-se que a partir da primeira experiência na escola médica, tal conceito de aprendizagem (em sua origem designada problem-based learning - $P B L$ ) "pareceu ser completamente bem sucedido, porque as novas escolas, criadas em anos subseqüentes, por exemplo, as Ciências da Saúde, Direito, Economia, Psicologia, e Artes, adotaram também métodos próximos ao PBL" (MOUST, VAN BERKEL e SCHMIDT, 2005). A Figura 3, abaixo, proposta pelos autores, apresenta uma visão do PBL, indicando-o "conectado com os vários princípios de aprendizagem subjacentes, em cada fase do aprendizado dos estudantes": 


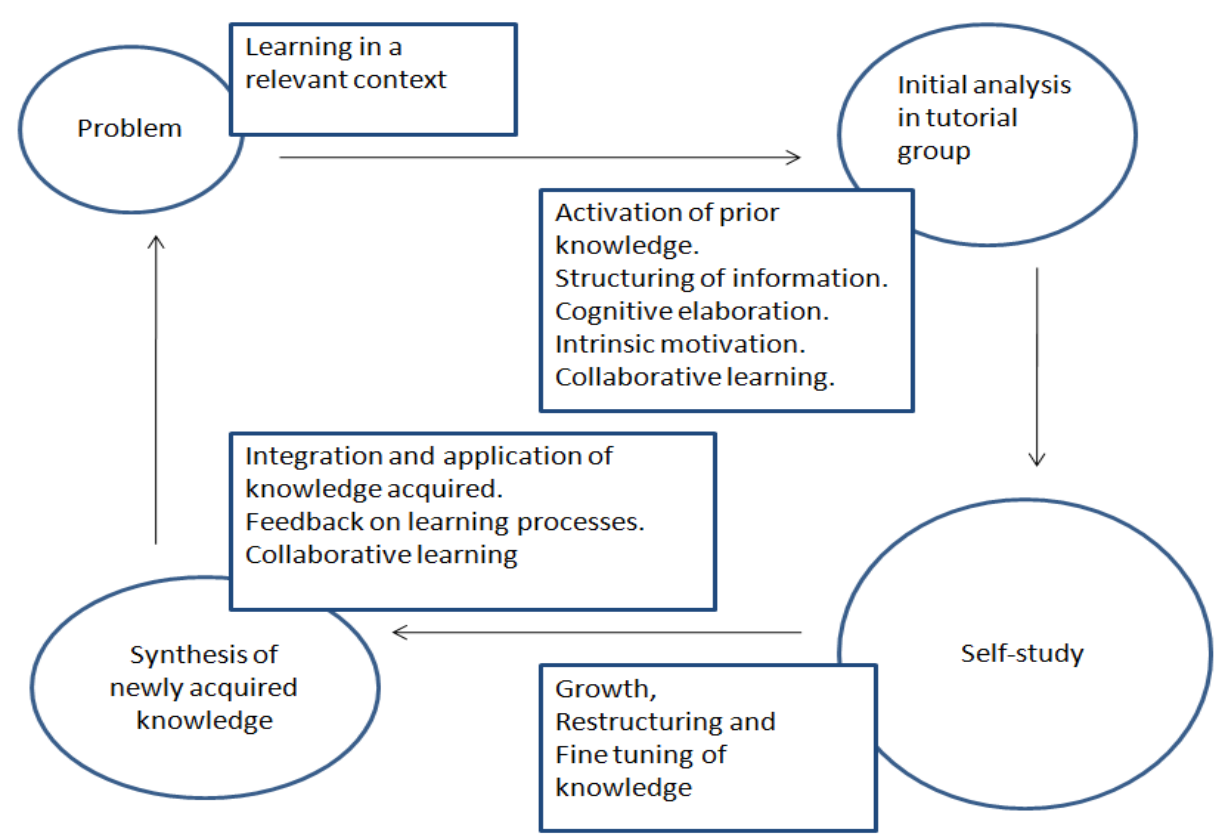

Figura 03 - Caracteristics of PBL and its cognitive psychological processes (MOUST, VAN BERKEL, SHMIDT, 2005)

Com efeito, de um modo em geral, a aprendizagem baseada em problemas desenvolve-se observando 07 etapas. Esta descrição é mencionada por Berbel (1998, p. 146-147), com base em descrição apresentada pela Universidade Estadual de Londrina (atualmente não disponível no endereço indicado) e por Must, Van Berkel e Schmidt (2005) entre outros, mas para se mostrar sucintamente estas etapas, colocam-se as manifestações dos autores mencionados - lado a lado -, para que sua leitura se complete:

\begin{tabular}{|c|c|c|}
\hline Etapas & Descrição citada por Berbel & $\begin{array}{c}\text { Descrição citada por Must, Van } \\
\text { Berkel e Schmidt }\end{array}$ \\
\hline 01 & $\begin{array}{l}\text { Leitura do problema, identificação e } \\
\text { esclarecimento de termos } \\
\text { desconhecidos; }\end{array}$ & Descrição do problema. \\
\hline 02 & $\begin{array}{l}\text { Identificação dos problemas } \\
\text { propostos pelo enunciado; }\end{array}$ & $\begin{array}{l}\text { Definição do problema; que significa: } \\
\text { descrever exatamente que fenômenos } \\
\text { têm que ser explicados ou } \\
\text { compreendidos. }\end{array}$ \\
\hline 03 & $\begin{array}{l}\text { Formulação de hipóteses explicativas } \\
\text { para os problemas identificados no } \\
\text { passo anterior (os alunos se utilizam } \\
\text { nesta fase dos conhecimentos de que } \\
\text { dispõem sobre o assunto); }\end{array}$ & $\begin{array}{l}\text { Brainstorm: usando seu conhecimento } \\
\text { prévio e sentido comum, tentativa de } \\
\text { produzir possíveis explanações } \\
\text { diferentes. }\end{array}$ \\
\hline 04 & Resumo das hipóteses; & $\begin{array}{l}\text { Elaboração das explanações } \\
\text { propostas: tentar construir uma teoria }\end{array}$ \\
\hline
\end{tabular}




\begin{tabular}{|c|c|c|}
\hline & & $\begin{array}{lll}\text { pessoal coerente e detalhada dos } \\
\text { processos } & \text { subjacentes } & \text { aos } \\
\text { fenômenos. } & & \\
\end{array}$ \\
\hline 05 & $\begin{array}{l}\text { Formulação dos objetivos de } \\
\text { aprendizado (trata-se da identificação } \\
\text { do que o aluno deverá estudar para } \\
\text { aprofundar os conhecimentos } \\
\text { incompletos formulados nas } \\
\text { hipóteses explicativas); }\end{array}$ & $\begin{array}{lllr}\text { Formulação } & \text { de } & \text { objetivos de } \\
\text { aprendizagem } & \text { para } & \text { aprendizagem } \\
\text { auto-dirigida. } & & \end{array}$ \\
\hline 06 & $\begin{array}{l}\text { Estudo individual } \text { dos assuntos } \\
\text { levantados nos objetivos de } \\
\text { aprendizado; }\end{array}$ & $\begin{array}{l}\text { Tentativa de preencher as lacunas em } \\
\text { seu conhecimento com o auto-estudo. }\end{array}$ \\
\hline 07 & $\begin{array}{l}\text { Retorno ao grupo tutorial para } \\
\text { rediscussão do problema frente aos } \\
\text { novos conhecimentos adquiridos na } \\
\text { fase de estudo anterior. }\end{array}$ & $\begin{array}{l}\text { Compartilhamento de suas bases de } \\
\text { informações com o grupo e tentativa } \\
\text { de integração do conhecimento } \\
\text { adquirido, em uma explanação } \\
\text { apropriada para os fenômenos. } \\
\text { Verificação de suficiência do } \\
\text { conhecimento. Avaliação do processo } \\
\text { de aquisição do conhecimento. }\end{array}$ \\
\hline
\end{tabular}

Tabela 13 - Descrição das etapas para o desenvolvimento da aprendizagem baseada em problemas

Por certo, para o funcionamento da aprendizagem baseada em problemas é importante que se tenha uma Comissão de Proposição de Problemas, que "deve reunir um grupo habilitado na técnica de propor problemas adequados ao desenvolvimento dos temas elaborados pela Comissão de Currículo" (BERBEL, 1998, p. 147-148). Como salienta Gil (2006, p. 181), esta formulação de problemas "constitui um dos aspectos mais críticos da ABP", dada sua vida relativamente curta por se referirem a situações reais e serem fortemente "afetados por descobertas científicas e por fatores econômicos, políticos e sociais", além de que o "problema apresentado precisa ser suficiente para abranger tanto os mais amplos objetivos da disciplina quanto os objetivos específicos que possibilitem aos estudantes encontrar sua solução". Destas considerações se percebe que o trabalho de formulação dos problemas precisará promover uma constante revisão sobre as propostas elaboradas, de maneira a atender às perspectivas que o tempo e os acontecimentos exigirão. Mas esta preocupação tem seu contraponto positivo, na medida em que essa constante revisão promove a atualização das abordagens, atendendo aos movimentos sociais identificados ao tempo de suas proposições.

Os problemas são propostos a grupos de oito a dez alunos. Como observa Carlini (2008, p. 218), que vão trabalhar juntos durante o período de duração de 
cada um dos módulos e depois serão modificados, "permitindo aos alunos que convivam sucessivamente com colegas diferentes ao longo de todo o curso". Os grupos de alunos são coordenados por um professor que pode ser chamado de tutor ou facilitador. A autora lembra que ambas expressões têm uma certa rejeição, visto poder significar "uma tarefa menor do que aquela que deve ser desempenhada por um professor".

De qualquer maneira, as reuniões são realizadas semanalmente, iniciando-se pela apresentação dos envolvidos, do planejamento das atividades, formas de avaliação, bibliografia sugerida e atividades complementares. Os alunos recebem o problema com as explicações e discussões necessárias para a sua compreensão. A partir deste reconhecimento, cada aluno deverá realizar pesquisas e estudos de forma individual, para que possa construir suas reflexões, que serão apresentadas na próxima reunião tutorial, quando cada um terá oportunidade de apresentar os resultados obtidos. Com apoio do Professor (tutor/facilitador), será promovida uma discussão sobre os resultados obtidos, que poderão exigir novas pesquisas até que se possam obter resultados satisfatórios ao problema proposto, os quais serão registrados num relatório (CARLINI, 2008, p. 219-221). Todas as etapas podem ser submetidas às avaliações, tanto pelos alunos como pelos tutores e esta diversidade de avaliações é lembrada por Gil (2006, p. 182), pela natureza de sua complexidade, bem diferente dos meios tradicionais, quando as avaliações se "caracterizam pela praticidade, precisão e objetividade", diversos da ABP que requer "múltiplos procedimentos de avaliação, que envolvem: análise de projetos, provas práticas, avaliação pelos pares, auto-avaliação, apresentações orais, análise de relatórios etc".

Barrows (1996, apud RIBEIRO e MIZUKAMI, 2004 p. 92) identifica alguns objetivos educacionais da aprendizagem baseada em problemas para o ensino de medicina aplicáveis ao ensino de outras áreas de conhecimento:

(a) a aquisição de uma base de conhecimento integrada;

(b) a aquisição de uma base de conhecimento estruturada ao redor de problemas reais encontrados no campo de atuação do profissional em questão; 
(c) a aquisição de uma base de conhecimento vinculada a processos de solução destes problemas e o desenvolvimento de um processo eficaz e eficiente de solução de problemas; e

(d) o desenvolvimento de habilidades de aprendizagem autônoma eficaz e de habilidades de trabalho em grupo.

Por certo, a aprendizagem baseada em problemas é uma "metodologia formativa que estimula o estudante a uma atitude ativa e que apresenta uma lógica semelhante à da pesquisa científica, já que, a partir de um problema, constroem-se hipóteses, buscam-se dados, que são analisados e discutidos até se chegar a uma conclusão" (GIL, 2006, p. 177).

Diante desta forma de conceber o aluno ativamente, enfatizando "o papel do aprendiz no processo de construção do conhecimento e a mudança do papel do professor, que deixa de ser o de transmissor de idéias e passa a ser o facilitador da aprendizagem", Gil (idem) ressalta que os fundamentos de tal aprendizagem "podem ser encontrados nas teorias pedagógicas formuladas por diferentes autores, desde Comenius, passando por Piaget, Bruner, Vigotsky, Rogers, Paulo Freire e muito outros", destacando-se a contribuição do Construtivismo.

A aprendizagem baseada em problemas possui diversas vantagens: permite uma maior compreensão dos assuntos, pela relevância e aplicabilidade dos conceitos aprendidos, favorecendo a retenção dos conhecimentos, mas indo além do nível da memorização para auxiliar na "transferência dos conhecimentos e habilidades aprendidos em classe para o mundo do trabalho". Incentiva também a responsabilidade pela própria aprendizagem, por conta da menor intervenção do professor e das ações exigidas na pesquisa e em razão dos recursos que passam a utilizar para seus estudos. Amplia-se a interação social, pela importância dada às atividades "que requerem a cooperação grupal e a formação de equipes"; sua forma de promover os estudos de maneira independe é mais interessante, estimulante e agradável aos alunos, contribuindo para sua automotivação. Sua maior eficácia se dá quando se incorpora ao próprio currículo, representando "uma das mais importantes atividades que podem ser desenvolvidas no âmbito dos cursos universitários em prol da interdisciplinaridade", já que a solução de problemas, "de modo geral não pode pertencer a uma disciplina específica", contribuindo para a 
"identificação das relações entre duas ou mais disciplinas e para a interação de professores e estudantes nela envolvidos" (GIL, 2006, p. 178-180).

Com efeito, as ações empreendidas para a execução da aprendizagem baseada em problemas atende as reclames apontados no presente estudo. Afasta-se o professor como centro de informações e das verdades; foca a aprendizagem na perspectiva ativa do discente; quebra a separação das disciplinas, promovendo a integração entre os professores e alunos, além de incentivar a interdisciplinaridade; aceita o instrumental fornecido pela teoria da aprendizagem significativa, incentiva a motivação e aproxima a prática.

É certo que a formatação apresentada da aprendizagem baseada em problemas não incorpora a prática propriamente dita, já que pode ser executada em concomitância com o próprio estágio. Sua realização é voltada para o cumprimento do currículo e os estudos de conteúdos que poderiam ser novamente vistos por disciplinas estanques, mas altera o processo para colocar um problema como elemento catalisador dos diversos conhecimentos abordados unidisciplinarmente. Ao meu ver, concebida a prática não necessariamente com a realização de ações profissionais simuladas mas, sim, por conta da tomada de atitudes, tal metodologia de aprendizagem a contempla perfeitamente, envolvendo a ação (prática) do aluno como elemento fundamental.

Entretanto, há diversos aspectos que precisam ser observados, que podem afetar a integração dessa metodologia. Não somente a repercussão negativa das resistências naturais às mudanças, destacada por Berbel (1998, p. 140), é preciso atentar às experiências narradas por Moust, Van Berkel e Schmidt (2005), ao lançar o olhar sobre as três décadas da aprendizagem baseada em problemas na Universidade de Maastricht, identificando o que chamam de "sinais da erosão", a ponto de sugerirem propostas para sua revitalização. Como qualquer instrumento que depende de ações humanas para seu desenvolvimento é natural que corra riscos de ter desvios em seu planejamento, com o desgaste normal de qualquer técnica se não se submeter a avaliações e reflexões periódicas.

Com efeito, ainda que a proposta da aprendizagem baseada em problemas apresente fundamentos e características que se harmonizam com uma opção adequada para o aprimoramento da aprendizagem, é possível prever que sua implantação num Curso de Direito deve ser precedida de um trabalho de conscientização que também é necessário para a própria formação de um ambiente 
de aprendizagem. A ABP é uma evolução do sistema tradicional, mas sem a formação adequada para primeiro se compreender a própria revisão da tradição que envolve as ações pedagógicas, é arriscado imaginar que o sistema funcione adequadamente, já que os mesmos problemas do método tradicional poderão continuar existindo.

A disposição dos professores para alterar sua metodologia de trabalho será um grande ponto a ser enfrentado. Considerando todos os sentimentos que envolvem o status do professor de Direito, transformá-lo em tutor/facilitador dependerá da sua compreensão diferenciada do papel do docente diante da aprendizagem. Precisará superar a tendência de se constituir como fonte a fim de evitar agir excessivamente nesta nova metodologia, eliminando a possibilidade de investigação do próprio aluno. Essa é uma tendência que foi apontada por Moust, Berkel e Schmidt (2005) na avaliação da Universidade de Maastricht, pelas modificações do processo por ações de professores que, não acreditando na capacidade dos alunos "de cobrirem suficientemente o assunto da matéria, de maneira independente, através do autoaprendizado dirigido", empreendem ações como limitar a indicação das referências, transformando o manual do tutor em livro texto, retomando o papel de serem os responsáveis pela aprendizagem dos alunos (retirando-Ihes a autonomia neste sentido), entre outros aspectos. Note-se que estas "erosões" foram detectadas 30 anos depois do início da aplicação da aprendizagem baseada em problemas, mas sua inserção completa num Curso de Direito, diante da cultura que predomina de quais são as funções do professor (mais por falta de informações do que por má vontade), provavelmente, enfrentariam esta mesma situação logo na sua origem.

Da mesma forma em relação aos alunos, a superação da postura passiva - que muitas vezes agrada pela ausência de responsabilidades -, precisaria ser revisada, com procedimentos de conscientização dos alunos para o desenvolvimento de suas habilidades para o auto-estudo.

Ainda que as ações decorrentes da aprendizagem baseada em problemas provoquem uma motivação nos envolvidos, com ampliação da integração entre eles, como relatam diversos autores (RIBEIRO, 2008, p. 29; HORTA, 2009, p. 3118-3120; RODRIGUES, FONSECA e PIRES, 2008, p. 1591-1593; SIQUEIRA et al, 2009; CARLINI, 2010, p. 263, 267), é necessário um acompanhamento adequado para evitar-se a diminuição do empenho exigido. Nas análises realizadas por Moust, Berkel e Schmidt (2005), observou-se que as mudanças realizadas pelos alunos do 
processo de aprendizagem baseada em problemas, decorreram da diminuição do tempo de estudo para a auto-aprendizagem; numa preparação minimalista para o grupo tutorial; da supressão das etapas 3 e 4 já citadas (de brainstorming e de elaboração de fases), não ativando seus conhecimentos prévios, produzindo relatórios curtos sem a opinião pessoal do discente; estudando as mesmas referências (e se não encontrando nada de novo nas análise dos seus pares), tornando a exposição das pesquisas sem qualquer acréscimo de valor e afastandose do problema original, desfocando da habilidade de transferência do conhecimento obtido.

Acrescente-se, ademais, que a aprendizagem baseada em problemas exige bem mais do que a vontade de participação dos docentes e discentes, tendo em vista as projeções que promovem mudanças no currículo e na estrutura do Curso. Depende de mais recursos humanos e materiais, o que repercute em investimento (GIL, 2006, p. 181), considerando o número de alunos por tutor e materiais para os estudos. Moust, Berkel e Schmidt (2005) afirmam que as ações no sentido de aumentar o número de alunos por tutor (passando de 6-8 para até 19 estudantes) prejudicaram a aprendizagem em razão de inibições e aproveitamento de esforços alheios sem contribuição, além da desunião. Também relatam a contratação de estudantes avançados para atuar como tutores, compensando a ausência de professores para esta finalidade, mas isso também provocou relatos de diferenciação de tratamento (pela comparação com professores), risco da ausência de uma visão crítica a respeito do assunto da matéria e insuficiente conhecimento pedagógico para auxiliar os estudantes.

Mas mesmo considerando todas as intempéries possíveis, acredito que a alternativa dada pela aprendizagem baseada em problemas precisa merecer a atenção do ensino do Direito, dadas as possibilidades que são apontadas, mesmo não havendo garantias de que os alunos de Direito serão melhores profissionais se passaram por tal processo, em diferença daqueles que não o fizerem. Como Lee Shulman - um dos pioneiros na aplicação deste processo em Michigan - ressaltou em uma entrevista, "não há evidências consistentes de que os estudantes submetidos ao ABP são mais bem sucedidos em seu trabalho ou que se lembrem com maior facilidade dos conteúdos aprendidos do que aqueles que estudaram sob os métodos tradicionais de ensino", mas tem-se evidenciado que a ABP "favorece 
com que os estudantes sejam mais motivados e tenham atitudes mais positivas do que os estudantes tradicionais" (2010).

Desenvolvendo-se este processo de aprendizagem que considera problemas do mundo real, "a formação de grupos no PBL também potencializa a abrangência e a intensidade do debate", promovendo as "capacidades políticas, sociais e cognitivas por igual, possibilitando o desenvolvimento de um cidadão mais crítico consigo mesmo e com o mundo" (SOUSA, 2011, p. 244). Logo, não se pode negar as possibilidades que o PBL permite, sem, contudo, admiti-lo como "um método definitivo a ser proposto". Seguindo o que afirma Souza, na busca da implementação de novas metodologias que almejam superar o paradigma escolar obsoleto, o PBL pode surgir em uma forma híbrida "com o ensino tradicional ou mesmo uma reconstrução das metodologias problematizadoras, no sentido de fortalecer a capacidade dos estudantes para trabalharem coletivamente, contribuir para uma postura autônoma na resolução de problemas e desenvolver competências para uma efetiva intervenção na sociedade".

Carlini (2010, p. 259-261), ao realizar um projeto exploratório aplicando a aprendizagem baseada em problemas na área de relações de consumo envolvendo parte de um grupo de alunos de um Curso de Direito (dentro de um programa com estrutura tradicional), conclui ter obtido resultados positivos, com a percepção dos alunos da importância de não se estudar a ciência do Direito de forma estanque, nem sendo necessário o acompanhamento artigo por artigo para se construir o conhecimento sobre uma determinada área. A interdisciplinaridade ganhou destaque na abordagem, bem como a pesquisa, os conhecimentos prévios dos acadêmicos e a facilidade de aprendizagem a partir dos casos concretos propostos, com a valorização do trabalho em grupo, formando laços de companheirismo e amizade, além das repercussões para os estudos individuais. A aproximação com a tutora e a inexistência do sentimento de superioridade nas relações docente/discente também surgiram nas percepções obtidas, permitindo-a concluir que há resultados positivos perceptíveis.

Tal experiência, voltada a uma área do Direito, pode indicar que a aprendizagem baseada em problemas pode ser incorporada parcialmente no ensino do Direito para que ganhe proporções maiores na medida em que romper com os padrões tradicionais, com a intervenção da coordenação pedagógica do Curso (e até mesmo Institucional) para direcionar experiências neste sentido, até que se possa ousar sua 
extensão para a formatação do Curso, a exemplo dos Cursos de Medicina e das experiências estrangeiras neste sentido.

Registre-se, por fim, que apresentar, nesta ocasião, uma estrutura de um Curso de Direito transformado para a aplicação da aprendizagem baseada em problemas não é adequado. Uma proposta de tal natureza não deve ser produzida por uma só pessoa, não somente pela limitação que esta visão única teria (por mais que bem intencionada), já que a construção de um curso integralmente estruturado em problemas deve se projetar em todas as áreas (do Direito e afins). Isso depende, fundamentalmente, da participação de diversos professores das mais diversas áreas, tanto das disciplinas fundamentais como das profissionalizantes, reforçando a característica integradora do referido processo. Além disso, uma proposta de uma nova estrutura para um Curso de Direito fundado na ABP dependeria do reconhecimento das influências que a regionalização do curso exige, já que a problematização não poderia abandonar as características locais, mesmo almejando capacitar o aluno para uma problemática global.

Desta maneira, seja pensando numa proposta de aplicação do processo de aprendizagem baseada em problemas em uma área do Direito, seja pensando num Curso como um todo, é fundamental que se tenha em mente a atenção ao planejamento de currículo, da formulação e atualização dos problemas e das avaliações, para que sua aplicação não se restrinja a simples discussões em grupo ou práticas simuladas.

Com isso, ainda que não se apresente uma proposta de currículo para um Curso de Direito lastreado no processo de aprendizagem baseada em problemas nesta oportunidade, pode-se inferir por analogia a distribuição da carga horária já apontada pelo Curso de Medicina da Universidade Estadual de Londrina, desenvolvida em aulas teóricas, aulas práticas, tutoria, estudos orientados e avaliação, elementos que podem ser direcionadores para as ações a serem empreendidas.

Assim, finaliza-se esta pesquisa para ressaltar a importância da compreensão do estudo do Direito em suas diversas interferências, afirmando-se pela possibilidade de novos caminhos, que somente poderão ser seguidos a partir de uma profunda e contínua reflexão sobre a importância da aprendizagem e da responsabilidade de todos os sujeitos nela envolvidos. 


\section{CONSIDERAÇÕES FINAIS}

A História do ensino do Direito aponta que os problemas envolvendo a relação professor-aluno e a aprendizagem sempre existiram. As diversas mudanças legislativas realizadas para a regulamentação do Curso de Direito, culminando com as Diretrizes Curriculares Nacionais estabelecidas pela Resolução n. 9/2004, não puderam atender ao propósito de eliminar os problemas existentes do desenvolvimento dos Cursos de Direito, mas evoluíram de maneira a indicar objetivos no que respeitam à formação do aluno. Os problemas podem ser apontados mais para as ações dos sujeitos participantes do processo educativo no ensino do Direito do que propriamente a sua regulamentação estatal.

Enquanto objeto, o Direito provoca um movimento crítico que questiona os seus paradigmas, o que revela um primeiro aspecto a ser analisado por qualquer proposta que discuta o contexto pedagógico desta área. Refletir sobre o ensino do Direito depende da reflexão sobre a amplitude de seus significados e das interferências que o constroem. Por outro lado, desenvolver-se o movimento crítico sobre o que é o Direito sem que isso tenha sua projeção na formação dos futuros profissionais (pensando-se as reflexões no plano pedagógico), corre o risco de elitizar um discurso sem atentar aos seus efeitos no plano educativo, fundamento para a construção e reconstrução de qualquer objeto.

Ainda que o presente estudo não tenha se proposto a realizar uma análise profunda das teorias críticas desenvolvidas neste âmbito, é preciso reconhecer a sua existência e a importância de se conceber um Direito aberto a muitas significações, sem desprender-se da finalidade humanista, constituindo seu objetivo maior.

Esta concepção humanista, quando projetada no ensino do Direito, muitas vezes pode perder seu amplo significado por conta das representações dos professores de Direito no desenvolvimento de suas ações, praticadas com base em experiências e vivências nem sempre apoiadas em reflexões produzidas por outras áreas que não a jurídica (em especial no aspecto pedagógico). A concepção de que o ensino do Direito é objeto distinto com particularidades não suscetíveis às concepções didático-pedagógicas, vistas de forma generalizadas e não sistematizadas, pode produzir uma resistência às reflexões inerentes ao processo educativo, gerando discursos que procuram justificar as ações docentes por conta 
da experiência técnico-jurídica, dando-Ihe maior importância do que a didáticopedagógica. Esta observação pode ser inferida por conta das contratações dos docentes na área do Direito, que privilegiam a caracterização profissional dentro do Direito supondo sua experiência em sala de aula pelo conhecimento técnico que possui. Isso se observa dos dados colhidos no presente estudo, quando indicam que todos os professores são advogados. Mas esta percepção pode ir além dos dados relatados, confirmando-se que a relação professor de Direito com a formação profissional jurídica se reproduz facilmente.

O grande desafio que se percebe é aproximar as discussões pedagógicas às práticas docentes realizadas por esses profissionais. Proporcionar um ambiente de formação continuada para o professor de Direito pode depender desse rompimento da barreira cultural de isolamento da área, que pode ser reflexo desta cultura em que ensinar direito depende do conhecimento jurídico e não do conhecimento teórico-pedagógico. O intercâmbio e a soma entre as duas fazem parte dessa perspectiva de superação.

De fato, este isolamento se revela em vários momentos, como se pode notar das dificuldades de integração dos professores entre si, deles com os alunos, em relação ao planejamento do curso e com outros cursos, o que também ocorre com as ações interdisciplinares. A compartimentalização e disciplinaridade compõem um ambiente estrutural que revela os eixos indicados pelas Diretrizes Curriculares Nacionais (eixos de formação fundamental, profissional e prática) como movimentos estanques. É possível que cada disciplina concebida para a execução de tais eixos seja realizada sem a percepção da necessidade da sua integração com as demais, perdendo-se o foco da integração em prol da preocupação com o cumprimento da abordagem de seu conteúdo. As manifestações dos professores pesquisados apontando a ausência de um fluente diálogo entre os professores das disciplinas teóricas e os professores das disciplinas práticas representam apenas uma exemplificação de várias outras interferências que podem estar acontecendo no desenvolvimento de um Curso de Direito.

Nessa perspectiva de observar o Curso de Direito, colocou-se em tela a preocupação concernente à realização da aprendizagem. Num contexto em que se revela a centralização no professor, na esteira de uma abordagem tradicional do processo educativo (onde o professor fala e o aluno escuta), a pergunta que transita 
pelo presente estudo é como anda o olhar sobre a aprendizagem no Curso de Direto.

Com efeito, a exposição dos discursos neste estudo, pela particularidade do caráter exploratório, procura significados com a expectativa de sua projeção para outras realidades, que podem somar outras experiências para refletir sobre sua própria execução. Na preocupação de considerar o movimento contínuo de reflexão sobre o processo educativo, dá-se atenção ao curso de Direito, numa perspectiva pessoal que deixa revelar as próprias limitações que o olhar de dentro do objeto sofre: partilham-se angústias construídas pela própria experiência, mas buscam-se elementos para formar reflexões com a análise dos sinais que o curso de Direito aponta por seus interlocutores, formando outros sinais que a própria pesquisa promove.

Assim, não se prega a concepção de que os cursos de Direito têm problemas generalizados e que os professores deste Curso se alienam conscientemente dos elementos didáticos para a realização da aprendizagem de seus alunos. Mesmo os discursos desenvolvidos para apontar problemas no ensino do Direito (além do que ora se apresenta) - que partem, provavelmente, de pessoas que estão nele envolvidas -, já indica um sinal da construção de um movimento em prol de sua revisão. A preocupação com o curso de Direito se revela em muitos estudos que a cada dia tem surgido, o que aponta sinais de reflexão sobre seus fundamentos e objetivos, mas há muitas ações para serem realizadas quando se percebe que há incômodos das mais diversas espécies transitando sobre a formação jurídica. A escolha da aprendizagem para as discussões do presente trabalho faz um recorte dentre todas as possibilidades que a análise do estudo do Direito permite, ainda que exija o tratamento de muitos temas para construir qualquer sinalização neste âmbito.

Acreditamos, pois, que a presente pesquisa se individualiza na medida em que parte do contexto da aprendizagem e das ações docentes e discentes para estabelecer a reflexão mais delineada sobre o desenvolvimento das aulas teóricas: uma aula pode ser realizada com ou sem o conhecimento dos pontos que ora apresentamos, mas a diferença de se concebê-la considerando os pressupostos contextualizados e sistematizados nessa pesquisa contribui para que ela possa ir além de uma aula-conferência, tão costumeiramente aplicada nos Cursos de Direito.

De uma forma sintética, a questão que se coloca em pauta é o quanto o professor de Direito olha para suas ações e nelas reconhece os pressupostos que 
justificam os procedimentos e resultados obtidos, bem como o que faz a partir desse reconhecimento, numa reflexão sobre as suas ações e numa posterior reflexão sobre essa própria reflexão.

Ao se tratar da aprendizagem significativa, pretendeu-se trazer à tona elementos que estão presentes no processo de assimilação de conteúdos e no desenvolvimento do conhecimento, reconhecendo-se a importância do que existe na estrutura cognitiva do aluno e nas possibilidades de sua reconstrução e evolução. Não se ignorou a importância da formação de um aluno crítico e socialmente responsável, o que se acredita ser favorecido pela compreensão da prática como uma ação voltada a algo mais do que apenas entender o significado do que se estuda. A perspectiva para a compreensão do Direito demanda uma especial atenção à alteridade, já que é nas relações com o outro que se justifica sua própria existência.

Logo, uma aula pode ser desenvolvida dentro da atenção que a aprendizagem merece dentro do processo educativo e a percepção de que o professor de Direito pode ser um mediador/facilitador da aprendizagem sem lhe retirar a importância desse processo é um caminho que poderá ser experimentado, em revisão diametralmente oposta à realidade que se observa.

De qualquer modo, o que se coloca também como ponto principal da tese formulada é o quanto a realização de atividades práticas (e, portanto, o envolvimento das ações discentes) pode contribuir para a aprendizagem. Acreditava-se existir um ambiente, desenvolvido pelas práticas docentes, que não valorizava as ações discentes durante as abordagens teóricas e esta hipótese não foi negada pelos dados coletados.

Deste modo, a relevância que se espera apontar neste estudo é a de chamar a atenção para uma reconstrução principalmente da aula envolvendo a parte teórica do estudo do Direito, de maneira a realizar ações que demandem uma postura ativa do discente, nas observações imediatas dos conhecimentos submetidos à aprendizagem independentemente da existência do Estágio ou reformulação do currículo. Muitas ações podem ser empreendidas no desenvolvimento do Curso de Direito, desde o seu primeiro ano, concebendo mais as práticas discentes e menos os discursos docentes. São ilações que podem ser submetidas a novos estudos, a fim de se confirmar ou negar as hipóteses da eficiência de outro padrão de ensino do Direito, mas que precisa ser reconhecido - antes - como uma possibilidade. 
Reconstruir a aula teórica com foco na aprendizagem e na ação discente pela prática, independentemente do Estágio, é a essência da provocação que se espera revelar a partir da análise dos dados e da revisão bibliográfica que se produziu neste estudo.

O mesmo se dá ao trazer a metodologia envolvendo a aprendizagem baseada em problemas enquanto reformulação do curso de Direito. É uma opção que reconstrói a forma como conduzir o ensino que merece atenção, na medida em que parte de importantes pressupostos para o reconhecimento da ação discente em prol da aprendizagem.

É certo que mesmo para os cursos onde ela já está sendo aplicada (no Brasil, em especial na área da Saúde), a atenção e revisão sobre o seu funcionamento devem ser medidas constantes, numa dialética imprescindível para se conceber os movimentos entre as formas de interação da aprendizagem com as ações dos sujeitos. Assim, uma parte do Curso de Direito poderia ser realizada pela execução desta metodologia? Um curso inteiro poderia ser reformulado para ser desenvolvido nesta perspectiva metodológica? Os estudos encontrados utilizando essa proposta para o Direito no Brasil, em parte de conteúdos, indica sua viabilidade. Estudos com sua integral execução para outras áreas indicam a necessidade de sua revisão. Todas elas são contribuições para se pensar o Curso de Direito no Brasil com outra formatação, sem que isso implique em fórmulas mágicas para a solução de problemas que possam ser identificados a partir da realidade que ora se vivencia.

Todas as medidas não passam de propostas, mas o que merece chamar a atenção é como anda a aprendizagem no curso de Direito e se ela pode ser vista sob o plano da prática, sem que se imagine um estágio (tanto real como simulado) para esta finalidade. Nas visões dos professores de estágio simulado e de alunos durante as aulas deste estágio apresentadas neste estudo, sinaliza-se que os conteúdos teóricos tratados em momento distinto apresentam dificuldades e esse indicador pode promover um questionamento que pode ser generalizado a outras experiências em cursos de Direito: como andam os conteúdos teóricos abordados no estudo do Direito durante as aulas de prática simulada e durante a prática real vivenciada ainda durante a formação acadêmica? Se o Exame de Ordem para ingresso nos quadros da OAB aventam, a toda hora, supostos problemas para a formação jurídica; se os discursos no cotidiano do ambiente jurídico manifestam o fato de que a prática é uma coisa e a teoria é outra; e se os professores e alunos, 
durante o estágio, afirmam que encontram dificuldades para 0 tratamento dos conteúdos teóricos, parece claro que há indicativos para novas proposições de aprendizagem e uma melhor compreensão de seu desenvolvimento para as aulas de Direito.

Assim, o presente estudo, longe de buscar a afirmação de verdades ou inverdades, representa a intenção de se apontar perspectivas que o Curso de Direito pode conceber, especialmente atento aos sujeitos envolvidos e a aprendizagem, elementos imprescindíveis para a compreensão do processo educativo que precisa se manter num continuum de análises e revisões, das quais o Direito não pode se afastar. 


\section{REFERÊNCIAS}

ABREU, M. C. de; MASETTO, M. T. O professor universitário em aula. 8. ed. São Paulo: MG Ed. Associados, 1990.

AGUIAR, R. A. R. de. Habilidades: ensino jurídico e contemporaneidade. Rio de Janeiro: DP\&A, 2004.

ALMEIDA FILHO, J. C. de A. (Org.) 180 anos do Ensino Jurídico no Brasil. Campinas: Millennium. 2008.

ALMEIDA JÚNIOR, F. F. de. Os atuais objetivos do ensino de Direito no Brasil. In: CARLINI, A.; CERQUEIRA, D. T. de e ALMEIDA FILHO, J. C. de A. 180 anos do Ensino Jurídico no Brasil. Campinas: Millennium, 2008.

ANTUNES, C. A dimensão de uma mudança: atenção, criatividade, disciplina, distúrbios de aprendizagem, propostas e projetos. Campinas, SP: Papirus, 1999.

Professor bonzinho = aluno difícil: a questão da indisciplina em sala de aula. 3. ed. Petrópolis, RJ: Vozes, 2002a.

. Novas maneiras de ensinar, novas formas de aprender. Porto Alegre: ArtMed, 2002b.

. Resiliência: a construção de uma nova pedagogia para a uma escola pública de qualidade, fascículo 13. Petrópolis: Vozes, 2003.

ARMSTRONG, T. Inteligências múltiplas na sala de aula. 2. ed. Tradução de Maria Adriana Veríssimo Veronese. Porto Alegre: ArtMed, 2001.

AUSUBEL, D. P. Aquisição e retenção de conhecimentos: uma perspectiva cognitiva. Tradução de Lígia Teopisto. Lisboa: Paralelo, 2003. 
AUSUBEL, D. P.; NOVAK, J. D. e HANESIAN, H. Psicologia educacional. 2. ed. Tradução de Eva Nick, Heliana de Barros Conde Rodrigues, Luciana Peotta, Maria Ângela Fontes e Maria da Glória Rocha Maron. Rio de Janeiro: Interamericana, 1980.

AZEVEDO, P. F. Crítica à dogmática e hermenêutica jurídica. Porto Alegre: Sérgio Fabris, 1989.

BASTOS, A. W. O ensino jurídico no Brasil. 2. ed. Rio de Janeiro: Lumen Juris, 2000.

BEHRENS, M. A. Formação continuada dos professores e a prática pedagógica. Curitiba: Champagnat, 1996.

BERBEL, N. A. N. A problematização e a aprendizagem baseada em problemas: diferentes termos ou diferentes caminhos? Interface - Comuni, Saúde, Educ 2. 1998. Disponível em http://www.fm.usp.br/cedem/did/preceptores/ BAS3 PBL x Problematizacao.pdf. Acesso em 18.10.2010.

BITTAR, E. C. B. Estudos sobre ensino jurídico: pesquisa, metodologia, diálogo e cidadania. 2. ed. São Paulo: Atlas, 2006.

BRASIL. Lei de 11 de agosto de 1827. Disponível em http://www.planalto.gov.br/ccivil 03/revista/Rev 63/Lei 1827.htm. Acesso em 29.08.2009. 2009a.

BRASIL. Conselho Nacional de Educação/Câmara de Educação Superior. Parecer n. CES/CNE 0146/2002. Disponível em http://portal .mec.gov.br/cne/arquivos/pdf/CES0146.pdf. Acesso em 02.09.2209, 2009b.

BRASIL. Superior Tribunal de Justiça. Decisão liminar em Mandado de Segurança 8.592-DF (2002/107490-7). Disponível em: http://www2.sti.jus.br/websecsti/cgi/revista/REJ.cgi/MON?seq=49699\&formato=PDF. Acesso em 05.10.2009, 2009c. 
BRASIL. Superior Tribunal de Justiça. Acórdão no Mandado de Segurança 8.592-DF (2002/107490-7). Disponível em: http://www2.sti.jus.br/revistaletronica/Abre Documento.asp?Link=ATC\&sSeq=754223\&Ree $=200201074907 \&$ sData $=20030623$ \&sTipo $=5 \&$ formato=PDF. Acesso em 05.10.2009, 2009d.

BRASIL. Conselho Nacional de Educação/Câmara de Educação Superior. Resolução CNE/CES n. 9, de 29 de setembro de 2004. Disponível em: http://portal.mec.gov.br/cne/arquivos/pdf/rces09 04.pdf. Acesso em 05.10.2009, 2009 e.

BRASIL. Câmara dos Deputados. Projeto de Lei PL-6068/2009. Disponível em http://www.camara.gov.br/sileg/Prop Detalhe.asp?id=450668. Acesso em 09.10.2010. 2010a

BRASIL. Ministério da Educação. Conselho Nacional de Educação. Parecer n. CNE/CES 055/2004. Reexaminado pelo Parecer CNE/CES 211/2004. Disponível em: http://portal.mec.gov.br/cne/arquivos/pdf/2004/ces0055 2004.pdf. Acesso em 09.09.2010. 2010b

CAMBI, E. Neoconstitucionalismo e neoprocessualismo: direitos fundamentais, políticas públicas e protagonismo judiciário. São Paulo: Revista dos Tribunais, 2009.

CAMPOS, V. T. B. Marcas indeléveis da docência no ensino superior: representações relativas a docência no ensino superior de pós-graduandos de instituições federais de ensino superior. Tese de doutorado. São Paulo: Biblioteca Digital da Universidade de São Paulo. Disponível em: http://www.teses.usp.br/teses/disponiveis/48/48134/tde-14062010-123952/pt-br.php. Acesso em 13.12.2010.

CARLINI, A. L. O professor de Direito e a identidade docente: construindo reflexões a partir da aprendizagem baseada em problemas. In: TAGLIAVINI, J. V. (Org.). A superação do positivismo jurídico no ensino do Direito: uma releitura de Kelsen que possibilita ir além de um positivismo restrito e já consagrado. Araraquara: Junqueira\&Marin, 2008. 
Aprendizagem baseada em problemas aplicada ao ensino do Direito: projeto exploratório na área de relações de consumo. Tese de Doutorado. São Paulo: Pontifícia Universidade Católica de São Paulo, 2006. Disponível em: http://www.sapientia.pucsp.br/tde busca/arquivo.php? codArquivo=4118. Acesso em 28.09.2010.

CASTRO, A. G. de. Inter-relacionamento docente nos eixos e matérias curriculares. $O A B$ ensino jurídico - A docência jurídica no contexto do ensino superior na contemporaniedade. Brasília, DF: OAB, Conselho Federal, 2009.

Chamlian, H. C. Docência na Universidade: professores inovadores na USP. Cadernos de Pesquisa (Fundação Carlos Chagas), n. 118, março, 2003.

COELHO, L. F. Aulas de introdução ao Direito. Barueri, SP: Manole, 2004.

. Lógica jurídica e aplicação das leis. 2. ed. Rio de Janeiro: Forense, 1981. . Uma teoria crítica do Direito. Estudo em homenagem a Luiz Legaz y Lacambra. Curitiba: Bonijuris, 1993.

COELHO, F. U. Curso de Direito Civil. São Paulo: Saraiva, v. 1, 2003.

CONSULTOR JURÍDICO. MEC cruzará dados do Enade e Exame da OAB em prol da qualidade. Publicado em 27.07.2007. Disponível em http://www. conjur.com.br/2007-jul-27/mec cruzara informacoes enade exame ordem. Acesso em 10.11.2010.

CORTELLA, M. S. A escola e o conhecimento: fundamentos epistemológicos e políticos. 5. ed. São Paulo: Cortez, 2001.

CRUZ, E. P. et al. 180 anos de ensino do Direito no Brasil - olhares e perspectivas discente. In: CARLINI, A.; CERQUEIRA, D. T. de e ALMEIDA FILHO, J. C. de A. 180 anos do Ensino Jurídico no Brasil. Campinas: Millennium, 2008.

CURY, V. de A. R. Introdução à formação jurídica no Brasil. Campinas: Edicamp, 2002. 
DEMO, P. Mitologias da avaliação: de como ignorar, em vez de enfrentar os problemas. 2. ed. Campinas, SP: Autores Associados, 2002.

. Desafios modernos da educação. 2. ed. São Paulo: Vozes, 1993.

. Metodologia Científica em Ciências Sociais. 3. ed. São Paulo: Atlas, 1995.

. Introdução à Metodologia da Ciência. São Paulo: Atlas, 1985.

DINIZ, M. H. Compêndio de introdução à Ciência do Direito. 8. ed. São Paulo: Saraiva, 1995.

FAGÚNDEZ, P. R. Á. (Org.) A crise do conhecimento jurídico: perspectivas e tendências do Direito contemporâneo. Brasília: OAB Editora, 2004.

A crise do ensino jurídico. In: RODRIGUES, H. W. Ensino jurídico para que(m)?. Florianópolis: Fundação Boiteux, 2000, p. 35-46.

FARIA, J. E. A reforma do ensino jurídico. Porto Alegre: Sergio Antonio Fabris, 1987.

FAZENDA, I. C. A. Interdisciplinaridade: definição, projeto, pesquisa. In: FAZENDA, I. C. A. (Org.). Práticas interdisciplinares na escola. 6. ed. São Paulo: Cortez, 1999.

FELDMAN, D.. Ajudar a ensinar: relações entre didática e ensino. Tradução de Valério Campos. Porto Alegre: ARTMED, 2001.

FERRAZ JÚNIOR, T. S. Introdução ao estudo do direito: técnica, decisão, dominação. 2. ed. São Paulo: Atlas, 1994.

FERREIRA, S. L. Introduzindo a noção de interdisciplinaridade. In: FAZENDA, I. C. A. (Org.). Práticas interdisciplinares na escola. 6. ed. São Paulo: Cortez, 1999.

FERREIRA, A. B. de H. Dicionário Aurélio Eletrônico - Século XXI. Lexikon Informática Ltda. 1999.

FREIRE, P. Pedagogia da autonomia. 26. ed. São Paulo: Paz e Terra, 1996. 
FREIRE, M. O sentido dramático da aprendizagem. In: GROSSI, E. P. e BORDIN, J. (Org.). Paixão de aprender. 12. ed. Petrópolis, RJ: Vozes, 2001.

GAGLIANO, P. S.; PAMPLONA FILHO, R. Novo curso de Direito Civil: parte geral. 8. ed. São Paulo: Saraiva, v. 1, 2006.

GARDNER, H.; KORNHABER, M. L.; WAKE, W. K. Inteligência: múltiplas perspectivas. Tradução Maria Adriana Veríssimo Veronese. Porto Alegre: ArtMed, 1998.

GIL, A. C. Metodologia do Ensino Superior. São Paulo: Atlas, 2005.

. Didática do Ensino Superior. São Paulo: Atlas, 2006.

GROSSI, E. P. Um novo paradigma sobre aprendizagem. In: GROSSI, E. P. e BORDIN, J. (Org.). Paixão de aprender. 12. ed. Petrópolis, RJ: Vozes, 2001.

GUSMÃO, P. D. de. Introdução ao estudo do Direito. 28. ed. Rio de Janeiro: Forense, 2000.

HIRONAKA, G. M. F. N. e MONACO, G. F. de C. Passado, presente e futuro do Direito. As arcadas e sua contribuição para o ensino do Direito no Brasil. In: CARLINI, A.; CERQUEIRA, D. T. de; e ALMEIDA FILHO, J. C. de A. 180 anos do Ensino Jurídico no Brasil. Campinas: Millennium, 2008.

HORTA, R. de C. A. Metodologia de aprendizagem baseada nos problemas: uma proposta de ensino da prática em educação social. Actas do X Congresso Internacional Galego-Português de Psicopedagogia, Braga: Universidade do Minho, 2009, disponível em http://www.educacion.udc.es/grupos/gipdae/ congreso/Xcongreso/pdfs/t7/t7c230.pdf. Acesso em 02.12.2010.

IMBERNÓN, F. Formação docente e profissional: formar-se para a mudança e a incerteza. 6. ed. São Paulo: Cortez, 2006.

IOCOHAMA, C. H. Professor: a aula de Direito Processual pode ser mais interessante? Prática Jurídica. Brasília: Consulex, v. 2, p. 20-23, 2003. 
. Posturas reflexivas para uma avaliação da aprendizagem no curso de direito. Educere - Revista de Educação da UNIPAR. Umuarama: UNIPAR, v. 4, n. 2, 2004a.

- Reflexões sobre a cola nas avaliações do Curso de Direito e indicação de uma alternativa viável para sua superação. Revista de Ciências Jurídicas e Sociais da UNIPAR. Toledo: UNIPAR, v. 7, p. 25-40, 2004b.

ISERHARD, A. M. A formação continuada do docente para um ensino jurídico de qualidade. In: MELO FILHO, Á. (Coord.). A docência no contexto do ensino superior na contemporaneidade. Brasília, $\mathrm{OAB}$, Conselho Federal, Comissão Nacional de Ensino Jurídico, 2009.

KAMII, C.; DEVRIES, R. O conhecimento físico na educação pré-escolar: implicações da Teoria de Piaget. Tradução de Maria Cristina R. Goulart. Porto Alegre: Artes Médicas, 1985.

KIPPER, A. O discurso jurídico na sala de aula: convencimento de um único paradigma. In: RODRIGUES, H. W. Ensino jurídico para que(m)?. Florianópolis: Fundação Boiteux, 2000, p. 65-74.

KLAUSMEIER, H. J; GOODWIN, W. Manual de Psicologia Educacional. Tradução de Célia Teixeira Azevedo de Abreu. São Paulo: Harper \& Row do Brasil, 1977.

LIBÂNEO, J. C. Didática. São Paulo: Cortez, 1994.

Adeus professor, adeus professora? Novas exigências educacionais e profissão docente. 9. ed. São Paulo: Cortez, 2006.

LIEURY, A.; FENOUILLET, F. Motivação e aproveitamento escolar. Trad. Yvone Maria de Campos Teixeira da Silva. São Paulo: Loyola, 2000.

LOPES, A O. Relação de interdependência entre ensino e a aprendizagem. In: VEIGA, I. P. A. (Org.). Didática: o ensino e suas relações. Campinas, SP: Papirus, 1996.

LÜCK, H. Pedagogia interdisciplinar: fundamentos teórico-metodoloógicos. 9. ed. Petrópolis, RJ: Vozes, 2001. 
LUCKESI, C. C. Filosofia da Educação. São Paulo: Cortez, 1994.

Avaliação da aprendizagem escolar. 14 ed. São Paulo: Cortez, 2002.

MARCONI, M. de A.; LAKATOS, E. M. Fundamentos de Metodologia Científica. 6. ed. São Paulo: Atlas, 2009.

MARPEAU, J. O processo educativo: a construção da pessoa como sujeito responsável por seus atos. Tradução de Cláudia Schilling. Porto Alegre: ArtMed, 2002.

MASETTO, M. Professor universitário: um profissional da educação na atividade docente. In: MASETTO, M. (Org.). Docência na Universidade. 2. ed. Campinas, SP: Papirus, 1998.

. Competência pedagógica do professor universitário. São Paulo: Summus, 2003.

MASINI, E. F. S. (Org.); SANTOS, E. M. e SHIRAHIGE, E. E. Psicopedagogia na escola: buscando condições para a aprendizagem significativa. 2. ed. São Paulo: Unimarco, 1997.

MESQUITA, M. S. O fetichismo da lei e o ensino do Direito. In: TAGLIAVINI, J. V. (Org.). A superação do positivismo jurídico no ensino do Direito: uma releitura de Kelsen que possibilita ir além de um positivismo restrito e já consagrado. Araraquara: Junqueira\&Marin, 2008.

MIAILLE, M. Introdução Crítica ao Direito. Lisboa: Editorial Estampa, 1994.

MIZUKAMI, M. da G. N. Ensino: as abordagens do processo. São Paulo: EPU, 2007.

MIZUKAMI, M. da G. N. et al. Escola e aprendizagem da docência: processos de investigação e formação. São Carlos: EdUFSCar, 2002.

MONTEIRO, W. de B. Curso de Direito Civil: parte geral. 39. ed. Atualizado por Ana Cristina de Barros Monteiro França Pinto. São Paulo: Saraiva, v. 1, 2003. 
MOREIRA, M. A.; MASINI, E. F. S. Aprendizagem significativa: a teoria de David Ausubel. São Paulo: Moraes, 1982.

MORIN, E. Os sete saberes necessários à educação do futuro. Tradução de Catarina Eleonora F. da Silva e Jeanne Sawaya. 9. ed. São Paulo: Cortez; Brasília, DF: UNESCO, 2004.

MOUST, J. H. C. ; VAN BERKEL, H. J. M e SCHMIDT, H. G. Signs of erosion; Reflections on three decades of problem-base learning at Maastrich University. Higher Education, Springer, 2005, p. 665-683, DOI 10.1007/s10734-004-6371-z, Tradução de Luiz Novaes, disponível em http://www.famema.br/capacitacao/ signs of erosion pt br.pdf. Acesso em 01.01.2011.

$O A B$ Ensino Jurídico. $O$ futuro da universidade e os curós de direito: novos caminhos para a formação profissional. Brasília: OAB, Conselho Federal, 2006.

O GLOBO Educação. MEC vai fazer cruzamento entre resultados do ENADE e exame da OAB. Publicação de 27.07.2007. Disponível em http://oglobo.globo.com/educacao/mat/2007/07/27/297011933.asp. Acesso em 10.11.2010.

PENIN, S. T. de S. Cotidiano e escola: a obra em construção (O poder das práticas cotidianas na transformação da Escola). São Paulo: Cortez, 1989.

A aula: espaço de conhecimento, lugar de cultura. Campinas, SP: Papirus, 1994.

. O ensino como "acontecimento". Cadernos de Pesquisa (Fundação Carlos Chagas), São Paulo: FCC, v. 98, p. 14-23, 1996.

. Contribuição de Jean Piaget à reflexão sobre o ensino. Cadernos do EDM - Departamento de Metodologia do Ensino e Educação Comparada. FEUSP, v. 1, p. 3-16, 1988.

PENTEADO, H. D.; VALLE FILHO, M. R.; PENIN, S. T. de S. Aspectos cognitivos do trabalho escolar. Revista da Faculdade de Educação (USP), São Paulo, v. 18, p. 216-233, 1992. 
PÉRISSÉ, P. M. O educador aprendedor. São Paulo: Cortez, 2004.

PIMENTA, S. G. O Estágio na formação de Professores: unidade teoria e prática? 4. ed. São Paulo: Cortez, 2001.

PÔRTO, I. da F. Ensino jurídico, diálogos com a imaginação: construção do projeto didático no ensino jurídico. Porto Alegre: Sergio Antonio Fabris, 2000.

POZO, J. I. Aprendizes e mestres: a nova cultura da aprendizagem. Tradução de Ernani Rosa. Porto Alegre: ArtMed, 2002.

QUADROS, C. S. de O. O estudante de Direito. In: ZIMERMAN, D. e COLTRO, A. C. M. (Org.) Aspectos ideológicos na prática jurídica. Campinas: Millennium, 2002.

RAYS, O. A. A relação teoria-prática na didática escolar crítica. In: VEIGA, I. P. A. (Org.). Didática: o ensino e suas relações. Campinas, SP: Papirus, 1996.

REBOUL, O. O que é aprender? Tradução de Emile Planchard. Coimbra: Almedina, 1982.

RIBEIRO, L. R. de C. Aprendizagem baseada em problemas (PBL) na educação em Engenharia. Revista de Ensino de Engenharia, v. 27, n. 2, p. 23-32, 2008. Disponível em http://www.upf.br/seer/index.php/ree/article/ viewFile/396/259. Acesso em 23.10.2010.

RIBEIRO, L. R. de C.; MIZUKAMI, M. da G. N.. Uma Implementação da Aprendizagem Baseada em Problemas (PBL) na Pós-Graduação em Engenharia sob a Ótica dos Alunos. Semina: Ciências Sociais e Humanas, Londrina, v. 25, p. 89-102, set. 2004.

RIBEIRO JÚNIOR, J. A formação pedagógica do professor de direito. 2. ed. Campinas: Papirus, 2003.

RIOS, T. A. Ética e competência. 16 ed. São Paulo: Cortez, v. 16, 2006.

RODRIGUES, H. W. Novo currículo mínimo dos Cursos Jurídicos. São Paulo: Revista dos Tribunais, 1995. 
. Ensino jurídico para que(m)? Florianópolis: Fundação Boiteux, 2000.

- O direito errado que se conhece e ensina: a crise do paradigma epistemológico na área do Direito e seu ensino. In: FAGÚNDEZ, P. R. Á. (Org.). A crise do conhecimento jurídico: perspectivas e tendências do Direito contemporâneo. Brasília: OAB Editora, 2004, p. 93-133.

. Roberto Lyra Filho: a importância de sua obra na História do ensino do Direito brasileiro. In: CARLINI, A.; CERQUEIRA, D T. de; e ALMEIDA FILHO, J. C. de A. 180 anos do Ensino Jurídico no Brasil. Campinas: Millennium, 2008.

RODRIGUES, E. L.; FONSECA, A. da S.; PIRES, P. da S. Aprendizagem baseada em problemas: o significado para discentes de enfermagem. VIII Congresso Nacional de Educação - EDUCERE. Curitiba. 2008. Disponível em http://www.pucpr.br/eventos/educere/ educere2008/anais/pdf/404 915.pdf. Acesso em 20.11.2010.

RODRíGUEZ, V. G. O argumento de autoridade e o valor do pronunciamento do experto. Escola Superior de Advocaica. Ordem dos Advogados do Brasil Seção de São Paulo. Disponível em: http://www2.oabsp.org.br/asp/esa/comunicacao/ esa1.2.3.1.asp?id noticias=31. Acesso em 13.10.2010.

ROHDEN, H. Educação do homem integral. 7. ed. São Paulo: Martin Claret, 1998. RONCA, A. C. C. O modelo de ensino de David Ausubel. In: PENTEADO, W. M. A. (Org.). Psicologia e ensino. São Paulo: Papelivros, 1980.

RONCA, A. C. C., ESCOBAR, V. F. Técnicas pedagógicas: domesticação ou desafio à participação? 3. ed. Petrópolis: Vozes, 1984.

RONCA, P. A. C.; TERZI, C. do A. A aula operatória e a construção do conhecimento. 7. ed. São Paulo: EDESPLAN, 1995.

SACRISTÁN, J. G.; GÓMEZ, A. I. P. Compreender e transformar o ensino. 4. ed. Tradução de Ernani F. da Fonseca Rosa. Porto Alegre: ArtMed, 1998. 
SANT'ANNA, I. M.; MENEGOLLA, M. Didática: aprender a ensinar - técnicas e reflexões pedagógicas para formação de formadores. 7. ed. São Paulo: Loyola, 2002.

SAVIANI, D.. Educação: do senso comum à consciência filosófica. 12. ed. Campinas: Autores Associados, 1996.

SCHMITZ, E. F. Didática moderna: fundamentos. Rio de Janeiro: LTC - Livros Técnicos e Científicos Editora S.A., 1984.

SCHÖN, D. A. Educando o profissional reflexivo: Um novo design para o ensino e aprendizagem. Tradução de Roberto Cataldo Costa. Porto Alegre: Artes Médicas Sul, 2000.

SILVA, A. S.; MAIA, A. da; TEIXEIRA, J. P. Pesquisa em Direito e a superação das escolas-de-um-só. Uma profecia às avessas? In: CARLINI, A.; CERQUEIRA, D. T.; ALMEIDA FILHO, J. C. de A. (Orgs.). 180 anos de Ensino Jurídico no Brasil. Campinas/SP: Millennium, 2008.

SIQUEIRA, J. R. M. de; et al. Aprendizagem baseada em problemas: o que os médicos podem ensinar para os contadores. 9 Congresso USP de Controladoria e Contabilidade. 30 e 31 de julho de 2009. Disponível em: http://www.congressousp.fipecafi.org/artigos92009/187.pdf. Acesso em 02.12.2010.

SHULMAN, L. A aprendizagem Baseada em Problemas (ABP) requer que os estudantes assumam os riscos de expor suas opiniões e ideias. Entrevista. Com Ciência - Revista Eletrônica de Jornalismo Científico, n. 115.10.02.2010. Disponível em: http://www.oei.es/divulgacioncientifica/entrevistas 071.htm. Acesso em 11.01.2011.

SOUSA, S. de O. Aprendizagem baseada em problemas como estratégia para promover a inserção transformadora na sociedade. Acta Scientiarum. Education. Maringá, v. 32, n. 2, p. 237-245, 2010, DOI: 10.4025/actascieduc.v32i2.11170. Disponível em: $\quad$ http://periodicos.uem.br/ojs/index.php/ActaSciEduc/article/ viewFile/11170/11170. Acesso em 20.01.2011. 
SOUSA JUNIOR, J. G. de. Responsabilidade social das Instituições de Ensino Superior. In: $O A B$ ensino jurídico - $O$ futuro da universidade e os cursos de direito: novos caminhos para a formação profissional. Brasília, DF: OAB, Conselho Federal, 2006.

SOUZA, C. A. M. de. As tendências contemporâneas da ideologia e práticas jurídicas. In: ZIMERMAN, D. e COLTRO, A. C. M. (Org.) Aspectos ideológicos na prática jurídica. Campinas: Millennium, 2002.

STRECK, L. L. Hemenêutica jurídica e(m) crise: uma exploração hermenêutica da construção do Direito. 5. ed. Porto Alegre: Livraria do Advogado, 2004.

TAGLIAVINI, J. V. (Org.) A superação do positivismo jurídico no ensino do Direito: uma releitura de Kelsen que possibilitar ir além de um positivismo restrito e já consagrado. Araraquara: Junqueira \& Marin, 2008.

TAVARES, J. Relações interpessoais em uma Escola Reflexiva. In: ALARCÃO, I. Escola reflexiva e nova racionalidade. Porto Alegre: ArtMed, 2001.

UEL - UNIVERSIDADE ESTADUAL DE LONDRINA. Curso de Medicina. Organização Curricular. Disponível em: http://www.uel.br/prograd/catalogocursos/catalogo 2010/organizacao curricular/medicina.pdf. Acesso em 28.12.2010.

VASCONCELOS, M. L. M. C. A formação do professor no Ensino Superior. 2. ed. São Paulo: Pioneira, 2000.

VENANCIO FILHO, A. Das arcadas ao bacharelismo: 150 anos de ensino jurídico no Brasil. São Paulo: Perspectiva, 2004.

WERNECK, H. Ensinamos demais, aprendemos de menos. 19. ed. Petrópolis, RJ: Vozes, 2002.

WOLKMER, A. C. Introdução ao pensamento jurídico crítico. 3. ed. São Paulo: Saraiva, 2001.

. Pluralismo jurídico: fundamentos de uma nova cultura no Direito. São Paulo: Alfa-Omega, 1994. 
ZABALA, A. A prática educativa: como ensinar. Tradução de Ernani F. da F. Rosa. Porto Alegre: ArtMed, 1998.

ZABALZA, M. A. O ensino universitário - seu cenário e seus protagonistas. Tradução de Ernani Rosa. Porto Alegre: ARTMED, 2004.

ZITSCHER, H. C. Metolodogia do ensino jurídico com casos: teoria e prática (com exemplos do Direito do Consumidor e Direito Civil). Apresentação de Cláudia Lima Marques. Belo Horizonte: Del Rey, 1999. 
ANEXO A

MATRIZES CURRICULARES DE 40 (QUARENTA) CURSOS DE DIREITO 
CEAP - CENTRO DO ENSINO SUPERIOR DO AMAPÁ

Disponível em: http://www.ceap.br/v2/grad_direito_matriz.php

Acesso em outubro/2010

\begin{tabular}{|c|c|c|}
\hline SEMESTRE & DISCIPLINA & $\begin{array}{c}\text { CARGA } \\
\text { HORÁRIA }\end{array}$ \\
\hline \multirow[t]{7}{*}{$1^{\mathrm{o}}$} & INTRODUÇÃO AO ESTUDO DO DIREITO & 72 \\
\hline & SOCIOLOGIA GERAL E JURÍDICA & 72 \\
\hline & CIÊNCIA POLÍTICA E TEORIA DO ESTADO & 72 \\
\hline & PORTUGUÊS E ARGUMENTAÇÃO JURÍDICA & 72 \\
\hline & DIREITOS HUMANOS E CIDADANIA & 36 \\
\hline & ATIVIDADES COMPLEMENTARES & 68 \\
\hline & PSICOLOGIA GERAL E JURÍDICA & 36 \\
\hline \multirow{6}{*}{$2^{\circ}$} & DIREITO AMBIENTAL & 72 \\
\hline & TEORIA DA CONSTITUIÇÃO & 72 \\
\hline & METOD. DO TRAB. ACADÊMICO COM INICIAÇÃO CIENTÍFICA & 72 \\
\hline & TEORIA GERAL DO DIREITO CIVIL & 72 \\
\hline & ATIVIDADES COMPLEMENTARES & 68 \\
\hline & TEORIA GERAL DO PROCESSO & 72 \\
\hline \multirow[t]{7}{*}{$3^{\circ}$} & FILOSOFIA GERAL E JURÍDICA & 36 \\
\hline & DIREITO CONSTITUCIONAL & 72 \\
\hline & DIREITO CIVIL - OBRIGAÇÕES & 72 \\
\hline & TEORIA GERAL DO DIREITO PENAL & 72 \\
\hline & DIREITO PROCESSUAL CIVIL - PROCESSO DE CONHECIMENTO & 72 \\
\hline & ECON. REGIONAL, MEIO AMBIENTE E POLÍTICAS PÚBLICAS & 36 \\
\hline & ATIVIDADES COMPLEMENTARES & 68 \\
\hline \multirow{7}{*}{$4^{\circ}$} & DIREITO ADMINISTRATIVO & 72 \\
\hline & DIREITO CIVIL - CONTRATOS & 72 \\
\hline & DIREITO PENAL - DA AÇÃO PENAL À EXTINÇÃO DA PUNIBILIDADE & 72 \\
\hline & DIREITO DA CRIANÇA E DO ADOLESCENTE & 36 \\
\hline & DIREITO PROC. CIVIL - DA SUSP. E DA EXTIN. DO PROCESSO & 72 \\
\hline & DIREITO PROCESSUAL CONSTITUCIONAL & 36 \\
\hline & ATIVIDADES COMPLEMENTARES & 68 \\
\hline \multirow[t]{7}{*}{$5^{\circ}$} & ATIVIDADES COMPLEMENTARES & 68 \\
\hline & ANTROPOLOGIA GERAL E JURÍDICA & 36 \\
\hline & DIREITO CIVIL - DIREITOS REAIS & 72 \\
\hline & DIREITO PENAL - DOS CRIMES C/PESS AOS CRIMES C/DIGN SEXUAL & 72 \\
\hline & DIREITO PROCESSUAL CIVIL - PROC CAUTELAR E PROCED ESPECIAIS & 72 \\
\hline & DIREITO INDIVIDUAL E COLETIVO DO TRABALHO & 72 \\
\hline & LICITAÇÕES E CONTRATOS & 36 \\
\hline \multirow[t]{7}{*}{$6^{\circ}$} & DIREITO PROCESSUAL DO TRABALHO & 72 \\
\hline & DIREITO CIVIL - FAMÍLIA & 72 \\
\hline & DIREITO PROCESSUAL CIVIL - RECURSOS E PROC DE EXECUÇÃO & 72 \\
\hline & DIREITO PENAL - DOS CRIMES C/FAMÍLIA AOS CRIMES C/ADM PÚBLIC & 72 \\
\hline & DIREITO DAS MINORIAS & 36 \\
\hline & PRÁTICA JURÍDICA CONSTITUCIONAL E ADMINISTRATIVA & 36 \\
\hline & ESTÁGIO CURRICULAR SUPER VISIONADO & 72 \\
\hline \multirow[t]{7}{*}{$7^{\circ}$} & DIREITO FINANCEIRO & 36 \\
\hline & DIREITO CIVIL - SUCESSÕES & 72 \\
\hline & LEGISLAÇÃO PENAL ESPECIAL & 72 \\
\hline & ESTÁGIO CURRICULAR SUPER VISIONADO & 72 \\
\hline & MÉTODOS ALTERNATIVOS PARA A SOLUÇÃO DE CONFLITOS & 72 \\
\hline & PRÁTICA JURÍDICA TRABALHISTA & 36 \\
\hline & DIREITO EMPRESARIAL - PARTE GERAL E SOCIEDADES & 72 \\
\hline \multirow[t]{7}{*}{$8^{\circ}$} & DIREITO EMPRESARIAL - TÍTULOS DE CRÉDITO E FALÊNCIA & 72 \\
\hline & DIREITO PROCESSUAL PENAL - PARTE GERAL & 72 \\
\hline & SISTEMA CONSTITUCIONAL TRIBUTÁRIO & 72 \\
\hline & DIREITO AMBIENTAL URBANO & 36 \\
\hline & METODOLOGIA DA PESQUISA EM DIREITO & 72 \\
\hline & PRÁTICA JURÍDICA CÍVEL E EMPRESARIAL & 36 \\
\hline & ESTÁGIO CURRICULAR SUPERVISIONADO & 72 \\
\hline \multirow[t]{4}{*}{$9^{\circ}$} & HISTORIA DO DIREITO & 36 \\
\hline & DIREITO INTERNACIONAL & 72 \\
\hline & DIREITO TRIBUTÁRIO & 72 \\
\hline & OPTATIVA I & 36 \\
\hline
\end{tabular}




\begin{tabular}{|l|l|c|}
\hline & DIREITO PROCESSUAL PENAL - PROCESSOS E PROCEDIMENTOS & 72 \\
\hline & TRABALHO DE CURSO & 36 \\
\hline & PRÁTICA JURÍDICA TRIBUTÁRIA & 36 \\
\hline & ESTÁGIO CURRICULAR SUPERVISIONADO & 72 \\
\hline & & 36 \\
\hline $10^{\circ}$ & OPTATIVA II & 72 \\
\hline & DIREITO DA SEGURIDADE SOCIAL & 72 \\
\hline & TUTELA JUDICIAL DO MEIO AMBIENTE & 36 \\
\hline & DIREITO DO CONSUMIDOR & 72 \\
\hline & PRÁTICA JURÍDICA CRIMINAL & 72 \\
\hline & ESTÁGIO CURRICULAR SUPERVISIONADO & 72 \\
\hline
\end{tabular}

CESMAC - CENTRO DE ESTUDOS SUPERIORES DE MACEIÓ

Disponível em: http://www.fejal.com.br/faculdades/grade.php?c=14

Acesso em outubro/2010

\begin{tabular}{|c|c|c|}
\hline PERÍODO & DISCIPLINA & $\begin{array}{c}\text { CARGA } \\
\text { HORÁRIA }\end{array}$ \\
\hline \multirow[t]{6}{*}{$1^{\circ}$} & FILOSOFIA GERAL E JURÍDICA & 80 \\
\hline & FUNDAMENTOS DAS CIÊNCIAS SOCIAIS & 40 \\
\hline & HISTÓRIA DO DIREITO & 80 \\
\hline & INTRODUÇÃO AO ESTUDO DO DIREITO I & 80 \\
\hline & PORTUGUES FORENSE & 40 \\
\hline & TEORIA DO ESTADO DEMOCRÁTICO & 40 \\
\hline \multirow[t]{6}{*}{$2^{\circ}$} & INTRODUÇÃO AO ESTUDO DO DIREITO II & 80 \\
\hline & METODOLOGIA DA PESQUISA JURÍDICA & 40 \\
\hline & PSICOLOGIA JURÍDICA & 40 \\
\hline & SOCIOLOGIA DAS INSTITUIÇÕES JURÍDICAS & 80 \\
\hline & TEORIA DA CONSTITUIÇÃO & 80 \\
\hline & TEORIA ECONÔMICA APLICADA AO DIREITO & 40 \\
\hline \multirow[t]{5}{*}{$3^{\circ}$} & DIREITO CIVIL I & 80 \\
\hline & DIREITO CONSTITUCIONAL I & 80 \\
\hline & DIREITO PENAL I & 120 \\
\hline & HERMENÊUTICA JURÍDICA & 40 \\
\hline & TEORIA GERAL DO PROCESSO & 80 \\
\hline \multirow[t]{5}{*}{$4^{\circ}$} & DIREITO CIVIL II & 80 \\
\hline & DIREITO CONSTITUCIONAL II & 80 \\
\hline & DIREITO INDIVIDUAL DO TRABALHO & 80 \\
\hline & DIREITO PENAL II & 80 \\
\hline & DIREITO PROCESSUAL CIVIL I & 80 \\
\hline \multirow[t]{6}{*}{$5^{\circ}$} & DIREITO CIVIL III & 80 \\
\hline & DIREITO COLETIVO DO TRABALHO & 80 \\
\hline & DIREITO CONSTITUCIONAL III & 40 \\
\hline & DIREITO DO CONSUMIDOR & 40 \\
\hline & DIREITO PENAL III & 80 \\
\hline & DIREITO PROCESSUAL CIVIL II & 80 \\
\hline \multirow[t]{5}{*}{$6^{\circ}$} & DIREITO CIVIL IV & 80 \\
\hline & DIREITO PENAL IV & 80 \\
\hline & DIREITO PROCESSUAL CIVIL III & 80 \\
\hline & DIREITO PROCESSUAL DO TRABALHO & 80 \\
\hline & DIREITO PROCESSUAL PENAL I & 80 \\
\hline \multirow[t]{5}{*}{$7^{\circ}$} & DIREITO CIVIL V & 80 \\
\hline & DIREITO EMPRESARIAL I & 80 \\
\hline & DIREITO PROCESSUAL CIVIL IV & 80 \\
\hline & DIREITO PROCESSUAL PENAL II & 80 \\
\hline & DIREITO TRIBUTÁRIO I & 80 \\
\hline \multirow[t]{7}{*}{$8^{\circ}$} & DIREITO ADMINISTRATIVO I & 80 \\
\hline & DIREITO CIVIL VI & 80 \\
\hline & DIREITO EMPRESARIAL II & 80 \\
\hline & DIREITO INTERNACIONAL PÚBLICO & 40 \\
\hline & DIREITO PROCESSUAL PENAL III & 40 \\
\hline & DIREITO TRIBUTÁRIO II & 40 \\
\hline & PRÁTICA DE TRABALHO DE CONCLUSÃO DE CURSO & 40 \\
\hline $9^{\circ}$ & CRIMINOLOGIA & 40 \\
\hline
\end{tabular}




\begin{tabular}{|l|l|r|}
\hline & DIREITO ADMINISTRATIVO II & 80 \\
\hline & DIREITO CIVIL VII & 80 \\
\hline & DIREITO DA INFÂNCIA E DA JUVENTUDE & 40 \\
\hline & DIREITO INTERNACIONAL PRIVADO & 40 \\
\hline & LABORATÓRIO DE PRÁTICA FORENSE CIVIL I & 40 \\
\hline & LABORATÓRIO DE PRÁTICA FORENSE PENAL I & 40 \\
\hline & MEDICINA LEGAL & 40 \\
\hline & & 40 \\
\hline $10^{\circ}$ & CRIMINALÍSTICA & 40 \\
\hline & DIREITO AMBIENTAL & 40 \\
\hline & DIREITO PREVIDENCIÁRIO & 80 \\
\hline & LABORATÓRIO DE PRÁTICA FORENSE CIVIL II & 80 \\
\hline & LABORATÓRIO DE PRÁTICA FORENSE PENAL II & 40 \\
\hline
\end{tabular}

CESUC - CENTRO DE ENSINO SUPERIOR DE CATALÃO

Disponível em: http://www.cesuc.br/portal/?secao=conteudo\&id=mtg

Acesso em outubro/2010

\begin{tabular}{|c|c|c|}
\hline PERÍODO & DISCIPLINA & $\begin{array}{c}\text { CARGA } \\
\text { HORÁRIA }\end{array}$ \\
\hline \multirow[t]{5}{*}{$1^{\circ}$} & INTRODUÇÃO E HISTORIA DO DIREITO & 60 \\
\hline & FILOSOFIA & 60 \\
\hline & PSICOLOGIA & 60 \\
\hline & CIÊNCIA POLÍTICA & 60 \\
\hline & METODOLOGIA CIENTÍFICA & 60 \\
\hline \multirow[t]{5}{*}{$2^{\circ}$} & COMUNICAÇÃO E EXPRESSÃO & 60 \\
\hline & SOCIOLOGIA E ANTROPOLOGIA & 60 \\
\hline & DIREITO CIVIL I & 60 \\
\hline & DIREITO PENAL I & 60 \\
\hline & DIREITO CONSTITUCIONAL I & 60 \\
\hline \multirow[t]{5}{*}{$3^{\circ}$} & DIREITO CONSTITUCIONAL II & 60 \\
\hline & DIREITO CIVIL II & 60 \\
\hline & DIREITO PENAL II & 60 \\
\hline & ECONOMIA E GESTÃO & 60 \\
\hline & TEORIA GERAL DO PROCESSO & 60 \\
\hline \multirow[t]{5}{*}{$4^{\circ}$} & DIREITO CIVIL III & 60 \\
\hline & DIREITO PENAL III & 60 \\
\hline & DIREITO ADMINISTRATIVO I & 60 \\
\hline & DIREITO PROCESSUAL PENAL I & 60 \\
\hline & DIREITO PROCESSUAL CIVIL I & 60 \\
\hline \multirow[t]{5}{*}{$5^{\circ}$} & DIREITO CIVIL IV & 60 \\
\hline & DIREITO PENAL IV & 60 \\
\hline & DIREITO ADMINISTRATIVO II & 60 \\
\hline & DIREITO PROCESSUAL PENAL II & 60 \\
\hline & DIREITO PROCESSUAL CIVIL II & 60 \\
\hline \multirow[t]{5}{*}{$6^{\circ}$} & DIREITO CIVIL V & 60 \\
\hline & DIREITO PENAL V & 60 \\
\hline & DIREITO PROCESSUAL CIVIL III & 60 \\
\hline & DIREITO PROCESSUAL PENAL III & 60 \\
\hline & DIREITO EMPRESARIAL I & 60 \\
\hline \multirow[t]{6}{*}{$7^{\circ}$} & DIREITO CIVIL VI & 60 \\
\hline & DIREITO EMPRESARIAL II & 60 \\
\hline & DIREITO PROCESSUAL CIVIL IV & 60 \\
\hline & DIREITO PROCESSUAL PENAL IV & 60 \\
\hline & DIREITO DO TRABALHO I & 60 \\
\hline & ESTAGIO I & 120 \\
\hline \multirow[t]{6}{*}{$8^{\circ}$} & DIREITO CIVIL VII & 60 \\
\hline & DIREITO EMPRESARIAL III & 60 \\
\hline & DIREITO DIFUSOS E COLETIVOS I & 60 \\
\hline & ARGUMENTAÇÃO E HERMENÊUTICA & 60 \\
\hline & DIREITO DO TRABALHO II & 60 \\
\hline & ESTAGIO II & 120 \\
\hline $9^{\circ}$ & DIREITO ECONÔMICO E FINANCEIRO & 60 \\
\hline
\end{tabular}




\begin{tabular}{|l|l|c|}
\hline & DIREITO PROCESSUAL TRABALHISTA & 60 \\
\hline & TÓPICOS EMERGENTES I & 60 \\
\hline & DIREITO INTERNACIONAL PÚBLICO E PRIVADO & 60 \\
\hline & DIREITO DIFUSOS E COLETIVOS II & 60 \\
\hline & ESTAGIO III & 80 \\
\hline & & 60 \\
\hline $10^{\circ}$ & DIREITO TRIBUTÁRIO & 60 \\
\hline & TÓPICOS EMERGENTES II & 60 \\
\hline & ÉTICA & 60 \\
\hline & DIREITO PREVIDENCIÁRIO & 60 \\
\hline & TÉCNICAS DE PRATICAS JURÍDICAS & 80 \\
\hline & ESTAGIO IV & \\
\hline & & 200 \\
\hline & ATIVIDADES COMPLEMENTARES* & 200 \\
\hline
\end{tabular}

FACCAR - FACULDADE PARANAENSE

Disponível em: http://www.faccar.com.br/dir.php

Acesso em outubro/2010

\begin{tabular}{|c|c|c|}
\hline SÉRIE & DISCIPLINA & $\begin{array}{c}\text { CARGA } \\
\text { HORÁRIA }\end{array}$ \\
\hline \multirow[t]{8}{*}{$1^{\circ}$} & CIÊNCIA POLÍTICA E TEORIA GERAL DO ESTADO & 68 \\
\hline & DIREITO CONSTITUCIONAL & 136 \\
\hline & ECONOMIA APLICADA AO DIREITO & 68 \\
\hline & FILOSOFIA GERAL E JURÍDICA & 68 \\
\hline & INTRODUÇÃO AO ESTUDO DO DIREITO & 136 \\
\hline & METODOLOGIA E LINGUAGEM JURÍDICA & 68 \\
\hline & SOCIOLOGIA GERAL E JURÍDICA & 68 \\
\hline & TEORIA GERAL DO DIREITO & 68 \\
\hline \multirow[t]{8}{*}{$2^{\circ}$} & DIREITO AMBIENTAL E URBANÍSTICO & 68 \\
\hline & DIREITO CIVIL I & 136 \\
\hline & DIREITO EMPRESARIAL I & 68 \\
\hline & DIREITO INTERNACIONAL & 68 \\
\hline & DIREITO PENAL I & 136 \\
\hline & ÉTICA E DIREITOS HUMANOS & 68 \\
\hline & PSICOLOGIA APLICADA AO DIREITO & 68 \\
\hline & TEORIA GERAL DO PROCESSO & 68 \\
\hline \multirow[t]{6}{*}{$3^{\circ}$} & DIREITO CIVIL II & 136 \\
\hline & DIREITO DO TRABALHO & 136 \\
\hline & DIREITO FINANCEIRO E TRIBUTÁRIO & 68 \\
\hline & DIREITO PENAL II & 68 \\
\hline & DIREITO PROCESSUAL CIVIL I & 136 \\
\hline & DIREITO PROCESSUAL PENAL I & 136 \\
\hline \multirow[t]{9}{*}{$4^{\circ}$} & DIREITO ADMINISTRATIVO & 68 \\
\hline & DIREITO CIVIL III & 136 \\
\hline & DIREITO PENAL III & 68 \\
\hline & DIREITO PROCESSUAL CIVIL II & 136 \\
\hline & DIREITO PROCESSUAL DO TRABALHO & 68 \\
\hline & DIREITO PROCESSUAL PENAL II & 68 \\
\hline & ESTÁGIO I - LABORATÓRIO DE PRÁTICA JURÍDICA I & 68 \\
\hline & ESTÁGIO II - SERVIÇO DE ASSISTÊNCIA JUDICIÁRIA I & 68 \\
\hline & TRABALHO DE CURSO I & 68 \\
\hline \multirow[t]{11}{*}{$5^{\circ}$} & DIREITO AGRÁRIO & 68 \\
\hline & DIREITO CIVIL IV & 68 \\
\hline & DIREITO DA SEGURIDADE SOCIAL E INFORTUNÍSTICA & 68 \\
\hline & DIREITO DO CONSUMIDOR & 68 \\
\hline & DIREITO EMPRESARIAL II & 68 \\
\hline & DIREITO PROCESSUAL CIVIL III & 68 \\
\hline & DIREITO PROCESSUAL CONSTITUCIONAL, ADMINISTRATIVO E TRIBUTÁRIO & 68 \\
\hline & ESTÁGIO III - LABORATÓRIO DE PRÁTICA JURÍDICA II & 68 \\
\hline & ESTÁGIO IV - SER VIÇO DE ASSISTÊNCIA JUDICIÁRIA II & 68 \\
\hline & ÉTICA PROFISSIONÁL E ORGANIZAÇÃO JUDICIÁRIA & 68 \\
\hline & TRABALHO DE CURSO II & 68 \\
\hline
\end{tabular}


FACULDADES DOCTUM

Disponível em: http://www.doctumtec.com.br/doctum/unidades/teofilootoni/graduacao/direito/dados/grade

Acesso em outubro/2010

\begin{tabular}{|c|c|c|}
\hline PERÍODO & DISCIPLINA & $\begin{array}{c}\text { CARGA } \\
\text { HORÁRIA }\end{array}$ \\
\hline \multirow[t]{6}{*}{$1^{\circ}$} & CIÊNCIA POLÍTICA & 36 \\
\hline & METODOLOGIA DO TRABALHO CIENTÍFICO I & 36 \\
\hline & ANTROPOLOGIA SOCIAL & 72 \\
\hline & INTRODUÇÃO AO ESTUDO DO DIREITO I & 72 \\
\hline & ECONOMIA POLÍTICA & 72 \\
\hline & LÍNGUA PORTUGUESA I & 72 \\
\hline \multirow{7}{*}{$2^{\circ}$} & TEORIA GERAL DO ESTADO & 36 \\
\hline & FILOSOFIA GERAL & 72 \\
\hline & TEORIA DA CONSTITUIÇÃO & 72 \\
\hline & INTRODUÇÃO AO ESTUDO DO DIREITO II & 36 \\
\hline & LÍNGUA PORTUGUESA II & 36 \\
\hline & HISTÓRIA DO DIREITO & 36 \\
\hline & DIREITO CIVIL I & 72 \\
\hline \multirow[t]{5}{*}{$3^{\circ}$} & SOCIOLOGIA JURÍDICA & 72 \\
\hline & DIREITO CIVIL II & 72 \\
\hline & DIREITO CONSTITUCIONAL I & 72 \\
\hline & TEORIA GERAL DO PROCESSO & 72 \\
\hline & DIREITO PENAL I & 72 \\
\hline \multirow{5}{*}{$4^{\circ}$} & DIREITO EMPRESARIAL I & 72 \\
\hline & DIREITO CIVIL III & 72 \\
\hline & DIREITO PROCESSUAL CIVIL I & 72 \\
\hline & DIREITO CONSTITUCIONAL II & 72 \\
\hline & DIREITO PENAL II & 72 \\
\hline \multirow{5}{*}{$5^{\circ}$} & DIREITO EMPRESARIAL II & 72 \\
\hline & DIREITO CIVIL IV & 72 \\
\hline & DIREITO ADMINISTRATIVO I & 72 \\
\hline & DIREITO PENAL III & 72 \\
\hline & DIREITO PROCESSUAL CIVIL II & 72 \\
\hline \multirow[t]{6}{*}{$6^{\circ}$} & DIREITO ADMINISTRATIVO II & 72 \\
\hline & DIREITO CIVIL V & 72 \\
\hline & DIREITO AMBIENTAL I & 36 \\
\hline & DIREITO EMPRESARIAL III & 36 \\
\hline & DIREITO PENAL IV & 72 \\
\hline & DIREITO PROCESSUAL CIVIL III & 72 \\
\hline \multirow{7}{*}{$7^{\circ}$} & DIREITO CIVIL VI & 72 \\
\hline & FILOSOFIA DO DIREITO & 72 \\
\hline & DIREITO DO TRABALHO I & 72 \\
\hline & DIREITO PROCESSUAL PENAL I & 72 \\
\hline & DIREITO AMBIENTAL II & 36 \\
\hline & DIREITO PROCESSUAL CIVIL IV & 36 \\
\hline & PRÁTICA JURÍDICA SIMULADA I & 80 \\
\hline \multirow[t]{7}{*}{$8^{\circ}$} & RELAÇÕES FAMILIARES I & 36 \\
\hline & DIREITO CIVIL VII & 72 \\
\hline & DIREITO PROCESSUAL PENAL II & 72 \\
\hline & DIREITO DO TRABALHO II & 72 \\
\hline & DIREITO TRIBUTÁRIO I & 72 \\
\hline & DIREITO ECONÔMICO & 36 \\
\hline & PRÁTICA JURÍDICA SIMULADA II & 80 \\
\hline \multirow[t]{8}{*}{$9^{\circ}$} & DIREITO DO CONSUMIDOR & 36 \\
\hline & RELAÇÕES FAMILIARES II & 36 \\
\hline & DIREITO PROCESSUAL DO TRABALHO & 72 \\
\hline & PRÁTICA JURÍDICA REAL I & 80 \\
\hline & DIREITO INTERNACIONAL & 72 \\
\hline & DEONTOLOGIA JURÍDICA & 72 \\
\hline & MONOGRAFIA I & 36 \\
\hline & DIREITO TRIBUTÁRIO II & 36 \\
\hline
\end{tabular}




\begin{tabular}{|l|l|c|}
\hline $10^{\circ}$ & DIREITO MUNICIPAL E URBANÍSTICO & 36 \\
\hline & MEDICINA LEGAL E PSIQUIATRIA FORENSE & 36 \\
\hline & DIREITO ELEITORAL & 36 \\
\hline & DIREITO PREVIDENCIÁRIO & 36 \\
\hline & PRÁTICA JURÍDICA REAL II & 80 \\
\hline & MONOGRAFIA II & 36 \\
\hline & ARBITRAGEM JURÍDICA & 36 \\
\hline & INFORMÁTICA JURÍDICA & 36 \\
\hline & PSICOLOGIA JURÍDICA & 36 \\
\hline & DIREITO DA CRIANÇA E ADOLESCENTE & 36 \\
\hline
\end{tabular}

FAG FACULDADE ASSIS GURGACZ

Disponível em: http:// http://www.fag.edu.br/graduacao/direito/arquivos/grade2006.pdf

Acesso em outubro/2010

\begin{tabular}{|c|c|c|}
\hline SEMESTRE & DISCIPLINA & $\begin{array}{c}\text { CARGA } \\
\text { HORÁRIA }\end{array}$ \\
\hline \multirow[t]{7}{*}{$1^{\circ}$} & INTRODUÇÃO AO DIREITO & 72 \\
\hline & TEORIA GERAL DO DIREITO PRIVADO & 36 \\
\hline & FILOSOFIA E FILOSOFIA DO DIREITO & 72 \\
\hline & ANTROPOLOGIA DO DIREITO & 36 \\
\hline & HISTÓRIA DO DIREITO & 36 \\
\hline & LÍNGUA PORTUGUESA & 72 \\
\hline & METODOLOGIA CIENTÍFICA & 36 \\
\hline \multirow[t]{6}{*}{$2^{\circ}$} & DIREITO CIVIL I - PARTE GERAL I & 72 \\
\hline & DIREITO PENAL I - PARTE GERAL I & 72 \\
\hline & CIÊNCIA POLÍTICA E TEORIA DO ESTADO & 72 \\
\hline & SOCIOLOGIA E SOCIOLOGIA DO DIREITO & 72 \\
\hline & ECONOMIA POLÍTICA & 36 \\
\hline & INTRODUÇÃO AO ESTUDO DAS RELAÇÕES INTERNACIONAIS & 36 \\
\hline \multirow[t]{6}{*}{$3^{\circ}$} & DIREITO CIVIL II - PARTE GERAL II & 72 \\
\hline & DIREITO PENAL II - PARTE GERAL II & 72 \\
\hline & DIREITO CONSTITUCIONAL I & 72 \\
\hline & DIREITO INTERNACIONAL PÚBLICO & 72 \\
\hline & DIREITO ECONÔMICO & 36 \\
\hline & PSICOLOGIA DO DIREITO & 36 \\
\hline \multirow[t]{6}{*}{$4^{\circ}$} & DIREITO DAS OBRIGAÇÕES & 72 \\
\hline & DIREITO PENAL III - PARTE ESPECIAL I & 72 \\
\hline & DIREITO CONSTITUCIONAL II & 72 \\
\hline & TEORIA GERAL DO PROCESSO & 72 \\
\hline & DIREITO DA CONCORRÊNCIA & 36 \\
\hline & HERMENÊUTICA E APLICAÇÃO DO DIREITO & 36 \\
\hline \multirow{6}{*}{$5^{\circ}$} & DIREITO DAS COISAS I & 72 \\
\hline & TEORIA GERAL DOS CONTRATOS & 36 \\
\hline & DIREITO PENAL IV - PARTE ESPECIAL II & 72 \\
\hline & DIREITO PROCESSUAL PENAL I & 72 \\
\hline & DIREITO PROCESSUAL CIVIL I - PROCESSO DE CONHECIMENTO & 72 \\
\hline & DIREITO AMBIENTAL & 36 \\
\hline \multirow[t]{6}{*}{$6^{\circ}$} & DIREITO DAS COISAS II & 36 \\
\hline & CONTRATOS EM ESPÉCIE & 72 \\
\hline & LEGISLAÇÃO PENAL EXTRAVAGANTE I & 36 \\
\hline & DIREITO DO TRABALHO I & 72 \\
\hline & DIREITO PROCESSUAL CIVIL II & 72 \\
\hline & DIREITO PROCESSUAL PENAL II & 72 \\
\hline \multirow[t]{9}{*}{$7^{\circ}$} & DIREITO DE FAMÍLIA & 72 \\
\hline & DIREITO ADMINISTRATIVO I & 72 \\
\hline & DIREITO DO TRABALHO II & 72 \\
\hline & DIREITO PROCESSUAL CIVIL III - EXECUÇÕES & 72 \\
\hline & DIREITO PROCESSUAL PENAL III & 36 \\
\hline & LEGISLAÇÃO PENAL EXTRAVAGANTE II & 36 \\
\hline & PRÁTICA SIMULADA DE PROCESSO CIVIL I - (ESTÁGIO SUPERVISIONADO ) & 36 \\
\hline & PRÁTICA SIMULADA DE PROCESSO PENAL I - (ESTÁGIO SUPER VISIONADO ) & 36 \\
\hline & PRÁTICA REAL I - (ESTÁGIO SUPER VISIONADO ) & 36 \\
\hline \multirow[t]{3}{*}{$8^{\circ}$} & DIREITO DAS SUCESSÕES & 72 \\
\hline & DIREITO EMPRESARIAL I & 72 \\
\hline & DIREITO ADMINISTRATIVO II & 72 \\
\hline
\end{tabular}




\begin{tabular}{|c|c|c|}
\hline & DIREITO PROCESSUAL CIVIL IV & 72 \\
\hline & DIREITO CONSTITUCIONAL PROCESSUAL & 36 \\
\hline & DIREITO PROCESSUAL DO TRABALHO I & 36 \\
\hline & PRÁTICA SIMULADA DE PROCESSO CIVIL II - (ESTÁGIO SUPERVISIONADO) & 36 \\
\hline & PRÁTICA SIMULADA DE PROCESSO PENAL II - (ESTÁGIO SUPERVISIONADO) & 36 \\
\hline & PRÁTICA REAL II - (ESTÁGIO SUPERVISIONADO ) & 36 \\
\hline \multirow[t]{12}{*}{$9^{\circ}$} & TRABALHO DE CURSO I & 36 \\
\hline & DIREITO EMPRESARIAL II & 72 \\
\hline & DIREITO TRIBUTÁRIO I & 72 \\
\hline & DIREITO INTERNACIONAL PRIVADO I & 36 \\
\hline & DIREITO PROCESSUAL CIVIL V - PROCEDIMENTOS ESPECIAIS & 36 \\
\hline & DIREITO PROCESSUAL DO TRABALHO II & 36 \\
\hline & DIREITO DO CONSUMIDOR & 36 \\
\hline & PROPRIEDADE INTELECTUAL & 36 \\
\hline & SEMINÁRIOS TEMÁTICOS I & 36 \\
\hline & PRÁTICA SIMULADA DE PROCESSO CIVIL III (ESTÁGIO SUPERVISIONADO) & 36 \\
\hline & PRÁTICA SIMULADA DO PROCESSO TRABALHO I (ESTÁGIO SUPERVISIONADO) & 36 \\
\hline & PRÁTICA REAL III (ESTÁGIO SUPER VISIONADO) & 36 \\
\hline \multirow[t]{12}{*}{$10^{\circ}$} & TRABALHO DE CURSO II & 36 \\
\hline & DIREITO EMPRESARIAL III & 72 \\
\hline & DIREITO TRIBUTÁRIO II & 72 \\
\hline & DIREITO INTERNACIONAL PRIVADO II & 36 \\
\hline & RESPONSABILIDADE CIVIL & 36 \\
\hline & DIREITO ADUANEIRO & 36 \\
\hline & ÉTICA GERAL E DAS PROFISSÕES JURÍDICAS & 36 \\
\hline & SEMINÁRIOS TEMÁTICOS II & 36 \\
\hline & SEMINÁRIOS TEMÁTICOS III & 36 \\
\hline & PRÁTICA SIMULADA DE PROCESSO CIVIL IV (ESTÁGIO SUPERVISIONADO) & 36 \\
\hline & PRÁTICA SIMULADA DO PROCESSO TRABALHO II (ESTÁGIO SUPERVISIONADO) & 36 \\
\hline & PRÁTICA REAL IV (ESTÁGIO SUPERVISIONADO) & 36 \\
\hline
\end{tabular}

FARN - FACULDADE NATALENSE PARA O DESENVOLVIMENTO DO RIO GRANDE DO NORTE

Disponível em: http://www.farn.br/2011/cursos/grades/grade_direito.pdf

Acesso em outubro/2010

\begin{tabular}{|c|c|c|}
\hline PERÍODO & DISCIPLINA & $\begin{array}{c}\text { CARGA } \\
\text { HORÁRIA }\end{array}$ \\
\hline \multirow[t]{5}{*}{$1^{\mathrm{o}}$} & INTRODUÇÃO AO ESTUDO DO DIREITO I & 60 \\
\hline & INTRODUÇÃO À ECONOMIA POLÍTICA & 60 \\
\hline & INTRODUÇÃO ÀS CIÊNCIAS SOCIAIS (SOCIOLOGIA E ANTROPOLOGIA) & 72 \\
\hline & HISTÓRIA DO DIREITO & 72 \\
\hline & LÍNGUA PORTUGUESA & 60 \\
\hline \multirow[t]{6}{*}{$2^{\circ}$} & INTRODUÇÃO AO ESTUDO DO DIREITO II & 60 \\
\hline & INTRODUÇÃO À CIÊNCIA POLÍTICA E À TEORIA DO ESTADO & 60 \\
\hline & SOCIOLOGIA JURÍDICA & 60 \\
\hline & INSTITUTOS DE DIREITO ROMANO & 36 \\
\hline & FILOSOFIA GERAL E TEORIA DO CONHECIMENTO & 72 \\
\hline & LÓGICA E TÉCNICAS DE ARGUMENTAÇÃO & 36 \\
\hline \multirow[t]{6}{*}{$3^{\circ}$} & TEORIA GERAL DO PROCESSO & 72 \\
\hline & DIREITO CONSTITUCIONAL I (TEORIA DA CONSTITUIÇÃO) & 36 \\
\hline & DIREITO CIVIL I (TEORIA GERAL DO DIREITO CIVIL) & 60 \\
\hline & HERMENÊUTICA JURÍDICA & 60 \\
\hline & DIREITO PENAL I (TEORIA GERAL I) & 72 \\
\hline & ÉTICA I (TEORIA GERAL) & 36 \\
\hline \multirow[t]{6}{*}{$4^{\circ}$} & DIREITO CONSTITUCIONAL II (D. FUNDAMENTAL E ORGAN. DO ESTADO) & 36 \\
\hline & DIREITO PROCESSUAL CIVIL I (PROCESSO DE CONHECIMENTO) & 72 \\
\hline & DIREITO CIVIL II (OBRIGAÇÕES) & 60 \\
\hline & FILOSOFIA DO DIREITO & 60 \\
\hline & DIREITO PENAL II (TEORIA GERAL II) & 72 \\
\hline & METODOLOGIA DA PESQUISA JURÍDICA & 36 \\
\hline \multirow[t]{6}{*}{$5^{\circ}$} & DIREITO CONSTITUCIONAL III (ORGANIZAÇÃO DOS PODERES) & 36 \\
\hline & DIREITO PROCESSUAL CIVIL II (RECURSOS) & 60 \\
\hline & DIREITO PENAL III (CRIMES EM ESPÉCIE) & 72 \\
\hline & DIREITO CIVIL III (TEORIA GERAL DOS CONTRATOS) & 36 \\
\hline & DIREITO ELEITORAL & 60 \\
\hline & PSICOLOGIA APLICADA AO DIREITO & 60 \\
\hline
\end{tabular}




\begin{tabular}{|c|c|c|}
\hline $6^{\circ}$ & DIREITO CONSTITUCIONAL IV (PROCESSO CONSTITUCIONAL) & 36 \\
\hline & DIREITO PROCESSUAL PENAL I & 60 \\
\hline & DIREITO CIVIL IV ( CONTRATOS EM ESPÉCIE) & 72 \\
\hline & DIREITO PROCESSUAL CIVIL III (PROCESSO DE EXECUÇÃO) & 60 \\
\hline & DIREITO DO CONSUMIDOR & 36 \\
\hline & DIREITO DO TRABALHO I (TEORIA GERAL) & 72 \\
\hline & PRÁTICA JURÍDICA I (PRÁTICA CIVIL E NOTARIAL) & 90 \\
\hline $7^{\circ}$ & DIREITO CIVIL V (FAMÍLIA) & 60 \\
\hline & DIREITO ADMINISTRATIVO I & 72 \\
\hline & DIREITO PROCESSUAL CIVIL IV (PROCESSO CAUTELAR) & 60 \\
\hline & DIREITO DO TRABALHO II (CONTRATOS) & 72 \\
\hline & DIREITO PROCESSUAL PENAL II & 60 \\
\hline & PRÁTICA JURÍDICA II (PRÁTICA PENAL) & 60 \\
\hline $8^{\circ}$ & DIREITO DO TRABALHO III (DIREITO COLETIVO) & 36 \\
\hline & DIREITO ADMINISTRATIVO II & 60 \\
\hline & DIREITO CIVIL VI ( DIREITOS REAIS) & 60 \\
\hline & DIREITO DA CRIANÇA E ADOLESCENTE & 36 \\
\hline & DIREITO PROCESSUAL CIVIL V (PROCEDIMENTOS ESPECIAIS) & 60 \\
\hline & DIREITO INTERNACIONAL PUBLICO & 60 \\
\hline & PRÁTICA JURÍDICA III (PRÁTICA TRABALHISTA) & 72 \\
\hline $8^{\circ}$ & DIREITO CIVIL VII (SUCESSÕES) & 60 \\
\hline & DIREITO EMPRESARIAL I (DIREITO DA EMPRESA) & 72 \\
\hline & DIREITO FINANCEIRO E TRIBUTÁRIO & 72 \\
\hline & DIREITO PROCESSUAL DO TRABALHO & 60 \\
\hline & TEORIA DA ARGUMENT AÇÃO JURÍDICA & 36 \\
\hline & ELABORAÇÃO DE TRABALHO DE CURSO & 36 \\
\hline & PRÁTICA JURÍDICA IV (PRÁTICA ADMINISTRATIVA) & 60 \\
\hline $10^{\circ}$ & DIREITO CIVIL VIII (RESPONSABILIDADE CIVIL) & 60 \\
\hline & DIREITO AMBIENTAL E URBANÍSTICO & 60 \\
\hline & DIREITO EMPRESARIAL II (TÍTULOS DE CREDITO, FALÊNCIA E CONCORDATA) & 72 \\
\hline & DIREITOS HUMANOS E CIDADANIA & 36 \\
\hline & DIREITO PREVIDENCIÁRIO & 60 \\
\hline & ÉTICA II (ÉTICA E DIREITO) & 36 \\
\hline ATIVIDADES & TÓPICOS ESPECIAIS EM DIREITO I & 48 \\
\hline & TÓPICOS ESPECIAIS EM DIREITO II & 48 \\
\hline & TÓPICOS ESPECIAIS EM DIREITO III & 48 \\
\hline & TÓPICOS ESPECIAIS EM DIREITO IV & 48 \\
\hline ORIENTAÇÃO DE & ORIENTAÇÃO DE TRABALHO DE CURSO I & 48 \\
\hline & ORIENTAÇÃO DE TRABALHO DE CURSO II & 4 \\
\hline
\end{tabular}

FCJ FACULDADE CENECISTA DE JOINVILLE

Disponível em: http://www.fci.com.br/index.php?link=228

Acesso em outubro/2010

\begin{tabular}{|l|l|c|}
\hline SÉRIE & DISCIPLINA & $\begin{array}{c}\text { CARGA } \\
\text { HORÁRIA }\end{array}$ \\
\hline $1^{\mathbf{a}}$ & CIÊNCIA POLÍTICA E TEORIA GERAL DO ESTADO & 160 \\
\hline & FILOSOFIA GERAL E JURÍDICA & 160 \\
\hline & HISTÓRIA DO PENSAMENTO JURÍDICO & 80 \\
\hline & INTRODUÇÃO AO ESTUDO DE DIREITO & 80 \\
\hline & LINGUAGEM JURÍDICA & 80 \\
\hline & METODOLOGIA CIENTÍFICA & 80 \\
\hline & SOCIOLOGIA GERAL E JURÍDICA & 160 \\
\hline & & 80 \\
\hline $2^{\mathrm{a}}$ & DIREITO CIVIL I (PARTE GERAL) & 160 \\
\hline & DIREITO CONSTITUCIONAL I & 160 \\
\hline & DIREITO PENAL I (PARTE GERAL) & 80 \\
\hline & DIREITO INTERNACIONAL PRIVADO & 80 \\
\hline & DIREITO INTERNACIONAL PÚBLICO & 80 \\
\hline & TEORIA GERAL DO PROCESSO & 80 \\
\hline & ANTROPOLOGIA E DIREITO & 80 \\
\hline & ECONOMIA POLÍTICA & 160 \\
\hline
\end{tabular}




\begin{tabular}{|c|c|c|}
\hline & DIREITO CIVIL III (FAMÍLIA E SUCESSÕES) & 160 \\
\hline & DIREITO PROCESSUAL CIVIL I & 80 \\
\hline & DIREITO CONSTITUCIONAL II & 80 \\
\hline & DIREITO PENAL II (PARTE ESPECIAL) & 160 \\
\hline & DIREITO PROCESSUAL PENAL I & 80 \\
\hline & DIREITO DO TRABALHO & 80 \\
\hline \multirow[t]{9}{*}{$4^{\mathrm{a}}$} & DIREITO PROCESSUAL CIVIL II & 160 \\
\hline & DIREITO PROCESSUAL PENAL II & 80 \\
\hline & DIREITO PROCESSUAL TRABALHISTA & 80 \\
\hline & DIREITO EMPRESARIAL I & 80 \\
\hline & DIREITO ADMINISTRATIVO & 160 \\
\hline & DIREITO CIVIL IV (DIREITOS REAIS) & 80 \\
\hline & METODOLOGIA DA PESQUISA JURÍDICA & 40 \\
\hline & PSICOLOGIA APLICADA AO DIREITO & 40 \\
\hline & DIREITO TRIBUTÁRIO & 80 \\
\hline \multirow[t]{14}{*}{$5^{a}$} & DIREITO PROCESSUAL CIVIL III & 80 \\
\hline & DIREITO PROCESSUAL PENAL III & 80 \\
\hline & DIREITO EMPRESARIAL II & 80 \\
\hline & DIREITO CIVIL V (RESP. CIVIL) & 40 \\
\hline & DIREITO DA SEGURIDADE SOCIAL & 40 \\
\hline & DIREITOS HUMANOS & 40 \\
\hline & DIREITO DA CRIANÇA E DO ADOLESCENTE & 40 \\
\hline & DIREITO AMBIENTAL & 80 \\
\hline & ORIENTAÇÃO METODOLÓGICA A MONOGRAFIA JURÍDICA & 80 \\
\hline & DIREITO DAS RELAÇÕES DE CONSUMO & 40 \\
\hline & ÉTICA PROFISSIONAL & 40 \\
\hline & DISCIPLINA OPTATIVA I & 40 \\
\hline & DISCIPLINA OPTATIVA II & 40 \\
\hline & DISCIPLINA OPTATIVA III & 40 \\
\hline
\end{tabular}

FDDJ - FACULDADE DE DIREITO DAMÁSIO DE JESUS

Disponível em: http://fddj.damasio.edu.br/templates/fddj/pdf/grade_curricular2007.pdf

Acesso em outubro/2010

\begin{tabular}{|c|c|c|}
\hline PERÍODO & DISCIPLINA & $\begin{array}{c}\text { CARGA } \\
\text { HORÁRIA }\end{array}$ \\
\hline \multirow[t]{10}{*}{$1^{\circ}$} & INTRODUÇÃO AO ESTUDO DO DIREITO & 54 \\
\hline & SOCIOLOGIA GERAL E JURÍDICA & 36 \\
\hline & ECONOMIA & 36 \\
\hline & CIÊNCIA POLÍTICA COM TEORIA GERAL DO ESTADO & 36 \\
\hline & REDAÇÃO E LINGUAGEM JURÍDICA & 36 \\
\hline & TEORIA GERAL DO DIREITO CONSTITUCIONAL & 36 \\
\hline & FILOSOFIA GERAL E ÉTICA & 36 \\
\hline & PSICOLOGIA & 18 \\
\hline & TEORIA GERAL DO DIREITO PENAL & 36 \\
\hline & TEORIA GERAL DO DIREITO CIVIL & 36 \\
\hline \multirow[t]{6}{*}{$2^{\circ}$} & DIREITO CIVIL I - PARTE GERAL & 72 \\
\hline & DIREITO PENAL I & 72 \\
\hline & DIREITO CONSTITUCIONAL I & 72 \\
\hline & TEORIA GERAL DO PROCESSO CIVIL & 72 \\
\hline & HERMENÊUTICA JURÍDICA & 36 \\
\hline & ANTROPOLOGIA E HISTÓRIA DO PENSAMENTO JURÍDICO & 36 \\
\hline \multirow[t]{6}{*}{$3^{\circ}$} & DIREITO CIVIL II - OBRIGAÇÕES & 72 \\
\hline & DIREITO PENAL II & 72 \\
\hline & DIREITO CONSTITUCIONAL II & 72 \\
\hline & DIREITO PROCESSUAL CIVIL I & 72 \\
\hline & DIREITO EMPRESARIAL I & 36 \\
\hline & DIREITO PROCESSUAL PENAL I & 36 \\
\hline \multirow[t]{6}{*}{$4^{\circ}$} & DIREITO CIVIL III - CONTRATOS I & 72 \\
\hline & DIREITO ADMINISTRATIVO I & 54 \\
\hline & DIREITO PROCESSUAL PENAL II & 54 \\
\hline & DIREITO PROCESSUAL CIVIL II & 72 \\
\hline & DIREITO PENAL III & 72 \\
\hline & DIREITO EMPRESARIAL II & 36 \\
\hline \multirow[t]{2}{*}{$5^{\circ}$} & DIREITO CIVIL IV - CONTRATOS II & 72 \\
\hline & DIREITO PROCESSUAL CIVIL III & 72 \\
\hline
\end{tabular}




\begin{tabular}{|c|c|c|}
\hline & DIREITO PROCESSUAL PENAL III & 54 \\
\hline & DIREITO ADMINISTRATIVO II & 54 \\
\hline & DIREITO PENAL IV & 54 \\
\hline & DIREITO DO TRABALHO I & 54 \\
\hline \multirow[t]{6}{*}{$6^{\circ}$} & DIREITO CIVIL V - RESPONSABILIDADE CIVIL & 54 \\
\hline & DIREITO PENAL V & 72 \\
\hline & DIREITO PROCESSUAL CIVIL IV & 72 \\
\hline & LEGISLAÇÃO PENAL ESPECIAL & 54 \\
\hline & DIREITO TRIBUTÁRIO I & 54 \\
\hline & DIREITO TRABALHO II & 54 \\
\hline \multirow[t]{10}{*}{$7^{\circ}$} & DIREITO CIVIL VI - REAIS I & 72 \\
\hline & DIREITO EMPRESARIAL III & 54 \\
\hline & DIREITO TRIBUTÁRIO II & 72 \\
\hline & DIREITO DO CONSUMIDOR & 36 \\
\hline & PROPRIEDADE IMATERIAL E INTELECTUAL & 18 \\
\hline & PROCESSO DO TRABALHO & 36 \\
\hline & $\begin{array}{l}\text { NÚCLEO DE PRÁTICA JURÍDICA - LABORATÓRIO DE PRÁTICA JURÍDICA FORENSE I } \\
\text { (CIVIL) }\end{array}$ & 36 \\
\hline & NÚCLEO DE PRÁTICA JURÍDICA - PESQUISAS E PARECERES & 18 \\
\hline & ESTÁGIO SUPERVISIONADO I & 72 \\
\hline & $\begin{array}{l}\text { NÚCLEO DE PRÁTICA JURÍDICA - LABORATÓRIO DE PRÁTICA JURÍDICA NÃO FORENSE } \\
\text { (PRÁTICAS CONTRATUAIS) }\end{array}$ & 18 \\
\hline \multirow[t]{12}{*}{$8^{\circ}$} & DIREITO CIVIL VII - REAIS II & 36 \\
\hline & DIREITO EMPRESARIAL IV & 36 \\
\hline & DIREITO INTERNACIONAL PÚBLICO & 36 \\
\hline & DIREITO AMBIENTAL & 36 \\
\hline & METODOLOGIA CIENTÍFICA & 36 \\
\hline & ARBITRAGEM E MEDIAÇÃO & 36 \\
\hline & FILOSOFIA JURÍDICA & 36 \\
\hline & MONOGRAFIA L & 36 \\
\hline & $\begin{array}{l}\text { NÚCLEO DE PRÁTICA JURÍDICA - LABORATÓRIO DE PRÁTICA JURÍDICA FORENSE II } \\
\text { (PENAL) }\end{array}$ & 36 \\
\hline & DIREITO CIVIL VIII - FAMÍLIA & 36 \\
\hline & DIREITO PENAL EMPRESARIAL & 36 \\
\hline & ESTÁGIO SUPER VISIONADO II & 72 \\
\hline \multirow[t]{12}{*}{$9^{\circ}$} & DIREITO CIVIL IX - SUCESSÕES & 36 \\
\hline & DIREITO INTERNACIONAL PRIVADO & 36 \\
\hline & DIREITO ECONÔMICO E DIREITO COMERCIAL INTERNACIONAL & 36 \\
\hline & MONOGRAFIA II & 36 \\
\hline & $\begin{array}{l}\text { NÚCLEO DE PRÁTICA JURÍDICA - LABORATÓRIO DE PRÁTICA JURÍDICA FORENSE III } \\
\text { (TRABALHO) }\end{array}$ & 18 \\
\hline & TERCEIRO SETOR & 18 \\
\hline & DIREITO CIVIL $\mathrm{X}$ & 36 \\
\hline & ESTATUTO DA CRIANÇA E DO ADOLESCENTE & 36 \\
\hline & TUTELA COLETIVA & 18 \\
\hline & DIREITOS HUMANOS E DIREITO PENAL INTERNACIONAL & 36 \\
\hline & DIREITO PREVIDENCIÁRIO & 36 \\
\hline & ESTÁGIO SUPERVISIONADO III & 54 \\
\hline Núcleo I & $\begin{array}{l}\text { ADVOCACIA PRIVADA - TÉCNICAS DE NEGOCIAÇÃO E GESTÃO DE ESCRITÓRIOS DE } \\
\text { ADVOCACIA E ADVOCACIA PÚBLICA - LEGISLAÇÃO, PRÁTICA E GESTÃO PÚBLICA }\end{array}$ & 72 \\
\hline Núcleo II & $\begin{array}{l}\text { MAGISTRATURA E MINISTÉRIO PÚBLICO - LEGISLAÇÃO, PRÁTICA E GESTÃO PÚBLICA E } \\
\text { REGISTRO PÚBLICO - PRÁTICA NOT ARIAL E MEDICINA LEGAL }\end{array}$ & 72 \\
\hline \multirow[t]{12}{*}{$10^{\circ}$} & DIREITO CIVIL XI - TÓPICOS ESPECIAIS E ATUALIZAÇÃO & 36 \\
\hline & DIREITO PROCESSUAL CIVIL V - TÓPICOS ESPECIAIS E ATUALIZAÇÃO & 36 \\
\hline & DIREITO PENAL VI - TÓPICOS ESPECIAIS E ATUALIZAÇÃO & 36 \\
\hline & DIREITO PROCESSUAL PENAL IV - TÓPICOS ESPECIAIS E ATUALIZAÇÃO & 36 \\
\hline & DIREITO CONSTITUCIONAL III - TÓPICOS ESPECIAIS E ATUALIZAÇÃO & 36 \\
\hline & DIREITO ADMINISTRATIVO III - TÓPICOS ESPECIAIS E ATUALIZAÇÃO & 36 \\
\hline & $\begin{array}{l}\text { NÚCLEO DE PRÁTICA JURÍDICA - LABORATÓRIO DE PRÁTICA JURÍDICA FORENSE IV } \\
\text { (CIVIL) }\end{array}$ & 36 \\
\hline & ESTÁGIO SUPER VISIONADO IV & 54 \\
\hline & DIREITO TRIBUTÁRIO III - TÓPICOS ESPECIAIS E ATUALIZAÇÃO & 36 \\
\hline & DIREITO EMPRESARIAL V - TÓPICOS ESPECIAIS E ATUALIZAÇÃO & 36 \\
\hline & DIREITO DO TRABALHO III - TÓPICOS ESPECIAIS E ATUALIZAÇÃO & 36 \\
\hline & ÉTICA PROFISSIONAL & 18 \\
\hline
\end{tabular}


ISCHF LA SALLE - INSTITUTOS SUPERIORES DE ENSINO

Disponível em: http://www.lasallerj.org/admIN/upload/cursos/direito.pdf

Acesso em outubro/2010

\begin{tabular}{|c|c|c|}
\hline PERÍODO & DISCIPLINA & $\begin{array}{c}\text { CARGA } \\
\text { HORÁRIA }\end{array}$ \\
\hline \multirow[t]{8}{*}{$1^{\circ}$} & INTRODUÇÃO AO ESTUDO DE DIREITO I & 72 \\
\hline & INTRODUÇÃO À SOCIOLOGIA & 36 \\
\hline & ANTROPOLOGIA & 36 \\
\hline & HISTÓRIA DO DIREITO & 36 \\
\hline & INTRODUÇÃO Ȧ ECONOMIA & 72 \\
\hline & INTRODUÇÃO À CIÊNCIA POLÍTICA & 36 \\
\hline & LEITURA E PRODUÇÃO DE TEXTOS I & 36 \\
\hline & ATIVIDADES COMPLEMENTARES I & 36 \\
\hline \multirow[t]{7}{*}{$2^{\circ}$} & INTRODUÇÃO AO ESTUDO DE DIREITO I I & 72 \\
\hline & SOCIOLOGIA JURÍDICA & 72 \\
\hline & HISTÓRIA DO DIREITO BRASILEIRO & 36 \\
\hline & TEORIA GERAL DO ESTADO & 72 \\
\hline & LEITURA E PRODUÇÃO DE TEXTOS II & 36 \\
\hline & DIREITO CIVIL I (GERAL) & 72 \\
\hline & ATIVIDADES COMPLEMENTARES II & 36 \\
\hline \multirow[t]{7}{*}{$3^{\circ}$} & FILOSOFIA GERAL & 36 \\
\hline & MÉTODOS E TÉCNICAS DA PESQUISA & 36 \\
\hline & DIREITO CONSTITUCIONAL I & 72 \\
\hline & DIREITO CIVIL II (OBRIGAÇÕES) & 72 \\
\hline & DIREITO PENAL I & 72 \\
\hline & DIREITO GERAL DO PROCESSO & 72 \\
\hline & ATIVIDADES COMPLEMENTARES III & 36 \\
\hline \multirow[t]{7}{*}{$4^{\circ}$} & FILOSOFIA JURÍDICA & 36 \\
\hline & LÓGICA E TEORIA DA ARGUMENTAÇÃO & 36 \\
\hline & DIREITO CONSTITUCIONAL II & 72 \\
\hline & DIREITO CIVIL III (TEORIA GERAL DOS CONTRATOS) & 72 \\
\hline & DIREITO PENAL II & 72 \\
\hline & DIREITO PROCESSUAL CIVIL I (CONHECIMENTO E CAUTELAR) & 72 \\
\hline & ATIVIDADES COMPLEMENTARES IV & 36 \\
\hline \multirow[t]{6}{*}{$5^{\circ}$} & DIREITO CIVIL IV(CONTRATOS EM ESPÉCIE) & 72 \\
\hline & DIREITO PENAL III & 72 \\
\hline & DIREITO PROCESSUAL CIVIL II (RECURSOS) & 72 \\
\hline & DIREITO PROCESSUAL PENAL I & 72 \\
\hline & DIREITO DE EMPRESA I & 72 \\
\hline & ATIVIDADES COMPLEMENTARES V & 36 \\
\hline \multirow[t]{6}{*}{$6^{\circ}$} & DIREITO CIVIL V (RESPONSABILIDADE CIVIL) & 72 \\
\hline & DIREITO PENAL IV & 72 \\
\hline & DIREITO PROCESSUAL CIVIL III (EXECUÇÕES) & 72 \\
\hline & DIREITO PROCESSUAL PENAL II & 72 \\
\hline & DIREITO DE EMPRESA II & 72 \\
\hline & ATIVIDADES COMPLEMENTARES I & 36 \\
\hline \multirow[t]{8}{*}{$7^{\circ}$} & ÉTICA GERAL & 36 \\
\hline & DIREITO CIVIL VI (REAIS) & 72 \\
\hline & DIREITO PROCESSUAL CIVIL IV(ESPECIAIS) & 72 \\
\hline & DIREITO PROCESSUAL PENAL III & 72 \\
\hline & DIREITO DE EMPRESA III & 72 \\
\hline & ATIVIDADES COMPLEMENTARES VII & 36 \\
\hline & O HOMEM CONTEMPORÂNEO E O FENÔMENO RELIGIOSO & 36 \\
\hline & ESTÁGIO SUPER VISIONADO I (NPJ) & 90 \\
\hline \multirow[t]{9}{*}{$8^{\circ}$} & MEDICINA LEGAL & 36 \\
\hline & MÉTODOS E TÉCNICAS DA PESQUISA JURÍDICA & 36 \\
\hline & DIREITO CIVIL VII (FAMÍLIA) & 72 \\
\hline & DIREITO ADMINISTRATIVO I & 72 \\
\hline & DIREITO DO TRABALHO I & 72 \\
\hline & DIREITO URBANÍSTICO & 36 \\
\hline & ECUMENISMO E HISTÓRIA DAS RELIGIÕES & 36 \\
\hline & ESTÁGIO SUPER VISIONADO II (NPJ) & 90 \\
\hline & ATIVIDADES COMPLEMENTARES VIII & 36 \\
\hline
\end{tabular}




\begin{tabular}{|l|l|c|}
\hline $9^{\circ}$ & DIREITO CIVIL VIII (SUCESSÕES) & 72 \\
\hline & DIREITO INTERNACIONAL PÚBLICO & 72 \\
\hline & DIREITO ADMINISTRATIVO II & 72 \\
\hline & DIREITO TRIBUTÁRIO I & 72 \\
\hline & DIREITO DO TRABALHO II & 72 \\
\hline & MONOGRAFIA I & 36 \\
\hline & ESTÁGIO SUPER VISIONADO III (NÚCLEO DE PRÁTICA JURÍDICA) & 90 \\
\hline & ATIVIDADES COMPLEMENTARES IX & 36 \\
\hline & & 36 \\
\hline & DEONTOLOGIA JURÍDICA & 72 \\
\hline & DIREITO DO CONSUMIDOR & 72 \\
\hline & DIREITO INTERNACIONAL PRIVADO & 72 \\
\hline & DIREITO TRIBUTÁRIO II & 72 \\
\hline & DIREITO PROCESSUAL DO TRABALHO & 36 \\
\hline & DIREITO AMBIENTAL & 90 \\
\hline & ESTÁGIO SUPER VISIONADO IV (NÚCLEO DE PRÁTICA JURÍDICA) & 36 \\
\hline & MONOGRAFIA II & 36 \\
\hline & INTRODUÇÃO Ã TEOLOGIA & 36 \\
\hline
\end{tabular}

PONTIFÍCIA UNIVERSIDADE CATÓLICA DE SÃO PAULO

Disponível em: http://www.pucsp.br/direito/conteudo/composicao curricular/curriculo vigente.htm

Acesso em outubro/2010

\begin{tabular}{|c|c|c|}
\hline SÉRIE & DISCIPLINA & $\begin{array}{c}\text { CARGA } \\
\text { HORÁRIA }\end{array}$ \\
\hline \multirow[t]{8}{*}{$1^{\mathrm{a}}$} & REDAÇÃO E LINGUAGEM JURÍDICA & 120 \\
\hline & LÓGICA JURÍDICA & 90 \\
\hline & INTRODUÇÃO AO ESTUDO DO DIREITO & 90 \\
\hline & CIÊNCIA POLIITICA E TEORIA GERAL DO ESTADO & 90 \\
\hline & FUNDAMENTOS DO DIREITO PÚBLICO & 120 \\
\hline & TEORIA GERAL DO DIREITO PRIVADO & 90 \\
\hline & SOCIOLOGIA GERAL E JURÍDICA & 90 \\
\hline & INTRODUÇÃO AO PENSAMENTO TEOLÓGICO & 60 \\
\hline \multirow[t]{8}{*}{$2^{\mathrm{a}}$} & DIREITO CIVIL I & 120 \\
\hline & DIREITO PROCESSUAL CIVIL I & 90 \\
\hline & DIREITO PENAL I & 90 \\
\hline & INTRODUÇÃO À FILOSOFIA & 90 \\
\hline & DIREITO CONSTITUCIONAL I & 120 \\
\hline & DIREITO COMERCIAL I & 90 \\
\hline & DIREITO DO TRABALHO & 90 \\
\hline & ECONOMIA & 60 \\
\hline \multirow[t]{8}{*}{$3^{\mathrm{a}}$} & DIREITO CIVIL II & 120 \\
\hline & DIREITO PROCESSUAL CIVIL II & 90 \\
\hline & DIREITO PENAL II & 90 \\
\hline & DIREITO PROCESSUAL PENAL I & 90 \\
\hline & DIREITO ADMINISTRATIVO I & 120 \\
\hline & DIREITO COMERCIAL II & 90 \\
\hline & DIREITO CONSTITUCIONAL II & 90 \\
\hline & FILOSOFIA DO DIREITO & 60 \\
\hline \multirow[t]{9}{*}{$4^{\mathrm{a}}$} & DIREITO CIVIL III & 90 \\
\hline & DIREITO PROCESSUAL CIVIL III & 90 \\
\hline & DIREITO PENAL III & 90 \\
\hline & DIREITO PROCESSUAL PENAL II & 90 \\
\hline & DIREITO ADMINISTRATIVO II & 90 \\
\hline & DIREITO COMERCIAL III & 90 \\
\hline & DIREITO TRIBUTÁRIO I & 90 \\
\hline & DIREITO PREVIDENCIÁRIO & 60 \\
\hline & DIREITOS HUMANOS & 60 \\
\hline \multirow[t]{7}{*}{$5^{a}$} & DIREITO CIVIL IV & 90 \\
\hline & DIREITO TRIBUTÁRIO II & 90 \\
\hline & PRÁTICA FORENSE "A" & 60 \\
\hline & ÉTICA PROFISSIONAL & 30 \\
\hline & DIREITO PROCESSUAL CIVIL IV & 90 \\
\hline & DIREITO INTERNACIONAL & 60 \\
\hline & PRÁTICA FORENSE "B" & 60 \\
\hline
\end{tabular}


UEM - UNIVERSIDADE ESTADUAL DE MARINGÁ

Disponível em: http://www.ddp.uem.br/index.php?option=com_content\&view=article\&id=49\&itemid=63

Acesso em outubro/2010

\begin{tabular}{|c|c|c|}
\hline SÉRIE & DISCIPLINA & $\begin{array}{c}\text { CARGA } \\
\text { HORÁRIA }\end{array}$ \\
\hline \multirow[t]{6}{*}{$1^{\mathrm{a}}$} & INTRODUÇÃO À PESQUISA JURÍDICA & 68 \\
\hline & INTRODUÇÃO AO DIREITO & 204 \\
\hline & CIÊNCIA POLÍTICA I & 136 \\
\hline & FILOSOFIA DO DIREITO & 136 \\
\hline & SOCIOLOGIA JURÍDICA & 68 \\
\hline & ECONOMIA POLÍTICA & 68 \\
\hline \multirow[t]{5}{*}{$2^{\mathrm{a}}$} & DIREITO CIVIL I & 204 \\
\hline & DIREITO PENAL I & 136 \\
\hline & DIREITO CONSTITUCIONAL & 136 \\
\hline & INTRODUÇÃO AO PROCESSO CIVIL & 136 \\
\hline & CIÊNCIA POLÍTICA II & 68 \\
\hline \multirow[t]{5}{*}{$3^{\mathrm{a}}$} & DIREITO ADMINISTRATIVO & 136 \\
\hline & DIREITO COMERCIAL I & 102 \\
\hline & DIREITO PROCESSUAL CIVIL I & 136 \\
\hline & DIREITO CIVIL II & 204 \\
\hline & DIREITO PENAL II & 102 \\
\hline \multirow[t]{9}{*}{$4^{\mathrm{a}}$} & DIREITO PENAL III & 102 \\
\hline & DIREITO DO TRABALHO I & 102 \\
\hline & DIREITO PROCESSUAL CIVIL II & 136 \\
\hline & DIREITO PROCESSUAL PENAL & 136 \\
\hline & DIREITO CIVIL III & 68 \\
\hline & DIREITO COMERCIAL II & 136 \\
\hline & PRÁTICA DE CONTRATOS & 34 \\
\hline & PRÁTICA DE PROCESSUAL CIVIL I & 68 \\
\hline & PRÁTICA PROCESSUAL PENAL I & 34 \\
\hline \multirow[t]{10}{*}{$5^{\mathrm{a}}$} & DIREITO PENAL IV & 102 \\
\hline & DIREITO COMERCIAL III & 102 \\
\hline & DIREITO DO TRABALHO II & 136 \\
\hline & DIREITO INTERNACIONAL PÚBLICO & 102 \\
\hline & DIREITO TRIBUTÁRIO & 102 \\
\hline & MONOGRAFIA JURÍDICA & 68 \\
\hline & DIREITO CIVIL IV & 136 \\
\hline & PRÁTICA PROCESSUAL CIVIL II & 68 \\
\hline & PRÁTICA PROCESSUAL PENAL II & 68 \\
\hline & PRÁTICA PROCESSUAL TRABALHISTA & \\
\hline
\end{tabular}

UEPG - UNIVERSIDADE ESTADUAL DE PONTA GROSSA

Disponível em: http://www.uepg.br/catalogo/setor6/direito.pdf

Acesso em outubro/2010

\begin{tabular}{|l|l|c|}
\hline SÉRIE & DISCIPLINA & CARGA \\
& & HORÁRIA \\
\hline $1^{\circ}$ & ECONOMIA POLÍTICA & 68 \\
\hline & SOCIOLOGIA DO DIREITO & 68 \\
\hline & FILOSOFIA DO DIREITO & 136 \\
\hline & ÉTICA PROFISSIONAL & 51 \\
\hline & METODOLOGIA DA PESQUISA JURÍDICA & 68 \\
\hline $2^{\circ}$ & & 136 \\
\hline & INTRODUÇÃO AO ESTUDO DO DIREITO & 136 \\
\hline & DIREITO PENAL I & 136 \\
\hline & DIREITO PENAL II & 136 \\
\hline & DIREITO ADMINISTRATIVO I & 68 \\
\hline & DIREITO CONSTITUCIONAL & 136 \\
\hline & DIREITO CONSTITUCIONAL II & 51 \\
\hline & DIREITO INTERNACIONAL PRIVADO & 68 \\
\hline & DIREITO INTERNACIONAL PÚBLICO & 51 \\
\hline & DIREITO PREVIDENCIÁRIO & 102 \\
\hline & DIREITO TRIBUTÁRIO I & \\
\hline $3^{\text {o }}$ & DIREITO TRIBUTÁRIO II & 51 \\
\hline & ESTATUTO DA CRIANÇA E DO ADOLESCENTE & 51 \\
\hline & TEORIA GERAL DO ESTADO E CIÊNCIA POLÍTICA & 136 \\
\hline & DIREITO PROCESSUAL CIVIL I & 136 \\
\hline
\end{tabular}




\begin{tabular}{|c|c|c|}
\hline & DIREITO PROCESSUAL CIVIL II & 102 \\
\hline & DIREITO PROCESSUAL CIVIL III & 102 \\
\hline & ESTÁGIO DE PRÁTICA FORENSE CIVIL & 102 \\
\hline & ESTÁGIO DE PRÁTICA FORENSE CIVIL II & 102 \\
\hline & ESTÁGIO DE PRÁTICA FORENSE PENAL I & 68 \\
\hline & ESTÁGIO DE PRÁTICA FORENSE PENAL II & 68 \\
\hline \multirow[t]{11}{*}{$4^{\circ}$} & DIREITO PROCESSUAL PENAL & 68 \\
\hline & DIREITO PROCESSUAL PENAL II & 68 \\
\hline & DIREITO CIVIL I & 136 \\
\hline & DIREITO CIVIL II & 136 \\
\hline & DIREITO CIVIL III & 136 \\
\hline & DIREITO CIVIL IV & 136 \\
\hline & DIREITO COMERCIAL I & 102 \\
\hline & DIREITO COMERCIAL II & 102 \\
\hline & ORIENTAÇÃO DE TRABALHO DE CONCLUSÃO DE CURSO & 34 \\
\hline & DIREITO DO TRABALHO I & 102 \\
\hline & DIREITO DO TRABALHO II & 68 \\
\hline \multirow[t]{13}{*}{$5^{\circ}$} & CRIMINOLOGIA CRÍTICA & 51 \\
\hline & DIREITO ADMINISTRATIVO II & 51 \\
\hline & DIREITO PENAL III & 51 \\
\hline & DIREITO PROCESSUAL CONSTITUCIONAL & 51 \\
\hline & DIREITOS HUMANOS & 51 \\
\hline & DIREITO PROCESSUAL CIVIL IV & 51 \\
\hline & DIREITO PROCESSUAL PENAL III & 51 \\
\hline & DIREITO AGRÁRIO & 68 \\
\hline & DIREITO AMBIENTAL & 51 \\
\hline & DIREITO DO CONSUMIDOR & 68 \\
\hline & DIREITO IMOBILIÁRIO & 51 \\
\hline & DIREITO URBANÍSTICO & 51 \\
\hline & MEDIAÇÃO E ARBITRAGEM & 34 \\
\hline
\end{tabular}

UESC - UNIVERSIDADE ESTADUAL DE SANTA CRUZ

Disponível em: http://www.uesc.br/cursos/graduacao/bacharelado/direito/index.php?item=conteudo_disciplinas.php Acesso em outubro/2010

\begin{tabular}{|c|c|c|}
\hline SEMESTRE & DISCIPLINA & $\begin{array}{l}\text { CARGA } \\
\text { HORÁRIA }\end{array}$ \\
\hline \multirow[t]{6}{*}{$1^{\circ}$} & ECONOMIA & \\
\hline & INTRODUÇÃO AO DIREITO I & \\
\hline & LEITURA E PRODUÇÃO DE TEXTOS I & \\
\hline & METODOLOGIA CIENTIFICA & \\
\hline & PRATICA DE EDUCAÇÃO FÍSICA I & \\
\hline & SOCIOLOGIA GERAL & \\
\hline \multirow[t]{6}{*}{$2^{\circ}$} & CIÊNCIA POLÍTICA & \\
\hline & INTRODUÇÃO AO DIREITO II & \\
\hline & LEITURA E PRODUÇÃO DE TEXTOS II & \\
\hline & PRATICA DE EDUCAÇÃO FÍSICA II & \\
\hline & SOCIOLOGIA JURÍDICA & \\
\hline & TEORIA GERAL DO DIREITO PRIVADO & \\
\hline \multirow[t]{6}{*}{$3^{\circ}$} & DIREITO DAS OBRIGAÇÕES & \\
\hline & DIREITO PENAL I & \\
\hline & FILOSOFIA & \\
\hline & PESQUISA JURÍDICA & \\
\hline & TEORIA DO ESTADO & \\
\hline & TEORIA GERAL DO DIREITO PÚBLICO & \\
\hline \multirow[t]{7}{*}{$4^{\circ}$} & CONTABILIDADE E ANALISE DE BALANÇO & \\
\hline & DIREITO COMERCIAL I & \\
\hline & DIREITO CONSTITUCIONAL I & \\
\hline & DIREITO DOS CONTRATOS & \\
\hline & DIREITO PENAL II & \\
\hline & FILOSOFIA JURÍDICA & \\
\hline & FUNDAMENTOS DE ADMINISTRAÇÃO & \\
\hline \multirow[t]{4}{*}{$5^{\circ}$} & DIREITO ADMINISTRATIVO I & \\
\hline & DIREITO COMERCIAL II & \\
\hline & DIREITO CONSTITUCIONAL II & \\
\hline & DIREITO DAS COISAS & \\
\hline
\end{tabular}




\begin{tabular}{|c|c|c|}
\hline & DIREITO PENAL III & \\
\hline & DIREITO PROCESSUAL CIVIL I & \\
\hline & FUND. DE ÉTICA GERAL E PROFISSIONAL & \\
\hline & PRÁTICA JURÍDICA - SER VIÇO DE ASSISTÊNCIA JURÍDICA & \\
\hline \multirow[t]{7}{*}{$6^{\circ}$} & DIREITO ADMINISTRATIVO II & \\
\hline & DIREITO COMERCIAL III & \\
\hline & DIREITO DE FAMÍLIA & \\
\hline & DIREITO DO TRABALHO I & \\
\hline & DIREITO PENAL IV & \\
\hline & DIREITO PROCESSUAL CIVIL II & \\
\hline & DIREITO TRIBUTÁRIO I & \\
\hline \multirow[t]{11}{*}{$7^{\circ}$} & DIREITO DAS SUCESSÕES & \\
\hline & DIREITO DO TRABALHO II & \\
\hline & DIREITO PROCESSUAL CIVIL III & \\
\hline & DIREITO PROCESSUAL PENAL I & \\
\hline & DIREITO TRIBUTÁRIO II & \\
\hline & LÍNGUA ESPANHOLA II & \\
\hline & LÍNGUA FRANCESA II & \\
\hline & LÍNGUA INGLESA II & \\
\hline & MEDICINA LEGAL & \\
\hline & PSICOLOGIA GERAL II & \\
\hline & RELAÇÕES HUMANAS II & \\
\hline \multirow[t]{23}{*}{$8^{\circ}$} & CRIMINOLOGIA I & \\
\hline & DIREITO AGRÁRIO & \\
\hline & DIREITO AMBIENTAL & \\
\hline & DIREITO BANCÁRIO E MERC.DE CAPITAIS & \\
\hline & DIREITO CIVIL APLICADO & \\
\hline & DIREITO DA CRIANÇA E DO ADOLESCENTE & \\
\hline & DIREITO DO CONSUMIDOR & \\
\hline & DIREITO ECONÔMICO & \\
\hline & DIREITO FALIMENTAR & \\
\hline & DIREITO FINANCEIRO APLICADO & \\
\hline & DIREITO INDIVIDUAL E COLETIVO DO TRABALHO & \\
\hline & DIREITO INTERNACIONAL PÚBLICO & \\
\hline & DIREITO MARÍTIMO & \\
\hline & DIREITO PREVIDENCIÁRIO & \\
\hline & DIREITO PROCESSUAL DO TRABALHO I & \\
\hline & DIREITO PROCESSUAL PENAL II & \\
\hline & DIREITO SINDICAL & \\
\hline & DIREITO TRIBUTÁRIO APLICADO & \\
\hline & MEDICINA FORENSE & \\
\hline & NOÇÕES DE CONTABILIDADE EMPRESARIAL & \\
\hline & PRÁTICA JURÍDICA I & \\
\hline & TEMAS DE DIREITO PENAL & \\
\hline & TEORIA GERAL DO DIREITO DO TRABALHO & \\
\hline \multirow[t]{6}{*}{$9^{\circ}$} & CRIMINOLOGIA II & \\
\hline & DIREITO INTERNACIONAL PRIVADO & \\
\hline & DIREITO PROCESSUAL DO TRABALHO II & \\
\hline & DIREITO PROCESSUAL PENAL III & \\
\hline & MONOGRAFIA I & \\
\hline & PRÁTICA JURÍDICA II & \\
\hline \multirow[t]{3}{*}{$10^{\circ}$} & DIREITO MUNICIPAL & \\
\hline & MONOGRAFIA II & \\
\hline & PRÁTICA JURÍDICA III & \\
\hline
\end{tabular}

UFAC - UNIVERSIDADE FEDERAL DO ACRE

Disponível em: http://www.ufac.br/ensino/cursos/curso_direito/grade_curricular2.html Acesso em outubro/2010

\begin{tabular}{|l|l|c|}
\hline SEMESTRE & DISCIPLINA & CARGA \\
HORÁRIA \\
\hline $1^{\circ}$ & FILOSOFIA DO DIREITO & 60 \\
\hline & ANTROPOLOGIA DO DIREITO & 60 \\
\hline & INTRODUÇÃO Ȧ CIÊNCIA DO DIREITO I & 60 \\
\hline & METODOLOGIA DE ESTUDO EM DIREITO & 60 \\
\hline & HISTÓRIA DO DIREITO & 60 \\
\hline
\end{tabular}




\begin{tabular}{|c|c|c|}
\hline \multirow{7}{*}{$2^{\circ}$} & & \\
\hline & FUNDAMENTOS DE ECONOMIA & 60 \\
\hline & SOCIOLOGIA DO DIREITO & 60 \\
\hline & DIREITO CONSTITUCIONAL I & 60 \\
\hline & DIREITO CIVIL I & 60 \\
\hline & DIREITO PENAL I & 60 \\
\hline & DIREITO INTERNACIONAL PRIVADO & 60 \\
\hline \multirow[t]{6}{*}{$3^{\circ}$} & DIREITO CONSTITUCIONAL II & 60 \\
\hline & DIREITO CIVIL II & 60 \\
\hline & DIREITO PENAL II & 60 \\
\hline & DIREITO INTERNACIONAL PÚBLICO & 60 \\
\hline & TEORIA GERAL DO PROCESSO & 60 \\
\hline & ELETIVA I & 60 \\
\hline \multirow[t]{6}{*}{$4^{\circ}$} & DIREITO DA SEGURIDADE SOCIAL & 60 \\
\hline & DIREITO CIVIL III & 60 \\
\hline & DIREITO PENAL III & 60 \\
\hline & MEDICINA LEGAL & 60 \\
\hline & DIREITO PROCESSUAL PENAL I & 60 \\
\hline & DIREITO PROCESSUAL CIVIL I & 60 \\
\hline \multirow[t]{7}{*}{$5^{\circ}$} & DIREITO ADMINISTRATIVO I & 60 \\
\hline & DIREITO CIVIL IV & 60 \\
\hline & DIREITO PENAL IV & 60 \\
\hline & DIREITO PROCESSUAL PENAL II & 60 \\
\hline & DIREITO PROCESSUAL CIVIL II & 60 \\
\hline & PRÁTICA JURÍDICA I & 90 \\
\hline & ELETIVA II & 60 \\
\hline \multirow[t]{7}{*}{$6^{\circ}$} & DIREITO ADMINISTRATIVO II & 60 \\
\hline & DIREITO CIVIL V & 60 \\
\hline & DIREITO DO CONSUMIDOR & 60 \\
\hline & DIREITO PROCESSUAL PENAL III & 60 \\
\hline & DIREITO PROCESSUAL CIVIL III & 60 \\
\hline & PRÁTICA JURÍDICA II & 90 \\
\hline & ELETIVA III & 60 \\
\hline \multirow[t]{7}{*}{$7^{\circ}$} & DIREITO EMPRESARIAL I & 60 \\
\hline & DIREITO CIVIL VI & 60 \\
\hline & PSICOLOGIA DO DIREITO & 60 \\
\hline & DIREITO PROCESSUAL CIVIL IV & 60 \\
\hline & PRÁTICA JURÍDICA III & 90 \\
\hline & DIREITO DO TRABALHO I & 60 \\
\hline & ESTÁGIO CURRICULAR SUPER VISIONADO I & 90 \\
\hline \multirow[t]{7}{*}{$8^{\circ}$} & DIREITO COMERCIAL II & 60 \\
\hline & DIREITO CIVIL VII & 60 \\
\hline & ÉTICA GERAL E PROFISSIONAL & 60 \\
\hline & DIREITO DO TRABALHO II & 60 \\
\hline & METODOLOGIA DA PESQUISA EM DIREITO & 90 \\
\hline & PRÁTICA JURÍDICA IV & 90 \\
\hline & ESTÁGIO CURRICULAR SUPERVISIONADO II & 90 \\
\hline \multirow[t]{6}{*}{$9^{\circ}$} & DIREITOS HUMANOS & 60 \\
\hline & DIREITO DA CRIANÇA E DO ADOLESCENTE & 60 \\
\hline & DIREITO TRIBUTÁRIO I & 60 \\
\hline & DIREITO AMBIENTAL & 60 \\
\hline & PESQUISA EM DIREITO & 60 \\
\hline & ESTÁGIO CURRICULAR SUPER VISIONADO III & 90 \\
\hline \multirow[t]{6}{*}{$10^{\circ}$} & DIREITO AGRÁRIO & 60 \\
\hline & DIREITO DE PROPRIEDADE DOS CONHECIMENTOS TRADICIONAIS & 60 \\
\hline & DIREITO TRIBUTÁRIO II & 60 \\
\hline & DIREITO DA INTEGRAÇÃO E GLOBALIZAÇÃO & 60 \\
\hline & MONOGRAFIA JURÍDICA & 90 \\
\hline & ESTÁGIO CURRICULAR SUPER VISIONADO IV & 90 \\
\hline \multirow[t]{4}{*}{ ELETIVAS } & TÉCNICA DE REDAÇÃO JURÍDICA & 60 \\
\hline & BIOÉTICA E DIREITO & 60 \\
\hline & DIREITO E GÊNERO & 60 \\
\hline & DIREITO ECONÔMICO & 60 \\
\hline
\end{tabular}




\begin{tabular}{|l|l|c|}
\hline & TUTELA JURÍDICA DA FLORA E DA FAUNA & 60 \\
\hline & HERMENÊUTICA E APLICAÇÃO DO DIREITO & 60 \\
\hline & LINGUAGEM E ARGUMENTAÇÃO JURÍDICA & 60 \\
\hline & CRIMINOLOGIA & 60 \\
\hline & PERÍCIA CRIMINALÍSTICA & 60 \\
\hline & TEMAS EMERGENTES DE DIREITO & 60 \\
\hline & DIREITO ELEITORAL & 60 \\
\hline & INSTITUIÇÕES DE DIREITO PÚBLICO & 60 \\
\hline & INSTITUIC̃ÕES DE DIREITO PRIVADO & 60 \\
\hline & DIREITOS HUMANOS E MEIO AMBIENTE & 60 \\
\hline & METODOLOGIA DO ENSINO JURÍDICO & 60 \\
\hline & LÍNGUA PORTUGUESA & 60 \\
\hline & NEGOCIAÇÃO, CONCILIAÇÃO, MEDIAÇÃO E JUSTIÇA COMUNITÁRIA & 60 \\
\hline
\end{tabular}

UFG - UNIVERSIDADE FEDERAL DE GOIÁS

Disponível em: http://www.ufg.br/page.php?menu_id=179\&pos=esq

Acesso em outubro/2010

\begin{tabular}{|c|c|c|}
\hline SÉRIE & DISCIPLINA & $\begin{array}{c}\text { CARGA } \\
\text { HORÁRIA }\end{array}$ \\
\hline \multirow{7}{*}{$1^{\mathrm{a}}$} & CIÊNCIA POLÍTICA & 48 \\
\hline & CRIMINOLOGIA & 32 \\
\hline & ECONOMIA POLÍTICA & 48 \\
\hline & HISTÓRIA DO PENSAMENTO JURÍDICO & 48 \\
\hline & INTRODUÇÃO AO DIREITO & 64 \\
\hline & METODOLOGIA DO TRABALHO CIENTÍFICO & 32 \\
\hline & SOCIOLOGIA GERAL & 48 \\
\hline \multirow[t]{6}{*}{$2^{\mathrm{a}}$} & DIREITO CIVIL I (PARTE GERAL I) & 64 \\
\hline & DIREITO PENAL I & 64 \\
\hline & HERMENÊUTICA JURÍDICA E DIREITO INTERTEMPORAL & 48 \\
\hline & SOCIOLOGIA JURÍDICA & 64 \\
\hline & TEORIA DA CONSTITUIÇÃO & 32 \\
\hline & TEORIA GERAL DO ESTADO & 64 \\
\hline \multirow{13}{*}{$3^{\mathrm{a}}$} & DIREITO CIVIL II (PARTE GERAL II) & 48 \\
\hline & DIREITO CONSTITUCIONAL I & 64 \\
\hline & DIREITO INTERNACIONAL PÚBLICO & 64 \\
\hline & DIREITO PENAL II & 64 \\
\hline & FILOSOFIA GERAL & 48 \\
\hline & METODOLOGIA DA PESQUISA EM DIREITO & 32 \\
\hline & TEORIA GERAL DO PROCESSO & 64 \\
\hline & DIREITO CIVIL III (OBRIGAÇÕES) & 64 \\
\hline & DIREITO CONSTITUCIONAL II & 64 \\
\hline & DIREITO PENAL III & 64 \\
\hline & DIREITO PROC. CIVIL I & 64 \\
\hline & FILOSOFIA JURÍDICA & 64 \\
\hline & MEDICINA LEGAL & 64 \\
\hline \multirow[t]{7}{*}{$5^{\mathrm{a}}$} & DIREITO ADMINISTRATIVO I & 64 \\
\hline & DIREITO CIVIL IV (CONTRATOS) & 64 \\
\hline & DIREITO EMPRESARIAL I & 64 \\
\hline & DIREITO PENAL IV & 64 \\
\hline & DIREITO PROC. CIVIL II & 48 \\
\hline & DIREITO PROC. PENAL I & 64 \\
\hline & ESTÁGIO SUPERVISIONADO I & 32 \\
\hline \multirow[t]{7}{*}{$6^{\mathrm{a}}$} & DIREITO ADMINISTRATIVO II & 64 \\
\hline & DIREITO CIVIL V (DIREITOS REAIS) & 64 \\
\hline & DIREITO EMPRESARIAL II & 64 \\
\hline & DIREITO PROC. CIVIL III & 64 \\
\hline & DIREITO PROC. PENAL II & 64 \\
\hline & ESTÁGIO SUPERVISIONADO II & 32 \\
\hline & ÉTICA PROFISSIONAL JURÍDICA & 48 \\
\hline \multirow{7}{*}{$7^{\mathrm{a}}$} & DIREITO CIVIL VI (FAMÍLIA) & 64 \\
\hline & DIREITO DO TRABALHO I & 64 \\
\hline & DIREITO ECONÔMICO E CONCORRÊNCIA & 48 \\
\hline & DIREITO EMPRESARIAL III & 64 \\
\hline & DIREITO PROC. CIVIL IV & 64 \\
\hline & DIREITO PROC. PENAL III & 64 \\
\hline & ESTÁGIO SUPERVISIONADO III & 32 \\
\hline
\end{tabular}




\begin{tabular}{|l|l|r|}
\hline & & \\
\hline $8^{\mathrm{a}}$ & DIREITO CIVIL VII (SUCESSÕES) & 64 \\
\hline & DIREITO DO TRABALHO II & 64 \\
\hline & DIREITO PROC. CIVIL V & 64 \\
\hline & DIREITO PROC. PENAL IV & 64 \\
\hline & DIREITO TRIBUTÁRIO I & 64 \\
\hline & ESTÁGIO SUPERVISIONADO IV & 32 \\
\hline & MONOGRAFIA JURÍDICA I (PROJETO) & 32 \\
\hline & & 64 \\
\hline $9^{\mathrm{a}}$ & DIREITO AMBIENTAL & 64 \\
\hline & DIREITO PROCESSUAL TRABALHISTA & 64 \\
\hline & DIREITO TRIBUTÁRIO II & 32 \\
\hline & ESTÁGIO SUPERVISIONADO V & 48 \\
\hline & LABORATÓRIO DE PRÁTICA JURÍDICA (CIVIL I) & 48 \\
\hline & LABORATÓRIO DE PRÁTICA JURÍDICA (PENAL I) & 32 \\
\hline & MONOGRAFIA JURÍDICA II (ELABORAÇÃO E DEFESA) & 64 \\
\hline $10^{\mathrm{a}}$ & & 48 \\
\hline & DIREITO AGRÁRIO & 48 \\
\hline & LABORATÓRIO DE PRÁTICA JURÍDICA (CIVIL II) & 48 \\
\hline & LABORATÓRIO DE PRÁTICA JURÍDICA (PENAL II) & 48 \\
\hline
\end{tabular}

UFMG - UNIVERSIDADE FEDERAL DE MINAS GERAIS

Disponível em: http://www.direito.ufmg.br/docs/grade\%202003-2.pdf

Acesso em outubro/2010

\begin{tabular}{|c|c|c|}
\hline PERÍODO & DISCIPLINA & $\begin{array}{c}\text { CARGA } \\
\text { HORÁRIA }\end{array}$ \\
\hline \multirow[t]{5}{*}{$1^{\circ}$} & INTRODUÇÃO A TEORIA DEMOCRÁTICA & 60 \\
\hline & INTRODUÇÃO A CIÊNCIA DO DIREITO I & 45 \\
\hline & ECONOMIA A I & 60 \\
\hline & INTRODUÇÃO A FILOSOFIA: ÉTICA & 60 \\
\hline & MODERNIDADE E MUDANÇA SOCIAL & 60 \\
\hline \multirow[t]{5}{*}{$2^{\circ}$} & TEORIA GERAL DO DIREITO PRIVADO I & 60 \\
\hline & TEORIA GERAL DO ESTADO I & 60 \\
\hline & TEORIA DA CONSTITUIÇÃO & 60 \\
\hline & INTRODUÇÃO A CIÊNCIA DO DIREITO II & 60 \\
\hline & TEORIA GERAL DO DIREITO I & 60 \\
\hline \multirow[t]{7}{*}{$3^{\circ}$} & TEORIA GERAL DO DIREITO PRIVADO II & 60 \\
\hline & DIREITO PENAL I & 60 \\
\hline & DIREITO CONSTITUCIONAL I & 60 \\
\hline & TEORIA GERAL DO ESTADO II & 45 \\
\hline & METODOLOGIA DE PESQUISA EM DIREITO & 15 \\
\hline & TEORIA GERAL DOS CONTRATOS & 30 \\
\hline & TEORIA GERAL DO DIREITO II & 30 \\
\hline \multirow[t]{5}{*}{$4^{\circ}$} & DIREITO CIVIL I - OBRIG. RESPONS. CIVIL & 60 \\
\hline & DIREITO COMERCIAL I & 60 \\
\hline & DIREITO PENAL II & 60 \\
\hline & DIREITO CONSTITUCIONAL II & 60 \\
\hline & DIREITO INTERNACIONAL PUBLICO & 60 \\
\hline \multirow[t]{5}{*}{$5^{\circ}$} & GERAL DO PROCESSO & 60 \\
\hline & DIREITO CIVIL II - CONTRATOS & 60 \\
\hline & DIREITO COMERCIAL II & 60 \\
\hline & DIREITO PENAL III & 60 \\
\hline & DIREITO ADMINISTRATIVO I & 60 \\
\hline \multirow[t]{7}{*}{$6^{\circ}$} & DIREITO PROCESSUAL CIVIL I & 60 \\
\hline & DIREITO CIVIL III - CONTRATOS & 30 \\
\hline & DIREITO CIVIL IV - SUCESSÕES & 30 \\
\hline & DIREITO COMERCIAL III & 60 \\
\hline & DIREITO PENAL IV & 60 \\
\hline & DIREITO ADMINISTRATIVO II & 60 \\
\hline & CARGA ESTAGIO & 150 \\
\hline \multirow[t]{3}{*}{$7^{\circ}$} & DIREITO PROCESSUAL CIVIL II & 60 \\
\hline & DIREITO CIVIL V - DIREITOS REAIS & 60 \\
\hline & DIREITO FINANCEIRO I & 60 \\
\hline
\end{tabular}




\begin{tabular}{|c|c|c|}
\hline & HERMENÊUTICA JURÍDICA & 60 \\
\hline & DIREITO DO TRABALHO I & 60 \\
\hline & CARGA ESTAGIO & 50 \\
\hline \multirow[t]{7}{*}{$8^{\circ}$} & DIREITO PROCESSUAL CIVIL III & 60 \\
\hline & DIREITO PROCESSUAL PENAL I & 60 \\
\hline & DIREITO TRIBUTÁRIO I & 60 \\
\hline & DIREITO ECONÔMICO I & 60 \\
\hline & ELABORAÇÃO DE PROJETO DE MONOGRAFIA & 15 \\
\hline & DIREITO DO TRABALHO II & 60 \\
\hline & CARGA OPTATIVA COMPLEMENTAR & 90 \\
\hline \multirow[t]{7}{*}{$9^{\circ}$} & PROCESSO DE EXECUÇÃO CONCURSAL I & 30 \\
\hline & DIREITO PROCESSUAL PENAL II & 60 \\
\hline & DIREITO ECONÔMICO II & 45 \\
\hline & ELABORAÇÃO DE MONOGRAFIA & 15 \\
\hline & SOCIOLOGIA JURÍDICA & 45 \\
\hline & DIREITO PROCESSUAL DO TRABALHO I & 45 \\
\hline & CARGA OPTATIVA COMPLEMENTAR & 90 \\
\hline \multirow[t]{5}{*}{$10^{\circ}$} & DIREITO CIVIL VI - DIREITO DE FAMÍLIA & 45 \\
\hline & DIREITO INTERNACIONAL PRIVADO & 45 \\
\hline & DEFESA DE MONOGRAFIA & 15 \\
\hline & FILOSOFIA DO DIREITO & 60 \\
\hline & CARGA OPTATIVA & 50 \\
\hline \multirow{3}{*}{$\begin{array}{l}\text { ESTAGIO } \\
\text { SUPERVISIO } \\
\text { NADO }\end{array}$} & PRATICA JURÍDICA SIMULADA & 30 \\
\hline & ESTAGIO SUPER VISIONADO - PRATICA REAL 20 & 300 \\
\hline & ESTAGIO SUPER VISIONADO - PRATICA REAL 18 & 270 \\
\hline \multirow{39}{*}{$\begin{array}{l}\text { DISCIPLINAS } \\
\text { OPTATIVAS } \\
\end{array}$} & MEDICINA LEGAL & 60 \\
\hline & FINANÇAS E CONTABILIDADE PUBLICA & 15 \\
\hline & SERVIÇOS NOTARIAIS E REGISTRAIS & 45 \\
\hline & DIREITO MINERARIO & 45 \\
\hline & DIREITO ROMANO & 45 \\
\hline & TEORIA JURÍDICA DOS MERCADOS COMUNS & 45 \\
\hline & DIREITO DO COMERCIO EXTERIOR & 45 \\
\hline & DIREITO DO MERCOSUL & 45 \\
\hline & ARBITRAGEM JURÍDICA & 45 \\
\hline & DIREITO DE INFORMÁTICA & 45 \\
\hline & TÓPICOS EM DIREITO CIVIL & 30 \\
\hline & TÓPICOS EM DIREITO COMERCIAL & 30 \\
\hline & TÓPICOS EM DIREITO PROCESSUAL CIVIL & 30 \\
\hline & PROCESSO DE EXECUÇÃO CONCURSAL II & 30 \\
\hline & PSICOLOGIA JURÍDICA & 45 \\
\hline & POLÍTICA CRIMINAL & 45 \\
\hline & CRIMINOLOGIA & 45 \\
\hline & TÓPICOS EM DIREITO PENAL & 30 \\
\hline & TÓPICOS EM DIREITO PROCESSUAL PENAL & 30 \\
\hline & PRATICA JURÍDICA PENAL SIMULADA & 30 \\
\hline & DIREITO URBANÍSTICO & 30 \\
\hline & DIREITO PARLAMENTAR & 45 \\
\hline & DIREITO DO CONSUMIDOR & 45 \\
\hline & DIREITO AMBIENTAL & 45 \\
\hline & DIREITO DAS ORGANIZAÇÕES INTERNACIONAIS & 45 \\
\hline & DIREITO DO MAR & 45 \\
\hline & DIREITO TRIBUTÁRIO II & 45 \\
\hline & RELAÇÕES INTERNACIONAIS & 45 \\
\hline & DIREITOS FUNDAMENTAIS & 45 \\
\hline & TÓPICOS EM DIREITO CONSTITUCIONAL & 30 \\
\hline & TÓPICOS EM DIREITO INTERNACIONAL & 30 \\
\hline & TÓPICOS EM DIREITO ADMINISTRATIVO & 30 \\
\hline & TÓPICOS EM DIREITO TRIBUTÁRIO & 30 \\
\hline & DIREITO ADMINISTRATIVO DA FUNÇÃO PUBLICA & 45 \\
\hline & TÓPICOS EM TEORIA DO ESTADO & 30 \\
\hline & DIREITO FINANCEIRO II & 60 \\
\hline & DIREITO ADMINISTRATIVO III & 60 \\
\hline & DIREITO ELEITORAL & 30 \\
\hline & PROGRAMA DE INICIAÇÃO A DOCÊNCIA I & 60 \\
\hline
\end{tabular}




\begin{tabular}{|c|c|c|}
\hline & PARTICIPAÇÃO EM EVENTOS I & 15 \\
\hline & PARTICIPAÇÃO EM EVENTOS II & 30 \\
\hline & PARTICIPAÇÃO EM EVENTOS III & 45 \\
\hline & PARTICIPAÇÃO EM EVENTOS IV & 60 \\
\hline & APRENDIZAGEM A DISTANCIA I & 15 \\
\hline & APRENDIZAGEM A DISTANCIA II & 30 \\
\hline & APRENDIZAGEM A DISTANCIA III & 45 \\
\hline & PROG. DE INTEGRAÇÃO COM POS GRADUAÇÃO I & 15 \\
\hline & PROG.DE INTEGRAÇÃO COM POS GRADUAÇÃO II & 30 \\
\hline & PROG.DE INTEGRAÇÃO COM POS GRADUAÇÃO III & 45 \\
\hline & PROG. DE INTEGRAÇÃO COM POS GRADUAÇÃO IV & 60 \\
\hline & PROGRAMA DE INICIAÇÃO CIENTIFICA I & 15 \\
\hline & PROGRAMA DE INICIAÇÃO CIENTIFICA II & 30 \\
\hline & PROGRAMA DE INICIAÇÃO CIENTIFICA III & 45 \\
\hline & PROGRAMA DE INICIAÇÃO CIENTIFICA IV & 60 \\
\hline & PROGRAMA DE APRIMORAMENTO DISCENTE I & 60 \\
\hline & PROGRAMA DE APRIMORAMENTO DISCENTE II & 60 \\
\hline & PROGRAMA DE FORMAÇÃO LIVRE I & 15 \\
\hline & PROGRAMA DE FORMAÇÃO LIVRE II & 30 \\
\hline & PROGRAMA DE FORMAÇÃO LIVRE III & 45 \\
\hline & PROGRAMA DE FORMAÇÃO LIVRE IV & 60 \\
\hline & PUBLICAÇÃO I & 15 \\
\hline & PUBLICAÇÃO II & 30 \\
\hline & GRUPO DE ESTUDOS I & 15 \\
\hline & GRUPO DE ESTUDOS II & 30 \\
\hline & GRUPO DE ESTUDOS III & 45 \\
\hline & GRUPO DE ESTUDOS IV & 60 \\
\hline & ATIVIDADES DE EXTENSÃO I & 15 \\
\hline & ATIVIDADES DE EXTENSÃO II & 30 \\
\hline & ATIVIDADES DE EXTENSÃO III & 45 \\
\hline & ATIVIDADES DE EXTENSÃO IV & 60 \\
\hline & PROGRAMA DE FORMAÇÃO LIVRE V & 75 \\
\hline & CONTRATOS TRABALHISTAS ESPECIAIS & 45 \\
\hline & DIREITO TUTELAR DO TRABALHO & 45 \\
\hline & DIREITO INTERNACIONAL DO TRABALHO & 45 \\
\hline & DIREITO COLETIVO DO TRABALHO & 45 \\
\hline & TÓPICOS EM DIREITO DO TRABALHO & 30 \\
\hline & HISTORIA DO PENSAMENTO JURID. OCIDENTAL & 45 \\
\hline & HISTORIA DO DIREITO BRASILEIRO & 45 \\
\hline & INT.AOS GRANDES SIST.CONTEMPORAN.DIREITO & 45 \\
\hline & BIOÉTICA E DIREITO & 45 \\
\hline & TÓPICOS EM FILOSOFIA DO DIREITO & 30 \\
\hline & TÓPICOS EM TEORIA GERAL DO DIREITO & 30 \\
\hline & DIREITO PROCESSUAL DO TRABALHO II & 60 \\
\hline & PRATICA JURÍDICA TRABALHISTA SIMULADA & 30 \\
\hline & DIREITO AGRÁRIO & 30 \\
\hline & PREVIDÊNCIA SOCIAL & 30 \\
\hline & LÍNGUA LATINA I & 60 \\
\hline
\end{tabular}

UFMS - UNIVERSIDADE ESTADUAL DO MATO GROSSO DO SUL

Disponível

http://www.sien.ufms.br/index.php?_rav=fhghdm98_adsfas_hasakjhij7728hnjsnfjhghdffadfyioasfyasytoxontzojm6imfsdci7czoloijncmfkzsi $7 \mathrm{fq}==\&$ cen_cod=7\&cur_cod $=0739$

Acesso em outubro/2010

\begin{tabular}{|l|l|l|}
\hline SÉRIE & DISCIPLINA & CARGA \\
& & HORÁRIA \\
\hline $1^{\mathrm{a}}$ & ANTROPOLOGIA & \\
\hline & CIÊNCIA POLÍTICA & \\
\hline & DIREITO CIVIL I & \\
\hline & DIREITO PENAL I & \\
\hline & ECONOMIA & \\
\hline & FILOSOFIA & \\
\hline & HISTÓRIA DO DIREITO & \\
\hline & INTRODUÇÃO AO ESTUDO DO DIREITO & \\
\hline & PSICOLOGIA APLICADA AO DIREITO & \\
\hline & SOCIOLOGIA JURÍDICA & \\
\hline $2^{\mathrm{a}}$ & & \\
\hline & DIREITO AMBIENTAL & \\
\hline & DIREITO CIVIL II & \\
\hline
\end{tabular}




\begin{tabular}{|l|l|l|}
\hline & DIREITO DO TRABALHO I & \\
\hline & DIREITO PENAL II & \\
\hline & DIREITOS HUMANOS & \\
\hline & INTRODUÇÃO À METODOLOGIA DE PESQUISA JURÍDICA & \\
\hline & PORTUGUÉS FORENSE & \\
\hline & TEORIA GERAL DO PROCESSO & \\
\hline $3^{\text {o }}$ & & \\
\hline & DIREITO CIVIL III & \\
\hline & DIREITO CONSTITUCIONAL II & \\
\hline & DIREITO DO TRABALHO II & \\
\hline & DIREITO PENAL III & \\
\hline & DIREITO PROCESSUAL CIVIL I & \\
\hline & DIREITO PROCESSUAL DO TRABALHO & \\
\hline & DIREITO PROCESSUAL PENAL I & \\
\hline & & \\
\hline & DIREITO ADMINISTRATIVO & \\
\hline & DIREITO CIVIL IV & \\
\hline & DIREITO EMPRESARIAL I & \\
\hline & DIREITO PROCESSUAL CIVIL II & \\
\hline & DIREITO PROCESSUAL PENAL II & \\
\hline & DIREITO TRIBUTÁRIO & \\
\hline & ESTÁGIO SUPERVISIONADO - PRÁTICA JURÍDICA I & \\
\hline & & \\
\hline & DIREITO CIVIL V & \\
\hline & DIREITO EMPRESARIAL II & \\
\hline & DIREITO INTERNACIONAL & \\
\hline & DIREITO PROCESSUAL CIVIL III & \\
\hline & ESTÁGIO SUPERVISIONADO - PRÁTICA JURÍDICA II & \\
\hline & ÉTICA PROFISSIONAL \\
\hline & TRABALHO DE CONCLUSÃO & \\
\hline
\end{tabular}

UFMT - UNIVERSIDADE FEDERAL DE MATO GROSSO

Disponível em: http://www.ufmt.br/fd/Texto/Graducao/Grade-Curricular.htm

Acesso em outubro/2010

\begin{tabular}{|c|c|c|}
\hline SÉRIE & DISCIPLINA & $\begin{array}{c}\text { CARGA } \\
\text { HORÁRIA }\end{array}$ \\
\hline \multirow[t]{7}{*}{$1^{\circ}$} & DIREITO CIVIL I & 60 \\
\hline & ECONOMIA POLÍTICA & 60 \\
\hline & HISTÓRIA DO DIREITO & 60 \\
\hline & FILOSOFIA GERAL E DO DIREITO & 120 \\
\hline & INTRODUÇÃO AO ESTUDO DO DIREITO & 120 \\
\hline & CIÊNCIA POLÍTICA E TEORIA GERAL DO ESTADO & 120 \\
\hline & SOCIOLOGIA GERAL E DO DIREITO & 120 \\
\hline \multirow[t]{7}{*}{$2^{\circ}$} & TEORIA GERAL DO PROCESSO & 60 \\
\hline & METODOLOGIA CIENTÍFICA & 60 \\
\hline & DIREITO INTERNACIONAL & 60 \\
\hline & DIREITO FINANCEIRO & 60 \\
\hline & DIREITO CONSTITUCIONAL & 120 \\
\hline & DIREITO PENAL I & 120 \\
\hline & DIREITO CIVIL II & 120 \\
\hline \multirow[t]{6}{*}{$3^{\circ}$} & DIREITO TRIBUTÁRIO & 60 \\
\hline & DIREITO DO TRABALHO I & 60 \\
\hline & DIREITO PROCESSUAL PENAL I & 120 \\
\hline & DIREITO PROCESSUAL CIVIL I & 120 \\
\hline & DIREITO PENAL II & 120 \\
\hline & DIREITO CIVIL III & 120 \\
\hline \multirow[t]{8}{*}{$4^{\circ}$} & MEDICINA LEGAL & 60 \\
\hline & DIREITO DO TRABALHO II & 60 \\
\hline & DIREITO PROCESSUAL PENAL II & 60 \\
\hline & DIREITO DA CRIANÇA E DO ADOLESCENTE & 60 \\
\hline & DIREITO COMERCIAL & 120 \\
\hline & DIREITO PROCESSUAL CIVIL II & 120 \\
\hline & DIREITO CIVIL IV & 120 \\
\hline & PRÁTICA FORENSE I & 120 \\
\hline $5^{\circ}$ & DIREITO AMBIENTAL & 60 \\
\hline
\end{tabular}




\begin{tabular}{|l|l|c|}
\hline & DIREITO PROCESSUAL DO TRABALHO & 60 \\
\hline & ORIENTAÇÃO MONOGRAFIA & 60 \\
\hline & DIREITO AGRÁRIO & 120 \\
\hline & DIREITO ADMINISTRATIVO & 120 \\
\hline & DIREITO PROCESSUAL CIVIL III & 120 \\
\hline & DIREITO CIVIL V & 120 \\
\hline & PRÁTICA FORENSE II & 150 \\
\hline
\end{tabular}

UFOP - UNIVERSIDADE FEDERAL DE OURO PRETO

Disponível em: http://www.prograd.ufop.br/downloads/matriz-curricular/direito.pdf

Acesso em outubro/2010

\begin{tabular}{|c|c|c|}
\hline SÉMESTRE & DISCIPLINA & $\begin{array}{c}\text { CARGA } \\
\text { HORÁRIA }\end{array}$ \\
\hline \multirow[t]{6}{*}{$1^{\circ}$} & INTRODUÇÃO ESTUDO DIREITO I & 60 \\
\hline & CIÊNCIA POLÍTICA & 60 \\
\hline & DIREITO CIVIL - PARTE GERAL I & 60 \\
\hline & FILOSOFIA GERAL & 60 \\
\hline & SOCIOLOGIA GERAL & 30 \\
\hline & ECONOMIA & 30 \\
\hline \multirow[t]{5}{*}{$2^{\circ}$} & INTRODUÇÃO ESTUDO DIREITO II & 60 \\
\hline & FILOSOFIA JURÍDICA & 60 \\
\hline & SOCIOLOGIA JURÍDICA & 30 \\
\hline & DIREITO CIVIL - PARTE GERAL II & 60 \\
\hline & TEORIA DA CONSTITUIÇÃO & 60 \\
\hline \multirow[t]{5}{*}{$3^{\circ}$} & DIREITO CIVIL - OBRIGAÇÕES I & 60 \\
\hline & DIREITO CONSTITUCIONAL I & 60 \\
\hline & DIREITO FINANCEIRO E TRIBUTÁRIO I & 30 \\
\hline & DIREITO PENAL I & 60 \\
\hline & DIREITO COMERCIAL I & 60 \\
\hline \multirow[t]{5}{*}{$4^{\circ}$} & DIREITO CIVIL - OBRIGAÇÕES II & 60 \\
\hline & DIREITO CONSTITUCIONAL II & 60 \\
\hline & DIREITO FINANCEIRO E TRIBUTÁRIO II & 30 \\
\hline & DIREITO PENAL II & 60 \\
\hline & DIREITO COMERCIAL II & 60 \\
\hline \multirow[t]{5}{*}{$5^{\circ}$} & DIREITO CIVIL - CONTRATOS & 60 \\
\hline & DIREITO FINANCEIRO E TRIBUTÁRIO III & 30 \\
\hline & DIREITO ADMINISTRATIVO I & 60 \\
\hline & DIREITO PENAL III & 60 \\
\hline & DIREITO COMERCIAL III & 60 \\
\hline \multirow[t]{6}{*}{$6^{\circ}$} & METODOLOGIA DE MONOGRAFIA JURÍDICA & 30 \\
\hline & DIREITO CIVIL - POSSE E PROPRIEDADE & 60 \\
\hline & DIREITO ADMINISTRATIVO II & 60 \\
\hline & DIREITO PENAL IV & 60 \\
\hline & DIREITO COMERCIAL IV & 60 \\
\hline & TEORIA GERAL DO PROCESSO & 30 \\
\hline \multirow[t]{5}{*}{$7^{\circ}$} & DIREITO ADMINISTRATIVO III & 60 \\
\hline & DIREITO CIVIL - REAIS LIMITADOS & 30 \\
\hline & DIREITO DO TRABALHO I & 60 \\
\hline & DIREITO PROCESSUAL CIVIL I & 60 \\
\hline & DIREITO PROCESSUAL PENAL I & 60 \\
\hline \multirow[t]{6}{*}{$8^{\circ}$} & ELABORAÇÃO DE PROJETO DE MONOGRAFIA & 30 \\
\hline & DIREITO CIVIL - FAMÍLIA & 60 \\
\hline & DIREITO INTERNACIONAL PÚBLICO & 60 \\
\hline & DIREITO DO TRABALHO II & 60 \\
\hline & DIREITO PROCESSUAL CIVIL II & 60 \\
\hline & DIREITO PROCESSUAL PENAL II & 60 \\
\hline \multirow[t]{4}{*}{$9^{\circ}$} & DIREITO CIVIL - SUCESSÕES & 60 \\
\hline & DIREITO PROCESSUAL DO TRABALHO & 60 \\
\hline & DIREITO PROCESSUAL CIVIL III & 60 \\
\hline & DIREITO PROCESSUAL PENAL III & 60 \\
\hline \multirow[t]{3}{*}{$10^{\circ}$} & DIREITO PREVIDENCIÁRIO & 60 \\
\hline & DIREITO INTERNACIONAL PRIVADO & 30 \\
\hline & DEONTOLOGIA E DICEOLOGIA FORENSE & 30 \\
\hline
\end{tabular}




\begin{tabular}{|l|l|l|}
\hline & & \\
\hline & MONOGRAFIA JURİDICA & 120 \\
\hline & ESTÁGIO CURRICULAR SUPERVISIONADO & 300 \\
\hline & ATIVIDADES COMPLEMENTARES DE GRADUAÇÃO & 300 \\
\hline
\end{tabular}

UFRJ - UNIVERSIDADE FEDERAL DO RIO DE JANEIRO

Disponível em: https://www.siga.ufrj.br/sira/temas/zire/frameConsultas.jsp?mainPage=/repositorio-curriculo/9BAE61EE-92A4-F713-002D7A1004A03372.html

Acesso em outubro/2010

\begin{tabular}{|c|c|c|}
\hline PERÍODO & DISCIPLINA & $\begin{array}{c}\text { CARGA } \\
\text { HORÁRIA }\end{array}$ \\
\hline \multirow[t]{6}{*}{$1^{\circ}$} & ECONOMIA E DIREITO I & 30 \\
\hline & SOCIOLOGIA JURÍDICA I & 30 \\
\hline & INTRODUÇÃO AO DIREITO I & 60 \\
\hline & METODOLOGIA DO DIREITO I & 30 \\
\hline & HIST E INSTITUIÇÕES DO DIR ROM & 60 \\
\hline & TEORIA DO ESTADO & 60 \\
\hline \multirow[t]{5}{*}{$2^{\circ}$} & ECONOMIA E DIREITO II & 60 \\
\hline & SOCIOLOGIA JURÍDICA II & 60 \\
\hline & INTRODUÇÃO AO DIREITO II & 30 \\
\hline & METODOLOGIA DO DIREITO II & 30 \\
\hline & INTRODUÇÃO AO DIREITO CIVIL & 60 \\
\hline \multirow[t]{5}{*}{$3^{\circ}$} & DIREITO DAS OBRIGAÇÕES & 60 \\
\hline & DIREITO CONSTITUCIONAL I & 60 \\
\hline & DIR INTERNACIONAL PUBLICO I & 30 \\
\hline & DIREITO PENAL I & 60 \\
\hline & INTROD AO DIREITO PROCESSUAL & 60 \\
\hline \multirow[t]{5}{*}{$4^{\circ}$} & TEORIA DO CONTRATO & 60 \\
\hline & DIREITO CONSTITUCIONAL II & 60 \\
\hline & DIR INTERNACIONAL PUBLICO II & 30 \\
\hline & DIREITO PENAL II & 60 \\
\hline & DIREITO PROCESSUAL CIVIL I & 60 \\
\hline \multirow[t]{5}{*}{$5^{\circ}$} & DIREITO COMERCIAL & 60 \\
\hline & DIREITO CONTRATUAL & 60 \\
\hline & DIREITO PENAL III & 60 \\
\hline & DIR PROCESSUAL CIVIL II & 60 \\
\hline & DIREITO ADMINISTRATIVO I & 60 \\
\hline \multirow[t]{5}{*}{$6^{\circ}$} & TÍTULOS DE CREDITO & 60 \\
\hline & DIREITO REAIS I & 60 \\
\hline & DIREITO PENAL IV & 60 \\
\hline & DIREITO ADMINISTRATIVO II & 60 \\
\hline & DIREITO PROCESSUAL CIVIL III & 60 \\
\hline \multirow[t]{6}{*}{$7^{\circ}$} & DIREITO DO TRABALHO I 4.0 & 60 \\
\hline & DIREITO DA NAVEGAÇÃO & 60 \\
\hline & DIREITOS REAIS II & 30 \\
\hline & DIREITO PROCESSUAL PENAL I & 60 \\
\hline & DIREITO PROCESSUAL CIVIL IV & 60 \\
\hline & ESTÁGIO PRÁTICA JURÍDICA I & 60 \\
\hline \multirow[t]{6}{*}{$8^{\circ}$} & DIREITO DO TRABALHO II & 60 \\
\hline & DIREITO FALIMENTAR & 60 \\
\hline & INTROD AO DIREITO TRIBUTÁRIO & 60 \\
\hline & DIREITO DE FAMÍLIA & 30 \\
\hline & DIREITO PROCESSUAL PENAL II & 60 \\
\hline & ESTÁGIO PRÁTICA JURÍDICA II & 60 \\
\hline \multirow[t]{6}{*}{$9^{\circ}$} & DIREITO TRIBUTÁRIO II & 30 \\
\hline & FILOSOFIA DO DIREITO I & 30 \\
\hline & DIR INTERNACIONAL PRIVADO I & 60 \\
\hline & DIREITO DAS SUCESSÕES & 30 \\
\hline & ESTÁGIO PRÁTICA JURÍDICA III & 90 \\
\hline & MONOGRAFIA JURÍDICA I & 60 \\
\hline $10^{\circ}$ & FILOSOFIA DO DIREITO II & 30 \\
\hline
\end{tabular}




\begin{tabular}{|l|l|c|}
\hline & DIR INTERNACIONAL PRIVADO II & 30 \\
\hline & ESTÁGIO PRÁTICA JURIDICA IV & 90 \\
\hline & ATIVIDADES COMPLEMENTARES & 300 \\
\hline & MONOGRAFIA JURÍDICA II & 60 \\
\hline
\end{tabular}

UNAMA - UNIVERSIDADE DA AMAZÔNIA

Disponível em: http://www.unama.br/graduacao/cursos/direito/download/estrutura-curricular.pdf Acesso em outubro/2010

\begin{tabular}{|c|c|c|}
\hline SEMESTRE & DISCIPLINA & $\begin{array}{r}\text { CARGA } \\
\text { HORÁRIA }\end{array}$ \\
\hline \multirow[t]{5}{*}{$1^{\circ}$} & ECONOMIA POLÍTICA & 72 \\
\hline & INTRODUÇÃO AO DIREITO I & 72 \\
\hline & LÍNGUA PORTUGUESA - LEITURA E PRODUÇÃO DE TEXTOS & 72 \\
\hline & SOCIOLOGIA GERAL E JURÍDICA & 72 \\
\hline & CONHECIMENTO E MÉTODO & 36 \\
\hline \multirow[t]{5}{*}{$2^{\circ}$} & INTRODUÇÃO À FILOSOFIA & 36 \\
\hline & INTRODUÇÃO AO DIREITO II & 72 \\
\hline & TEORIA GERAL DO ESTADO & 72 \\
\hline & DIRETOS HUMANOS & 36 \\
\hline & TEORIA GERAL DO DIREITO CIVIL & 72 \\
\hline \multirow[t]{5}{*}{$3^{\circ}$} & DIREITO CIVIL-DAS OBRIGAÇÕES & 72 \\
\hline & DIREITO PENAL I & 72 \\
\hline & DIREITO CONSTITUCIONAL I & 72 \\
\hline & DIREITO INTERNACIONAL & 36 \\
\hline & DIREITO FINANCEIRO & 72 \\
\hline \multirow[t]{5}{*}{$4^{\circ}$} & DIREITO CIVIL - DOS CONTRATOS I & 72 \\
\hline & DIREITO PENAL II & 72 \\
\hline & DIREITO CONSTITUCIONAL II & 72 \\
\hline & DIREITO TRIBUTÁRIO & 72 \\
\hline & DIREITO ADMINISTRATIVO I & 72 \\
\hline \multirow[t]{5}{*}{$5^{\circ}$} & DIREITO CIVIL - DOS CONTRATOS II & 72 \\
\hline & DIREITO PENAL III & 72 \\
\hline & DIREITO EMPRESARIAL & 72 \\
\hline & DIREITO ADMINISTRATIVO II & 72 \\
\hline & TEORIA GERAL DO PROCESSO & 32 \\
\hline \multirow[t]{4}{*}{$6^{\circ}$} & DIREITO CIVIL - DAS COISAS & 72 \\
\hline & DIREITO PENAL IV & 72 \\
\hline & DIREITO AMBIENTAL & 72 \\
\hline & DIREITO PROCESSUAL CIVIL - DO PROCESSO DE CONHECIMENTO I & 72 \\
\hline \multirow[t]{5}{*}{$7^{\circ}$} & DIREITO CIVIL - DA FAMÍLIA & 72 \\
\hline & DIREITO DO TRABALHO I & 72 \\
\hline & DIREITO FALIMENTAR & 36 \\
\hline & DIREITO PROCESSUAL CIVIL - DO PROCESSO DE CONHECIMENTO II & 72 \\
\hline & DIREITO PROCESSUAL PENAL I & 72 \\
\hline \multirow[t]{6}{*}{$8^{\circ}$} & DIREITO CIVIL- DAS SUCESSÕES & 72 \\
\hline & DIREITO PROC.L PENAL II & 72 \\
\hline & DIREITO PROCESSUAL CIVIL - DOS RECURSOS E DA AÇÃO RESCISÓRIA & 72 \\
\hline & DIREITO DO TRABALHO II & 72 \\
\hline & METODOLOGIA DA PESQUISA & 36 \\
\hline & ESTÁGIO SUPERVISIONADO I & 36 \\
\hline \multirow[t]{6}{*}{$9^{\circ}$} & FILOSOFIA JURÍDICA E ÉTICA & 36 \\
\hline & DIREITO PROCESSUAL DO TRABALHO I & 72 \\
\hline & DIREITO PROCESSUAL CIVIL - DO PROCESSO DE EXECUÇÃO & 72 \\
\hline & ÁREA DE ESPECIALIZAÇÃO 1 & 72 \\
\hline & MONOGRAFIA I & 36 \\
\hline & ESTÁGIO SUPERVISIONADO II & 36 \\
\hline \multirow[t]{4}{*}{$10^{\circ}$} & $\begin{array}{l}\text { DIREITO PROCESSUAL CIVIL - DO PROCESSO CAUTELAR E DOS PROCEDIMENTOS } \\
\text { ESPECIAIS }\end{array}$ & 72 \\
\hline & DIR. PROCESSUAL DO TRABALHO II & 72 \\
\hline & ÁREA DE ESPECIALIZAÇÃO 2 & 72 \\
\hline & MONOGRAFIA II & 36 \\
\hline
\end{tabular}


\begin{tabular}{|l|l|c|}
\hline & ESTÁGIO SUPERVISIONADO III & 36 \\
\hline
\end{tabular}

UNDB - UNIDADE DE ENSINO SUPERIOR DOM BOSCO

Disponível em: www.undb.com.br/.../download.php?...grade curso de direito...cursos

Acesso em outubro/2010

\begin{tabular}{|c|c|c|}
\hline SEMESTRE & DISCIPLINA & $\begin{array}{c}\text { CARGA } \\
\text { HORÁRIA }\end{array}$ \\
\hline \multirow[t]{6}{*}{$1^{\circ}$} & CIÊNCIA POLÍTICA E TEORIA GERAL DO ESTADO 60 & 60 \\
\hline & ECONOMIA 60 & 60 \\
\hline & FILOSOFIA 80 & 80 \\
\hline & INTRODUÇÃO AO ESTUDO DO DIREITO I & 60 \\
\hline & HERMENÊUTICA JURÍDICA & 60 \\
\hline & SOCIOLOGIA & 60 \\
\hline \multirow[t]{6}{*}{$2^{\circ}$} & FILOSOFIA DO DIREITO & 80 \\
\hline & INTRODUÇÃO AO ESTUDO DO DIREITO II & 60 \\
\hline & SOCIOLOGIA JURÍDICA & 60 \\
\hline & TEORIA DO DIREITO CONSTITUCIONAL & 60 \\
\hline & TEORIA DO DIREITO PENAL & 60 \\
\hline & TEORIA DO DIREITO PRIVADO & 60 \\
\hline \multirow[t]{6}{*}{$3^{\circ}$} & DIREITO CONSTITUCIONAL I & 60 \\
\hline & DIREITO DAS OBRIGAÇÕES & 60 \\
\hline & DIREITO PENAL ESPECIAL I & 80 \\
\hline & METODOLOGIA DA PESQUISA CIENTÍFICA & 60 \\
\hline & TEORIA DO DIREITO COMERCIAL & 60 \\
\hline & TEORIA DO PROCESSO & 60 \\
\hline \multirow[t]{6}{*}{$4^{\circ}$} & CONTRATOS CÍVEIS & 60 \\
\hline & CONTRATOS COMERCIAIS & 60 \\
\hline & DIREITO CONSTITUCIONAL II & 60 \\
\hline & DIREITO DA CRIANÇA E DO ADOLESCENTE & 60 \\
\hline & DIREITO PENAL ESPECIAL II & 60 \\
\hline & PROCESSO DE CONHECIMENTO & 80 \\
\hline \multirow[t]{6}{*}{$5^{\circ}$} & DIREITO DO CONSUMIDOR & 60 \\
\hline & DIREITO PENAL ESPECIAL III & 80 \\
\hline & DIREITOS REAIS & 60 \\
\hline & METODOLOGIA DA PESQUISA EM DIREITO & 60 \\
\hline & RECURSOS NO PROCESSO CIVIL & 60 \\
\hline & TÍTULOS DE CRÉDITO & 60 \\
\hline \multirow[t]{6}{*}{$6^{\circ}$} & DIREITO ADMINISTRATIVO I & 60 \\
\hline & DIREITO DE FAMÍLIA E SUCESSÕES & 80 \\
\hline & DIREITO ECONÔMICO & 60 \\
\hline & DIREITO PROCESSUAL PENAL I & 60 \\
\hline & FALÊNCIA E CONCORDATA & 60 \\
\hline & PROCESSO DE EXECUÇÃO & 60 \\
\hline \multirow[t]{6}{*}{$7^{\circ}$} & DIREITO ADMINISTRATIVO II & 60 \\
\hline & DIREITO INDIVIDUAL DO TRABALHO & 60 \\
\hline & DIREITO PROCESSUAL PENAL II & 60 \\
\hline & DIREITO TRIBUTÁRIO I & 60 \\
\hline & PROCEDIMENTOS ESPECIAIS E PROCESSO CAUTELAR & 80 \\
\hline & TÉCNICAS DE ELABORAÇÃO DE MONOGRAFIA I & 60 \\
\hline \multirow[t]{7}{*}{$8^{\circ}$} & DIREITO AMBIENTAL & 60 \\
\hline & DIREITO COLETIVO DO TRABALHO & 60 \\
\hline & DIREITO FINANCEIRO & 40 \\
\hline & DIREITO INTERNACIONAL PRIVADO & 40 \\
\hline & DIREITO INTERNACIONAL PÚBLICO & 60 \\
\hline & DIREITO TRIBUTÁRIO II & 60 \\
\hline & EXECUÇÕES PENAIS & 60 \\
\hline \multirow[t]{5}{*}{$9^{\circ}$} & DIREITO PROCESSUAL DOTRABALHO & 60 \\
\hline & ELETIVA I & 60 \\
\hline & ELETIVA II & 60 \\
\hline & PRÁTICA JURÍDICA I (ESTÁGIO) & 200 \\
\hline & TÉCNICAS DE ELABORAÇÃO DE MONOGRAFIA II & 60 \\
\hline $10^{\circ}$ & PRÁTICA JURÍDICA II (ESTÁGIO) & 200 \\
\hline
\end{tabular}




\begin{tabular}{|c|l|c|}
\hline & DIREITO DA SEGURIDADE SOCIAL & 60 \\
\hline & DIREITO AGRÁRIO & 60 \\
\hline & ELETIVA III & 60 \\
\hline & ELETIVA IV & 60 \\
\hline $\begin{array}{l}\text { ÁREA ELETIVA I } \\
-\begin{array}{c}\text { DIREITO } \\
\text { AMBIENTAL }\end{array}\end{array}$ & DIREITO PENAL AMBIENTAL & 60 \\
\hline & & \\
\hline & DIREITO COMUNITÁRIO E INTERNACIONAL AMBIENTAL & 60 \\
\hline $\begin{array}{c}\text { ÁREA ELETIVA II } \\
\text { DIREITO } \\
\text { EMPRESARIAL }\end{array}$ & DIREITO EMPRESARIAL & 60 \\
\hline & & 60 \\
\hline & DIREITO BANCÁRIO & 60 \\
\hline & & 60 \\
\hline $\begin{array}{c}\text { ÁREA ELETIVA } \\
\text { COMPLEMENTAR }\end{array}$ & DIREITO ELEITORAL & 60 \\
\hline & DIREITO COMUNITÁRIO & 60 \\
\hline & MEDICINA LEGAL & 60 \\
\hline
\end{tabular}

UNI-ANHANGUERA - CENTRO UNIVERSITÁRIO DE GOIÁS

Disponível em: http://anhanguera.edu.br/home/index.php?option=com_content\&task=view\&id=460\&Itemid=112

Acesso em outubro/2010

\begin{tabular}{|c|c|c|}
\hline PERÍODO & DISCIPLINA & $\begin{array}{c}\text { CARGA } \\
\text { HORÁRIA }\end{array}$ \\
\hline \multirow[t]{6}{*}{$1^{\circ}$} & INTRODUÇÃO AO ESTUDO DO DIREITO & 60 \\
\hline & SOCIOLOGIA GERAL E JURÍDICA & 60 \\
\hline & ANTROPOLOGIA & 60 \\
\hline & METODOLOGIA DO TRABALHO CIENTÍFICO & 60 \\
\hline & DIREITO CIVIL I & 60 \\
\hline & ÉTICA GERAL E PROFISSIONAL & 60 \\
\hline \multirow[t]{5}{*}{$2^{\circ}$} & ECONOMIA POLÍTICA & 60 \\
\hline & FILOSOFIA GERAL E JURÍDIC & 60 \\
\hline & CIÊNCIA POLÍTICA E T. G. E. & 60 \\
\hline & DIREITO CIVIL II & 60 \\
\hline & HISTÓRIA DO DIREITO & 60 \\
\hline \multirow[t]{6}{*}{$3^{\circ}$} & DIREITO PENAL I & 60 \\
\hline & DIREITO CIVIL III & 60 \\
\hline & DIREITO CONSTITUCIONAL I & 60 \\
\hline & PSICOLOGIA JURÍDICA & 60 \\
\hline & DIREITO PROCESSUAL CIVIL I & 60 \\
\hline & DIREITOS HUMANOS & 60 \\
\hline \multirow[t]{5}{*}{$4^{\circ}$} & DIREITO PENAL II & 60 \\
\hline & DIREITO CIVIL IV & 60 \\
\hline & DIREITO PROCESSUAL CIVIL II & 60 \\
\hline & DIREITO CONSTITUCIONAL II & 60 \\
\hline & DIREITO EMPRESARIAL I & 60 \\
\hline \multirow[t]{5}{*}{$5^{\circ}$} & DIREITO EMPRESARIAL II & 60 \\
\hline & DIREITO PENAL III & 60 \\
\hline & DIREITO CIVIL V & 60 \\
\hline & DIREITO PROCESSUAL PENAL I & 60 \\
\hline & DIREITO PROCESSUAL CIVIL III & 60 \\
\hline \multirow[t]{5}{*}{$6^{\circ}$} & DIREITO PROCESSUAL PENAL II & 60 \\
\hline & DIREITO PENAL IV & 60 \\
\hline & DIREITO CIVIL VI & 60 \\
\hline & DIREITO PROCESSUAL CIVIL IV & 60 \\
\hline & DIREITO EMPRESARIAL III & 60 \\
\hline \multirow[t]{6}{*}{$7^{\circ}$} & DIREITO PROCESSUAL PENAL III & 60 \\
\hline & DIREITO DO TRABALHO I & 60 \\
\hline & DIREITO CIVIL VII & 60 \\
\hline & DIREITO ADMINISTRATIVO I & 60 \\
\hline & DIREITO PROCESSUAL CIVIL V & 60 \\
\hline & PRÁTICA JURÍDICA I & 75 \\
\hline
\end{tabular}




\begin{tabular}{|l|l|r|}
\hline & & \\
\hline $8^{\circ}$ & DIREITO ADMINISTRATIVO II & 60 \\
\hline & DIREITO FINANCEIRO & 60 \\
\hline & DIREITO AGRÁRIO & 60 \\
\hline & DIREITO DO TRABALHO II & 60 \\
\hline & DISCIPLINA OPTATIVA & 60 \\
\hline & PRÁTICA JURÍDICA II & 75 \\
\hline & T.C.C. I (MONOGRAFIA OU ARTIGO CIENTÍFICO) & 50 \\
\hline & & 60 \\
\hline $9^{\circ}$ & DIREITO TRIBUTÁRIO & 60 \\
\hline & DIREITO PREVIDENCIÁRIO & 60 \\
\hline & DIREITO PROCESSUAL DO TRABALHO & 60 \\
\hline & DISCIPLINA OPTATIVA & 60 \\
\hline & TÓPICOS ESPECIAIS I & 75 \\
\hline & PRÁTICA JURÍDICA III & 50 \\
\hline & T.C.C. II (MONOGRAFIA OU ARTIGO CIENTÍFICO) & \\
\hline & & 60 \\
\hline $10^{\circ}$ & DIREITO INTERNACIONAL & 60 \\
\hline & DISCIPLINA OPTATIVA & 60 \\
\hline & TÓPICOS ESPECIAIS II & 60 \\
\hline & TÓPICOS ESPECIAIS III & 75 \\
\hline
\end{tabular}

UNIC - UNIVERSIDADE DE CUIABA

Disponível em: www.unic.br/site/index.php?pg=cursos\&posg=214\&tp=graduacao

Acesso em outubro/2010

\begin{tabular}{|c|c|c|}
\hline SEMESTRE & DISCIPLINA & $\begin{array}{c}\text { CARGA } \\
\text { HORÁRIA }\end{array}$ \\
\hline \multirow[t]{7}{*}{1} & DIREITOS HUMANOS & 60 \\
\hline & ECONOMIA POLÍTICA & 30 \\
\hline & CRIMINOLOGIA & 30 \\
\hline & TEORIA DO DIREITO & 60 \\
\hline & TEORIA DA ARGUMENTAÇÃO JURÍDICA & 90 \\
\hline & PSICOLOGIA & 30 \\
\hline & E.D.1 & 15 \\
\hline \multirow[t]{6}{*}{$2^{\circ}$} & DIREITO CIVIL I (PARTE GERAL) & 90 \\
\hline & CIÊNCIA POLÍTICA & 60 \\
\hline & FILOSOFIA DO DIREITO & 60 \\
\hline & HOMEM, CULTURA E SOCIEDADE & 60 \\
\hline & INICIAÇÃO À PESQUISA CIENTÍFICA & 30 \\
\hline & E.D.2 & 15 \\
\hline \multirow[t]{6}{*}{$3^{\circ}$} & DIREITO CONSTITUCIONAL I & 60 \\
\hline & DIREITO CIVIL II (OBRIGAÇÕES) & 60 \\
\hline & DIREITO PENAL I & 60 \\
\hline & TEORIA DO PROCESSO E DA JURISDIÇÃO & 60 \\
\hline & ÉTICA, POLÍTICA E SOCIEDADE & 60 \\
\hline & E.D.3 & 15 \\
\hline \multirow[t]{6}{*}{$4^{\circ}$} & DIREITO DO TRABALHO I & 60 \\
\hline & DIREITO CIVIL III (CONTRATOS) & 60 \\
\hline & DIREITO CONSTITUCIONAL II & 60 \\
\hline & DIREITO PENAL II (PARTE GERAL) & 60 \\
\hline & DIREITO PROCESSUAL CIVIL I (PROCESSO DE CONHECIMENTO) & 60 \\
\hline & E.D.4 & 15 \\
\hline \multirow[t]{6}{*}{$5^{\circ}$} & DIREITO PENAL III (PARTE ESPECIAL) & 60 \\
\hline & DIREITO PROCESSUAL PENAL I & 60 \\
\hline & DIREITO PROCESSUAL CIVIL II (PROCESSO DE CONHECIMENTO) & 60 \\
\hline & DIREITO DO TRABALHO II & 60 \\
\hline & DIREITO CIVIL IV (FAMILIA) & 60 \\
\hline & E.D.5 & 15 \\
\hline \multirow[t]{6}{*}{$6^{\circ}$} & DIREITO CIVIL V (SUCESSÕES) & 60 \\
\hline & DIREITO PROCESSUAL PENAL II & 60 \\
\hline & DIREITO PENAL IV (PARTE ESPECIAL) & 60 \\
\hline & DIREITO PROCESSUAL DO TRABALHO & 60 \\
\hline & DIREITO PROCESSUAL CIVIL III (RECURSOS) & 60 \\
\hline & E.D.6 & 15 \\
\hline $7^{\circ}$ & DIREITO CIVIL VI (POSSE E PROPRIEDADE) & 60 \\
\hline
\end{tabular}




\begin{tabular}{|c|c|c|}
\hline & DIREITO PROCESSUAL PENAL III & 60 \\
\hline & DIREITO DA INFÂNCIA E DA ADOLESCÊNCIA & 30 \\
\hline & TRABALHO DE CURSO I (PROJETO) & 80 \\
\hline & RESPONSABILIDADE CIVIL & 30 \\
\hline & DIREITO PROCESSUAL CIVIL IV (EXECUÇÃO) & 60 \\
\hline & ESTÁGIO SUPER VISIONADO I & 80 \\
\hline & E.D.7 & 15 \\
\hline \multirow[t]{9}{*}{$8^{\circ}$} & DIREITO PROCESSUAL CIVIL V (CAUTELARES E PROCEDIMENTOS ESPECIAIS) & 60 \\
\hline & TRABALHO DE CURSO II (ORIENTAÇÃO INDIVIDUAL) & 40 \\
\hline & ESTÁGIO SUPER VISIONADO II & 80 \\
\hline & DIREITO CIVIL VII (DIREITOS REAIS) & 30 \\
\hline & DIREITO EMPRESARIAL & 60 \\
\hline & DIREITO DAS RELAÇÕES INTERNACIONAIS & 60 \\
\hline & LEGISLAÇÃO PENAL EXTRAVAGANTE E EXECUÇÃO PENAL & 60 \\
\hline & CONCILIAÇÃO, MEDIAÇÃO E ARBITRAGEM & 30 \\
\hline & E.D.8 & 15 \\
\hline \multirow[t]{9}{*}{$9^{\circ}$} & DIREITO FINANCEIRO & 30 \\
\hline & DIREITO ADMINISTRATIVO I & 60 \\
\hline & DIREITO AMBIENTAL & 60 \\
\hline & DIREITO DAS RELAÇÕES DE CONSUMO & 60 \\
\hline & DIREITO CAMBIAL E CONTRATOS MERCANTIS & 60 \\
\hline & DIREITO DA SEGURIDADE SOCIAL & 30 \\
\hline & ESTÁGIO CURRICULAR SUPER VISIONADO III & 80 \\
\hline & TRABALHO DE CURSO III (ORIENTAÇÃO E DEFESA TC) & 20 \\
\hline & E.D.9 & 15 \\
\hline \multirow[t]{9}{*}{$10^{\circ}$} & OPTATIVA & 30 \\
\hline & DIREITO TRIBUTÁRIO & 60 \\
\hline & DIREITO DE RECUPERAÇÃO E FALÊNCIA DE EMPRESAS & 30 \\
\hline & ÉTICA PROFISSIONAL & 30 \\
\hline & BIODIREITO & 30 \\
\hline & DIREITO PROCESSUAL CONSTITUCIONAL & 60 \\
\hline & DIREITO ADMINISTRATIVO II & 60 \\
\hline & ESTÁGIO SUPER VISIONADO IV & 80 \\
\hline & E.D.10 & 15 \\
\hline
\end{tabular}

UNICEUB - CENTRO UNIVERSITÁRIO DE BRASÍLIA

Disponível em: http://www.uniceub.br/curso/graduacao/cur010_matrizcurricular.aspx?HB=9e9c92\&CS=9e9c88 Acesso em outubro/2010

\begin{tabular}{|c|c|c|}
\hline SEMESTRE & DISCIPLINA & $\begin{array}{c}\text { CARGA } \\
\text { HORÁRIA }\end{array}$ \\
\hline \multirow[t]{5}{*}{$1^{\circ}$} & CIÊNCIA POLÍTICA & 75 \\
\hline & INSTITUIÇÕES JURÍDICAS & 75 \\
\hline & INTRODUÇÃO AO DIREITO & 75 \\
\hline & LÍNGUA PORTUGUESA & 75 \\
\hline & SOCIOLOGIA GERAL E JURÍDICA & 75 \\
\hline \multirow[t]{5}{*}{$2^{\circ}$} & DIREITO CIVIL - PESSOAS E BENS & 75 \\
\hline & DIREITO CONSTITUCIONAL I & 75 \\
\hline & DIREITO PENAL - TEORIA DO CRIME & 75 \\
\hline & ECONOMIA POLÍTICA & 75 \\
\hline & HISTÓRIA E CULTURA JURÍDICA BRASILEIRA & 75 \\
\hline \multirow[t]{6}{*}{$3^{\circ}$} & DIREITO CIVIL - FATOS JURÍDICOS & 75 \\
\hline & DIREITO CONSTITUCIONAL II & 75 \\
\hline & DIREITO PENAL - TEORIA DA PENA & 75 \\
\hline & ÉTICA, CIDADANIA E REALIDADE BRASILEIRA I & 30 \\
\hline & FILOSOFIA & 75 \\
\hline & TEORIA GERAL DO PROCESSO & 75 \\
\hline \multirow[t]{6}{*}{$4^{\circ}$} & DIREITO CIVIL - OBRIGAÇÕES & 75 \\
\hline & DIREITO EMPRESARIAL - SOCIETÁRIO & 75 \\
\hline & DIREITO INTERNACIONAL PÚBLICO & 75 \\
\hline & DIREITO PENAL - PARTE ESPECIAL I & 75 \\
\hline & DIREITO PROCESSUAL CIVIL - PARTE GERAL & 75 \\
\hline & ÉTICA, CIDADANIA E REALIDADE BRASILEIRA II & 30 \\
\hline \multirow[t]{2}{*}{$5^{\circ}$} & DIREITO CIVIL - CONTRATOS & 75 \\
\hline & DIREITO DO TRABALHO I & 75 \\
\hline
\end{tabular}




\begin{tabular}{|c|c|c|}
\hline & DIREITO EMPRESARIAL - CAMBIÁRIO & 75 \\
\hline & DIREITO PENAL - PARTE ESPECIAL II & 75 \\
\hline & DIREITO PROCESSUAL CIVIL - PROCESSO DE CONHECIMENTO & 75 \\
\hline \multirow[t]{5}{*}{$6^{\circ}$} & DIREITO CIVIL - COISAS & 75 \\
\hline & DIREITO DO TRABALHO II & 75 \\
\hline & DIREITO EMPRESARIAL - FALIMENTAR & 75 \\
\hline & DIREITO PROCESSUAL CIVIL - EXECUÇÃO E CAUTELAR & 75 \\
\hline & DIREITO PROCESSUAL PENAL I & 75 \\
\hline \multirow[t]{6}{*}{$7^{\circ}$} & DIREITO ADMINISTRATIVO I & 75 \\
\hline & DIREITO CIVIL - FAMÍLIA & 75 \\
\hline & DIREITO PROCESSUAL CIVIL - RECURSOS & 75 \\
\hline & DIREITO PROCESSUAL PENAL II & 75 \\
\hline & ESTÁGIO & 75 \\
\hline & FILOSOFIA DO DIREITO & 75 \\
\hline \multirow[t]{6}{*}{$8^{\circ}$} & DIREITO ADMINISTRATIVO II & 75 \\
\hline & DIREITO PROCESSUAL DO TRABALHO I & 75 \\
\hline & ESTÁGIO & 75 \\
\hline & MONOGRAFIA I & 75 \\
\hline & TÓPICO ESPECIAL I & 75 \\
\hline & TÓPICO ESPECIAL II & 75 \\
\hline \multirow[t]{6}{*}{$9^{\circ}$} & DIREITO CIVIL - SUCESSÕES & 75 \\
\hline & DIREITO TRIBUTÁRIO & 75 \\
\hline & ESTÁGIO & 75 \\
\hline & MONOGRAFIA II & 75 \\
\hline & TÓPICO ESPECIAL III & 75 \\
\hline & TÓPICO ESPECIAL IV & 75 \\
\hline \multirow[t]{8}{*}{$10^{\circ}$} & DEFESA DA CONSTITUIČÃO & 75 \\
\hline & DIREITO INTERNACIONAL PRIVADO & 30 \\
\hline & DIREITO PROCESSUAL CIVIL - PROCEDIMENTO ESPECIAIS & 75 \\
\hline & ESTÁGIO & 75 \\
\hline & ÉTICA PROFISSIONAL & 45 \\
\hline & MONOGRAFIA III & 75 \\
\hline & TÓPICO ESPECIAL V & 75 \\
\hline & TÓPICO ESPECIAL VI & 75 \\
\hline
\end{tabular}

UNICEUMA - CENTRO UNIVERSITÁRIO DO MARANHÃO

Disponível em: http://www.extranet.ceuma.br/graduacao_grade.asp?codigo=grad_06_direito

Acesso em outubro/2010

\begin{tabular}{|c|c|c|}
\hline SEMESTRE & DISCIPLINA & $\begin{array}{c}\text { CARGA } \\
\text { HORÁRIA }\end{array}$ \\
\hline \multirow[t]{8}{*}{$1^{\circ}$} & METODOLOGIA DA PESQUISA & 40 \\
\hline & CIÊNCIA POLÍTICA & 80 \\
\hline & ECONOMIA & 40 \\
\hline & INT.AO EST.DO DIREITO & 80 \\
\hline & FILOSOFIA GERAL & 40 \\
\hline & SOCIOLOGIA GERAL & 40 \\
\hline & PSICOLOGIA & 40 \\
\hline & ANTROPOLOGIA & 40 \\
\hline \multirow[t]{5}{*}{$2^{\circ}$} & DIREITO CIVIL I(TEORIA GERAL) & 80 \\
\hline & DIREITO PENAL I(TEORIA GERAL-1 ${ }^{\text {a }}$ PARTE) & 80 \\
\hline & FILOSOFIA DO DIREITO & 80 \\
\hline & SOCIOLOGIA JURÍDICA & 80 \\
\hline & TEORIA GERAL DO PROCESSO & 80 \\
\hline \multirow[t]{5}{*}{$3^{\circ}$} & DIREITO CIVIL II(OBRIGAÇÕES) & 80 \\
\hline & DIREITO PENAL II(TEORIA GERAL-2ª PARTE) & 80 \\
\hline & DIREITO COMERCIAL I(TEORIA GERAL E DIREITO SOCIETÁRIO) & 80 \\
\hline & DIREITO CONSTITUCIONAL I(TEORIA GERAL DA CONSTITUIÇÃO) & 80 \\
\hline & DIREITO PROCESSUAL CIVIL I(CONHECIMENTO-1 ${ }^{\mathrm{a}}$ PARTE) & 80 \\
\hline \multirow[t]{5}{*}{$4^{\circ}$} & DIREITO CIVIL III(CONTRATOS) & 80 \\
\hline & DIREITO PENAL III(PARTE ESPECIAL-1 ${ }^{\text {a }}$ PARTE) & 80 \\
\hline & DIREITO COMERCIAL II(TIT.DE CREDITO E CONTRATOS MERCANTIS) & 80 \\
\hline & DIREITO CONSTITUCIONAL II(DIREITO CONSTITUCIONAL POSITIVO) & 80 \\
\hline & DIREITO PROCESSUAL CIVIL II(CONHECIMENTO-2ª PARTE) & 80 \\
\hline
\end{tabular}




\begin{tabular}{|c|c|c|}
\hline $5^{\circ}$ & DIREITO CIVIL IV(COISAS) & 80 \\
\hline & DIREITO PENAL IV(PARTE ESPECIAL-2 ${ }^{\mathrm{a}}$ PARTE) & 80 \\
\hline & DIREITO PROCESSUAL CIVIL III(RECURSOS) & 80 \\
\hline & DIREITO DO TRABALHO I & 80 \\
\hline & DIREITO COMERCIAL III(DIREITO FALIMENTAR) & 40 \\
\hline & DIR. CONSTITUCIONAL III(DIREITOS E GARANTIAS FUNDAMENTAIS) & 40 \\
\hline \multirow[t]{5}{*}{$6^{\circ}$} & DIREITO CIVIL V(FAMÍLIA) & 80 \\
\hline & DIREITO PENAL V(PARTE ESPECIAL-3 ${ }^{\text {a }}$ PARTE) & 80 \\
\hline & DIREITO PROCESSUAL CIVIL IV(EXECUÇÃO) & 80 \\
\hline & DIREITO PROCESSUAL PENAL I & 80 \\
\hline & DIREITO DO TRABALHO II & 80 \\
\hline \multirow[t]{5}{*}{$7^{\circ}$} & DIREITO CIVIL VI(SUCESSÕES) & 80 \\
\hline & DIREITO PROCESSUAL CIVIL V(CAUTELAR) & 40 \\
\hline & DIREITO PROCESSUAL PENAL II & 80 \\
\hline & DIREITO PROCESSUAL DO TRABALHO & 80 \\
\hline & ESTAGIO I(PRATICA SIMULADA I) & 80 \\
\hline \multirow[t]{5}{*}{$8^{\circ}$} & DIREITO PROCESSUAL CIVIL VI(PROCEDIMENTOS ESPECIAIS) & 80 \\
\hline & DIREITO PROCESSUAL PENAL III & 80 \\
\hline & ESTAGIO II(PRATICA SIMULADA II) & 80 \\
\hline & DIREITO ADMINISTRATIVO I & 80 \\
\hline & HERMENÊUTICA E REDAÇÃO JURÍDICA & 80 \\
\hline \multirow[t]{6}{*}{$9^{\circ}$} & DIREITO DO CONSUMIDOR & 40 \\
\hline & DIREITO AMBIENTAL E AGRÁRIO & 80 \\
\hline & ESTAGIO III(PRATICA REAL I) & 80 \\
\hline & DIREITO ADMINISTRATIVO II & 80 \\
\hline & DIREITO TRIBUTÁRIO & 40 \\
\hline & DIREITO ELEITORAL E PARTIDÁRIO & 40 \\
\hline \multirow[t]{5}{*}{$10^{\circ}$} & ESTAGIO IV(PRATICA REAL II) & 80 \\
\hline & DIREITO INTERNACIONAL & 40 \\
\hline & ÉTICA GERAL E PROFISSIONAL & 40 \\
\hline & DIREITO DA CRIANÇA E DO ADOLESCENTE & 40 \\
\hline & TRABALHO DE CURSO & 40 \\
\hline
\end{tabular}

UNIDESC - CENTRO UNIVERSITÁRIO DE DESENVOLVIMENTO DO CENTRO OESTE

Disponível em: http://www.unidesc.com/cursos/bacharelado/direito/

Acesso em outubro/2010

\begin{tabular}{|c|c|c|}
\hline PERÍODO & DISCIPLINA & $\begin{array}{c}\text { CARGA } \\
\text { HORÁRIA }\end{array}$ \\
\hline \multirow[t]{6}{*}{$1^{\circ}$} & INTRODUÇÃO AO DIREITO & 36 \\
\hline & INTRODUÇÃO AO DIREITO & 72 \\
\hline & INTRODUÇÃO À ECONOMIA & 72 \\
\hline & SOCIOLOGIA GERAL E JURÍDICA & 36 \\
\hline & INTRODUÇÃO À CIÊNCIA POLÍTICA & 72 \\
\hline & METODOLOGIA CIENTÍFICA EM DIREITO & 72 \\
\hline \multirow[t]{6}{*}{$2^{\circ}$} & FILOSOFIA GERAL E JURÍDICA & 72 \\
\hline & DIREITO PENAL I & 72 \\
\hline & TEORIA GERAL DO ESTADO & 36 \\
\hline & TEORIA GERAL DO DIREITO CIVIL & 72 \\
\hline & HISTÓRIA DO DIREITO & 72 \\
\hline & PSICOLOGIA & 36 \\
\hline \multirow[t]{5}{*}{$3^{\circ}$} & DIREITO DAS OBRIGAÇÕES & 72 \\
\hline & TEORIA GERAL DO PROCESSO & 72 \\
\hline & DIREITO PENAL II & 72 \\
\hline & DIREITO CONSTITUCIONAL I & 72 \\
\hline & DIREITO COMERCIAL E EMPRESARIAL I & 72 \\
\hline \multirow[t]{5}{*}{$4^{\circ}$} & CONTRATOS CIVIS & 72 \\
\hline & ANTROPOLOGIA & 72 \\
\hline & DIREITO PENAL III & 72 \\
\hline & DIREITO CONSTITUCIONAL II & 72 \\
\hline & DIREITO COMERCIAL E EMPRESARIAL II & 72 \\
\hline \multirow[t]{3}{*}{$5^{\circ}$} & DIREITO DAS COISAS & 72 \\
\hline & PROCESSO CIVIL I & 72 \\
\hline & DIREITO PENAL IV & 72 \\
\hline
\end{tabular}




\begin{tabular}{|c|c|c|}
\hline & PROCESSO PENAL I & 72 \\
\hline & DIREITO CONSTITUCIONAL III & 72 \\
\hline \multirow[t]{5}{*}{$6^{\circ}$} & DIREITO DA FAMÍLIA & 72 \\
\hline & PROCESSO CIVIL II & 72 \\
\hline & DIREITO PENAL V & 72 \\
\hline & PROCESSO PENAL II & 72 \\
\hline & ÉTICA GERAL E PROFISSIONAL & 72 \\
\hline \multirow[t]{6}{*}{$7^{\circ}$} & DIREITO DAS SUCESSÕES & 36 \\
\hline & PROCESSO CIVIL III & 72 \\
\hline & DIREITO TRIBUTÁRIO I & 72 \\
\hline & PROCESSO PENAL III & 36 \\
\hline & DIREITO ADMINISTRATIVO I & 72 \\
\hline & ESTÁGIO DE PRÁTICA JURÍDICA CÍVEL & 80 \\
\hline \multirow[t]{5}{*}{$8^{\circ}$} & DIREITO ADMINISTRATIVO II & 72 \\
\hline & DIREITO TRIBUTÁRIO II & 72 \\
\hline & DIREITO DO TRABALHO I & 72 \\
\hline & PROCESSO CIVIL IV & 72 \\
\hline & ESTÁGIO DE PRÁTICA JURÍDICA PENAL & 80 \\
\hline \multirow[t]{7}{*}{$9^{\circ}$} & PROCESSO DO TRABALHO & 72 \\
\hline & TÓPICOS DE ATUALIZAÇÃO DO DIREITO I & 36 \\
\hline & DIREITO DO TRABALHO II & 72 \\
\hline & ORIENTAÇÃO DE MONOGRAFIA I & 36 \\
\hline & ESTÁGIO DE PRÁTICA JURÍDICA TRABALHISTA & 80 \\
\hline & RESPONSABILIDADE CIVIL & 36 \\
\hline & TÓPICOS DE ATUALIZAÇÃO DO DIREITO II & 36 \\
\hline \multirow[t]{6}{*}{$10^{\circ}$} & DIREITO PREVIDENCIÁRIO & 36 \\
\hline & ORIENTAÇÃO DE MONOGRAFIA II & 72 \\
\hline & TÓPICOS DE ATUALIZAÇÃO DO DIREITO III & 72 \\
\hline & TÓPICOS E ATUALIZAÇÃ̉O DO DIREITO IV & 36 \\
\hline & DIREITO INTERNACIONAL & 72 \\
\hline & ESTÁGIO DE PRÁTICA JURÍDICA RECURSAL & 80 \\
\hline
\end{tabular}

UNIFEB - CENTRO UNIVERSITÁRIO DA FUNDAÇÃO EDUCACIONAL DE BARRETOS

Disponível em: http://www.feb.br/cursos_direito/

Acesso em outubro/2010

\begin{tabular}{|c|c|c|}
\hline SEMESTRE & DISCIPLINA & $\begin{array}{c}\text { CARGA } \\
\text { HORÁRIA }\end{array}$ \\
\hline \multirow[t]{8}{*}{$1^{\circ}$} & ECONOMIA I & 36 \\
\hline & INTRODUÇÃO AO ESTUDO DO DIREITO I & 54 \\
\hline & PORTUGUÊS I & 36 \\
\hline & RETÓRICA E ARGUMENTAÇÃO JURÍDICA I & 36 \\
\hline & SOCIOLOGIA GERAL E JURÍDICA I & 54 \\
\hline & TEORIA GERAL DO DIREITO CIVIL I & 54 \\
\hline & TEORIA GERAL DO DIREITO PENAL I & 54 \\
\hline & TEORIA GERAL DO ESTADO I & 36 \\
\hline \multirow[t]{8}{*}{$2^{\circ}$} & ECONOMIA II & 36 \\
\hline & INTRODUÇÃO AO ESTUDO DO DIREITO II & 54 \\
\hline & PORTUGUÊS II & 36 \\
\hline & RETÓRICA E ARGUMENTAÇÃO JURÍDICA II & 36 \\
\hline & SOCIOLOGIA GERAL E JURÍDICA II & 54 \\
\hline & TEORIA GERAL DO DIREITO CIVIL II & 54 \\
\hline & TEORIA GERAL DO DIREITO PENAL II & 54 \\
\hline & TEORIA GERAL DO ESTADO II & 36 \\
\hline \multirow[t]{8}{*}{$3^{\circ}$} & DIREITO ADMINISTRATIVO I & 36 \\
\hline & DIREITO CONSTITUCIONAL I & 72 \\
\hline & DIREITO DAS OBRIGAÇÕES & 54 \\
\hline & DIREITO DO TRABALHO I & 36 \\
\hline & DIREITO EMPRESARIAL I & 36 \\
\hline & DIREITO PENAL I & 54 \\
\hline & FILOSOFIA I (GERAL E JURÍDICA) & 36 \\
\hline & TEORIA GERAL DO PROCESSO I & 36 \\
\hline \multirow[t]{3}{*}{$4^{\circ}$} & DIREITO ADMINISTRATIVO II & 36 \\
\hline & DIREITO CONSTITUCIONAL II & 72 \\
\hline & DIREITO DOS CONTRATOS & 54 \\
\hline
\end{tabular}




\begin{tabular}{|c|c|c|}
\hline & DIREITO DO TRABALHO II & 36 \\
\hline & DIREITO EMPRESARIAL II & 36 \\
\hline & DIREITO PENAL II & 54 \\
\hline & FILOSOFIA II (GERAL E JURÍDICA) & 36 \\
\hline & TEORIA GERAL DO PROCESSO II & 36 \\
\hline \multirow[t]{7}{*}{$5^{\circ}$} & DIREITO CONSTITUCIONAL III & 54 \\
\hline & DIREITOS REAIS I & 54 \\
\hline & DIREITO DO TRABALHO III & 36 \\
\hline & DIREITO PENAL III & 54 \\
\hline & DIREITO PREVIDENCIÁRIO I & 36 \\
\hline & DIREITO PROCESSUAL CIVIL I & 72 \\
\hline & INICIAÇÃO CIENTÍFICA I & 54 \\
\hline \multirow[t]{7}{*}{$6^{\circ}$} & DIREITO CONSTITUCIONAL IV & 54 \\
\hline & DIREITOS REAIS II & 54 \\
\hline & DIREITO DO TRABALHO IV & 36 \\
\hline & DIREITO PENAL IV & 54 \\
\hline & DIREITO PREVIDENCIÁRIO II & 36 \\
\hline & DIREITO PROCESSUAL CIVIL II & 72 \\
\hline & INICIAÇÃO CIENTÍFICA II & 54 \\
\hline \multirow[t]{7}{*}{$7^{\circ}$} & DIREITO DE FAMÍLIA E SUCESSÕES I & 54 \\
\hline & DIREITO FINANCEIRO E TRIBUTÁRIO I & 36 \\
\hline & DIREITO PENAL V & 54 \\
\hline & DIREITO PROCESSUAL CIVIL III & 54 \\
\hline & DIREITO PROCESSUAL PENAL I & 54 \\
\hline & PRÁTICA JURÍDICA I & 72 \\
\hline & TÓPICOS ESPECIAIS I (CRIMINOLOGIA/MEDICINA LEGAL) & 36 \\
\hline \multirow[t]{7}{*}{$8^{\circ}$} & DIREITO DE FAMÍLIA E SUCESSÕES II & 54 \\
\hline & DIREITO FINANCEIRO E TRIBUTÁRIO II & 36 \\
\hline & DIREITO PENAL VI & 54 \\
\hline & DIREITO PROCESSUAL CIVIL IV & 54 \\
\hline & DIREITO PROCESSUAL PENAL II & 54 \\
\hline & PRÁTICA JURÍDICA II & 72 \\
\hline & TÓPICOS ESPECIAIS II (CRIMINOLOGIA/MEDICINA LEGAL) & 36 \\
\hline \multirow[t]{7}{*}{$9^{\circ}$} & DIREITO DE RESPONSABILIDADE CIVIL I & 36 \\
\hline & DIREITO PROCESSUAL PENAL III & 54 \\
\hline & DIREITO PROCESSUAL CIVIL V & 54 \\
\hline & ÉTICA GERAL E PROFISSIONAL I & 36 \\
\hline & LEGISLAÇÃO PENAL I & 54 \\
\hline & PRÁTICA JURÍDICA III & 72 \\
\hline & TÓPICOS ESPECIAIS III (DIREITOS DIFUSOS E COLETIVOS) & 54 \\
\hline \multirow[t]{7}{*}{$10^{\circ}$} & DIREITO DE RESPONSABILIDADE CIVIL & 36 \\
\hline & DIREITO PROCESSUAL PENAL IV & 54 \\
\hline & DIREITO PROCESSUAL CIVIL VI & 54 \\
\hline & ÉTICA GERAL E PROFISSIONAL II & 36 \\
\hline & LEGISLAÇÃO PENAL III & 54 \\
\hline & PRÁTICA JURÍDICA IV & 72 \\
\hline & TÓPICOS ESPECIAIS IV (DIREITOS DIFUSOS E COLETIVOS) & 54 \\
\hline
\end{tabular}

\section{UNIFEMM - CENTRO UNIVERSITÁRIO DE SETE LAGOAS}

Disponível em: http://www.unifemm.edu.br/v2/ files/matriz-direito.pdf

Acesso em outubro/2010

\begin{tabular}{|l|l|c|}
\hline SÉRIE & DISCIPLINA & CARGA \\
HORÁRIA \\
\hline $1^{\mathbf{a}}$ & PORTUGUÊS & 70 \\
\hline & CIÊNCIA POLÍTICA & 140 \\
\hline & ECONOMIA E HISTÓRIA DO PENSAMENTO ECONÔMICO & 70 \\
\hline & FILOSOFIA GERAL & 70 \\
\hline & INTRODUÇÃO Ã TEORIA DO DIREITO & 140 \\
\hline & DIREITOS FUNDAMENTAIS E TEORIA DA CONSTITUIÇÃO & 140 \\
\hline & SOCIOLOGIA E ANTROPOLOGIA & 70 \\
\hline $2^{\text {a }}$ & & 70 \\
\hline & DIREITO EMPRESARIAL & 140 \\
\hline & TEORIA DO DELITO E TEORIA DA PENA & 140 \\
\hline & DIREITO CIVIL: PARTE GERAL E OBRIGAÇÕES & 70 \\
\hline & DIREITO CONSTITUCIONAL: ORGANIZAÇÃO DO ESTADO & 70 \\
\hline
\end{tabular}




\begin{tabular}{|c|c|c|}
\hline & METODOLOGIA DA PESQUISA & 70 \\
\hline & PSICOLOGIA APLICADA AO DIREITO & 70 \\
\hline & FILOSOFIA DO DIREITO E ÉTICA PROFISSIONAL & 70 \\
\hline \multirow[t]{7}{*}{$3^{\mathrm{a}}$} & ESTUDO DOS CRIMES EM ESPÉCIE & 140 \\
\hline & PROCESSO DO CONHECIMENTO & 140 \\
\hline & DIREITO DAS COISAS E CONTRATOS & 140 \\
\hline & TEORIA DA ARGUMENTAÇÃO JURÍDICA & 70 \\
\hline & DIREITO CONSTITUCIONAL: FUNÇÕES DO ESTADO, ORDEM SOCIAL E ECONÔMICA & 70 \\
\hline & PRÁTICA JURÍDICA SIMULADA: ESTUDO DE CASO CONCRETO & 70 \\
\hline & REGIME JURÍDICO ADMINISTRATIVO & 70 \\
\hline \multirow[t]{8}{*}{$4^{\mathrm{a}}$} & OPTATIVA I & 70 \\
\hline & PROJETO DE MONOGRAFIA & 70 \\
\hline & DIREITO DE FAMÍLIA E SUCESSÕES & 140 \\
\hline & RECURSOS E EXECUÇÃO & 70 \\
\hline & DIREITO PROCESSUAL PENAL E PRÁTICA DE PROCESSO PENAL & 140 \\
\hline & SISTEMA TRIBUTÁRIO CONSTITUCIONAL & 70 \\
\hline & DIREITO ADMINISTRATIVO & 70 \\
\hline & PRÁTICA JURÍDICA PROCESSUAL CIVIL & 70 \\
\hline \multirow[t]{9}{*}{$5^{\mathrm{a}}$} & OPTATIVA II & 70 \\
\hline & OPTATIVA III & 70 \\
\hline & DIREITO DO TRABALHO E PROCESSO DO TRABALHO & 140 \\
\hline & DIREITO INTERNACIONAL & 70 \\
\hline & DIREITO TRIBUTÁRIO & 70 \\
\hline & PROCESSO CAUTELAR E PROCEDIMENTOS ESPECIAIS & 70 \\
\hline & PRÁTICA JURÍDICA SIMULADA: DIREITO PÚBLICO & 70 \\
\hline & PRÁTICA JURÍDICA REAL & 140 \\
\hline & ATIVIDADES COMPLEMENTARES & 200 \\
\hline
\end{tabular}

UNIMONTE - CENTRO UNIVERSITÁRIO MONTE SERRAT

Disponível em: http://www.unimonte.br/curso/graduacao/direito/grade

Acesso em outubro/2010

\begin{tabular}{|c|c|c|}
\hline MÓDULO & DISCIPLINA & $\begin{array}{c}\text { CARGA } \\
\text { HORÁRIA }\end{array}$ \\
\hline \multirow[t]{6}{*}{$1^{\circ}$} & LÍNGUA PORTUGUESA & 80 \\
\hline & INTRODUÇÃO AO ESTUDO DE DIREITO & 80 \\
\hline & FILOSOFIA GERAL & 40 \\
\hline & CIÊNCIA POLÍTICA & 80 \\
\hline & SOCIEDADE E CULTURA I & 80 \\
\hline & PSICOLOGIA FORENSE & 40 \\
\hline \multirow{6}{*}{$2^{\circ}$} & ECONOMIA & 80 \\
\hline & TEORIA GERAL DO ESTADO & 80 \\
\hline & SOCIEDADE E CULTURA II & 80 \\
\hline & HISTÓRIA DO DIREITO & 40 \\
\hline & SOCIOLOGIA JURÍDICA & 40 \\
\hline & DIREITO CIVIL I & 80 \\
\hline \multirow[t]{5}{*}{$3^{\circ}$} & DIREITO CIVIL II & 80 \\
\hline & DIREITO CONSTITUCIONAL I & 80 \\
\hline & DIREITO EMPRESARIAL I & 80 \\
\hline & DIREITO PENAL I & 80 \\
\hline & FILOSOFIA DO DIREITO & 80 \\
\hline \multirow[t]{5}{*}{$4^{\circ}$} & DIREITO CIVIL III & 80 \\
\hline & DIREITO PENAL II & 80 \\
\hline & DIREITO EMPRESARIAL II & 80 \\
\hline & DIREITO CONSTITUCIONAL II & 80 \\
\hline & TEORIA GERAL DO PROCESSO & 80 \\
\hline \multirow{5}{*}{$5^{\circ}$} & DIREITO CIVIL IV & 80 \\
\hline & DIREITO PENAL III & 80 \\
\hline & DIREITO PROCESSUAL CIVIL I & 80 \\
\hline & DIREITO EMPRESARIAL III & 80 \\
\hline & DIREITO ADMINISTRATIVO I & 80 \\
\hline \multirow[t]{4}{*}{$6^{\circ}$} & DIREITO CIVIL V & 80 \\
\hline & DIREITO ADMINISTRATIVO II & 80 \\
\hline & DIREITO PROCESSUAL CIVIL II & 80 \\
\hline & DIREITO EMPRESARIAL IV & 80 \\
\hline
\end{tabular}




\begin{tabular}{|c|c|c|}
\hline & DIREITO PENAL IV & 80 \\
\hline \multirow[t]{6}{*}{$7^{\circ}$} & DIREITO CIVIL VI & 80 \\
\hline & DIREITO PROCESSUAL CIVIL III & 80 \\
\hline & DIREITO PROCESSUAL PENAL I & 80 \\
\hline & PRÁTICA JURÍDICA CÍVEL SIMULADA & 80 \\
\hline & DIREITO PENAL V & 40 \\
\hline & METODOLOGIA DA PESQUISA JURÍDICA & 40 \\
\hline \multirow[t]{6}{*}{$8^{\circ}$} & DIREITO CIVIL VII & 80 \\
\hline & MONOGRAFIA I & 80 \\
\hline & DIREITO TRIBUTÁRIO I & 80 \\
\hline & DIREITO DO TRABALHO I & 80 \\
\hline & DIREITO DO CONSUMIDOR & 40 \\
\hline & DIREITO PROCESSUAL PENAL II & 80 \\
\hline \multirow[t]{6}{*}{$9^{\circ}$} & DIREITO CIVIL VIII & 80 \\
\hline & DIREITO INTERNACIONAL PÚBLICO & 80 \\
\hline & DIREITO DO TRABALHO II & 80 \\
\hline & DIREITO TRIBUTÁRIO II & 80 \\
\hline & PRÁTICA JURÍDICA PENAL SIMULADA I & 40 \\
\hline & MONOGRAFIA II & 80 \\
\hline \multirow[t]{8}{*}{$10^{\circ}$} & DIREITO PROCESSUAL DO TRABALHO & 80 \\
\hline & DIREITO INTERNACIONAL PRIVADO & 40 \\
\hline & DIREITO MARÍTIMO & 80 \\
\hline & DIREITO AMBIENTAL & 40 \\
\hline & PRÁTICA JURÍDICA PENAL SIMULADA II & 40 \\
\hline & DIREITO PREVIDENCIÁRIO & 80 \\
\hline & MONOGRAFIA III & 60 \\
\hline & ESTÁGIO CURRICULAR & 130 \\
\hline
\end{tabular}

UNIMONTES - UNIVERSIDADE ESTADUAL DE MONTES CLAROS

Disponível em: http://www.unimontes.br/noticias.php?id=22

Acesso em outubro/2010

\begin{tabular}{|c|c|c|}
\hline PERÍODO & DISCIPLINA & $\begin{array}{c}\text { CARGA } \\
\text { HORÁRIA }\end{array}$ \\
\hline \multirow[t]{6}{*}{$1^{\circ}$} & INTRODUÇÃO AO ESTUDO DO DIREITO & 72 \\
\hline & METODOLOGIA DA PESQUISA E DO TRABALHO JURÍDICO & 72 \\
\hline & SOCIOLOGIA GERAL & 36 \\
\hline & ONTOGNOSIOLOGIA JURÍDICA I & 36 \\
\hline & DIREITO CIVIL I (PARTE GERAL I) & 72 \\
\hline & CIÊNCIA POLÍTICA/TEORIA DO ESTADO & 72 \\
\hline \multirow[t]{6}{*}{$2^{\circ}$} & ANTROPOLOGIA JURÍDICA & 36 \\
\hline & DIREITO CONSTITUCIONAL I & 72 \\
\hline & ONTOGNOSIOLOGIA JURÍDICA II & 72 \\
\hline & DIREITO CIVIL II (PARTE GERAL II) & 72 \\
\hline & DIREITO PENAL I (PARTE GERAL I) & 72 \\
\hline & HISTÓRIA DO DIREITO & 36 \\
\hline \multirow[t]{7}{*}{$3^{\circ}$} & DIREITO CIVIL III (OBRIGAÇÕES) & 72 \\
\hline & DIREITO CONSTITUCIONAL II & 72 \\
\hline & DIREITO PENAL II & 72 \\
\hline & FUNDAMENTOS DA ECONOMIA PARA O DIREITO & 36 \\
\hline & DIREITO MERCANTIL I (PARTE GERAL E SOCIEDADES) & 72 \\
\hline & DIREITO FINANCEIRO & 36 \\
\hline & DISCIPLINA OPTATIVA & 36 \\
\hline \multirow[t]{7}{*}{$4^{\circ}$} & DIREITO CIVIL IV (CONTRATOS) & 72 \\
\hline & TEORIA DO PROCESSO & 36 \\
\hline & DIREITO MERCANTIL II (S/A E SOCIEDADE POR COTAS DE RESPONSABILIDADE LTDA) & 72 \\
\hline & DIREITO PENAL III & 72 \\
\hline & DIREITO DO TRABALHO I & 36 \\
\hline & DIREITO TRIBUTÁRIO I & 72 \\
\hline & DISCIPLINA OPTATIVA & 36 \\
\hline \multirow[t]{5}{*}{$5^{\circ}$} & DIREITO DO TRABALHO II & 36 \\
\hline & DIREITO PENAL IV & 72 \\
\hline & DIREITO PROCESSUAL CIVIL I & 72 \\
\hline & DIREITO CIVIL V (RESPONSABILIDADE) & 36 \\
\hline & DIREITO MERCANTIL III (TÍTULOS DE CRÉDITO) & 72 \\
\hline
\end{tabular}




\begin{tabular}{|c|c|c|}
\hline & DIREITO TRIBUTÁRIO II & 72 \\
\hline & DISCIPLINAS OPTATIVAS & 36 \\
\hline \multirow[t]{7}{*}{$6^{\circ}$} & DIREITO CIVIL VI (FAMÍLIA) & 72 \\
\hline & DIREITO PROCESSUAL CIVIL II & 72 \\
\hline & DIREITO MERCANTIL IV (FALÊNCIA E RECUPERAÇÃO DE EMPRESAS) & 72 \\
\hline & DIREITO PENAL V & 36 \\
\hline & DIREITO PROCESSUAL TRABALHISTA & 72 \\
\hline & DIREITO INTERNACIONAL PÚBLICO & 36 \\
\hline & DISCIPLINA OPTATIVA & 36 \\
\hline \multirow[t]{11}{*}{$7^{\circ}$} & DIREITO INTERNACIONAL PRIVADO & 36 \\
\hline & DIREITO PROCESSUAL CIVIL III & 72 \\
\hline & DIREITO PROCESSUAL PENAL I & 36 \\
\hline & DIREITO CIVIL VII (SUCESSÕES) & 36 \\
\hline & DIREITO ADMINISTRATIVO I & 72 \\
\hline & PRÁTICA JURÍDICA CIVIL & 36 \\
\hline & DEONTOLOGIA JURÍDICA & 36 \\
\hline & DIREITO PENAL VI & 36 \\
\hline & ESTÁGIO SUPER VISIONADO I & 75 \\
\hline & TRABALHO DE CONCLUSÃO DE CURSO I & 50 \\
\hline & DISCIPLINA OPTATIVA & 36 \\
\hline \multirow[t]{10}{*}{$8^{\circ}$} & DIREITO CIVIL VIII (DIREITOS REAIS) & 72 \\
\hline & DIREITO PROCESSUAL CIVIL IV & 72 \\
\hline & DIREITO PROCESSUAL PENAL II & 36 \\
\hline & DIREITO ADMINISTRATIVO II & 72 \\
\hline & PRÁTICA JURÍDICA PENAL & 36 \\
\hline & PSICOLOGIA JURÍDICA & 36 \\
\hline & DIREITO EMPRESARIAL I & 36 \\
\hline & ESTÁGIO SUPER VISIONADO II & 75 \\
\hline & TRABALHO DE CURSO II & 50 \\
\hline & DISCIPLINA OPTATIVA & 36 \\
\hline \multirow{10}{*}{$9^{\circ}$} & CRIMINOLOGIA & 36 \\
\hline & PRÁTICA JURÍDICA TRABALHISTA & 36 \\
\hline & DIREITO PROCESSUAL CIVIL V & 72 \\
\hline & DIREITO EMPRESARIAL II & 36 \\
\hline & DIREITO PROCESSUAL PENAL III & 36 \\
\hline & DIREITO PROCESSUAL CONSTITUCIONAL & 36 \\
\hline & DIREITO PREVIDENCIÁRIO I & 36 \\
\hline & ESTÁGIO SUPER VISIONADO III & 75 \\
\hline & TRABALHO DE CURSO III & 50 \\
\hline & DISCIPLINA OPTATIVA & 36 \\
\hline \multirow[t]{10}{*}{$10^{\circ}$} & DIREITO PROCESSUAL CIVIL & 72 \\
\hline & DIREITO PREVIDENCIÁRIO & 36 \\
\hline & DIREITO AMBIENTAL E AGRÁRIO & 36 \\
\hline & DIREITO PROCESSUAL PENAL IV & 36 \\
\hline & SOCIOLOGIA JURÍDICA & 36 \\
\hline & DIREITO DO CONSUMIDOR & 36 \\
\hline & DIREITO MÉDICO-LEGAL & 36 \\
\hline & ESTÁGIO SUPER VISIONADO IV & 75 \\
\hline & TRABALHO DE CURSO IV & 50 \\
\hline & DISCIPLINA OPTATIVA & 36 \\
\hline
\end{tabular}

UNIOESTE - UNIVERSIDADE ESTADUAL DO OESTE DO PARANÁ

Disponível em: http://www.unioeste.br/campi/beltrao/bel-direito.asp

Acesso em outubro/2010

\begin{tabular}{|l|l|c|}
\hline SÉRIE & DISCIPLINA & $\begin{array}{c}\text { CARGA } \\
\text { HORÁRIA }\end{array}$ \\
\hline $1^{\text {a }}$ & LÍNGUA PORTUGUESA & 102 \\
\hline & INTRODUÇÃO AO ESTUDO DO DIREITO & 136 \\
\hline & SOCIOLOGIA GERAL E JURÍDICA & 136 \\
\hline & INTRODUÇÃO À FILOSOFIA & 102 \\
\hline & INTRODUÇÃO À ECONOMIA & 102 \\
\hline & CIÊNCIA POLÍTICA E TEORIA DO ESTADO & 102 \\
\hline & METODOLOGIA DA PESQUISA & 68 \\
\hline & & 102 \\
\hline $2^{\text {a }}$ & DIREITO CONSTITUCIONAL I & 136 \\
\hline & DIREITO PENAL I & 102 \\
\hline
\end{tabular}




\begin{tabular}{|c|c|c|}
\hline & TEORIA DO PROCESSO & 102 \\
\hline & TEORIA DA ARGUMENTAÇÃO & 68 \\
\hline & DIREITO COMERCIAL I & 102 \\
\hline & DIREITO INTERNACIONAL PÚBLICO & 136 \\
\hline \multirow[t]{8}{*}{$3^{\mathrm{a}}$} & DIREITO CONSTITUCIONAL II & 102 \\
\hline & DIREITO PENAL II & 102 \\
\hline & DIREITO CIVIL II & 136 \\
\hline & DIREITO PROCESSUAL CIVIL I & \\
\hline & DIREITO COMERCIAL II & 102 \\
\hline & DIREITO DO TRABALHO I & 68 \\
\hline & SEGURIDADE SOCIAL & 68 \\
\hline & DIREITO PROCESSUAL PENAL I & 102 \\
\hline \multirow[t]{9}{*}{$4^{\mathrm{a}}$} & DIREITO PENAL III & 102 \\
\hline & DIREITO CIVIL III & 136 \\
\hline & DIREITO DO TRABALHO II & 68 \\
\hline & DIREITO PROCESSUAL CIVIL II & 136 \\
\hline & DIREITO PROCESSUAL PENAL II & 102 \\
\hline & DIREITO ADMINISTRATIVO & 136 \\
\hline & FILOSOFIA DO DIREITO & 68 \\
\hline & TÉCNICA DE PESQUISA JURÍDICA & 68 \\
\hline & ESTÁGIO DE PRÁTICA JURÍDICA I & 102 \\
\hline \multirow[t]{8}{*}{$5^{\mathrm{a}}$} & DIREITO CIVIL IV & 136 \\
\hline & DIREITO AGRÁRIO E AMBIENTAL & 136 \\
\hline & DIREITO FINANCEIRO E TRIBUTÁRIO & 136 \\
\hline & CRIMINOLOGIA & 68 \\
\hline & DEONDOLOGIA JURÍDICA & 68 \\
\hline & DIREITO PROCESSUAL DO TRABALHO & 102 \\
\hline & DISCIPLINA INDEPENDENTE & 68 \\
\hline & ESTÁGIO DE PRÁTICA JURÍDICA II & 204 \\
\hline
\end{tabular}

UNIPAR - UNIVERSIDADE PARANAENSE

Disponível em: http://tapajo.unipar.br/graduacao/matriz/cia/direito.pdf

Acesso em agosto/2010

\begin{tabular}{|c|c|c|}
\hline SÉRIE & DISCIPLINA & $\begin{array}{c}\text { CARGA } \\
\text { HORÁRIA } \\
\end{array}$ \\
\hline \multirow[t]{8}{*}{$1^{\mathrm{a}}$} & CIÊNCIA POLÍTICA & 80 \\
\hline & INTRODUÇÃO AO ESTUDO DO DIREITO & 160 \\
\hline & ECONOMIA POLÍTICA & 80 \\
\hline & SOCIOLOGIA GERAL E JURÍDICA & 80 \\
\hline & ÉTICA E FILOSOFIA GERAL E DO DIREITO & 80 \\
\hline & PSICOLOGIA FORENSE E PESQUISA JURÍDICA & 80 \\
\hline & LINGUAGEM JURÍDICA & 80 \\
\hline & DIREITO CIVIL I (PARTE GERAL) & 160 \\
\hline \multirow[t]{6}{*}{$2^{\mathrm{a}}$} & DIREITO PENAL I & 160 \\
\hline & DIREITO CONSTITUCIONAL & 160 \\
\hline & DIREITO PROCESSUAL CIVIL I & 80 \\
\hline & DIREITO DO TRABALHO & 160 \\
\hline & TEORIA DOS DIREITOS FUNDAMENTAIS & 80 \\
\hline & DIREITO CIVIL II (DAS OBRIGAÇÕES) & 160 \\
\hline \multirow[t]{6}{*}{$3^{\mathrm{a}}$} & DIREITO PROCESSUAL CIVIL II & 160 \\
\hline & DIREITO PROCESSUAL DO TRABALHO & 80 \\
\hline & DIREITO PENAL II & 160 \\
\hline & DIREITO EMPRESARIAL I & 80 \\
\hline & DIREITO CIVIL III (DOS CONTRATOS) & 160 \\
\hline & DIREITO ADMINISTRATIVO & 160 \\
\hline \multirow[t]{9}{*}{$4^{\mathrm{a}}$} & DIREITO CIVIL IV (DAS COISAS) & 80 \\
\hline & DIREITO PROCESSUAL PENAL I & 160 \\
\hline & DIREITO PROCESSUAL CIVIL III & 160 \\
\hline & DIREITO PENAL III & 80 \\
\hline & DIREITO CIVIL VI (FAMÍLIA E SUCESSÕES) & 160 \\
\hline & ESTÁGIO SUPERVISIONADO SIMULADO: PRÁTICA DE PROCESSO CIVIL I & 80 \\
\hline & ESTÁGIO SUPER VISIONADO SIMULADO: PRÁTICA DE PROCESSO DO TRABALHO & 80 \\
\hline & DIREITO EMPRESARIAL II & 80 \\
\hline & ESTÁGIO SUPERVISIONADO REAL DE PRÁTICA JURÍDICA I & 80 \\
\hline $5^{\mathrm{a}}$ & DIREITO DIFUSOS E COLETIVOS & 160 \\
\hline
\end{tabular}




\begin{tabular}{|l|l|c|}
\hline & DIREITO PROCESSUAL PENAL II & 160 \\
\hline & DIREITO PROCESSUAL CIVIL IV & 80 \\
\hline & DIREITO CIVIL VII (RESPONSABILIDADE CIVIL) & 80 \\
\hline & ESTÁGIO SUPER VISIONADO SIMULADO: PRÁTICA DE PROCESSO PENAL & 80 \\
\hline & ESTÁGIO SUPER VISIONADO SIMULADO: PRÁTICA DE PROCESSO CIVIL II & 80 \\
\hline & DIREITO TRIBUTÁRIO & 80 \\
\hline & DIREITO DAS RELAÇÕES INTERNACIONAIS & 80 \\
\hline & ESTÁGIO SUPERVISIONADO REAL DE PRÁTICA JURÍDICA & 80 \\
\hline
\end{tabular}

UNISUL - UNIVERSIDADE DO SUL DE SANTA CATARINA

Disponível em: http://portal2.unisul.br/content/navitacontent_/userFiles/File/cursos/cursos_graduacao/novasgrades/direito20071.pdf Acesso em outubro/2010

\begin{tabular}{|c|c|c|}
\hline SEMESTRE & DISCIPLINA & $\begin{array}{c}\text { CARGA } \\
\text { HORÁRIA } \\
\text { (CRÉDITOS) }\end{array}$ \\
\hline \multirow[t]{5}{*}{$1^{\circ}$} & INTRODUÇÃO À CIÊNCIA DO DIREITO & 04 \\
\hline & FILOSOFIA & 04 \\
\hline & CIÊNCIA POLÍTICA E TEORIA GERAL DO ESTADO & 04 \\
\hline & LEITURA E PRODUÇÃO TEXTUAL & 04 \\
\hline & CIÊNCIA E PESQUISA & 04 \\
\hline \multirow[t]{5}{*}{$2^{\circ}$} & DIREITO CIVIL I & 04 \\
\hline & DIREITO CONSTITUCIONAL I & 04 \\
\hline & DIREITO PENAL I & 04 \\
\hline & SOCIOLOGIA & 04 \\
\hline & TEORIA GERAL DO PROCESSO & 04 \\
\hline \multirow[t]{5}{*}{$3^{\circ}$} & DIREITO CIVIL II & 04 \\
\hline & DIREITO CONSTITUCIONAL II & 04 \\
\hline & DIREITO PENAL II & 04 \\
\hline & DIREITO PROCESSUAL CIVIL I & 04 \\
\hline & DIREITO PROCESSUAL PENAL I & 04 \\
\hline \multirow[t]{5}{*}{$4^{\circ}$} & DIREITO PROCESSUAL PENAL II & 04 \\
\hline & DIREITO CIVIL III & 04 \\
\hline & DIREITO CONSTITUCIONAL III & 04 \\
\hline & DIREITO PENAL III & 04 \\
\hline & DIREITO PENAL III & 04 \\
\hline \multirow[t]{6}{*}{$5^{\circ}$} & DIREITO PROCESSUAL PENAL III & 04 \\
\hline & DIREITO CIVIL IV & 04 \\
\hline & DIREITO PENAL IV & 04 \\
\hline & DIREITO PROCESSUAL CIVIL III & 04 \\
\hline & FILOSOFIA DO DIREITO & 02 \\
\hline & SOCIOLOGIA DO DIREITO & 02 \\
\hline \multirow[t]{6}{*}{$6^{\circ}$} & DIREITO CIVIL V & 04 \\
\hline & DIREITO CONSTITUCIONAL IV & 04 \\
\hline & DIREITO PROCESSUAL CIVIL IV & 04 \\
\hline & DIREITO DO TRABALHO I & 04 \\
\hline & DIREITO ADMINISTRATIVO I & 04 \\
\hline & ESTÁGIO SUPER VISIONADO EM DIREITO I & 04 \\
\hline \multirow[t]{6}{*}{$7^{\circ}$} & DIREITO CIVIL VI & 04 \\
\hline & DIREITO ADMINISTRATIVO II & 04 \\
\hline & DIREITO DO TRABALHO II & 04 \\
\hline & DIREITO PROCESSUAL CIVIL V & 04 \\
\hline & DIREITO PROCESSUAL DO TRABALHO I & 04 \\
\hline & ESTÁGIO SUPER VISIONADO EM DIREITO II & 04 \\
\hline \multirow[t]{7}{*}{$8^{\circ}$} & DIREITO CIVIL VII & 04 \\
\hline & DIREITO EMPRESARIAL I & 04 \\
\hline & CRIMINOLOGIA & 02 \\
\hline & TRABALHO DE CURSO EM DIREITO I & 02 \\
\hline & DIREITO PROCESSUAL DO TRABALHO II & 04 \\
\hline & ESTÁGIO SUPER VISIONADO EM DIREITO III & 04 \\
\hline & NÚCLEO ORIENTADO & 04 \\
\hline \multirow[t]{3}{*}{$9^{\circ}$} & DIREITO CIVIL VIII & 02 \\
\hline & DIREITO TRIBUTÁRIO I & 04 \\
\hline & DIREITO EMPRESARIAL II & 02 \\
\hline
\end{tabular}




\begin{tabular}{|l|l|c|}
\hline & DIREITO DAS RELAÇÕES DE CONSUMO & 04 \\
\hline & TRABALHO DE CURSO EM DIREITO II & 05 \\
\hline & ESTÁGIO SUPER VISIONADO EM DIREITO IV & 04 \\
\hline & NÚCLEO ORIENTADO & 04 \\
\hline & & 04 \\
\hline $10^{\circ}$ & DIREITO EMPRESARIAL III & 04 \\
\hline & DIREITO TRIBUTÁRIO II & 04 \\
\hline & DIREITO INTERNACIONAL & 04 \\
\hline & PSICOLOGIA NAS INSTITUIÇÕES JURÍDICAS & 04 \\
\hline & ESTÁGIO SUPER VISIONADO EM DIREITO V & 04 \\
\hline
\end{tabular}

UNITA - UNIVERSIDADE DE ITAÚNA

Disponível em: http://www.uit.edu.br/portal/index.php?option=com_content\&view=article\&id=97\&Itemid=171

Acesso em outubro/2010

\begin{tabular}{|c|c|}
\hline PERÍODO & DISCIPLINA \\
\hline \multirow{6}{*}{ ק } & FILOSOFIA \\
\hline & SÓCIO-ANTROPOLOGIA \\
\hline & ECONOMIA \\
\hline & CIÊNCIA POLÍTICA \\
\hline & INTRODUÇÃO À CIÊNCIA DO DIREITO \\
\hline & TEORIA GERAL DO DIREITO PRIVADO I \\
\hline \multirow{6}{*}{$2^{\circ}$} & TEORIA GERAL DO DIREITO PRIVADO II \\
\hline & TEORIA GERAL DA CONSTITUIÇÃO \\
\hline & METODOLOGIA DE PESQUISA \\
\hline & SOCIOLOGIA JURÍDICA \\
\hline & TEORIA GERAL DO ESTADO \\
\hline & DIREITO PENAL I \\
\hline \multirow{6}{*}{$3^{\circ}$} & DIREITO ELEITORAL \\
\hline & DIREITO AMBIENTAL \\
\hline & DIREITO CIVIL I \\
\hline & DIREITO PENAL II \\
\hline & DIREITO CONSTITUCIONAL I \\
\hline & DIREITO ECONÔMICO \\
\hline \multirow{5}{*}{$4^{\circ}$} & TEORIA GERAL DO PROCESSO \\
\hline & DIREITO PENAL III \\
\hline & DIREITO COMERCIAL I \\
\hline & DIREITO CIVIL II \\
\hline & DIREITO CONSTITUCIONAL II \\
\hline \multirow{6}{*}{$5^{\circ}$} & DIREITO CIVIL III \\
\hline & DIREITO PENAL IV \\
\hline & DIREITO PROCESSUAL CIVIL I \\
\hline & DIREITO COMERCIAL II \\
\hline & DIREITO DA CRIANÇA, DO ADOLESCENTE E DO IDOSO \\
\hline & DIREITO FINANCEIRO \\
\hline \multirow{5}{*}{$6^{\circ}$} & DIREITO ADMINISTRATIVO I \\
\hline & DIREITO PROCESSUAL CIVIL II \\
\hline & DIREITO TRIBUTÁRIO \\
\hline & DIREITO CIVIL IV \\
\hline & DIREITO PROCESSUAL PENAL I \\
\hline \multirow{7}{*}{$7^{\circ}$} & DIREITO ADMINISTRATIVO II \\
\hline & DIREITO PROCESSUAL PENAL II \\
\hline & DIREITO PROCESSUAL CIVIL III \\
\hline & PRÁTICA JURÍDICA CIVIL \\
\hline & ÉTICA GERAL E PROFISSIONAL \\
\hline & DIREITO CIVIL V \\
\hline & ESTÁGIO DE PRÁTICA JURÍDICA I \\
\hline \multirow{6}{*}{$8^{\circ}$} & DIREITO ADMINISTRATIVO III \\
\hline & DIREITO PROCESSUAL CIVIL IV \\
\hline & DIREITO PROCESSUAL PENAL III \\
\hline & DIREITO DO TRABALHO I \\
\hline & DIREITO CIVIL VI \\
\hline & ESTÁGIO DE PRÁTICA JURÍDICA II \\
\hline
\end{tabular}




\begin{tabular}{|l|l|}
\hline \multirow{5}{*}{$9^{\circ}$} & DIREITO PROCESSUAL PENAL IV \\
\cline { 2 - 3 } & DIREITO INTERNACIONAL PÚBLICO \\
\cline { 2 - 3 } & DIREITO CIVIL VII \\
\cline { 2 - 3 } & MEDICINA LEGAL I \\
\cline { 2 - 3 } & DIREITO PROCESSUAL DO TRABALHO \\
\cline { 2 - 3 } & PRÁTICA JURIDICA PENAL \\
\cline { 2 - 2 } & DIREITO DO TRABALHO II \\
\cline { 2 - 2 } & ESTÁGIO DE PRÁTICA JURÍDICA III \\
\cline { 2 - 3 } & \\
\hline \multirow{5}{*}{$0^{\circ}$} & TEORIA E PRÁTICA CIVIL \\
\cline { 2 - 2 } & TEORIA E PRÁTICA PENAL \\
\cline { 2 - 2 } & TEORIA E PRÁTICA TRABALHISTA \\
\cline { 2 - 2 } & DIREITO INTERNACIONAL PRIVADO \\
\cline { 2 - 2 } & MEDICINA LEGAL II \\
\cline { 2 - 2 } & DIREITO CIVIL VIII \\
\cline { 2 - 2 } & ESTÁGIO DE PRÁTICA JURÍDICA IV \\
\cline { 2 - 2 } & TRABALHO DE CURSO (ATIVIDADE EXTRACLASSE) \\
\hline
\end{tabular}

UNIUBE - UNIVERSIDADE DE UBERABA

Disponível em: http://www.uniube.br/proes/grade_curricular.php?curriculo=18\&curso=30\&etapas=10\&cod_area=4\&tipo=g Acesso em outubro/2010

\begin{tabular}{|c|c|c|}
\hline ETAPA & DISCIPLINA & $\begin{array}{c}\text { CARGA } \\
\text { HORÁRIA }\end{array}$ \\
\hline \multirow[t]{7}{*}{$1^{\circ}$} & ATIVIDADES COMPLEMENTARES & 50 \\
\hline & ECONOMIA & 60 \\
\hline & FUNDAMENTOS DO DIREITO & 60 \\
\hline & HISTÓRIA DAS IDÉIAS POLÍTICAS & 75 \\
\hline & HISTÓRIA DOS SISTEMAS JURÍDICOS & 40 \\
\hline & LINGUAGEM JURÍDICA & 40 \\
\hline & METODOLOGIA DO TRABALHO CIENTÍFICO & 50 \\
\hline \multirow[t]{6}{*}{$2^{\circ}$} & ARGUMENTAÇÃO JURÍDICA & 55 \\
\hline & ATIVIDADES COMPLEMENTARES & 50 \\
\hline & FILOSOFIA JURÍDICA & 60 \\
\hline & SOCIOLOGIA JURÍDICA & 60 \\
\hline & TEORIA DO DIREITO PRIVADO & 60 \\
\hline & TEORIA DO DIREITO PÚBLICO & 75 \\
\hline \multirow[t]{8}{*}{$3^{\circ}$} & ATIVIDADES COMPLEMENTARES & 50 \\
\hline & DIREITO CONSTITUCIONAL I & 75 \\
\hline & DIREITO DAS OBRIGAÇÕES & 55 \\
\hline & DIREITO INTERNACIONAL PÚBLICO & 35 \\
\hline & ESTUDOS INTERDISCIPLINARES & 50 \\
\hline & ÉTICA JURÍDICA & 35 \\
\hline & TEORIA DO DIREITO PENAL - $1^{\text {a }}$ PARTE & 75 \\
\hline & TEORIA DO PROCESSO & 55 \\
\hline \multirow[t]{8}{*}{$4^{\circ}$} & ANTROPOLOGIA JURÍDICA & 35 \\
\hline & ATIVIDADES COMPLEMENTARES & 50 \\
\hline & DIREITO CONSTITUCIONAL II & 75 \\
\hline & DIREITO DOS CONTRATOS & 75 \\
\hline & DIREITO INTERNACIONAL PRIVADO & 35 \\
\hline & DIREITO PROCESSUAL CIVIL I & 55 \\
\hline & ESTUDOS INTERDISCIPLINARES & 50 \\
\hline & TEORIA DO DIREITO PENAL - $2^{\mathrm{a}}$ PARTE & 55 \\
\hline \multirow{8}{*}{$5^{\circ}$} & ATIVIDADES COMPLEMENTARES & 50 \\
\hline & DIREITO DAS COISAS & 55 \\
\hline & DIREITO DE EMPRESA I & 55 \\
\hline & DIREITO GLOBAL & 35 \\
\hline & DIREITO PENAL I & 55 \\
\hline & DIREITO PROCESSUAL CIVIL II & 75 \\
\hline & ESTUDOS INTERDISCIPLINARES & 50 \\
\hline & RESPONSABILIDADE CIVIL & 55 \\
\hline \multirow[t]{6}{*}{$6^{\circ}$} & ATIVIDADES COMPLEMENTARES & 50 \\
\hline & DIREITO DE EMPRESA II & 55 \\
\hline & DIREITO DE FAMÍLIA & 75 \\
\hline & DIREITO DO TRABALHO I & 55 \\
\hline & DIREITO PENAL II & 75 \\
\hline & DIREITO PROCESSUAL CIVIL III & 55 \\
\hline
\end{tabular}




\begin{tabular}{|c|c|c|}
\hline & ESTUDOS INTERDISCIPLINARES & 50 \\
\hline \multirow[t]{8}{*}{$7^{\circ}$} & DIREITO ADMINISTRATIVO & 95 \\
\hline & DIREITO DAS SUCESSÕES & 55 \\
\hline & DIREITO DO TRABALHO II & 55 \\
\hline & DIREITO PROCESSUAL CIVIL IV & 55 \\
\hline & DIREITO PROCESSUAL PENAL I & 55 \\
\hline & ESTÁGIO I & 70 \\
\hline & ESTUDOS INTERDISCIPLINARES & 50 \\
\hline & PSICOLOGIA APLICADA AO DIREITO & 35 \\
\hline \multirow[t]{9}{*}{$8^{\circ}$} & DEFESA DA ORDEM ECONÔMICA & 35 \\
\hline & DIREITO AMBIENTAL & 35 \\
\hline & DIREITO PROCESSUAL CIVIL V & 55 \\
\hline & DIREITO PROCESSUAL DO TRABALHO & 55 \\
\hline & DIREITO PROCESSUAL PENAL II & 55 \\
\hline & DIREITO TRIBUTÁRIO & 75 \\
\hline & ESTÁGIO II & 70 \\
\hline & ESTUDOS INTERDISCIPLINARES & 50 \\
\hline & FALÊNCIA E RECUPERAÇÃO DE EMPRESAS & 55 \\
\hline \multirow[t]{6}{*}{$9^{\circ}$} & ESTÁGIO III & 70 \\
\hline & ESTUDOS INTEGRADOS EM DIREITO DO TRABALHO E PREVIDENCIÁRIO & 40 \\
\hline & ESTUDOS INTEGRADOS EM DIREITO PENAL I & 40 \\
\hline & ESTUDOS INTEGRADOS EM DIREITO PRIVADO I & 40 \\
\hline & ESTUDOS INTEGRADOS EM DIREITO PÚBLICO I & 40 \\
\hline & TRABALHO DE CONCLUSÃO DE CURSO & 35 \\
\hline \multirow[t]{5}{*}{$10^{\circ}$} & ESTÁGIO IV & 90 \\
\hline & ESTUDOS INTEGRADOS EM DIREITO PENAL II & 40 \\
\hline & ESTUDOS INTEGRADOS EM DIREITO PRIVADO II & 40 \\
\hline & ESTUDOS INTEGRADOS EM DIREITO PÚBLICO II & 40 \\
\hline & ESTUDOS INTEGRADOS EM DIREITOS DIFUSOS E COLETIVOS & 40 \\
\hline OPTATIVA & PROCESSOS INTERATIVOS COM A PESSOA SURDA - LIBRAS & 120 \\
\hline
\end{tabular}

UNIVAG - CENTRO UNIVERSITÁRIO VÁRZEA GRANDE

Disponível em: http://www.univag.edu.br/v1/cursos/visualizar_curso.aspx?id=2

Acesso em outubro/2010

$I^{\circ}$ NÚCLEO

EIXO TEMÁTICO: APRENDER A APRENDER

\section{DISCIPLINAS}

PRODUÇÃO DE LEITURA E DE TEXTO

DIREITO CIVIL - PARTE GERAL

INTRODUÇÃO À ADMINISTRAÇÃO

TEORIA GERAL DO ESTADO

INVESTIGAÇÃO CIENTIIFICA

ECONOMIA

DIREITO CIVIL - FATOS E ATOS JURÍDICOS

FILOSOFIA

HERMENÊUTICA JURÍDICA

PSICOLOGIA

INTRODUČ̃̃O AO DIREITO

DIREITO CIVIL - OBRIGAÇÕES

TEORIA GERAL DO PROCESSO

DIREITO PENAL - PARTE GERAL

SOCIOLOGIA

II $^{\circ}$ NÚCLEO

EIXO TEMÁTICO: APRENDER A SER/CONVIVER

DISCIPLINAS

DIREITO CONSTITUCIONAL - CONTROLE DE CONSTITUCIONALIDADE

DIREITO CIVIL - CONTRATOS

DIREITO PROCESSUAL CIVIL - PROCESSO DE CONHECIMENTO

DIREITO PENAL - DAS PENAS

DIREITO DO TRABALHO - PARTE GERAL

DIREITO CONSTITUCIONAL - DIREITOS SOCIAIS E POLÍTICOS

DIREITO CIVIL - RESPONSABILIDADE CIVIL

DIREITO PROCESSUAL CIVIL - PROCEDIMENTO PROCESSUAL

DIREITO PENAL - PARTE ESPECIAL - CRIMES CONTRA PESSOA

DIREITO PROCESSUAL PENAL - INQUÉRITO / AÇÃO

CARGA

HORÁRIA

\begin{tabular}{|l|}
\hline 60 \\
\hline 60 \\
\hline 60 \\
60 \\
\hline 60 \\
\hline 60 \\
\hline 60 \\
60 \\
\hline 60 \\
\hline 60 \\
\hline 60 \\
\hline 60 \\
\hline 60 \\
\hline 60 \\
\hline 60 \\
\hline
\end{tabular}




\begin{tabular}{|l|c|}
\hline DIREITO DO TRABALHO - PARTE ESPECIAL & 60 \\
\hline DIREITO CIVIL - FAMÍLIA & 60 \\
\hline DIREITO PROCESSUAL CIVIL - RECURSOS & 60 \\
\hline DIREITO PENAL - CRIMES CONTRA COSTUMES / LEIS ESPECIAIS & 60 \\
\hline DIREITO PROCESSUAL DO TRABALHO & 60 \\
\hline
\end{tabular}

\section{III ${ }^{\circ}$ NÚCLEO}

EIXO TEMÁTICO: APRENDER A FAZER

DISCIPLINAS

DIREITO PROCESSUAL PENAL - RECURSOS

DIREITO CIVIL - POSSE E PROPRIEDADE

DIREITO PROCESSUAL CIVIL - PROCESSO CAUTELAR

ESTÁGIO SUPER VISIONADO - PRÁTICAS SIMULADAS

ÉTICA PROFISSIONAL

DIREITO DO CONSUMIDOR

DIREITO TRIBUTÁRIO

DIREITO PREVIDENCIÁRIO

DIREITO CIVIL - SUCESSÕES

DIREITO PROCESSUAL CIVIL - PROCEDIMENTO ESPECIAL

ESTÁGIO SUPERVISIONADO - ASSISTÊNCIA JUDICIÁRIA/ NÍVEL BÁSICO

DIREITO EMPRESARIAL - TEORIA DA EMPRESA

DIREITO AGRÁRIO

DIREITO ADMINISTRATIVO - ATOS ADMINISTRATIVOS

DIREITOS HUMANOS - ESTATUTO DA CRIANÇA E DO ADOLESCENTE

ESTÁGIO SUPERVISIONADO - ASSISTÊNCIA JUDICIÁRIA/ NÍVEL INTERMEDIÁRIO

DIREITO EMPRESARIAL - TÍTULOS DE CRÉDITOS

PRODUÇÃO DE TRABALHO ACADÊMICO

DIREITO INTERNACIONAL

DIREITO ADMINISTRATIVO - SER VIÇOS PÚBLICOS

DIREITO AMBIENTAL

ESTÁGIO SUPERVISIONADO - ASSISTÊNCIA JUDICIÁRIA/ NÍVEL AVANÇADO

DIREITO EMPRESARIAL - FALÊNCIA E CONCORDATA

CARGA

HORÁRIA

\section{ESUMO DOS COMPONENTES CURRICULARES}

CONTEÚDOS CIENTÍFICOS

ESTÁGIO SUPER VISIONADO

TRABALHO DE CONCLUSÃO DE CURSO

ATIVIDADES COMPLEMENTARES

ATIVIDADES NÃO PRESENCIAIS

\section{UNIVEN - FACULDADE DE NOVA VENÉCIA}

Disponível em: http://www.univen.edu.br/grades\%5Cgrade_dir.pdf Acesso em outubro/2010

\begin{tabular}{|l|l|c|}
\hline PERÍODO & DISCIPLINA & $\begin{array}{c}\text { CARGA } \\
\text { HORÁRIA }\end{array}$ \\
\hline $1^{\circ}$ & & 80 \\
\hline & INTRODUÇÃO AO ESTUDO DO DIREITO & 60 \\
\hline & SOCIOLOGIA GERAL E DO DIREITO & 80 \\
\hline & TEORIA GERAL DO ESTADO E DA CONSTITUIÇÃO & 40 \\
\hline & HISTÓRIA DO DIREITO & 80 \\
\hline & LÍNGUA PORTUGUESA I & 40 \\
\hline & ECONOMIA POLÍTICA & 80 \\
\hline $2^{\circ}$ & & 80 \\
\hline & DIREITO CIVIL I - PARTE GERAL & 80 \\
\hline & DIREITO PENAL I & 60 \\
\hline & DIREITO CONSTITUCIONAL I & 80 \\
\hline & FILOSOFIA DO DIREITO & \\
\hline $3^{\circ}$ & LÍNGUA PORTUGUESA II & 80 \\
\hline & & 80 \\
\hline & DIREITO CIVIL II - OBRIGAÇÕES & 80 \\
\hline & DIREITO PROCESSUAL CIVIL I & 60 \\
\hline & DIREITO CONSTITUCIONAL II & 80 \\
\hline & CIÊNCIA POLÍTICA & 80 \\
\hline $4^{\circ}$ & DIREITO PENAL II & 80 \\
\hline & DIREITO CIVIL III - RESPONSABILIDADE CIVIL & 80 \\
\hline & DIREITO PENAL III & 80 \\
\hline
\end{tabular}




\begin{tabular}{|c|c|c|}
\hline & ANTROPOLOGIA DO DIREITO & 60 \\
\hline \multirow[t]{5}{*}{$5^{\circ}$} & DIREITO CIVIL IV - CONTRATOS & 80 \\
\hline & DIREITO PROCESSUAL PENAL II & 80 \\
\hline & DIREITO DO TRABALHO I & 80 \\
\hline & DIREITO PROCESSUAL CIVIL III & 80 \\
\hline & DIREITO ADMINISTRATIVO I & 80 \\
\hline \multirow[t]{5}{*}{$6^{\circ}$} & DIREITO CIVIL V - COISAS & 80 \\
\hline & DIREITO DO TRABALHO II & 80 \\
\hline & DIREITO EMPRESARIAL I & 80 \\
\hline & DIREITO PROCESSUAL CIVIL IV & 80 \\
\hline & DIREITO ADMINISTRATIVO II & 80 \\
\hline \multirow[t]{5}{*}{$7^{\circ}$} & DIREITO CIVIL VI - FAMÍLIA & 80 \\
\hline & DIREITO EMPRESARIAL II & 80 \\
\hline & PRÁTICA JURÍDICA SIMULADA I & 80 \\
\hline & DIREITO PROCESSUAL DO TRABALHO & 80 \\
\hline & DIREITO TRIBUTÁRIO I & 80 \\
\hline \multirow[t]{5}{*}{$8^{\circ}$} & DIREITO CIVIL VII - SUCESSÕES & 80 \\
\hline & DIREITO EMPRESARIAL III & 80 \\
\hline & PRÁTICA JURÍDICA SIMULADA II & 80 \\
\hline & DIREITO TRIBUTÁRIO II & 80 \\
\hline & METODOLOGIA DO TRABALHO CIENTÍFICO & 40 \\
\hline \multirow[t]{6}{*}{$9^{\circ}$} & DIREITO INTERNACIONAL PÚBLICO & 40 \\
\hline & DIREITO DO CONSUMIDOR & 40 \\
\hline & PSICOLOGIA DO DIREITO & 40 \\
\hline & PRÁTICA JURÍDICA SIMULADA III & 80 \\
\hline & MONOGRAFIA I & 80 \\
\hline & OPTATIVA I & 40 \\
\hline \multirow[t]{6}{*}{$10^{\circ}$} & DIREITO INTERNACIONAL PRIVADO & 40 \\
\hline & DIREITO AMBIENTAL & 60 \\
\hline & ÉTICA GERAL E PROFISSIONAL & 40 \\
\hline & PRÁTICA JURÍDICA SIMULADA IV & 80 \\
\hline & MONOGRAFIA II & 80 \\
\hline & OPTATIVA II & 40 \\
\hline
\end{tabular}

UNIVERSIDADE DO ESTADO DE SÃO PAULO - USP

Disponível em: HTTP://WWW.DIREITO.USP.BR/GRADUACAO/ARQUIVOS/GRADE_CURRICULAR_1_AO_4ANO.PDF E HTTP://WWW.DIREITO.USP.BR/GRADUACAO/ARQUIVOS/GRADE_CURRICULAR 5ANO.PDF

\begin{tabular}{|c|c|c|}
\hline \multicolumn{3}{|c|}{ Acesso em outubro/2010 } \\
\hline SEMESTRE & DISCIPLINA & $\begin{array}{c}\text { CARGA } \\
\text { HORÁRIA } \\
\text { (CRÉDITOS) }\end{array}$ \\
\hline \multirow[t]{5}{*}{$1^{\circ}$} & DIREITO ROMANO I & 21 \\
\hline & T. G. DIREITO PRIVADO I & 21 \\
\hline & TEORIA DO ESTADO I & 21 \\
\hline & INTROD. ESTUDO AO DIREITO I & 21 \\
\hline & ECONOMIA POLÍTICA & 21 \\
\hline \multirow[t]{8}{*}{$2^{\circ}$} & DIREITO ROMANO II & 28 \\
\hline & T. G. DIREITO PRIVADO II & 28 \\
\hline & INT. LATIM JURÍDICO I & 28 \\
\hline & TEORIA DO ESTADO II & 28 \\
\hline & DIREITO CONSTITUCIONAL I & 28 \\
\hline & INTROD. ESTUDO DO DIREITO II & 28 \\
\hline & FUNDAMENTOS DA ECONOMIA & 28 \\
\hline & INTROD. A SOCIOLOGIA & 28 \\
\hline \multirow[t]{9}{*}{$3^{\circ}$} & T. G. DIR. COM. - DIR COM. I & 31 \\
\hline & TEORIA GERAL DAS OBRIGAÇÕES & 31 \\
\hline & INT. LATIM JURÍDICO II & 31 \\
\hline & HISTORIA DO DIRETO I & 31 \\
\hline & DIREITO FINANCEIRO & 31 \\
\hline & DIREITO CONSTITUCIONAL II & 31 \\
\hline & SOCIOLOGIA JURÍDICA & 31 \\
\hline & TEORIA GERAL PROCESSO & 31 \\
\hline & TEORIA GERAL DIREITO PENAL I & 31 \\
\hline
\end{tabular}




\begin{tabular}{|c|c|c|}
\hline \multirow{7}{*}{$4^{\circ}$} & P. ESP. DO DCO - DCO II & 28 \\
\hline & FONTES DAS OBRIGAÇÕES - T. G. DOS CONTRATOS E CONTR. DO CÓDIGO CIVIL & 28 \\
\hline & HISTORIA DO DIREITO II & 28 \\
\hline & DIREITOS FUNDAMENTAIS & 28 \\
\hline & LÓGICA E METOD. JURÍDICA & 28 \\
\hline & DIREITO PROCESSUAL CIVIL I & 28 \\
\hline & TEORIA GERAL DIREITO PENAL II & 28 \\
\hline & & \\
\hline \multirow[t]{9}{*}{$5^{\circ}$} & DIREITO COM. III - P. ESPEC. & 30 \\
\hline & FONTES DAS OBRIGAÇÕES: CONTR. ESP., ATOS UNIL., RESP.. CIVIL, OUTRAS FONTES & 30 \\
\hline & DIREITO ADMINISTRATIVO I & 30 \\
\hline & FILOSOFIA DO DIR. I (P. GERAL) & 30 \\
\hline & DIREITO INTERNACIONAL PÚBLICO I & 30 \\
\hline & DIREITO PROCESSUAL CIVIL II & 30 \\
\hline & DIREITO PROCESSUAL PENAL I & 30 \\
\hline & DIR. PENA I - PARTE ESPECIAL & 30 \\
\hline & DIREITO DO TRABALHO I & 30 \\
\hline \multirow[t]{9}{*}{$6^{\circ}$} & PARTE ESP. DO DCO IV & 31 \\
\hline & DIREITOS REAIS & 31 \\
\hline & DIREITO ADMINISTRATIVO II & 31 \\
\hline & FILOSOFIA DO DIREITO II (P. ESP.) & 31 \\
\hline & DIREITO INTERNACIONAL PÚBLICO II & 31 \\
\hline & DIREITO PROCESSUAL CIVIL III & 31 \\
\hline & DIREITO PROCESSUAL PENAL II & 31 \\
\hline & DIREITO PENAL II - PARTE ESP & 31 \\
\hline & DIREITO DO TRABALHO II & 31 \\
\hline \multirow[t]{8}{*}{$7^{\circ}$} & DIREITO DE FAMÍLIA & 26 \\
\hline & DIREITO TRIBUTÁRIO I & 26 \\
\hline & METODOLOGIA P/ MONOGRAFIA & 26 \\
\hline & DIREITO INTERNACIONAL PRIVADO & 26 \\
\hline & ORGANIZAÇÃO INTERNACIONAL & 26 \\
\hline & DIREITO PROCESSUAL CIVIL IV & 26 \\
\hline & DIREITO PROCESSUAL PENAL III & 26 \\
\hline & DIREITO PENAL III - P.ESPECIAL & 26 \\
\hline \multirow[t]{3}{*}{ OPTATIVA } & INSTITUIÇÕES JUDICIÁRIAS I & \\
\hline & DIREITO DAS RELAÇÕES INTERNAC. & \\
\hline & DIR. DOS SEGUROS PRIV. E GESTÃO ATUARIAL I & \\
\hline \multirow[t]{10}{*}{$8^{\circ}$} & DIREITO DAS SUCESSÕES & 26 \\
\hline & DIREITO TRIBUTÁRIO II & 26 \\
\hline & DIREITO ECONÔMICO & 26 \\
\hline & ÉTICA PROFISSIONAL & 26 \\
\hline & DIREITO DO COMÉRCIO INTERNAC. I & 26 \\
\hline & TRATAMENTO DA PESSOA E DOS BENS NA ORDEM INTERNACIONAL & 26 \\
\hline & MEDICINA FORENSE I & 26 \\
\hline & COMPORT. HUMANO FORENSE I & 26 \\
\hline & NOVAS TENDÊNCIAS DO DIR. PROC. & 26 \\
\hline & SEGURIDADE SOCIAL & 26 \\
\hline \multirow[t]{4}{*}{ OPTATIVA } & INSTITUIÇÕES JUDICIÁRIAS II & \\
\hline & HISTORIA DAS IDÉIAS POLÍTICAS & \\
\hline & SOLUÇÕES DE DISPUTAS(PRINC.GERAIS) & \\
\hline & DIR. DOS SEGUROS PRIV. E GESTÃO ATUARIAL II & \\
\hline \multicolumn{3}{|l|}{$9^{\circ}$} \\
\hline \multirow{6}{*}{$\begin{array}{l}\text { ÁREA I DIREITO } \\
\text { POLITICO } \\
\text { ADMINISTRATIVO }\end{array}$} & & \\
\hline & DIREITO ECONÔMICO & 13 \\
\hline & LIBERDADES PUBLICAS I & 13 \\
\hline & ATOS ADMINSITRATIVOS & 13 \\
\hline & DIR. DO COMÉRCIO INTERNACIONAL II & 13 \\
\hline & DIREITO DE INTEGRAÇÃO & 13 \\
\hline \multirow{5}{*}{$\begin{array}{l}\text { ÁREA II - DIREITO } \\
\text { PENAL E } \\
\text { CRIMINOLOGIA }\end{array}$} & & \\
\hline & MEDICINA FORENSE II & 12 \\
\hline & DIREITO PROC. PENAL IV-PARTE ESPECIAL & 12 \\
\hline & DIREITO PENAL IV PARTE ESPECIAL & 12 \\
\hline & TEMAS FUNDAM. DE DIREITO PENAL I & 12 \\
\hline
\end{tabular}




\begin{tabular}{|c|c|c|}
\hline $\begin{array}{ll}\text { ÁREA III } & - \\
\text { DIREITO } & \\
\text { PRIVADO } & \text { E } \\
\text { PROCESSO CIVIL } & \end{array}$ & DIREITO FALIMENTAR & 13 \\
\hline & DIREITO AGRÁRIO & 13 \\
\hline & DIREITO CIVIL APLICADO I & 13 \\
\hline & MEDICINA FORENSE III & 13 \\
\hline & DIREITO PROCESSUAL CIVIL (PROC. ESPECIAIS I ) & 13 \\
\hline $\begin{array}{lrr}\text { ÁREA } & \text { IV } & - \\
\text { DIREITO } & & \text { DE } \\
\text { EMPRESA } & & \\
\end{array}$ & DIREITO CONCORRENCIAL & 12 \\
\hline & DIREITO FALIMENTAR & 12 \\
\hline & DIREITO TRIBUTÁRIO APLICADO I & 12 \\
\hline & DIREITO ECONÔMICO & 12 \\
\hline $\begin{array}{l}\text { ÁREA V - DIREITO } \\
\text { DO TRABALHO E } \\
\text { DE SEGURANÇA } \\
\text { SOCIAL }\end{array}$ & DIREITO INDIVIDUAL DO TRABALHO I & 13 \\
\hline & DIREITO COLETIVO DO TRABALHO I & 13 \\
\hline & DIREITO PROCESSUAL DO TRABALHO I & 13 \\
\hline & TEORIA GERAL DO DIREITO DO TRABALHO I & 13 \\
\hline OPTATIVAS & DIREITO DA CRIANÇA E DO ADOLESCENTE & \\
\hline & DIREITO AMBIENTAL I & \\
\hline & DIREITO ECONÔMICO INTERNACIONAL & \\
\hline & DIREITO DO CONSUMIDOR & \\
\hline & DIREITO CONSTITUCIONAL ESTADUAL & \\
\hline & DIREITO INTERNACIONAL PROCESSUAL & \\
\hline & COMPORTAMENTO HUMANO FORENSE II & \\
\hline & INFORTUNÍSTICA MEDICO FORENSE - DIR.TRAB & \\
\hline & CRIMINOLOGIA I & \\
\hline & DIREITO PROCESSUAL PENAL - PROC. ESP. I & \\
\hline & DIREITO PROCESSUAL CIVIL APLICADO I & \\
\hline & TUTELA JURISDICIONAL DOS INTERESSES TRANSIND. & \\
\hline & LEGISLAÇÃO PENAL ESPECIAL I & \\
\hline & DIREITO DA SEGURANÇA SOCIAL I & \\
\hline $10^{\circ}$ & & \\
\hline ÁREA I DIREITO & & \\
\hline POLÍTICO E & DIREITO FINANCEIRO APLICADO & 12 \\
\hline & LIBERDADES PUBLICAS II & 12 \\
\hline & ADMINISTRAÇÃO INDIRETA & 12 \\
\hline & SISTEMAS POLÍTICOS E ELEITORAIS & 12 \\
\hline ÁREA II - DIREITO & & \\
\hline $\begin{array}{l}\text { PENAL } \\
\text { CRIMINOLOGIA }\end{array}$ & DIREITO PROC. PENAL V - PARTE ESPECIAL & 12 \\
\hline & DIREITO PENAL V - PARTE ESPECIAL & 12 \\
\hline & TEMAS FUNDAM. DE DIREITO PENAL II & 12 \\
\hline & CRIMINOLOGIA II & 12 \\
\hline $\begin{array}{ll}\text { ÁREA } & \text { III } \\
\text { DIREITO } & \\
\text { PRIVADO } & \text { E } \\
\text { PROCESSO CIVIL }\end{array}$ & DIREITO CIVIL APLICADO II & 10 \\
\hline & DIREITO DO AUTOR & 10 \\
\hline & MEDICINA FORENSE IV & 10 \\
\hline & DIREITO PROCESSUAL CIVIL (PROC. ESPECIAIS II) & 10 \\
\hline ÁREA IV - & & \\
\hline $\begin{array}{l}\text { DIREITO } \\
\text { EMPRESA }\end{array}$ & DIREITO BANCÁRIO & 13 \\
\hline & MERCADO DE CAPITAIS & 13 \\
\hline & DIREITO TRIBUTÁRIO APLICADO II & 13 \\
\hline & NOÇÕES DE CONTABILIDADE EMPRESARIAL & $\begin{array}{c}3+1 \text { CRED } \\
\text { TRAB }=4\end{array}$ \\
\hline $\begin{array}{l}\text { ÁREA V - DIREITO } \\
\text { DO TRABALHO E } \\
\text { DE SEGURANÇA }\end{array}$ & DIREITO INDIVIDUAL DO TRABALHO II & 13 \\
\hline & DIREITO COLETIVO DO TRABALHO II & 13 \\
\hline & DIREITO PROCESSUAL DO TRABALHO II & 13 \\
\hline & TEORIA GERAL DO DIREITO DO TRABALHO II & 13 \\
\hline OPTATIVAS & DIREITO ECONÔMICO APLICADO & \\
\hline
\end{tabular}




\begin{tabular}{|l|l|l|}
\hline & DIREITO AMBIENTAL II & \\
\hline & DIREITO INTERNACIONAL DO TRABALHO & \\
\hline & DIREITO INTERNACIONAL TRIBUTÁRIO & \\
\hline & DIREITO PENAL INTERNAC. EDIR.INTERNAC. PENAL & \\
\hline & CRIMINALÍSTICA & \\
\hline & DIREITO PROCESSUAL PENAL - PROC. ESP. II & \\
\hline & DIREITO PROCESSUAL CIVIL APLICADO II & \\
\hline & LEGISLAÇÃO PENAL ESPECIAL II & \\
\hline & DIREITO DA SEGURANÇA SOCIAL II & \\
\hline
\end{tabular}


ANEXO B

QUESTIONÁRIO APLICADO

AOS

DISCENTES 
ANEXO B - Questionário - Corpo Discente - para alunos do $5^{\circ}$ Ano

\section{INSTRUCÕES PARA O PREENCHIMENTO}

1. Este questionário visa colher informações sobre as dificuldades encontradas na condução das disciplinas de prática de estágio de Processo Civil para a formação do Bacharel em Direito a partir da visão do(a) acadêmico(a).

2. Todas as respostas são confidenciais e o preenchimento é anônimo.

3. A sua sinceridade nas respostas é muito importante, assim como o preenchimento de todas as questões, pois a realização deste estudo depende da sua participação.

4. Em todas as questões ou itens de cada tabela deverá ser escolhida uma única alternativa como resposta.

5. O tempo necessário para o preenchimento do questionário é de aproximadamente 15 minutos.

6. Preencha-o individualmente.

7. Ao acabar de respondê-lo, entregue-o ao pesquisador responsável que se encontra no local. 


\section{PARTE}

\section{Sexo:}
a) Masculino
b) Feminino

\section{Período das aulas}
a)
b) Matutino.

1. Série que está cursando atualmente na Graduação em Direito:
a)
b)
c)
d)
e) $\square$ a Série.

\section{Outras atividades acadêmicas no corrente ano (2010):}
a) Atua em projetos de pesquisa sem bolsa (PIC).
b) Atua em projetos de pesquisa com bolsa (PIBIC).
c) Atua em projetos de extensão na Instituição (exemplo: Assistência Judiciária Gratuita).
d) Atua em projetos artístico-culturais da Instituição de Ensino.
e) Atua em projetos desportivos da Instituição de Ensino.

\section{Você trabalha?}
a) Não.
b) Trabalho na área jurídica * sem remuneração.
c) Trabalho na área jurídica * com remuneração e registro em carteira de trabalho.
d) Trabalho na área jurídica * com remuneração e sem registro em carteira de trabalho.
e) Trabalho, mas não na área jurídica *.

* Considera-se área jurídica atividades realizadas em Cartórios, com juízes, com membros do Ministério Público ou com advogados/procuradores. 


\section{PARTE}

1. Avalie as técnicas utilizadas pelo seu professor de Direito Processual Civil I para o processo de ensino-aprendizagem da disciplina:

\begin{tabular}{|c|c|c|c|c|c|}
\hline $\begin{array}{ll} & \text { Utilização das técnicas de aprendizagem } \\
\text { Técnicas de aprendizagem } & \end{array}$ & $\begin{array}{l}\text { Nunca } \\
\text { (Zero) }\end{array}$ & $\begin{array}{l}\text { Raramente } \\
\text { (1x mês) }\end{array}$ & $\begin{array}{l}\text { Regularmente } \\
\text { (2x por mês) }\end{array}$ & $\begin{array}{l}\text { Quase } \\
\text { sempre } \\
\text { (3x por } \\
\text { mês) }\end{array}$ & $\begin{array}{l}\text { Sempre } \\
\text { (4x por } \\
\text { mês) }\end{array}$ \\
\hline a) Aula predominantemente com exposição oral pelo Professor & & & & & \\
\hline b) Discussões em grupo de alunos & & & & & \\
\hline c) Pesquisas extraclasses pelos alunos & & & & & \\
\hline d) Respostas orais do(s) aluno(s) por perguntas diretas do professor & & & & & \\
\hline $\begin{array}{l}\text { e) Exposições orais dos alunos em razão de seminários/apresentação de } \\
\text { trabalhos em grupo }\end{array}$ & & & & & \\
\hline $\begin{array}{l}\text { f) Exposição oral de aluno em razão de seminários/apresentação de } \\
\text { trabalhos individuais }\end{array}$ & & & & & \\
\hline g) Leituras de textos pelos alunos em sala de aula & & & & & \\
\hline h) Leituras de textos pelos alunos fora de sala de aula & & & & & \\
\hline Realização de atividades práticas simuladas pelo aluno & & & & & \\
\hline
\end{tabular}


2. Avalie as técnicas utilizadas pelo seu professor de Direito Processual Civil II para o processo de ensino-aprendizagem da disciplina:

\begin{tabular}{|c|c|c|c|c|c|}
\hline Utilização das técnicas de aprendizagem & $\begin{array}{l}\text { Nunca } \\
\text { (Zero) }\end{array}$ & $\begin{array}{l}\text { Raramente } \\
\text { (1x mês) }\end{array}$ & $\begin{array}{l}\text { Regularmen } \\
\text { te } \\
\text { (2x por } \\
\text { mês) }\end{array}$ & $\begin{array}{l}\text { Quase } \\
\text { sempre } \\
\text { (3x por } \\
\text { mês) }\end{array}$ & $\begin{array}{c}\text { Sempre } \\
\text { (4x por } \\
\text { mês) }\end{array}$ \\
\hline a) Aula predominantemente com exposição oral pelo Professor & & & & & \\
\hline b) Discussões em grupo de alunos & & & & & \\
\hline c) Pesquisas extraclasses pelos alunos & & & & & \\
\hline d) Respostas orais do(s) aluno(s) por perguntas diretas do professor & & & & & \\
\hline $\begin{array}{l}\text { e) Exposições orais dos alunos em razão de seminários/apresentação de } \\
\text { trabalhos em grupo }\end{array}$ & & & & & \\
\hline $\begin{array}{l}\text { f) Exposição oral de aluno em razão de seminários/apresentação de } \\
\text { trabalhos individuais }\end{array}$ & & & & & \\
\hline g) Leituras de textos pelos alunos em sala de aula & & & & & \\
\hline h) Leituras de textos pelos alunos fora de sala de aula & & & & & \\
\hline i) Realização de atividades práticas simuladas pelo aluno & & & & & \\
\hline
\end{tabular}


3. Durante suas aulas de Prática de Processo Civil no 40 Ano, na Instituição (Estágio Supervisionado Simulado), você necessitou de conteúdos teóricos das disciplinas de Processo Civil I e Processo Civil II.

Assim, assinale a alternativa que mais corresponda às dificuldades enfrentadas, durante o referido $\underline{40}$ Ano (na disciplina de Prática de Processo Civil) sobre os conteúdos abaixo:

\begin{tabular}{|c|c|c|c|c|c|c|}
\hline & $\begin{array}{l}\text { Conteúdos teóricos tratados } \\
\text { durante as aulas de Prática no 40 Ano }\end{array}$ & $\begin{array}{c}\text { Nunca } \\
\text { houve } \\
\text { dificuldades } \\
\text { ( } 0 \% \text { das vezes) }\end{array}$ & $\begin{array}{c}25 \% \text { das vezes } \\
\text { houve } \\
\text { dificuldades }\end{array}$ & $\begin{array}{c}50 \% \text { das } \\
\text { vezes houve } \\
\text { dificuldades }\end{array}$ & $\begin{array}{c}75 \% \text { das } \\
\text { vezes houve } \\
\text { dificuldades }\end{array}$ & $\begin{array}{c}100 \% \text { das } \\
\text { vezes houve } \\
\text { dificuldades }\end{array}$ \\
\hline a) & A matéria de princípios de Processo Civil (Processo Civil I) & & & & & \\
\hline b) & A matéria relativa à competência (Processo Civil I) & & & & & \\
\hline c) & A matéria de organização Judiciária (Processo Civil I) & & & & & \\
\hline d) & A matéria condições da ação (Processo Civil I) & & & & & \\
\hline e) & A matéria atos processuais (Processo Civil I) & & & & & \\
\hline f) & A matéria petição inicial (Processo Civil II) & & & & & \\
\hline g) & A matéria contestação (Processo Civil II) & & & & & \\
\hline h) & A matéria provas (Processo Civil II) & & & & & \\
\hline i) & A matéria sentença (Processo Civil II) & & & & & \\
\hline k) & A matéria recursos (Processo Civil II) & & & & & \\
\hline
\end{tabular}




\section{ANEXO C}

\section{QUESTIONÁRIO APLICADO \\ AOS}

\section{DOCENTES DAS DISCIPLINAS TEÓRICAS}


ANEXO C - Questionário - Corpo Docente - Professores das disciplinas teóricas de Processo Civil I ou Processo Civil II

\section{INSTRUCÕES PARA O PREENCHIMENTO}

1. Este questionário visa colher informações sobre as dificuldades encontradas na condução das disciplinas de prática de estágio de Processo Civil para a formação do Bacharel em Direito a partir da visão do professor da disciplina teórica (de Processo Civil I ou Processo Civil II).

2. Todas as respostas são confidenciais e o preenchimento é anônimo.

3. A sua sinceridade nas respostas é muito importante, assim como o preenchimento de todas as questões, pois a realização deste estudo depende da sua participação.

4. Em todas as questões ou itens de cada tabela deverá ser escolhida uma única alternativa como resposta.

5. O tempo necessário para o preenchimento do questionário é de aproximadamente 10 minutos.

6. Preencha-o individualmente.

14. Ao acabar de respondê-lo, entregue-o ao responsável que se encontra no local. 


\section{PARTE}

Sexo:
a)
b)
Masculino
Feminino

\section{1. Área de atuação profissional não-docente:}
a) Atuação exclusivamente como docente.
b) Atuação na área jurídica como advogado(a) e como docente.
c) Atuação como membro do Ministério Público ou Juiz(íza) e como docente.
d) Atuação como Delegado(a) e como docente.
e) Atuação em outras atividades não-jurídicas e como docente.

\section{Maior Titulação acadêmica:}
a) Bacharel.
b) Especialista.
c) Mestre.
d) Doutor.
e) Pós-doutor.

3. Formação pedagógica (escolha a alternativa que mais se aproxime de sua situação):
a) Licenciatura (Pedagogia, Letras, História, Matemática etc.)
b) Pós-graduação em Metodologia do Ensino Superior ou Docência do Ensino Superior.
c) Disciplinas pedagógicas realizadas em cursos de Especialização e/ou Mestrado.
d) Participação em eventos de caráter pedagógico promovidos pela própria universidade.
e) Sem formação pedagógica.

\section{Tempo de atuação como docente no Ensino Superior:}
a) Menos de 02 anos.
b) De 02 a 04 anos.
c) De 05 a 07 anos.
d) De 08 a 10 anos.
e) $\square$ Mais de 10 anos. 


\section{Carga horária contratual em 2009:}
a) Horista: de 08 a 20 horas/semanais.
b) Horista: mais de 20 horas/semanais.
c) $T-20$.
d) $\quad T-30$.
e) $\square \mathrm{T}-40$.

\section{Distribuição da carga horária:}

\begin{tabular}{|c|c|c|c|}
\hline & Distribuição & Sim & Não \\
\hline a) & Sala de aula. & & \\
\hline b) & Orientação em trabalhos de conclusão de curso. & & \\
\hline c) & Projetos de ensino. & & \\
\hline d) & Projetos de pesquisa. & & \\
\hline e) & Projetos de extensão. & & \\
\hline f) & Cursos extracurriculares. & & \\
\hline g) & Atendimento acadêmico remunerado. & & \\
\hline h) & Atividade administrativa (chefia, coordenação, direção etc.). & & \\
\hline
\end{tabular}

8. Série(s) em que exerce a docência com disciplina(s) teórica(s):

\begin{tabular}{|c|c|c|c|}
\hline & Série & Sim & Não \\
\hline a) & Primeira & & \\
\hline b) & Segunda & & \\
\hline c) & Terceira & & \\
\hline d) & Quarta & & \\
\hline & Quinta & & \\
\hline
\end{tabular}

9. Série(s) em que exerce a docência com disciplina(s) práticas (estágio):

\begin{tabular}{|ll|l|l|}
\hline & \multicolumn{1}{c|}{ Série } & Sim & Não \\
\hline a) & Primeira & & \\
\hline b) & Segunda & & \\
\hline c) & Terceira & & \\
\hline d) & Quarta & & \\
\hline e) & Quinta & & \\
\hline
\end{tabular}




\section{PARTE}

\section{Avalie as técnicas utilizadas por você para o processo de ensino-aprendizagem da(s) disciplina(s) lecionada:}

\begin{tabular}{|c|c|c|c|c|c|}
\hline $\begin{array}{llll}\text { aprendizagem } & \text { Utilização das técnicas de } \\
\text { Técnicas de aprendizagem } & & \\
\end{array}$ & $\begin{array}{l}\text { Nunca } \\
\text { (Zero) }\end{array}$ & $\begin{array}{l}\text { Raramente } \\
\text { (1x mês) }\end{array}$ & $\begin{array}{l}\text { Regularmente } \\
\text { (2x por mês) }\end{array}$ & $\begin{array}{c}\text { Quase } \\
\text { sempre } \\
\text { (3x por mês) }\end{array}$ & $\begin{array}{c}\text { Sempre } \\
\text { (4x por mês) }\end{array}$ \\
\hline a) Aula com exposição oral predominante & & & & & \\
\hline b) Discussões em grupo & & & & & \\
\hline c) Pesquisas extraclasses & & & & & \\
\hline d) Exposições orais do(s) aluno(s) por perguntas diretas do professor & & & & & \\
\hline $\begin{array}{l}\text { e) Exposições orais dos alunos em razão de seminários/apresentação de } \\
\text { trabalhos em grupo }\end{array}$ & & & & & \\
\hline $\begin{array}{l}\text { f) Exposição oral de aluno em razão de seminários/apresentação de } \\
\text { trabalhos individuais }\end{array}$ & & & & & \\
\hline g) Leituras de textos em sala de aula & & & & & \\
\hline h) Leituras de textos fora da sala de aula & & & & & \\
\hline $\begin{array}{l}\text { i) Acompanhamento de atividades escritas dos alunos com orientações } \\
\text { para o desenvolvimento de peças práticas }\end{array}$ & & & & & \\
\hline
\end{tabular}


2. Tendo em foco a aprendizagem do aluno envolvendo o processo civil, avalie as técnicas de aprendizagem abaixo:

\begin{tabular}{|c|c|c|c|c|c|}
\hline \begin{tabular}{|cc} 
& $\begin{array}{c}\text { Aplicação das técnicas de aprendizagem } \\
\text { para o conhecimento do aluno }\end{array}$ \\
Técnica de Aprendizagem &
\end{tabular} & $\begin{array}{l}\text { Não } \\
\text { Necessária } \\
\text { (zero) }\end{array}$ & $\begin{array}{l}\text { Pouco } \\
\text { Necessária } \\
\text { (De } 1 \% \text { a } \\
25 \% \text { de } \\
\text { importância) }\end{array}$ & $\begin{array}{l}\text { Moderadamente } \\
\text { Necessária } \\
\text { (De } 26 \% \text { a } 50 \% \\
\text { de importância) }\end{array}$ & $\begin{array}{c}\text { Muito } \\
\text { Necessária } \\
\text { (De 51\% a 75\% } \\
\text { de } \\
\text { importância) }\end{array}$ & $\begin{array}{l}\text { Altamente } \\
\text { Necessária } \\
\text { (De } 76 \text { a } \\
100 \% \text { de } \\
\text { importância) }\end{array}$ \\
\hline b) Discussões em grupo & & & & & \\
\hline c) Pesquisas extraclasse & & & & & \\
\hline $\begin{array}{l}\text { e) Exposições orais dos alunos em razão de seminários/apresentação de } \\
\text { trabalhos em grupo }\end{array}$ & & & & & \\
\hline $\begin{array}{l}\text { f) Exposição oral de aluno em razão de seminários/apresentação de } \\
\text { trabalhos individuais }\end{array}$ & & & & & \\
\hline
\end{tabular}


3. Assinale a alternativa que mais corresponder à sua expectativa da disciplina de processo civil e a prática sobre o conhecimento que você proporciona:

\begin{tabular}{|c|c|c|c|c|c|c|}
\hline \multicolumn{2}{|c|}{ Questão } & $\begin{array}{c}\text { Discordo } \\
\text { plenamente }\end{array}$ & $\begin{array}{l}\text { Discordo } \\
\text { parcialmente }\end{array}$ & $\begin{array}{l}\text { Não concordo } \\
\text { nem discordo }\end{array}$ & $\begin{array}{l}\text { Concordo } \\
\text { parcialmente }\end{array}$ & $\begin{array}{l}\text { Concordo } \\
\text { plenamente }\end{array}$ \\
\hline a) & $\begin{array}{l}\text { Durante a aula de Processo Civil (I ou II), é necessário fazer com que } \\
\text { os alunos realizem atividades práticas, mesmo sem a disciplina de } \\
\text { Prática (Estágio Simulado) }\end{array}$ & & & & & \\
\hline b) & $\begin{array}{l}\text { É possível desenvolver a aprendizagem do Processo Civil (I ou II) } \\
\text { sem a realização de atividades práticas pelos alunos }\end{array}$ & & & & & \\
\hline c) & $\begin{array}{l}\text { O ensino da parte teórica do processo civil não exige que o aluno } \\
\text { realize atividades práticas (no segundo ou terceiro ano) }\end{array}$ & & & & & \\
\hline d) & $\begin{array}{l}\text { Devido ao tempo, o ensino da parte teórica é incompatível com as } \\
\text { atividades práticas }\end{array}$ & & & & & \\
\hline
\end{tabular}

\section{Sua relação com a disciplina de Estágio/Prática de Processo Civil:}

\begin{tabular}{|c|c|c|c|c|c|}
\hline Questão $\quad$ Avaliação & $\begin{array}{l}\text { Nunca } \\
\text { (Zero) }\end{array}$ & $\begin{array}{l}\text { Raramente } \\
\text { (1x mês) }\end{array}$ & $\begin{array}{l}\text { Regularmente } \\
\text { (2x por mês) }\end{array}$ & $\begin{array}{c}\text { Quase } \\
\text { sempre } \\
\text { (3x por } \\
\text { mês) }\end{array}$ & $\begin{array}{l}\text { Sempre } \\
\text { (4x por } \\
\text { mês) }\end{array}$ \\
\hline $\begin{array}{l}\text { a) Tem conhecimento das dificuldades enfrentadas pelos alunos } \\
\text { quanto ao conhecimento teórico da disciplina de processo civil e } \\
\text { sua aplicação na prática/estágio? }\end{array}$ & & & & & \\
\hline $\begin{array}{l}\text { b) É consultado pelo professor da Prática/Estágio sobre os } \\
\text { procedimentos de aprendizagem aplicados na disciplina teórica? }\end{array}$ & & & & & \\
\hline $\begin{array}{l}\text { c) Tem conhecimento das práticas exigidas durante a disciplina de } \\
\text { Estágio/Prática de Processo Civil envolvendo o conteúdo da } \\
\text { disciplina teórica? }\end{array}$ & & & & & \\
\hline
\end{tabular}




\section{ANEXO D}

\section{QUESTIONÁRIO APLICADO \\ AOS}

\section{DOCENTES DAS DISCIPLINAS PRÁTICAS}


ANEXO D - Questionário - Corpo Docente - Professores das disciplinas de prática de Processo Civil

\section{INSTRUCÕES PARA O PREENCHIMENTO}

1. Este questionário visa colher informações sobre as dificuldades encontradas na condução das disciplinas de prática de estágio de Processo Civil para a formação do Bacharel em Direito.

2. Todas as respostas são confidenciais e o preenchimento é anônimo.

3. A sua sinceridade nas respostas é muito importante, assim como o preenchimento de todas as questões, pois a realização deste estudo depende da sua participação.

4. Em todas as questões ou itens de cada tabela deverá ser escolhida uma única alternativa como resposta.

5. O tempo necessário para o preenchimento do questionário é de aproximadamente 10 minutos.

6. Preencha-o individualmente.

7. Ao acabar de respondê-lo, entregue-o ao responsável que se encontra no local. 


\section{PARTE}

\section{Sexo:}
a)
Masculino
b)
Feminino

\section{1. Área de atuação profissional não-docente:}
a) Atuação exclusivamente como docente.
b) Atuação na área jurídica como advogado(a) e como docente.
c) Atuação como membro do Ministério Público ou Juiz(íza) e como docente.
d) Atuação como Delegado(a) e como docente.
e) Atuação em outras atividades não-jurídicas e como docente.

\section{Maior Titulação acadêmica:}
a) Bacharel.
b) Especialista.
c) Mestre.
d) Doutor.
e) Pós-doutor.

3. Formação pedagógica (escolha a alternativa que mais se aproxime de sua situação):
a)
b) Licenciatura (Pedagogia, Letras, História, Matemática etc.)
c) Pós-graduação em Metodologia do Ensino Superior ou Docência do Ensino Superior.
d) Disciplina(s) pedagógica(s) realizada(s) em cursos de Especialização e/ou Mestrado.
Somente participação em eventos de caráter pedagógico promovidos pela própria universidade.
e) Sem formação pedagógica.

\section{Tempo de atuação como docente no Ensino Superior:}
a) Menos de 02 anos.
b) De 02 a 04 anos.
c) De 05 a 07 anos.
d) De 08 a 10 anos.
e) $\square$ Mais de 10 anos. 


\section{Carga horária contratual em 2009:}
a) Horista: de 08 a 20 horas/semanais.
b) Horista: mais de 20 horas/semanais.
c) $\mathrm{T}-20$.
d) $T-30$.
e) $\mathrm{T}-40$.

\section{Distribuição da carga horária:}

\begin{tabular}{|c|c|c|c|}
\hline & Distribuição & Sim & Não \\
\hline a) & Sala de aula & & \\
\hline b) & Orientação em trabalhos de conclusão de curso & & \\
\hline c) & Projetos de ensino & & \\
\hline d) & Projetos de pesquisa & & \\
\hline e) & Projetos de extensão & & \\
\hline f) & Cursos extracurriculares & & \\
\hline g) & Atendimento acadêmico remunerado & & \\
\hline h) & Atividade administrativa (chefia, coordenação, direção etc.) & & \\
\hline
\end{tabular}

7. Série(s) em que exerce a docência com disciplina(s) teórica(s):

\begin{tabular}{|ll|l|l|}
\hline & \multicolumn{1}{c|}{ Série } & Sim & Não \\
\hline a) & Primeira & & \\
\hline b) & Segunda & & \\
\hline c) & Terceira & & \\
\hline d) & Quarta & & \\
\hline e) & Quinta & & \\
\hline
\end{tabular}

8. Série(s) em que exerce a docência com disciplina(s) práticas (estágio - Prática de Processo Civil):

\begin{tabular}{|ll|c|c|}
\hline & Série & Sim & Não \\
\hline a) & Primeira & & \\
\hline b) & Segunda & & \\
\hline c) & Terceira & & \\
\hline d) & Quarta & & \\
\hline e) & Quinta & & \\
\hline
\end{tabular}




\section{PARTE}

1. Avalie as técnicas utilizadas por você para o processo de ensino-aprendizagem da(s) disciplina(s) de estágio/prática:

\begin{tabular}{|c|c|c|c|c|c|}
\hline $\begin{array}{l}\text { Utilização das técnicas de aprendizagem } \\
\text { Técnicas de aprendizagem }\end{array}$ & $\begin{array}{l}\text { Nunca } \\
\text { (Zero) }\end{array}$ & $\begin{array}{l}\text { Raramente } \\
\text { (1x mês) }\end{array}$ & $\begin{array}{c}\text { Regularmen } \\
\text { te } \\
\text { (2x por } \\
\text { mês) }\end{array}$ & $\begin{array}{c}\text { Quase } \\
\text { sempre } \\
\text { (3x por } \\
\text { mês) }\end{array}$ & $\begin{array}{l}\text { Sempre } \\
\text { (4x por } \\
\text { mês) }\end{array}$ \\
\hline a) Aula com sua exposição oral predominante & & & & & \\
\hline b) Discussões em grupo & & & & & \\
\hline c) Pesquisas extraclasses pelos alunos & & & & & \\
\hline d) Exposições orais do(s) aluno(s) por perguntas diretas do professor & & & & & \\
\hline $\begin{array}{l}\text { e) Exposições orais dos alunos em razão de seminários/apresentação de } \\
\text { trabalhos em grupo }\end{array}$ & & & & & \\
\hline $\begin{array}{l}\text { f) Exposição oral de aluno em razão de seminários/apresentação de } \\
\text { trabalhos individuais }\end{array}$ & & & & & \\
\hline g) Leituras de textos em sala de aula pelos alunos & & & & & \\
\hline $\begin{array}{l}\text { h) Acompanhamento de atividades escritas dos alunos com orientações para } \\
\text { o desenvolvimento das peças práticas }\end{array}$ & & & & & \\
\hline
\end{tabular}


2. Na sua prática docente (como Professor da disciplina de Prática - Estágio Simulado de Processo Civil), assinale a alternativa que mais corresponda à reação dos alunos, em sua maioria, quanto aos assuntos que se relacionam com as disciplinas teóricas de Direito Processual Civil I e II:

\begin{tabular}{|c|c|c|c|c|c|c|}
\hline & Reações dos Acadêmicos & Nunca & $\begin{array}{c}\text { Menos da } \\
\text { metade dos } \\
\text { alunos }\end{array}$ & $\begin{array}{l}\text { A metade dos } \\
\text { alunos }\end{array}$ & $\begin{array}{c}\text { Mais da } \\
\text { metade dos } \\
\text { alunos }\end{array}$ & Sempre \\
\hline a) & Dificuldades com os princípios de Processo Civil (Processo Civil I) & & & & & \\
\hline b) & Dificuldades com a matéria relativa à competência (Processo Civil I) & & & & & \\
\hline c) & Dificuldades com a matéria de organização Judiciária (Processo Civil I) & & & & & \\
\hline d) & Dificuldades com a matéria condições da ação (Processo Civil I) & & & & & \\
\hline e) & Dificuldades com a matéria atos processuais (Processo Civil I) & & & & & \\
\hline f) & Dificuldades com a matéria petição inicial (Processo Civil II) & & & & & \\
\hline g) & Dificuldades com a matéria contestação (Processo Civil II) & & & & & \\
\hline h) & Dificuldades com a matéria provas (Processo Civil II) & & & & & \\
\hline i) & Dificuldades com a matéria sentença (Processo Civil II) & & & & & \\
\hline k) & Dificuldades com a matéria recursos (Processo Civil II) & & & & & \\
\hline
\end{tabular}

\section{Na sua relação com o(s) professor(es) da(s) disciplina(s) teórica(s) de Processo Civil:}

\begin{tabular}{|c|c|c|c|c|c|}
\hline (2) & $\begin{array}{l}\text { Nunca } \\
\text { (Zero) }\end{array}$ & $\begin{array}{l}\text { Raramente } \\
\text { (1x mês) }\end{array}$ & $\begin{array}{c}\text { Regularme } \\
\text { nte } \\
\text { (2x por } \\
\text { mês) }\end{array}$ & $\begin{array}{c}\text { Quase } \\
\text { sempre } \\
\text { (3x por } \\
\text { mês) }\end{array}$ & $\begin{array}{l}\text { Sempre } \\
\text { (4x por } \\
\text { mês) }\end{array}$ \\
\hline $\begin{array}{l}\text { a. Informa o professor da disciplina teórica de processo civil das } \\
\text { dificuldades enfrentadas pelos alunos quanto ao conhecimento teórico da } \\
\text { disciplina de processo civil e sua aplicação na prática/estágio? }\end{array}$ & & & & & \\
\hline $\begin{array}{l}\text { b. Consulta o professor da disciplina teórica de processo civil sobre os } \\
\text { procedimentos de aprendizagem aplicados? }\end{array}$ & & & & & \\
\hline
\end{tabular}


ANEXO E

\section{PLANOS DE ENSINO DE DIREITO \\ PROCESSUAL CIVIL I E DIREITO \\ PROCESSUAL CIVIL II}




\section{PLANO DE ENSINO DE DISCIPLINA}

\begin{tabular}{|c|}
\hline Ano Letivo \\
\hline 2008 \\
\hline
\end{tabular}

\begin{tabular}{|c|c|c|c|c|}
\hline 1 - Identificação & & & & \\
\hline 1.1. Unidade: $X$ & & & & \\
\hline 1.2. Curso: Direito & & & & \\
\hline 1.3. Instituto Superior: Ciências & licadas & & & \\
\hline 1.4. Disciplina: Direito Processu & & & & \\
\hline 1.5. Código: 99-8169-02 & & & & \\
\hline 1.6. Carga Horária: Prática & Teórica & 80 & Carga Horária Total & 80 \\
\hline
\end{tabular}

\subsection{Regime: Anual/Presencial}

\subsection{Série: $2^{\mathrm{a}}$}

\section{Contextualização da Disciplina no Curso}

A disciplina de Direito Processual Civil I justifica-se como componente curricular no Curso de Direito por possibilitar ao acadêmico embasamento teórico para fomentar habilidades de reconhecer no fenômeno social a importância do processo judicial a fim de solucionar conflitos e aplicar estes conhecimentos de forma técnica em situações práticas no cotidiano do cidadão comum.

\section{Ementa}

Processo e contexto social. Direito material e direito processual. Princípios do processo civil. Tutela jurídica e tutela jurisdicional. Jurisdição e sua classificação. Ação: conceito, elementos e condições. Competência: critérios determinativos. Sujeitos do processo. Litisconsórcio. Intervenção de terceiros. Atos processuais.

\section{Objetivos Específicos}

- Compreender a aplicação do processo nos conflitos individuais e sociais;

- Diferenciar o Direito material do Direito Processual;

- Reconhecer as fontes do Direito Processual Civil;

- Reconhecer os meios de interpretação da norma processual e saber aplicá-los;

- Identificar e aplicar os princípios processuais, constitucionais e infraconstitucionais relativos à teoria geral do processo;

- Diferenciar a tutela jurídica da tutela jurisdicional;

- Identificar o significado, abrangência e aplicação de jurisdição;

- Identificar os elementos e as condições da ação e suas conseqüências;

- Identificar os critérios para a fixação da competência e sua modificação;

- Diferenciar a capacidade civil da capacidade processual;

- Compreender os critérios éticos de atuação das partes;

- Reconhecer as prerrogativas profissionais e os critérios éticos de atuação do advogado;

- Identificar as hipóteses de pluralidade de partes e suas conseqüências processuais; 
- Compreender e diferenciar as hipóteses de intervenção de terceiros, bem como suas conseqüências processuais e materiais;

- Reconhecer os atos processuais praticados pelos sujeitos do processo e os critérios de sua validade;

- Identificar os meios de comunicação dos atos processuais;

- Manipular e pesquisar informações em índices do CPC.

\section{Descrição do Conteúdo}

1. DIREITO MATERIAL, DIREITO PROCESSUAL E PRINCÍPIOS

- Direito, processo e ordenamento jurídico

- Natureza jurídica de direito material e processual

- Fontes do direito processual

- Interpretação da norma processual

- Autonomia do direito processual civil

- Princípios do Processo Civil

- Atividades práticas

\section{JURISDIÇÃO, AÇÃO E COMPETÊNCIA}

- Tutela jurídica

- Tutela jurisdicional

- Condições da ação

- Elementos da ação

- Competência

- Atividades práticas

\section{COMPETÊNCIA, PARTES E INTERVENÇÃO DE TERCEIROS}

- Modificações da competência: causas, conflitos, prevenção

- Partes - capacidade, deveres e substituição

- Litisconsórcio

- Intervenção de terceiros

- Atividades práticas

\section{SUJEITOS DO PROCESSO E ATOS PROCESSUAIS}

- Procuradores - prerrogativas e critérios éticos

- A magistratura

- O Ministério Público

- Os Auxiliares da Justiça

- Atos processuais - classificação, comunicação, prazos e validade

- Atividades práticas

\section{Procedimentos Didáticos}

Exposição oral, discussões em grupo, manipulação de processos, pesquisas extraclasse, análise de textos, estudo de casos. 
O resultado da avaliação será obtido através da realização de 04 (quatro) provas oficiais bimestrais, presenciais e escritas, nos valores de 0 (zero) a 10 (dez) realizadas durante o ano letivo. A nota da prova bimestral oficial escrita representará no mínimo 50\% (cinqüenta por cento) da composição da nota bimestral quando somadas às outras formas de avaliação. Os escores obtidos pelo aluno através de outras formas de avaliação como: debates, trabalhos individuais ou grupais, seminários, resenhas de livros/filmes, documentários, estudo de casos e relatórios, deverão representar, no máximo 50\%, sendo registrados na folha de prova oficial e no diário de classe. A média bimestral será apurada realizando-se a somatória dos valores obtidos na prova oficial escrita e dos valores obtidos nas outras formas de avaliação, totalizando 10 (dez) pontos.

OBS: As avaliações devem conter, no mínimo, duas questões subjetivas, com valor 2,0 pontos cada uma.

\section{Bibliografia}

8.1. Básica (Livros e Periódicos)

THEODORO JÚNIOR, Humberto. Processo de conhecimento: teoria geral do direito processual civil e processo de conhecimento. Rio de Janeiro: Forense, 2007, v. 1.

WAMBIER, Luiz Rodrigues. Curso avançado de processo civil : teoria geral do processo e processo de conhecimento. ed. 9. São Paulo: Revista dos Tribunais, 2007 , v.1.

8.2. Complementar (Livros e Periódicos)

ALVIM, José Manoel de Arruda. Manual de Direito Processual Civil. 11. ed. São Paulo: Revista dos Tribunais, 2007, v. 1

Manual de Direito Processual Civil. 11. ed. São Paulo: Revista dos Tribunais, 2007, v. 2.

BEDAQUE, José Roberto dos Santos. Direito e processo - Influência do direito material sobre o processo. São Paulo: Malheiros.

BUENO, Cássio Scarpinella. Curso Sistematizado de Direito Processual Civil. 2. ed. São Paulo: Saraiva, 2008, v. 1.

CARNEIRO, Athos Gusmão. Jurisdição e competência. 10 ed. São Paulo: Saraiva, 2007.

CHIOVENDA, Giuseppe. Instituições de direito processual civil. São Paulo: Saraiva.

CINTRA Antônio C. de Araújo; DINAMARCO, Cândido Rangel; GRINOVER, Ada Pelegrini. Teoria geral do processo. São Paulo: Malheiros.

DINAMARCO, Cândido Rangel. Instituições de Direito Processual Civil. São Paulo: Malheiros, 2001, v. 1.

Instituições de Direito Processual Civil. São Paulo: Malheiros, 2001, v. 2. 
GONÇAlveS, Marcus Vinicius Rios. Novo Curso de Direito Processual Civil. 5. ed. São Paulo: Saraiva, 2008, v.1.

GRECO FILHO, Vicente. Direito Processual Civil brasileiro. 19. ed. São Paulo: Saraiva, 2007, v. 1.

Direito Processual Civil brasileiro. 18. ed. São Paulo: Saraiva, 2007, v. 2.

IOCOHAMA, Celso Hiroshi. Litigância de má-fé e lealdade processual. Curitiba: Juruá, 2006.

MARINONI, Luiz Guilherme. Novas Linhas do Processo Civil. 9. ed. São Paulo: Revista dos Tribunais, 2006.

MARQUES, José Frederico. Instituições de direito processual civil. Rio de Janeiro: Forense, v. 1.

NERY JUNIOR, Nelson; NERY, Rosa Maria Andrade. Código de Processo Civil Comentado. 9. ed. São Paulo: Revista dos Tribunais, 2006.

SANTOS, Ernane Fidélis dos. Manual do Direito Processual Civil. 11. ed. São Paulo: Saraiva 2006, v. 1.

SANTOS, Moacir Amaral. Primeira Linhas de Direito Processual Civil. 25. ed. São Paulo: Saraiva, 2007, v. 1.

SANTOS, Moacir Amaral. Primeira Linhas de Direito Processual Civil. 24. ed. São Paulo: Saraiva, 2007, v. 2.

SILVA, Ovídio A. Baptista da; GOMES, Fábio. Teoria geral do processo. 4. ed. São Paulo: Revista dos Tribunais, 2006.

9. Aprovação do Colegiado de Curso

Aprovado em Reunião do Colegiado de Curso em: 01 de fevereiro de 2008.

Data

Carimbo e Assinatura do Coordenador do Curso 


\section{PLANO DE ENSINO DE DISCIPLINA}

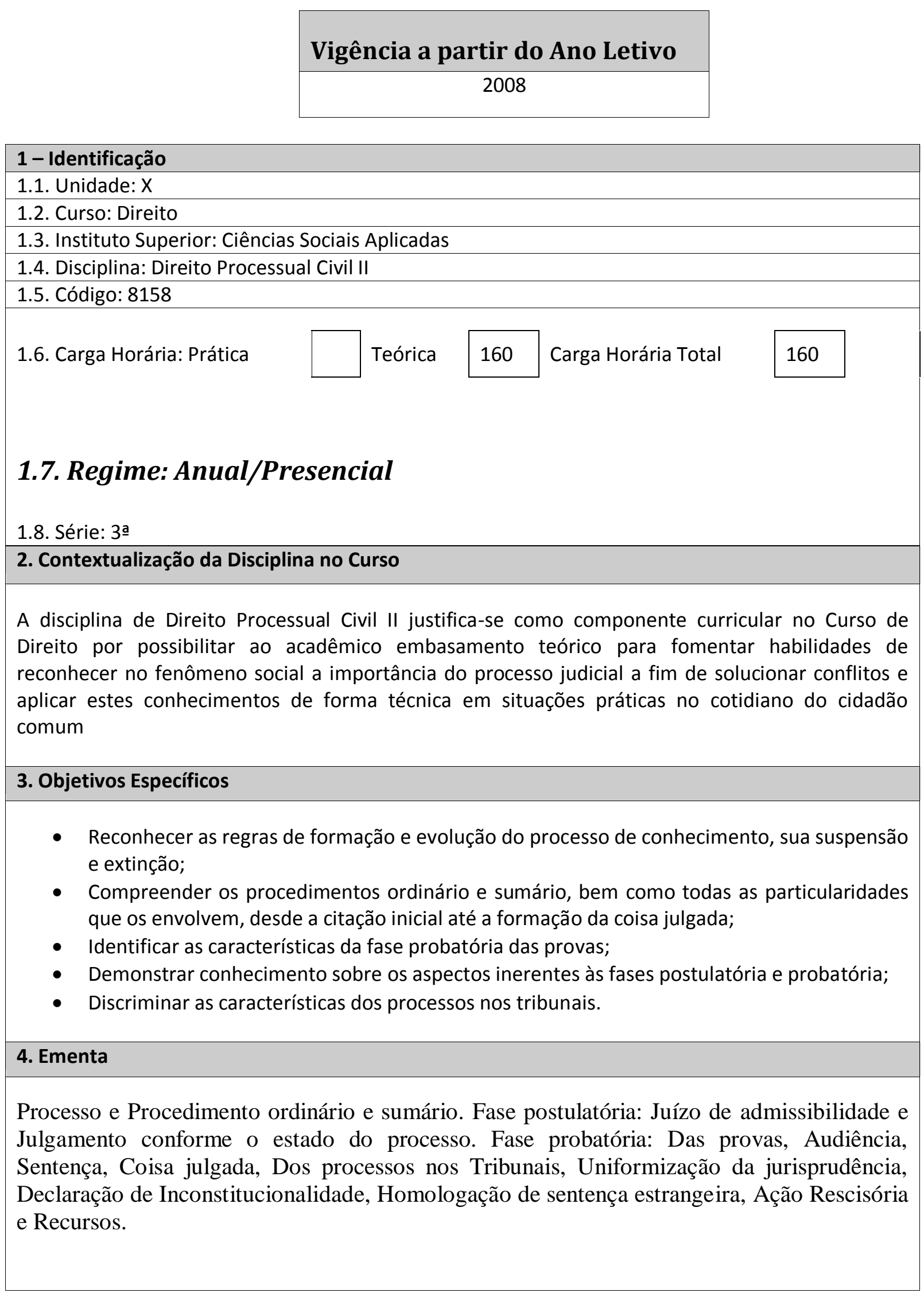




\section{Descrição do Conteúdo/Unidades e Carga Horária por Unidade}

\subsection{PROCESSO E PROCEDIMENTO - $40 \mathrm{~h} / \mathrm{a}$}

- Procedimento Ordinário e Sumário: fase postulatória: petição inicial (requisitos), causa de pedir e pedido; valor da causa - impugnação;

- Juízo de admissibilidade: indeferimento da inicial, resposta do réu (contestação, exceções e reconvenção), revelia, providências preliminares, fatos impeditivos, modificativos e extintivos do pedido, alegações do réu;

- Julgamento conforme o estado do processo: extinção do processo, julgamento antecipado da lide e saneamento do processo.

\section{- ATIVIDADE PRÁTICA}

\subsection{FASE PROBATÓRIA E DAS PROVAS - 40 h/a}

- Depoimento pessoal - confissão;

- Exibição de documento ou coisa;

- Prova documental: força probante e sua produção, argüição de falsidade;

- Prova testemunhal: admissibilidade, valor e produção;

- Prova pericial: formulação de quesitos e indicação de assistente técnico;

- Inspeção judicial

- ATIVIDADE PRÁtICA

\subsection{AUDIÊNCIA, SENTENÇA E COISA JULGADA - 40 h/a}

- Audiência: disposições gerais: conciliação, instrução e julgamento;

- Alegações finais: formas e matérias que podem ser deduzidas;

- Sentença: espécies;

- Coisa julgada: conceito de coisa julgada formal e material, elementos objetivos e subjetivos da coisa julgada

- ATIVIDADE PRÁTICA

\subsection{DOS PROCESSOS NOS TRIBUNAIS - $40 \mathrm{~h} / \mathrm{a}$}

- Uniformização de jurisprudência;

- Declaração de inconstitucionalidade;

- Homologação de sentença estrangeira;

- Ordem dos processos no tribunal;

- Ação Rescisória;

- Recursos: teoria geral, duplo grau de jurisdição, pressupostos, adequação;

- Recurso de terceiro prejudicado;

- Recursos em espécie: apelação, agravo, embargos de declaração, embargos infringentes, recurso especial, recurso ordinário, recurso extraordinário

- ATIVIDADE PRÁTICA

\section{Procedimentos Didáticos}

Preleção; resolução de problemas; estudo de casos; leitura e interpretação de textos e de livros; pesquisas e outras atividades pedagógicas orientadas; análise crítica de textos, vídeos e filmes; construção de textos;

\section{Critérios de Avaliação}

O resultado da avaliação será obtido através da realização de 04 (quatro) provas oficiais bimestrais, presenciais e escritas, nos valores de 0 (zero) a 10 (dez) realizadas durante o 
ano letivo. A nota da prova bimestral oficial escrita representará no mínimo 50\% (cinquienta por cento) da composição da nota bimestral quando somadas às outras formas de avaliação. Os escores obtidos pelo aluno através de outras formas de avaliação como: debates, trabalhos individuais ou grupais, seminários, resenhas de livros/filmes, documentários, estudo de casos e relatórios, deverá representar, no máximo 50\%, sendo registrados na folha de prova oficial e no diário de classe. A média bimestral será apurada realizando-se a somatória dos valores obtidos na prova oficial escrita e dos valores obtidos nas outras formas de avaliação, totalizando 10 (dez) pontos.

8. Bibliografia

8.1. Básica (Livros e Periódicos)

ARRUDA ALVIM, José M. Manual de Direito Processual Civil. 5 ed. São Paulo: Editora Revista dos Tribunais, 2005, v. 1 e 2.

GRECO FILHO, Vicente. Direito Processual Civil Brasileiro. São Paulo: Saraiva, 2000, v. 1,2 e 3 .

THEODORO JÚNIOR, Humberto. Processo de conhecimento. Rio de Janeiro: Forense, v. 1 e 2 .

WAMBIER, Luiz Rodrigues. Curso avançado de processo civil. São Paulo: Revista dos Tribunais, 2005, v. 1 e 2.

8.2. Complementar (Livros e Periódicos)

BARBI, Celso Agrícola. Comentários ao Código de Processo Civil. Rio de Janeiro: Forense.

CÂMARA, Alexandre de Freitas. Lições de direito processual civil. Rio de Janeiro: Freitas Bastos Editora.

CHIOVENDA, Giuseppe. Instituições de direito processual civil. São Paulo: Saraiva.

DINAMARCO, Cândido Rangel. Instituições de Direito Processual Civil. São Paulo: Malheiros.

\section{Aprovação do Colegiado de Curso}

Aprovado em Reunião do Colegiado de Curso em:

Data

Carimbo e Assinatura do Coordenador do Curso 